\title{
Liberation by Emigration: Italian Communists, the Cold War, and West-East Migration from Venezia Giulia, 1945-1949
}

Luke Gramith

West Virginia University, Iwgramith@mix.wvu.edu

Follow this and additional works at: https://researchrepository.wvu.edu/etd

Part of the European History Commons, Intellectual History Commons, Labor History Commons, Political History Commons, and the Social History Commons

\section{Recommended Citation}

Gramith, Luke, "Liberation by Emigration: Italian Communists, the Cold War, and West-East Migration from Venezia Giulia, 1945-1949" (2019). Graduate Theses, Dissertations, and Problem Reports. 3914.

https://researchrepository.wvu.edu/etd/3914

This Dissertation is protected by copyright and/or related rights. It has been brought to you by the The Research Repository @ WVU with permission from the rights-holder(s). You are free to use this Dissertation in any way that is permitted by the copyright and related rights legislation that applies to your use. For other uses you must obtain permission from the rights-holder(s) directly, unless additional rights are indicated by a Creative Commons license in the record and/ or on the work itself. This Dissertation has been accepted for inclusion in WVU Graduate Theses, Dissertations, and Problem Reports collection by an authorized administrator of The Research Repository @ WVU.

For more information, please contact researchrepository@mail.wvu.edu. 


\title{
LIBERATION BY EMIGRATION: \\ ITALIAN COMMUNISTS, THE COLD WAR, AND WEST-EAST \\ MIGRATION FROM VENEZIA GIULIA, 1945-1949
}

\author{
Luke Gramith
}

\author{
Dissertation submitted \\ to the Eberly College of Arts and Sciences \\ at West Virginia University
}

in partial fulfillment of the requirements for the degree of

\author{
Doctor of Philosophy \\ in \\ History
}

\begin{abstract}
Joshua Arthurs, Ph.D., Chair
Katherine Aaslestad, Ph.D.

Robert Blobaum, Ph.D.

James Siekmeier, Ph.D.

Maura Hametz, Ph.D.
\end{abstract}

Department of History

Morgantown, West Virginia
2019

Keywords: Italy, Yugoslavia, Monfalcone, Adriatic Border, Fascism, Communism, Cold War, Cold War Migration, Iron Curtain, Ideology, Everyday History

Copyright 2019 Luke Gramith 


\section{ABSTRACT \\ Liberation by Emigration: Italian Communists, the Cold War, and West-East Migration from Venezia Giulia, 1945-1949}

\section{Luke Gramith}

In the years after World War II, several thousand Italians from the Italo-Yugoslav borderlands emigrated eastward across the emerging Iron Curtain, hoping to start new and better lives in Communist Yugoslavia. This dissertation explores what these migrants hoped Communism would be and how the experiences of everyday life under the preceding Fascist dictatorship shaped these hopes. It suggests that these Italians envisioned Communist society as one purged of certain social categories - shopkeepers, foremen, and piecework clerks — who had become known as quintessential Fascists due to the way Fascism interwove itself with local power. Marxist doctrine played a relatively minor role in shaping their expectations. Despite being rather mundane in its motivations, this migration was misconstrued as subversive, catalyzing Cold War divisions. Ultimately, the project offers a new, bottom-up approach to early Cold War history, exploring how ordinary people understood, navigated, and shaped this critical period. 


\section{Acknowledgements}

This dissertation is the product of the time and effort of many people, some of whom I have known for a long time and others of whom I met during the course of my research. Without their assistance, this project would have emerged in much poorer form, or perhaps not at all. I will do my best to thank each deserving person by name, but I expect I will fall short of distributing recognition as widely as is deserved. The difficulty of the task a testament to the strength of the support networks I have had in my personal life, at WVU, and in the wider history community over the past years.

First, I would like to thank my advisor, Dr. Joshua Arthurs. He took me under his wing just as I finished my undergraduate studies and gave me steady guidance for seven long years. What I am as a scholar, I owe in large part to his tutelage. Throughout my time at WVU, he always provided me with insightful criticism without being harsh, even though much of my early work likely deserved severity. He constantly pushed me to think about my research in new ways, while also keeping my analysis on point. Readers should be especially thankful that he repeatedly emphasized a need for concision. Without his reminders, this dissertation may have ended up twice as long and half as good. It was the right choice, and I probably could have done more to take his sound advice. It was and is a privilege to be his first doctoral advisee.

Special thanks also go out to Dr. Katherine Aaslestad, who not only sat on my dissertation committee, but also served almost like a second advisor throughout my time in graduate school. She strove endlessly to broaden my knowledge and my frame of reference beyond the twentieth century, which has made me a more well-rounded scholar. I am incredibly thankful for all the effort she put into my development, including in the form of directing independent studies and supporting my search for outside research funding. I am certain that her efforts opened doors for me that otherwise would have remained closed.

I would also like to thank Dr. Maura Hametz, my outside reader, who brought her intimate knowledge of the northern Adriatic region to this study and always kept me honest. Her comments pushed me to consider more closely the relationship between events in the small corner of the world I study and what was happening beyond that corner. She encouraged me to question my categories of analysis and provided far more attention to the project than I could have ever expected, for which the manuscript is not only much more readable, but also more accurate.

Thanks are also due to Dr. Robert Blobaum and Dr. James Siekmeier for their contributions as members of the dissertation committee. Dr. Blobaum pushed me to question my methodological and analytical concepts, including my understanding of everyday history and everyday ethnicity. Unfortunately for readers, the true value of his comments will be clear only at a later date, when I release a revised version of this dissertation in book form. Dr. Siekmeier brought to the project an invaluable familiarity with the US National Archives and expertise in Cold War history. He not only made me aware of sources I otherwise would have overlooked, but also helped me situate my study more clearly in a global Cold War context.

In addition to my committee members, I owe an enormous debt to the many librarians and archivists who made my research possible. The librarians at WVU put up with endless Inter- 
Library Loan requests for obscure, foreign-language sources, and only in the rarest cases were they unable to get their hands on the materials in question. Without heir tireless work, my study would be on much shakier historiographical ground. The librarians at the Narodna in študijska knjižnica in Trieste and the Biblioteca statale Isontina in Gorizia opened their doors to allow me to examine collections of old newspapers and Italian-language books, for which I am incredibly thankful. In no particular order, thanks also go out to the staffs of the Archivio centrale dello Stato, Archivio di stato di Gorizia, Archivio di stato di Trieste, Archivio di stato di Udine, Archivio generale della Presidenza del Consiglio dei Ministri, Istituto Gramsci, Biblioteca comunale di Monfalcone, Archivio storico diplomatico del Ministero Affari Esteri, Arhiv Republike Slovenije, Istituto friulano per la storia del movimento di liberazione, Istituto regionale per la storia del movimento di liberazione di Friuli-Venezia Giulia, and the National Archives and Records Management in College Park, MD. I am especially thankful for those Italian archivists who stuck with me through my research process, even though my poor spoken Italian made things difficult. They were always willing to listen through the grammatical errors and help me find what I was looking for. Special thanks go out to Federica Puglisi, Emanuela Zollia, and Annalisa Filippo of the Archivio di Stato di Gorizia for helping me gain legal access to otherwise sealed records, as well as to Tadej Cankar for helping me with the same process at the Arhiv Republike Slovenije.

And then there is the issue of funding. In this regard, I owe a considerable debt to both the Cesare Barbieri Endowment for Italian Culture and the American Council of Learned Societies. The former's Research Grant in Modern Italian History allowed me to expand the scope of my research and take a deeper dive into the relevant archival material. Moreover, the Cesare Barbieri Endowment's invitation to speak at Trinity College and the questions posed by Dr. John Alcorn and Dr. Dario del Puppo helped identify weak points in my analysis. The ACLS's generous Dissertation Completion Fellowship afforded me the opportunity to write and polish the dissertation to the best of my ability.

In addition to professional debts, I am substantially indebted to family and friends for their constant support. First, thanks are due to my parents, Kurt and Ann Gramith, and my sisters, Kirstin and Rachel, for seeing me through five years of undergraduate studies and seven years of graduate school. I recall speaking with my parents toward the end of high school about skipping college and going straight into the workforce. (Really, my plan was to make it big with my band, but with the benefit of hindsight, "workforce" sounds much better.) How strange it is that their success in narrowly convincing me to give college a try turned into over a decade of additional schooling and a terminal degree. It was the right path for me, and their support never flagged along the way. Throughout the dissertation process, they showed (or at least convincingly faked!) interest in my research, and their periodic visits to the Mountain State provided much-needed periods of rest and fun. Without them, I doubt I could have kept my head on straight.

During my seven years in Morgantown, I was lucky to meet some of the finest classmates and friends a person could have. Among them are Marc and Amanda Sanko, Zac Cowsert, Jeridan Green, Chuck Welsko, Justin Power, Tyler Krahe, Cole Volman, Alex Burns, Henry Himes, and several more. These were the people who were there to help me blow off steam when I was overwhelmed with comps and to recharge my batteries when I was run down. Justin, Marc, and Zac accompanied me on camping and backpacking trips to the Dolly Sods, which did wonders for my state of mind. Chuck and Cole became close running buddies and made sure I saw the sun. In 
the process, they helped me iron out whatever organizational or analytical problems I was having at the time. Tyler was a great roommate and put up with my guitar playing even when he probably wanted peace and quiet. And when I hit a rough patch in early 2017, Marc and Amanda responded with generosity and kindness that far exceeded my expectations. I am thankful that the renewed Backyard Brawl will bring all of us back together again in 2022.

Finally, I am thankful for the constant support of my partner, Dr. (!) Christine Anzur. We met in mid-2017 shortly before she took her comps, and within a year she had already defended a dissertation and found one of those elusive jobs. For most of the time I have known her, she has been one step ahead of me, showing me how to get things done and telling me when to stop tinkering and hit the "send" button. She has put up with more proofreading requests and dissertation-related ramblings than anyone should reasonably be asked to endure, and she has been by my side to encourage me as I passed through each of the final stages of the dissertation process. Even when it was massively inconvenient for her, she has been there for me, and it is difficult to express how appreciative I am of that support. I hope she sticks around to see me through my next research project and each one that comes after, because life is certainly better with her around.

And, of course, Christine brought our pup Aesa into my life and provided me with my most reliable writing partner. Every day at 3:00pm, like clockwork, Aesa wandered into my home office and jumped on my lap, reminding me that I had at least two more hours of writing before the day was done. When I was frustrated, her presence helped me push through. Though she never shared with me her undoubtedly brilliant insights about Fascism and Communism in the northern Adriatic region, she, like so many others, helped me bring this project to a successful conclusion. 


\title{
Table of Contents
}

\begin{abstract}
Acknowledgments

Table of Content

List of Tables and Charts

List of Figures .

List of Abbreviations .

Note on Placenames

Introduction: .

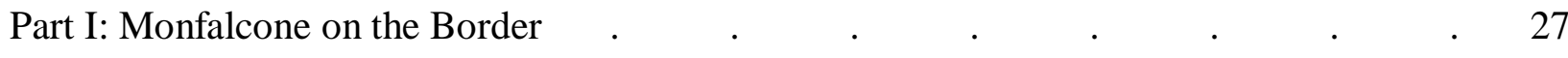

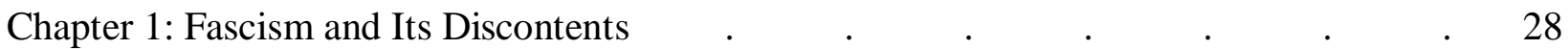

Chapter 2: Civil War and Visions of a New World $\ldots \quad$. $\quad . \quad$. $\quad . \quad$. 68

Chapter 3: The Myth of Yugoslavia: Visions of Utopia in a Town Straddling Two
\end{abstract} Worlds.

Chapter 4: Fascist Continuities: Everyday "Fascism" and the Struggle for Change in Contested Monfalcone

Chapter 5: The Loss of "Monfalcone antifascista:" Demonstrations, Dynamite, and Disillusionment

Part II: Monfalconesi on the Move

Chapter 6: The Controesodo: Ideology and Necessity in the Choice to Cross the Iron Curtain

Chapter 7: A New Life Beyond the Iron Curtain $\ldots$

Chapter 8: West-East Migration, Cold War Paranoia, and the Construction of the Iron Curtain .

Conclusion

Appendices 
Appendix A: Glossary of Political, Economic, Cultural, and Other Organizations

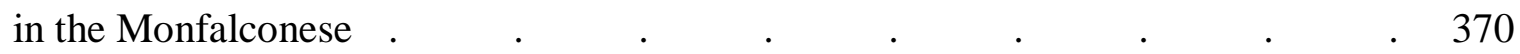

Appendix B: Chart of Postwar Organizations in the Monfalconese by Type and

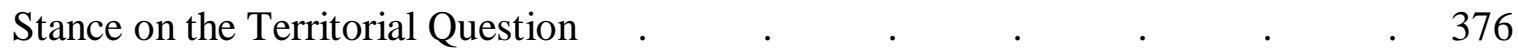

Appendix C: The Monfalconese Emigration by the Numbers . . . . . 377

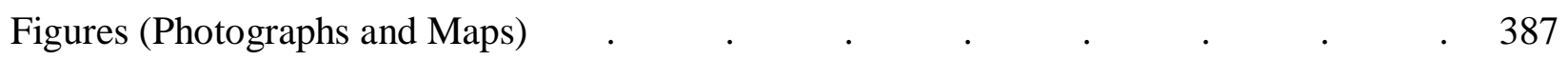

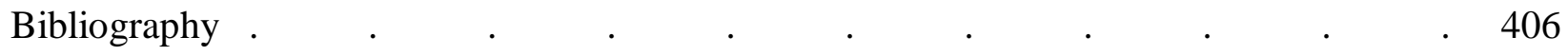




\section{List of Tables and Charts}

Table 1. Chart of Postwar Organizations in the Monfalconese by Type and Stance

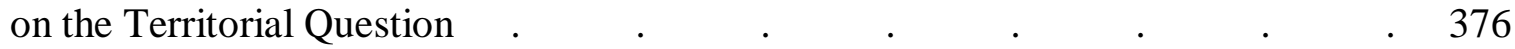

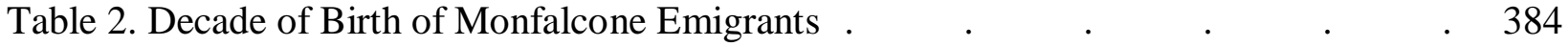

Chart 1. Migration Destination in Yugoslavia $\quad . \quad$. $\quad . \quad$. $\quad$. $\quad 384$

Chart 2. Migrants to Fiume with Unaccounted-For Families . $\quad$ 385

Chart 3. Migrants to Pola with Unaccounted-For Families . 385

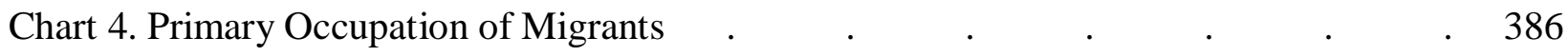




\section{List of Figures}

Figure 1. Mussolini speaks to a crowd of workers at the Monfalcone shipyard,

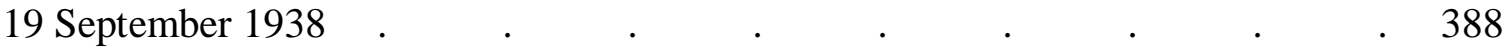

Figure 2. Map of Friuli and Venezia Giulia before the Great War ～. 389

Figure 3. The workers' quarter of Panzano with the shipyard on the right 390

Figure 4. Socialist meeting outside of the Monfalcone shipyard during the biennio

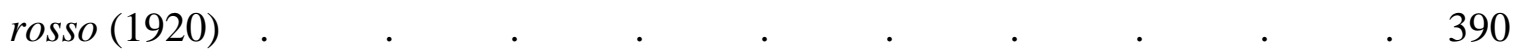

Figure 5. Monfalconese Fascists surround Francesco Giunta ～～～～～～～～～～ 391

Figure 6. Workers gather outside the CRDA in anticipation of an anti-Fascist,

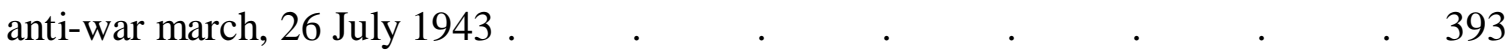

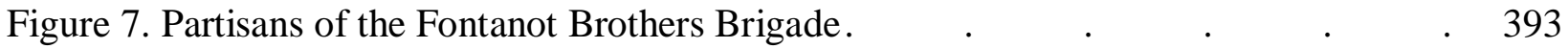

Figure 8. The Central Command of the Garibaldi Division-Natisone along with

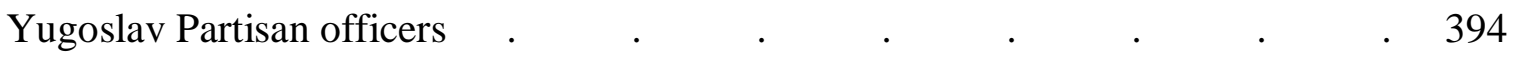

Figure 9. Monfalconesi greet the Yugoslav troops, 1 May 1945 . 395

Figure 10. A crowd of pro-Yugoslavs gather outside Monfalcone City Hall shortly after

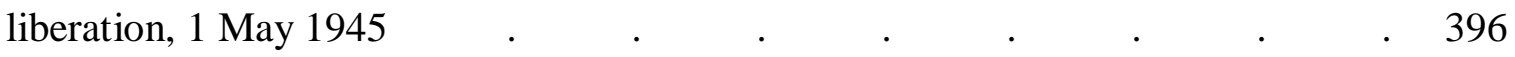

Figure 11. Map of the two military occupation zones as they existed between June 1945

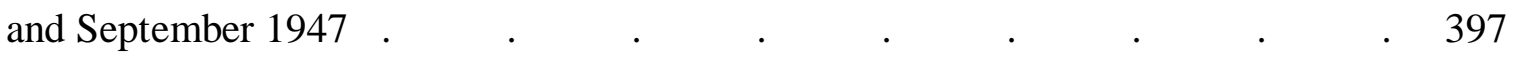

Figure 12. Map of the Free Territory of Trieste (1947-1954) showing Monfalcone as part

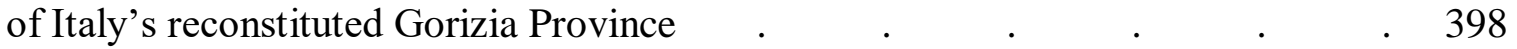

Figure 13. The common pro-Yugoslav slogan "we want popular power" adorns the wall

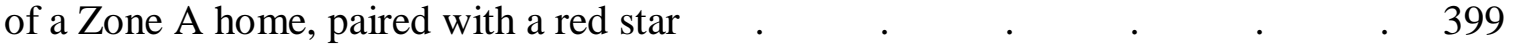

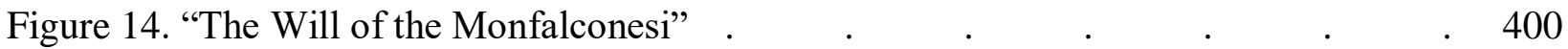

Figure 15. The pro-Yugoslav residents of the outlying village of Pieris gather in the village's central piazza as part of an UAIS demonstration on an unknown date $\quad$. $\quad$. 401

Figure 16. A pro-Yugoslav procession passes through Monfalcone on an unknown date $\quad$ • 402

Figure 17. The pro-Yugoslavs of the Monfalconese gather in Monfalcone's central piazza

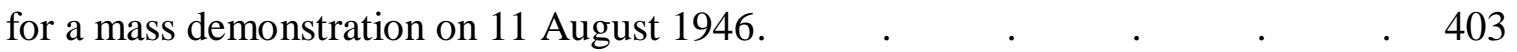

Figure 18. Reproduction of a threat letter delivered to the home of Sergio Bortolutti, head of the UAIS in the Monfalconese, in September 1946 . $\quad$. $\quad$. $\quad$. 404

Figure 19. A photograph of the terrain between Gorizia and San Floriano 405

Figure 20. Another photo of the terrain between Gorizia and San Floriano . 405

\section{List of Abbreviations}




\section{In Body (Organizations, Titles, etc.)}

AMG - Allied Military Government

APG - Associazione partigiani giuliani

API - Associazione partigiani italiani

CAO - Civil Affairs Officer

CCLM - Cooperativa di Consumo Lavoratori del Monfalconese

CDLN - Comitato distrettuale di liberazione nazionale

CLN - Comitato di liberazione nazionale

CLNAI - Comitato di liberazione nazionale-Alta Italia

CL - Cooperativa del Lavoro

CLT - Consiglio di Liberazione per la Città di Trieste

CNT - Cantiere Navale Triestino

CO - Cooperative operaie di Trieste, Istria e Friuli

CRDA - Cantiere riuniti dell'Adriatico

DC - Democrazia cristiana

DG - Divisione Gorizia

DP - Difesa Poplare

FYP - Five Year Plan

GAP - Gruppo d'azione pattriotica

GC - Gioventù comunista

GL - Giustizia e Libertà

GNR - Guardia nazionale repubblicana

GSI - General Staff Intelligence

IRI - Istituto per la Ricostruzione Industriale

KPH - Komunistička partija Hrvatske

KPJ - Komunistička partija Jugoslavije (Комунистичка партија Југославије)

KPS - Komunistička partija Slovenije

LN - Lega nazionale

OF - Osvobodilna fronta

OVRA - Organizzazione per la Vigilanza e la Repressione dell'Antifascismo

OZNA - Odjeljenje za zaštitu naroda or Odeljenje za zaštitu naroda (Одељење за заштиту народа)

PCdI - Partito comunista d'Italia

PCI - Partito comunista italiano

PCIVG - Partito comunista di Venezia Giulia

PCRG - Partito comunista della Regione Giulia

PCTLT - Partito comunista del Territorio Libero di Trieste (Komunistična partija Svobodnega tržaškega ozemlja)

PdA - Partito d'Azoine

PFR - Partito fascista repubblicano

PNF - Partito nazionale fascista

RSI - Repubblica Sociale Italiana 
SACMED - Supreme Allied Command in the Mediterranean

SCAO - Senior Civil Affairs Officer

SEPRAL - Sezione Provinciale dell'Alimentazione

SG - Sindacati Giuliani

SU - Sindacati Unici

TLT - Territorio Libero di Trieste (Free Territory of Trieste)

TRUST - Trieste United States Troops

UAIS - Unione antifascista italo-sloveno (later: Unione antifascista italo-slavo)

UIIF - Unione degli Italiani dell'Istria e di Fiume

UDAIS - Unione delle donne antifasciste italo-slava

UGARG - Unione gioventù antifascista della Regione Giulia

UDBA - Uprava državne bezbednosti armije

UO - Unità operaia

VGPC - Venezia Giulia Polizia Civile

CID - Criminal Investigative Division

\section{In Notes}

ACS - Archivio centrale dello Stato

CPC - Casellario Politico Centrale

DGPS - Direzione Generale Pubblica Sicurezza

Div AA GG RR - Divisione Affari Generali e Riservati

Div AA RR - Divisione Affari Riservati

DP - Divisione Polizie

PCM - Presidenza del Consiglio dei Ministri

SIS - Divisione Servizi Informativi e Speciali

AGPCM - Archivio generale della Presidenza del Consiglio dei Ministri

UZC - Ufficio per le Zone di Confine

AS - Arhiv Republikee Slovenije

ASBCM - Archivio storico della Biblioteca comunale di Monfalcone

ASDMAE - Archivio storico diplomatico at the Ministero Affari Esteri

AA PP - Affari Politici

DGAP - Direzione Generale Affari Politici

MG - Ministero della Guerra

UI - Uffucio Informazioni

ASG - Archivio di stato di Gorizia

AST - Archivio di stato di Trieste

ASU - Archivo di stato di Udine

b - box or busta

CC - Comitato Centrale (Central Committee)

CCM - Consorzio Culturale del Monfalconese

CLG - Centro isontino di ricerca e documentazione storica e sociale "Leopoldo Gasparini"

f - file or fascicolo

FVG - Friuli-Venezia Giulia 
FSS - Field Security Service

Gab - Gabinetto

IFSML - Istituto friulano per la storia del movimento di liberazione

IG - Istituto Gramsci

AM - Archivio Mosca

APC - Archivio partito comunista

IRSML-FVG - Istituto regionale per la storia del movimento di liberazione, Friuli-VeneziaGiulia

Jug - Jugoslavia (Yugoslavia)

NARA - National Archives and Records Management II RG - Record Group

PCRG-CCM - Partito comunista della Regione Giulia-Comitato Cittadino Monfalconese

PCRG-CDM - Partito comunista della Regione Giulia-Comitato Distrettuale Monfalconese Pref - Prefettura

Sez - Sezione 


\section{Note on Placenames}

This dissertation focuses on a region that had long served as a crossroads of the Germanic, Slavic, and Italian worlds. The territories and settlements discussed in the work's pages have been home to a range of ethnic groups that speak a variety of languages, and these territories and settlements have regularly changed hands during the past centuries. As a result, most go by multiple names, dependent upon the language (and politics) of the speaker(s) in question. In cases where a region or settlement has multiple placenames, this dissertation most often uses the Italian name. It does so not to suggest that Italians have a more legitimate claim to these territories, but rather because these were the names used by the (mostly) Italian-speaking subjects of study. Thus, this study uses "Fiume" instead of "Rijeka" (Croatian), "Reka" (Slovenian), or "Sankt Veit am Flaum" (German). Similarly, it uses "Monfalcone" instead of "Tržič" (Slovenian) or "Falkenberg" (German); "Trieste" instead of "Trst" (Slovenian, Croatian) or "Triest" (German); and "Pola" instead of "Pula" (Croatian). 


\section{Introduction}

There are others - besides those of Pola - there are others who go away, or who cannot wait to go away: those of Monfalcone. They too have home and family, they have possessions and memories in the town and in the nearby villages, they have tombs of their dead. And they are ready to leave everything. ${ }^{1}$

With these words, printed on 17 January 1947, Trieste's Communist daily drew attention to a wave of Italians from the nearby shipbuilding town of Monfalcone ${ }^{2}$ who were quitting their jobs, packing their bags, and moving to start new lives in Tito's New Yugoslavia. That very day, as the ink dried on Il Lavoratore's pages, a further sixty-seven workers chose to quit and depart for the other side of the Iron Curtain, among them Silvio D. and Marcelliano C. ${ }^{3}$ The former was the type one might expect to be eager to make such a leap. He was a longtime operative of Italy's underground Communist Party whom the Fascist regime had arrested and tried in the mid-1930s for subversive activity before releasing him under strict terms of surveillance. ${ }^{4}$ But Marcelliano was different. Working in the same shipyard as Silvio, he had risen to a position as a skilled machine operator over the course of a thirty-year career, during which he married, fathered a child, and seemingly steered clear of subversive politics - or at least he never garnered the suspicion of the Fascist police. Nevertheless, on the same day as Silvio, Marcelliano quit his job to move his entire family across the Iron Curtain, "lured," in the words of police, "by the proposals and rumors of prosperity and wellbeing he would find in Yugoslavia."5 These were early stirrings of what would become a mass migration of thousands of Monfalcone residents (monfalconesi) to Yugoslavia, and Il Lavoratore did what it could to make sure the happening was well-known.

\footnotetext{
1 “E questi perchè se ne vanno?” Il Lavoratore, 17 January 1947.

${ }^{2}$ Monfalcone sits just northwest of Trieste at the northernmost point of the Adriatic Sea.

${ }^{3}$ Unsigned, "Elenco degli operai licenziati spontaneamente dall'1 gennaio al 29 gennaio 1947," 5 February 1947, NARA, RG331, UD1981, b 9189, f 11304/115/308

${ }^{4}$ ACS, MI, DGPS, CPC, b 1820, f 119741; Silvio D[x], “Anketni List - Questionario,” 1946, AS 1815/9/107.

${ }^{5}$ Comm. di PS-Monfalcone, “C[x] Marcelliano fu E[x],” (N. 9027), 27 August 1948, ASG, Questura 1948, b 3, f 458. The police of the Italian Republic also determined that Marcelliano had never engaged in any "antinational activity."
} 
The mobility of Silvio, Marcelliano, and the other Monfalconese emigrants was significant for Il Lavoratore for the exact reason it appears so striking today: it ran counter to the prevailing migratory currents that spanned the European continent in the first postwar and Cold War years. Though these years were marked by an unprecedented mobility of peoples - POWs, orphans, camp survivors, and expelled ethnic minorities were all on the move - rarely did individuals or groups chose to go east. ${ }^{6}$ Limited mainly to repatriating DPs and POWs and isolated Communist fugitives seeking refuge beyond the Iron Curtain, the eastward trickle paled in comparison to the westward flood of those seeking to escape the Communist world, as a result of which it has been completely overshadowed by westward movement in both historiography and the popular imagination. ${ }^{7}$

Yet if the monfalconesi's migration diverged strikingly from trends of continental scope, it was regional circumstances and regional movements that most concerned Il Lavoratore. Indeed, the cataclysm of world war had thrown Monfalcone and the often-contested Italo-Yugoslav borderlands into chaos. During the war, the Yugoslav Partisan forces of Josip Broz (Tito) had announced Yugoslavia's intention to annex Italian territory up to the Isonzo River, and even a

\footnotetext{
${ }^{6}$ Idith Zertal, From Catastrophe to Power: Holocaust Survivors and the Emergence of Israel (Berkeley: University of California Press, 1998); Michael Robert Marrus, The Unwanted: European Refugees in the Twentieth Century (Philadelphia: Temple University Press, 2002); Anna Marta Holian, Between National Socialism and Soviet Communism: Displaced Persons in Postwar Germany (Ann Arbor: University of Michigan Press, 2011); Tara Zahra, The Lost Children: Reconstructing Europe's Families after World War II (Cambridge: Harvard University Press, 2011); Andrew Demshuk, The Lost German East: Forced Migration and the Politics of Memory, 1945-1970 (New York: Cambridge, University Press, 2012).

${ }^{7}$ On the passage of Italian Communists into Czechoslovakia, see Giuseppe Fiori, Uomini ex: lo strano destino di un Gruppo di comunist italiani (Turin: Einaudi, 1993); Philip Cooke, "Red Spring: Italian Political Emigration to Czechoslovakia," The Journal of Modern History 84, no. 4 (2012): 861-96. For general studies of postwar migration that do not discuss West-East migration outside the scope of the categories mentioned, see Klaus Bade, Migration in European History (Malden, MA: Blackwell, 2003); Rainer Ohlinger and Karen Schönwaelder (eds), European Encounters: Migrants, Migration, and European Societies since 1945 (Aldershot, England and Burlington, VT: Ashgate, 2003). There are a select few studies of migration from Western countries to the Soviet Union in the interwar years, but they lack the Cold War implications. Tim Tzouliadis, The Forsaken: An American Tragedy in Stalin's Russia (New York: Penguin Books, 2008); Annemaire Sammartino, The Impossible Border: Germany and the East, 1914-1922 (Ithaca, NY: Cornell University Press, 2010), ch. 3; Benjamin Sawyer, "Shedding the White and Blue: American Migration and Soviet Dreams in the Era of the New Economic Policy," Ab Imperio 1 (2013): 65-84; Julia Mickenberg, American Girls in Red Russia: Chasing the Soviet Dream (Chicago and London: University of Chicago Press, 2017).
} 
year-and-a-half after war's end, the location of the Italo-Yugosalv border remained an open question. From war's end through the printing of Il Lavoratore's article, the territory stretching from Monfalcone in the northwest through the Istrian Peninsula in the southeast had hung in the balance between the two powers, much of it administered by an Anglo-American occupying force. In the diplomatic battle that ensued, called the "Trieste Question" after the region's capital city, the claimant states made their cases using the Wilsonian language of ethno-demographics and nation-states - that is, citing the presence of Italian- or Slavic-speaking populations - which gave the impression that this was a continuation of longstanding nationalist struggles over an ethnicallymixed borderland. But the states' competing ideologies and the involvement in the conflict of the United States and the Soviet Union on behalf of Italy and Yugoslavia respectively also gave the struggle an inflection as the "first battle of the Cold War."

With the stakes of border-drawing so high, borderland residents across the zone had taken to the streets, demonstrating in favor of one side or the other and often returning home bloodied

\footnotetext{
${ }^{8}$ Christian Jennings, Flashpoint Trieste: The First Battle of the Cold War (Lebanon, NH: ForeEdge, 2017). Historians have dedicated substantial ink to studying the diplomatic aspects of this struggle. See Bogdan Novak, Trieste, 19411954: The Ethnic, Political, and Ideological Struggle (Chicago: University of Chicago Press, 1970); Roberto Rabel, "Prologue to Containment: The Truman Administration's Response to the Trieste Crisis of May 1945," Diplomatic History 10, no. 2 (1986): 141-160; J. R. Whittam, "Drawing the Line: Britain and the Emergence of the Trieste Question, January 1941-May 1945," The English Historical Review 106, no. 419 (1991): 346-370; Luciano Monzali, "La questione jugoslava nella politica estera italiana dalla prima guerra mondiale al trattati di Osimo (1914-1975)," in Europa adriatica: storia, relazioni, economia, eds. Franco Botta and Italo Garzia, 15-72 (Rome and Bari: Laterza, 2004). Scholars have also examined the relationship between external state actors and local political forces within the contested territories. Particularly interesting are studies that have revealed the complex, if generally supportive relationship of the Italian state with native Italian nationalist forces committed to bringing Trieste back into the Italian fold. The complexity arises from the fact that some Italian nationalists at Trieste had unsavory Fascist pasts or openly neo-Fascist politics. Ivan Buttignon, "Il sentimento nazionale italiano durante il periodo di occupazione alleata della Zona A (1945-1954) secondo l'Archivio del Ministero dell'Interno italiano," Quaderni 25 (2014): 97-141; Diego D'Amelio, Andrea Di Michele, and Giorgio Mezzalira (eds), La difesa dell'italianità: l'Ufficio per le zone di confine a Bolzano, Trento e Trieste (1945-1954) (Bologna: Il Mulino, 2015); Fabio Capano, "Fighting for Trieste: Nationalism and Political Violence at the Edge of the Iron Curtain," Journal of Modern Italian Studies 21, no. 4 (2016): 603-626. Still others have shone light upon the difficulties this question posed for relations between the Italian, Yugoslav, and Soviet Communist Parties, and particularly the metaphorical tightrope that Italian Communist Party (PCI) leader Palmiro Togliatti had to walk, balancing the mollification of Stalin's and Tito's desires with his party's postwar electoral need to avoid the stigma of being an "antinational" party. Eric Terzuolo, Red Adriatic: The Communist Parties of Italy and Yugoslavia (Boulder, CO: Westview Press, 1985); Elena Agarossi and Victor Zaslavsky, Stalin and Togliatti: Italy and the Origins of the Cold War (Stanford: Stanford University Press, 2011).
} 
after clashes with their opponents. The territorial question became the overriding framework for the zone's politics, and the population, intent on being participants as well as prizes, fractured into opposing camps that favored Italian sovereignty, Yugoslav sovereignty, or regional autonomy. Despite attempts by some political actors to elide national and political identities in pursuit of political gain - to forge derogatory categories such as "Slavo-Communists" or label all Italians who supported an Italian Trieste as Fascists - the coalitions that emerged were tremendously complex, ethnicity being just one, often minor consideration in a participant's alignment with a given faction. ${ }^{9}$ Such was the case with Silvio and Marcelliano: they were "red" Italians who had privileged politics over ethnicity and gone into the streets to try to bring Yugoslavia to their town.

For a year-and-a-half, Il Lavoratore had provided commentary on this struggle, attempting to shift the Yugoslav border westward, but recently that game had come to an end and a new one had begun. As diplomats announced the placement of the border, borderland residents to both east and west felt their homes fell on the wrong side of the line. This was true for Silvio, Marcelliano, and thousands of other monfalconesi, who, finding their town slotted to return to Italy, made preparations to depart. But such was also the case for hundreds of thousands of ethnic Italians from

\footnotetext{
${ }^{9}$ Historians have long recognized that within each camp there were significant variations in ethnicity, class, and politics. See especially Novak, Trieste. For an immediate "prehistory" of the political alignments that would emerge after May 1945, see Raoul Pupo, Trieste '45 (Rome: Laterza, 2010). On the development and deployment of the term "Slavo-Communist," see Sabina Mihelj, "Drawing the East-West Border: Narratives of Modernity and Identity in the Northeastern Adriatic (1947-1954)," in Cold War Cultures: Perspectives on Eastern and Western European Societies, edited by Annette Vowinckel, Marcus Payk, and Thomas Lindenberger, 279-296 (New York: Berghahn Books, 2012). On the pro-Italians, see Ivan Buttignon, "Lega Nazionale e Governo Militare Alleato: La lotta per l'egemonia cultura nella Venezia Giulia," Quaderni 24 (2013): 63-116. On the pro-Yugoslav faction and organizations, see the work of Nevenka Troha, especially "La regione giulia fra Italia e Jugosalvia, 1945-1947," trans. Giuditta Giraldi, Storia Contemporanea in Friuli 33 (2003): 9-47; Chi avrà Trieste? Sloveni e italiani tra due stati, trans. Monica Rebeschini (IRSML-FVG: Trieste, 2009); “L'Azione della Jugoslavia e delle forze filojugoslave della Venezia Giulia nella lotta per il nuovo confine italo-jugoslavo 1945-1954," in La difesa dell'italianità, ed. D'Amelio, Di Michele, and Mezzalira, op. cit., 439-466. The fact that ethnicity was not always a major consideration is in line with works on "national indifference" in Habsburg borderlands, among them Tara Zahra, Kidnapped Souls: National Indifference and the Battle for Children in the Bohemian Lands, 1900-1948 (Ithaca: Cornell University Press, 2008); Zahra, "Imagined Noncommunities: National Indifference as a Category of Analysis," Slavic Review 69, no. 1 (2010): 93119.
} 
eastern-Adriatic towns like Pola (Pula) whose homes were destined for Yugoslavia. By the time of Il Lavoratore's article, the postwar flight from the eastern Adriatic of over 250,000 ethnic Italians was well underway. Their flight, which has been intensely scrutinized by historians in recent decades and which dominates contemporary Italians' understanding of postwar migration, had already assumed the Biblically-inflected name of the exodus (esodo). ${ }^{10}$

It was this westward movement that concerned Il Lavoratore, and it was because of it that Silvio and Marcelliano mattered. As one part of Europe's postwar "disentanglement of populations," the esodo, with its images of Italians abandoning everything to escape Titoist horrors, gave rise to accusations that Yugoslavia was ethnically cleansing its new lands. ${ }^{11}$ The eastward movement of monfalconesi stood in stark contrast, belying such claims. Soon termed the counter-exodus (controesodo), their movement was a voluntary re-entanglement of populations. It afforded Il Lavoratore a counternarrative - an opportunity to transform the flight of easternAdriatic "exiles" (esuli) from a question of ethnic cleansing into one of politics. Those who fled, the paper labelled as Fascists and reactionaries whose nationalism clashed irreconcilably with the

\footnotetext{
${ }^{10}$ The esodo occurred in a series of successive waves between 1945 and 1954, each of which resulted from different mixtures of Italian national sentiments, anti-Communist politics, and personal fear. For a detailed history of the esodo, see Raoul Pupo, Il lungo esodo: Istria: le persecuzioni, le foibe, l'esilio (Milan: Rizzoli, 2006). For memory studies regarding the esodo, including discussions of its impact on Italian politics, see Pamela Ballinger, History in Exile: Memory and Identity at the Borders of the Balkans (Princeton: Princeton University Press, 2003); Guido Crainz, Il dolore e l'esilio: l'Istria e le memorie divise d'Europa (Rome: Donzelli, 2005); John Foot, "Memories of an Exodus: Istria, Fiume, Dalmatia, Trieste, Italy, 1943-2010," in Totalitarian Dictatorship: New Histories, eds. Daniela Baratieri, Mark Edele, and Giuseppe Finaldi, 232-250 (New York, Routledge, 2014).

11 Jessica Reinisch and Elizabeth White, The Disentanglement of Populations: Migration, Expulsion and Displacement in Post-War Europe, 1944-9 (Basingstoke, England and New York: Palgrave Macmillan, 2011). The debate over "ethnic cleansing" is linked to a debate over the foibe killings, or the killing of ethnic Italians of Trieste, Istria, and Dalmatia by Yugoslav actors in September 1943 and May-June 1945. Raoul Pupo has made a convincing argument that the foibe killings were not an ethnic cleansing as such, but rather a "preventive purge" of anyone opposed to the Communist regime and the westward projection of the Yugoslav border. Pupo, Il lungo esodo. For a nuanced examination of motives, see Gaia Baracetti, "Foibe: Nationalism, Revenge and Ideology in Venezia Giulia and Istria 1943-5," Journal of Contemporary History 44, no. 4 (2009): 657-674. For a notable proponent of the ethnic cleansing thesis, see Arrigo Petacco, A Tragedy Revealed: The Story of the Italian Population of Istria, Dalmatia, and Venezia Giulia, 1943-1956, trans. Konrad Eisenbichler (Toronto: University of Toronto Press, 2005). For a work that pushes back against the ethnic cleansing thesis and high estimations of those killed (often at or above 3000), see Claudia Cernigoi, Operazione "foibe": tra storia e mito (Udine: Kappa Vu, 2012).
} 
progressive society being built upon the ruins of Fascist empire; progressive Italians from the militant Silvio to the unremarkable Marcelliano, Yugoslavia welcomed with open arms.

If the Monfalconese migration was useful propaganda for Il Lavoratore, it is equally useful for the historian. The fact is, as hundreds of thousands of Italians fled westward from Yugoslavia and the Communist world, thousands travelled on the same rails, roads, and paths in the opposite direction. Whether a longtime militant like Silvio or simply an "ordinary" Italian "lured" across the border like Marcelliano, each migrant made the choice to depart. Moreover, each migrant's choice came as Monfalcone passed through the watershed transitions between Fascism and postFascism, occupation and liberation, World War and Cold War. Exploring how and why migrants made this choice affords new insights on each of these transitions. For all their differences, these migrants had three things in common: all had shared the experience of twenty years of Fascist dictatorship, all (or most) had sought to prevent their town from returning to Italy after 1945 and instead advocated for Yugoslavia, and all were conscious that the jump across the Italo-Yugoslav border was a jump toward something called "socialism." Because of this, the story of Monfalcone and the "psychosis of departure" that gripped the town in 1947 does more than just provide new perspectives on postwar mobility. ${ }^{12}$ As a focal point to study the relationship between the quotidian experience of Fascism and the formation of radical visions for the post-Fascist future, it can also address hitherto unanswered questions about the legacies of dictatorship, the formation of popular ideology, and the origins of the Cold War in the Italo-Yugoslav borderlands and beyond.

\footnotetext{
${ }^{12}$ A participant used this term in his memoirs. Mario Tonzar, La valigia e l'idea. Memorie di Mario Tonzar, ed. Alessandro Morena (Ronchi dei Legionari: Consorzio Culturale del Monfalconese, 2006), 104.
} 


\section{Monfalcone between Fascism and Cold War}

Despite the striking phenomenon of mass West-East movement, Monfalcone has not received the attention one might expect. Within the Anglophone world, the town, its residents' participation in the Italo-Yugolav territorial struggle, and the consequent migration are virtually unknown. Nearly all English-language literature related to the Trieste Question focuses on Trieste proper, and historians have made only passing reference to the controesodo in works otherwise concerned with the esodo or inter-Communist Party relations. ${ }^{13}$ In Italian, Slovenian, and Croatian circles, historians have paid greater attention to both the historical experience of Monfalcone through the early twentieth century and the controesodo emanating from that town. Scholars like Galliano Fogar and Nevenka Troha have long recognized Monfalcone as a stronghold first of Communist-led anti-Fascist organization and then of the region's pro-Yugoslav movement, though the former's study concludes with the Second World War and the latter's overlooks the experiences of monfalconesi that generated and resulted from pro-Yugoslav activity in favor of the outcomes of the politics of "Italo-Slavic fraternity" on a regional level. ${ }^{14}$ Only recently have regionally-minded historians begun to explore the social experience of Monfalcone between Fascism and the postwar years, most often relying on oral testimonies, which they have sought to gather before the memories of participants are lost to oblivion. ${ }^{15}$ Though these works are important efforts to reach beyond standard political-diplomatic narratives of Monfalcone's twentieth century, they tend to reveal more about the memory of events than historical events themselves.

\footnotetext{
13 Terzuolo, Red Adriatic, 83-90; Petacco, A Tragedy Revealed, 125-26; Foot, "Memories of an Exodus," 244-245.

${ }^{14}$ Galliano Fogar, L'antifascismo operaio monfalconese tra le due guerre (Milan: Vangelista, 1982); Troha, "La regione giulia fra Italia e Jugosalvia;" Chi avrà Trieste?; "L'Azione della Jugoslavia e delle forze filojugoslave."

${ }_{15}$ Marco Puppini (ed), Il mosaico giuliano: società e politica nella Venezia Giulia del secondo dopoguerra (19451954) (Gradisca d'Isonzo: CLG, 2003; Anna Di Gianantonio et al, L'immaginario imprigionato: dinamiche sociali, nuovi scenari politici e costrizione della memoria nel secondo dopoguerra monfalconese (Ronchi dei Legionari and Trieste: CCM and IRSML-FVG, 2005); Enrico Cernigoi, Scelte politiche e identità nazionale: ai confini orientali d'Italia dalla Resistenza alla guerra fredda (Udine: Gaspari, 2006).
} 
With this renewed focus on the Monfalconese, scholars have dedicated substantial attention to exploring the controesodo. From the first major publication, scholars have been interested in defining the contexts from which monfalconesi departed - the administrative, economic, and political conditions of the town - and especially the degree to which the departures were motivated by either economic necessity or an ideological commitment to "constructing socialism." 16 A notable shortcoming of this approach, however, was the failure to interrogate what "constructing socialism" or even "socialism" meant for monfalconesi. It was assumed that monfalconesi envisioned socialism through the same lens as the Yugoslav Communist Party that ruled their destination country - that of Marxism-Leninism. Though subsequent works have weighed in on the motivations for emigration, often bringing oral-historical methods to bear on the question and even situating this movement of people in a longer perspective that accounts for the town's antiFascist and left-wing credentials, they too have largely operated within the same framework. They fruitfully incorporated ordinary participants' voices in their narratives and highlighted additional motivating factors such as migrants' fear of reprisals for pro-Yugoslav activities and their exhaustion and disillusionment after years of fighting on behalf of Yugoslavia, but they also failed to interrogate the meaning of "socialism" for monfalconesi and its relationship to Fascist-era experiences. ${ }^{17}$ Moreover, no single study brought to bear the entirety of available archival evidence on the topic. Often left untouched were critical AMG holdings that lay across the Atlantic and Communist Party sources located in Slovenia. ${ }^{18}$

At the same time certain scholars were writing histories of monfalconesi departing to

\footnotetext{
${ }^{16}$ This is a critical tension that runs through the essays in Puppini (ed), Il mosaico giuliano. Representative of explanations involving the poles of "constructing socialism" and "economic necessity" are the essays by Puppini and Mellinato respectively.

${ }^{17}$ Andrea Berrini, Noi siamo la classe operaio: i duemila di Monfalcone (Milan: Baldani Castoldi Dalai, 2004); Di Gianantonio et al, L’immaginario imprigionato; Cernigoi, Scelte politiche e identità nazionale .

${ }^{18}$ An exception to this is Di Gianantonio et al, L'immaginario imprigionato, which uses some archival evidence, particularly from Slovenian archives, even if still relies primarily on oral testimonies.
} 
"construct socialism," others turned their attention to the disappointing experiences of monfalconesi once they arrived in Yugoslavia. Key to their studies was the critical Cominform Resolution of 1948, after which many monfalconesi, caught up in the Tito-Stalin Split, ended up in Tito's gulag on the island of Goli Otok, tormented by their former comrades for real or alleged "Cominformism."19 Perhaps because the end-point was suffering, the visions that drove monfalconesi to emigrate have not been considered by these scholars either. Thus, at present, the two dominant themes of the Italian-language literature on the controesodo are "constructing socialism" and "Goli Otok" - hope and suffering - though the latter looms larger in the picture. This is unfortunate, because, as Julia Mickenberg points out in her study of "American girls in Red Russia," the focus on disenchantment "clouds our ability to understand the enchantment itself: the real depth of interest, hope, and fascination" with the host country and the alternate world being imagined. ${ }^{20}$ In the case of the monfalconesi, it clouds not only the motivations for their departure - a useful avenue of inquiry in itself for understanding the Cold War - but also the complex origins of these motivations, particularly as they relate to the town's experiences with twenty years of Fascist dictatorship.

The study of monfalconesi's mid-century experience has the potential to contribute to several ongoing historiographical discussions, often with implications far beyond Venezia Giulia. First, it provides an opportunity to extend research on the relationship between political and ethnic identities in a borderland context. Recent research suggests that for many residents of the Julian borderland, which existed within the multiethnic space of the Habsburg Empire until the Great

\footnotetext{
${ }^{19}$ Mladen Plovanić, "O nekim zbivanjima u Rijeci vezanim uz objavljivanje Rezolucije Informbiroa 1948. Godine," Dometi 18, no. 11 (1985): 57-70; Alfredo Bonelli: Fra Stalin e Tito: cominformisti a Fiume, 1948-1956 (Trieste: IRSML-FVG, 1994); Giacomo Scotti, Goli Otok: Italiani nel gulag di Tito (Trieste: LINT, 2002). For a novel on the controesodo, see Claudio Magris, Alla cieca (Milan: Garzanti, 2005).

${ }^{20}$ Mickenberg, American Girls in Red Russia, 5.
} 
War and within the Italo-Yugoslav borderland thereafter, ethnic identity was situational and performative. Rather than possessing a single, immutable ethnic "identity," residents possessed a cross-cultural toolkit that allowed them to put forward a particular "identification" given prevailing circumstances. $^{21}$ Though this flexibility was not unlimited - the region's ethnic identities hardened somewhat in the late nineteenth century as a result of regional labor migration, ${ }^{22}$ the arrival of teachers and priests from Italy proper and the wider Habsburg Empire, ${ }^{23}$ the gradual partitioning of organizational life along ethnic lines, ${ }^{24}$ and the emergence of nationalist discourses among professional, intellectual, and (Italian) state $\operatorname{circles}^{25}$ - Habsburg imperial subjects developed complex loyalties in which civic loyalty to the crown often coexisted with "Italian," "Slavic," "Croatian," or "Slovenian" identities. ${ }^{26}$ Many even questioned the desirability of Wilsonian nationstates and ethno-national sovereignty, proposing alternatives in times of upheaval. ${ }^{27}$ An analysis of Monfalcone builds upon this line of research. With the addition of the Cold-War dynamic after 1945 and the absence of a fixed border - indeed, the opportunity to try to shift the border - each political action undertaken by a monfalconese reflected his or her prioritization of ethnic, political,

\footnotetext{
${ }^{21}$ Vanni D'Alessio, "Istrians, Identifications and the Habsburg Legacy: Perspectives on Identities in Istria," Acta Histriae 14, no. 1 (2006), 24-26. For example, economic elites of various backgrounds often adopted cultural Italianness, thus blurring the line between class and ethnic identities and giving class-based politics an ethnic inflection. Maura Hametz, Making Trieste Italian: 1918-1954 (Rochester, NY: Boydell Press, 2005), 112-24; Glenda Sluga, The Problem of Trieste and the Italo-Yugoslav Border: Difference, Identity, and Sovereignty in TwentiethCentury (Albany: State University of New York Press, 2001), 44.

${ }^{22}$ Silvano Benvenuti, "La nascità del cantiere di Monfalcone e le prime lotte operaie (1908-1910)," Il Territorio 4 (1980), 26-27.

${ }^{23}$ Vanni D'Alessio, "From Central Europe to the Northern Adriatic: Habsburg Citizens between Italians and Croats in Istria," Journal of Modern Italian Studies 13, no. 2 (2008): 247-250; Il cuore conteso: il nazionalismo in una comunità multietnica: l'Istria asburgica (Naples: Filema, 2003).

${ }^{24}$ D'Alessio, "From Central Europe to the Northern Adriatic," 250-253.

${ }^{25}$ Hametz, Making Trieste Italian, 106; D'Alessio, "From Central Europe to the Northern Adriatic," 247-50.

${ }^{26}$ For example, Hametz suggests that the nationalism that came to permeate professional and intellectual circles of Trieste was largely absent from the commercial elites, many of whom adopted a cultural Italianness, while still intermixing with other groups and seeing their economic interests as tied to Habsburg rule of Trieste. Hametz, Making Trieste Italian, 104-111; Sluga, The Problem of Trieste, 14, 18-20.

${ }^{27}$ Regarding the rejection of the Wilsonian conception of sovereignty, Sluga point out that in the immediate wake of the Great War, many Triestine socialists (both Italian and Slavic) sought the creation of an independent multinational Republic of Venezia Giulia or even Soviet Republic of Venezia Giulia. Ibid., 41-42.
} 
and other concerns. If the response of Trieste's residents to these strains have been well-examined, the responses of monfalconesi were different, shaped by the distinct composition of the town and the town's more direct path back to the Italian state. ${ }^{28}$

Second, the study of Monfalcone can shed light on Italy's complex experiences of Resistance and liberation from Fascism. Since Claudio Pavone's monumental Civil War (1991), historians have increasingly understood the Italian Resistance not only as a patriotic war against the German occupiers of 1943-45, but also a civil and class war that divided Italians among themselves. In an attempt to re-assert the value and morality of Resistance, Pavone focused on the subjective standpoint of the Resistance fighter - why he or she chose to fight and how he or she defined "just" violence, for example - rather than the activities of political parties in Resistance or the fighters' military failures and successes. ${ }^{29}$ This line of inquiry revealed profound differences between the political hopes of rank-and-file fighters and the strategically-devised political lines of parties positioning for postwar power. It acknowledged the gap between the Italian Communist Party (PCI) line and the hopes of many of the revolution-minded combatants in the Communistaffiliated Garibaldi Brigades, which led the PCI to work to reign in calls for revolution and "spontaneous leftism."30

Working within this framework, subsequent scholars have developed the notion of the "long liberation." They have suggested that Italy's liberation is best understood not as an event happening in late April of 1945, but rather as a process that continued to play out for years after the guns stopped firing, as different factions of the civil and class wars sought to realize their

\footnotetext{
${ }^{28}$ Monfalcone returned to Italy in 1947, Trieste in 1954.

${ }^{29}$ This intention is clear from the subtitle of the original Italian version: "a historical essay on morality in the Resistance." Claudio Pavone, A Civil War: A History of the Italian Resistance, ed. Stanislao Pugliese, trans. Peter Levey (London and New York: Verso, 2014), first published as Una guerra civile: saggio storico sulla moralità nella Resistenza (Turin: Bollati Boringhieri, 1991).

${ }^{30}$ Pavone, A Civil War, 182-183. See also 12, 418, 422-423, 431.
} 
understandings of justice and their desired transformations in the country. In the schema of Mirco Dondi, Italy passed from the spontaneous and cathartic killing of Fascists during the "insurrectional" period (April-May 1945) to a wave of "inertial violence" as the ambiguities and limits of transformation became apparent (spring-summer 1945), and finally to a period of "residual" class violence as Italian radicals, frustrated by the failures to purge Fascism from society, engaged in violence against the supposed class allies of Fascism in an effort to spark revolution (fall 1945-fall 1946). ${ }^{31}$ Related to the focus on the "long liberation" have been studies concerned with "Fascist continuities" across 1945, which most often focus on issues of limited punishment of Fascists by the courts and the continuity of state institutions and personnel - that is, on the perceived limits of transformation that in turn inspired acts of postwar violence. ${ }^{32}$

Though these studies have probed the choice to participate in armed Resistance, the morality of Resistance violence, and the reverberations of the Resistance in the postwar, they have certain shortcomings. On the one hand, the framework of overlapping patriotic, civil, and class wars does not fit neatly with the Julian borderlands, where, due to the proximity of Tito's Partisans, pro-Yugoslavism emerged as a uniquely Julian way of fighting the class war against the "armed bourgeoisie" and the civil war against native Fascists. ${ }^{33}$ Perhaps more importantly, existing studies have failed to sketch in concrete detail the specific, heterogenous, and unrealized visions for postFascist society held by rank-and-file participants, particularly those with ties to the Communist

\footnotetext{
${ }^{31}$ Mirco Dondi, La lunga liberazione: giustizia e violenza nel dopoguerra italiano (Rome: Editori riuniti, 1999), esp. 91. See also Sarah Morgan, Rappresaglie dopo la resistenza: l'eccidio di Schio tra guerra civile e guerra fredda (Milan: Paravia Bruno Mondadori Editori, 2002); Jonathan Dunnage (ed), After the War: Violence, Justice, Continuity and Renewal in Italian Society: Papers Given at the Contemporary History Conference 'After the War was Over', University of Sussex, July 1996 (Market Harborough, England: Troubador, 1999).

${ }^{32}$ For key works on Fascist continuities, see Claudio Pavone, Alle origini della repubblica: scritti su fascismo, antifascismo e continuità dello stato (Turin: Bollati Boringhieri, 1995); Angelo Michele Imbriani, Vento del sud: moderati, reazionari, qualunquisti, 1943-1948 (Bologna: Il Mulino, 1996); Dondi, La lunga liberazione; Dunnage (ed), After the War.

${ }^{33}$ Pavone touches on such distinctions in passing, never addressing the region systematically. Pavone, A Civil War, 187, 344, 408.
} 
partisan forces (garibaldini). Though Pavone hints at the ill-defined ways in which some partisans used the term "Communism," including usage that was more or less synonymous with "intransigently anti-Fascist," he did not pursue the implications of this ambiguity for the postwar. ${ }^{34}$ In light of this elision, it appears that studies focused on the continuity of state institutions and the acquittal of Fascist cardholders in postwar trials have missed a critical counterpart to objective continuities in personnel and institutions, namely continuities of experiences subjectively associated with Fascism, if not inherently or exclusively Fascist. A close study of Monfalcone can thus nuance and further develop the expansive literature on Italy's Resistance, Fascist continuities, and long liberation, providing a clearer picture of how ordinary Italians envisioned post-Fascist society and how giuliani experienced a distinct strain of "long liberation" that ended with many pursuing liberation with their feet.

Finally, the study of monfalconesi between Fascism and emigration contributes in two ways to debates about the nature and origins of the Cold War. First, it answers the call issued by Geoff Eley to explore the inchoate and unarticulated hopes that made the immediate postwar years so politically dynamic, as well as the suggestion of Martin Conway that historians pay greater attention popular aspirations as they existed outside the formal organizations of unions and "working-class" political parties. ${ }^{35}$ If Sarah Morgan is correct that Italy’s long liberation played out "between civil war and Cold War," then examining the Monfalconese experience affords a greater understanding not only of how ordinary Italians conceptualized the anti-Fascist struggle,

\footnotetext{
${ }^{34}$ See especially Pavone, Civil War, 446-447, 480-481. Pavone attributes this to a lack of available sources. Pavone, A Civil War, 382. Yet the lack of examination also appears to reflect a belief that all non-theoretical (esp. non-Marxist) visions of social transformation are inherently impotent. He writes that "the resistenti had the sentiment but not the theory of liberty" and that there was an "absence of economic, political and institutional planning, as if the vagueness of content was compensated for by the intensity of aspiration." Pavone, A Civil War, 690-693.

${ }^{35}$ Geoff Eley, "When Europe was New: Liberation and the Making of the Post-War Era," in The Lasting War: Society and Identity in Britain, France and Germany after 1945, eds. Monica Riera and Gavin Schaffer (New York: Palgrave Macmillan, 2008): 17-46; Martin Conway, "The Rise and Fall of Western Europe's Democratic Age, 1945-1973," Contemporary European History 13, no. 1 (2004): 73-74.
} 
but also of the complex relationship between anti-Fascism, Communist theoretical training, and support for the Communist powers as the world polarized into two camps. ${ }^{36}$ As historians increasingly write about the role of (typically) state-directed cultural production in the "cultural Cold War" ${ }^{\prime 37}$ and the ways in which the Soviet Union generated a mythical self-representation through the hosting of foreign intellectuals, politicians, and other important figures, ${ }^{38}$ the study of the monfalconesi returns the focus to unorganized, ordinary people and their understanding of the struggle. As participants in the struggle who quite deliberately chose to pursue life in Communist Yugoslavia, a close examination of their aspirations affords an opportunity to explain how such ordinary people viewed the Communist world in 1945 - including the distinctions they drew (if any) between the countries that composed the Communist world - before they possessed the benefit of hindsight. ${ }^{39}$ A study of the motivations of monfalconesi illuminates the degree to which the myth-making around the Communist world bore fruit, under which circumstances and after which experiences people found official cultural production compelling, and the centrality (or not) of Communist ideology to the ways in which ordinary people lined up in the struggle.

A focus on the Monfalconese migration can also contribute to the decades-long debate on the origins of the Cold War, which, through successive stages of orthodoxy, revisionism, and post-

\footnotetext{
${ }^{36}$ Morgan, Rappresaglie dopo la Resistenza. This is part of the subtitle of the book.

${ }^{37}$ John Lewis Gaddis, The Cold War: A New History (New York: Penguin Press, 2005); Reinhold Wagnleitner, CocaColonization and the Cold War: The Cultural Mission of the United States in Austria after the Second World War (Chapel Hill: University of North Carolina Press, 1994); Jessica Gienow-Hecht, Transmission Impossible: American Journalism as Cultural Diplomacy in Postwar Germany, 1945-1955 (Baton Rouge: Louisiana State University Press, 1999); Laura Belmonte, Selling the American Way: U.S. Propaganda and the Cold War (Philadelphia: University of Pennsylvania Press, 2008).

${ }^{38}$ Many studies deal primarily with myth-making efforts during the interwar years, but the myths they describe carried over (with additions) into the postwar period. Paul Hollander, Political Pilgrims: Travels of Western Intellectuals to the Soviet Union, China, and Cuba, 1928-1978 (New York: Oxford University Press, 1981); Ludmilla Stern, Western Intellectuals and the Soviet Union, 1920-40: From Red Square to the Left Bank (London and New York: Routledge, 2006); Michael David-Fox, Showcasing the Great Experiment: Cultural Diplomacy and Western Visitors to the Soviet Union, 1921-1941 (Oxford and New York: Oxford University Press, 2012); Tony Judt, Past Imperfect: French Intellectuals, 1944-1956 (New York: New York University Press, 2011).

${ }^{39}$ In this, Mickenberg has set a useful precedent with her study of American women who relocated to the Soviet Union during the interwar years. Mickenberg, American Girls in Red Russia.
} 
revisionism, has consistently focused on the policymakers at the centers of power at the expense of considering the impact of ordinary people on the ground. ${ }^{40}$ In these debates - and particularly the early stages - focus was squarely on Washington and Moscow, with the Cold War understood as a conflict that was imposed upon Europe from without by the two superpowers, which bore varying degrees of fault. In the past four decades, and especially after the Cold War's end, historians have increasingly shifted away from the bipolar imposition model and from what Federico Romero, drawing upon a phrase of Odd Arne Westad, has called a "'relentlessly UScentered' reductionism." ${ }^{41}$ Instead, they have taken a more multilateral approaching, granting power to various European and extra-European nations to influence the conflict and even manipulate it to their own ends. The historiography of Italy in the Cold War has been no exception. ${ }^{42}$ Notable work highlighted Italy as a crucial early battleground, particularly in the leadup to the first postwar election in 1948, stressing both the genuine fears within some US circles that the election would end in civil war and the ability of Alcide De Gasperi and Italian Christian Democracy to instrumentalize these fears for party gain. ${ }^{43}$ Subsequent work even made the compelling case that it was in Italy in 1947-48 that the United States developed the methods and structures of "political warfare" that would define US policy for the rest of that conflict, its selfattributed successes in stopping a Communist accession to power in Italy justifying containment and turning the US into "a legend in its own mind." 44 This new historiography of Italy in the Cold

\footnotetext{
${ }^{40}$ For historiographical essays summarizing these stages of debate, see John Lewis Gaddis, "The Emerging PostRevisionist Synthesis on the Origins of the Cold War," Diplomatic History 7, no. 3 (1983): 171-190; and Timothy White, "Cold War Historiography: New Evidence Behind Traditional Typographies," International Social Science Review 75, no. 3/4 (2000): 35-46.

${ }^{41}$ Federico Romero, "Cold War Historiography at the Crossroads," Cold War History 14, no. 4 (2014): 691-692.

42 Antonio Varsori, "Cold War History in Italy," Cold War History 8, no. 2 (2008): 157-187.

${ }^{43}$ Agarossi and Zaslavsky, Stalin and Togliatti. Giampaolo Valdevit's study of the significance of the "Trieste Question" to the origins of the Cold War is within this same vein. Valdevit, La questione di Trieste.

${ }^{44}$ Kaetan Mistry, "The Case for Political Warfare: Strategy, Organization and US Involvement in the 1948 Italian Election," Cold War History 6, no. 3 (2006): 316.
} 
War shifted the focus of Cold War origins southward, away from Germany, where the Berlin crisis of 1948-49 was (and to a degree still is) often defined as the moment the Cold War crystallized into an enduring conflict. ${ }^{45}$ Still, their analyses remained in the realm of high politics, the subjects being diplomats, politicians, and military leaders.

A focus upon the Monfalconese migration both reinforces the critical role of Italy in global Cold War polarization and affords new perspectives on the range and type of actors critical to that process. Historians have little acknowledged the common man or woman as an actor capable of having a causative role in the origins story of the Cold War, and the Monfalconese migration is no exception. Because Italy's Cold War studies programs are so steeped in the national tradition of the "history of treaties," there remains a disconnect between regional histories of the controesodo and national histories of Italy in the Cold War. ${ }^{46}$ The former, due to their regionalist perspective and privileging of oral over archival sources, treat the phenomenon as something occurring within the Cold War, but having no bearing upon the Cold War. The latter overlook the controesodo altogether. I seek to bridge this gap and elucidate the connections between the Monfalconese migration and Cold War polarization on a national and even global scale - to show the monfalconesi's role in the definition of what Romero calls the "structure and grammar" of the Cold War. ${ }^{47}$ To do so requires a methodological approach distinct from those that have previously been applied to the controesodo.

\footnotetext{
${ }^{45}$ Ernest May, “America's Berlin: Heart of the Cold War," Foreign Affairs 77, no. 4 (1998): 148-160; Paul Steege, Black Market, Cold War: Everyday Life in Berlin, 1946-1949 (Cambridge: Cambridge University Press, 2009), 7-12.

${ }^{46}$ Varsori, "Cold War History in Italy."

${ }^{47}$ Romero, "Cold War Historiography," 697.
} 


\section{New Methods and New Findings}

In telling the story of the monfalconesi between Fascism and Cold War, I draw on the two methodological schools of Italian microhistory (microstoria) and German everyday history (Alltagsgeschichte). Whereas microhistory restricts the scope of analysis to generate new understandings about relations, processes, and phenomena that are impossible to detect at a higher plane, everyday history seeks to understand how structures and transformations of global importance are constituted within the processes and spaces of everyday life. ${ }^{48}$ As Alf Lüdtke, the pioneer of everyday history suggests, everyday history seeks to avoid "rais[ing] fundamental secular changes to a level detached from human agents, occurring behind their backs, as it were," and instead to "demonstrate how social impositions or stimuli are perceived and processed as interests and needs, anxieties and hopes; indeed, how they are generated in the very process." ${ }^{49}$ In doing so, it restores autonomy and potency to the activity of "ordinary people."

Though studies applying this methodological combination to Fascist-era and postwar Italy have been scarce, ${ }^{50}$ historians of the Cold War Germanies have applied it to great effect, transcending the "imposition" and high-political approaches to Cold War origins and showing the centrality of everyday concerns to peoples' strategies of navigating the first postwar years. Paul

\footnotetext{
${ }^{48}$ Microhistory, which emerged first in Italy, is thus distinct from local history or "case study" history, in that it seeks to do more than just "flesh out" the unfolding of historical processes that can already be detected when beginning one's analysis on a higher plane. Two great examples are Carlo Ginzburg, The Cheese and the Worms: The Cosmos of a Sixteenth-Century Miller, trans. John and Anne Tedeschi (New York: Penguin Books, 1980); and Giovanni Levi, Inheriting Power: The Story of an Exorcist, trans. Lydia G. Cochrane (Chicago: University of Chicago Press, 1988). On everyday history see Alf Lüdtke (ed), The History of Everyday Life: Reconstructing Historical Experiences and Ways of Life, trans. William Templer (Princeton: Princeton University Press, 1995). Both emerged in the late 1980s as a rejection of rigidly structural social history and institutionally-focused labor history.

${ }^{49}$ Lüdtke, "Introduction," in The History of Everyday Life, ed. Lüdtke, op. cit., 5-7. Like the Italian microhistorians, Lüdtke believed it essential for historians of everyday life to delimit the scope of analysis to see sufficient detail to achieve their ends. Ibid., 20.

${ }^{50}$ Few historians have applied everyday historical methods to the contexts of Fascist Italy. Two exceptions are Kate Ferris, Everyday Life in Fascist Venice, 1929-40 (London: Palgrave Macmillan, 2012); Joshua Arthurs, Michael Ebner, and Kate Ferris (eds), The Politics of Everyday Life in Fascist Italy: Outside the State? (New York: Palgrave Macmillan, 2017).
} 
Steege's work on Cold War Berlin, for example, has suggested that ordinary Berliners played a key role in transforming that contested city into one of the first Cold War battlefields, particularly when they routed the SED from municipal power in 1946 - two years before the critical blockade - largely because the Soviet-aligned party proposed to revise the supply and rationing system in a way that defied popular aspirations. ${ }^{51}$ Similar disciples of everyday history have stressed the critical role of East and West Germans in pushing forward the creation of the intra-German Iron Curtain, largely as a response to everyday concerns as mundane as distaste for cross-border beggars. ${ }^{52}$ Such studies reveal the tremendous potential of everyday history and microhistory to improve our understanding of how the Cold War came to be as it was.

From these studies and from the work of a second generation of largely American everyday historians, I borrow key methodological practices, among them a strong emphasis on serial experiences and actions taking place in specific places of quotidian life. By focusing on repeated actions in such places - here the factory workshop and the marketplace - the everyday historian shows how the individual constructs structure and meaning on a wider level, the mundane and unexceptional often playing a key role. This focus allows the everyday historian to "integrate the micro and the macro, cause and consequence," and thus to interrogate "the very distinction between our analytic categories of micro- and macrohistory, structure and agency." ${ }^{53}$ To capture the combination of serial interaction and archetypicality that characterize the spaces so fruitful investigated by the everyday historian, I use the term "lived spaces."

\footnotetext{
${ }^{51}$ In particular, the SED promised to root out black market activity and expand the rationing system. By contrast, Berliners who had come to rely on the black market for their own survival feared that the disciplining of illicit exchange activity would leave them worse off than before. Steege, Black Market, Cold War.

${ }^{52}$ Edith Sheffer, Burned Bridge: How East and West Germans Made the Iron Curtain (New York: Oxford University Press, 2011); Sagi Schaefer, States of Division: Border and Boundary Formation in Cold War Rural Germany (Oxford and New York: Oxford University Press, 2014).

${ }^{53}$ Paul Steege et al, "The History of Everyday Life: A Second Chapter," The Journal of Modern History 80, no. 2 (2008): 361-362, 366-367.
} 
A focus on "lived spaces" affords the opportunity to examine not only how ordinary people participated in the constitution of key social and economic structures that shaped their world, but also the key mental structures and ideologies through which they understood the world around them. As recent everyday histories have shown, it was in spaces like marketplaces that twentiethcentury Europeans often conceptualized and defined the limits of "community." In fact, if communities such as nations are "imagined," then it is in lived spaces like the marketplace that "imagined communities are constituted-or dismantled." ${ }^{54}$ It follows that encounters between individuals in lived spaces are not just (or not always just) encounters between individuals. Rather they are encounters during which participants bump up against and perceive the structures, systems, and groups that bind them, mediated by interaction with specific individuals. Such encounters are thus opportunities for the generation of social imaginaries based on the perception of grievance and antagonism, or cooperation and harmony. In this process, individuals come to contemplate and define justice and injustice, as well as the desirability of the inclusion and exclusion of particular social categories in society. And in conceptualizing justice versus injustice, inclusion versus exclusion, they posit a reshaping of the world and formulate new social imaginaries and political ideologies.

In the specific case of Fascist-era and postwar Monfalcone, this approach affords the opportunity to better understand how ordinary monfalconesi thought about the rather ambiguous term "Fascism," understood not just as a political party or state, but also as a constellation of individuals with whom the subject has repeated social interaction and the sum of these serial

\footnotetext{
${ }^{54}$ Ibid., 364. Benedict Anderson, Imagined Communities: Reflections on the Origin and Spread of Nationalism (London and New York: Verso, 1991). For a work that demonstrates the impact of marketplace interactions on the formation of national identities and antipathies, see Maureen Healy, Vienna and the Fall of the Habsburg Empire: Total War and Everyday Life in World War I (Cambridge and New York: Cambridge University Press, 2004).
} 
experiences. ${ }^{55}$ It affords a better understanding of the complex ways in which monfalconesi perceived and attributed culpability for the regime and the ways in which they reacted to the persistent physical presence of individuals who served as mental stand-ins for the wider system of "Fascism" both during the Resistance and after war's end. ${ }^{56}$ Moreover, it enables an exploration of the continuities between Fascism and postwar that goes beyond a focus on Fascist cardholders and instead focuses on continuities of subjective experience. These mental processes and experiential continuities were inextricably bound to how monfalconesi thought of "socialism" and how they engaged in politics from Resistance through emigration.

A central difficulty in implementing this method in the study of Monfalcone is finding sources. This is difficult not only because ordinary monfalconesi lived their lives without regard for the future historian's needs, but also because the town changed hands five times during the period under study, scattering the existing source material throughout several different countries. Extant sources fall into three basic categories. First, press sources form a particularly important font for this study. Articles in the Triestine Communist daily Il Lavoratore indicate the rhetorical strategies by which the regional Communist Party attempted to win over monfalconesi.

Second, ego documents - those letters, testimonies, journals, and other sources in which the narrator's subjective "I" comes through clearly - reveal monfalconesi's subjective experiences of everyday Fascism. Though these documents provide the clearest picture of how monfalconesi

\footnotetext{
55 The approach thus builds upon Pavone's work and responds to his suggestion that historians examine "the physiognomy of the Fascist as seen by the factory" and the "meaning that the workers attributed to the word fascista." It explores how the term "Fascist" "acquired, with particular intensity, a meaning that went beyond the concrete and specific historical experience of Fascism, eventually coming to denote a kind of human being with negative connotations from every public and private point of view." Pavone, A Civil War, 313-314, 420-21.

${ }^{56}$ Steege has emphasized the importance of continuity to great effect. Steege, Black Market, Cold War, 12-13. For discussions of postwar ideas of collective guilt and the significance of physical presence of those perceived to be culpable of offenses (in this case in the context of wartime occupation rather than native dictatorship), see István Deák, "Introduction," in The Politics of Retribution in Europe: World War II and Its Aftermath, eds. István Deák, Jan Gross, and Tony Judt, 3-14 (Princeton: Princeton University Press, 2000), esp. 6; and Martin Conway, "Justice in Postwar Belgium: Popular Passions and Political Realities," in The Politics of Retribution, op. cit. 133-156, esp. 142-44.
} 
understood Fascism, they are regrettably few in number. The single largest holding of pertinent ego-documents comes from a series of interviews collected by the Italian Communist functionary Alfredo Bonelli. ${ }^{57}$ These interviews, undertaken in the late 1970s and early 1980s and held at the IRSML-FVG, are far from contemporaneous indications of monfalconesi's perception, and they run the risk of distorting the past given that Bonelli's purpose was to compile information about the Titoist persecution of Italians in Yugoslavia after the Cominform Resolution. Nevertheless, by rooting the subjective perspectives presented in such interviews within the verifiable everyday conditions of life as revealed in contemporaneous documentary sources, it is possible to limit distortions and to understand the controesodo on the participants' own terms.

The final and most voluminous category of sources are traditional archival documents. These records, drawn from twelve archives across the United States, Italy, and Slovenia, fall into four subcategories: (1) local administrative reports from the Fascist era and the period of AngloAmerican military occupation; (2) district-level and workshop-level reports by the region's Communist Parties, both during the Italian period and the years of Yugoslav organizational domination from 1944 to 1947; (3) central state reports from Italy's police and diplomatic offices and from the Allied occupation forces and intelligence services; and (4) the provincial police's individual surveillance files on migrants for the year $1948 .{ }^{58}$ The first two subcategories enable the reconstruction of both the living conditions and actions of monfalconesi down to the level of minutia. The last two are essential for uncovering the interrelation between the actions of monfalconesi and those of actors in the halls of power, while the final category also enables the reconstruction of migrants' social and familial networks to an unprecedented degree.

\footnotetext{
${ }^{57}$ IRSML, Fondo Cominform, b 99.

${ }^{58}$ I received exceptional access from Italy's Interior Ministry to view the files from 1948 but have not accessed files for subsequent years. ASG, Questura 1948.
} 
Yet even with this array of sources, the problem persists that there are not sufficient egodocuments to support a microanalytical everyday history of Monfalcone in and of themselves. As a result, I have had to read archival documents for veiled "ego" indications. Particularly fruitful have been local Communist Party reports, which have survived with remarkable thoroughness. ${ }^{59}$ Most often written by workers with limited political training, these sources can themselves to some degree reveal the subjective perspective of the Monfalconese worker. More significantly, a reader who ascends to district-level report finds repeated reference to instances of worker "errors," "deviations," and other transgressions, in which the author describes in detail the action or discussions that provoked criticism. In these misunderstandings and disagreements, the "ego" of Monfalconese worker shows through. Even if filtered through the writing of the critical comrade, such moments afford contemporaneous evidence of monfalconesi's subjectivity, enabling an analysis of how monfalconesi thought of Fascism, socialism, and events unfolding around them. ${ }^{60}$

What becomes clear from reading sources in this way is that the pro-Yugoslav struggle and the subsequent Monfalconese migration were above all motivated by a desire to escape "everyday" Fascism in the postwar era. Part one of this two-part study examines the processes by which this hope emerged and its impact on Monfalcone before the period of mass departures. The first three chapters trace the formation of monfalconesi hopes for postwar society during the Fascist era period and their coalescence into a Monfalconese conception of socialism. Chapter one focuses on the Fascist years. It examines how Fascism and Fascists imbricated themselves in Monfalconese society and how this led workers to conceptualize certain social categories - particularly the

\footnotetext{
59 These are held in AS 1570.

60 This parallels the approach of Italian microhistorians, who necessarily study the "rebels, heretics, and criminals" who, by nature of their challenge to authorities, are the most likely to leave behind documentary traces. Edward Muir, "Introduction: Observing Trifles," in Microhistory and the Lost Peoples of Europe, edited by Edward Muir and Guido Ruggiero, trans. Eren Branch (Baltimore: Johns Hopkins University Press, 1991), xiv.
} 
shopkeeper and piecework clerk - as fundamentally unredeemable and quintessentially "Fascist," regardless of an individual's actual politics. Chapter two elucidates how this experiential baggage informed the actions of monfalconesi during the last two years of the Second World War, during which the fall of Mussolini, the descent of Italy into civil war, and Yugoslav annexationist ambitions presented monfalconesi with a wide range of opportunities to envision post-Fascist society and to pursue radical transformation. It traces the emergence of a local pro-Yugoslav faction tied closely to the Communist Resistance and the abortive efforts to remake society during the month of Yugoslav rule that followed Axis defeat but preceded the establishment of AngloAmerican military governance. Set during the period of Anglo-American occupation, the third chapter details the coalescence of a "myth of Yugoslavia" that sustained Monfalcone's proYugoslav movement by mobilizing popular frustrations with everyday Fascism and casting Tito's Yugoslavia as a foil to stagnant Monfalcone.

The final two chapters of part one turn to the postwar territorial struggle in Monfalcone. They trace the rise and then defeat of a pro-Yugoslav faction whose members were above all concerned with purging local society of "everyday" Fascism, but for whom Yugoslav annexation seemed the easiest path toward that end. Chapter four examines monfalconesi's concrete and often mutually irreconcilable efforts simultaneously to remake local society in the first year of Allied occupation and to advocate for Yugoslav annexation. It suggests that much of the pro-Yugoslav fervor resulted from the AMG's inability or unwillingness to address monfalconesi's grievances about everyday Fascism in the marketplace and workplace, which fueled accusations that the AMG was allowing or even encouraging the persistence of Fascism. The pro-Yugoslav push climaxed in the summer of 1946 with a failed general strike, after which the movement fell into disarray and disillusionment. Chapter five traces the denouement that followed this defeat and subsequent news 
in late 1946 that Monfalcone would return to Italy. It suggests that, as the pro-Yugoslav movement dissolved and the hopes for radical local transformation disappeared, monfalconesi began to look for a way out - a way to liberate themselves from everyday Fascism by other means.

Many found emigration to be the only path forward. Part two turns concretely to the controesodo, viewing it as just one outcome of a long battle over the nature of postwar Monfalcone. Chapter six details the controesodo as a multi-staged phenomenon. It pays special attention to how and why monfalconesi made their choices to depart and interrogates the relationship between "political" and "apolitical" migration. Chapter seven then examines the experiences of Monfalconese migrants once they arrived in Yugoslavia. It suggests that, as Yugoslavia lurched toward its socialist transition under Communist Party guidance, state policy generated market- and workplace hardships that not only clashed with monfalconesi's hopes for socialism, but also replicated their idea of "everyday" Fascism. This drove a trickle of monfalconesi to return home after just a short stay, which became a flood following the Tito-Stalin Split of 1948. Yet in returning home, monfalconesi played an important role in polarizing Italian politics into Cold War camps, and the final chapter explores the impact of monfalconesi on the Cold War. The mobility of ordinary monfalconesi was misconstrued as part of a global Communist plot to prepare for armed Communist takeovers in Greece and Italy, which spurred political polarization in Italy, helped Italian anti-Communists pull Italy under the US containment umbrella, and drove the Italian state to begin constructing a rigid bordering apparatus on its eastern border - an Italian Iron Curtain - in an effort to pen perceived Communists within the West.

Because I aim to conduct an intense microstudy of Monfalcone's pro-Yugoslav population, there are two limitations in scope of which readers should be aware from the outset. First, not all monfalconesi and not all parts of Monfalcone's political spectrum receive equal space and 
consideration. I have written a necessarily subjective history. I give preference to the perspective of one subset of the population, albeit a large one. Second, I make no claim that the findings of this microhistorical study apply universally to all other areas of Italy, let alone to Europe more broadly. As the literature on "border Fascism" (fascismo di confine) suggests, Fascism took on a unique inflection in Italy's northeastern borderlands, which in turn shaped how it manifested itself in everyday life. ${ }^{61}$ Given variations in economic, social, political, and historical conditions across the peninsula, this means that much of the Monfalconese experience may be area-specific.

Even if that is the case, this dissertation traces a process of ideological formation and of coming to terms with dictatorship that likely occurred elsewhere, if reflecting local specificities. This process is an important one for understanding how ordinary people lived and acted through the twentieth century, and the project suggests that historians must readjust or replace the lenses through which they have traditionally viewed key historical moments. It suggests the need to rethink the meaning of "Fascist continuities" that persisted across 1945 and to consider such continuities from a subjective as well as objective standpoint. It also suggests a need to decenter narratives of the early Cold War in more than one respect. From an ideological perspective, greater attention must be paid to the diversity of political thought even within the portion of the population that aligned itself with the Soviet Union and its allies. In Monfalcone, Marxism-Leninism (or Marxism more generally) played only a minor role in the ordinary person's thinking about socialism during the first postwar years. The Monfalconese "encounter" with Marxist-Leninist Yugoslavia and even with those few native militants well-versed in official theory resembles the encounter of various Third-World socialists with Marxist-Leninist states during the postwar years, as when Tanzanian exchange students trained in the African socialist tradition of ujamaa arrived

\footnotetext{
${ }^{61}$ Annamaria Vinci, Sentinelle della patria: il fascismo al confine orientale: 1918-1941 (Rome: Laterza, 2011).
} 
in the DDR, wrestling with the contradictions between their own beliefs and the scientific socialism of the host country. ${ }^{62}$

Beyond ideological decentering, the story of the Monfalconese migration helps decenter narratives of Cold War origins from the geographical and social perspective. As the Monfalconese case makes clear, ordinary people had tremendous power to affect actors in the central halls of power, particularly if they resided at the peripheries of the state. Far from being imposed upon ordinary people such as monfalconesi, the Cold War was just as much provoked by them. The mobility of monfalconesi and the consequences of this mobility suggests that greater emphasis must be placed on the Mediterranean theater of the early Cold War as a point of tension and escalation. The movement of unruly monfalconesi played no small contribution to the emergence and spread in Italy and other Western countries of the notion of fundamental interconnectedness of the Mediterranean countries' fates and thus too of the need for universal containment.

But before the monfalconesi like Silvio and Marcelliano made their migration and did their part to usher in the Cold War order, they first passed through twenty years of Fascism. It was during these years that the seeds were planted for their eventual choice to side with Tito.

\footnotetext{
${ }^{62}$ Eric Burton, "Navigating Global Socialism: Tanzanian Students in and beyond East Germany," Cold War History (2018), DOI: 10.1080/14682745.2018.1485146 (online).
} 
Part I: Monfalcone on the Border 


\section{Chapter 1: Fascism and Its Discontents}

The shipyard is like a sun that shines light on the entire zone. In large part, the entire zone depends politically on the life of the shipyard. ${ }^{1}$

- "Lorenzo," Communist militant in Monfalcone’s anti-Fascist Resistance, 1943.

On the afternoon of 19 September 1938, Benito Mussolini climbed a platform bedecked with fasces and Italian tricolors to face a crowd of over ten-thousand workers and deliver a speech that glorified labor and reinforced the notion that workers were contributing to Fascism's historic mission of restoring Italy to its rightful place on the world stage. Though the content of this speech may not have been noteworthy, the location certainly was. The Duce delivered his speech at one of Italy's largest industrial sites and one of the most important for his regime's ongoing war preparations: the Monfalcone shipyard and aeronautical works. The workers had recently finished setting the keels of two new submarines, and Mussolini had arrived to laud their contribution to bolstering Italy's martial power in the skies and the sea. ${ }^{2}$ Fittingly, then, the platform from which he spoke consisted of an airplane body fused with the conning tower of a submarine (Figure 1). Yet more striking than the content or reception of the speech is the contrast between the setting of this Fascist spectacle and the qualities of this same space as recently as the turn of the twentieth century. Just three decades before, the space had been untamed coastal plain on the outskirts of an insignificant fishing village founded by the Romans in the era of the Republic. By 1938, however, after three decades of industrialization, this formerly forgettable settlement had become the social, political, and industrial hub of a new territorial unit stretching from the Isonzo River in the west to the Timavo River in the east, to which it gave the name the Municipality of Monfalcone, or "Monfalconese" (Figure 2), and Mussolini believed the Monfalconese to be worthy of a visit.

\footnotetext{
1 “Lorenzo," “Oservazioni” [sic], December 1943, APC-IG, Fondo PCI Direzione Nord, FVG-Jug., f 2.

${ }^{2}$ Benito Mussolini, Opera Omnia, vol. 29, eds. Edoardo and Duilio Susmel (Florence: La Fenice, 1959 ), 149.
} 
With industrialization came major social transformation and the transformation of the Monfalconese into a stronghold of left-wing radicalism, which, though superficially contained by thirteen years of Fascist dictatorship, continued to simmer beneath the surface even at the time of Mussolini's visit. In the years following Mussolini's speech, these simmering tensions would erupt, unleashing resentments built up over the eighteen years between the foundation of Monfalconese Fascism and the Duce's visit to the shipyard. Wartime mobilization, foreign occupation, and bitter civil war would shape popular expectations for postwar society. To understand the hopes of monfalconesi in the postwar years, it is necessary to understand the formative years of the municipality and the way that Fascism functioned in local society. These decades were ones of repeated social, economic, and political convulsions, and, as the anonymous anti-Fascist militant "Lorenzo" made clear, at the heart of it all was the shipyard.

\section{The Late Habsburg Years and the Birth of the Cantiere Navale Triestino (CNT)}

The Monfalconese municipality was born in the early twentieth century due to a combination of geographical fortune and historical circumstance. Geographically, Monfalcone is situated in the narrow strip of flat land between the Adriatic Sea and the pre-Alpine limestone plateau known as the Carso. It thus sits along the easiest land route for transit between cities like Venice and Udine to its west and Trieste to its southeast. As such, it became a vital transit node as the Habsburgs, then the rulers of much of Venezia Giulia, connected these cities by rail in the second half of the nineteenth century. With such infrastructural projects, Monfalcone was integrated into the regional economy at the precise historical moment at which steam power was

turning naval technology on its head, causing a transportation revolution and a scramble by 
European states to outfit their navies with ever-larger warships. ${ }^{3}$ The Habsburgs and their subjects were no exceptions to these trends and, thanks to the activity of major shipping firms like that of the Cosulich brothers, the major Habsburg port of Trieste boomed, becoming one of the world's most active and splendorous port cities. ${ }^{4}$ In this context, the monarchy's interest in expanding its naval and maritime capacity and the self-interest of the Cosuliches converged. The latter, utilizing Habsburg subsidies for new shipbuilding ventures, decided to take a step toward vertical integration, founding the Triestine Naval Shipyards (Cantiere Navale Triestino, CNT) in $1908 .{ }^{5}$

Despite being headquartered in Trieste, the CNT chose Monfalcone as the site of its new shipyard, as it was well-connected by rail but not yet a major urban area. At that time, the nearby area consisted of two relatively distinct parts. The largest settlement was Monfalcone, abutting the Adriatic Sea, which was surrounded to the northwest by an inner arc of smaller communes that included Ronchi dei Legionari and Staranzano, as well as their hamlets (frazioni) of Selz, Vermegliano, Dobbia, and Begliano. This area had begun the first steps of light industrialization but was also reliant on fishing and artisanal activities. Surrounding these central settlements was a distinct outer arc of agro-artisanal villages, which, excepting landlocked Doberdò del Lago, followed the southwesterly flow of the Isonzo River from the Alps to the Adriatic Sea and included Sagrado, Fogliano-Redipuglia, San Pier d'Isonzo, Turriaco, Pieris, and San Canzian d'Isonzo. ${ }^{6}$

\footnotetext{
${ }^{3}$ The South Austrian Railway (1865) connected Udine to Trieste by way of Monfalcone. By 1894, an additional line connected Monfalcone to Venice. Gualtiero Pin and Edino Valcovich, "Il quartiere di Panzano e le condizioni socioeconomiche del territorio (1850-1913)," Il Territorio 2 (1979): 88.

${ }^{4}$ The Cosulich family was from the island of Lussino, or Lošinj, formerly a Venetian trading post and now belonging to Croatia. In the late nineteenth and early twentieth centuries, the Cosuliches were involved in global passenger shipping. For a history of the Cosulich, see Giulio Mellinato, Cosulich: dinastia adristica (Milan: Cinisello Balsamo, 2008).

${ }^{5}$ On the formation of the CNT and its relationship to the wider commercial economy of the region, see Benvenuti, "La nascità del cantiere," 23-30; Paolo Fragiacomo, La grande fabbrica, la piccola città: Monfalcone e il cantiere navale: la nascità di una company town 1860-1940 (Milan: Angeli, 1997), esp. chs 3-4; Giulio Mellinato, Crescita senza sviluppo: l'economia marittima della Venezia Giulia tra impero asburgico ed autarchia, 1914-1936 (Ronchi dei Legionari: CCM, 2001).

${ }^{6}$ Pin and Valcovich, "Il quartiere di Panzano e le condizioni socio-economiche del territorio," 85-92; Benvenuti, "La nascità del cantiere;" Fogar, L'antifascismo operaio monfalconese, 10.
} 
In the final years before the Great War, the new shipyard expanded rapidly, as did the population of the Monfalconese's inner arc of communes. In a six-year period, the population of Monfalcone nearly tripled, rising from roughly 5000 (1907) to some 14,000 (1913) and bringing with it clear social strains and political transformation. At first, much of the growth was not centered in historic Monfalcone itself, but rather in the nearby factory-town of Panzano, created according to "garden city" norms with the dual paternalistic purposes of controlling the workforce and assuring a career-long commitment from skilled workers (Figure 3). Within a few years, however, the new Viale San Marco connected Monfalcone and Panzano and the two slowly fused. ${ }^{7}$ With the creation of the new shipyard and the growth of both Monfalcone and Panzano, the Monfalconese began to form as an industrial center, the local social fabric woven increasingly in accordance with the shipyard's demands. The Cosuliches hired skilled workers from the shipyards of nearby Trieste and Muggia and drew in both Slovenian-speaking artisans of the nearby Carso and Italian-speaking artisans from the villages on the nearby plains. Moreover, the shipyard dragged even the outlying villages through this transformation, as agrarian families even those from the communes right along the Isonzo River - increasingly responded to rent crises and land shortages by sending their sons to work in the shipyard. To these locals, management added skilled workers and technicians from England and from the Habsburgs' Germanic and Bohemian lands, as well as unskilled laborers from the Italian Mezzogiorno. ${ }^{8}$ By 1914 , the CNT employed 2500 workers and a truly multiethnic workforce was in embryo. ${ }^{9}$ Joining it were smaller,

\footnotetext{
${ }^{7}$ Benvenuti, "La nascità del cantiere;" Enrico Cernigoi, Marco Puppini, and Sergio Valcovich (eds), Cento anni di cantiere: un secolo di storia di emancipazione umana e sociale al cantiere navale di Monfalcone (Rome: Ediesse, 2010), ch. 1; Pin and Valcovich, "Il quartiere di Panzano (1908-1912). I primi edifice per la residenza," Il Territorio 3 (1979): 73-82 and "Il quartiere di Panzano: La seconda fase costruttiva (1913-1921)," Il Territorio 5 (1980): 65-80. ${ }^{8}$ Silvano Benvenuti, "La nascità del cantiere," 26-27; and "Il cantiere di Monfalcone: Gli anni dello sviluppo: 19111914. Aspetti generali," Il Territorio 5 (1980), 20. The importation of Italian (and especially Southern Italian) labor had been ongoing in Trieste since the 1880s. Hametz, Making Trieste Italian, 108-11.

${ }^{9}$ Fogar, L'antifascismo operaio monfalconese, 10. On the formation of the proletariat in Panzano, see Silvia Fragiacomo, “"Allora il mondo finiva a Panzano': la memoria del quartiere in una ricerca di sociologia," Il Territorio
} 
but not insignificant workforces in other ventures, primarily the Adria Werke chemical plant (later Solvay), the Luzzatto vegetable oil plant, the Cotonificio Triestino cotton mill, and the Ditte Passero, a plant for the manufacture of food tins. ${ }^{10}$

With industrialization and the influx of workers from England, Italy, and the Habsburgs lands there arrived in the Monfalconese a host of new political ideas and the first stirrings of labor agitation. Unskilled workers tended to embrace anarchism and quickly adopted spontaneous striking. The shipyard's first political strike, in October 1909, came in protest of the execution of the anarchist Francisco Ferrer in Spain. By contrast, skilled workers - especially the metallurgical group headed by Giovanni Fontanot of Muggia - tended to prefer socialism and a strategy of cautious bargaining, befitting their indispensability to the firm and their greater social and organizational coherence. Though the socialists launched a campaign in the early 1910s to build a unified workers' movement and overcome tensions between unskilled anarchists and skilled socialists, such efforts bore few fruits in the first decade of the shipyard's existence. ${ }^{11}$

But along with new political ideas, industrialization and the arrival of migrant workers also spurred new ways of thinking about ethnicity among native monfalconesi. Such workers arrived in a territory that straddled the blurry boundary between the Slavic (especially Slovenian) and Italian worlds. Though it is impossible to draw a distinct ethnic boundary, not least of all because to do so would defy the realities of many borderland residents' social lives and self-conception, those residing in Monfalcone proper and the villages of the more populous western half of the zone largely spoke a variant of the Venetian dialect of Italian, while Slovenian became more common

4 (1995): 29-45; Fabbrica e comunità a Monfalcone: dal sogno alla realtà: il Villaggio del Cantiere, la colonia della Solvay (Ronchi dei Legionari: Centro culturale pubblico polivalente del Monfalconese, 1996).

${ }^{10}$ Fragiacomo, La grande fabbrica, 94-121.

${ }^{11}$ Early Monfalcone socialism hovered uneasily between the reformism of the Austro-Marxist tradition and the more maximalist stance embraced by many Italians of the Habsburg Littoral. Silvano Benvenuti, "Il cantiere di Monfalcone," 21-23 and "Fabbrica e Società: Il gruppo metallurgico di Monfalcone nel 1911 e il ruolo dei fratelli Fontanot," Il Territorio 10 (1984): 45-60. 
in the northern and eastern villages, including in the overwhelmingly Slovenian village of Doberdò del Lago. ${ }^{12}$ Yet even among those who spoke the Venetian dialect, not all identified exclusively as "Italian." Many instead considered themselves a sort of hybrid people called bisiachi. In fact, due to a long history of exchange with both Carsic Slovenes coming to visit Monfalcone's market - Tržič, the Slovenian name for Monfalcone, means just that - and inhabitants of the Slovenianmajority communes abutting the Adriatic Sea southeast of Monfalcone, the local dialect bore many Slovenian influences and many monfalconesi bore Slovenian surnames. ${ }^{13}$

The formation of the shipyard wrenched many monfalconesi from this localized world and incorporated them more fully into the world of nationalist discourses and identities. Migrant workers from the Mezzogiorno often arrived with nationalist convictions, ${ }^{14}$ and even ethnically Italian workers from Trieste and Muggia brought the language of ethnic difference with them. They arrived from cities steeped in nationalist discourses and in which even leftist politics often operated with the presumption of distinct, if cooperative nationalities (as with Austro-Marxism). Moreover, the arrival of workers from distant lands created opportunities for cross-ethnic interactions that highlighted difference. While many monfalconesi continued to view themselves as ethnically hybrid or to display "national indifference" into the 1910s, others began to consider themselves more exclusively Italian, distinct from Slovenes. Not always did this translate into anti-

\footnotetext{
${ }^{12}$ See late-Habsburg language map, including "Distribution of Races in Austria-Hungary," in William R. Shepherd, Historical Atlas (New York: Henry Hold and Company, 1911), 168. It also reflects data from the first interwar census. See fn 20.

${ }^{13}$ The origin of the term is disputed, but one explanation is that it derives from the medieval Latin phrase "bis acquae," or "between the waters," referring to the Isonzo in the west and the Timavo in the east. The dialect also bore many Friulan influences. Debates over what it meant to be a bisiaco were common in the local historical journal Il Territorio in the 1980s, but much of the discussion focused on the origins and usage of the dialect, not wider cultural characteristics that might distinguish bisiachi from the broader category of Italians. See Anna Boileau, "I Bisiachi descrivono se stessi," Il Territorio 4 (1980): 41-46; Boileau, "I Bisiachi descrivono se stessi (II parte)," Il Territorio 5 (1980): 37-46; Doria, "Nè friulano, nè triestino: Il Vocabolario fraseologico del dialetto 'bisiàc'," Il Territorio 15 (1985): 53-61.

${ }^{14}$ The arrival in the Hapsburg Littoral of strongly nationalist Southern Italians generated major ethnic tensions during the late Habsburg era. Thus, imperial officials banned Italian citizens from holding positions in Trieste's city administration. Cattaruzza, Italy and Its Eastern Border, 43.
} 
Habsburg sentiment or aggressive Italian nationalism, but questions of collective identity were on many monfalconesi's minds when, in the sixth year of the CNT's life, Europe went to war. ${ }^{15}$

\section{The Arrival of the Italian "Motherland:" Postwar Upheaval and Local Fascism}

When the Great War came to Monfalcone in summer 1915, it had a devastating effect. Monfalcone sat squarely on the front line. The Habsburg trench line ran right up to the train station on the eastern edge of town, and the first months of fighting effectively demolished the CNT. This destruction would provide the Cosuliches with the long-term benefit of a fresh start in the interwar years by allowing them to reorganize the shipyard and equip it with the most modern tooling, though for the duration of the war the destruction led to great suffering. ${ }^{16}$

But the most drastic outcome of the Great War for Monfalcone was that it brought the town back into its supposed Italian "motherland," which garnered a range of local reactions. On the one hand, Monfalcone had long been part of the "unredeemed" lands after which Italian irredentists pined. Italian nationalists and irredentists had a foothold in the Monfalconese, and such individuals celebrated the eastward thrust of Italy's border with an annual communal parade. ${ }^{17}$ On the other hand, ardent irredentism appears to have been a minority opinion, and nationalist sentiment was less pronounced than in nearby Gorizia and Trieste. The composition of local society lent itself to socialist and anarchist politics of an internationalist type, and even among those monfalconesi who viewed their bisiachi identity as reinforcing rather than challenging their belonging to the Italian nation, many greeted Italy with apathy or ambivalence. ${ }^{18}$

\footnotetext{
${ }^{15}$ Benvenuti, "La nascità del cantiere," 26-27. On the concept of "national indifference, as well as additional Central European comparisons, see Zahra, Kidnapped Souls and "Imagined Noncommunities."

${ }^{16}$ Fragiacomo, La grande fabbrica, 238-39; Mellinato, Crescita senza sviluppo, 129-34.

${ }^{17}$ See, for example, Giovanni Bonavia, the first mayor of Italian Monfalcone. Fragiacomo, La grande fabbrica, 17374.

${ }^{18}$ Such indifference was not uncommon. Maura Hametz identifies similar tendencies among the Slovenian and Croatian minorities caught up in interwar Italianization campaigns. Most "appeared to acquiesce to the name changes, accepting them as a fact of life in Italy under Fascism" rather than actively embracing or resisting them. Hametz,
} 
For nationalists and for Italy - both Liberal and later Fascist Italy - ambiguity and indifference on the border were a threat, especially when the issue was the mixing of Italians with supposedly inferior Slavs in vital contested territories. Italian nationalists had long claimed that the Habsburg Empire had made an effort to "Slavify" the city and its surroundings to undercut Italian claims on Trieste, and the Italian state continued to propagate this idea after the war. ${ }^{19}$ Though the first Italian census in the area revealed (or, perhaps, asserted) that the Monfalconese had largely escaped the feared "Slavicization" - there were 30,667 "Italians" compared to just 1616 Slovenes - the state recognized that realities and sentiments on the ground were not as clearcut as these politically expedient statistics suggested. ${ }^{20}$ Thus, in the years after annexation the Italian state initiated a program of "Italianization," seen as part of a wider process of generating a healthy national body through "human reclamation" (bonifica umana). ${ }^{21}$ The state Italianized Julian place-names, overriding locally and regionally significant names with "national" referents. It closed Slavic- and German-language schools and replaced local teachers with those who could be trusted to teach a new, nationalist curriculum. Over time - and particularly after the rise and consolidation of Fascism - it pursued the Italianization of Slavic, German, and other surnames. ${ }^{22}$

\footnotetext{
"Borderlands," in The Politics of Everyday Life in Fascist Italy, eds. Arthurs, Ebner, and Ferris, op. cit., 166. Silvano Benvenuti, "I primi anni del Cantiere di Monfalcone: Partito socialista, gruppo metallurgico, organizzazione operaia in fabbrica (1908-1911)," Il Territorio 8 (1983): 33-48.

${ }^{19}$ Sluga, The Problem of Trieste, 27 and 44; Marina Cattaruzza, Italy and Its Eastern Border, 1866-2016, trans. Daniela Gobetti (London and New York: Routledge, 2017), 42-43.

${ }^{20}$ It seems that the primary criterion was language. These statistics are reproduced in HQ AMG-VG, "Project for the Provisional Administration of the Attual [sic] Province of Trieste," 7 July 1945, NARA, RG331, UD1981, b 9147, f $11304 / 115 / 11$.

${ }^{21}$ On bonifica umana and how the efforts to Italianize the northeastern border territories fit within wider Liberal and Fascist efforts to revitalize the nation and eliminate internal threats as wide-ranging as Slavs, the mafia, "degenerates," and others, see Ruth Ben-Ghiat, Fascist Modernities: Italy, 1922-1945 (Berkeley: University of California Press, 2001), 17-20. As Marina Cattaruzza points out, this policy was not "racist" in the same sense as Nazi racism, with its emphasis on biological determinism and racial disentanglement. Instead, Fascist policy was one of violent cultural assimilation. Cattaruzza, Italy and Its Eastern Border, 136.

22 The Fascist program of compulsory name changes began in 1928 and impacted some 100,000 giuliani. A much smaller number had voluntarily pursued name changes before 1928 in accommodation with the new reality of Italian sovereignty. Hametz, Making Trieste Italian, 117-19, 124-28. The closure of minority schools had a minimal impact on the Monfalconese. Adriano Andri and Giulio Mellinato, Scuola e confine: Le istituzioni educative della Venezia Giulia, 1915-1945 (Trieste: IRSML-FVG, 1994).
} 
In this context, monfalconesi often experienced the arrival of Italy not as national liberation, but rather as a form of cultural oppression. Thus, when one longtime leftist militant reflected on the arrival of Italy, he insisted that "no one is unfamiliar with the hostility with which Italy has always viewed us, from the Redemption onwards.... [I]n the end, [the working class] experienced almost solely persecution, not the least of which was for ethno-linguistic reasons, and it therefore saw the so-called 'motherland' filtered through the uniforms of the carabinieri, the policemen, and the Fascists, a motherland, which, in effect, has always considered us second- or third-class Italians." ${ }^{23}$ And he was not wrong. Nearly two decades after Italy’s arrival, the public security commissar in Monfalcone would lament that "there exists a true and proper Chinese wall that seems eternally to divide the Old Italy from the Redeemed Lands," the locals exhibiting an "utter and silent hostility toward all that which is of the Old Kingdom."24

But the most important reason that many monfalconesi looked upon Italian annexation with regret - certainly a contributing factor to the hostility (or indifference) described in the preceding quotation - was that the arrival of Italy brought violent political repression, particularly of the left. From the moment that an Italian military administration arrived in the region in 1918 through the transition to a civilian administration in mid-1920, military administrators decried the unreliability and subversiveness of the local population. They warned that the whole area was populated with "Slav irredentists" and "Bolshevik subversives" and often elided left-wing radicalism and Slavic ethnicity in a way that "Slavicized" radicalism and placed Italian leftists beyond the pale of the national community. In those years, industrial and agricultural workers entered their local CGIL or Federterra branch in droves and the old socialists transferred into the Italian Socialist Party

\footnotetext{
${ }^{23}$ Fogar, "Terza parte dell'intervista registrata rilasciata da Ruggero Bersa," November 1981, op. cit.

${ }^{24}$ Comm. di PS-Monfalcone, Report to Questore di Trieste (N. 263/Gab), 7 February 1936, AST, Pref. Gab. 1923-52, b 503, f 0111, sf 0111: CRDA: Vigilanza sul personale.
} 
(Partito socialista italiano, PSI) almost immediately embracing a maximalist rhetoric that ran counter to the national leadership's strategic hesitancy. Though local anarchist, Catholic, and Republican parties soon emerged, they were dwarfed by the PSI. Only in the fishing village of Grado did any of these parties muster a serious challenge, but even there the Republicans managed only a strong opposition. In the absence of viable nationalist parties that might provide an electoral vindication of the Italian annexation, the state responded with direct crackdowns on any agitation perceived as anti-Italian or social-revolutionary. ${ }^{25}$

And there were many agitations during the aptly named Red Biennium (biennio rosso). Inspired by the recent Bolshevik Revolution and seeing their membership totals balloon in parallel with postwar unemployment and inflation, Socialist ${ }^{26}$ and labor organizations began to agitate in the fields and the factories. In the fields, the new Friuli-Venezia Giulia branch of Federterra sought above all to revise existing mezzadria (sharecropping) contracts so that sharecroppers kept $90 \%$ of the harvest, as opposed to half. The drama climaxed in mid-1920 when 7000 sharecroppers marched on Cervignano to free their leader, who had been jailed for threatening landlords with land seizures. ${ }^{27}$ In the factories, the situation was equally volatile, as workers demanded that employers recognize the CGIL's authority to negotiate collective contracts and organize the election of internal commissions to govern internal shop procedures (Figure 4). The Cosuliches, like most of the region's industrialists, refused to bend, fearing the implications of yielding even the slightest bit of ground to this rising "Bolshevism." Instead, they blacklisted Socialist militants

\footnotetext{
${ }^{25}$ Benvenuti, "L'Isontino nel maggio 1920: Il giudizio dei Comandi militari sulla situazione politica e sociale," Il Territorio 7 (1982): 35-48; Fogar, L'antifascismo operaio monfalconese, 10-14.

${ }^{26}$ Use of the capitalized term "Socialist" refers specifically to members, organizations, and programs of the formal Socialist Party (in this case the Italian Socialist Party), whereas lowercase "socialist" and "socialism" refer to more general, often heterogenous family of ideas. A similar distinction is drawn signified with the terms "Communist" and "communist."

${ }^{27}$ Benvenuti, "L'Isontino nel maggio 1920,” 38-39
} 
and syndical organizers, to which workers responded by hanging portraits of Lenin on the walls. ${ }^{28}$

Mirroring the actions of industrialists throughout Italy, the Cosulich brothers then began aligning themselves with the nascent Fascist movement, seeing this as the only way to reassert control over a restive workforce. In June 1920, the brothers and much of the shipyard's top management lent support to Francesco Giunta who, having just founded the Triestine fascio, oversaw the formation of a Monfalcone branch (Figure 5). ${ }^{29}$ Among the management figures who supported Monfalconese Fascism were Federico Martinoli, simultaneously the shipyard's hiring director and the head of the Panzano action squad, and the Nationalist Antonio Colummi, head of the firm's Control Office and second-in-command within the communal administration. These two, working with the leadership of the Monfalcone fascio, including its head Aurelio Barbettani, and the head of the Monfalcone city action squad Nicola Bruni, increasingly hired squadristi and anti-leftist workers from the Old Provinces, placing them in positions as team leaders and company guards specifically to counterbalance the Socialists and Communists. ${ }^{30}$ Moreover, from the moment of the fascio's foundation, the Monfalcone squadristi engaged in punitive expeditions, attacking Socialists, syndical organizers, Federterra representatives, and Slovenian cultural and political figures. Though the firm's support of and use of Fascism sparked an extended strike in

28 Ibid., 37-38

${ }^{29}$ Giunta was a Tuscan lawyer who had joined Mussolini's organization in Milan in May 1920 before being sent to Trieste. He headed the burning of the Slovenian Cultural Center (Narodni Dom) in Trieste that July, which De Felice has labelled the "baptism of organized squadrismo" in Italy. Renzo De Felice, Mussolini il rivoluzionario 1883-1920 (Turin: Einaudi, 1965), 624. The Cosuliches' cooperation with the Fascists came despite the fact that some Fascists and nationalist politicians doubted the sincerity of the Cosuliches' Italian patriotism. Fragiacomo, La grande fabbrica, 173-74.

30 The term "squadrista" (pl: squadristi) refers to the first-hour Fascists formed into armed bands to confront Socialists, strikers, and organized peasants in the streets, factories, and fields. The term "fascio" (pl: fasci) is shorthand for the physical headquarters of local Fascist branch, the Casa del Fascio, but it can also refer to the collection of individuals who compose each branch. CRDA-Direzione Centrale, "Curriculum del Comm. Dott. Ing. Federico Martinoli...," 12 March 1936; Aurelio Barbettani, "Dichiarazione," 17 October 1934; Nicola Bruni, "Dichiarazione," 25 October 1934; Ministero della Marina-Gab, "Cantiere navale di Monfalcone” (N. B.2004), 31 March 1936, all in AST, Pref-Gab 1923-52, b 503, f 0111, sf 0111: CRDA: Vigilanza sul personale. On Colummi, see Fragiacomo, La grande fabbrica, 175. 
late August and early September of 1920 , the strike failed to change these hiring policies. ${ }^{31}$

Thus, a clear opposition formed between Socialists (and soon Communists) on one side and the Fascists, industrialists, and forces of order on the other. ${ }^{32}$ The climax came in 1921 in the form of two deadly clashes in the CNT. The first occurred on 11 February when a group of leftists gathered in the workshops to hear speeches condemning Fascist attacks on the headquarters of leftwing organizations. Certain Fascist workers intervened, stirring up the leftist crowd, which then proceeded to march to the central shipyard offices to attack Fascist and philo-Fascist clerks. Events devolved into an all-out brawl, with the Fascist workers aided by the other members of the Monfalcone fascio, factory guards, and the carabinieri. Under unclear circumstances, some shots were fired. The leftists soon fled, unable to withstand the onslaught. For the remainder of the day, the carabinieri struggled to keep order in the town as squadristi from the Monfalcone fascio, aided by truckloads of Triestine Fascists, terrorized the dispersed workers. By day's end, the Fascists had killed one, seriously injured five, beaten countless others, and sacked the local labor headquarters. ${ }^{33}$ Seven months later, a September strike of the CNT metalworkers ended in violent clashes in which Triestine Fascists killed two workers. ${ }^{34}$

With this wave of violence, the Socialist and Communist Parties soon found themselves in retreat. From the fall of 1921 to the fall of 1922, the Fascists continued their offensive, increasingly imbricated within the shipyard workforce. In October 1922, many of these Fascists would march on Rome, leaving as thugs and returning with a mandate to transform their repressive actions into a durable system of social control and Italianization, supported by their new prime minister, Benito

\footnotetext{
${ }^{31}$ Cernigoi, Puppini, and Valcovich (eds), Cento anni di cantiere, 30-31.

${ }^{32}$ The Communist Party of Italy (Partito comunista d'Italia, PCdI) was founded in January 1921 and, due to its more maximalist stance, by 1924 it had become the more popular party in the Monfalconese. Fogar, L'antifascismo operaio monfalconese, 41-48.

33 "I conflitti di ieri tra fascisti e comunisti al Cantiere navale di Monfalcone," Il Piccolo, 12 February 1921.

${ }^{34}$ Cernigoi, Puppini, and Valcovich (eds), Cento anni di cantiere, 30-31.
} 
Mussolini. As in the rest of Italy, in the Monfalconese the March on Rome was followed by the slow erosion of democratic pluralism. Between 1922 and 1923, the Socialists and Communists of Monfalcone, though still possessing the legal right to organize, were forced to enter a semiclandestine state due to a two-pronged offensive from the squadristi and the local industrialists. The former continued their punitive missions, and the latter continued to blacklist radical activists and give hiring preference to Fascists. Anti-Fascist militants and unions found themselves outmatched. Union bargaining power was undercut by a continual influx of job-seeking youths from the outlying agrarian communes, as well as strongly nationalist and/or pro-Fascist workers from Puglia, Calabria, and Sicily, recruited now not just to fill the shipyard's labor needs, but also to further simultaneously the regime's ends of "Italianization" and anti-leftist repression. ${ }^{35}$ By the time Mussolini declared the dictatorship in 1925, the leftist parties were in crisis and the much smaller moderate parties were under attack.

Yet repressive actions, yielding temporary successes, also sowed the seeds of future problems for Fascism and the Italian state. Increasingly equating "Italy" with "Fascism" and looking nostalgically upon Habsburg era, many monfalconesi brought their children and grandchildren up on a steady diet of anti-Fascist and anti-nationalist teachings, setting the stage for a surge in national indifference or even outright hostility to the Italian state (if not "Italianness" more broadly) among those youths who would come of age during the early 1940s. As one member of this generation would later reflect, "nationalist sentiment was not felt in these parts. This is because there had been Fascism and thus there had always been a bit of anti-Italian feeling. This

\footnotetext{
${ }^{35}$ Fogar, L'antifascismo operaio monfalconese, 17-22, 31-41, 52-59, 64-67. This recruitment practice continued into the 1930s. For example, see the experience of Giacomo Morena, who came to Monfalcone from Bari in 1935 at the age of seven when the CRDA recruited his father, a Great War veteran and fervent nationalist. Giacomo would grow up to be strongly nationalist, like his father. Di Gianantonio et al, L'immaginario imprigionato, 34-35, 149. If such recruitment became a conscious strategy under Fascism, it should be remembered that the migration to the region of Southern Italians predated the arrival of Italy. See fn 15.
} 
sentiment was inside us, the elders had always deplored Italy and mourned Austria."36

\section{Everyday Fascism and Everyday "Fascists" in Monfalcone's Shipyard}

The biennio rosso, the March on Rome, and the proclamation of the Fascist dictatorship were exceptional moments that soon gave way to two decades of Fascist rule. It is thus of critical importance to understand how Fascism operated in the Monfalconese not just in its spectacular form - in street violence and political display - but also in its mundane and quotidian form. The existence of the ostensibly totalitarian and extraordinary dictatorship did not preclude "ordinary life" from continuing contemporaneously, even if the former had notable impacts on the latter. As everyday life continued to unfold, there were ample opportunities for monfalconesi to develop subjective understandings of "Fascism" and "Fascists," based on their quotidian experiences in the zone's lived spaces, chief among them the workplace. In fact, most monfalconesi had their most regular and sustained interaction with perceived "points of contact" with the Fascist regime on the workshop floor. Monfalcone's workers lived through two decades of Fascism's attempts to solidify its control in the workplace through a capillary penetration of workplace hierarchies and to increase productivity through the implementation of "modernizing" reforms. The terms "Fascism" and "Fascists" took on meanings well beyond the PNF's regime and membership. Such transformations combined to frustrate deeply workers' personal ambitions, leading to the blurring of the distinction between grievances with industrial-capitalist practices and grievances with Fascism, antagonisms with superiors often understood as antagonism with Fascism and the failure

\footnotetext{
${ }^{36}$ Cernigoi, Scelte politiche e identità nazionale, 228-29. This is a common theme. Silvano Cosolo, who would emigrate to Yugoslavia in 1946 as a teenager, indicates in his memoirs that, despite Fascist efforts to inculcate nationalism in school, his love of the motherland always remained "latent" because his grandfather, an "Austrophile," "never missed the opportunity to instill in me his fond feelings regarding Austria, making sure the whole thing served as 'antibodies' to the Fascist education." Cosolo, Amare... Sarajevo (estate 1946-estate 1948) (Ronchi dei Legionari: CCM, 2008), 15-16. Such comments might be interpreted as attempts to distance oneself from Fascism and Italian nationalism given its disastrous consequences, but the fact that Fascist-era officials shared this assessment suggests they contain a core of truth, as do the interwar politics of many monfalconesi.
} 
to find material or spiritual fulfillment understood as a failure of Fascism.

This mental assimilation resulted in large part from changes in how the shipyard organized and deployed labor during the ventennio, which for workers translated into changes in the everyday experience of labor. In the first years of the CNT's existence, the workforce was organized primarily into subcontracted work teams (squadre) headed by a skilled, experienced team leader (caposquadra or mistro) and consisting of anywhere from three to thirty additional workers. teams performing more specialized tasks like riveting tended to be smaller, while larger teams were of less specialized labor such as the "iron carpenters" responsible for carrying the large sheets of metal from the tracing room or the various parts workshops to one of the seven grand mountings where workers operated various winches to hold these sheets in place and affix them with either nails (pre-1914) or rivets (post-1914). ${ }^{37}$ A notable feature of this system was the autonomy granted to each team. In fact, the CNT's top management took a hands-off approach, announcing deadlines for the setting of the keel, the launching of the ship, and other key stages of production, but leaving the details to the shipyard head and the inspectors (later called workshop heads) who oversaw the teams. In this system, each team leader was responsible for devising the specific work methods and tasks for his team members, as well as for selecting workers to hire. Additionally, apart from a few categories of workers (i.e. riveters) who had fixed piece-rates, teams - or rather team leaders - generally had the power to negotiate directly with management for his team's contract in wage or piece rates. ${ }^{38}$

This system, which held team leaders as intermediaries between management and workers, had a localizing effect on the dynamics of work relations. On the one hand, relations between team

\footnotetext{
${ }^{37}$ Only in 1920 did the firm begin to modernize this process, constructing cranes and an internal railway. Silvano Benvenuti, "Il cantieri di Monfalcone," 23-26. Cernigoi, Puppini, and Valcovich (eds), Cento anni di cantiere, 25-27. ${ }^{38}$ Benvenuti, "Il cantieri di Monfalcone," 23-26; Benvenuti, "Fabbrica e Società," 45-50; Fragiacomo, La grande fabbrica, 239-40.
} 
leaders and workers could become quite tense, as team leaders were the primary force imposing discipline on the teams and worker pay depended on the ability of the team head to negotiate and to organize effectively. At times, work-related tensions combined with political tensions between Socialist team leaders and anarchist unskilled workers to fuel assaults on malicious team leaders. On the other hand, effective team leaders could negotiate favorable contracts and organize work in such as a way that team members had a degree of autonomy and pride. In the years immediately preceding the Great War, the general dynamics within teams had tended to improve as team heads increasingly reached out to unskilled team members to bring them into the Socialist network. ${ }^{39}$

With the rise of Fascism, however, a system of Fascist capillary penetration of the workplace emerged to reinvest work processes with political antagonism. Constructed through the cooperation of CNT managers like Federico Martinoli and Antonio Colummi with Fascist strongmen like Aurelio Barbettani, this network consisted in part of factory guards and paid informants among the workers. ${ }^{40}$ But it also consisted of an ever-larger percentage of the workteam leaders and workshop heads. As the worker Livio Borsi recalls, "the squadristi, for the most part, were bosses and clerks, or warehouse operators and the like. That is, they had jobs in which they didn't labor." ${ }^{41}$ As such, the terms "bosses" and "Fascists" became increasingly coterminous, and resentment rose as workers perceived squadristi to be rewarded with positions requiring little

\footnotetext{
${ }^{39}$ Benvenuti, "Fabbrica e Società," 45-50, Cernigoi, Puppini, and Valcovich (eds), Cento anni di cantiere, 27.

${ }^{40}$ This system of control would persist throughout the regime. Still in 1943, for example, it was the Monfalcone fascio head, Giuseppe Versace, who headed the CRDA guards. Federale Macola (PNF-Trieste), "Attivita' sovversiva"" (N. LC/SG/627/RR.89), 14 July 1943, AST, Pref Gab 1923-52, b 452, f 064. Regarding spies, Leopoldo Gasperini produced a list of over 150 CRDA workers suspected of collecting the "second purse," or supplementary pay for information. Leopoldo Gasperini, "Squadristi in Cantiere a Monfalcone," IRSML, Fondo Gasperini, b 4, d 131. Similarly, Mario Tonzar recalls possessing a list of 280 such spies. Mario Tonzar, La valigia e l'idea: memorie di Mario Tonzar, ed. Alessandro Morena (Ronchi dei Legionari: CCM, 2006), 70. On Fascist capillary surveillance networks, as well as the range of motives that led Italians to become informants, see Paul Corner, The Fascist Party and Popular Opinion in Mussolini's Italy (Oxford: Oxford University Press, 2012), 172-80.

${ }^{41}$ Here Borsi was specifically discussing the critical moment of 25 July 1943, when he was deciding whom to trust. Fogar, L'antifascismo operaio monfalconese, 286.
} 
effort. Though anti-Fascist team leaders remained to serve as the Communist Party's principle recruiters among apprentices, an increasingly large body of Fascist team leaders and workshop heads emerged, blurring the boundary between workplace discipline and political oppression. ${ }^{42}$

Such was the case with the worker Ferruccio Levi, who, shortly after liberation, submitted a personal statement to the Communist Party enumerating the crimes of Fascism in the workplace, and particularly those of his boss, Francesco Biasini, nicknamed "The Terror." Levi, a selfidentified hothead, had been fired from his post as an Electromechanical Department warehouse organizer for insubordination in early 1931 and had endured over three years of punitive demotion to unskilled labor. ${ }^{43}$ When he returned to his original post, he came under Biasini's authority, and the two repeatedly had altercations caused, in Levi's view, by Biasini's attempt to "reign as a sovereign in the shipyard." One day, after a quarrel with a minor boss, Levi was called before his superiors, including Biasini. According to Levi, they informed him that he would be pardoned for his offence, given his status as head of family, but that this was his final chance. Levi then explained his situation and that he needed his job to support his large family, to which Biasini responded that he himself "had two families to maintain." Though Levi became enraged, he immediately recognized this as an attempt by his Fascist boss to provoke him into an act for which he could be fired. Instead of taking the bait, Levi thought of his family, remained silent, and kept his job. Notably, in assessing the situation, Levi casts this minor personal victory not just as a victory against a cruel and authoritarian superior, but as a victory against Fascism itself. ${ }^{44}$

\footnotetext{
${ }^{42}$ The apprentice-master relationship often receives much attention in memoirs and interviews, particularly in the case of anti-Fascist master, as with Mario Tonzar and Renato Papais. In Papais's testimony, having an anti-Fascist mistro was even explicitly linked to enjoying work. When asked about his work experience, Papais responds that "I enjoyed going to work. I enjoyed work. I found 'mistri' who were anti-Fascists. They knew that my father too was an antiFascist and they trusted him." Alessandro Morena, "Intervista a Papais Renato," 0830hrs, 28 June 2001, Sede CGIL Monfalcone, held at CCM. Tonzar, La valigia e l'idea, 67-70.

${ }^{43}$ The timeline, though not precisely laid out in the document, is important in Levi's story given his Jewish surname. It suggests that the events in question happened before the anti-Semitic Racial Laws of 1938 went into effect.

${ }^{44}$ Ferruccio Levi, "Dichiarazione," 20 June 1945, AS 1815/2/56.
} 
The Fascistization of the workplace hierarchy was part the regime's and managers' efforts to maintain control over the workers and their labor as Monfalcone shipyard rapidly expanded. From a pre-WWI high of roughly 2800, by 1927 the workforce had grown to over 7300. Many were employed in new railcar, electromechanical, and aeronautical workshops that the Cosuliches had constructed to reduce the CNT's vulnerability to cyclical fluctuations in shipbuilding contracts. ${ }^{45}$ This figure would shrink to fewer than 5000 during the Great Depression, but by 1936 it rebounded and surpassed pre-Depression levels. ${ }^{46}$ Moreover, Fascistization ran in parallel to a wider regime push to subordinate organized labor to the needs of the state and to marginalize the national syndicalist strain of Fascism led by Edmondo Rossoni. This process began with the passing of the Rocco Syndical Laws of 1926, which transformed Rossoni's two-million-strong General Confederation of Syndicate Corporations (the "Fascist Syndicates") into the sole legal organization representing Italian labor and subordinated it to Mussolini's Interior Ministry. It ended two years later when Mussolini dismissed the labor-oriented Rossoni and created the corporative state, disaggregating Rossoni's confederation into industry-specific organizations and critically hamstringing organized labor. ${ }^{47}$

A decisive moment in the Fascistization of the shipyard - and one that had a critical impact on the everyday experience of labor - came with the state's acquisition of the firm in 1933. In that year, unwilling to leave a vital firm under private ownership in the context of Depression, Italy's

\footnotetext{
${ }^{45}$ Fragiacomo, La grande fabbrica, 163-67; Mellinato, Crescita senza sviluppo, 211-13.

${ }^{46}$ Accompanying the growth of the shipyard was a population explosion in the Monfalconese and the continual social redefinition of the zone. Monfalcone proper, for example, increased from 11,838 in 1921 to 19,656 in 1936 and by 1931 the ratio of proletarian to agrarian families was already 4574 to 1245 . These latter figures are determined by the occupation of the head-of-household. It is worth noting that the division was not always clear-cut. Many families had members employed in both categories and it was not uncommon for smallholders and tenant farmers to work in the CNT part time or seasonally. Fogar, L'antifascismo operaio monfalconese, 41-48; Fragiacomo, La grande fabbrica, 34.

${ }^{47}$ Carmen Haider, Capital and Labor Under Fascism (New York, 1930; reprint, New York: AMS Press, Inc., 1968), 59, 82, 93-94, 214-15; David Roberts, The Syndicalist Tradition and Italian Fascism (Chapel Hill: University of North Carolina Press, 1979), 239.
} 
Industrial Reconstruction Institute (Istituto per la Ricostruzione Industriale, IRI) purchased majority control of what by then was known as the United Shipyards of the Adriatic (Cantieri Riuniti dell'Adriatico, CRDA), a shipbuilding conglomerate led by the Cosuliches, in which Monfalcone was the largest worksite. With the nationalization of the CRDA, the Cosuliches remained members of the management council and retained de facto managerial control over their Monfalcone "fief," but the presidency was given to none other than Francesco Giunta. ${ }^{48}$

Once the CRDA was under IRI control, Monfalcone emerged as a testing-ground for regime-backed workplace "modernization" efforts and thus as one of the few firms in Fascist Italy in which the principles of scientific management received rigorous application.$^{49}$ The most notable change, initiated by private management some years before but truly perfected only after the state acquired control of the firm, involved the transformation and extension of the piecework system, in which piecework shifted from a system of work-team autonomy to one of restrictions upon and regulation of workers and work-team leaders. ${ }^{50}$ As the firm reported to President Giunta that year, "we have dedicated particular attention to the organization of the Piecework Office and we have verified that these are organized, or are on the way to being organized, according to modern norms

\footnotetext{
${ }^{48}$ Fragiacomo, La grande fabbrica, 229. In addition to founding the Triestine fascio, Giunta had served briefly as the PNF secretary before the declaration of the dictatorship. Fogar, L'antifascismo operaio monfalconese, 205-209. The firm returned to private ownership briefly in 1935 but was once again under state control by 1937 . Eventually, management of the wider conglomerate shifted to Genoa, reflecting a weakening of the Cosuliches' power beyond Monfalcone. See Fragiacomo, La grande fabbrica, 221-28; Mellinato, Crescita senza sviluppo, chs. 4-6. In 1939, there was a major struggle between the Cosuliches and Giunta over control of the Monfalcone shipyard, which Giunta lost when IRI deemed the maintenance of Cosulich authority to be economically expedient. Fragiacomo, La grande fabbrica, 234-37.

${ }^{49}$ The limited application resulted in part from Italy's relatively low degree of industrial concentration. Other firms applying scientific management included the Angelli's FIAT works in Turin, the Olivetti typewriter factory in Ivrea, and the light engineering factory of Magneti Marelli in Milan. Tobias Abse, "Italian Workers and Italian Fascism," in Fascist Italy and Nazi Germany: Comparisons and Contrasts, ed. Richard Bessel (Cambridge: Cambridge University Press, 1996), 52-53.

${ }^{50}$ Though it cannot receive extensive attention here, another change was the pioneering application of assembly-line production methods in the railway workshops of Monfalcone beginning in 1926. They were the first in Italy to use such methods. CRDA-Monfalcone, "Officinee Ferroviarie Monfalcone," 7 February 1934, ACS, Fondo IRI, Numerazione Nera, b STO/510.
} 
and ideas." By "modern norms," the firm meant that each department of the CRDA had its own Piecework Office "for the calculation of the time required by the different processes." 51 As one worker recalls, upon the arrival of the Taylor system, "everything was subjected to the stopwatch." ${ }^{, 52}$ Under the direction of the wider Works Office (Ufficio lavori), piecework clerks calculated the hypothetical productivity that could be achieved by the ideal work team and, from this, the piece rates were devised to force workers to a continual, rapid work pace. The Works Office assumed unilateral power to determine piece rates, standardized rates within each department, increased the importance of piecework relative to wage pay, and began to issue both rigid workshop-level timelines for construction (instruzioni esecutive) and detailed production guidelines that precisely laid out the increasingly subdivided, simplified, and regulated tasks that workers performed (ordini di officina). The firm offered piecework contracts in increasingly short durations, which allowed it to reduce rates whenever it devised newer, more productive methods. ${ }^{53}$

These reforms marked a death knell for the independent "craftsman" within the CRDA and, in large part, frustrated many workers, whose professional ambitions often involved climbing the skill hierarchy. The autonomous work-team leader disappeared, and with it the autonomy that work teams had possessed to determine how they would meet production quotas. ${ }^{54}$ Piecework and the accompanying rationalization of production spurred a shift in workforce composition away from high levels of specialized workers to a workforce that consisted, in large part, of workers of

\footnotetext{
${ }^{51}$ Migliorini, Budini, and Chiesa, "Rapporto dei Sindaci a S.E. On. Francesco Giunta," 7 November 1933, AST, Pref Gab 1923-52, b 503, f 053 and 011, sf 053 Situazione sindacale.

${ }^{52}$ Fragiacomo, Fabbrica e comunità, 118-19.

${ }^{53}$ Fragiacomo, La grande fabbrica, 240-43 (quotation on 241); CRDA-Monfalcone, "Ufficio Lavori," Undated, ACS, Fondo IRI, Numerazione Rossa, b R1592; Cernigoi, Puppini, and Valcovich (eds), Cento anni di cantiere, 35.

${ }^{54}$ Team leaders also lost the power to select their own workers, as this was placed in the hands of the clerks who ran each sector of the firm, the clerks' decisions subject to review by Fascist inspectors. CRDA-Direzione Centrale, "Promemoria sul procedimento nell'assunzione degli operai," 24 February 1936, AST, Pref Gab 1923-52, b 503, f 0111, sf 0111: CRDA: Vigilanza sul personale.
} 
a low or medium technical qualification. ${ }^{55}$ It became a tool for accelerating work rhythms to a frenetic pace, but also for controlling how teams operated down to the minutia of the productive process. As Galliano Fogar has asserted, "the old figure of the work-team leader was swept away and in its place grew up the piecework directors [cottimisti]," with piecework becoming "a true and proper instrument of repression." 56 As one former clerk recalls, the Works Office was "most severe with the workers." ${ }^{57}$ Soon some sixty percent of workhours were performed as piecework and the results were shocking. ${ }^{58}$ In its ruthless drive toward efficiency, the Works Office transformed the CRDA-Monfalcone into Italy's most efficient shipyard and reduced work hours by two-thirds. ${ }^{59}$

For workers subjected to these changes, it was easy to find individuals to blame, and they were almost always Fascists. First among them was the former squadrista chief Federico Martinoli, who emerged as the principal architect of the new system and, from 1937, the acting director of the Monfalcone shipyard. ${ }^{60}$ In the realm of more everyday contact, however, workers cast blame upon the ranks of the expanded clerical staff (impiegatizia), the members of which were required to have close political ties with the regime. By the IRI years, the CRDA required that clerks applying to work at the CRDA present a PNF party card before receiving consideration, and

\footnotetext{
${ }^{55}$ In 1934, the firm praised the Monfalcone site as the "most organic shipyard in the Mediterranean," as a result of which it "can employ mostly non-specialized labor." CRDA, "Considerazioni riassuntive e generali," 3 December 1934, ACS, Fondo IRI, Numerazione Rossa, b R1591. This system differed greatly from that of Britain, where there were a high number of skilled workers and a general specialization of types of ships produced between various shipyards. Fragiacomo, La grande fabbrica, 249-50.

${ }^{56}$ The firm did hire some new workers - young workers - with contracts based primarily on wage pay, but this was an attempt to prevent the formation of universally shared grievances among the workforce. Fogar, L'antifascismo operaio monfalconese, 67-72.

${ }^{57}$ Fragiacomo, La grande fabbrica, 241.

${ }^{58}$ CRDA, "Consiglio 28 novembre 1946, 28 November 1946, ACS, Fondo IRI, Numerazione Rossa, b R1588.

${ }^{59}$ By the late 1930s, IRI considered the Monfalcone shipyard a model to be emulated by others such as the Ansaldo works in Genoa. "Dati consegnati dall'Ing. Martinoli all'Ing. Giaccone...," 27 November 1937, ACS, Fondo IRI, Numerazione Nera, b STO/510; Fragiacomo, La grande fabbrica, 247.

60 "Dati consegnati dall'Ing. Martinoli all'Ing. Giaccone...," 27 November 1937, op. cit.; CRDA, "Cantieri di construzioni navali," April 1938, ACS, Fondo IRI, Numerazione Rossa, b R1591; CRDA, "Dirigenti dei Cantieri Riuniti dell'Adriatico,” 3 May 1937, ACS, Fondo IRI, Numerazione Rossa, b R1591.
} 
the results were staggering. ${ }^{61}$ Of the 671 clerks employed at the Monfalcone site in 1936, some $480(71.5 \%)$ were Fascists (including two former heads of the Monfalcone fascio and three members of its Directorate) and nearly one in ten was an active member of the Fascist Militia (MVSN). ${ }^{62}$ Though many of these clerks certainly were Fascists by necessity (some even had antiFascist pasts), many were true adherents. ${ }^{63}$ Among the latter appear to have been the majority of the piecework clerks, often drawn from the ranks of Martinoli's and Bruni's old squadristi underlings. ${ }^{64}$ Because of how Fascism interwove itself with local society, it was the very same squadristi who the decade prior had imposed the dictatorship with the force of their truncheons who later arrived in the workshops to impose a new labor system with the force of their stopwatches and ordini di officina. This system, characterized by de-skilling, standardization, regimentation, and pace increases, was understood as essentially "Fascist" because of its implementation during the Fascist period by Fascist believers.

The Fascistization of CRDA clerkdom was reinforced by the fact that the cultural life of the clerical personnel was closely bound up with local Fascism. For example, the clerks' cultural circle (the Circolo impiegati) was housed within the Casa del Fascio. As the construction surveyor (geometra) Spartaco Romano would reflect, it was possible to attend the circle without joining the fascio, as he did, but the very act of frequenting this establishment tarnished his reputation. Despite

\footnotetext{
${ }^{61}$ CRDA-Direzione Centrale, "Promemoria sul procedimento nell'assunzione degli operai," 24 February 1936, op. cit.

${ }^{62}$ Ministero della Marina-Gab, "Cantiere navale di Monfalcone" (N. B.2004), 31 March 1936, AST, Pref Gab 192352, b 503, f 0111, sf 0111: CRDA Vigilanza sul personale.

${ }^{63}$ For example, one could contrast the deep Fascist conviction of the clerk Luigi D. C., an eventual volunteer in the ultra-Fascist X Mas in 1943-45, with that of Renato G., who had been a member of the town's PSI executive committee in the pre-Fascist years and retained these sympathies throughout the entire period, rejoining the PSI in the postwar. Commissariato Epurazione-Bari, "D[x] C[x] Luigi..." (N. 2207), 2 November 1945, ASBCM, b 513, f Ctg II, sf Cl 2; Dott. C. Contrada, Comm. di PS-Monfalcone, "Monfalcone - Consigli tributari..." (N. 0264), 22 February 1948, ASG, Questura 1948, b 8, f 1230.

${ }^{64}$ When in 1946 the National Liberation Committee of Monfalcone drew up a list of residents still sought for prior "anti-popular" activity, it included three cottimisti (importantly noted as a distinct category) of whom all were Fascists and two were squadristi. CLN-Monfalcone, "Elenco nominativo degli elementi antipopolari nella città di Monfalcone," 4 December 1946, AS 1815/4/80.
} 
having anti-Fascist sympathies and belonging to a longtime Socialist family - his father was a close friend of Giovanni Fontanot and a key voice of local intewar Socialism - Romano felt himself distrusted by the bulk of anti-Fascist workers due to his attendance at the circle. And his perception was borne out by the fact that, despite immediately joining the anti-Fascist Resistance in September 1943, Romano was put on trial in absentia by a group of partisans for ties with Fascism, the sole evidence being his frequenting of the circle. Only the intervention of his cousin, the esteemed Communist militant Vinicio Fontanot (son of Giovanni), secured his absolution. ${ }^{65}$

The trial of Spartaco Romano reflected worker tendencies to blame middle managers and clerks for workplace "Fascism" and to conflate clerks with Fascists. In fact, such associations became so strong in the minds of many workers that they were often applied to clerks and workshop heads who fell within the anti-Fascist camp. Illustrating this tendency is a postwar encounter between the CRDA mechanic and Communist partisan, Raffaele B. and a man named Tortona, the former secretary for the head of a lathe workshop. As Tortona recounted, during an encounter between the two in 1946, Raffaele, who had spent over a year in Fascist prisons before the regime's collapse in 1943, learned of Tortona's occupation and had an "eruption like a volcano, offending [him] in the most humiliating way, saying that all the gabibi [a slur for Southern Italians] are ruffians, spies, and so on." When Tortona insisted he had always been a "good, sincere comrade," having become a clerk only because his small stature made him unfit for physical labor, Raffaele shouted that "all the gabibi should be destroyed" and that it was necessary "to burn all the towns of the South." As Tortona tried to argue that there were reliable comrades among the clerks, Raffaele responded that "it's one percent and even these are Fascists. Yesterday they shouted 'Viva the Duce,' today they shout 'Viva Communism,' tomorrow they will shout for

\footnotetext{
${ }^{65}$ Alfredo Bonelli, “Terza testimonianza del monfalconese Romano Spartaco," 11 February 1981, IRSML, Fondo Cominform, b 99, f 2 .
} 
another party." Hearing that Tortona was a clerk - and possibly also hearing a Southern accent, though Tortona never specifies his birthplace - triggered in Raffaele an associational triad of clerkFascist-Southerner. Tortona's personal history and current politics meant nothing, as he was, in Raffaele's mind, guilty of Fascism by association with the clerical category. ${ }^{66}$

Notably, the workers of the Monfalcone CRDA immediately and continually protested the piecework system from the moment of its implementation, often referring to it as the Fascist "whip" of the workers. In fact, immediately in after its implementation in 1933, workers had elected a delegation to protest the change to the Fascist Syndicates and to try to raise piece-rates, but nothing came of the protest. ${ }^{67}$ That same year, formal complaints over piecework filed with the Fascist Syndicates more than quintupled, despite a substantial drop in the workforce. ${ }^{68}$ Throughout the next decade, workers unsuccessfully pushed back against this system, viewing it as a tool to transform them into unskilled beasts of burden. As the worker Sergio Parenzan would later reflect, even when he entered the shipyard as an apprentice in 1940, the system provoked serious discontent. Despite being apprenticed to a "good worker" named Centazzo, Parenzan and the apprentices regularly clashed with Centazzo over piecework, particularly the fact that Centazzo “didn't have enough courage to protest piecework and therefore the pace always increased and we

\footnotetext{
${ }^{66}$ As is the case here, much of the evidence available to demonstrate this associational nexus comes from the postwar period, when workers were more likely to express their resentments and organizations like the Communist Party were more likely to leave paper trails capturing them. The term "gabibo" seems to be a reference to the laboring population of Timbuktu during the Songhai Empire. As such, the slur plays on longstanding Northern Italian stereotypes of Southerners as "primitive" and "African," while also mobilizing the assumption common in Monfalcone's anti-Fascist circles that Fascism was imported from the South. Comp. Tortona, Handwritten Report "Al PCG di Monfalcone'," Undated (1946), AS 1570, b 9, f 6, sf Archivio.

${ }^{67}$ Questore Peruzzi (Trieste), "Pro-memoria," 4 August 1933, AST Pref Gab 1923-52, b 503, f 053 and 011, sf 053 Situazione sindacale. This was such a significant moment that it made it in to the memoirs of the future step-daughter of one of the delegation members. Mirella Pin-Giuricin, "I motivi di una scelta: Una vita vissuta tra Monfalcone e Fiume," Quaderni 17 (2006), 345-46.

${ }^{68}$ Firm-wide complaints rose from 25 to 136, despite a drop in the workforce from 10,549 to 7088. Migliorini, Budini, and Chiesa, "Rapporto dei Sindaci a S.E. On. Francesco Giunta," 7 November 1933, op. cit.
} 
had to get to work to try to earn any money." 69 Ferruccio Levi, the abovementioned worker tormented by his boss, "The Terror," indicated that piecework not only oppressed the workers, but helped the bosses to line their pockets: "I too was part of the mass of the so-called REGIA, that is 'expenses,' that, if they are a bit too high, diminish the commission due to the managers, administrators, bosses, etc. etc. And it will always happen this way if, in the future, special privileges are granted to these masters, which cause harm to the mass both of workers and of small clerks [piccoli impiegati] who work with conscience and good will like the other categories of pieceworkers and petty clerks [impiegati inferiori]." Though Levi was more generous than many of his contemporaries toward the "petty clerks" - seemingly the white-collar staff integrated into the workshops, not the managerial clerks isolated in distinct offices - his belief in a fundamental irreconcilability between the interests of "pieceworkers" and self-serving Fascist bosses shines through. ${ }^{70}$

\section{Anti-Fascism in Monfalcone: The 1930s}

The inability of workers to mount any real challenge to the new piecework system stemmed from the fact that they lacked any political or labor organizations through which they could overtly resist the Fascist regime. The Fascist state followed the proclamation of the dictatorship with an extensive campaign to shatter organized opposition and, by 1930, the defeat of the anti-Fascist political parties was complete. The bulk of the Fascists' repressive campaign targeted the

\footnotetext{
${ }^{69}$ Alessandro Morena, "Intervista a Sergio Parenzan," 1000hrs, 30 May 2001, performed at CGIL headquarters in Monfalcone, held at the CCM.

${ }^{70}$ The connection with Fascism should be remembered here, too, as Levi quite explicitly labels his statement as a testimony of Fascist abuses in the CRDA. Ferruccio Levi, "Dichiarazione," op cit. In a few select cases both before and after liberation, workers indicated that they supported piecework. For example, Spartaco Colussi recounted that, as an exceptionally strong man, he performed his job as an unloader at well-above-average rates and each day took home a week's pay. Alessandro Morena, "Intervista a Spartaco Colussi," 1600hrs, 11 January 2001, held at the CCM. Colussi was anything but a friend of the regime, eventually becoming a partisan and Communist Party member. Alessandro Morena, "Il Monfalconese tra guerra e lungo dopoguerra: L'importanza delle fonti orali," in Il mosaico giuliano, eds. Altieri and Puppini, op. cit., 128-29.
} 
Communist Party of Italy (Partito comunista d'Italia, PCdI), which had been pushed deep underground by 1934, its top leadership either arrested or fled into exile, often to the USSR. ${ }^{71}$ As part of this campaign, in 1930-31, the Fascist security apparatus identified and destroyed the leadership of Communist Federation of Trieste, which had formerly given direction to the Communists of the Monfalconese. Though this crackdown left the Monfalconese militants in complete disorder and isolated from the Party's center, Monfalcone's Communists responded with rapid local reconstruction, facilitated by resentments over workplace reforms, a general expansion of the workforce, and growing economic hardship from the Great Depression. ${ }^{72}$

In this context, local PCdI militants took the initiative in launching a new recruitment wave, setting the local Party on a trajectory that ran in striking contrast to that of the Party on a national scale. By 1934, the local Party had grown to over 200 members, accounting for nearly $8 \%$ of the total 2591 Communist militants in Italy, despite the Monfalconese being home to just a fraction of one percent of the nation's population. ${ }^{73}$ Moreover, this network assumed a leading role in the reformation of a regional committee, linking the committees of Udine, Gorizia, and Monfalcone and reestablishing contact with the Party's leadership in exile, though in practice the Monfalconese Party was less a single, tightly-bound organization and more a collection of somewhat autonomous groups. ${ }^{74}$ Among those who rose to positions of leadership in these groups were many who would contribute greatly to the postwar pro-Yugoslav movement. In the early 1930s, for example,

\footnotetext{
${ }^{71}$ On Fascist methods of breaking anti-Fascists on the national level, see Michael Ebner, Ordinary Violence in Mussolini's Italy (New York: Cambridge University Press, 2011), esp. ch. 4.

${ }^{72}$ Fogar, L'antifascismo operaio monfalconese, 155-60.

${ }^{73}$ The number of supporters of this organization was much higher, but only the most disciplined and dedicated were initiated as members. Hundreds more donated to the Red Aid (Soccorso Rosso) to support the families of blacklisted or arrested militants.

${ }^{74}$ Fogar, L'antifascismo operaio monfalconese, 41-48, 72-76, 155-64, 168-73.
} 
Ruggero Bersa (Calvo) ${ }^{75}$ a sector committee head in his early twenties, began working with longtime militants to link various cells in Monfalcone proper to those in the shipyard. Simultaneously, a separate group existed in the CRDA, organized by Armidio, Licio, and Vinicio Fontanot, the three sons of Giovanni. Separate still was the Communist Youth (Gioventù Comunista) which, under the leadership of Otto Ferlettich (Ferletti) and others, organized a parallel cell structure to the Party and pursued the long-term infiltration of the PNF, the police, and the military with undercover "Red premilitaries" (premilitari rossi). To safeguard these groups, each was kept isolated from the others, though all were in contact with a four-man federal committee. ${ }^{76}$ As these groups grew, however, so too did the risk of discovery. In 1932, OVRA, the secret police, began to infiltrate Communist organizations in the Monfalconese and the wider region and, in mid-1934, it managed to crack the local organization. The police carried out a wave of arrests, including some 107 individuals in total, among them the entire federal committee, most of the PCdI sector heads (including Bersa), much of the leadership of the Communist Youth, and the militant Silvio D. The regime tried the group before the Special Tribunal and most spent multiple years in prison or confino. ${ }^{77}$ Importantly, however, the Fontanot group and many low-level militants escaped arrest. In the second half of the 1930s, these individuals cautiously reestablished connections between cells, recruited new members, and escalated the anti-Fascist leaflet campaign. Still, the Party was hesitant to confront the regime directly. It orchestrated the clandestine passage of militants to Spain, where they could fight against the Nationalists in the ongoing civil war (1936-

\footnotetext{
${ }^{75}$ Names in parentheses are pseudonyms adopted by militants so they could operate clandestinely during the Fascist era. I include them because they often appear in lieu of real names in Party documents and postwar oral testimonies and interviews.

${ }^{76}$ Fogar, L'antifascismo operaio monfalconese, 82-86, 155-68.

${ }^{77}$ Ibid., 176-87. The record of the investigations and trials, with over 500 pages of documentation, can be found at the ACS, TSDS, ff processuali, b 513, f 05232.
} 
39), but within Italy the concern remained long-term preparation. ${ }^{78}$ The regime remained firmly in place and the task at hand was simple: organize, infiltrate, and wait. ${ }^{79}$

\section{Marketplace "Fascists:" Shopkeepers and Black-Marketeers in Peace and War}

And so, in the late 1930s, the Communists of the Monfalconese dutifully prepared and waited, unaware that the war looming on the horizon would radically transform their political opportunities and resistance. When news came in August 1939 of the shocking MolotovRibbentrop Pact, the local leadership made every effort to assure that local militants complied with the Comintern's truce with Nazi Germany. Particularly important in this regard was Ruggero Bersa, who, having returned from confino in 1938, slowly and cautiously reintegrated into the local Party network. Bersa assured his disconcerted comrades that "Germany remained enemy number one" and that this was merely a tactical truce. ${ }^{80}$ Bersa's leadership would not last long, however, as he was caught up in a new wave of preventive arrests in the Monfalconese around the time of Mussolini's June 1940 declaration of Italian "cobelligerency" in the Second World War. ${ }^{81}$ For the wider body of workers, Italy's entry into the war brought about a radical decline of their material conditions of life, an explosion of long-simmering resentments centered in the "lived space" of the marketplace, and the conceptualization of the local shopkeeper as a quintessential "Fascist."

\footnotetext{
78 Fogar, L'antifascismo operaio monfalconese, 209-224; Marco Puppini, "Quel viaggio dall'Isonzo all'Ebro: Attraverso ricerche d'archivio e interviste, dodici 'internazionali' isontini rievocano quegli anni di lotta in Spagna," Il Territorio 13 (1985): 31-42.

${ }^{79}$ The most enduring legacy of the late-1930s organizational push came in the form of the Party cell among the CRDA's pipefitters (tubisti), consisting of Giordano Tommasi/Tomasig, Vittorio Buttignon, Vittorio Cernigoi (Gip), Spartaco Padovan (Diego), Mario Fantini (Sasso), and Vittorio Vanon. This cell would give the anti-Fascist and, later, pro-Yugoslav movements much of their top leadership, Fantini as the commandant of Italy's largest partisan unit, the Divisione Garibaldi-Natisone, Padovan as the head of the partisan police, and Buttignon and Cernigoi as leading postwar workplace agitators. Fogar, L'antifascismo operaio monfalconese, 212.

${ }^{80}$ Even with Bersa's orders, certain components of the Party, especially the Fontanot group, continued to drop antiNazi, anti-war leaflets. Valerio Beltrame and Leopoldo Gasperini "Ricordi di Valerio Beltrame-Ario," IRSML-FVG, Fondo Gasperini, b 4, d 136.

${ }^{81}$ Fogar, L'antifascismo operaio monfalconese, 236-44; Fogar, Trieste in guerra 1940-1945: società e Resistenza (Trieste: IRSML-FVG, 1999), 1-5.
} 
That Fascism and marketplace exploitation would become so closely intertwined in the popular mind is somewhat curious, as early Fascists, including Mussolini himself, had been at the forefront of the popular attacks on merchants and shopkeepers in the years immediately after the Great War. Many had vilified such categories as parasitic exploiters and hoarders who used wartime scarcity to profit at the ordinary Italian's expense. ${ }^{82}$ Moreover, when faced with popular agitation over the high cost of living in the 1920s, the Fascist regime had continued to assign blame to "parasitic" commercial middlemen. It even introduced limited price controls on basic foodstuffs, compelled retailers to indicate clearly prices of all goods (that is, it outlawed price-negotiation), restricted the number of commercial licenses with the hopes of reducing retail overhead costs and thus prices, and briefly flirted with programs to introduce "modern" forms of commerce such as department and chain stores and PNF-controlled cooperatives. ${ }^{83}$

Such measures did not offset the reality that it was at the marketplace that ordinary Italians felt the burden of Fascism most heavily. Such was the result of the Battle for Wheat. From its beginning in 1925, this regime initiative aimed to promote self-sufficiency in food production, but, paired with consumer austerity, it translated into the lived experience of high food prices and hunger, particularly among the working poor. ${ }^{84}$ And the sacrifices demanded by Fascism only increased as the regime pursued its goals of expansion. Following the invasion of Ethiopia in 1935,

\footnotetext{
${ }^{82}$ Alceste De Ambris, a Fascist of syndicalist background, wrote in Mussolini's paper in 1919 that "where there is a shopkeeper, there is a thief." Jonathan Morris, "Retailers, Fascism and the Origins of the Social Protection of Shopkeepers in Italy," Contemporary European History 5, no. 3 (1996), 302-303; Kate Ferris, "Consumption," in The Politics of Everyday Life in Fascist Italy, eds. Arthurs, Ebner, and Ferris, op. cit., 123.

${ }^{83}$ Alexander Nützenadel, "Dictating Food: Autarchy, Food, Provision, and Consumer Politics in Fascist Italy, $1922-$ 1943," in Food and Conflict in Europe in the Age of the Two World Wars, eds. Frank Trentmann and Flemming Just (London: Palgrave Macmillan, 2006), 97; Jonathan Morris, “The Fascist 'Disciplining' of the Italian Retail Sector, 1922-40" Business History 40, no. 4 (1998), 142-43, 147.

${ }^{84}$ In the 1930s, Fascist policies and the Great Depression caused real wages to fall from 15 to $40 \%$. This, combined with the regime's high duties on food imports and use of export agriculture to balance its trade deficits, caused the per capita caloric intake of Italians to fall from 2883 in the late 1920s to 2664 a decade later, including major declines in meat, fruit, and vegetable consumption. Nützenadel, "Dictating Food," 94-96.
} 
Italy exported an increasingly large share of its agricultural produce in order to feed the Italian colonists settled in Africa and to exchange for industrial products with its new German ally. ${ }^{85}$ Thus, despite significant efforts to transform consumer austerity into a Fascist virtue and to supplant what the Fascist Minister of Corporations called the commercial "parasites and speculators" with a state-directed system of food collection, storage, and distribution, the marketplace became a primary location in which Italians bore the onerous costs of Fascist policies and where popular resentments toward Fascism came into focus. ${ }^{86}$

Beyond this, the marketplace also served as a location in which low-level Fascists manipulated the levers of local power to serve their self-interest, particularly through various forms of wartime black-marketeering and "hoarding." In this context, everyday marketplace experiences made clear the asymmetrical power relations between seller and purchaser and created opportunities for purchasers to associate the existing commercial system with "Fascism" and its practitioners as "Fascists." $"$ As the war progressed, this asymmetry became not only more profound, but also increasingly apparent to ordinary Italians.

Central to this process were both the wartime aggravation of conditions of material scarcity and the creation of many institutions and regulations originally designed to alleviate consumer hardship, especially the regime's rationing and price-control systems. Even before Italy entered

${ }^{85}$ Ibid., 98-101. Carol Helstosky, Garlic and Oil: Politics and Food in Italy (Oxford: Berg, 2006), 98-104. Importantly, however, consumers were not the only ones who bore heavy burdens from this campaign. Wholesaler prices rose further and faster than did retail prices, causing retailers' profit margins to decrease significantly. Morris, "Fascist 'Disciplining,," 149.

${ }^{86}$ The Fascist system developed from 1936 legally compelled producers to deliver 95\% of their grain to public storages, with goods then distributed through agricultural cooperatives and the state administration. However, the immensity of the task, combined with the refusal of many farmers to deliver their produce, the significant gap between food produced and food required, and the misallocation of goods through corruption or incompetence led to the system's partial failure. Nützenadel, "Dictating Food." 99-100. Regarding the Fascist propaganda campaigns in favor of austerity (often termed "anti-sanctions" campaigns given that the regime represented them as defensive measures against League of Nations sanctions), see Ibid., 101; Ferris, "Consumption."

87 Jonathan Morris has shown this association to be objectively false. Morris, "Retailers, Fascism" and "The Fascist 'Disciplining' of the Italian Retail Sector." 
the war in June 1940, the regime had begun rationing sugar, and following Mussolini's declaration of war, it extended the system of compulsory deliveries and rationing to edible oils and fats. ${ }^{88}$ Shortly thereafter, the regime established price controls that by 1942 applied to breads, fats, oils, cheeses, and meats, if not to most vegetables or fruits. ${ }^{89}$ The system consisted of three interlocking processes, each controlled by a different body. First was a state-directed supply system operated at a provincial level by the various Provincial Provisioning Section (Sezione Provinciale dell'Alimentazione, SEPRAL) bodies. Second, ration cards were issued by communal Rationing Offices, with consumers expected to file monthly goods reservations with local merchants, who then requested goods in the appropriate amount from SEPRAL. Finally, the local Annonarial Police were tasked with monitoring the actual exchange of goods at the point of sale to assure merchant compliance with rationing and price-fixing.

From the outset, however, this system functioned poorly, with vendors, farmers, butchers, and others seeking instead to exploit conditions of shortage and profit from ever-higher black market prices. ${ }^{90}$ As profit-rates from the black market increased, price-controlled goods simply disappeared from market stands and already by 1941 over half of the nation's grain yield was sold on the black market, and only $47 \%$ reaching the public storages. ${ }^{91}$ Thus, from mid-1941, the regime

\footnotetext{
${ }^{88}$ Consiglio Provinciale delle Corporazioni-Trieste, "Razione zucchero" (N. 591), 12 February 1940; Ministro per le corporazioni Ricci, "Decreto Ministeriale," 1 October 1940, both in ASBCM, b 1068, f Ctg XI.

${ }^{89}$ Comune di Monfalcone, "Listino prezzi massimi N. 39 in vigore dal 31 marzo 1942," 31 March 1942, ASBCM, b 1067, f 2. On these developments as a whole, see Nützenadel, "Dictating Food," 101-103.

${ }^{90}$ In Trieste Province, for example, the prefect regularly reported that butchers sold fresh pig fat outside of the rationing system and that people selling goods as simple as pasta and soup ingredients often violated these norms of sale. Prefetto Tamburini (Trieste), "Razionamento pasta e riso" (N. 3177/34167), 3 December 1940; Consiglio Provinciale delle Corporazioni (Trieste), "Vendita di grasso fresco" (N. 5897), 9 December 1940; and Prefetto Tamburini (Trieste), "Tesseramento" (N. 3177/3647), 7 February 1941, all in ASBCM, b 1068, f Ctg XI. Blackmarketeering ranged from underhanded trade (e.g. a doctor requiring a patient to hand over a portion of his or her rations before receiving treatment) to small-scale commerce in controlled goods with the sole purpose of survival to large-scale illicit commerce aimed at self-enrichment. See Steege, Black Market, Cold War, 49-50.

${ }^{91}$ Estimates suggest that the average Italian family was spending $40 \%$ of its income on the black market, though most working-class Italians, including most monfalconesi, simply could not afford black-market prices. Nützenadel, "Dictating Food," 101-103.
} 
continually reworked the system, drastically increasing penalties for violations - including the death penalty for the now-political crime of "economic treason," or speculation - and, more importantly, increasingly shifting responsibility for overseeing the nation's commerce into the hands of the PNF. Included in the latter was the placement of the Fascist federale of each province on the advisory committee for SEPRAL and the federali's responsibilities to investigate violations of rationing and price norms. In the Monfalconese, for example, provincial PNF secretary Giulio Dall'Ora was first to investigate rumors that local fishermen were skirting price-controls by selling their catches not at the Monfalcone market, but rather on nearby beaches at Duino and Sistiana. ${ }^{92}$ Yet, by appropriating ever more responsibility for market enforcement, the PNF sowed the seeds of its own de-legitimization. On the one hand, every negative market experience could now be associated with and blamed upon the Party, allowing these experiences to be viewed as living "Fascism." In this regard, the regime's decision to institute a bread ration in October 1941 was a watershed moment, destroying the last pillars of support for the regime. ${ }^{93}$ But even Fascist efforts to control prices could backfire, particularly due to their uneven application in different parts of the country. In 1943 the Ronchi fascio reported that "when the Party confronted the grave problem of the supervision of prices, the decision made a good impression; but the continual [price] increases, even if sanctioned by the bulletins, produces a sense of disillusionment," as did the

\footnotetext{
${ }^{92}$ Seg. Pol. Dall'Ora (PNF-Trieste), "Fornitura pesce” (N. 2129), 16 July 1943, ASBCM, b 504, fCtg 14, sf 5. Reports on the fasci of the Monfalconese in 1943 make clear that this was representative of a wider PNF claim to jurisdiction over policing the local markets. The San Canzian d'Isonzo fascio indicated that "the control of prices has, so far, been satisfactorily carried out by the Fascio," though reports from other communes indicate the PNF's efforts were not always so successful, nor could all members of the PNF be trusted to abide by regime regulations. Fascio di San Canzian d'Isonzo, "Comune di San Canzian d'Isonzo," Undated (Early 1943), AST, Pref-Gab 1923-52, b 456, unmarked tan folder. For the decrees that changed the functioning of this system and the punishment of violators, see Kingdom of Italy, "Legge 8 luglio 1941" (N. 645), 8 July 1941; SEPRAL-Trieste, "Conversione in legge del RDL 27 dicembre 1940 n 1716" 21 May 1941; and Kingdom of Italy, "Legge 22 aprile 1943" (N. 245), 22 April 1943, all in ASBCM, b 1068, f Ctg XI. The PNF had been trying to carve out a larger place for itself in monitoring market interactions since the autarchy campaign of the late 1930s. See Ferris, "Consumption."

${ }^{93}$ Simona Colarizi, "Vita alimentare degli italiani e razionamento (1941)," in L'Italia in guerra. Cinquant'anni dopo l'entrata dell'Italia nella 2 a guerra mondiale: aspetti e problemi storici, vol. 2 (Rome: Commissione Italiana di Storia Militare, 1991), 279-289.
} 
regime's failure to extend price controls and rationing to eggs, legumes, and potatoes as it had done in some of the larger urban centers. ${ }^{94}$ On the other hand, as the Party assumed a greater role in stamping out the black market at the provincial level, members of the Party at the local levelparticularly merchants and shopkeepers - used their authority to exploit rather than eliminate the black market. ${ }^{95}$ Such Fascists imbricated themselves within the structures of local power and in the offices tasked with implementing the system, turning them to their own advantage.

No case is more illustrative of this point than that of the wood and coal merchant Giovanni Linossi. In addition to being a prominent member of the local fascio, Linossi had managed by the early 1940s to secure positions as head of the local Rationing Office and of the Vigili Urbani (local police, which included the Annonarial Police), essentially holding all offices that were responsible for disciplining local markets. With these powers in hand, Linossi began using them to personal ends, falsifying ration cards and seemingly working with friendly (Fascist) merchants to secure the registration of purchases with these cards under false or duplicated names. Particularly egregious in the winter months of early 1942 was his use of his position as head of the Vigili Urbani to distribute unevenly a shipment of coal arriving from Yugoslavia, keeping the highestquality (and thus pricier) coal for himself, which he sold at tremendous profit out of a shop nominally under his mother's management. Linossi left behind only "dust" (polvere) for consumers to purchase through other merchants and regularly threatened to use his powers as head of the rationing office to withhold ration distributions from residents unless they purchased goods in his mother's shop. By April 1943, in response to growing popular discontent and Party

\footnotetext{
${ }^{94}$ Fascio di Ronchi dei Legionari, "Comune di Ronchi dei Legionari," Undated (Early 1943), AST, Pref-Gab 192352 , b 456, unmarked tan folder.

${ }^{95}$ Even in a more general sense, when dealing with non-Fascist actors, it was much easier (but still not easy) for the regime to police the activities of large agricultural producers than the countless exchanges in small shops throughout the country. During the war years, it was in the small shop that the regime's system of regimenting production and distribution most clearly broke down. Nützenadel, "Dictating Food," 102.
} 
frustration over Linossi's "absolute lack of discipline," he would find himself expelled from the PNF. ${ }^{96}$ A year later, after Linossi had left town, suspended from his offices, the carabinieri sought to ban his return. His schemes to line his pockets had left him "hated by the entire population" and thus a threat to public order. ${ }^{97}$

But Linossi was far from the only local Fascist or merchant to become embroiled in these schemes. That same year, a butcher from Ronchi was expelled from the PNF for the contravention the ration laws for meat and bone sales and the head of the Guardie Municipali (Municipal Guard) of nearby Grado was expelled for black-marketing and corruption involving the fish trade. ${ }^{98}$ Simultaneously, a Monfalcone merchant who in 1936 had been expelled from the PNF was caught again attempting to use his Fascist contacts to sell 36.38 hectoliters of black-market wine. For a decade before his expulsion, this man had sat on the Communal Commission for Commercial Licenses, using his power to carve out a protected commercial position for his shop before eventually being chewed up and spit out in a factional struggle of the local Party. ${ }^{99}$ In doing so, he had subverted the central Party's efforts to protect consumers from commercial "parasites." He utilized the institution that was intended to reduce the number of retailers (restricting licenses) and thereby reduce commercial mark-ups instead to further his own personal ends. ${ }^{100}$ Identified by the

\footnotetext{
${ }^{96}$ Consumers were upset by Linossi, but so too were non-Fascist shopkeepers, who became victims of extortion under threat of fines or closures. Seg. Fed, Giovanni Spangaro (PNF-Trieste) "Attività Giovanni Linossi" (N. LC/Me/3334/VI.Ris), 2 April 1943, Archivio di Stato di Trieste, Prefettura: Gabinetto, 1923-1952, b 456, f 053, sf 053: Monfalcone - Rapporto Squadristi - Incidente.

${ }^{97}$ Ten Col Comandante Petrini (CC RR-Trieste), "Promemoria Riservato Personale" (N. 6/9), 6 April 1944, AST, Pref-Gab, 1923-52, b 481, f 058, sf Linossi Giovanni.

${ }^{98}$ See the documents in AST, Pref-Gab, 1923-52, b 481, f 058, sf. 024: F[x] Giuseppe: Capo delle Guardie municipali grado.

${ }_{99}$ Dott. Contrada, "Monfalcone - Consigli tributari..." (N. 0264), 22 February 1948, op. cit.

${ }^{100}$ For information on Fascist-era licensing rules and institutions, see Morris, "Fascist 'Disciplining,," 152-54. Morris makes the point that complaints about clientelism and corruption in the granting of licenses were common and that the licensing and price-control systems often served to protect the interests of entrenched retailers and drive competitors out of business. Ibid., 154; Morris, "Retailers, Fascism," 318. The same could be said about the "surveillance squads" constituted to enter shops and assure that retailers were not selling goods at extreme mark-ups. Such squads were supposedly composed of "honest traders and sincere Fascists" drawn from the local Fascist traders' syndicate, but could easily fall prey to clientelistic abuses. Ibid., 315 .
} 
regional Party boss as a "merchant without scruples and profoundly dishonest," he received an "exemplary" punishment in an attempt to clear the Party from guilt by association. ${ }^{101}$ Significantly, in each of these cases, a local Fascist used his power and PNF contacts to gain what the state, the populace, and even the PNF leadership deemed to be an unfair commercial advantage. In none did these schemes remain hidden from the public eye.

For many ordinary people, then, it became difficult to distinguish between shortages caused by Fascist corruption, those caused by bureaucratic incompetence, and those arising from circumstance (war, the difficulties posed to agriculture and transport by Italy's natural geography, etc.). Italians, monfalconesi included, began to elide wartime shortage and Fascist corruption, believing that perhaps behind the closed doors of the local Fascist headquarters awaited stores of cheese, meat, and fresh fruits. ${ }^{102}$ Shortly after liberation, a group of Monfalcone's ambulant vendors would complain that during the ventennio the local market commission had served as an in-club for exploiters, the commissar a "component of the fascio [who] robbed and trafficked for the benefit of the Fascists, removing the mouthful of milk from the poor people from our children, wasting it by giving it to his associates." ${ }^{103}$ In contrast to the self-aggrandizing activities of particular Fascists, by early 1943 the fasci of the Monfalconese were almost universally reporting that, even if the war was won and the regime survived, the population expected a system of greater

\footnotetext{
${ }^{101}$ Seg. Fed. Giulio Dall'Ora (PNF-Trieste), "F[x] Francesco" (N. 77/Ris), 7/14/43, AS-BCM, b 503, f ctg 14, sf 5. ${ }^{102}$ One of the greatest contributing factors to this process was the scarcity of locally-produced goods at local markets, their having been taken by the state and distributed elsewhere. It was very difficult for Southern Italians, for example, to see so much fresh fruit produced around them, yet to see so little make it to the local market stand. Colarizi, "Vita alimentare," 285.

${ }^{103}$ Unsigned, "Una protesta" (N. 60), 14 May 1945, AS 1815/2/55. On the provincial level, too, the close association between black-marketeering and the PNF was well entrenched. In 1943, anonymous propagandists spread posters throughout Trieste listing twenty-six merchants associated with the black market and proclaiming that "almost all these members are enrolled in the PNF and they profit by practicing black-marketeering undisturbed." Notably, in his comments on this poster, the Questore revealed that there was a degree of truth to the matter, with three of the listed shops already having been investigated and charged with black-marketeering. Sfasc Tasso Plinio denuncia commercianti borsa nera, 1943, AST, Pref-Gab, 1923-52, b 456, f 0321.
} 
"social justice" in the postwar years, particularly regarding markets and "just" prices. ${ }^{104}$

\section{Monfalconese Anti-Fascists between Italy and Yugoslavia}

By 1943, resentments over everyday Fascism in workplace and marketplace had become particularly acute, but the war also brought a radically expanded range of opportunities for antiFascist action. Though Italy's declaration of war was a key moment for the nation, for monfalconesi it was the Axis invasions of Yugoslavia (April 1941) and the USSR (June 1941) that marked the true watershed. The first saw the collapse of the Yugoslav state, the establishment of brutal Axis occupation or puppet regimes, and the first stirrings of Yugoslav resistance movements. ${ }^{105}$ The second freed Communist militants in the Monfalconese, Yugoslavia, and elsewhere from the Comintern's awkward truce with Hitler.

With Operation Barbarossa, Tito’s Partisan movement emerged, and with it the expansion of anti-Fascist possibilities. Following Barbarossa, the Slovenian Communist Party (Komunistička partija Slovenije, KPS), part of the Yugoslav Communist Party (Komunistička partija Jugoslavije, KPJ), emerged as the driving force behind a multi-party Slovenian Liberation Front (Osvobodilna fronta, OF). ${ }^{106}$ Shortly after the invasion of the USSR, KPS head Edvard Kardelj called the OF

\footnotetext{
104 The San Pier d'Isonzo fascio reported that "generally there is the opinion that, the war having ended, the Regime must peacefully dedicate itself to the resolution of the social problem in the sense of achieving... a greater justice and a lessening of the distance between the various social categories." Fascio di S. Pier d'Isonzo, "Comune S. Pier d'isonzo," Undated (Early 1943), op. cit.

${ }^{105}$ On the Axis occupation of Yugoslavia and Yugoslav responses (collaboration and resistance), see Gregor Joseph Kranjc, To Walk with the Devil: Slovene Collaboration and Axis Occupation, 1941-1945 (Toronto and Buffalo: University and Toronto Press, 2013); Stevan Pavlowitch, Hitler's New Disorder: The Second World War in Yugoslavia (New York: Columbia University Press, 2008); Davide Rodogno, Il nuovo ordine mediterraneo: le politiche di occupazione dell'Italia fascista in Europa (1940-1943) (Turin: Bollati Boringhieri, 20030); Geoff Swain, Tito: A Biography (London and New York: I.B. Tauris, 2011); Jozo Tomasevich, War and Revolution in Yugoslavia, 1941-1945: Occupation and Collaboration (Stanford: Stanford University Press, 2001).

106 Though the OF was a united front organization under which all anti-fascist Slovenes could unify in the struggle for liberation, the KPS retained strict control of the organization, subordinating other parties and using the OF into a way to delegitimize any form of resistance that emerged outside of the control of the Communists. See the contributions by Tamara Griesser-Pečar, Damjan Hančič, and Renato Podbersič in Mateja Čoh Kladnik (ed.), Slovenia in the $20^{\text {th }}$ Century: The Legacy of Totalitarian Regimes (Ljubljana: Study Centre for National Reconciliation, 2016), chs. 3, 6, and 7 respectively.
} 
into active struggle against the forces occupying Yugoslavia, proclaiming the intention to unite all Slovenes, including those of the Primorska (Slovenian Littoral) - an area whose western boundary roughly overlaps with that of Italian Venezia Giulia - in a liberated state. The OF claimed even the Italian-majority coastal settlements of the region, which in the OF mind naturally gravitated toward their rural Slovenian "hinterland." Most often, claims involved all territory east of the Isonzo River, making the Monfalconese the westernmost extent of the Primorska. ${ }^{107}$

The OF stance complicated PCdI-KPS relations, in addition to opening new opportunities for anti-Fascist activities for the Communists of the Monfalconese. Though the PCdI had long accepted the idea of Slovenian annexation of the Slovene-majority areas of Venezia Giulia, the issue of Italian-majority areas like the Monfalconese and Trieste had never been resolved. Moreover, the PCdI's acceptance of many Slovenian claims had been paired with the assumption that the party would be the organizational pole for this struggle among both Slovenes and Italians living within Italian borders. From late 1941, however, the KPS initiated a campaign of institutional conquest of the PCdI in Venezia Giulia. Kardelj exchanged a series of letters with Umberto Massola (Quinto), a member of the PCdI Central Committee, in which he requested that all members of the PCdI in Trieste Province, including those of the Monfalconese, pass into the KPS and aid in the Slovenian liberation struggle. Massola immediately rejected this proposal, suggesting that the PCdI was slowly laying the groundwork for a mass movement to overthrow Mussolini's regime entirely, which, in the grand scheme of things, was a more important task than merely breaking off a chunk of the dictatorship's territory. ${ }^{108}$

\footnotetext{
${ }^{107}$ In a few cases, the OF would express claims on the territory up to the Tagliamento, but these were far less common. On the KPS/OF claims in 1941-43 and negotiations with the PCdI, see the introduction to Troha, Chi avrà Trieste?, 2009.

${ }^{108}$ Undoubtedly, the relatively firm footing of Mussolini's dictatorship and police state, which contrasted greatly with the chaos unfolding in occupied Slovenia and Yugoslavia, was part of the reason that the PCdI continued its longstanding policy of slow infiltration at this time rather than embracing armed confrontation. Umberto Massola, "Sulla nostra politica..." January 1942, APC-IG, fondo PCI Direzione Nord, FVG-Jug, f 2, sf Massola agli Jugoslavi,
} 
Despite this PCdI refusal, the KPS leadership decided to push forward with the formation of KPS and OF cells in Venezia Giulia. According to Rudi Uršič (Rodolfo Ursini), a primary KPS organizer in the Primorska, the KPS sent its representative Oskar Kovačič to Monfalcone, where together with local Slovenes he began to establish KPS cells and an OF committee for the Monfalconese. Though the initial reception was cool, Uršič suggests that by mid-1942, the KPS and OF had gained a foothold among the radical workers in the shipyard, even if the militants of the outlying villages remained more distant. Particularly fruitful was a secret meeting in Trieste in the fall of 1942, during which members of the Bersa group, bolstered by a new class of militants that included the young Valerio Beltrame (Ario), met with OF representatives and decided to assist in creating local committees. Within a couple of weeks Beltrame and three other monfalconesi were caught up in a wave of arrests in Trieste Province, but not before they had established the skeleton of a local OF network. ${ }^{109}$ Though the OF in the Monfalconese would remain marginal until the final two years of the war, the Fascist regime's inability to resolve problems of food shortage, inflation, unreliable rations, and black-marketeering, as well as its relentless push to hasten work rhythms and "militarize" work discipline, made the Monfalconese increasingly fruitful ground for OF recruitment, particularly as the workforce ballooned to over 11,000 by 1943. ${ }^{110}$

More broadly, the longtime strains of everyday Fascism and the aggravating context of the

d 20-2-A; KPS, Letter to PCI, January 1942, AM-IG, mf 93, f C, d C:9 ;Massola, "Maria arrivata bene..." February 1942, APC-IG, fondo PCI Direzione Nord, FVG-Jug, f 2, sf Massola agli Jugoslavi, d 20-2-B.

${ }^{109}$ According to Uršič, the meeting was in early October, but Beltrame places it in September. Despite the different dates, they generally agree on the content of the meeting and the arrests that followed. Beltrame and Gasperini "Ricordi di Valerio Beltrame-Ario," op. cit.; Rodolfo Uršič, Attraverso Trieste: un rivoluzionario pacifista in una città di frontiera (Rome: Studio i, 1996), 153-59. On the slow initial reception, see KPS, Letter to PCI, January 1942, op. cit.

${ }^{110}$ Fragiacomo, Fabbrica e comunità, 34. Regarding work rhythms, nine shipbuilders died in October 1941 during the deadliest of the various wartime accidents. Giulio Mellinato, "Strategie imprenditoriali e sviluppo del Cantiere di Monfalcone," Il Territorio 9 (1988), 25-26. The "militarization" of the shipyard included the trial of absenteeism before military tribunals. See Cernigoi, Puppini, and Valcovich (eds), Cento anni di cantiere, 36. 
war made monfalconesi more willing to speak against the regime, even if only in spaces thought to be safe. By 1943, as Italian defeat loomed more and more clearly on the horizon, regime forces noted a marked increase in defeatist and anti-Fascist "grumbling" in the Monfalconese, a phenomenon distinct from the overtly anti-Fascist leafletting of the PCdI and OF. ${ }^{111}$ The 1943 reports for the local fasci provide insight into this growing discontent. In Monfalcone, the fascio reported that, though the political situation was "good" in the historic town center, the CRDA workers were not yet "sufficiently oriented and catechized," instead tending to skip Party rallies and even to participate in cautious counter-demonstrations. ${ }^{112}$ In nearby Ronchi, the situation was worse: "it is much polluted both on the part of elements who frequent the shipyard and by the Slavism of nearby Doberdò del Lago." This was particularly the case among the youth, who had a greater tendency than others to participate in negative "murmurings and discussions about the men and actions of the Regime." In sum, the fascio concluded that, "the educative activity of Fascism has been and remains superficial."113

As war conditions continued to deteriorate for residents of the Monfalconese and as Axis war effort flagged, many monfalconesi began to consider direct action against the regime. When the workers of Turin, Milan, and other northern Italian cities engaged in the strikes of March 1943, the monfalconesi considered joining them, but decided against it given the exceptional disciplinary regime already imposed on the region as part of the anti-OF campaign. ${ }^{114}$ Unable to engage in such a strike, some of the boldest anti-Fascists decided to join their Slovenian comrades in armed

\footnotetext{
111 The PCdI continued to drop leaflets with phrases such as "Sabotage the Fascist War!," "Long live the Rebels!," "Down with the Duce!," and "We will lose the war!" S Ten Comandante Sedita (CC RR-Monfalcone), "Segnalazione" (N. 6/13), 4 April 1943; and Capo Delegazione Mitrani (Ministero della Produzione Bellica), "Scritta sovversiva Cantieri Navali di Monfalcone (Aus A)" (N. 1832/R-TR), 8 July 1943, both in AST, Pref-Gab 1923-52, b 452 f 06.

${ }^{112}$ Fascio di Monfalcone, "Comune di Monfalcone," Undated (Early 1943), AST, Pref-Gab 1923-52, b 456, unmarked $\tan$ folder.

${ }^{113}$ Fascio di Ronchi dei Legionari, “Comune di Ronchi dei Legionari," Undated (Early 1943), op. cit.

114 This disciplinary system by 1942 already included strict curfews and the rather arbitrary deportation of suspected subversives. Fogar, L'antifascismo operaio monfalconese, 280-85.
} 
struggle. That same March, Vinicio Fontanot, having avoided the waves of arrests that had swept up many of his closest collaborators, began negotiating with the KPS leaders in Trieste to send Monfalconese youths to train as guerrillas with the OF in the Slovenian interior, with the goal of them returning home and further disseminating this training. Though Fontanot's initiative had the support of the Party secretary in Trieste, it soon stalled when central leadership learned of and rejected the plan. ${ }^{115}$

The Fascist security apparatus stepped up its efforts to uncover the Communist and OF networks of the Monfalconese in early July. It targeted individuals like the young Renato Rigonat, whose brother Desiderio the regime had recently unmasked as a PCdI infiltrator within the PNF and Italian Army. In this context, many monfalconesi became restive. After watching the Fascist police search Renato's home for weapons and throw him into a Triestine prison, some ten militants, Fontanot among them, took up arms and joined the OF. Thus, even before the collapse of Mussolini's regime, the partisan war had come to the Monfalconese. ${ }^{116}$ For participants in this struggle, as well as the wider body of monfalconesi, the past and continuing experience of everyday Fascism would play a major role in shaping how they conceptualized their armed resistance and how they imagined the postwar society for which they fought, their range of options shaped by their indeterminate position, straddling Italy and Yugoslavia.

\footnotetext{
${ }^{115}$ Uršič, Attraverso Trieste, 218-25. In March 1943, in the nearby Natisone Valleys of eastern Friuli, the PCdI militant Mario Lizzero had already formed the first Italian partisan unit, the Garibaldi Detachment (Distaccamento Garibaldi), after direct negotiations with the commandants of the OF forces. Cernigoi, Scelte politiche e identità nazionale, 8687.

116 Desiderio Rigonat, who had taken the Fascist oath and joined the army with the goal of covertly spreading Communist ideas, was discovered and tried by the Special Tribunal along with his comrade Mario Blason in 1941-42. Renato Rigonat, Memorie (Ronchi dei Legionari: Consorizio Culturale del Monfalconese, 2012), 29-30, 41-43. Cernigoi, Scelte politiche e identità nazionale, 88-89; Fogar, L'antifascismo operaio monfalconese, 255-56.
} 


\section{Chapter 2: Civil War and Visions of a New World}

Fascism did not die with the death of Hitler and Mussolini, just as it was not born from them.... Fascism has been defeated but not entirely. It has left heirs. They mask themselves in various forms, in various ways, lurking always in the shadows. When they come into the light they take different shapes. If one doesn't want to fall prey, one must be careful to cut out their roots to the very bottom! ... It is necessary to unmask the remnants of Fascism."1

- From a Communist-aligned broadsheet in Monfalcone, 11 January 1946.

This call to action was printed some thirty months after Vinicio Fontanot and his small band of monfalconesi partisans departed to join the OF in early July 1943. Much had happened in the interim, but the fundamental idea that undergirded this call - the idea that "Fascism" was not merely the Duce or even the body of PNF cardholders, but rather something more amorphous was well entrenched in their thinking when they made the choice to take up arms. After living twenty years of everyday Fascism, these and other Monfalconese anti-Fascists understood Fascism to be the Duce and PNF plus certain reviled social categories and resented social interactions. Fascism was something as mundane as dealing with an exploitative shopkeeper or working for a domineering boss in a mindless and thoroughly routinized job. As such, it was something that could be extirpated only through social and political revolution and the reshaping of society's dominant values, without which, even if the dictatorship was toppled, the Fascist threat would reconstitute itself in a "masked" form.

When Fontanot and his band set off in early July, the prospects of bringing such a revolution to the Monfalconese seemed a fantasy - but then, suddenly, it did not. Just a few weeks after their departure, news reached Monfalcone that Mussolini had been toppled and that it was not his longtime Communist enemies who were responsible. Rather, shortly after the Allied landing in Sicily, the Duce's former allies removed him from power in a palace coup, attempting

\footnotetext{
${ }^{1}$ Una compagna, "Fascismo," Unità Operaia (Spremitura) (N. 1.), 11 January 1946, AS 1570, b 12, f 8. Italics added.
} 
to save their own skins. When the news of Mussolini's fall reached Monfalcone the next morning, there was genuine euphoria. For monfalconesi, apart from a now small number genuinely invested in the Fascist Party, Mussolini's fall on 25 July 1943 was a sublime moment in which the people suddenly regained power after being kept in a state of political infancy by twenty years of dictatorship. It was a moment in which everything suddenly seemed possible, even those hopes which had been mere pipedreams earlier that month. ${ }^{2}$

\section{July: The Fall of Fascism, the "Hunt for Fascists," and Business as Usual}

In Monfalcone, spontaneous demonstrations erupted, centered around the proud display of the banned color red. Accompanying them was a non-lethal "hunt for Fascists" (caccia al fascista), in which violence was more symbolic than life-threatening. According to Mario Tonzar, a shipyard worker and future Communist militant, he and others went immediately to the CRDA director to demand a celebratory work-stoppage. The director obliged and Tonzar recalls that "someone from Turriaco who had the Italian flag, had rolled up the green and the white in such a way that only the red of the flag was seen and it was put at the head of the procession." 3 Similarly, Spartaco Romano, whose Socialist father had long opposed the Fascists, "spontaneously went to shout in the streets among the crowd. Those who remained in the shipyards began to dye the Fascists red with minium [a red mineral] and to force them to flee."4 Others gathered around the shipyard's internal train, which brought the clerks and managers from their distant and comfortable housing

\footnotetext{
${ }^{2}$ In memoirs and interviews about this moment, emphasis is placed on the improvised and excited nature of the immediate anti-Fascist demonstrations. See Di Gianantonio et al., L'immaginario imprigionato, 43-45. On further discussion of the fall of Fascism and then the Resistance as a chance to begin anew or as a coming-of-age moment, see Pavone, A Civil War, 35-39.

${ }^{3}$ Tonzar, La valigia e l'idea, 71-72.

${ }^{4}$ I have been unable to locate any other sources that confirm Romano's testimony about dying Fascists red. In any case, this action can be interpreted as a ritual inversion of the squadrista practice of feeding castor oil to their Socialist enemies. Alfredo Bonelli, "Seconda testimonianza del monfalconese Romano Spartaco," 19 March 1981, IRSML, Fondo Cominform, b 99, f 2 .
} 
to the worksite, bombarding these quintessential "Fascists" with stones as they arrived for work. ${ }^{5}$

Yet the collapse of Mussolini's regime meant far less immediate change than was at first assumed. The new royal government of Marshal Pietro Badoglio was no more democratic, nor less anti-Communist than the Fascist government that had proceeded it. Moreover, the war was still on, and at least for the time being, Italy remained an Axis power. In such contexts, there was a limit to how much agitation the forces of order would accept. These forces willingly accepted a period of primarily symbolic purging but expected this to be brief and only moderately violent. They did little to stop workers from physically expelling Fascists, and especially squadristi, from the CRDA. In fact, Admiral Rizzo, who had replaced Giunta as CRDA president, immediately suspended all squadristi employed by the firm. ${ }^{6}$ However, when events threatened to go further, as they did by the evening of 26 July, Badoglio's government stepped in. On that day, workers formed a processional column, marching and issuing demands for Italy's immediate surrender and the restoration of democratic liberties. (Figure 6). When the increasingly bold workers, already having sacked Monfalcone's GIL headquarters, set off toward the fascio, the Carabinieri feared events were slipping out of control. To disperse the workers, they shot into the crowd and threw a grenade, which killed one worker and wounded fifteen more. ${ }^{7}$ That same evening in Turriaco some 200 workers assaulted the fascio headquarters, striking Fascist symbols from the façade. Before they could break into the building, however, the local Carabinieri intervened, throwing a "warning" grenade, which had the desired effect. ${ }^{8}$

Admiral Rizzo wasted no time in responding to the disorders, ordering the arrest of 200

\footnotetext{
${ }^{5}$ Fogar, L'antifascismo operaio monfalconese, 285-91.

${ }^{6}$ Mellinato, "Strategie imprenditoriali," 26-29.

${ }^{7}$ Fogar, L'antifascismo operaio monfalconese, 285-91; Tonzar, La valigia e l'idea, 71-72; Cernigoi, Scelte politiche e identità nazionale, 91-92.

${ }^{8}$ CC RR-Monfalcone, “Segnalazione” (N. 60/26-1), 27 July 1943, AST, Pref-Gab 1923-52, b 452, f 064.
} 
individuals with subversive "precedents" and sending some 200 policemen and Carabinieri and 500 soldiers to restore order to Monfalcone on the morning of 27 July, particularly inside the CRDA. Accompanying the soldiers were four prominently displayed ambulances, meant to send the message that these forces had orders to fire. ${ }^{9}$ Despite this warning, a column of over 400 workers gathered to march through the shipyard, shouting anti-war phrases, seeking out remaining Fascists, and even beating isolated policemen. ${ }^{10}$ When workers continued to strike and demonstrate, now protesting the presence of soldiers in the workplace, Rizzo responded with a "show of force." He ordered troops to fire into the crowds, wounding seven, one fatally. ${ }^{11}$ The following afternoon, when a crowd gathered outside the CRDA gate in protest, the forces of order again opened fire, wounding another. In the face of such violence, most workers simply gave up on demands for democratic liberties and returned to work. As Spartaco Romano would later reflect: "Then, with Badoglio's government, I re-entered the shipyard."12 The abruptness of his comments reflects, in many ways, the abruptness with which the euphoria of Mussolini's fall soon passed.

Yet business as usual was no longer acceptable for many monfalconesi - and not only for those few KPS- and OF-loyal militants who had attempted to bring the town's residents into their struggle for Yugoslav annexation. While the KPS again unsuccessfully attempted to convince the PCdI to pass its Julian militants into the ranks of the KPS, independently-minded PCdI militants formed a clandestine "city committee" that would provide political leadership for Monfalcone in

\footnotetext{
${ }^{9}$ Mellinato, "Strategie imprenditoriali," 29.

${ }^{10}$ Prefetto Cocuzza (Trieste), "MORELLO Giuseppe - Guardia di P.S...." (N. 34127), 19 August 1943, ACS, MI, DGPS, Seg del Capo della Polizia, Servizi di Polizia Attiva, b 54, f 89, sf 13. Very few Fascists showed their faces in those days. As one of the participants later recounted, workers had already gone into the villages and seized the uniforms of Fascists, burning them in a bonfire and later warning those few Fascists who had "always behaved themselves well" to stay home from work. By contrast, "the majority of Fascists, those who were more compromised, had gone away." Cernigoi, Scelte politiche e identità nazionale, 92.

${ }^{11}$ For Rizzo's account of events, see Amm. Luigi Rizzo, "Diario," 2 August 1943, ACS, Fondo IRI, Numerazione Rossa, b R1591.

${ }^{12}$ Bonelli, "Seconda testimonianza del monfalconese Romano Spartaco," 19 March 1981, op. cit.
} 
the case of a power vacuum, attempting also to form an independent syndicate, headed by a factory committee within the CRDA. ${ }^{13}$ Perhaps most ominously, in a poster dated 28 July and spread throughout the town (including posted to carabinieri headquarters), local Communists, no doubt enraged by the recent bloodletting, called for the overthrow of the Badoglio regime and the violent elimination of the Fascists. Addressed to Italian soldiers, the poster indicated that

[t]he Italian people rise to fight against the new, bloody governors of Italy - against Badoglio - Badoglio now has power in the most important Italian cities, in the heart of the Italian liberation movement: Turin, Milan, Bologna, Florence, and elsewhere. $\ldots$

The Communist Party of Italy has given birth to the INF. In this there are five parties united, among them the PCI and the Catholic party. At Turin the press has communicated the proclamation of the INF; in this proclamation it invited the Italian people to fight against Badoglio and the other remnants of Fascism....

$\cdots$ Italian workers, citizens, and soldiers, go into the streets and demand immediate peace, the expulsion of the Germans, and liberty....

Kill the hated Fascists and policemen. ${ }^{14}$

Yet despite the seething resentments felt by such a large number of monfalconesi and the open call for revolutionary action, nothing of the sort was carried out in Monfalcone. A small trickle of Slovenian and Italian-speaking Communist youth continued to flow into the OF military forces, and workers increasingly contemplated what it might mean to be truly done with Fascism, but clandestine preparation remained the party line for the PCdI.

\section{September 1943 and the Explosion of Armed Resistance:}

A spark would be necessary to transform the poster's calls for revolution into a reality, and that spark came on 8 September, when Italy had made peace with the Allies. Having long suspected that the Badoglio government was negotiating with the Allies, the Germans had devised a plan to

\footnotetext{
${ }^{13}$ CC-PCS to Compagno Quinto [PCI], 20 August 1943, AM-IG, mf 93, d C:14; Fogar, L'antifascismo operaio monfalconese, 285-91, 318.

${ }^{14}$ Ten. Com. Sedita (CC RR-Monfalcone), "Segnalazione" (N. 2/38-1), 3 September 1943, AST, Pref-Gab 1923-52, b 452, f 064. Underlining in original.
} 
invade and occupy Italy in such a scenario. Included in the plan was the direct annexation of Venezia Giulia to the Reich under the name Adriatic Littoral (Adriatisches Küstenland), as this was vital transit territory linking German operations in Italy and the Balkans with the Reich itself. ${ }^{15}$ It was the German decision to execute this plan after 8 September that provided the necessary spark. In one of the most striking instances of the Italian Resistance, the workers of the Monfalconese rose immediately to meet them. When word arrived that the Germans were advancing southward through Gorizia Province, 700-900 monfalconesi, primarily workers from the CRDA (many still wearing their blue work outfits), gathered to form a partisan brigade, calling themselves the Proletarian Brigade (Brigata Proletaria). PCdI militants formed these ill-trained hundreds into three battalions, scrambling to find weapons with which to equip them. The workers marched into the hills on 10 September and by month's end, some hundred lay dead, the Brigade shattered by the seasoned Wehrmacht in the so-called Battle of Gorizia. The remainder struggled to return home without being detected by the Germans, now the occupiers of their town. ${ }^{16}$

Though the decision of the monfalconesi to confront the Wehrmacht in September 1943 may seem like a fool's errand which could (and did) only end in disaster, the willingness of so many to risk their lives in this venture was indicative of a broad and intense sentiment that the moment was ripe for a fundamental restructuring of society - but one that could only happen if the Germans were kept out. What is notable about the Monfalconese in the nineteen months of German occupation was that, even after this defeat, its residents continued to resist with markedly atypical intensity. Though a comprehensive examination of the activity of Monfalconese's

\footnotetext{
${ }^{15}$ Fogar, L'antifascismo operaio monfalconese, 303-05.

${ }^{16}$ Fighting beside the Proletarian Brigade were also certain units composed of Italian soldiers and carabinieri officers. The numerical estimates come from Fogar, L'antifascismo operaio monfalconese, 306-14. See also Cernigoi, Scelte politiche e identità nazionale, 97-102; Luciano Patat, La battaglia partigiana di Gorizia: la resistenza dei militari e la 'Brigata proletaria' (8-30 settembre 1943) (Gradisca d'Isonzo: Centro 'Leopoldo Gasparini,' 2015).
} 
partisans is beyond the scope of this dissertation, it should be noted that, even after the Proletarian Brigade was dispersed, its members, joined by a continual flow of recruits primarily from the CRDA, formed the cores of two additional primarily Monfalconese partisan brigades (Figure 7). ${ }^{17}$ Moreover, it was the CRDA pipefitter (tubista) Mario Fantini (Sasso) who served as longtime commandant of the largest partisan unit of the Italian Resistance, the Garibaldi Division-Natisone (Divisione Garibaldi-Natisone), with many monfalconesi by his side (Figure 8). ${ }^{18}$

The armed struggle to expel the Germans received wide popular support in the district. Undergirding these district's partisan brigades was a wide range of support institutions dedicated to the maintenance of communications, to the creation, collection, or requisition of supplies, and to the transport of supplies to the partisans in the field. Most notable in this regard was the “Montes” Intendency (Intendenza “Montes”), named after its founder Silvio Marcuzzi (Montes), which oversaw the monthly gathering, requisitioning, and manufacturing of tens of metric tons of supplies. ${ }^{19}$ Within the shipyards, workers of the Communist-directed Workers' Unity (Unità operaia) - often reactivated cells of outlawed anti-Fascist organizations - performed various sabotage and pro-partisan theft operations, at times in concert with sympathetic warehouse operators and managers. By December 1944, this organization would claim 6000 adherents in Monfalcone alone, and over the course of 1943-45, some 503 employees of the CRDA-

17 These were the Triestine Assault Brigade (Brigata d'Assolto Triestina), formed in April 1944 after the reorganization of a battalion-level unit, and the Fontanot Brothers Brigade (Brigata Fratelli Fontanot), formed in December 1944 and named after Vinicio Fontanot's fallen brothers, Armidio and Licio. Cernigoi, Scelte politiche e identità nazionale, 119-20, 135-40, 168-70.

${ }^{18}$ Ibid., 187. On Mario Fantini and his role in the growth of the Divisione Natisone, see Luciano Patat, Mario Fantini "Sasso": comandante della Divisione "Garibaldi Natisone" (Udine: IFSML, 2000).

${ }^{19}$ In September 1944, for example, it gathered over 20,100kg of solid foodstuffs, including 5390kg of meat and over $6000 \mathrm{~kg}$ of flour, the latter of which it baked into $250 \mathrm{gr}$ ration loaves in its clandestine bakeries. The Intendancy also operated secret tailoring and shoemaking workshops. Francesco Dilizza (Intendente-Brigata Triestina), "Relazione per il Concorso indetto dal Comando Generale NOV e POS per il period 1-30 settembre," 23 October 1944; Unsigned, "Cronistoria del Battaglione Misto Intendenza Sabotaggio," Undated; Unsigned, "UFFICIO Intendatura" (N. 13/3), Undated, all from IFSML, Fondo Giacuzzo, b 4, f 123. 
Monfalcone would die either as partisans in the field or in anti-partisan crackdowns. ${ }^{20}$ In the words of one militant, the shipyard served as a "sun that shines light on the entire zone."21

\section{Violence and Civil War in Monfalcone: Fascists and the Gruppo d'Azione Patriotica (GAP)}

The Resistance was a struggle to expel the Germans, but also a civil war experienced as intense and bitter conflict at the local level, and the Monfalconese was one of its bloodier theaters. ${ }^{22}$ The intensity of the Monfalconese's civil war resulted from many factors. Critical among them were the zone's location in contested territory and the nature of the contesting parties (especially the Yugoslav Communists), which drove many locals into collaboration with the Germans, as well as the fact that the Allies extensively bombed the CRDA beginning in April 1944, intensifying resentment for those deemed responsible for starting the war. ${ }^{23}$ Finally, Fascist repressive actions against OF partisans and their civilian supporters began in Venezia Giulia earlier than elsewhere in Italy (and Axis control persisted longer), driving a cyclical escalation of violence that reached

\footnotetext{
${ }^{20}$ The origins of Worker's Unity are found in Trieste in the time even before 8 September 1943, when the PCdI and KPS attempted to lay the foundations for a joint Italo-Slovenian mass anti-Fascist movement. OK KPS za Trst, "Politično in organizacijsko poročilo ODE-ja tržšega Okrožja," 12 December 1944, IFSML, Fondo Slovenia: Documenti in copia..., b 4, f 351. The idea of joint Italo-Slovenian action also had longer precedents in Haspburg-era Austro-Marxist politics and in the activities of the region's armed anti-Fascist and Slavic-nationalist group TIGR, which at times worked with Italian anti-Fascists ranging from Giustizia e Libertà to the PCdI. Cattaruzza, Italy and Its Eastern Border, 140, 170; Uršič, Attraverso Trieste, 87-92. On the dead from the CRDA-Monfalcone, see Cernigoi, Puppini, and Valcovich (eds), Cento anni di cantiere, 39.

21 "Lorenzo," "Oservazioni," December 1943, op. cit. The Communist-led workers' resistance was not the only resistance revolving around the CRDA. Even the Cosuliches worked against the Germans in certain respects late in the war, mainly through their longtime ally (and onetime agent) Bruno Coceani, prefect of Trieste from 1943-45. With the goal of maintaining an Italian, non-Communist Trieste, he at first worked with the Germans, but later lent aid to the CLN-Trieste and pushed for a transfer of control from the Germans to the pro-Italian CLN. Fogar, Trieste in guerra, 83-92.

${ }_{22}$ Pavone, A Civil War.

${ }^{23}$ Much Julian collaboration thus resulted not from the collaborators' ideological commitment to Fascism or Nazism, but rather uncertainties related to the joint national and ideological threats posed by Tito's Partisans. As the Kingdom of the South's Naval Ministry informed Prime Minister Ivanoe Bonomi in November 1944, "the Italians of Istria, of Trieste, and of the Goriziano... feel themselves to be under the protection of the Germans because, after what happened in September 1943 [the first wave of foibe killings], they fear to be massacred by Tito's Partisans. It will presumably be necessary to eliminate this fear to permit them to disengage morally from the Germans." Ministero della Marina, Stato Maggiore, SIS, "Aspetti della questione adritica," 13 November 1944, ACS, PCM, Gab, AA GG, Fascc per categorie, 1944-47, b 3535, f 15/2 N. 15204. See also Fogar, Trieste in guerra, 83-92. On the bombings, see.Carlo Alberto Borioli, "Bombe su Monfalcone," Il Territorio 3 (1995): 48-56.
} 
frightening heights by $1945 .^{24}$

But the most important factor that played into the intensity of the Resistance in the Monfalconese was the strength of the Communist organs, and particularly of the Patriotic Action Group (Gruppo d'azione patriotica, GAP). This organization had started to take shape during the late-July "hunt for Fascists," consisting of roughly fifty men divided into small tactical squads suited for urban partisan activities. When the newly-renamed Italian Communist Party (Partito comunista italiano, PCI) embraced armed resistance after 8 September, the unit took off, gaining a significant boost when Vinicio Fontanot (Petronio) took command that December. Under Fontanot, the GAP engaged in various activities including seizing German supplies and performing sabotage actions, the most notable among them a daring raid on the Ronchi airport on the night of 4/5 February 1944, in which it destroyed three of the thirty Axis warplanes stationed there. ${ }^{25}$ Fontanot would build the Monfalcone GAP into one of the most feared organizations of the Italian Resistance, its field of activity stretching from the outskirts of Trieste all the way to the lower Friulan plain, often in cooperation with the GAP's Slovenian counterpart, the VDV, and Tito's secret police, the Department for People's Protection (Odjeljenje za zaštitu narodna, OZNA). ${ }^{26}$

But the GAP's primary purpose was far bloodier than sabotage. Shortly after the Germans arrived and restored Mussolini to power, now as a head of the new Republican Fascist Party

\footnotetext{
${ }^{24}$ According to internal OF Liberation Committee reports produced after the war, between 1941 and 1945 the Fascists and then Germans summarily executed 22 monfalconesi (excluding partisans in arms) and arrested over 525, of whom nearly 100 died or vanished in Axis camps. Ronchi, which fared the worst per capita, suffered 7 executions, 196 arrests and deportations, and 32 dead or missing in camps. Unfortunately, the reports do not reveal the precise reason of each arrest or execution and one must keep in mind that the figures may be somewhat inflated, whether for political reasons or because it took individuals some time to return home from the camps after the war. See commune-level reports in AS 1818/232/3023.

${ }^{25}$ Prefetto Coceani, "Aeroporto di Ronchi dei Legionari - Incendio apparecchi” (N. 01482.U.P.), 11 February 1944, ACS, MI, DGPS, A5G II Guerra, b 150, f 226, sf 2.

${ }^{26}$ For an account of the GAP's formation and activity from one of its members, see Riccardo Giacuzzo's various typescript notes, compiled in the 1970s and held at the IFSML, Fondo Giacuzzo, b 5, f 134. On connections between the GAP and OZNA, see Rolf Wörsdörfer, Il confine orientale: Italia e Jugoslavia dal 1915 al 1955 (Bologna: Mulino, 2009), 231.
} 
(Partito fascista repubblicano, PFR), the GAP began a campaign to "liquidate" spies and individuals who had played or continued to play important roles in Monfalconese Fascism. This included prominent squadristi, former heads of the district's fasci, and those belonging to the PFR and its paramilitary bodies. The first murder that can reasonably be attributed to the GAP occurred on 8 December 1943, when individuals identified as "partisans" by a PCI militant murdered a local squadrista named Falchi, attempting at the same time "to bring the Fascist secretary [of Monfalcone] to justice," but managing only to wound him. ${ }^{27}$ A month later, on 9 January 1944, the squadrista Ferraro Pasquale was murdered. Immediately after, Prefect Coceani indicated to the carabinieri that both murders followed a pattern and resembled "preordained executions." In both, the task was entrusted to "young cyclists, those with knowledge of the place, who quickly, after committing the misdeed, are able to escape with the bicycles." The triggermen, without doubt, were drawn from among "the Communists and suspected partisan element." ${ }^{28}$

In the sixteen months of civil war that followed, the GAP would continue this offensive, becoming particularly bold after March 1944, following the militarization and mobilization of all Triestine squadristi within the National Republican Guard (Guardia Nazionale Repubblicana, GNR). ${ }^{29}$ A cyclical escalation of violence followed, with the GNR and PFR members arresting and torturing those suspected of connections to the partisans, as well as performing arbitrary and widespread searches of the homes of suspected anti-Fascists. ${ }^{30}$ Indicative of this trend are the

\footnotetext{
27 “Lorenzo," "Questioni della "Venezia Giulia"” and Attached, 20 December 1943, AM-IG, mf 93, f 1, sf b, d 17.

${ }^{28}$ Pref. Coceani (Trieste), Untitled Report (N. 0523), 11 January 1944, AST, Pref-Gab 1923-52, b 481, f 058, sf Ferraro Pasquale.

${ }^{29}$ Born in late 1943, the GNR consisted of the merged carabinieri, regular PS, and MVSN members. The mobilization of all squadristi within this force, in addition to preexisting militiamen, marked a major escalation of the civil war. Federale L. Ruzzier (PFR-Trieste), Report N. 05627/S.P., 14 March 1944, AST, Pref-Gab 1923-52, b 482, f 051, sf 051 Guardia nazionale repubblicana.

${ }^{30}$ In mid-April 1944, the GNR arrested "five notoriously subversive persons" in Monfalcone and took them to the Monfalcone fascio where they were "interrogated" and then handed over to the Germans. GNR, "Notiziario dall'Interno," 16 April 1944. The Fondazione Luigi Micheletti in Brescia hosts a digitized, searchable database of GNR bulletins (notiziari), consisting of the holdings from that institution's Fondo Notiziari della Guardia Nazionale
} 
experiences of Fontanot's cousin, Spartaco Romano. According to Romano, after fighting with the Proletarian Brigade in the Battle of Gorizia, he returned to Monfalcone, but did not go home or back to work for fear of being arrested; instead he hid in the home of his father-in-law, a butcher. One day in the summer of 1944, out of the blue, a group of PFR members pulled up to the house to search him out, but Romano managed to escape thanks to a neighbor's warning. The Fascists then rummaged through the house, raiding the meat cellars and carrying away two butchered animals, which they claimed were destined for the partisans. The most significant element of Romano's recollections, however, comes when he indicates that he knew well one of the men involved in the search. This man, Quinto, was "one of the Fascists who, in 1922, the Shipyard Direction had imported from the South to keep an eye on the Monfalcone workers. Quinto thus knew my father as one of those Socialists who were well-respected. That same day, Quinto was killed by gappisti in front of the cemetery." 31

This campaign climaxed in mid-1944, when the GAP began targeting current and former fascio heads. On 15 May alone, it kidnapped a former head of the Ronchi fascio, executed the current political commissar of that fascio, and seriously wounded one of the district's most notorious squadristi, who survived to identify one of his attackers as "Fontanot." 32 In response to this wave of attacks, which at times involved attacks on entire families, forces sympathetic to Salò, as well as SS and Wehrmacht soldiers, scoured the district on the night of 23 May, arresting 68 known Communists, "all individually identified as political commissars, components of on-the-

Repubblicana. This database can be accessed, as of May 2017, at the website www.notiziarignr.it/home. All GNR bulletins consulted were accessed through this database.

${ }^{31}$ Bonelli, "Seconda testimonianza del monfalconese Romano Spartaco," 19 March 1981, op. cit. Italics added.

${ }^{32}$ GNR, "Notiziario dall'Interno," 20 May 1944; GNR, "Notiziario dall'Interno," 23 May 1944; GNR, "Notiziario dall'Interno," 28 May 1944; GAP-Monfalcone, "Attivita' dei G.A.P." (N. 09176), 17 May 1944, APG-IG, Archivio Storico della Resistenza, fondo BG, sez IX, cart 2, f 7 Veneto-Friuli: GAP Monfalcone. 
ground partisan police groups, and couriers. ${ }^{.33}$ Yet the attacks continued and a GNR report from late June noted that "the Monfalconese remains always the nerve center for Communist agitation, which leads to frequent acts of terrorism." ${ }^{34}$ The GAP itself reported the "liquidation" of five more enemies in July. ${ }^{35}$ Though assessing the number of those killed by the Monfalcone GAP is very difficult - few GAP reports have survived - the figure was almost certainly well above $100 .{ }^{36}$ Whatever the figure, as a member of the Communist-aligned Commission for the Anti-Fascist Struggle would reflect frankly a year after war's end, with the GAP campaign, all the "great criminal exponents [of local Fascism] have been eliminated during the liberation struggle." ${ }^{37}$

\section{Resistance as Local Revolution: The Struggle against Everyday Fascism:}

But from its very beginnings, resistance in both the Monfalconese and wider Italy was far more than just an armed struggle to expel the German occupiers or an effort to "liquidate" the "big fish" among the cardholding Fascists. For many rank-and-file partisans of the left, if not all the political parties that claimed to represent them, it was also a revolutionary war. For them, 8 September unleashed a wide range of seething resentments and opened a wide range of potential activities for social transformation. ${ }^{38}$ The initiation of this seemingly decisive phase of the struggle

\footnotetext{
${ }^{33}$ The Italain Social Republic (RSI), or Republic of Salò, was constructed as a German puppet state after they rescued Mussolini from imprisonment in September. Though the RSI had no jurisdiction in the German Adriatic Littoral, it and the PFR did have local supporters. Isp. Gen. della Pol. Gueli, Telegramma a mano (N. 01523), 24 May 1944, AST, Pref-Gab 1923-52, b 482, f 064.

${ }^{34}$ GNR, "Notiziario dall'Interno," 24 June 1944.

${ }^{35}$ GAP-Monfalcone, "Attivita' dei G.A.P. di Monfalcone nel mese di luglio 1944" (N. 09256), Undated, APG-IG, Archivio Storico della Resistenza, fondo BG, sez IX, cart 2, f 7 Veneto-Friuli: GAP Monfalcone.

${ }^{36}$ An internal Communist Party document reveals that the commandant from December 1944 until war's end was responsible for 54 homicides. "G" [PCRG information services], Report N. 330/Z, 12 September 1945, AS 1570, b 9, f 6, sf Informazioni.

${ }^{37}$ CE-UAIS Trieste, Commissione per la Lotta Antifascista, "Verbale della seduta (riunione svoltasi il giorno 9 agosto 946," 9 August 1946, AS 1818/62/962.

${ }^{38}$ As Pavone shows, the PDA was much more open than the PCI in its embrace of the language of Resistance-asrevolution, though the PDA often used the language of a political "democratic revolution" rather than of a class-based "proletarian revolution." The PCI leadership, by contrast, worked to quiet calls for social revolution in the form of Resistance. Pavone, A Civil War, 428-33.
} 
against the Germans and local Fascists led to increasing contemplation of the potential form of post-Fascist society. Yet little work has been done to explore how the visions and pursuit of various facets of the Resistance struggle was shaped by the everyday experiences of Fascism. ${ }^{39}$ In fact, the ways in which monfalconesi had come to think about "Fascism" and "Fascists" during twenty years of everyday Fascism had a significant impact on how they conceptualized Resistance and liberation, just as the harsh conditions of everyday life during this struggle exacerbated existing tendencies to apply the term "Fascist" flexibly to entire social categories. ${ }^{40}$

In the workshops, the general frustration with the nature of labor and the more specific piecework question became increasingly significant as the Fascist regime crumbled. Even before the regime's collapse, a steady reduction of piece-rates during the war years had forced a hastening of work rhythms to frenetic and increasingly unsafe paces until, in October 1941, a major accident in the Shipbuilding Department left nine workers dead. An internal investigation revealing that fault lay with the department head for driving the workers at such an accelerated pace. ${ }^{41}$ The tendency to speed work continued through 1943 and thus in December 1943, after the collapse of the regime, the CRDA workers of Monfalcone elected a delegation (all Communists), sending it to present a four-part list of demands to management, one of which was the "elimination of labor

\footnotetext{
${ }^{39}$ Here "everyday experiences" is understood not in the narrow sense of measurable quality of life indicators such as low wages, food shortages, heating and housing shortages, etc. Scholars of the Resistance have repeatedly emphasized that poor conditions gave rise to anti-Fascist sentiments and actions and how such conditions played central roles in the propaganda of the anti-Fascist parties. For the role of these conditions in the anti-Fascist politics of the PCI, PSI, and PDA, see Pavone, A Civil War, 401-404. Instead, "everyday experiences" is used in the sense of Alltagsgeschichte, as a reference to serial interpersonal interactions, in which the repetitiveness and interpersonality of the interaction are considered in addition to more traditional measurable conditions.

${ }^{40}$ This not to say that Monfalcone's Resistance was monolithic. There were different factions of the Resistance, but the working-class and Communist-Party influence in Monfalcone's Resistance was so predominant that there was never the same need or desire for Communist-aligned forces to pursue a strategy of multi-party anti-Fascist unity as was so critical (and difficult) in nearby Trieste. Cernigoi, Scelte politiche e identità nazionale, 116-17.

${ }^{41}$ Mellinato, "Strategie imprenditoriali," 26.
} 
by piecework, where currently such a system eats into the average earnings of the laborers." 42

Management avoided the demands. It claimed the workers needed to file complaints via the Fascist

Syndicates, recently reconstituted by the German occupiers. According to one Communist militant's interpretation, management "hid itself behind the German bayonets." 43

This focus on the piecework system is significant. The abolition of piecework - a revolution against the clerks and a revolution of daily experience of "Fascist" labor - had emerged as a central component of the local, popular conception of the Resistance after 8 September. Yet this vision of Resistance, bearing a concreteness and significance for workers that equaled that of expelling the German occupiers, clashed with the centrally-sanctioned strategies of the Communist Party. ${ }^{44}$ In fact, the PCI-Trieste soon issued a formal rebuke of the monfalconesi, whom it accused of engaging in supposedly narrow economic negotiations while they should have been preparing for armed insurrection during an "acutely revolutionary situation.",45

Despite the rebuke, workers continued to demand the abolition of piecework and to engage in an increasingly intense propaganda campaign against the bosses and clerks. ${ }^{46}$ The month after,

\footnotetext{
42 The other demands were an increase in wages, the creation of a supplementary indemnity for workers who were heads of families, and more action by the firm to try to solve the problem of food shortage. "Noi sottoscritti operai ed impiegati..." 1 December 1943, APC-IG, Fondo PCI, Direzione Nord, FVG, f 2, d 20-2-2.

${ }^{43}$ Lorenzo, "Agitazione Cantiere di Monfalcone," December 1943, APC-IG, Fondo PCI, Direzione Nord, FVG, f 2 , d 20-2-3.

${ }^{44}$ A similar, though more generalized idea that the Resistance was about getting rid of "bad bosses" can be found in the memoirs of Silvano Cosolo. Reflecting on his time in Sarajevo and, more specifically, his encounters with two "bad bosses" who had kept their jobs in the first Tito years due to their technical skill, he writes that he repeatedly wondered "how it could be possible that the new power, administered by those forces that had fought in the Resistance to liberate themselves from this type of scum [gentaglia], had failed, even in the immediate postwar, to throw that filthy individual out of the factory." Cosolo, Amare... Sarajevo, 134.

${ }^{45}$ Comitato Direttivo del PCI-Trieste, "Lettera a tutta l'organizzazione di P. del Crda. Monfalcone," 23 January 1944, APC-IG, Fondo PCI, Direzione Nord, FVG, f 2, d 20-2-10. The PCI-Trieste understood economic grievances as means to achieve other ends rather than seeing their resolution as an end in itself. It sought to exploit economic grievances and turn economic demands (and the expected Fascist and German rejection of them) into political and insurrectionary activity. Pavone, A Civil War, 408.

46 This happened despite there being a section of the clerical staff that participated actively in the Communist Resistance. Key members in this group were Spartaco Romano, Domenico Piccardi, Albano Olivieri, and Antonia Comar, the last the wife of Angelo and herself the most active organizer of Monfalcone's anti-Fascist women. In addition, a certain portion of clerks took part in the much smaller, but still active Actionist bands. Cernigoi, Scelte politiche e identità nazionale, 131-32.
} 
the CLN of Monfalcone (likely Communist militants acting in the CLN's name) clandestinely put up posters in the CRDA addressed to the "directors, engineers, head technicians, office heads, head workers, [and] clerks," which exhorted them to sabotage the Nazi-Fascist war and to avoid at all costs "obstructing the demands of the workers" or betraying resisters. It concluded that these groups "HAVE ALL BEEN WARNED" and, alluding to the recent foibe killings, claimed that those who failed to obey would "bitterly regret it. The events of Istria show!" ${ }^{47}$ In December 1944, as the Communists and the $\mathrm{OF}$ were preparing for the moment of liberation, the local Communist Party secretary ordered the creation of "a Commission composed of the craftsmen of the greatest establishments," which would address, among other things, the continual popular demand for the abolition of piecework in its entirety. ${ }^{48}$ For many workers and partisans, including the pipefitterturned-partisan-commander Mario Fantini, there was simply no question of going back to an unreformed workplace, only the prospect of creating a work environment in which he felt free and independent, no longer subjected to the whistle of the workshop siren. ${ }^{49}$

Yet the abolition of piecework and the remaking of work life were not the only reform issues grafted onto local notions of Resistance and liberation. Another involved a reworking of the marketplace experience, fueled by longstanding resentments toward shopkeepers and the fact that conditions went from poor to dire as Monfalcone plunged into civil war. In fact, in line with worker demands throughout wider Italy, the CRDA delegation's fourth and final demand to management in December 1943 had been that the firm take an increasingly active role to "help [the workers] by

\footnotetext{
${ }^{47}$ CLN-Monfalcone, "DIRIGENTI, INGEGNERI, CAPITECNICI, CAPI UFFICI, CAPI OPERAI, IMPIEGATI...," February 1944, AST, Pref Gab 1923-52, b 482, f 064, sf 064 Manifestini sovversini. On the foibe killings, see footnote 97.

${ }^{48}$ Dušan (Com. pol.-III Zona, PCI-Monfalcone), Unnumbered Circolare "A tutti i comitati politici di settore," 18 December 1944, AS 1570, b 9, f Circolari.

${ }^{49}$ Thus, though the CRDA was legally obligated to rehire Fantini to his old position after the war, Fantini refused the job, instead starting a construction cooperative with many of his fellow partisans. Patat, Mario Fantini "Sasso", 17482.
} 
every means for the improvement of the alimentary situation." ${ }^{50}$ The workers, in short, proposed an increased effort to bypass local merchants and shopkeepers on the questions of supply, using their collective purchasing power and the firm's weight to do so.

Such hopes were bound up intimately with the "Fascist" egoism of shopkeepers, which had existed even in the prewar years, but intensified with the dire problems of food shortage, blackmarketeering, and black-market inflation connected to the war. ${ }^{51}$ Interestingly, the Germans had immediately recognized such problems when they arrived in Monfalcone in September 1943. Shortly after their arrival, German officials reported on the need to establish a system of "just prices," as well as an efficient enforcement system. They established price commissions and fixed prices, outlawed hoarding and profiteering, established a rationing system and a state monopoly over the exchange of essential goods, and created a network of informants that afforded them a window into the black market. Still, such measures never succeeded in resolving the problem. ${ }^{52}$ Within this framework, the CRDA bent to worker demands for the expansion of internal shops and the sale of staple goods below fixed prices. However, the German regulatory regime and supply

\footnotetext{
50 "Noi sottoscritti operai," 1 December 1943, op cit. Pavone, A Civil War, 404. This demand built upon interwar experiences. In 1921, the CNT had created a firm-managed (but not worker-run) market in Panzano with 27 covered shops. The shops provided foodstuffs and basic goods at relatively low prices, reaching nearly 2,000,000 lire of sales in 1927 and garnering the ire of local retailers. It appears that the Fascist rationing system swallowed up these shops in subsequent years, but the experience may have had an effect on how workers began to think about post-Fascist commerce. Fragiacomo, La grande fabbrica, 207-208.

${ }^{51}$ These associations appear to have transcended Monfalcone and were recognized by the highest leadership of the RSI. In fact, to rehabilitate Fascism's image in the winter of 1944/45 and disassociate it from shopkeeper egoism, the RSI announced a return to Fascism's anti-shopkeeper roots and the radical expansion of state-supported consumer cooperatives. These were to "eradicate definitively the black market and the egoism of the well-known intermediary categories who, from the beginning of the war, contributed to the rising cost of living." Ernesto Marchiandi (Commissario, Confederazione Generale del Lavoro della Tecnica e delle Arti), Untitled Directive (P.C. 375), Undated, ACS, PCM, Gab: RSI, Fascicoli per categoria, 1943-45, b 54, f 3.1.10/1. See also Giovanni Fabbrici (President, Alleanza nazionale delle Cooperative), "Organizzazione della cooperazione di consumo," (N. 2254 Seg. Ris.), 2 January 1945, ACS, PCM, Gab: RSI, Fascicoli per categoria, 1943-45, b 54, f 3.1.10/1.

${ }^{52}$ Steiner, "Relazioni sulla situazione dei prezzi e dell'approvvigionamento." (N. 5503), 25 March 1944, ASBCM, b 1067, f 4; Der Oberste Kommissar Rainer, "18. Verordnung, 24 January 1944, and "19. Verordnung," 4 March 1944, ACS, Fondo IRI, Numerazione Rossa, b R1590.
} 
and transport shortages prevented such shops from meeting worker expectations. ${ }^{53}$

Instead, conditions continued to deteriorate. By the summer of 1944, though rationed foodstuffs still arrived in the town somewhat regularly, clothing and specialty foods were completely absent, as were price-controlled goods like fish. The shortage in locally-produced goods occurred because sellers could easily sell their goods at higher prices on Trieste's lucrative black market or in the less-well-monitored markets of outlying communes, which had lost their primary mechanism of market discipline with the collapse of the PNF. By mid-1944, cooking oils sold on the black market at L1000 per liter, or sixty-six times the official fixed price of L15.10. ${ }^{54}$ By fall, the last fruits and vegetables disappeared from the market and even the rationed foodstuffs arrived very irregularly. ${ }^{55}$ By March 1945, only "laughable" quantities of rationed goods reached the markets, and starving town-dwellers began to venture into the countryside to steal food from the fields or purchase from farmers at "absurd prices." 56

Scarcity created ever-greater opportunities for black-marketeers, particularly in the outlying communes, as well as an increasing likelihood of tense market interactions. At times, this led to hostility between the urbanites and the peasants, the former accusing the latter of "starving the people" for profit. ${ }^{57}$ But most often the ire fell upon merchants and shopkeepers - and

\footnotetext{
${ }^{53}$ CRDA shops at a firm-wide level, for example, were increased from two to six; and they began to sell rationed or controlled goods such as butter, oil, pasta, a cheese at roughly $10 \%$ below fixed prices. The cost of such shops for the firm increased from 3191L in 1942 to 11,645L between 1943 and February 1944. It is unclear if such figures are adjusted for inflation. Unsigned, "Generi razionati e contingentati venduti agli Spacci a prezzi inferiori al al [sic] calmiere," 28 March 1944; Amm. Luigi Rizzo, Letter to Avv. Vincenzo Tecchio (IRI-Milan), 30 March 1944; and CRDA-Trieste, "Previdenze Sociali Volontarie," 26 June 1944, all in ACS, Fondo IRI, Numerazione Rossa, b R1590. ${ }^{54}$ Comm. Pref. Monfalcone, "Relazione situazione prezzi e dell'approvvigionamento" (N. 7301/P.1572), 21 July 1944, ASBCM, b 1067, f 4..

${ }^{55}$ Comm. Pref. Monfalcone," Relazione situazione prezzi e dell'approvvigionamento" (N. 10006/P1572), 21 October 1944, ASBCM, b 1067, f4; Comm. Pref. Monfalcone, "Segnalazione" (N. 10707-XI-3), 22 November 1944, ASBCM, b 1068, f Ctg XI.

${ }^{56}$ Comm. Pref. Monfalcone, "Questionario prezzi Marzo s.c." (N. 2290), 31 March 1945, ASBCM, b 1067, f 4.

${ }^{57}$ Segretario (CC-UO), "Riunione C.U.O. di Fabbrica," 28 March 1945, AS 1570, b 13, f 9; UDAIS-Monfalcone, "Relazione del lavoro svolto dalla D.A.I.S. dal giorno 8-10-45 al giorno 23-10-45, 28 October 1945, AS 1570, b 13, f 10, sf UDAIS.
} 
particularly those who were Fascists well-known for having used and continuing to use their Party connections for personal gain. Accusation sheets compiled by the OF committee for the village of San Canzian d'Isonzo in the immediate post-liberation months, which are exceptionally detailed relative to those of the other communes of the Monfalconese, reveal at least four vendors who were deeply reviled for being both Fascists and black-marketeers. One of these, Oreste G., was identified as the commune's PNF secretary until 8 September, during which time he was "a practitioner of the black market in grand style. Yesterday a miserable merchant and today a great capitalist. Starver of the people." ${ }^{58}$ Another was noted as a squadrista from 1922, who, though then "a miserable worker," had "began to practice commerce; today he is a millionaire, living off the blood of the poor" through the black market. ${ }^{59}$ Thus Resistance-era "shopping" - if one can use that term to capture the complex amalgam of licit and elicit market exchange, direct barter, and theft by which monfalconesi attempted to survive - was a continuation and also an intensification of the difficult experiences captured in prewar market interactions with Fascists like Giovanni Linossi. Not only did repeated negative interactions with black-marketeers and profiteers spur many monfalconesi to view merchants and vendors as quintessential "Fascists," but also to consider the freeing of the workers from dependency upon such "Fascist" individuals as integral to liberation. Perhaps unsurprisingly then, local Communist leaders noted in December 1944 that workers' formerly imprecise demand for increased CRDA involvement in securing provisions had concretized into a demand for "the institution of internal shops on the part of the [industrial] firms, which will be managed by commissions elected from among the very workers." 60 They demanded

\footnotetext{
${ }^{58}$ CLN-San Canzian d'Isonzo (OF), "Elenco di tutte le persone che hanno collaborato con l'occupatore...," 7 October 1945, AS 1818/230/3000, sf S. Canzian d'Isonzo.

${ }^{59}$ CLN-San Canzian d'Isonzo (OF), "Elenco di tutte le persone che hanno collaboratocon l'occupatore...," 2 August 1945, AS 1818/230/3000, sf S. Canzian d'Isonzo.

${ }^{60}$ Dušan, Unnumbered Circolare "A tutti i comitati politici di settore," 18 December 1944, op. cit. (Italics added). The demand was not unique to the Monfalconese, appearing in the list of demands of many Resistance-era strikes. Pavone, A Civil War, 407.
} 
a new form of commerce freed from "Fascist" egoism, over which they would have direct control.

\section{The Rise of Yugoslav Annexationism and Early Visions of Tito's Yugoslavia}

In the context of intensified everyday antagonisms and civil war, monfalconesi began to consider their range of options for resistance, leading an increasingly large portion of even the Italian-speaking population to embrace Yugoslav annexation. However, this was a slow and convoluted process, closely tied to the shifting political and military situation of the region in the wake of 8 September. In the short term, the PCI's embrace of outright armed struggle after 8 September had hurled both Slovenes and Italians of the Littoral into unprecedented degrees of resistance. ${ }^{61}$ In the longer term, the return of veteran PCI militants like Luigi Frausin, Natale Kolarič, and Lino Zocchi from confino led to a strengthening of the PCI organization in Trieste Province and, perhaps unexpectedly, a sudden increase in tensions between the KPS and PCI.

The cause of these tensions was the emerging "Trieste Question" and the political quandary it posed for the PCI given the latter's efforts to transform itself into a mass democratic party recognized as part of an anti-Fascist unity coalition. The PCI had pursued this strategy, known as the Salerno Turn (Svolta di Salerno), from the moment that general secretary Palmiro Togliatti returned to liberated Italy from the Soviet Union in April 1944. The strategy, supported by Stalin himself, aimed not just to defeat the Axis as quickly as possible, but also to establish the legitimacy and mass appeal of the PCI for the postwar period. ${ }^{62}$ For the new PCI, the Trieste Question became a major liability. The annexationist stance of the KPS and KPJ regarding the Primorska reflected badly on the PCI in the eyes of many Italians and allowed it to be labeled "anti-national,"

\footnotetext{
${ }^{61}$ Regarding Slovenes under the German occupation, it should be noted that the German occupation also brought new opportunities for collaboration, as the Germans attempted to secure Slovene support by granting them a degree of cultural autonomy (which the Italians had always denied). As a result, 1943 not only saw a radicalization of the Slovenian liberation struggle, but also a deepening of civil war among Slovenes. Fogar, Trieste in guerra, 31-38; Kranjc, To Walk with the Devil, 77-81, 182-87.

${ }^{62}$ On Stalin's support for the Svolta di Salerno, see Agarossi and Zaslavsky, Stalin and Togliatti, chs. 2-3.
} 
threatening both the anti-Fascist unity coalition and the Party's postwar electoral appeal. The best solution that the PCI could come up with was to accept Slovenian claims to Slovene-majority areas, while also asserting the cultural Italianness (italianità) of cities like Trieste and Monfalcone and requesting that discussions of the territorial fate of these cities be tabled until after the war.

Within the narrower realm of Julian politics, navigating this dilemma became an impossible task for PCI Federation secretary Luigi Frausin, who had assumed that post after returning from confino in late 1943. Every compromise with the KPS led to a negative response of many of the parties of the Trieste National Liberation Committee (Comitato di liberazione nazionale, CLN), particularly those parties such as the Christian Democrats (Democrazia cristiana, DC) and Actionists (Partito d'Azione, PdA), who maintained Italy's territorial integrity as central to their platform. By contrast, compromise with the CLN would enrage the KPS and expose Frausin to accusations of Italian nationalism and "bourgeois" sentiments. ${ }^{63}$

Frausin ultimately pursued a policy that more closely aligned him with the CLN than the KPS, a decision which had a profound impact on the political situation in Monfalcone. Though certain monfalconesi had cooperated with the OF and KPS from 1941 to 1943, at the time of Frausin's return, these militants were almost all still organized in the PCI and organizationally subordinate to Trieste. ${ }^{64}$ When Frausin arrived in Trieste, he immediately set out to reestablish PCI control over the monfalconesi - and particularly over a group led by Ferdinando Marega, a principal organizer of the Proletarian Brigade, who in September 1943 had already accepted the idea of Yugoslav annexation of the Monfalconese. In the last months of 1943, Frausin issued

\footnotetext{
${ }^{63}$ Ibid., ch. 4; Novak, Trieste, ch. 5; Terzuolo, Red Adriatic, ch. 1.

${ }^{64}$ According to one of the KPS's own reports from January 1943, in that time "the so-called Italian Communist Party, distinctly proletarian, has 140 affiliated workers. The Slovenian Communist Party does not yet have positions here." Comitato Regionale del PCS pel Litorale, Untitled Report (N. 1), 17 January 1943, AST, Pref-Gab 1923-52, b 451, f 064.
} 
Marega an official rebuke and sent his agent Natale Kolarič to assist Ruggero Bersa, recently returned from confino, in shoring up the district's organizational structure. ${ }^{65}$

Yet if the winter of 1943/44 saw the Communists of the Monfalconese suddenly returned to the PCI-Trieste's orbit, the spring of 1944 brought another drastic shift. In April, the Soviets parachuted the veteran PCI militant Vincenzo Bianco (Vittorio) into Yugoslavia to serve as a liaison between Tito and Togliatti. Bianco soon urged Togliatti to approve a temporary Yugoslav occupation, if not annexation, of Trieste and Venezia Giulia. Togliatti took this advice, which isolated Frausin and his PCI Federation within Trieste's CLN. ${ }^{66}$ More significantly, in May, unknown individuals denounced Kolarič to the Germans, who captured and executed him, again severing the monfalconesi from the Trieste Federation. ${ }^{67}$ This afforded the KPS a window not just to organize distinct KPS cells, as Rudi Uršič done from late 1943, but also to appropriate the existing PCI network. Immediately after Kolarič's arrest, the KPS sent its own agent, Rodolfo Lenardič (Dušan), to take control of this network as district secretary. ${ }^{68}$ Three months later, Frausin himself was betrayed to the Germans and arrested. Without Frausin, the PCI members of Trieste too fell increasingly under the sway of the KPS and were soon expelled from the CLN. ${ }^{69}$

In this context, the pro-annexationist stance came to dominate the regional and local Communist Party directive committees, coming to a head in October 1944. As Bersa later

\footnotetext{
${ }^{65}$ Cernigoi, Scelte politiche e identità nazionale, 88-89, 117-20; Fogar, L'antifascismo operaio monfalconese, 25152.

${ }^{66}$ Togliatti's reasoning is clear in a letter written in October to Bianco, in which he claims that a temporary Yugoslav occupation of Venezia Giulia - as opposed to an "English occupation" or a "restoration of the reactionary Italian administration" - would create conditions for "a democratic situation in which it will be possible to destroy Fascism at its base." In the same letter he pushes back against outright Yugoslav annexation. Unsigned (Togliatti), Letter to "Carissimo Vittorio," 19 October 1944, AM-IG, Fondo Jug e VG, mf 133, f 4, cartella, IA, d 8. Cernigoi, Scelte politiche e identità nazionale, 161-63.

${ }^{67}$ In an August letter to the Party's central leadership, the Monfalcone committee indicated that there had been no contact with Trieste for some time. "Marco," Relazione del Comitato della III Zona-Monfalcone, 9 August 1944, AMIG, mf 93, b 54, f 1, B:6.

${ }^{68}$ Cernigoi, Scelte politiche e identità nazionale, 134-35.

${ }^{69}$ Cernigoi, Scelte politiche e identità nazionale, 154-56; Novak, Trieste, 112-19.
} 
recounted, after Lenardič arrived in Monfalcone, he slowly pushed the Yugoslav annexationist line upon the district committee, demoting individuals like Otto Ferlettich, who expressed disagreement. ${ }^{70}$ As a result, the Monfalcone PCI's district committee, including Bersa, Angelo Comar, Ottone Zanolla, and, begrudgingly, Ferlettich, officially embraced the pro-Yugoslav solution that month, leading to a fission of the Monfalcone CLN, particularly when various Socialists and members of the "bourgeois" parties rejected the decision. ${ }^{71}$ At the same time, the mass organizations of the Triestine Communists, calling themselves the "Antifascist Committees for the Annexation of Trieste to Yugoslavia," issued a statement in the name of the masses:

The mass organizations of the Italian people of Trieste, by way of its own representatives, gathered to discuss the various current political problems determined by the new political situation and particularly in regards to the problem of the future fate of the city of Trieste, [...] expressed the desire, with certainty, that Trieste become part of the new, great, democratic, and federative Yugoslavia, vanguard of democratic liberty and an example for all the oppressed peoples, in which we have all the guarantees of a better political, economic, and social future for the city of Trieste, for the certain and guaranteed advantage and wellbeing of the Italian portion. ${ }^{72}$

Given a lack of documentation, the precise details of PCI-Monfalcone's October declaration are unclear, and it is impossible to assess accurately the support the solution had among the wider population at that moment. It is unknown, for example, if its authors had accepted their district's annexation as part of Slovenia or if they had accepted the other increasingly popular variant of the annexationist line, namely that much of Venezia Giulia become an autonomous Italian-majority "Seventh Federative Republic" within the wider Yugoslav federation. ${ }^{73}$ It is clear that for many monfalconesi, only the latter was acceptable. For example, the unidentified militant

\footnotetext{
${ }^{70}$ Galliano Fogar, "Intervista registrata concessa da Ruggero Bersa," 8 June 1981, IRSML-FVG, Fondo Cominform, b 99 , f 9 .

${ }^{71}$ Fogar, L'antifascismo operaio monfalconese, 251-52; Cernigoi, Scelte politiche e identità nazionale, 224.

72 "O.d.g. di comitati antifascisti per l'annessione di Trieste alla Jugoslavia," 20 October 1944, AM-IG, fondo JVG, $\mathrm{mf} 93$, f 1 , sf b, d B:9.

${ }^{73}$ See this idea as expressed by the leading garibaldino of Friuli, Lino Zocchi (Mario/Ninci). "Mario," "Cari compagni” (Letter to PCI), Undated (February 1944?), APC-IG, Fondo PCI Direzione Nord, FVG-Jug, f 2, d 20-226. Parentheses in original.
} 
"Marco," who wrote to the PCI's leadership in August, criticizing the annexationist claims of Slovenia and stressing that "the comrades of our organization $[\ldots]$ see nothing other than the red flag" and "they think only about a soviet republic." 74 The Italian Communist partisan (garibaldino)

Giuseppe Lorenzon, would describe the choice in similar terms at a much later date:

We saw immediately that the Italian situation was not clear: Fascism returned [in liberated Italy]. It was necessary to unite [with Yugoslavia] in order not to lose the gains of the war, to make sure that the reaction didn't defeat us.... The great mass of combatants inevitably therefore favored the Seventh Federative Republic. Union with Yugoslavia was not pursued in order to become Slovenian or Yugoslav, but only for socialism. ${ }^{75}$

For such individuals, the Seventh Federative was preferable to Slovenian annexation, but even this moderated version of Yugoslav claims did not receive the universal support of the district's Communists. For example, one garibaldino of the Triestine Assault Brigade wrote to the Italian Ministry of Foreign Affairs at the time of liberation. He criticized that the district committee had "adhered [to the annexationist line] without difficulty (because it is composed of simple and weak people)," but indicated that, in his estimation, the wider populace rejected this. ${ }^{76}$

From October 1944, then, both Communist Parties present in Venezia Giulia, if not the entire rank-and-file of the PCI, began pushing the notion of Yugoslav annexation. By mid-October, with the PCI-Trieste in disarray and disconnected from the Party's center, Togliatti acquiesced to the passage of all garibaldini operating east of the Isonzo under direct Yugoslav command, which was followed in November by the merging of existing PCI and KPS structures in Venezia Giulia

\footnotetext{
74 “Marco," Relazione del Comitato della III Zona-Monfalcone, 9 August 1944, op. cit.

${ }^{75}$ Cernigoi, Scelte politiche e identità nazionale, 223. Similarly, the partisan Luigi Pasqualini later reflected that he supported the idea of "the seventh nation or little state [staterello] that with the other six would form part of the new united and independent Yugoslavia. With my ideas and the friendship that I had with the Slovenes, they having specified that we would govern ourselves under the direction of the SFRY, I accepted the project. It seemed good to me, as it seemed good to all my friends." Ibid., 228-29.

${ }^{76}$ Piero, "Relazione sugli avvenimenti politici nelle organizzazioni italiane di esistenza operanti nella terza zona (Monfalcone, Ronchi, Grado)..,", Undated (April or May 1945), ASDMAE, AA PP 1931-1945, Jug, b 151, f 2. Parentheses in original.
} 
into a jointly directed organization. ${ }^{77}$ Both in the Italian-language partisan press (Il corriere partigiano) and the clandestine Communist press (Il nostro avvenire and Il Lavoratore) initiated a campaign to popularize the notion of Yugoslav annexation, though always under the two conditions that (1) this occur under the formula of the Seventh Federative, not Slovenian annexation; and (2) the Italian-majority areas be given the chance to approve their annexation by a vote. ${ }^{78}$ In the Monfalconese, by February 1945 the district committee had committed itself to this campaign, though there remained telling differences in approach. Lenardič (Dušan) emphasized the creation of portraits of Tito and other Yugoslav trinkets - that is, nationalist trappings - while Bersa argued that emphasis be placed on the internationalist, workers' appeal of Yugoslavia, namely that Yugoslavia was a surrogate for the Soviet Union and a country in which the expansive local vision of Resistance could be realized. ${ }^{79}$

It was among the partisans, however, many of whom moved back and forth between their units in the mountains and the district itself, that this campaign to popularize Tito's Yugoslavia was pushed most forcefully. To reach such individuals, the Yugoslav forces, in concert with certain regional PCI leaders, created a Political Office for the Garibaldi units operating under Yugoslav command. In addition to organizing the printing of the clandestine pro-Yugoslav press, this office disseminated copies of Tito's speeches among the partisans and increasingly transformed the Garibaldi unit's "Political Hours" - the daily time in which garibaldini received political education from their political commissars - into discussions of the merits of Tito's new state. ${ }^{80}$

\footnotetext{
${ }_{77}$ Cernigoi, Scelte politiche e identità nazionale, 161-63, 187. Vincenzo Bianco (Vittorio), "Situazione Particolare delle Zone Miste della Venezia Giulia...," 24 March 1945, AM-IG, mf 133, f 47, cartella IA: VG, d 3.

${ }^{78}$ See the holdings in the AM-IG, mf 133, f 47, for example Il corriere partigiano, n. 3, anno 1, 30 October 1944, "Gli antifascisti triestini per l'unione alla nuovo Jugoslavia federativa" and Il nostro avvenire, n. 1, anno 1, 31 October 1944, "Verso il nostro nuovo destino." Additional copies of these papers can be found at the IRSML, Fondo Jaksetich, b 11 , f 95 and $\mathrm{f} 108$.

${ }^{79}$ PCI-Monfalcone, "Relazione della riunione C.P. 3o sett. del 17.2.1945," 20 February 1945, AS 1570, b 13, f 9.

${ }^{80}$ Ufficio politico dell'unità italiane nell'NOV in PO Slovenije, "Discorso del Maresciallo Tito: Dei diritti e dei confini della nuova Jugoslavia federativa e democratica," AM-IG, Fondo Jug e VG, b mf 133, f 47, d 28.
} 
In these lessons and through the press, partisans learned that Tito's Yugoslavia was in a unique position to bring prosperity and fulfillment to working people precisely because of the ongoing war. Propagandists stressed that the Axis occupation had marked a fundamental rupture in Yugoslav history. It had precipitated the complete collapse of the old state and social order, forced the Yugoslav peoples to unite in a life-or-death struggle against fascism, and thus paved the way for the construction of a fundamentally new society based on fraternal, multinational cooperation. ${ }^{81}$ It was due to these conditions that the Yugoslavs were to be emulated. They realized that the struggle would be over "only when every trace of fascist imperialism has been completely eliminated from the purged continent and when true democracy is definitively affirmed everywhere," 82 which meant an uncompromising struggle against "the more or less masked residues of fascism, which will try everywhere to reappear in new forms." 83

With these ideas increasingly circulating within the ranks of the monfalconesi partisans and undoubtedly making their way home through word-of-mouth and other means of transition, the stakes of liberation became increasingly clear. In fact, shortly before war's end, the issue was cast in Cold-War terms, partisan commissars impressing upon their comrades that the European continent was in the process of bifurcation. They asserted that, in one camp, "the demo-plutocratic influence of the Anglo-Americans will dominate, with their capitalist and imperialist traditions," while "from the other camp is already spreading and taking shape the new democratic-popularprogressive-irradiant ideal of the Soviet lands." They indicated that Venezia Giulia fell directly

\footnotetext{
${ }^{81}$ Maria Bernetich, "Insieme fino alla vittoria," Il corriere partigiano, N. 2, Anno 1, 20 October 1944, AM-IG, Fondo Jug e VG, b mf 133, f 47, d 43; Mario Abram, "Problemi del Giorno: Democrazia," Il corriere partigiano, N. 3, Anno 1, 30 October 1944, AM-IG, Fondo Jug e VG, b mf 133, f 47, d 34; "La Jugoslavia democratica," Il Lavoratore, No. 10, 11 November 1944, AM-IG, b mf 93, f 1, d B:10; Bruno P., "Nuova Jugoslavia: Nella lotta per la libertà sorge una moderna democrazia," Il nostro avvenire, N. 1, Anno 1, 31 October 1944, AM-IG, Fondo Jug e VG, b mf 133, f $47, \mathrm{~d} 45$.

82 "Popoli al bivio e popoli sulla dritta via," Il nostro avvenire, N. 7, Anno 1, 12 December 1944, AM-IG, Fondo Jug e VG, b mf 133, f 47, d 24.

${ }^{83}$ Bruno P. "Nuova Jugoslavia," Il nostro avvvenire, 31 October 1944, op. cit.
} 
along the emerging fault line between "the Europe of yesterday and that of tomorrow" and insisted that for both Italian and Slovenian giuliani the choice between the two was clear:

The light shining out from the East has already borne new fruits among several European peoples. First, among all the Yugoslav people there has been formed the first organic-democratic-popular-progressive state, with the abolition of national conflicts, with the principles of true liberty desired by all peoples, guaranteeing and respecting individual nationalities with their rights to language and flag, culture and art, with principles of equality and the possibility of improvement for all social classes, with the right to life and work for all. ${ }^{84}$

These ideas were at the core of what would emerge as an expansive and deeply-entrenched myth of Yugoslavia in the coming years. This myth, with its close linkages of Yugoslavia with social revolution, helps explain why, as the war drew closer to an end and the prospects of Yugoslav annexation increased, the Monfalconese fell into an ever-bloodier state of civil war. For the Communists and the workers who took an expansive view of Resistance, Tito's successes served as a source of inspiration for increasingly bold action at home. For anti-Fascist Italians of strong national sentiments - even those who shared transformative goals of Resistance navigating these years became exceedingly difficult, as they were caught between a rock (the Axis occupation) and a hard place (the threat of Yugoslav Communist annexation).

\section{May 1945: Liberation or Occupation?}

In the final months of the war, as the front lines approached Monfalcone, monfalconesi of all stripes eagerly awaited news of the advance of the Anglo-Americans from the west and the Yugoslavs from the east. Excepting the few diehard Fascists who had refused to flee, most of the population looked forward to the moment of liberation, though often with drastically different and even shifting hopes. Monfalconesi heard rumors about the failures of concrete reforms in liberated Italy and news of Titoist triumphs to their southeast, making it increasingly easy for workers to

${ }^{84}$ Commissario I Battaglione, Brigata Triestina, "Venezia Giulia - Jugoslavia" (N. 230), Undated (Spring 1945), IRSML-FVG, Fondo Jaksetich, b 9, f 74. 
view liberation by the Yugoslavs as more likely to bring about the concrete, local changes they hoped to realize and thus an increasingly large share of the town's workers lined up behind the pro-Yugoslav cause. At the same time, the emergence of an increasingly strong faction in favor of Yugoslav annexationism accelerated a political realignment in the town that had been ongoing since October 1944, shifting the dominant point of division from that between Fascists and antiFascists to that between pro-Italians and pro-Yugoslavs.

Beginning in the winter of 1944/45, the Communists, believing Tito's forces would arrive first, began making plans to assume control of the town, including directing all aspects of postliberation economic, social, and cultural life. ${ }^{85}$ As early as December 1944, Lenardič had given the order to begin organizing the Difesa Popolare (Popular Defense), a partisan police force divided into five- or six-member squads, consisting of the most disciplined members of the AntiFascist Youth Front. These squads, under the command of Spartaco Padovan (Diego), would have the dual tasks of supporting the GAP in eliminating spies and initiating the struggle against "Fascist" merchants and black-marketeers ${ }^{86}$ At the same time, Lenardič ordered the eight-man Central Committee of Worker's Unity to centralize the command structure of its committees, which were to serve as the basis for Party management of the CRDA and which had 6000 local adherents. ${ }^{87}$ Yet, as workers increasingly lined up behind the pro-Yugoslavs and the Communist leadership of the local Resistance, debates emerged within leadership circles as to the degree and rate at which their popular vision of liberation could be realized.

In March 1945, with the organizations preparing for liberation, members of the Central

\footnotetext{
${ }^{85}$ Comp. Otto (NOO-Monfalcone), "A tutti i comitati di Villaggio" (N. 42/45), 15 February 1945, AS 1570, b 9, f Circolari.

${ }^{86}$ Dušan, "Circolare No. 7: Ai comitati politici di settore," 12 December 1944, AS 1570, b 9, f Circolari.

${ }^{87}$ Dušan, Unnumbered Circolare "A tutti i comitati politici di settore," 18 December 1944, op. cit.; OK KPS za Trst, "Politično in organizacijsko poročilo ODE-ja tržšega Okrožja," 12 December 1944, op cit.
} 
Committee of Workers' Unity debated what should be done with the district's merchants and shopkeepers and the technical staff of the CRDA. Indicative of the radical strain of the local Resistance - one to which many workers subscribed - are the comments of one unidentified "Comrade ?" who noted that something had to be done to stop commercial interests "from strangling the workers" but that "there is little to do because they are animated by an egoistic spirit without equal." His rather grim conclusion was that "they are worthy only of being shot." With respect to the CRDA clerks, "Comrade ?" was equally uncompromising. Labeling them as "people too compromised with Fascism first and with the Germans today," with whom workers should refuse "even the possibility of any compromise," he suggested they be subjected to a "true purge." However, with an eye to stability, productivity, and order, one of the district's leading Communists, Comrade Flinn, retorted that this "Comrade ?" must have learned nothing from the experience of the Soviet anti-expert campaign during the First Five-Year Plan, in which the Soviets "liquidated" the experts to their own harm. Instead, Flinn suggested that "today it is premature to chase them from their posts." He proposed instead that the Communists ought to consider them “industrial patrimony, which must be conserved just like the machines." ${ }^{88}$ In this viewpoint, undoubtedly informed by an awareness of Yugoslavia's weak economy and its vulnerability along the fault line of a bifurcating Europe, the state's geopolitical interests received priority over local transformation, all strata of the workforce treated as human capital at the disposal of the developmental state.

Thus, some two months before liberation, the debate over how to deal with the social categories associated with everyday Fascism, later called the "remnants of Fascism," was already underway. Though there was something of an emerging consensus among the town's workers as

\footnotetext{
${ }^{88}$ Segretario (CC-UO), "Riunione referenti C.U.O. di Fabbrica," 15 March 1945, AS 1570, b 13, f 9.
} 
to which social categories required extirpation as "remnants of Fascism," there was not yet a clear plan as to how to achieve this, nor agreement among the Communist leadership as to the tactics and strategy they should employ to make good on this vision of Resistance and liberation, while also protecting Yugoslavia's interests. Rather, mirroring wider Italian trends, Party leadership exerted a limiting influence on more expansive popular approaches to liberation. ${ }^{89}$ The focus at the top remained on organization and the immediate task of expelling the Germans, seizing power, and maintaining order, as indicated when Workers' Unity's Central Committee reported later in March that "all the committees are prepared to control the entirety of the masses in order to assume [power] immediately after the collapse of the shipyard's Direction, and to keep it at full activity."90

The decisive moment, then, came on the night of 30 April and morning of 1 May. Some weeks prior, the district PCI had issued a general mobilization order for all able-bodied youth to go into the mountains and prepare for the final battle, its organizers staying behind to prepare the remaining workers for an uprising. ${ }^{91}$ On 30 April, following the German command's rejection of a Communist surrender ultimatum - the Germans preferred to surrender to the Western Allies units of the Difesa Popolare and armed workers led by PCI militants began arresting isolated German soldier and Fascists, even sacking the German barracks on the Viale San Marco. With the coming of the morning light, the DP seized the train station and other vital points, and the GAP, outfitted with motor vehicles and machineguns, descended from the hills, flanked to the north by

\footnotetext{
${ }^{89}$ In Italy, Togliatti and the PCI condemned radical workers' violence against bosses-qua-Fascists. Immediately following liberation, he spoke at the congress of the PCI-Turin and condemned as a "grave error" the removal of bosses "simply because they are disliked by the masses" and not because of clear collaborationist or Fascist crimes. Pavone, A Civil War, 198, 422-23.

${ }^{90}$ Segretario (CC-UO), "Riunione C.U.O. di Fabbrica," 28 March 1945, op. cit.

${ }^{91}$ Renato A[x] (PCI-Monfalcone), "Relazione della riunione della cellula del 30/3/945," 4 April 1945, AS 1570, b 13, f 9; Unione dei Lavoratori della Pesca-Monfalcone, "Relazione del movimento del periodo di mobilitazione," 6 May 1945, AS 1570, b 11, f 7, sf 12.
} 
the Ivan Granikova Brigade of the Yugoslav Army. ${ }^{92}$ As the gappista Riccardo Giacuzzo recounts, the town was in revolt by the time he arrived and soon these combined forces pushed the Germans entirely out of Monfalcone. The GAP disarmed the German garrisons, while the Yugoslavs continued through Ronchi, pushing the Germans back over the Isonzo. By the time the Western Allied vanguard arrived in the late afternoon, they found "an already-liberated Monfalcone," with celebrations and speeches underway in the central piazza (Figure 9). ${ }^{93}$ By the evening, the town was adorned with Italian and Yugoslav red-starred flags and upon the façade of the Town Hall, the liberating forces had erected a giant red star (Figure 10). ${ }^{94}$

The monfalconesi exiting their homes that afternoon and evening had mixed reactions. While those tainted by Fascist ties hunkered down, the anti- and non-Fascists of the Monfalconese emerged in possession of a range of hopes and political beliefs, not all Communist and proYugoslav. For some, the sight of ragged and dirty Partisan forces in the town was frightening, a sign of hierarchy subverted and the victory of the primitive over the cultured. ${ }^{95}$ According to the primary pro-Italian account of liberation, a report sent from the Italian CLN of Monfalcone to the CLNAI, others still were "stunned by the truly unexpected appearance of the Yugoslav flags."96 Though the report's implication that the arriving Partisans sprung the annexationist question upon an unsuspecting population is doubtful - Axis propaganda had used the Yugoslav annexationist threat as a boogeyman to mobilize local support and the report itself contains indications that the population knew the stakes - not all monfalconesi had come to terms with the contest. Even many

\footnotetext{
92 Unione dei Lavoratori della Pesca-Monfalcone, "Relazione del movimento del periodo di mobilitazione," 6 May 1945, op. cit.

${ }^{93}$ Riccardo Giacuzzo, Letter to Giuseppe Lorenzon (Pirano), 4 April 1980, IFSML, Fondo Giacuzzo, b 2, f 41.

${ }^{94}$ Unione dei Lavoratori della Pesca-Monfalcone, "Relazione del movimento del periodo di mobilitazione," 6 May 1945, op. cit.

${ }^{95}$ Di Gianantonio et al, L'immaginario imprigionato, 76-78.

${ }^{96}$ Capo di Stato Maggiore Ronco, MG, UI, "Situazione a Trieste, Monfalcone e Gorizia" (N. 67263/3/2), 25 May 1945, ASDMAE, AA PP 1931-45, Jug, b 152, f 3.
} 
left-leaning monfalconesi were ambivalent toward Yugoslav annexation, among them Spartaco Romano and Alberto Clemente. It was the pro-Italian Communist Romano who, emerging from his home to find that the Yugoslavs had planted Yugoslav flags in front of the Town Hall, put up a red-starred Italian tricolor alongside them. ${ }^{97}$ Similarly, the young, pro-Italian Clemente, a Turriaco resident from a Socialist family, recalls a sense of disappointment about the nationalistic displays of the Yugoslavs and the fact that, when he arrived the Monfalcone piazza on 1 May, he found Yugoslav red-starred tricolors in far greater numbers than their Italian counterparts. But for such individuals, the uneasiness caused by the presence of Yugoslav flags was mitigated by or stood alongside a tremendous hope that 1 May marked an opportunity to create a new world. For such individuals, hope often overshadowed unease in this initial period, not least of all because, in Clemente's words, the zone's history within the Habsburg Empire led monfalconesi to understand the prospect of leaving Italy behind "in a different, less dramatic way." 98

If many monfalconesi experienced 1 May as a celebratory moment, others saw it as the beginning of a second occupation, with Yugoslav conquerors replacing the Germans. This was especially the case for staunch anti-Communists and Italian nationalists, even if not of a Fascist variety. According to the Italian CLN, when such individuals began displaying Italian tricolors without the red star, "groups of Yugoslav Partisans, entering violently into the residences, quickly tore them apart." For them, the new reality set in on 2 May during a gathering in the town square headed by the president of the OF Liberation Committee, Dr. Viglione. In his speech, Viglione praised the Yugoslavs as liberators and asked if the crowd desired to join Tito's Yugoslavia, to which "the response, affirmative but weak, came from small groups of partisans who had the Tito flag and posters praising him.” According to the report, when Viglione suggested the popular will

\footnotetext{
${ }^{97}$ Bonelli, "Seconda testimonianza del monfalconese Romano Spartaco," 19 March 1981, op. cit.

${ }^{98}$ Di Gianantonio et al, L’immaginario imprigionato, 79-80.
} 
be made clear to the Allies and asked again if the crowd wanted Yugoslavia, the "great majority" neither cheered, nor applauded and one woman who shouted "no" was immediately taken away by "a heavily armed Tito supporter." 99 For these individuals, the arrival of the Yugoslavs was a nightmare. As the small, now-underground pro-Italian CLN would state in an appeal to the CLNAI, the town was "profoundly pained by having fallen under a regime of anti-democratic coercion more demagogic than that of Fascist terrorism."100

\section{May 1945: An Attempt to Remake the World}

It is impossible to know with certainty the percentage of monfalconesi who welcomed the Yugoslavs and those who rejected them at the moment of liberation. In fact, many with mixed feelings only chose a side because of post-liberation experiences. What is clear, however, is that the cessation of the fighting broadened what one monfalconese would reflectively term the "horizons of hope."101 After twenty years of Fascism and two of civil war, liberation by the Yugoslavs made it seem likely that a thoroughgoing social transformation was not only possible, but imminent. ${ }^{102}$

Carrying out this social revolution after 1 May was a complex and overlapping network of Yugoslav military forces and local OF-aligned institutions that had formerly operated

\footnotetext{
${ }^{99}$ Capo di Stato Maggiore Ronco, "Situazione a Trieste, Monfalcone e Gorizia" (N. 67263/3/2), 25 May 1945, op. cit. It is worth noting that the CLN-Trieste, to which the CLN-Monfalcone belonged, had long had tense relations with the CLNAI. This was because the latter was far more willing to negotiate with and grant territorial concessions to the OF than the CLN-Trieste, at least until such negotiations broke down in late 1944. Despite the removal of this stickingpoint, relations between the CLNAI and CLN-Trieste remained tense. Thus, the above report might also be read as a tactical (perhaps exaggerated) plea meant to regain CLNAI sympathy in a period of profound isolation. Novak, Trieste, $112-19$.

${ }^{100}$ Capo di Stato Maggiore Ronco, MG, UI, "Appello del Comitato Italiano di Liberazione di Monfalcone" (N. 67262/3/2), 4 May 1945, ASDMAE, AA PP 1946-50 Jug, b 152, f Informazioni Riservate su VG.

${ }^{101}$ Pin-Giuricin, "I motivi di una scelta," 358.

102 On similar views of the Resistance among partisans elsewhere in Italy, see Pavone, A Civil War, chs 6 and 8. These ideas of renovation and renewal were not limited to Italy. All throughout Europe there was a tremendous popular hope for social transformation after the war, during this time "when Europe was new." Eley, "When Europe was New," in The Lasting War, eds. Riera and Shaffer, op. cit.
} 
clandestinely, staffed mostly by Communist militants, sympathetic workers, and a handful of "progressive" clerks. Immediately after the Yugoslavs' arrival, such institutions stepped out of the shadows, with the OF organizing the election of a fourteen-person pro-Yugoslav administrative committee, the District Committee of National Liberation (CDLN), ${ }^{103}$ which soon pledged loyalty to Tito and announced the district's adhesion to Yugoslavia. ${ }^{104}$ Meanwhile, in the factories, the committees of the 6000-strong Workers' Unity stepped up to direct and control the workplaces. ${ }^{105}$

Yet for most workers and low-level Communist militants, more important than the creation of formal pro-Yugoslav institutions of "popular power" (potere popolare) was the transformation of their everyday experiences. Monfalconesi who joined the institutions of "popular power" often did so with the goal of establishing a just government rather than taking a stance on the territorial question. Danilo Verginella, a garibaldino who joined the DP, believed that "popular power" meant government in which "honest people" seized the levers of control from "the usurpers from before." Though he (initially) rejected Yugoslav annexation, becoming the object of his comrades' ridicule, his belief that the Yugoslavs were "honest people" drove him into cooperation. For such individuals, the dreams of local transformation could be realized only if there was a purge of the "remnants of Fascism" (resti del fascismo) - Verginella's "usurpers" - from the town. ${ }^{106}$ Though the GAP campaign had eliminated most of the "big fish" of local Fascism, the pressing question in May was what should be done about the small-fish cardholders, the minor squadristi, and those

\footnotetext{
${ }^{103}$ On the administrative structure of the OF-aligned CDLN, see Boris Gombač, "Controesodo tra poteri popolari e GMA," in Il mosaico giuliano, eds. Altieri and Puppini, 43-64.

${ }^{104}$ Notably, these elections did not use secret ballots, but rather the raising of hands. PCM-Gab ed altri "Situazione della Venezia Giulia e del Friuli" (N. 67514/3/2), 19 June 1945, ASDMAE, AA PP 1931-45, Jug, b 152, f 3; Radio Belgrade, Summary of Broadcast, 2245hrs, 4 July 1945, ASDMAE, AA PP 1931-45 Jug, b 151, f VG e Dalmazia: Commenti stampa e Radio Jugoslavia.

${ }^{105}$ As one example, in the CRDA, the UO Factory Committee stripped the management of the power to issue announcements (avvisi) unilaterally. Vittorio Cernigoi (Gip) (Comitato Sindacale di Zone), "Relazione" (N. 74), 15 May 1945, AS 1815/2/55.

${ }^{106}$ Di Gianantonio et al, L'immaginario imprigionato, 78-79.
} 
associated with "Fascism" due to their various "anti-popular" activities.

As early as March, the PCI had compiled a list of 260 such individuals. ${ }^{107}$ In May, the Yugoslavs and their local allies began carrying out the first stages of the purge seen as central to their Resistance. This purge, which in its wider Julian manifestation has been well-trodden in the historiography and which continued even after Anglo-American forces arrived in the town on the afternoon of liberation day, served the dual purposes of preparing the territory for annexation and effecting local social revolution. ${ }^{108}$ In the few cases of surviving major local Fascists, the GAP and DP searched for these figures in the days after liberation, often executing those they found. ${ }^{109}$ But they also carried out a large wave of arrests and deportations, the arrestees accused of various forms of "reactionarism and black-marketeering." 110 In this moment of transformative chaos, orders for such arrests came variably from the Yugoslav military command, the CDLN, or OZNA, and the experience was highly dependent upon one's social position.

In the factories, both workers and the Party immediately began their revolution against the clerks, the latter using the Difesa Popolare as its principal arm. In the Solvay, for example, a factory committee was established, headed by the DP officer, Antonio Farinea (Josko). When the workforce returned on 7 May, Farinea immediately ordered five clerks arrested and brought to the company mess hall, where each was "invited to exculpate himself in front of the workers," roughly

\footnotetext{
${ }_{107}$ AgitProp (PCI-Monfalcone), List of Reactionaries from the Monfalconese, 5 March 1945, AS 1815/1/29.

108 The historiographical debate has been especially concerned with the foibe killings of May 1945, with "foibe" referring to the natural sinkholes in the limestone of the Carso into which the perpetrators of these deportations and killings threw the bodies of the deceased. For a highly politicized and popular discussion of the topic, see Petacco, $A$ Tragedy Revealed. For various perspectives on the number of dead and the motivations of the perpetrators, see Raoul Pupo, including Il lungo esodo; Trieste '45; Troha, Chi avrà Trieste?, ch. 1; Jože Pirjevec (ed.), Foibe: una storia d'Italia (Turin: Einaudi, 2009). Cernigoi, Operazione "foibe".

109 This was the case for Ermanno Spanghero, an early squadrista from Turriaco who later became podestà and, after 8 September 1943, was an adherent of Salò. The GAP had been attempting to bring him to "justice" in the last months of the war for having betrayed four gappisti to the Germans. When the GAP located and captured him in the first days of May, its members took him into the hills of the Carso and executed him. Tonzar, La valigia e l'idea, 76.

${ }^{110}$ Unsigned, Untitled Report on the Situation in Yugoslav-Occupied VG by City, Undated, ASDMAE, AA PP 193145 Jug, b 151, f 2. Verginella reiterates the DP's efforts to "cleans" the three categories of Fascists, profiteers, and black-marketeers. Di Gianantonio et al, L'immaginario imprigionato, 78-79.
} 
500 in number. Before the clerks could speak, Farinea impressed the gravity of the situation upon the crowd, shouting that "before you all stand five individuals whom you must judge" and leaving no doubt that, in his mind, the only suitable punishment was for them to pay with their lives. For some time, workers hurled accusations at these clerks, after which the latter sought to defend themselves. The DP released one man immediately upon learning that he had never been a Fascist and receiving the endorsement of various workers with whom he was on friendly terms. The other four were found guilty. Two had been early squadristi who had then had long careers in the offices of the firm. The other two, though never Fascist cardholders, committed unspecified "Fascist" actions. Though there is little information on the first of these, the second, notably a clerk in the Solvay's Piecework Office, was accused of having refused to give a bike tire to a partisan who had come asking for one and thus of hindering the popular cause. After the crowd rendered its "guilty" verdicts, the four were taken to the local jail. The two squadristi were later deported to Yugoslavia, never to be heard from again. ${ }^{111}$ Such was the first stage of the revolution against the clerkdom in the Solvay.

These were four of several hundred monfalconesi arrested that May, of whom some threehundred were deported to the east. Most were sent to Trieste or nearby Yugoslav-controlled cities such as Aidussina (Ajdovščina), Vipacco (Vipava), and Postumia (Postojna), where they remained for roughly ten days before being released, though some 50 never returned. ${ }^{112}$ Not all arrestees were deported. Many languished in the local jail, including a large number of the district's clerks and shopkeepers. May 1945 was a dangerous time for such individuals, and they could expect little

\footnotetext{
111 The others were released after two weeks, probably for reasons of expertise (see below). Dott. C. Contrada, (Comm. di PS-Monfalcone), "DENUNCIA a carico di Farinea Antonio...," 22 February 1948, IFSML, Fondo Marini, b 6, f 126.

112 FSS-Monfalcone, "Information on Monfalcone," 11 June 1945, NARA, RG331, UD1981, b 9186, f $11304 / 115 / 278$.
} 
sympathy. ${ }^{113}$ Townspeople called for harsh punishments, pressuring the Yugoslav authorities to act. As one Communist militant noted, "the masses do not wish that we be bloodthirsty, but rather just avengers; thus, to eliminate the malcontent, [the detainees'] deportation to the New Yugoslavia of Tito for reconstruction [forced labor] would be opportune." 114

Within the CRDA, the situation was equally confused when workers returned on 3 May. ${ }^{115}$ There the UO and Party cell structures headed by Renato A. had not yet resolved the tension between the workers' impulse to purge and the state's need for stability. ${ }^{116}$ On the one hand, some degree of power, including that to oversee purges, passed into the hands of a series of three UO factory committees. From the beginning these committees made their central demands the removal of large numbers of resented managerial elements and the complete suppression of the Piecework Offices. ${ }^{117}$ On the other, the committees' OF and wider Yugoslav superiors saw the resumption of production in the CRDA (and other Julian firms) as critical to Yugoslavia's reconstruction needs, even placing orders for tens of ships by the end of the month. ${ }^{118}$ As a result, the Yugoslav military leadership in Trieste soon gathered Triestine industrialists to assure them Yugoslavia would respect private property, unless owners were liable to expropriation under the Partisans' 1942 law for the punishment of war criminals and collaborators. ${ }^{119}$

${ }^{113}$ The PCI's list of "anti-popular" individuals almost certainly served as the starting-point for this purge. AgitProp (PCI-Monfalcone), List of Reactionaries from the Monfalconese, 5 March 1945, op. cit.

114 Aldo F[x] (Fronte della Gioventù-Monfalcone), Report to the Com. Esec. of the CDLN-Monfalcone (N. 110), 18 May 1945, AS 1815/2/55.

115 Unsigned (CRDA), "Relazione," 18 May 1945, ACS, Fondo IRI, Numerazione Rossa, b R1590.

${ }^{116}$ Unsigned (UO), "Che cosa è l'Unità Operaia," Undated (May 1945), AS 1570, b 13, f SU: Relazioni con PC; PCCRDA, "Riunione del Birò del Partito," 22 May 1945, AS 1570, b 10, f 1, sf Rapisniki raznih celic 1945.

${ }^{117}$ Unsigned (CRDA), "Relazione," 18 May 1945, op. cit.; The UO had also constructed a clandestine information services branch, equipped with informants within each workshop and tasked with gathering information on and purging "suspected persons, spies, provokers, reactionaries, etc." Unsigned (UO), "Che cosa è l'Unità Operaia," Undated (May 1945), op. cit.

${ }^{118}$ See the report of an unidentified IRI official who met with Augusto Cosulich in Venice during late May or early June. Unsigned, "Cantieri Riuniti dell'Adriatico," Undated (Mid-June 1945), ACS, Fondazione IRI, Numerazione Rossa, b R1591.

${ }^{119}$ Unsigned, "Riunione al Municipio 8/5/45 ore 14," Undated, ACS, Fondo IRI, Numerazione Rossa, b R1590. 
While this tension remained unresolved in theory, in practice the actions of the firm's clerks, technicians, and managers made it superfluous during the first two weeks after liberation. ${ }^{120}$ A large share of such individuals simply refused to show at work, fearing for their safety, which resulted in a complete breakdown in both productivity and order within the shipyard. According to the major syndical organizer Vittorio Cernigoi (Gip), "in the Shipyard the masses degenerated, indulging in acts that were inconsistent with the moment." By May 15, Communist leadership and Yugoslav military command felt compelled to issue a "recall of the Bosses," who were given "the authority necessary to reestablish order inside the Shipyard." Realizing that this would incense many workers, the Party insisted that these individuals would have authority only regarding strictly technical matters and not the power to discipline "unruly workers." But, the result was the same: the purge was put on hold. ${ }^{121}$ On a regional level, this policy was approved by the Communist leadership. Ernesto Radich informed his subordinates that even those who had earned "the hatred and resentment of the working masses, both for reasons of politics and for reasons of work," would be purged only if a replacement was available. That said, he promised a future in which the "bosses, piecework officials, clerks, office heads, inspectors ... would be superfluous." 122

\footnotetext{
${ }^{120}$ Most of these individuals were pro-Italian and anti-Communist, though certain respected engineers like Nicola Costanzi seem to have supported Yugoslavia, while the Cousliches themselves were somewhat ambivalent at this stage, particularly as they suspected the Anglo-Americans intended to reduce Italy's shipbuilding capacity and cut the state contracts upon which the firm depended. Unsigned (CRDA), "Promemoria sulla situazione politica negli stabilimenti C.R.D.A. a Trieste," 4 February 1946, ACS, Fondo IRI, Numerazione Rossa, b R1587; Unsigned, "Cantieri Riuniti dell'Adriatico" Undated (Mid-June 1945), op. cit.

${ }^{121}$ Vittorio Cernigoi, "Relazione" (N. 74), 15 May 1945, op. cit. The CRDA management had been pushing for the Yugoslavs to exert a moderating force on the purge process since the latter arrived, stressing that "essential for good work is order and hierarchy" and thus that moderation was imperative for reconstruction. Unsigned (CRDA), "Riunione 7/5/1945 ore 17 - Presso il Comando Marina Jugoslava," 7 May 1945, ACS, Fondo IRI, Numerazione Rossa, b R1590.

122 "Carlo," "Seduta del Comitato centrale dei CRDA (Trieste)," 26 May 1945, AS 1570, b 10, f 1, sf Rapisniki raznih celic 1945. This was part of an overall policy of (at least short-term) cooperation with Julian industrialists originating in Ljubljana. Shortly after liberation, Slovenian Partisan leaders met with Julian industrialists, including Agosto Cosulich, promising to help fulfill existing contracts and, in the case of the CRDA, even arranging to supply industrial raw materials necessary for production. The goal was stability and a smooth transfer of power. Giulio Mellinato, "L'occasione, le circostanze, il movimento: il contoesodo in prospettiva economica," in Il mosaico giuliano eds. Altieri and Puppini, 102.
} 
The worker backlash was immediate. Workers began "calling loudly for a purge" and for the abolition of piecework, while also attacking low-level bosses, particularly the Southerners who had long received favoritism in promotions and who were associated most closely in locals' minds with the imported system of Fascist politics and labor. ${ }^{123}$ The Party leadership scrambled in the following days to find a way to manage this discontent, dispatching trusted organizers like Ottone Zanolla and Volmaro Buttignon to speak to workers in the most radical workshops, including those of Shipbuilding Department. These emissaries stressed that undesirable elements would be purged over time through selective layoffs, but the workers resisted such efforts at placation. ${ }^{124}$ Instead, workers from Seventh Workshop of the Shipbuilding Department sent a complaint to the Party to express discontent that "squadristi and similar dangerous elements circulate and still occupy their previous posts in the Establishment." Such "enemies of the people" had at first been arrested, but then released, which led workers to wonder, "Are there no laws to punish the oppressors of the people? Now that legally we can pass judgment in our full right, why are these individuals left to circulate, undermining our cleansing propaganda?" ${ }^{25}$ At the same time, Zanolla and Buttignon urged workers to accept the maintenance of piecework until the lira had stabilized, but many workers and Communist militants refused to accept this. In one particularly heated meeting, an electric welder named Lucio railed against piecework, calling the system the "ruination of the worker" and stating that, for his craft specifically, it was deadly. It had driven workers to such paces that they had inhaled poisonous fumes and "many workers have become sick and truly tens

\footnotetext{
${ }^{123}$ Vittorio Cernigoi, "Relazione," (N. 80), 16 May 1945, AS 1815/2/55. The attacks on Southerners are implied in the Communist broadsheet, Comp. Nicola, "Agli amici meridionali," La stella rossa (N. 23), 27 May 1945, AS 1570, b 12 , f 8 .

${ }^{124}$ Comp. B[x], Manuscript Verbale from Meeting of Operai and Capi of the I Reparto (Navale), 21 May 1945, AS 1570, b 12, f 8, sf AgitProp: CRDA. The Shipbuilding Department was and remained the most radical CRDA department. For context, in August 1946, by which time statistics became available, some $83 \%$ of workers were members of the UAIS and 38\% were part of the PCRG at one of its three ranks. Comp. D[x], "Relazione politicoorganizzativa," 21 August 1946, AS 1570, b 8, f 2.

${ }^{125}$ I Compagni [five signatures], Alla Commissione di Zona (A.G.P.R.O.) (N. 143), 21 May 1945, AS 1815/2/55.
} 
have died." Despite Buttignon's vague promise that "this was under the old regime" and that piecework would be different under a regime of popular power, a Party report concluded flatly that "the masses did not intend to work by piecework, but they promised to work conscientiously for reconstruction." ${ }^{126}$ As a result of worker intransigence, by the end of May, the Yugoslavs conceded that piecework be "completely abolished," even if the bosses had returned. ${ }^{127}$

Yet for most monfalconesi, the desire to achieve workplace reforms took a back seat to a much more pressing and immediate need: the fulfillment of their basic sustenance needs. The CDLN thus made the grave problem of provisioning its central focus in its first weeks of administration. On the one hand, this was a concrete necessity to prevent starvation and the supply of food was linked quite concretely to assuring the short-term approval of the population. On the other, because conditions of shortage had become linked in the popular mind to a thoroughly "antipopular" and "Fascist" commercial system, the long-term resolution of the supply problem was assumed to be proof of the extirpation of the "remnants of Fascism." As one member of the Monfalcone OF's AgitProp section indicated that month, putting this association into words, "one of the principal problems that our governing bodies currently seek to resolve is that of provisioning. The Nazi-Fascist reaction, having been defeated in the political field and in that of the military, has yet to be defeated in the economic field." 128

Tasked with meeting this challenge was the CDLN's Provisioning Section (Sezione Approvvigionamento), little more than the Montes Intendancy (Intendenza Montes) now working in conditions of legality. ${ }^{129}$ Immediately, the Provisioning Section and the wider CDLN set to work

\footnotetext{
${ }^{126}$ Comp. B[x], Manuscript Verbale from Meeting of Operai and Capi of the I Reparto (Navale), 21 May 1945, op. cit.

${ }^{127}$ CRDA, "Consiglio 28 novembre 1946," 28 November 1946, op. cit.

${ }^{128}$ Comp. M. Z[x] (OF-Monfalcone, AgitProp), Untitled Report, 26 May 1945, AS 1570, b 11, f 8, sf Za arhivo.

${ }^{129}$ CDLN-Monfalcone (KNOO-Monfalcone), "Relazione sulla riunione del Comitato di Liberazione distrettuale tenuta il 28.5.1945," 28 May 1945, AS 1815/1/1.
} 
to prevent starvation, ordering all mills to grind continually $85 \%$ pure wheat flour, implementing a price system on fish that incentivized the gathering of high volumes of lower-quality fish, confiscating and distributing goods from notoriously Fascist families, using various forms of persuasive and coercive pressure to secure livestock and other food products from the district's farmers, implementing extreme punishments for black-marketeering, and posting DP members to all shops to assure compliance with pricing and rationing norms. ${ }^{130}$ These policies played into popular expectations for the economy - namely that the state take an increasing role in mediating exchange and eradicating the black market - which had been fundamentally conditioned by experiences under Fascism. The workers were particularly quick to demand the expansion of the ration and price-control regime. For example, when an unrationed "batch of eggs" went to market in Panzano in mid-May, the population demanded the local OF committee ensure that "occurrences of the type never happen again." ${ }^{131}$ Similarly, there seems to have been significant support for the decisions of the CRDA Factory Committee to appropriate and run the firm's internal shops, supplied now by the OF. ${ }^{132}$ Though the precise mechanisms and forms of state control had not yet been articulated, the basic idea of state-mediated exchange had broad support.

Yet for all the efforts of the CDLN to resolve provisioning and price difficulties in the Monfalconese, the task was often too great. In part, this was due to the natural difficulties caused by Monfalcone's geographical position, as, according to the CDLN, few merchants voluntarily

\footnotetext{
${ }^{130}$ On these phenomena respectively, see Comitato Esecutivo (CDLN-Monfalcone [OF]), "Riunione del PLENUM e del Comitato Esecutivo," 13 May 1945, AS 1815/1/4 and CDLN-Monfalcone (OF), Circolare al Comitato di Villagio di Monfalcone, 6 June 1945, ASBCM, b 516, f Ctg XIV; Unione Lavoratori della Pesca-Monfalcone, Untitled Price List, 14 May 1945, AS 1815/4/73 and Unione Lavoratori della Pesca-Monfalcone, Report on Meeting, 16 May 1945, AS 1815/4/73; CE, CLN-Staranzano, Interni, "Difesa Nazionale" (N. 68), 3 July 1945, AS 1815/1/1; Antonio Z[x] (DP-Monfalcone), Untitled Report N. 66, 15 May 1945, AS 1815/2/55 and Mario F[x] (CLN-Turrico [OF]), Untitled Report, 18 May 1945, AS 1570, b 12, f 8, sf AgitProp: Turjak-[Illegible]; Mario F[x] (CLN-Turriaco [OF]), Untitled Report, 31 May 1945, AS 1570, b 12, f 8.

131 Aldo V[x] (CLN-Panzano [OF]), Untitled Report N. 82, 16 May 1945, AS 1815/2/55.

132 Vittorio Cernigoi (Comitato Sindacale di Zona), Relazione (N. 80), 16 May 1945, AS 1815/2/55.
} 
sold to Monfalcone when higher prices could be had in Trieste. Moreover, in communes like Turriaco, the requisitioning and distribution of goods among the citizenry was extremely popular, but the quantities were so small that provisioning remained a "complete debacle." 133 Thus the CDLN ordered that goods be purchased from Triestine and Friulan wholesalers (grossisti) and stored in a central warehouse. ${ }^{134}$ Nevertheless, by the end of May, the CDLN distributed just $200 \mathrm{~g}$ of bread every other day, supplemented with alternating distributions of cornmeal and monthly distributions of rice, flour, oil, rice, and other goods. Fresh produce remained absent. ${ }^{135}$ Meanwhile, with many of the district's shopkeepers and merchants sitting in jail cells awaiting punishment for their "antipopular" and "Fascist" activities, the mechanisms for distribution that had existed under SEPRAL and later the German occupation had been partially dismantled.

Thus, in the first month of the pro-Yugoslavs' attempt to remake the world and eliminate the "remnants of Fascism," the committees achieved very uneven results, limited by inescapable limits on resources, the impossibilities of reforming longstanding institutions and social practices overnight, and the Yugoslavs' own organizational necessity for order and productivity in the district. Nevertheless, among many pro-Yugoslav workers there persisted a hope that things would get better, particularly under a regime of popular power - and what news arrived from the rest of liberated Italy certainly reminded monfalconesi that things could be worse.

In this, the experiences of the young worker Mario F. are instructive. Mario, a member of

\footnotetext{
133 The figures included an unspecified amount of milk, $150 \mathrm{~kg}$ of wheat flour, $265 \mathrm{~kg}$ of cornmeal, $535 \mathrm{~kg}$ of potatoes, $55 \mathrm{~kg}$ of sugar, $18 \mathrm{~kg}$ of butter, $80 \mathrm{~kg}$ of pasta, $45 \mathrm{~kg}$ of rice, $9 \mathrm{~kg}$ of lard, and some $100 \mathrm{~kg}$ of dried beans. Further, the very needy families split 1300 eggs, 55 jars of evaporated milk, and roughly 100 cans of meat and sardines. Mario F[x] (CLN-Turriaco [OF]), Untitled Report, 25 May 1945, AS 1570, b 12, f 8, sf AgitProp: Turriaco.

134 Com. Esec., CDLN-Monfalcone, "Riunione del Plenum e del Comitato Esecutivo della Zona di Monfalcone," 21 May 1945, AS 1815/1/4.

135 Comp. Z[x], Untitled Report, 26 May 1945, op. cit. During its administration, the CDLN distributed 124 quintals of meat, 110 of oil, 50 of fats, 600 of sugar, 500 of white flour, 100 of rice, 100 of potatoes, 80 of legumes, 50 of soap, 130 of salt, 20 of cigarettes, 500 of soda, 140 of vinegar, 36 of wine, 150 of marmalade, 1000 of polenta meal, 2000 of bread flour, 4 of bread yeast, and some 150,000 eggs. CDLN-Monfalcone, Sezione Approvvigionamento, "Resoconto Sezione Approvvigionamento (N. 152/VIII), 5 March 1946, AS 1815/4/72.
} 
the Difesa Popolare and the Turriaco OF committee, had recently arrived home from Tarcento (Udine Province, Italy), where he had fought as a garibaldino until late April. In late May, however, after liberation, he was sent back to Tarcento on Communist Party business. What he saw shocked him. He walked through the city and saw Italian tricolors waving, adorned not with the red star, but rather the crest of the Savoy monarchy that had acquiesced to Mussolini's power grab in 1922 and lent legitimacy to his regime. As he wore his red neckerchief around town, he received suspicious and hostile glances from locals, undoubtedly because the latter saw him as a traitor to the nation rather than, as he saw himself, a proponent of progressive Italians and Yugoslavs joining in fraternal struggle to achieve the fullest liberation possible. Even worse than the looks, Mario witnessed "a Fascist in uniform with the emblems of the March on Rome" walk freely and defiantly in the streets. All he could do was ask himself in disbelief, "is this liberation?" Had the question not been rhetorical, the answer undoubtedly would have been "no." The Italians of the Old Provinces appeared mired in their nationalist, monarchist, and Fascist ways, their identities so closely tied to belonging to Italy that they could not see that Italy was little changed since the Duce's demise. Fatigued and disillusioned from his short stay in Italy, Mario started his journey home. Only upon reaching the Isonzo did he feel revitalized. Passing over the river and arriving in Monfalcone, "it seemed to me that I breathed a new air. It was the air of the New Yugoslavia." 136

\footnotetext{
${ }^{136}$ Mario F[x], "Viaggio a Tarcento," 29 May 1945, AS 1570, b 12, f 8. Mario's account is not implausible. Postwar reports suggest that, though roughly half of the Udinese population was politically "disinterested," the monarchists, qualunquisti, and neo-Fascists garnered significant support among the politically active. Unsigned [Likely Questore Durante], Report to Prefetto di Udine, 26 May 1946, ASU, Pref, Gab, b 43, f 153, sf 1. See also the reports of 27 February 1947 and 28 February 1948 in the same file.
} 


\section{Chapter 3: The Myth of Yugoslavia: Visions of Utopia in a Town Straddling Two Worlds}

A new Europe is arising from the ruins of the old Europe.... New governments form, which have the task of guaranteeing to the peoples [of Europe] those democratic liberties which they have acquired in their struggle against the occupier.... [D]evelopments in the various states will depend upon the degree to which individual peoples succeed in eliminating the more or less masked residues of fascism, which resurface everywhere in new forms. There is a place where, by contrast, a new state is already at work and a truly modern democracy has already been established, based on entirely new principles, that has nothing in common with the political forms now so rightly hated by these exhausted peoples: it is Yugoslavia. ${ }^{1}$

- From the clandestine Communist newspaper Il nostro avvenire, 31 October 1944.

When Mario F. crossed the Isonzo and caught his breath of fresh air, he returned to a Monfalconese that was now part of Tito's New Yugoslavia. Individuals like Mario had conceptualized the Resistance from its very beginning as not just liberation, but also as a fundamental transformation in daily lived experiences. To their great excitement, the Yugoslavs had arrived before the Anglo-Americans, their radical faction of the Resistance ascendant. The Yugoslav forces and their local allies had brought a Yugoslav-aligned committee to power and had begun to take concrete steps to address the gravest concerns of the suffering population. Thus, even though hardship still gripped the Monfalconese after a month of Yugoslav rule, Mario had great faith that all problems would soon be solved. With power in the hands of "the people," it seemed the only possible outcome. But Mario's faith in the imminent improvements to his and his neighbors' daily lives - his sense of breathing freely, even though the conditions of everyday life remained nearly as dire as in the months before liberation - was built upon more than just his trust that his faction of pro-Yugoslavs would be able administrators, wielding power effectively for the broadest possible good; it also resulted from a mythic vision of Tito and Yugoslavia, which had emerged during the last months of the war thanks to the work of pro-Yugoslav propagandists. ${ }^{2}$

\footnotetext{
${ }^{1}$ Bruno P., "Nuova Jugoslavia," Il nostro avvenire, N. 1, Anno 1, 31 October 1944, op. cit.

${ }^{2}$ Historians of postwar Monfalcone and Venezia Giulia have acknowledged this myth and its mobilizing power but have not carefully analyzed it. See Anna Di Gianantonio's preface to Tonzar, La valigia e l'idea; Gombač,
} 
Unfortunately for Mario, however, his hopes for radical transformation soon crashed headfirst into the realities of postwar geopolitics. Just forty-three days after their arrival, the Yugoslavs abruptly withdrew from the Monfalconese, replaced by an Anglo-American military administration. With Mario and his comrades left in shock, Monfalcone's air once again seemed fouled by the stench of "Fascism."

\section{The Allied Military Government and the Dismantling of "Popular Power"}

Though a shock for those on the ground, the Yugoslav withdrawal had followed a series of tense negotiations between the Soviet-backed Yugoslavs and the Anglo-Americans. It represented just a small part of a much larger Yugoslav withdrawal from northern and western Venezia Giulia, which, since early May, had been under a sort of dual occupation. On 9 June, having lost the backing of Stalin for their most aggressive claims, the Yugoslavs conceded the temporary partition of the region into two zones of military administration that would exist until the formalization of a peace treaty. Dividing these two zones was the Morgan Line, which curled eastward from the Adriatic coastline just south of Muggia, around Trieste city, turning northwards and passing east of Sesana and Gorizia before following the Isonzo River into the Alps (Figure 11). Territories to the south and east were to be administered by the Yugoslavs (Zone B). Those to the north and west (and the enclave port of Pola) became Zone A, administered by an Anglo-American Allied Military Government (AMG) and headed by a Senior Civil Affairs Officer (SCAO) responsible directly to

\footnotetext{
"Controesodo tra poteri popolari e GMA," in Il mosaico giuliano, eds. Altieri and Puppini, op. cit., 43; Cernigoi, Scelte politiche e identità nazionale, 294-95. The journalist Andrea Berrini has stressed that the monfalconesi's faith in Yugoslavia was not passive - not a mere faith (fede) that Yugoslavia was a better place. Rather, the myth emphasized their ability actively and collaboratively to "forge" (forgiare) a better future. Still, he does not thoroughly explicate the myth, in part because his interviewees are hesitant. Berrini, Noi siamo la classe operaia, 7-9. By contrast, Carol Lilly, Power and Persuasion: Ideology and Rhetoric in Communist Yugoslavia, 1944-1953 (Boulder, CO: Westview Press, 2001), explicates the mythic self-representation of Tito's regime within Yugoslavia proper.
} 
the Supreme Allied Command in the Mediterranean (SACMED). ${ }^{3}$

The coming of the AMG had an immediate impact on the ability of Mario F. and likeminded monfalconesi to realize their transformative goals, though not on their calls for such a transformation. At one of several rallies held by OF supporters immediately after the withdrawal, the veteran Communist Angelo Comar warned against abandoning the transformative struggle. He stressed that "Fascism still exists, some social classes exist that try to take away the fruits of our bloody [Resistance] struggle," claiming that all who wave the Italian tricolor with the Savoyard crest are Fascists. To lively applause, Comar concluded, "we will tell the Allied government that these are sympathizers with Fascism and that they refused to participate in the struggle and that they stayed comfortable in their plush armchairs while we and our brothers sacrificed their own lives to chase out Nazi-Fascism.... We must chase all these reactionaries away like poisonous snakes." 4 Two weeks later, the Communist daily Il Lavoratore issued a similar call to action:

To purge and to reconstruct are two words that today have politically the same meaning: to realize the first is indispensable for the practical realization of the second....

One defeats gangrene with amputation, and if the surgical intervention is not prompt and radical, the illness persists and spreads to all the parts of the afflicted body.... Fascism is the social gangrene that has poisoned our existence for more than twenty years, and it has dragged us into the mortal crisis of the war, and as gangrene it will be treated. ${ }^{5}$

For the AMG, which was in theory to be an "impartial" caretaker government managing lands whose territorial fate was undecided, such calls posed grave threats. ${ }^{6}$ They ran counter to the general political-economic vision that informed Anglo-American policymaking and also to the

\footnotetext{
${ }^{3}$ Stalin backed down because he feared Yugoslav claims might spark a Soviet-American war. The AMG in Venezia Giulia was institutionally distinct from that in the rest of Italy. Novak, Trieste, 199-205; Rabel, "Prologue to Containment."

${ }^{4}$ Corrispondente Jelen M[x] (Tanjug), "TANJUG" (N. 0109/45[?]), 15 June 1945, AS 1570, b 11, f 8, sf Corrispondenza.

5 "L'epurazione come un presupposto della ripresa economica," Il Lavoratore, 30 June 1945.

${ }^{6}$ On the supposed "impartiality" or "neutrality" of the AMG in mediating competing Italian and Yugoslav claims over Venezia Giulia, see Sluga, The Problem of Trieste, 112-18. The remainder of that chapter of Sluga's book dispels this pretense.
} 
Anglo-Americans' concrete goal of claiming Trieste for the anti-Communist world and turning it into a bulwark against a westward advance of Communism. Because the OF calls for an extensive purge threatened to destroy the social bases of the region's pro-Italian movement, a large portion of which the AMG hoped to coopt in its geopolitical game, "impartiality" was, from the beginning, far more a legitimizing discourse than an accurate description of AMG policy.

In fact, from a very early date, the AMG's civil affairs officers (CAOs) for the district first Major J. Reid and then Major J. Kitson-Harris - moved against the OF councils in some of the earliest Cold War battles. On the one hand, they nurtured anti-Communist and pro-Italian political parties, overseeing the creation of local chapters of the Actionists, Christian Democrats, and Socialists (leftist, but pro-Italian) by mid-July. ${ }^{7}$ On the other, they systematically undermined the OF administration and moved to dismantle the organs of "popular power." Included in the latter was an order given to the CDLN to disband the Difesa Popolare, the primary organization involved in policing the black market and the arm for leading the social revolution envisioned by many monfalconesi. Though the CDLN at first refused, when the AMG threatened to arrest the DP's members, it complied. ${ }^{8}$ Following the dissolution of the DP, the AMG disbanded the Yugoslav People's Courts (Tribunali del Popolo) charged with trying and purging former Fascists

\footnotetext{
${ }^{7}$ Soon after arrival, Reid met with the two secretaries of the CDLN, asking them if they would be willing to follow AMG orders if these orders clashed with orders from the higher OF committees in Trieste or Ljubljana. Tellingly, both secretaries refused to answer the question. Maj. Reid (CAO Monfalcone), "Weekly Report for the District of MONFALCONE...," 30 June 1945; and Maj. F. Cozens (CAO Monfalcone), "Weekly Report for the District of Monfalcone...," 19 July 1945, both in NARA, RG331, UD1981, b 9186, f 11304/115/278. Assessing the power of these parties is difficult. Per the Communist Party information services, as of January 1946, the DC claimed to have 3500 members in the District, though it had not had a conference in a month and a half. The Socialists had an estimated 300-350 supporters, the Actionists eighty - some the "scum of reaction and collaborationism," and some "elements of good faith." There would also emerge a very small Liberal Party chapter. Ruggero Bersa (PCRG-CDM), "V Relazione quindicinale sulla situazione politica del distretto di Monfalcone," 14 January 1946, AS 1570, b 8, f 2. ${ }^{8}$ CDLN-Monfalcone, "All'Ufficiale addetto al controllo dell'amministrazione civile...," 18 June 1945, AS 1815/2/55; Capt. Welsh, "Disbanding of the 'Difesa Populare"" [sic], 24 June 1945, NARA, RG331, UD1981, b 9139, f 11304/100/38. Upon the DP's dissolution, its leaders ordered members to attempt to enroll in and infiltrate the nascent AMG police force, the Venezia Giulia Civil Police (VGPC). The AMG and Anglo-American military forces soon learned of this, their distrust of the local Communists heightened greatly. Lt Col GS (Illegible), "56 (Lon) Div Op Instr No 21,” 22 June 1945, NARA, RG331, UD1981, b 9185, f 11304/115/272; Tonzar, La valigia e l'idea, 77.
} 
and arrested regional figures tied to the pro-Yugoslav Trieste Liberation Council and $\mathrm{Il}$ Lavoratore. ${ }^{9}$ Finally, in mid-August it ordered the dissolution of the CDLN itself which, having received both an invitation from the AMG to participate as a minority party in a multiparty council and orders from Ljubljana to pursue an all-or-nothing strategy, begrudging accepted Ljubljana's orders after "animated discussion." The CDLN thus paved the way to its own marginalization. ${ }^{10}$

The result was that the OF, enabled by the AMG's scarce knowledge of its organizations, returned to clandestine action and shadow administration, while throughout the zone the struggle to root out the "remnants of Fascism" ground to a halt. Even the push to purge cardholding Fascists slowed to a glacial pace, with SCAO Alfred Bowman ordering that all purge cases tried in the People's Courts be subject to AMG review. ${ }^{11}$ For those hoping that liberation would bring about a rapid and radical purge of "Fascists" and the accompanying social transformation, the closing of this brief chapter of "popular power" was a disaster. They experienced it as a sudden narrowing of the "horizons of hope" that had been so radically broadened in May.

\section{Borders, Demonstrations, and Myths}

Despite this blow, the Belgrade Agreement, which laid out the terms of the Yugoslav withdrawal in early June, did not leave the pro-Yugoslavs entirely devoid of hope. Though the power to decide the territorial fate of Venezia Giulia rested with the Council of Foreign Ministers, in this era of the Atlantic Charter and language of self-determination, there remained the hope that Tito might one day return. In the minds of pro-Yugoslavs, the organization of public demonstrations and lobbying campaigns - the demonstration to a global audience of an irrefutable

\footnotetext{
${ }^{9}$ On this process in the wider Zone A and especially Trieste, see Novak, Trieste, 219-33.

${ }^{10}$ PCI-Monfalcone, "Verbale della 23 seduta del giorno 23/7/45," 23 July 1945, AS 1570, b 8, f 1; Ruggero Bersa, Letter to CAO-Monfalcone, 21 August 1945, NARA, RG331, UD1981, b 9186, f 11304/115/283. For more on this debate, see Di Gianantonio et al., L'immaginario imprigionato, 96-101.

${ }^{11}$ SCAO Meeting Minutes, 1 October 1945, NARA, RG331, UD1981, b 9108, f 11302/115/88.
} 
"popular" will for Yugoslav annexation - remained a viable strategy through which to bring Yugoslavia back to the Monfalconese. ${ }^{12}$ Yet securing and sustaining mass participation sufficient to give an impression of unanimity required a powerful mobilizing impetus. Even in the Monfalconese, with its history of radicalism and activism, war fatigue and the difficulties of daily life dampened appetites for mass mobilization. Thus, the leadership of the pro-Yugoslav movement pushed ahead forcefully with the elaboration of a myth of Yugoslavia. ${ }^{13}$ The myth was a story of Yugoslavia's past, a description of its present, and a projection of its future. In some respects tethered firmly to "reality" and in others not, it gave narrative form to the values and "utopian social daydreaming" of much of the Monfalconese population. ${ }^{14}$ Investing Yugoslavia with those values, it inspired monfalconesi to mobilize for Yugoslav annexation. ${ }^{15}$

Already in embryo during the war, fostered through partisans" "Political Hours," the clandestine press, and word-of-mouth, myth-building became increasingly important with liberation and the emergence of the territorial contest. With liberation, myth-builders enjoyed a greater opportunity to pursue their ends, despite AMG opposition. ${ }^{16}$ Moreover, with liberation,

\footnotetext{
${ }^{12}$ Bogdan Novak has examined this campaign (as well as the competing pro-Italian campaign) with a special eye to events in Trieste, terming this strategy "lobbying in sound and fury." Novak, Trieste, 252.

13 "Myth" here is understood not as a colloquialism for "untruth," but rather as "an ideologically marked narrative which purports to give a true account of a set of past, present, or predicted political events and which is accepted as valid in its essentials by a social group." Christopher Flood, Political Myth: A Theoretical Introduction (London and New York: Routledge, 2013), 44. Flood further stresses that "what is important is not the objective truth or untruth of the narrative, but merely the fact that the story needs to be believed to be true by a social group if it is to have the particular functions which are fulfilled by myths." Ibid., 45.

${ }^{14}$ Richard Stites, Revolutionary Dreams: Utopian Vision and Experimental Life in the Russian Revolution (New York: Oxford University Press, 1989), 13. See also Marcello Flores and Francesca Gori (eds), Il mito dell'Urss: La cultura occidentale e l'unione sovietica (Milan: Franco Angeli, 1990), 10; and Hollander, Political Pilgrims, 3-7.

${ }^{15}$ Shortly after the Yugoslav withdrawal Ruggero Bersa revealed the Communist Party's new strategy of organizing pro-Yugoslav demonstrations, and the indispensibility of such a myth for that end. Di Gianantonio et al, L'immaginario impriogionato, 96-101.

${ }^{16}$ The AMG purposely amplified non-Fascist pro-Italian voices that were highly critical of Tito's Yugoslavia and quickly developed draconian censorship laws, banning the posting of "political posters of any type" and even threatening prison time or the death sentence for individuals convicted of publishing without an AMG-issued license or of owning an unlicensed radio. Such measures became a point of contention and resentment because they resembled Fascist-era censorship. PWB Unit No. 20, "Minutes of Meeting held on MONDAY 2nd July 1945 at 1500hrs," 2 July 1945; AIS-Trieste, "Minutes of Meeting held on Tuesday 18th December 1945 at 1000hrs," 18 December 1945, both in NARA, RG331, UD1981, b 9138, f 11304/100/4.
} 
monfalconesi could more readily listen to pro-Yugoslav radio stations such as Radio Belgrade (from late 1944) and Radio Trieste (May-June 1945), just as they could read the Communist press in the form of the licensed (though continually harassed) Triestine daily Il Lavoratore and local broadsheets (giornali murali) posted in Monfalconese workplaces. ${ }^{17}$ But perhaps most importantly, the pro-Yugoslavs fostered this myth by word-of-mouth, relying on AgitProp militants with ties to the Communist Party and OF-loyal organizations to spread mythical thinking during their everyday lives, as they shopped, ate, worked, and enjoyed their leisure time.

Through these and other means, the pro-Yugoslav forces of the Monfalconese and the wider Julian Region began immediately in 1945 to craft a myth of Tito's new Yugoslavia. This myth had a great deal of nuance. Its propagators made use of the flexibility with which monfalconesi had come to think of the terms "Fascism" to sell a Yugoslav alternative, tailoring the myth to the intended audience just as Titoist propagandists within Yugoslavia tailored their representations of the regime to respond to the aspirations of Yugoslavia's predominantly peasant society. ${ }^{18}$ In Monfalcone, the myth operated on two levels. The first might be called the "national" level, concerning grand ideological aspects of the New Yugoslavia, such as its reformed nationality

\footnotetext{
${ }^{17}$ Il Lavoratore's history in Trieste went back to the time of Habsburg-era Austro-Marxism. Suppressed in the Fascist years, the paper surfaced periodically as an underground publication and resumed life as a clandestine paper during the Resistance. During the period of Yugoslav occupation, the paper increasingly gravitated toward a pro-Yugoslav stance on the territorial question, which was solidified when the pro-Italian editor Ferrer Visentin resigned in favor of a post with L'Unità in Milan. In late 1945, the pro-Yugoslav Leopoldo Gasparini assumed the role of director. Circulation figures do not exist for the Monfalconese specifically, but the paper circulated between 18,000 and 26,000 copies daily in all of Venezia Giulia, reaching a much larger audience due to paper-sharing and word-of-mouth transmission. On personnel changes, see Giacomo Pellegrini, Letter to PCI- Direzione (N. 7826), 19 November 1945, AM-IG, Fondo Jug e VG, b mf 93, f 2, sf d, d D:15; AIS-Trieste, "Minutes of Meeting Held at AIS Trieste on Thursday, 3rd January 1946 at 1100 hours," NARA, RG331, UD1981, b 9138, f 11304/100/4. On circulation figures, see AISTrieste, "Activities Report No. 19. for week ending 5th January 1946," 5 January 1946; AIS-Trieste, "Activities Report No. 29 for week ending 16th March 1946," 16 March 1946; AIS- Trieste, "Activities Report No. 48 for the period from 18 ${ }^{\text {th }}$ August to 14th September 1946," 14 September 1946; AIS- Trieste, "Activities Report for the Month of May 1947” (N. 59), May 1947, all in NARA, RG331, UD1981, b 9138, f 11304/100/2.

${ }_{18}$ Within Yugoslavia, for example, propagandists emphasized the peasant origins of the Partisan forces and the rewards peasants received in the form of redistributed land seized from foreigners and "collaborators." Melissa Bokovoy, Peasants and Communists: Politics and Ideology in the Yugoslav Countryside, 1941-1953 (Pittsburgh: University of Pittsburgh Press, 1998), xv, 35-40.
} 
relations and its radically new economic system. However, undergirding and drawing upon this national myth was also a second myth, the "personal" or "everyday" myth, tailored to respond to daily experiences in the lived spaces of the workplace, the street, and, significantly, the marketplace. Though certain historians and commentators have tended to view mundane considerations arising in such lived spaces as existing outside the realm of idealism and myth perhaps even opposed to it - in fact the myth of Yugoslavia was very much about the mundane, the myths of the mundane and the ideal drawing upon and reinforcing one another. ${ }^{19}$

Though the myth and its dual aspect developed in a shifting context, this chapter provides a largely synchronic analysis of the myth as it existed in the first three postwar years, and the next ties this myth to the concrete, diachronic struggle for local reform. In the end, the myth both served as the inspiration for the pro-Yugoslav struggle and influenced how theoretically unprepared monfalconesi thought of socialism and Communism. It served as a critical "foil" against which they compared their own community and their efforts at radical postwar reconstruction.

\section{The Origins Story: A New Yugoslavia for the New Europe}

Of the two levels of myth, the national myth was the first to emerge, having its origins in wartime propaganda. Central to it was the notion that Yugoslavia was part of the Soviet world, often termed the "New Europe." The garibaldini had recognized even before liberation that the world was bifurcating into two camps, the Anglo-American camp of the old "demo-plutocratic" Europe and that inspired by "the new democratic-popular-progressive-irradiant ideal of the Soviet

\footnotetext{
${ }_{19}$ Andrea Berrini juxtaposes Monfalconese migrants' mythic hope for living and working within an ill-defined socialist economy with mundane concerns like finding a regular paycheck. This understanding of the impact of the mundane concerns seems mistaken because, as will be seen, the successful resolution of "mundane" concerns like a regular paycheck was often a central criterion to which workers held a socialist economy. Berrini, Noi siamo la classe operaia, ch. 25.
} 
lands. ${ }^{20}$ Following liberation, pro-Yugoslavs pushed this idea among the population, establishing Yugoslavia as the closest ally of the USSR. In early May, the PCI's AgitProp division made much of the recent Treaty of Friendship between the USSR and Yugoslavia. Militants emphasized the "reciprocal aid and collaboration" between the two countries that placed Yugoslavia alongside the USSR as "one of the pillars of the New Europe of tomorrow in the free democratic development of humanity." ${ }^{21}$ Within Communist circles, militants cast Yugoslavia as having assumed the mantel of revolutionary progress from the Soviet Union. They claimed that "Russia has passed all its work on to Yugoslavia" and that "it is up to the latter to bring the struggle for the institution of popular power to Europe," just as Mao was doing in Asia. ${ }^{22}$

By stressing these ties, pro-Yugoslavs aimed to tap into an older tradition of mythologizing about the Soviet Union that had preceded the war but intensified during it. ${ }^{23}$ Though it took different forms in different national and class contexts, there had developed in the interwar years a multifaceted myth of the USSR among Soviet sympathizers the world over, which had common emphases. Chief among the Soviet Union's virtues were its attainment of social justice and an unprecedented social cohesion that resulted; the ability of Soviet citizens to maximize their human potential rather than exist as mere beasts of burden; the regime's triumph over Russia's inherited backwardness and its rapid modernization of economic and social practices; the benevolence and simplicity of its leaders; and the transformation of formerly oppressive institutions such as prisons

\footnotetext{
${ }^{20}$ Commissario I Battaglione, Brigata Triestina, "Venezia Giulia - Jugoslavia" (N. 230), Undated (Spring 1945), op. cit.

${ }^{21}$ Unsigned (AgitProp), "Il trattato di amicizia sovietico Jugoslavo," 9 May 1945, AS 1570, b 11, f 8, sf Za arhivo. Print articles reiterated these themes, drawing attention to Tito's speeches which proclaimed his close bond with Stalin. "Riconoscenza della Jugoslavia per l'Unione sovietica," Il Lavoratore, 20 June 1945; "Parole di Tito a Mosca," Il Lavoratore, 29 May 1946.

${ }^{22}$ This idea originated with a speech of Edvard Kardelj. PCRG, "Relazione sulla seduta del regionale e del circondario del PC della RG avvenuta nel giorno 12 dicembre 1945," 13 December 1945, AS 1570, b 8, f 2.

${ }^{23}$ The failure of the PCI to elaborate a clear revolutionary program during the years of war and Resistance led Italians increasingly to project upon Stalin and the USSR their hopes for constructing a radically different future. Pavone, $A$ Civil War, 483-85.
} 
into sites of rehabilitation and the creation of the Soviet "new man." ${ }^{24}$ Cast as a dutiful partner of the USSR, Yugoslavia inherited the qualities associated with the Soviet Union.

Yet the emphasis on Yugoslavia's friendship with the USSR did not mean the reduction of Yugoslavia to a copy of the Bolshevik regime. Instead, mythmakers pushing the pro-Yugoslav cause honed an origins story that distinguished the Yugoslav regime from the USSR and attributed to it unique characteristics. Central to this story was the invasion and occupation during the Second World War, which, militants insisted, had served as a fundamental rupture in Yugoslav history due to the complete collapse of the prewar social and political orders of Yugoslavia. ${ }^{25}$ On the one hand, the collapse brought the disintegration of the Yugoslav state, a pitiless and rapacious Axis occupation, and widespread misery and death. On the other, this collapse and the accompanying misery had been an unexpectedly positive development. It provided the context from which to create a fundamentally new state, freed entirely from the burdens of a historical inheritance, and it also had catalyzed a fundamental transformation of the Yugoslav peoples' nature. Indeed, Eligio Simsig, a Communist militant who attended the PCRG Party School to train in propaganda, wrote in his school notebook the origins story of the New Yugoslavia that he and others would spread throughout the Monfalconese. ${ }^{26}$ His lesson notes stressed that during the war Tito's new "popular

\footnotetext{
${ }^{24}$ These factors of the myth are well covered in Hollander, Political Pilgrims. On this myth in a general sense, see Flores and Gori (eds), Il mito dell'Urss; and Walter Laqueur, The Dream that Failed: Reflections on the Soviet Union (New York: Oxford University Press, 1994). For a work that focuses specifically on French intellectuals and the myth of the Soviet Union, see Judt, Past Imperfect. For works that focus on the methods used by the Soviet Union to generate this myth, many of which would later be used by Tito's Yugoslavia, see David-Fox, Showcasing the Great Experiment; and Stern, Western Intellectuals and the Soviet Union.

${ }^{25}$ Thus, in the days after liberation, the radio waves were flooded with narratives that emphasized a complete rupture, as when the pro-Yugoslav Radio Trieste broadcasted an interview with the vice-commandant of the Trieste Liberation Council, who asserted that "the old Yugoslavia has disintegrated" and that "this is the New Yugoslavia, a Yugoslavia that has nothing more to do with the old." Radio Trieste, Summary of Broadcast, 2125hrs, 9 May 1945, ASDMAE, AA PP 1931-45, Jug, b 151, f Venezia Giulia e Dalmazia: Commenti Stampa e Radio Jugoslavia. See also A. Ross Johnson, The Transformation of Communist Ideology: The Yugoslav Case, 1945-1953 (Cambridge, MA and London: The MIT Press, 1972), 27-35.

${ }^{26}$ The Party School was at Abbazia (Opatija) in Croatia, near Fiume. Simsig attended in 1947, but all indications are that the content of the lessons had remained largely unchanged since its foundation in 1945. Simsig's notebook is held at the IFSML, Fondo Simsig, b 1, f 7. On this school, see the comments by Aldo Fumis and Valerio Beltrame, the first
} 
powers"

were constituted not only in liberated territory, but even in that of the enemy.... It is clear that the people did not want to have any trace of the old regime. The P[opular] P[owers] were the expression of the new State that was being created in the struggle.... The people's activity was part of the Liberation Army's activity. The characteristic was that the People constituted its own power and that the people made sacrifices. With its blood it created these powers. Thus, a new State was being forged, formed from the small P[opular] P[owers] often in the villages, rising from the ruins of the old institutions. ${ }^{27}$

In short, the war had caused the collapse of the Old Yugoslavia and widespread misery; the people's misery and suffering forced their participation in a base struggle for survival during which they experienced a moral regeneration; and from these morally regenerated peoples a fundamentally new state emerged, constructed on bottom-up support from the most local level. ${ }^{28}$ In keeping with the themes of rupture and novelty, pro-Yugoslav propagandists emphasized the regime's uncompromising purge of remnants of the old regime, most notably with a dramatic narration of the capture and trial of the Chetnik leader, Draža Mihailović. ${ }^{29}$

This origins story played on longstanding ideas of regenerative and purifying suffering, casting the Yugoslav nations as martyred and reborn nations par excellence. Intentionally downplaying all but the most extreme of collaborationist activities in occupied Yugoslavia, $I l$ Lavoratore and street-level propagandists stressed the near-unanimous upsurge of popular action against the occupiers, stressing that, as a result of these experiences, the nations of Yugoslavia

of whom was a teacher there, the second a student. Alfredo Bonelli, "Testimonianza del monfalconese Fumis Aldo," 15 November 1977, IRSML, Fondo Cominform, b 99, f 5; Alfredo Bonelli, "Memorie del monfalconese Beltrame Valerio," 29 November 1977, IRSML, Fondo Cominform, b 99, f 7.

${ }^{27}$ Eligio Simsig, "Lezione XXXII," 18 March 1947, IFSML, Fondo Simsig, b 1, f 7. Underlining in original. This origins story was often the discussed at Communist Party meetings and became a staple of Communist propaganda. See PCRG-Trieste, "Prima riunione dell'attivo comunista della R.G. per il Circondario di TRIESTE," 14 December 1945, AS 1570, b 1, f 3-A.

${ }^{28}$ For print reiterations of this origins story, see "Dalla Jugoslavia federativa e democratica," Il Lavoratore, 18 October 1945 and "Compatta partecipazione alle elezioni in Jugoslavia," Il Lavoratore, 13 November 1945.

${ }^{29}$ The most important articles in this drama, all from Il Lavoratore, include "La banda di Mihajlovic di fronte al Tribunale supremo jugoslavo," 1 August 1945; "Giustizia è resa al popolo serbo," 10 August 1945; "Draza Mihailovic è stato catturato," 25 March 1946; "Mihajlovic," 11 June 1946. 
became a single "community of suffering." ${ }^{30}$ In fact, when the Yugoslav Partisans had arrived in Monfalcone in May 1945, they quickly became known to pro-Yugoslavs as the "silent army," in reference to their shoelessness. In contrast to the Anglo-Americans, whose boots could be heard at every step, the eerie silence of marching Partisans, not to mention the gauntness and dirtiness of their bodies, reinforced the notion that the Yugoslav nations had suffered more than all others. ${ }^{31}$ Combined with the fact that Tito's Partisan movement had emerged victorious in liberation against seemingly insurmountable odds, this reinforced a sense that the Yugoslav nations had a moral superiority and that they had garnered strength from adopting the values of the mountains. ${ }^{32}$

Such portrayals - particularly that of the morally regenerated Partisan fighter - appealed greatly to monfalconesi, who often imagined their own Resistance as having a similar regenerative result and who hoped their struggle had purchased them an entry-ticket to participate in the Yugoslavs' project, even if in a position of deference to the superior Titoists. The idea that garibaldini in particular and monfalconesi in general had won a place within the community of suffering was reinforced by Yugoslav radio, which welcomed them into the community; ${ }^{33}$ and also

\footnotetext{
30 "Dalla Jugoslavia federativa e democratica," Il Lavoratore, 18 October 1945. The armed collaboration of Ante Pavelić's Ustasha regime and the late-war activity of Draža Mihailović's Chetniks often received attention, but not more mundane or non-ideological forms of collaboration. On collaboration in Slovenia, see Kranjc, To Walk with the Devil. On Serbia, see Alexander Prusin, Serbia Under the Swastika: A World War II Occupation (Urbana and Springfield: University of Illinois Press, 2017).

${ }^{31}$ Di Gianantonio et al., L'immaginario imprigionato, 78. This component of the myth inexactly paralleled components of the myth of the USSR, which held that, freed from certain exploitative and character-distorting institutions, the Soviet people existed in a sort of "natural" state of equality and community, possessing "strong communal feeling, commitment to public affairs, kindness, generosity, wisdom, and simple authenticity." Hollander, Political Pilgrims, 128-35.

${ }^{32}$ Even when Italy experienced institutional changes such as the abolition of the monarchy, certain monfalconesi held that these superficial changes did not reflect a transformation of values as had happened in Yugoslavia due to the experience of occupation and liberation struggle. PCRG-V Rione, "III Riunione del comitato del P.C.R.G.," 13 June 1946, AS 1570, b 8, f 1.

${ }^{33}$ The day after liberation, Radio Belgrade announced that Tito's state "guarantees to the Italian minority all the rights that will allow it to develop freely," particularly those who "refused to let themselves be tricked by Fascist propaganda" and instead fought against it. Sottoseg. per la Stampa e le Informazioni (PCM), "Questione di Trieste" (N. 924), 26 May 1945, ASDMAE, AA PP 1931-45, Jug, b 151, f Venezia Giulia e Dalmazia: Commenti stampa e Radio Jugoslavia. Similar themes were discussed on 24 May 1945. See Radio Belgrade, Summary of Broadcast, 1745hrs, 24 May 1945, in the same file.
} 
supported by many locals. If borderland residents possessed tools that allowed them to put forward a Slovenian "identification," they chose not to use them. ${ }^{34}$ Two weeks before the Yugoslav withdrawal, the veteran Communist Angelo Comar made this clear. Speaking at Turriaco to an eager crowd of OF supporters, Comar explained that neither he, nor those gathered denied being Italian. Instead, he affirmed the Italianness of monfalconesi, clarifying that "we want to live united with those peoples who, from a social point of view, have surpassed us and already for a time have been teaching us the just path to follow. The Italians and the Slovenes have lived together, have suffered. Why divide them today, when they are both free?" The crowd agreed, greeting Comar's words with "frenetic" applause. ${ }^{35}$

\section{Three Pillars of the National Myth of the New Yugoslavia}

Beyond feeding into rather abstract ideas about the Yugoslav nations' moral regeneration through suffering and struggle, the theme of rupture also served as a starting point for more concrete discussions about the new values, institutional structures, and programs of Tito's state. A seminal article in Il Lavoratore's first post-liberation issue sketched three basic features of the New Yugoslavia that distinguished it from the Old, laying the basis for a national myth that would be elaborated in the coming years. The article defined the New Yugoslavia by: (1) the spiritual unity of the nations of Yugoslavia and its concrete expression in their parity of rights and influence

\footnotetext{
${ }^{34}$ D'Alessio, "Istrians, Identifications."

${ }^{35}$ Mario F[x] (CLN-Turriaco [OF]), "Turriaco libera ha eletto ieri sera il suo Comitato," 25 May 1945, AS 1570, b 12, f 8, sf AgitProp: Turriaco. The Triestine Communist Eugenio Laurenti similarly developed the theme of the community of suffering when he spoke before an OF congress in Ljubljana in July, "thank[ing] the Slovene people in the name of the Italians of Trieste for having known to distinguish those culpable [for the war] from those not culpable and for having understood that a part of the Italian people also suffered under the Fascist regime, as did the Slovenes." "Il Congresso dell'O.F. a Lubiana," Il Lavoratore, 18 July 1945. Comar's unabashed embrace of Italian ethnicity and pro-Yugoslav politics is shared in certain Monfalconese broadsheets, as when one rebutted claims that the proYugoslavs were "sell-outs" with the assertion that "we too are Italians, but from the flag we have cut the coat of arms of that monarchy which ... betrayed the Italian people, and we have substituted the red star, symbol of fraternity and equality of all peoples of the world." Comp. Nicola, "Agli amici meridionali," La stella rossa (N. 23), 27 May 1945, op. cit.
} 
within the New Yugoslav state; (2) the perfect democratic structures of the country, providing a true democracy in which "the people" had a say (and which, according to later additions, was fully reconcilable with individual freedom); and (3) the rapid advancement of Yugoslav society into what would eventually be termed the "radiant future" (luminoso avvenire), defined by material prosperity and the full flourishing of the human subject. ${ }^{36}$

\section{The Unity and Equality of Nations within Yugoslavia}

These three pillars would be developed and elaborated in the coming years. The first - the notion of the moral unity and institutional equality of nations within Yugoslavia - drew heavily on the "brotherhood and unity" themes simultaneously developing within Yugoslavia. ${ }^{37}$ It emerged quickly as a means by which pro-Yugoslavs differentiated the New Yugoslavia from the Old and generally took two forms. The first was that which emphasized values, mobilizing the "community of suffering" idea to explain how the Yugoslav nations' had superseded completely old nationalist hatreds. While acknowledging that the collapse of bourgeois society played a role in the disappearance of nationalist antagonisms - a theme that drew upon facets of the myth of the USSR that explained such hatreds as an outcome of class exploitation ${ }^{38}$ - pro-Yugoslavs propagandists added to this by stressing that each of the Yugoslav nations had participated fully in the armed

\footnotetext{
36 "La lotta e le conquiste dei popoli jugoslavi," Il Lavoratore, 25 May 1945. The phrase "radiant future" occurred in "La disastrosa situazione dell'economia di Fiume durante il dominio del fascism," Il Lavoratore, 5 June 1945. For other uses of this or similar phrases, see the following Il Lavoratore articles: "Dove il potere è nelle mani del popolo," 23 October 1945; "Compatta partecipazione alla elezioni in Jugoslavia," 13 November 1945; "Uniti nella lotta, uniti e liberi nell'esercizio del potere," 5 March 1946; "Il vecchio e il nuovo," 22 July 1946; "Per l'edificazione di una vita migliore," 25 April 1947.

${ }^{37}$ On "brotherhood and unity," see Aleksa Djilas, The Contested Country: Yugoslav Unity and Communist Revolution, 1919-1953 (Cambridge, MA: Harvard University Press, 1991), 160-64; Dejan Jović, "Yugoslavism and Yugoslav Communism: From Tito to Kardelj," in Yugoslavism: Histories of a Failed Idea, 1918-1992, ed. Dejan Djokić (Madison: University of Wisconsin Press, 2003): 159-60; Andrew Wachtel, Making a Nation, Breaking a Nation: Literature and Culture Politics in Yugoslavia (Stanford: Stanford University Press, 1998), 133, 148-49;

${ }^{38}$ For example, black American fellow-travelers emphasized how the elimination of capitalist exploitation in the USSR had led to the complete disappearance of racial tensions, which contrasted greatly with the often labor-based racial tensions in American cities. See John Diggins, "Limping after Reality: American Intellectuals, the Six Myths of the USSR, and the Precursors of Anti-Stalinism," in Il mito dell'Urss, eds. Flores and Gori, op. cit., 288-90.
} 
liberation struggle, overcoming the internecine nationality conflicts that had so typified the Old Yugoslavia through this collective struggle and the consequent revolution in dominant values. ${ }^{39}$ As the future emigrant Silvano Cosolo wrote in his memoirs, revealing the lingering persistence of this idea, "at war's end, the victorious Partisan movement could show in its ranks the combatants and leaders of every ethnicity and every religion, such that it facilitated the rapid dissipation of hatreds and of religious and ethnic rancor that had arisen during the conflict."40

Running alongside this emphasis on values were institutionally-oriented explanations for the perfection of nationality relations within the New Yugoslavia. Such explanations focused on the new constitution of Tito's Yugoslavia, drafted and promulgated in the winter of 1945/46, and its move toward federalism. Pro-Yugoslavs emphasized that the wartime collapse of the Serbdominated Kingdom of Yugoslavia and the sudden popular uprising behind Tito allowed for the creation of a constitution in which no compromises had to be made with the old-regime exploiters and through which no single nation attempted to impose itself upon the others. Represented as a natural institutional enshrinement of the new Yugoslav values, ${ }^{41}$ the constitution, Il Lavoratore proclaimed, allowed each nation to be a "master in its own house," guaranteeing through its federal structure "the most complete national independence for single ethnic groups, paired with an equally absolute parity of rights." 42 In the Monfalconese, activists stressed that "the struggle

\footnotetext{
${ }^{39}$ As an example of an interpretation that merged the old class-based analysis with a new emphasis on occupation, suffering, and liberation as shared experiences forging a "community of suffering," see "Dalla Jugoslavia federativa e democratica," Il Lavoratore, 18 October 1945. See also Eligio Simsig, "Lezione XXXII," 18 March 1947, op. cit. ${ }^{40}$ Cosolo, Amare... Sarajevo, 44.

${ }^{41}$ As Simsig would write, the new constitution "is not the fruit of the study of intellectuals, but rather the fruit of the struggle, from which arises the new power atop the remains of the old" - or, in shorter form, the "Constitut[ion] = legislative form of the conquests." Eligio Simsig, "Lezione XXXV," 21 March 1947, IFSML, Fondo Simsig, b 1, f 7. Underlining in original.

42 "Dalla Jugoslavia federativa e democratica," Il Lavoratore, 18 October 1945. Similar ideas were spread by the Communist Party, which urged members to stress that "in Yugoslavia, every single federated country [that is, constituent republic] has its own constitution that reflects the ethnic, cultural, political, and economic conditions of said country." PCRG, "Relazione sulla seduta del regionale e del circondario del PC della RG...," 13 December 1945, op. cit.
} 
undertaken in common has created the conditions for a mature understanding between peoples, for an effective equality, for a national independence that is, in fact, not contradictory with the existence of a federation." The liberation struggle had effectively resolved the "problem of autonomy and centralism" both by giving rise to a state of federated, autonomous constituent republics and by morally unifying the peoples so that this very autonomy was superfluous. ${ }^{43}$

If these two points paralleled Yugoslav self-representation under the "brotherhood and unity" theme, the image of the new country's nationality relations presented to monfalconesi differed from that propagated in Yugoslavia. Within Yugoslavia, "brotherhood and unity" meant a unity of Yugoslav nations; to monfalconesi it was presented as a unity of nations within Yugoslavia. The former emphasized that shared values and a common ethnic background served as coequal bases for Yugoslav unity, whereas in Monfalcone, there was a singular emphasis on the political and experiential origins of this unity, ethnicity discarded. ${ }^{44}$ Emphasis on the autonomy of constituent republics played directly into the aspirations of Italian pro-Yugoslavs, whose visions of their union with Yugoslavia involved the creation of an Italian-majority Seventh Federative Republic of Yugoslavia with equal autonomy. Edvard Kardelj and other Yugoslav politicians regularly emphasized that this would be the case, ${ }^{45}$ and supporting the claim were various signs of Yugoslav goodwill, from mysterious gifts of food sent to hungry Italians ${ }^{46}$ to the commemoration of Italian partisans fallen in the fight to liberate Yugoslavia ${ }^{47}$ and the propagandization of the full

\footnotetext{
${ }^{43}$ The same AgitProp piece explained that the lack of a necessity for legal protections of federal autonomy was that the former "bourgeois" legality had been replaced by "an alternate legality: that of the great popular masses." Unsigned (AgitProp-PCRG), "Progetta di Costituzione della Nuova Jugoslavia," 9 January 1946, AS 1570, b 12, f 8, sf AgitProp: Circolari inviati a Trieste.

${ }^{44}$ Djilas suggests that, within Yugoslavia, "non-South Slav minorities (especially Germans and Italians, but also Hungarians and Albanians) were excluded" from ideas of brotherhood and unity. Djilas, The Contested Country, 162.

45 "Trieste come centro culturale italiano in Jugoslavia," Il Lavoratore, 9 October 1945.

46 "Solidarietà italo-slovena," Il Lavoratore, 8 June 1945.

47 "Monumento a un partigiano italiano a Zagabria," Il Lavoratore, 27 June 1945; "Come si esprimono oggi le nostre donne," Il Lavoratore, 14 February 1946.
} 
participation of Italian organizations in the construction of the country's new culture. ${ }^{48}$ ProYugoslav propagandists assured their audiences that the Italians of the Primorska had earned a right to their own autonomous republic through their sacrifices in the liberation struggle.

\section{“True Democracy" and Individual Freedom}

If the first pillar of the national myth involved the perfect relations between the nations of Yugoslavia, the second involved the perfect relationship between state and citizen, namely the ability of Tito's regime to deliver a genuinely "popular" democracy that balanced the pursuit of the collective interest with the protection of individual rights. In common representation, the oppressive, centralized state of the Karađorđević dynasty had given way to a bottom-up, decentralized democracy formed of a union of suffering villages. The "false democracy" of the Karađorđević state - a bourgeois-parliamentary democracy that served only the narrow interests of the ruling class - contrasted with Tito's "true democracy," which, formed by the people to meet their basic survival needs in war and continuing to serve the interests of the broadest and most vulnerable swath of Yugoslav society in peacetime, possessed the broadest possible mandate. ${ }^{49}$ Although there were persistent undertones recognizing that the formal mechanism of voting did not determine whether a system was "democratic" or not, there was also a strong propagandistic emphasis on the massive electoral victory of Tito's Popular Front forces in the first postwar election and the ability of formerly disenfranchised groups such as women and the youth to cast

\footnotetext{
${ }^{48}$ The most heavily propagandized organization was the Union of the Italians of Istria and Fiume (Unione degli Italiani dell'Istria e di Fiume). The UIIF was a left-wing organization loyal to the regime. There was far less room for the development of Italian culture in opposition to the regime. "Gli italiani dell'Istria e Convegno," Il Lavoratore, 3 February 1947.

${ }^{49}$ The distinction between "true" and "false" democracy had been mobilized by the partisan press and persisted as a major mode of expression after the war. See Mario Abram, "Problemi del Giorno: Democrazia," Il corriere partigiano, N. 3, Anno 1, 30 October 1944, op. cit.; PCRG, "Relazione sulla seduta del regionale e del circondario del PC della RG...," 13 December 1945, op. cit.
} 
their votes for Tito. ${ }^{50}$ In the end, however, the Titoist formulation of "true democracy," like the Stalinist understanding of "democratic centralism," was pliable enough to include even a popularly-oriented dictatorship, justified by Tito's supposedly crushing electoral victory and his dedication to using the power of the state to benefit of the oppressed.

Yet if Titoist self-representation was laced with contradictions regarding precisely where the power to select leaders and shape policy rested, less contradictory were Yugoslav propagandists" claims that Yugoslav "true democracy" did not mean a loss of individualism. In fact, the New Yugoslavia was known as a country granting a wide range of individual freedoms, with the new state said to guarantee to the citizen the freedoms of conscience and religion, the separation of church and state, the freedoms of the press, speech, and assembly, and a panoply of others. ${ }^{51}$ Indeed, a focal-point of myth-builders - particularly as they attempted to reach out to the Monfalconese's "petty and middle bourgeoisie..., influenced as they are by religious beliefs" was the complete freedom of the individual to determine and practice his or her religion without interference from other communities of believers or from the state, which would serve neither as a proponent of a particular religion, nor an obstacle to the practice of religion. ${ }^{52}$

Very early in the postwar era, then, apparent tensions emerged between the idea of Yugoslav "true democracy," so closely tied to the Communist collectivist ethos and the exercise of socially transformative power, and the simultaneous emphasis on decentralized power and the constitutional guarantee of spiritual and intellectual individualism. But this tension was more

\footnotetext{
${ }^{50}$ Under the previous Yugoslav constitution (1931), the voting age was 21. Though the late-1945 Constituent Assembly elections were far from free and fair as this phrase is commonly understood, Il Lavoratore developed the themes of freedom and fairness in a range of articles: "Compatta partecipazione alla elezioni in Jugoslavia" and "Primi risulttati," 13 November 1945; "Ho visto votare nella Slovenia," 20 November 1945; "Ho visto votare nella Slovenia," 21 November 1945.

51 "I popoli jugoslavi chiamati a discutere la nuova Costitutzione," Il Lavoratore, 7 December 1945. Of course, most of these freedoms had been formally granted by the 1931 constitution as well.

${ }^{52}$ PCRG, "Relazione sulla seduta del regionale e del circondario del PC della RG...," 13 December 1945, op. cit. See also Unsigned (AgitProp-PCRG), "Progetta di Costituzione della Nuova Jugoslavia," 9 January 1946, op. cit.
} 
apparent than real. It was resolved, as were other tensions within the myth, with reference to Yugoslavia's origins story: individual rights existed, but had become superfluous given that the exploiters had been chased out and that the victorious Yugoslav peoples had experienced a profound moral regeneration and unification through their struggle. ${ }^{53}$ Even if individuals had this full range of rights at their disposal, including the right to speak out against the government, the liberation struggle had created a core of shared values and a common vision of the future that made such rights unnecessary. ${ }^{54}$ Such was the joy of participating in a "true democracy."

\section{Building the "Radiant Future"}

The most expansive pillar of the national myth was that which declared the strikingly successes of Tito's regime in launching Yugoslav society toward the "radiant future" (avvenire luminoso). ${ }^{55}$ This pillar was built upon a core component of the myth of the Soviet Union, which had long been said to be rapidly ushering in modernity in formerly backwards parts of Europe. Informed by the idea that "true democracy" involved not just the attainment of the vote or negative freedoms but also a radically expanded panoply of positive freedoms, this view held that the Soviet Union was pulling the world toward a modernity characterized by material abundance, the realization of the human subject's true creative potential, and attainment of unprecedented happiness and personal fulfillment. ${ }^{56}$ In the postwar years, Tito's Yugoslavia assumed the role of flanking power in this endeavor, supporting the Soviet drive toward that luminous future.

One of the first themes of Yugoslavia's march into the radiant future was the emphasis on its rapid reconstruction in the wake of the most destructive war in human history. In the immediate

\footnotetext{
53 “I popoli jugoslavi chiamati a discutere la nuova Costitutzione," Il Lavoratore, 7 December 1945.

${ }^{54}$ Of course, this logic justified political repression of opponents. All those who criticized Tito's government could thereby be labeled as remnants of the Old Yugoslavia - those who had not undergone the moral regeneration shared by Tito's supporters and could thus be disqualified from exercising power or freely criticizing the regime.

${ }^{55}$ For an example of this term being used, see "Il vecchio e il nuovo," Il Lavoratore, 22 July 1946.

${ }^{56}$ Hollander, Political Pilgrims, 135-40; Diggins, "Limping after Reality," 280-83.
} 
postwar months, Il Lavoratore detailed the fantastic reconstructive efforts of the workers in Fiume (Rijeka), who voluntarily gave an extra hour of labor each day to remove rubble from the bombed factories, or organized voluntary "Days of Reconstruction." ${ }^{, 57}$ It stressed that, though the original estimate of time before Yugoslav industries returned to productive labor had been six months, by October the Kraljevica Shipyards in Spalato (Split) had been "brought back to efficiency" and had recently launched the first ship constructed entirely in the postwar period, four months ahead of schedule. ${ }^{58}$ The same had been achieved also in Fiume, and "he who returns... after being absent for just a few days is amazed at the progress made in the field of reconstruction," including noting new ships under construction at the Third of May Shipyards. ${ }^{59}$ These images contrasted with the mostly idle shipyards of Monfalcone, where a lack of contracts and the presence of rubble hindered the return to productive labor. Throughout 1946, the comparison of rapid reconstruction in Yugoslavia with the stagnation of Monfalcone became a central feature of pro-Yugoslav propaganda, including efforts to transport workers to an imagined industrious shipyard using sights and sounds: "It is enough to pass nearby the Quarnaro Shipyard [of Fiume], in front of the Torpedo Factory, to hear the hammers beating and the machines pulsing; they sing a hymn, that of labor." 60 But Yugoslavia's radiant economic future meant more than just rapid reconstruction; there also emerged a vision of a rapidly transforming economy, which drew on Marxist-Leninist terminology and emphasized the role of newly collectivized state and cooperative sectors in

\footnotetext{
57 “A Fiume si lavora," Il Lavoratore, 30 August 1945; "Dove il potere è nelle mani del popolo," Il Lavoratore, 23 October 1945.

58 "I cantieri di Spalato in efficenza," Il Lavoratore, 11 October 1945.

59 "Dove il potere è nelle mani del popolo," Il Lavoratore, 23 October 1945. The Third of May Shipyards had formerly been called the Shipyards of the Quarnaro/Kvarner after the nearby gulf. The new name reflected the date of Fiume's liberation in 1945.

60 "Nel clima della vera libertà," Il Lavoratore, 6 June 1946. See also "Un notevole articolo delle Isvestia," Il Lavoratore, 14 May 1946. The sounds of the workplace are often associated in memoirs with personal fulfillment through pride-inducing work. Even Mirella Pin-Giuricin, daughter of a CRDA worker, started her memoirs recalling such sounds. Pin-Giuricin, "I motivi di una scelta."
} 
marginalizing and then eradicating privately owned production. As Edvard Kardelj insisted in a speech disseminated by Monfalcone's AgitProp activists, "the state and cooperative sectors of our economic life, these are the primary supports through which our democratic power in the economy will be maintained." 61 Such claims were largely compatible with the myth of the USSR and its economic transition, though there existed notable differences of emphasis. Whereas visions of the Soviets' radiant economic future most often focused on production in massive state-owned factories like the Magnitogorsk steelworks, Yugoslav propagandists instead accorded greater importance to the cooperative sector, supported but not owned by the state. ${ }^{62}$ In fact, in a speech given at a congress of Zone A Communist militants in December 1945, a key speaker stressed that a combined offensive by state-owned industries and state-supported cooperatives would force private industry to its knees, but it was cooperatives that received the greatest attention:

the cooperatives allow the population to elevate its social position without supporting capital, with only the help of the state. Such a fact will contribute greatly to the development of progress and the improvement of the social conditions of all the masses....

Only tied to the state can the cooperatives develop their work. The state is obligated to protect both the interests of the workers and peasants and also that of the remaining laboring masses, a fact which signifies a radical change in the economic and social structure of the country. ${ }^{63}$

Those interested in the topic could learn that Tito's state facilitated cooperatives' purchasing of raw materials, granted them credit for the purchase of capital-intensive machinery, and organized courses to disseminate knowledge of cutting-edge productive methods. The availability of such resources and their deployment through large-scale state and cooperative ventures were to lead to a drastic increase in productivity, which would in turn allow workers in their collectivity to

\footnotetext{
${ }^{61}$ Unsigned (PCRG-Monfalcone), "Sui principali compiti attuali," Undated, AS 1570, b 11, f 8, Sf Za arhivo.

${ }^{62}$ Despite real differences emerging between the Soviet and Yugoslav developmental models, Yugoslav propagandists cast the Yugoslav strategies as compatible with Soviet practice. On these differences, see Susan Woodward, Socialist Unemployment: The Political Economy of Yugoslavia, 1945-1990 (Princeton: Princeton University Press, 1995).

${ }^{63}$ PCRG-Trieste, "Prima riunione dell'attivo comunista della R.G. per il Circondario di TRIESTE," 14 December 1945, op. cit.
} 
challenge the competitive advantage of large capital, driving the private sector to ruin. ${ }^{64}$

The cooperative economy also served the New Yugoslavia's perceived efforts to balance and harmonize the interests of the country's productive classes. As monfalconesi leaders stressed in their discussions on the new constitution, "the cooperativistic form [of production] is the most powerful and most effective means to draw the peasantry in particular into the general framework of production. ${ }^{\circ 5}$ Despite being a primarily industrial district with a largely proletarian population, monfalconesi were intensely interested in the New Yugoslavia's push for far-reaching agrarian reform and the creation of institutions to balance their own interests with those of their future agrarian compatriots. District militants emphasized the seizure of some half-million hectares of land from large landholders (those owning over 45 hectares) by the end of 1945 and its redistribution in the form of (1) privately owned plots given to landless individuals and, more importantly, (2) cooperatively-owned agricultural ventures, with the most modern agricultural sciences brought to bear in both cases to improve productivity. ${ }^{66}$ The importance of this "drawingin" through cooperative integration, as Il Lavoratore and others emphasized, was that the state could intervene and more effectively manage prices and distribution, balancing the interests of the country's productive classes, eliminating exploitation, and, most importantly, creating the economic bases for fraternal cooperation and unity across regional and urban-rural divides. ${ }^{67}$

\footnotetext{
${ }^{64}$ Eligio Simsig, "Lez. XLI," 31 March 1947, IFSML, Fondo Simsig, b 1, f 7. See also Simsig, "Lez. XXXIV,” 20 March 1947, IFSML, Fondo Simsig, b 1, f 7.

${ }^{65}$ Unsigned (AgitProp-PCRG), "Progetta di Costituzione della Nuova Jugoslavia," 9 January 1946, op. cit.

${ }^{66}$ Unsigned (AgitProp-PCRG), "La nuova politica economia della Jugoslavia," 24 December 1945, AS 1570, b 12, f 8, sf AgitProp: Relazioni.

${ }^{67}$ In one Il Lavoratore article reporting on a speech from the Yugoslav finance minister, the paper suggested that state intervention to control prices could accomplish three things: (1) create a standardized food price across all of Yugoslavia, preventing the erosion of real earnings in regions like Dalmatia, Montenegro, and Macedonia, where little food was produced; (2) offer assurance of reasonable food prices for urban workers; and (3) reduce the prices paid by farmers for industrial goods by some 10-30\% depending on the good (i.e. $20 \%$ for artificial fertilizer). "La politica dei prezzi in Jugoslavia," Il Lavoratore, 26 August 1946. Elsewhere propagandists stressed that lower agricultural prices (worker savings) would be offset for farmers by a higher volume of sale in the more productive cooperativistic system. Eligio Simsig, "Lez. XXXIV," 20 March 1947, op. cit. Similar ideas circulated too about the role of cooperatives in the Soviet Union, though with less frequency. In one early AgitProp piece, it was said that, with the help of the Soviet
} 
If the fostering of a cooperative sector was conceived as a means of fostering class harmony and increasing efficiency through aggregation, then the initially less-emphasized state sector was seen as a realm in which the state could take an even more active role in the form of outright direction. Informing the conceptualization of both was the idea that the state was radically increasing its role in rationally planning the country's economic development. Running as a constant thread through the myth of the Yugoslav economy was the underlying assumption that a rationally-planned economy was systemically superior to a free-market system, capable not only of delivering greater economic growth, but also a more stable path to growth. Il Lavoratore stressed that, in the world of free markets, "the crisis of capitalism is demonstrated by the persistence of economic precariousness," for which "one fruitlessly seeks to find a remedy." By contrast, in those countries with directed and planned economies, "'crisis' has no meaning. It is an empty word and a thing of the past that is already forgotten or nearly so." ${ }^{98}$ Particularly important to this line of thought were the Five Year Plans - the example of central direction and planning par excellence - which had been central to Soviet industrialization and which became a major topic of discussion for pro-Yugoslav militants. As Ruggero Bersa stressed before the plenary meeting of the pro-Yugoslav liberation councils in late 1946, the rational planning of the Five Year Plans had spared the Eastern Bloc countries the postwar economic volatility that had so crippled Italy. ${ }^{69}$ Playing on preexisting distinctions between the "two worlds" of capitalism and socialism, Bersa and others associated the former with the triad of rationality-planning-stability and the latter with that of impulse-spontaneity-chaos. Thus, when Tito announced Yugoslavia's own Five Year

\footnotetext{
cooperatives and other mechanisms, "the workers and the peasants have become brothers and their union is the greatest force in the hands of the Soviet state. The workers exchange with the peasants their products and the sincerest harmony is founded upon just and honest exchange." PCRG-CDM, "Il mercato libero," 2 November 1945, AS 1570, b 8, f 2.

68 "Due mondi," Il Lavoratore, 6 October 1945.

${ }^{69}$ The speech is reprinted in "Il plenum distrettuale dei Comitati popolari di liberazione," Il Lavoratore, 4 November 1946.
} 
Plan in January 1947, pro-Yugoslavs looked eagerly to the east, expecting increased productivity, greater stability, planned growth, and a more equitable distribution of the products of Yugoslavs' labor. $^{70}$

Alongside grand economic transformation, the myth of Yugoslavia's radiant future also forecasted that the new regime would maximize its citizens' human potential through a panoply of state-sponsored programs of cultural and social modernity. Il Lavoratore represented Tito's regime as actively conquering the darkness of night by orchestrating a massive electrification campaign in rural Yugoslavia, ${ }^{71}$ while also directing "Week of Hygiene" campaigns in which emissaries of modernity (including physicians) visited rural residents to teach feminine, domestic, and food hygiene. ${ }^{72}$ Moreover, the regime demonstrated its commitment to minority development through campaigns to "liquidate illiteracy," particularly among the Macedonians, Albanians, Turks, and others for whom illiteracy was the "gravest consequence of a long national oppression." And beyond just counteracting decades or centuries of minority oppression, such initiatives also "ha[d] the purpose of realizing the motto: "culture for the people'."73 All the while, the regime achieved such modernizing advances - including industrialization - without the accompanying effects of physical enervation and atrophy that had been so present in the European mind for well over a half

\footnotetext{
70 “Un discorso del Marescialo Tito," Il Lavoratore, 2 January 1947.

71 "Un discorso di Kidric," Il Lavoratore, 18 November 1946.

${ }^{72}$ Here Communist discourse shared a theme with that of Fascism. "Dove il popolo è padrone," Il Lavoratore, 29 September 1946.

${ }^{73}$ Il Lavoratore stressed that 2200 of the 5500 illiterates in Belgrade were already enrolled in special state-funded courses. "Dare la cultura al popolo," Il Lavoratore, 26 December 1946. The theme of cultural elevation was also evident in the fostering of opportunities for workers to attend the theater or cinema and to visit such places as Lake Bled, which "at one time was the place of holiday resorts of the imperial family of Austria and of the greatest Yugoslav industrial magnates." "Tra gli antiforni di Jesenice," Il Lavoratore, 27 May 1946. The emphasis on culture, education, and dignity for the working class was a staple of the myth of Communism generally, as well as of many very tangible Communist policies. On Italy see Stephen Gundle, Between Hollywood and Moscow: The Italian Communists and the Challenge of Mass Culture, 1943-1991 (Durham, NC: Duke University Press, 2000).
} 
century. ${ }^{74}$ Rather, Yugoslavia remained a place of strong, salubrious bodies. Its citizens remained in touch with nature, and anemic Italian children returned from summer camps in Croatia and Slovenia with sturdier bodies accompanying reinvigorated spirits. ${ }^{75}$

Finally, Yugoslavia's advance into its radiant future promised an expansion of freedoms that would maximize human happiness and fulfillment. Though far from the only sphere of life in which this was to be achieved, a prominent focus was on the new family life and the resolution of the question of women's rights. Many monfalconesi viewed the New Yugoslavia as a country in which families - especially families that deviated from the restrictive norms of Catholic Italy could find acceptance and legal recognition that would pave the way to happiness. Particular emphasis was placed here on Yugoslavia's abolition of the category of "illegitimate" children and its implementation of liberal divorce laws, which, in Italy, kept individuals in unhappy marriages and had clear legal ramifications for the members and children of couples involving separated-butmarried individuals. ${ }^{76}$ The collapse of the old order was also seen to have facilitated the liberation of women more broadly. Propagandists stressed that "new types of women, capable in productive labor" had emerged in the USSR with a "complete parity of rights" to men; they emphasized that the same was true for Yugoslavia, as the Yugoslav Constitution guaranteed equal pay for equal work (Article 34) and paid maternity leave (Article 24). ${ }^{77}$ As mythbuilders stressed, the New

\footnotetext{
${ }^{74}$ As just two examples, see Eugen Weber, France: Fin de Siècle (Cambridge, MA and London: Harvard University Press, 1986); and Daniel Pick, Faces of Degeneration: A European Disorder, c. 1848-1918 (Cambridge: Cambridge University Press, 1989).

75 "Bimbi italiani e sloveni alle colonie estive di Portorose," Il Lavoratore, 28 August 1945; "Aria e sole per i figli del popolo," Il Lavoratore, 28 June 1946; "Una lettera da Prestrane," Il Lavoratore, 13 August 1946.

${ }^{76}$ Among these was the illegitimacy of their offspring and the problematic questions of inheritance. On the abolition of illegitimacy, see the CRDA broadsheet La stella rossa, N. 29, 12 August 1946, AS 1570, b 12, f 8. On the question of divorce (and its relation to illegitimacy), see the memoirs of Mirella Pin-Giuricin, an illegitimate child, born to a Monfalcone shipyard worker named Eugenio Pin and a woman still married to her long-estranged husband and unable to get a divorce. This family would move to Yugoslavia in the postwar period in part because of the deep shame that her father felt at his child being deemed illegitimate and bearing the name of his partner's long-estranged husband. Pin-Giuricin, "I motivi di una scelta," 344-45, 360.

${ }^{77}$ Eligio Simsig, "Lez LIII," 15 April 1947, IFSML, Fondo Simsig, b 1, f 7. On the "women's question," see also "Lez LIV," 17 April 1947.
} 
Yugoslavia was just the second country in the world to introduce this new social legislation granting paid maternity leave and even paid annual vacations for workers, behind only the USSR. ${ }^{78}$ Such measures showcased the new regime's commitment to sweeping away the remnants of the Old Yugoslavia's oppressive familial culture and building a new one conducive to happiness, fulfillment, and love.

\section{The Cult of Tito}

Unifying all facets of this national myth was the leadership cult surrounding Marshal Tito, cast as a leader allied but not subservient to his Soviet counterpart. ${ }^{79}$ Indeed, though there were key similarities between the cults of Stalin and Tito, both leaders cast as selfless, simple, and modest men who sought and wielded power only for others' benefit, there were also considerable differences. Most significantly, the Tito cult drew more directly on his partisan past. ${ }^{80} \mathrm{Il}$ Lavoratore cast Tito as both a common member the Yugoslav community of suffering and its historic leader, stressing his exceptional military genius, his seemingly messianic arrival at the precise moment of the Yugoslavs' greatest need, and his choice to bear all the "risks and dangers, toils and sacrifices" of the common Partisan fighter. ${ }^{81}$ Tito was a personification of what the New Yugoslavia had become through the course of the hard liberation struggle. Born to a Croatian

\footnotetext{
78 "Il vecchio e il nuovo," Il Lavoratore, 22 July 1946.

${ }^{79}$ Hence the partisan song "Rosso levante e ponente," popular among Julian garibaldini, ended with a stanza that cast the two as coequal leaders. After several stanzas stressing that only the red flag and its followers could overthrow the fascists, it concludes: "People, rise up in arms / Tito shows us the way / People, rush to arms / behind Comrade STALIN!" Lyrics to "Rosso levante e ponente," AS 1570, b 11, f 8, sf Za arhivo. On the Tito cult in Yugoslavia, see James Gow, "The People's Prince - Tito and Tito's Yugoslavia: Legitimation, Legend, and Linchpin," in State-Society Relations in Yugoslavia, 1945-1992, eds Melissa Bokovoy, Jill Irvine, and Carol Lilly (New York: St. Martin's Press, 1997): 35-60.

${ }^{80}$ Hollander, Political Pilgrims, 167-73; Diggins, "Limping after Reality," 290-92.

${ }^{81}$ On his seemingly messianic arrival and his willingness to suffer, see "Tito," Il Lavoratore, 22 October 1945. At the same time, Il Lavoratore stressed his long suffering for the Yugoslav Communist movement, drawing attention to his stoic resolve during his 1928 trial for subversive activities. "Nel XXV anniversario della 'Borba,"'" Il Lavoratore, 20 February 1947. On his military importance, see "Onorificenza sovietica al compagno Tito," Il Lavoratore, 8 June 1945.
} 
father and a Slovenian mother, he was a living embodiment of Yugoslav multinationalism. ${ }^{82}$ Yet, as a simple, gifted mechanic, he had risen to become a head of state. He embodied the workingclass's seizure of power and the overturning of social hierarchies following the rupture of $1941 .^{83}$ All of this - his modest origins and modest lifestyle, his tireless self-sacrifice, his decisive action, his military genius, and his dedication to both the national liberation of his people and the social liberation of the oppressed classes - made for a comparison that resonated deeply with the Italians of the Monfalconese: Tito was the "Garibaldi of the twentieth century." 84

\section{Hoping and Propagandizing in the Monfalconese}

The national myth of Yugoslavia became firmly entrenched in the thinking of many monfalconesi in the time before and immediately after liberation. The exact content of word-ofmouth dissemination of this myth cannot be known, but the extent to which the pro-Yugoslav organizations dedicated themselves to propagating this myth can. Though the myth-building process would continue for years after liberation, discussions reached their apex in the winter of 1945/46 when Tito's regime first drafted and then promulgated its new constitution. In this context, at a December meeting of the Communist Party leadership in Zone A, Rudi Uršič and others impressed upon Party comrades that Yugoslavia must be valorized "among all strata of the population" through discussions hosted by the Party's mass organizations. Militants were to disseminate copies of the constitution in pamphlet form; Il Lavoratore was to print a running analytical series on the constitution's most novel aspects in order to reinforce these discussions. ${ }^{85}$

\footnotetext{
82 “Tito," Il Lavoratore, 22 October 1945; “Tito,” Il Lavoratore, 25 May 1946.

83 Tito himself made wide use of this theme, as when he saluted members of a syndical congress as "your one-time factory comrade," but also "as marshal of the New Yugoslavia." Radio Belgrade, Summary of Broadcast, $2340 \mathrm{hrs}, 4$ July 1945, ASDMAE, AA PP 1931-45, Jug, b 151, f Venezia Giulia e Dalmazia: Commenti stampa e Radio Jugoslavia. Such this theme in the Il Lavoratore articles "Orizzonti politici," 15 July 1945; "Tito," 22 October 1945; "Tito," 25 May 1946; "Tito," 24 May 1947.

84 “Tito," Il Lavoratore, 22 October 1945.

85 PCRG, "Relazione sulla seduta del regionale e del circondario del PC della RG...," 13 December 1945, op. cit.
} 
In the Monfalconese, pro-Yugoslav militants committed themselves wholly to this endeavor. The Communist Party organized study groups for the constitution to train supporters who would then lead wider discussions "in the shipyard, in the workplaces, during moments of rest, in the countryside, on the street, etc.," ${ }^{86}$ and in the last third of December 1945 alone, the district's pro-Yugoslav organizations held 108 meetings to discuss the Yugoslav constitution and life in Yugoslavia. ${ }^{87}$ According to internal Party reports, the reception among the attendees was quite favorable, and eager individuals even began discussing whether Tito might consider changing the name of the Federal People's Republic of Yugoslavia to the Union of People's Republics to reflect the inclusion of Italians in the federal state. Topics such as agrarian reform, the institutional framework of federation, the functioning of the administrative organs of popular power, and the transition to a new socio-economic order generated a great deal of excitement. The myth had become so widely believed and so compelling that the Party noted that certain attendees wondered aloud why the new constitution remained partially flexible toward private property given the (perceived) state of affairs. It was, in fact, certain members of the Communist Party rather than the wider masses who had a more measured outlook, largely because they were better informed. The Party report on these December meetings tellingly concluded that "the masses in general see poorly the true situation in [Yugoslavia], and they consider it a country where socialism is already existing and where there no longer exist antagonistic classes." 88

\footnotetext{
${ }^{86}$ PCRG-CDM, "Verbale XXIX seduta del Comitato," 17 December 1945, AS 1570, b 8, f 1. See also PCRG-CDM, "IV Rapporto sulla situazione politica nel distretto del P.C.R.G. per Monfalcone," 28 December 1945, AS 1570, b 8, f 2 .

${ }^{87}$ Of these, 101 were held by the UAIS (79 in the CRDA, 22 in the villages) and 7 by the PCRG. Unsigned (PCRGMonfalcone), "Relazione sul lavoro svolto per popolarizzare la costituzione jugoslava," 12 January 1946, AS 1570, b 8, f Relazioni politiche.

${ }^{88} \mathrm{Ibid}$.
} 


\section{The Personal Myth}

When monfalconesi thought about the utopia to the east, wrongly perceiving it to be "a country where socialism is already existing," they thought not only about nationality relations, participatory possibilities, and the marvelous potential of a planned economy; they also envisioned the transformation of quotidian social relations in lived spaces and thus the experience of everyday life. Running alongside the national myth - most often reinforcing it, but at times making notable deviations - was thus another plane of myth regarding the New Yugoslavia, which might be termed the personal myth. In reframing the national and historic in terms of the local and the quotidian, this myth responded more directly to the pressing concerns of monfalconesi and did so in such a way that made use of their flexible understand of "Fascist" and "Fascism" to dovetail popular but doctrinally undefined hopes for a purge of the remnants of the past regime with visions of a "Communist" utopia. This plane of the myth, though understudied, eventually came to dominate representations of Yugoslavia, even overshadowing the national myth. Particularly critical to this process were hundreds of articles and several running series that Il Lavoratore printed on the eastern utopia, most often in the form of letters received from Italian workers on work exchange in Yugoslav cities or recently returned from tours and travels throughout the country. ${ }^{89}$

\section{The Personal Myth: Shopping and the Marketplace}

The first facet of the personal myth began to take shape in the last months of 1945 in the context of the lean winter of 1945/46. This facet of the myth held, quite simply, that in Yugoslavia food was readily available, ordinary workers had the power to purchase abundant and varied food,

\footnotetext{
${ }^{89}$ It is impossible to know how many of these letters were real and how many were propagandistic fabrications. Whatever the figure, AIS identified these travel articles as a key method of pro-Yugoslav propaganda in Zone A. An October 1946 report focusing on Pola drew special attention to the fact that "articles frequently appear, usually written by a worker 'just returned from a visit to .........' [sic] showing how satisfactory conditions are, for the workers in Yugoslavia." AIS-Trieste, "Activities Report No. 51 for the two weeks 13th to 27th Oct 1946," Undated, NARA, RG331, UD1981, b 9138, f 11304/100/2.
} 
and they did not have to deal with economic "Fascists" like greedy shopkeepers. This emphasis on the bountiful, equitable marketplace was more than an appeal to empty stomachs; it represented Yugoslavia's commercial system as fundamentally transformed and played into an increasingly entrenched idea among monfalconesi, derived from their everyday experiences of Fascism and war, that it was a central moral obligation of the state to assure that exchange did not become a realm of exploitation or self-aggrandizement. This portion of the myth nested neatly within the national myth's emphasis on Yugoslavia's new morality and its economic renovation, though it always found concrete expression with reference to everyday shopping and eating practices.

Yet even if the practical content of this myth remained largely stable across time, the same cannot be said about the explanations of why Yugoslavia had been so singularly successful in creating a system of marketplace justice. In its first iterations, this facet of the myth tended to emphasize the role of the Titoist state in crushing economic "Fascists" and directly distributing goods at "just" prices. In the earliest days of liberation, Radio Trieste broadcasted news of the Yugoslav campaign against Triestine "profiteers" and those involved in black-marketeering and speculation, even asking the public to help "unmask" such enemies who inflated prices. ${ }^{90}$ Throughout the winter of 1945/46, pro-Yugoslav propagandists, including writers for Il Lavoratore, proclaimed the complete eradication of the black market in Yugoslavia and the fact that there "everything is distributed justly among the population." 91 Among many of Monfalcone's pro-Yugoslavs, the elimination of the black market in Yugoslavia was taken as a reality already by October 1945, when Ruggero Bersa urged monfalconesi to take the Yugoslavs' successful repressive campaign against the "free market" (used interchangeably with "black market") as an

\footnotetext{
${ }^{90}$ Radio Trieste, Summary of Broadcast, 2125hrs, 9 May 1945, op. cit.

91 "Interviste non anonime," Il Lavoratore, 1 September 1945. See also "Breve soggiorno a Belgrado," Il Lavoratore, 10 November 1945. The elimination of the black market remained a key emphasis for years to come, including in the training of Party School militants. See Eligio Simsig, "Lez. XXXIV," 20 March 1947, op. cit.
} 
example in their own struggle. ${ }^{92}$ In these earliest representations, Tito's regime had filled the void left by the repressed private commercial system by organizing the compulsory requisitioning of the necessary products from the peasants and undertaking the direct distribution of these goods through a comprehensive rationing system. ${ }^{93}$ According to a December 1945 AgitProp piece entitled "The New Political Economy of Yugoslavia," this state sector was the most important sector in the exchange of foodstuffs: "All state commerce is regulated through the "national warehouse,' which has branches in all of Yugoslavia.... The sale of cereals such as wheat, barley, and rye is the monopoly of the state. In this manner, bread is assured for all the working people, thus eliminating, in this field, any speculation." ${ }^{94}$

Perhaps more important for ordinary monfalconesi than how the system worked were the concrete results of this system of just exchange. The paper repeatedly printed lists detailing the availability and prices of rationed goods, with special emphasis placed on goods long unavailable to monfalconesi, especially shoes, meat, and coffee. One such article recounted the rations of an anonymous (perhaps fictitious) Italian working in an engine-assembly workshop near Spalato:

Our daily ration of food per person, which is passed out at the cafeteria, consists of the following: 250 grams of meat, 40 grams of fat, 30 grams of sugar, 20 grams of powdered milk, 10 grams of coffee, 340 grams of white flour, 60 of dark flour, 120 grams of white pasta. Beyond this, which one eats at the cafeteria, we receive in the workplace at 9:30 in the morning 200 grams of bread and 80 grams of prosciutto or bacon or cheese. For all this we pay 15 dinars per day. ${ }^{95}$

Availability and affordability of a wide range of goods - much wider than those given the so-called "political price" under Fascism and, as will be seen, the AMG - was thus a manifestation of Yugoslav marketplace justice. Moreover, the combination of black-market repression, rapid

\footnotetext{
${ }^{92}$ PCRG-CDM, "Verbale della seduta 25 del comitato distrettuale," 23 October 1945, AS 1570, b 8, f 1.

93 "Provvedimenti per la ripresa economica in Jugoslavia," Il Lavoratore, 22 June 1945. Unsigned (AgitProp-PCRG), "La nuova politica economia della Jugoslavia," 24 December 1945, op. cit.

${ }^{94}$ Ibid.

95 "Gli operai triestini in Dalmazia parlano della loro vita e del loro lavoro," Il Lavoratore, 2 January 1946. On shoes, see "Interviste non anonime," Il Lavoratore, 1 September 1945. Several other articles ran similar lists.
} 
reconstruction, and producer dedication was said to have yielded such successes that already from November of 1945 the state had removed certain finished goods (cigarettes, bricks, etc.) from the ration lists, to be followed by a wider range of goods (presumably including foods) soon after. ${ }^{96}$

Though the emphasis on requisitioning and rationing did not entirely disappear, ${ }^{97}$ it was gradually supplanted by an emphasis on state-sanctioned cooperatives as the basis of the bountiful Yugoslav marketplace. Such a transition was fully in line with the national myth's emphasis on the role of such cooperatives in transforming Yugoslav economy by increasing productivity and facilitating collective ownership. It merely added to this a focus on the cooperatives' role in transforming the consumer's experience. In one important Il Lavoratore article, a correspondent reported on a conversation he had with an unnamed Italian living in Ljubljana, the latter explaining that in Yugoslavia, the commercial intermediaries had been cut out, with peasants' cooperatives selling directly to consumers' cooperatives in the towns and hiring only a single shipper to deliver the exchanged goods. This system guaranteed to the peasants (and the shipper) a "just earning," but also assured a just price to the urban consumer, who was now protected by the state and by the collective purchasing power of the urban working class. By contrast,

those who lose are the speculators, the parasites, the adventurers. But for such people there is effectively no place in Tito's Yugoslavia.

Thus at Ljubljana we have not seen a trace of the black market, we have not seen prosciutto and salami at exorbitant prices in the shop windows. But at the simple cafeteria where we ate there was a little piece of pork in the window, also for the worker. ${ }^{98}$

Throughout 1946, Il Lavoratore reiterated these claims. In September, it stressed that "the rapid and regular distribution of products" has become "a criterion of justice" in the New Yugoslavia; thanks to the state-supported cooperatives, "at the markets and in the shops order has been

\footnotetext{
96 "La battaglia per la ricostruzione in Jugoslavia," Il Lavoratore, 1 November 1945.

97 "La politica dei prezzi in Jugoslavia," Il Lavoratore, 26 August 1946.

98 "Impressioni di un viaggio," Il Lavoratore, 12 November 1945. These themes remained points of emphasis well into 1946. See "La politica dei prezzi in Jugoslavia," Il Lavoratore, 9 September 1946.
} 
introduced, reducing the number of those who want to raise prices" and causing the price of foods in Zagreb to fall by an average of 58.28\% over the first half of 1946: $68.18 \%$ for flour, $60 \%$ for green peas, $72.22 \%$ for potatoes, $42.31 \%$ for pork, and $55.55 \%$ for cheese. ${ }^{99}$

Such ideas were pushed not only in the press, but also by pro-Yugoslav militants in the street. Militants emphasized the central role of such cooperatives in reshaping the Yugoslav shopping experience. In his journal, Eligio Simsig noted that cooperatives served the purpose that "comm[erce] is eliminated." When widespread and supported by the state,

they eliminate the merchant and retail commerce; the merchants are eliminated and thus a greater possibility between city and countryside and improvement [e quindi più possibilità fra città e campagna e miglioramento].... [The cooperatives] constitute a symbiotic cycle between the workers and the peasants and are the basis not only for the existence but for the construction of soc[ialism]. The coop[eratives] are the regulator of prices of goods. With the normalization of prices based on the state sector. The state continues its activity putting itself at the service of the consumers' cooperatives whose goods cost less... passing [goods on] directly, coop[eratives] will have prices lower than those of the private sector. ${ }^{100}$

In short, what had emerged was a particular social imaginary for the New Yugoslavia in which the quintessential "Fascist" shopkeeper (and the larger merchant) had been liquidated. This imaginary promised an end to all those exploitative and tension-ridden interactions which had characterized the interactions between working-class monfalconesi and the district's shopkeepers in the decades before and was a perfect location for the dovetailing of more orthodox Marxist analyses of commercial exploitation with less doctrinally-defined popular resentments toward the district's body of shopkeepers. Moreover, the heavy emphasis on consumer cooperatives in Monfalcone illustrates clearly how the myth of Yugoslavia was tailored to fit the expectations of monfalconesi,

\footnotetext{
99 "La politica dei prezzi in Jugoslavia," Il Lavoratore, 9 September 1946. The paper praised Fiume as a locale in which this new system was flourishing. There a City Procurement Company supposedly oversaw the purchase and distribution of all supplies and goods for shops ranging from pastry-shops to butchers, allowing the shops in turn to pass savings on to consumers. By contrast, in Trieste and its environs "the cost of living has risen to the heavens." "Trieste e Fiume," Il Lavoratore, 25 October 1946.

${ }^{100}$ The notes refer to the state sector because the lesson discussed cooperatives' place within a wider Communist economy. Eligio Simsig, "Lez. XLI," 31 March 1947, op. cit. Underlining in original. See also Simsig, "Lezione XXXV," 21 March 1947, op. cit.
} 
as the theme received less attention in the work of Yugoslav propagandists within Yugoslavia. ${ }^{101}$

A sense of the historic significance and everyday-transformative impact of the transition to cooperative commerce can be gleaned from the handbooks of various local cooperatives which, though not Yugoslav, certainly reflect how monfalconesi thought about the cooperative shopping experience generally. Important in this regard is an employee handbook for the large consumers' cooperative based in Trieste, the Workers' Cooperatives of Trieste, Istria, and Friuli (Cooperative operaie di Trieste, Istria e Friuli, CO). With great awareness of how worker fascination with cooperation went beyond price concerns and also included hopes for an essential transformation of the seller-customer relationship, the handbook urged that cooperative shop attendants

be aware that, in the current era, consumer cooperation is viewed as a form of distribution destined for a grand future.... The shop is the part of the company in immediate contact with the public, from which contact it can garner favorable or unfavorable impressions regarding the same cooperation. It is the duty of the manager to contribute with his work to the growth of the esteem that the Cooperative Operaie deserve, animated in this action by the pride of belonging to an institution that transforms the egoism of classical commerce into solidarity and cooperativistic mutuality of the consumers. ${ }^{102}$

The handbook provided a blueprint for the perfect consumer experience, stressing that cooperative shop attendants, no longer with a vested interest in profits, should clearly mark prices and sell only at set prices, preventing the heated haggling and shopkeeper gouging that had so long typified commerce in the Monfalconese black and other markets, facilitated by the shopkeeper's stranglehold over vital goods. Moreover, attendants were to avoid the old shopkeeper tricks of overweighing with rigged weights or double packaging, instead assuring that the customer was never cheated in any way. Finally, they were to treat all customers equally in a "cordial, affable,

\footnotetext{
${ }^{101}$ Propagandists in Yugoslavia placed emphasis on how cooperatives could better integrate peasants into the national economy and protect their interests as a class of producers. Yugoslav propagandists (and Yugoslav law) laid out a hierarchical typology of cooperatives, in which buying-selling cooperatives were the lowest type. Bokovoy, Peasants and Communists, 69-73.

${ }_{102}$ Cooperative operaie di Trieste, Istria e Friuli, "Norme sul disciplinamento dei servizi negli spacchi sociali," 1946, AS 1581, b 4, f Delavske Zadruga za Trst in Istro. Italics added.
} 
considerate, and above all serious" way, eschewing preferential treatment of friends and political allies and refraining from discussing any contentious or potentially upsetting topics. ${ }^{103}$ This was the vision that monfalconesi had of the daily experience of cooperative commerce.

To convince monfalconesi that this new system of exchange and shopping was already in place in Yugoslavia, pro-Yugoslav propagandists adopted the practice of sending delegations of sympathetic monfalconesi on tightly-controlled tours of the New Yugoslavia, to be shown the wonders of Tito's regime. ${ }^{104}$ In one tour, a delegation of monfalconesi who would later go to Paris to urge the Council of Foreign Ministers to give the Monfalconese to Yugoslavia arrived in Ljubljana to witness the great strides made in physical reconstruction and the transformations underway in the Slovenia. Greeting the delegation was a crowd of Slovenes, who applauded the delegates and threw flowers at their feet as they marched through Ljubljana with their red-starred Italian tricolor. Particularly important for this delegation was a visit to a textile factory at the nearby town of Kranj, during which they discussed life in Tito's new "progressive democracy" with the factory's workers. There the delegation learned that "a day of work is sufficient to eat for an entire week. The black market is unknown, while the rationing of goods of primary necessity like bread, oil, sugar is gradually being eliminated. For whoever works, the rations are most abundant." Summarizing their visit, the delegation reported that it had "given us a clearer vision

\footnotetext{
${ }^{103}$ Ibid. Though the Italian state required the clear marking of prices for all goods (and sale at posted prices) during the Fascist era, completing a gradual shift away from petty negotiations that had typified Italian commerce up to the Great War, not all retailers abided by such regulations, especially during the Second World War. The notion that cooperatives would remove the shopkeeper, keep prices low, and smooth the commercial process had existed in Italy for nearly a century, reappearing in times of economic hardship and social strain. The experience of Fascism amplified the appeal of this vision. Morris, "Retailers, Fascism;" Morris, The Political Economy of Shopkeepering in Milan, 1886-1922 (Cambridge: Cambridge University Press, 1993), 141, 145, 150-51, 273.

${ }^{104}$ The practice of hospitality was vital for fostering the myth of the USSR in the interwar era as well. It played to the visitor's dual sense of importance and of being under-appreciated in his or her homeland, making it psychologically difficult to criticize the host community. It also constructed in the visitor's mind a perceived "reality" for the host society that far outstripped actuality, making any observed social ills seem aberrations in a wider utopia. Hollander, Political Pilgrims, 16-21.
} 
of that which is sought after in our imagination, confirming for us the reality that wherever popular power exists, there is: BREAD, PEACE, WORK, AND LIBERTY."105 These were the conditions of the market in Tito's new society without shopkeepers: no dealing with ration cards, no negotiating prices from a hopelessly weak position with self-serving "Fascist" shopkeepers, and no threat of the perpetual hunger with which most monfalconesi had suffered for years.

\section{The Personal Myth: Work and the Workplace}

But, as the Monfalconese delegation's conclusions make clear, the marketplace was not the only lived space that pro-Yugoslavs believed to be radically transformed by the advent of Tito's regime. The same delegation also gave its (undetailed) impression that in the Kranj textile factory there had been a thoroughgoing reform of labor processes, noting that, "when the flag of the workers flies in the factories, when the managers are those same workers safeguarding their own interests, labor is not a burden to bear, but a conscious striving for the wellbeing of all." Though the delegation report provided no concrete description of what had been reformed and how, any monfalconese seeking answers to such questions could look to Il Lavoratore or elsewhere for abundant information. ${ }^{106}$ In the critical summer months of 1946, a second pillar of the personal myth of Yugoslavia began to emerge: that regarding work experiences and the ability of workers to realize their individual career ambitions within the workplace. ${ }^{107}$

This pillar of the personal myth, like that of the radically transformed marketplace,

\footnotetext{
${ }^{105}$ Unsigned, "Il viaggio dei delegati monfalconesi a Lubiana," Undated (First half of 1946), AS 1570, b 11, f 8, sf Corrispondenza This was just one of several delegations. In fall 1946, the district's AgitProp section sent a delegation of some fifty monfalconesi to Jesenice to observe life there. Among them were key AgitProp figures like Valerio Beltrame, veteran militants like Giuseppe Sponton, and a wide range of other activists, including many women. Unsigned, "Delegazione del Monfalconese che si porta a Jesenice," Undated (Probably Late October 1946), AS 1570, b 9, f 6, sf Archivio.

${ }^{106}$ Unsigned, "Il viaggio dei delegati monfalconesi a Lubiana," Undated, op. cit.

107 This pillar, as will be seen in subsequent chapters, emerged simultaneous with a wave of layoffs in the CRDA and the decline in real opportunities for personal advancement within the workplace hierarchy.
} 
interacted with components of the national myth - especially the themes of rational planning and rapid industrialization - but aimed to personalize them with reference to everyday experience and aspirations. In the second half of 1946 and then with an even increased vigor following the announcement of Yugoslavia's own Five Year Plan, propagators of the myth promoted the Yugoslav economy not through abstract concepts such as "planning" or "stability," but rather with an increasingly sensitive reference to the ways in which such properties translated into concrete improvements in life experiences, such as the ability to find work. ${ }^{108}$ Pro-Yugoslavs emphasized the superiority of rational planning not just in production and distribution - creating more goods and a more just distribution of goods than ever before - but also in the state's deployment of human capital. Running parallel to the national myth of planning and plenty was the potential to interpret this through a personal or familial lens. For semi-skilled and skilled workers, rational planning meant freedom from fear of job loss (or deskilling). There was a clear "nesting" of individual interests and the personal myth within the wider national myth of Communist economics. ${ }^{109}$ With this deep faith in rational planning in mind, a shipyard worker writing for Duemila, the proYugoslav broadsheet for young CRDA workers, asked rhetorically the mass of precariously employed youth in mid-1946: "Who knows why in Italy there are layoffs and unemployment while in Yugoslavia manpower is sought after?" ${ }^{110}$ For many youth, the answer was Yugoslav planning. As the pro-Yugoslav shipyard worker Sergio Parenzan remarked while reflecting on his decision to fight for Yugoslav annexation, it was widely said that with Yugoslavia's arrival "everyone will

\footnotetext{
108 "Un discorso del Maresciallo Tito," Il Lavoratore, 2 January 1947. Even before this announcement, however, Tito had touted the full employment in Yugoslavia, stressing the lack of both skilled and unskilled labor at a speech at Zlatibor, in the district of Užice. "Dichiarazioni del Maresciallo Tito," Il Lavoratore, 13 July 1946.

${ }^{109}$ The triad of planning-rationality-stability is discussed in many articles of Il Lavoratore, though the emphasis on individual family security within this wider systemic stability is mostly implicit. See, as two examples, "Il plenum distrettuale dei Comitati popolari di liberazione;" Il Lavoratore, 4 November 1946; "Nella nuova Jugoslavia," Il Lavoratore, 24 April 1947.

${ }^{110}$ Unsigned, Untitled, Duemila (N. 10), Undated (mid-1946), AS 1570, b 12, f 8.
} 
have work, everyone can live well."111

But the ability to find a job was not the only point of emphasis. From the announcement of Yugoslavia's Five Year Plan, propagandists began to link economic planning and modernization not just to full employment, but to the possibility of finding a fulfilling job that required a degree of skill and provided a degree of worker autonomy - conditions that workers felt they had lost under Fascism, and particularly under the piecework system that transformed them into mere beasts of burden. Of course, well before Tito's Yugoslavia existed, the myth of the USSR had held that the Communist system allowed the full realization of "positive freedoms," including the blossoming of the productive and creative self. ${ }^{112}$ Il Lavoratore did much to reinforce this idea and extend it to discussions of Yugoslavia, running articles that differentiated between the so-called "automatic-worker" (operaio-automatico) of the Fordist assembly line and "master-worker" (operaio-padrone) of the USSR and the world of "progressive democracy." While the former was nothing more than a "slave to the machine" or foreman, the latter were empowered producers who analyzed work plans and provided criticism when such plans could be improved. Of course, "to elaborate a counter-plan, to raise production, he needs to have a technical understanding. And it is for this that the workshops are transformed into true technical schools." ${ }^{113}$ In short, workers in the world of "progressive democracy" were free of the rigid control of foremen and there were

111 Cernigoi, Scelte politiche e identità nazionale, 213-14. In Yugoslavia, this had appeal particularly in underdeveloped areas like Bosnia, where the Five Year Plan seemed a promise to equalize prosperity and "provide 'jobs for the boys' from the backwoods." Dennison Rusinow, The Yugoslav Experiment, 1948-1974 (Berkeley and Los Angeles: University of California Press, 1978), 21.

112 Hollander, Political Pilgrims, ch 4. These positive freedoms were distinguished from the strict "negative freedoms" associated with classical liberalism, namely those that limited governmental powers. The sentiment is further captured in an article written by the PCI member Concetto Marchesi and reprinted in Il Lavoratore in August 1946. He provides statistics on schools and technical training programs in the Soviet Union and explains their purpose: "We wish the individual to be truly the crafter of his own destiny, not rising up over others, but rising up amid others, freely, with all the natural richness that he possesses. We desire that each have the means to cultivate these seeds of his own destiny. We reject as foolish and vile the pretense that assigns to the working class the function of laboring and not thinking.... We wish, as Engels said, for "humanity to leave the kingdom of necessity to enter that of freedom." "La persona umana nel comunismo," Il Lavoratore, 14 August 1946.

113 “Nell’U.r.s.s," Il Lavoratore, 28 June 1945. 
abundant opportunities to reverse the longstanding trend of deskilling and the centralization of decision-making and instead to climb the hierarchy of skill, impact decision-making, and find fulfillment through labor. This tenet of the personal myth, focused on the experiential nature of work, thus bumped up uncomfortably against certain aspects of the national myth. It privileged the creation of a liberating work experience over the consumption opportunities provided by mass production, breaking from the "Fordism" that often permeated early Soviet self-representation. ${ }^{114}$

According to myth-makers, the broad shift to a new work culture in the Communist world converged with two features more unique to Yugoslavia to create supposedly unrivaled potential for that country to provide workers with an atmosphere in which they could realize their ambitions for specialization and hierarchy-climbing. First, Il Lavoratore stressed that there had been a thorough political purge of the country's worksites and regularly ran articles detailing the purge of specific workplaces, including Istrian and Dalmatian shipyards. In one particularly significant case, the paper reported that the two major industrial sites of Fiume, the Third of May Shipyard and Torpedo Factory, had not just had their Fascist directors chased out, but also those "hidden collaborators" who had been placed in positions of social control and maintained due to "the tacit connivance of the elements of the management." 115 In fact, the idea that all "Fascist" style bosses had been purged from Yugoslav workplaces was so well entrenched that the young Silvano Cosolo, who later emigrated to Yugoslavia, was shocked when he arrived in Sarajevo to find that an "old regime" boss still ruled in the tobacco factory, managing in a way that was domineering, harsh,

\footnotetext{
${ }^{114}$ As Tzouliadis suggests, there was long a "cult of "American mechanization"” in the USSR that "heralded the advent of "Fordism"' and sought the "construction of a 'Soviet Detroit." Of course, its proponents purged the image of Fordism of its problematic elements (i.e. Ford's anti-trade unionism). Tzouliadis, The Forsaken, 31.

115 "Epurazione nelle fabbriche di Fiume," Il Lavoratore, 11 December 1945. There certainly was a purge, though the criteria for purging were disputed. According to an Italian state report, "the engineer De Lucanoto and fervent antiFascists, for having intervened in favor of some clerks of the shipyard, in large part Italians of the Old Provinces, ... has been purged and together with him the above-mentioned clerks." After this, the shipyard's management was taken over by the Yugoslav military authorities. MI-DGPS Div AA GG RR, "Fiume - Situazione" (N. 442/625), 18 January 1946, ASDMAE, AA PP 1946-1950, Jug, b 6, f 3.
} 
and entirely indifferent to worker conditions. ${ }^{116}$ Second, the paper emphasized that the rapid modernization of the Yugoslav economy generated a voracious appetite for skilled labor. It detailed the rapid recruitment of unskilled Yugoslav workers into technical schools to enable the successful completion of the electrification campaign and the Five Year Plan. The latter was estimated to require some 400,000 more skilled workers by 1951 than existed in Yugoslavia in 1947, including a total of 90,000 "technical cadres."117

By 1947, Yugoslavia's industrial sites were seen as virgin land, devoid of their politicallycompromised leadership and seeking a new vanguard of skilled workers and directors. ${ }^{118}$ According to this view, all workers in Yugoslavia had a chance to rise, the unskilled becoming skilled and the skilled becoming work-team leaders or plant managers. In one account, a visitor to the Slovenian town of Jesenice reported on an encounter he had with a Monfalcone native named Aldo, who had relocated there some time before and who informed him of an abundance of technical schools that train all those "who wish to specialize."119 After another pro-Yugoslav delegation visited Ljubljana and Belgrade in April 1947, the delegates reported that there was great state investment in apprenticeships, with apprentices working six hours per day and having two

\footnotetext{
${ }^{116}$ See chapter 7 for greater detail. Cosolo, Amare... Sarajevo, 133-34.

117 "Un discorso di Kidric," Il Lavoratore, 18 November 1946; "Il problema della mano d'opera nel piano quinquennale." Il Lavoratore, 11 July 1947. Marco Puppini deserves credit for uncovering this article. Marco Puppini, "Il Controesodo Monfalconese in Jugoslavia tra Trattato di Pace e Risoluzione del Cominform," in Il mosaico giuliano, eds. Altieri and Puppini, op. cit., 70. Subsequent articles reiterated the same point, among them "Curiosando, attraverso la Jugosalvia," Il Lavoratore, 6 August 1947 and "Lo sviluppo dell'economia pianificata jugoslava," Il Lavoratore, 23 February 1948.

118 Though Pola was not itself part of the Yugoslav-occupied zone and not subject to Yugoslav-led purges, it also fit within this image of the virgin land, as thousands of exiles (esuli) from Pola and elsewhere arrived in Monfalcone and began working in the CRDA as skilled workers. Thus, the press representation matched up with the observed reality that many skilled workers had left these towns. By late 1946, a majority of skilled laborers from the Pola shipyard had already departed or made plans to depart, leaving the shipyard with "only a small number of manual [unskilled] laborers of Slavic origins." Capo di Stato Maggiore dell'Aeronautica, "POLA" (N. 753377/C) and Attachment, 8 August 1946, ASDMAE, AA PP 1946-1950, Jug, b 7, f Pola.

119 "Una lettera dalla Slovenia," Il Lavoratore, 11 August 1947. In another from later in 1948, a reporter visited with a monfalconese named Giovanni Marega at Zagreb, who had left his job as a CRDA lather operator to work in Yugoslavia, quickly rising to leadership of a factory unit composed of 25 workers and 15 machines. "Due giorni a Zagabria," Il Lavoratore, 7 June 1948.
} 
hours of state-funded professional school afterwards. Thus, "according to one's capacity and one's will, one can become a technician or even engineer without putting strain on one's parents."120

At times, such articles implicitly or even explicitly made use of old, but retooled notions of Slavic inferiority vis-à-vis Italians, representing the latter as a more "advanced" proletarian nation than the largely agrarian Yugoslavs, capable not just of sharing their expertise, but also quickly climbing the workplace hierarchy. According to a reprinted letter received from a Triestine worker employed in the Spalato shipyards, Istrian and Triestine Italians "are today the chief engineers [in Yugoslav industries], and [who] enjoy a notable authority derived from their professional capacity." ${ }^{121}$ Such visions of Yugoslavia were reinforced by the reality that a handful of the most capable chief engineers (capitecnici) had been headhunted away from the CRDA by the Fiume shipyard in the winter of $1946 / 47$ so that they could begin "instructing the new labor force in Yugoslavia in the naval industry." 122

Ultimately, monfalconesi viewed Yugoslavia's worksites in slightly paradoxical terms. On the one hand, they were locations in which each worker worked with autonomy and was free of the politically adversarial foreman - and his principal "whip" of piecework - resulting in a pacification of workplace relations. On the other, they were often viewed as the perfect location to realize one's career ambitions, formulated within the logic of longstanding workplace hierarchies rather than a radically new vision of workplace organization. ${ }^{123}$ As will be seen, the emergence of

\footnotetext{
${ }^{120}$ The delegation brought back and began disseminating these ideas, including by providing booklets on the topic in the libraries of the local union. SU-Trieste, "Viaggio della delegazione triestina dei Sindacati Unici a Belgrado," May 1947, AS 1581, b 1, f 1.

121 “Uguali diritti," Il Lavoratore, 11 May 1946.

${ }^{122}$ Such individuals were consciously pampered, with the specific aim of fostering positive talk of Yugoslav work life and reinforcing the idea that Yugoslavia was a land of individual career opportunity. Unsigned (SU), Untitled List of Monfalcone Tecnici to Recruit to Cantiere 3 Maggio, Undated (Late 1946 or Early 1947), AS 1581, b 2, f 3-C.

${ }^{123}$ Thus, though historians such as Mark Pittaway have shown that in some Communist countries - in Pittaway's case Hungary - the state attempted to smash traditional workplace hierarchies to create a "new working class," the myth of Communist Yugoslavia made quite explicit use of this notion of hierarchy. Pittaway, "The Reproduction of
} 
this portion of the myth coincided with mass layoffs, the reduction of many workers to unskilled and undignified public works jobs, and a near-complete closing of apprenticeship programs. For individuals caught up in such traumas, the appeal of Communism in the workplace was not necessarily that it promised a socialization of the means of production or a chance to become the next Stakhanovite hero. It could be as simple as its uncompromising approach to the extirpation of "enemies of the people" from the workplace and its consequent affording of the possibility for secure employment and upwards mobility. Both dovetailed neatly with the concrete everyday needs of monfalconesi in the postwar and their hopes for a purge of particularly harsh bosses.

\section{Fiume: A Perfect Communist Community}

In constructing the myth of Yugoslavia, Il Lavoratore did not merely discuss life in the country broadly; it also developed myths about particular localities, the most important of which was the port-city of Fiume. This city had been contested territory between Italy and Yugoslavia before its annexation to Italy in 1924 and had served thereafter as a focal-point of Fascist mythmaking. Given Fascist propaganda needs, Mussolini’s regime had provided Fiume with economic concessions, including free-port status and direct subsidies to its shipyard. These measures were to alleviate the harmful effects of the border on the economy. ${ }^{124}$ More importantly, they would provide the basis of favorable press coverage that would show the positive impact of Fascist rule on daily life and marshal support for further irredentist conquests. Given its centrality to Fascist self-representation and tremendous similarities with Monfalcone, Fiume served as a natural counterimage to Monfalcone for Yugoslav propagandists. ${ }^{125}$ Thus the Fascist-era myth of Fiume

\footnotetext{
Hierarchy: Skill, Working-Class Culture, and the State in Early Socialist Hungary," The Journal of Modern History 74, no. 4 (2002): 737-769.

${ }^{124}$ Fiume sat along the Eneo River, which became the Italo-Yugoslav border in 1924.

${ }^{125}$ Like Monfalcone, Fiume was home to a major shipyard founded in the early twentieth cnetury with Habsburg subsidies. However, Fiume's shipyard experienced a much sharper collapse during the Great Depression before it was likewise acquired by IRI in 1933 and turned to war production. Mellinato, "L'occasione, le circostanze, il movimento,"
} 
was appropriated and reformulated, Fiume made central to the myth of the New Yugoslavia.

This reformulation began immediately after liberation, when Il Lavoratore placed Fiume front-and-center as a symbol of the Communist world's rapid reconstruction and revival. The fiumani of Il Lavoratore's pages were, in standard Communist parlance, "Stakhanovites" and "shock workers" who gave voluntary labor in glorious "Reconstruction Days," thus allowing the city rapidly to put the war behind it and to resume productive (as opposed to reconstructive) labor. ${ }^{126}$ Though early representations were limited to such questions of reconstruction, beginning in winter, new themes began to emerge. By reducing the scope of analysis to the local - especially to a well-known city closely tied to Fascism - the paper was able to unite the national myth with the personal myth through such themes and make both increasingly tangible to readers.

The first of these themes - the emphasis on culture and dignity - fits clearly within the wider pillar of creating a "radiant future" that expanded the opportunities of ordinary people. In contrast to Fascism's infamous educational reforms of 1923 (the Gentile Reforms), which had established career tracks for Italian youths based largely on class and denied "culture" to workingclass families, Il Lavoratore depicted Fiume as a city where workers had a range of opportunities to become educated and "cultured." In December 1945, the paper celebrated the inauguration of the People's University in Fiume as an effort to "elevate the level of the masses in all fields and spread knowledge in an integral form, pruning away [sfrondandolo] all veils in which Fascism wrapped [education] to make it a political instrument." ${ }^{127}$ Moreover, in keeping with the broader

\footnotetext{
in Il mosaico giuliano, eds. Altieri and Puppini, op. cit. 95-98, 105-109. This myth was also fostered in Pola as the Yugoslav authorities attempted first to win local support for Yugoslav annexation and then to prevent a mass exodus of skilled Italian laborers. AIS-Trieste, “Activities Report No. 15 for week ending 8th December 1945," 8 December 1945, NARA, RG331, UD1981, b 9138, f 11304/100/2.

${ }^{126}$ See the following Il Lavoratore articles: "La disastrosa situazione dell'economia di Fiume durante il dominio del fascismo," 5 June 1945; "Fervore di vita nelle campagne e nelle officine," 29 September 1945; "Dove il potere è nelle mani del popolo," 23 October 1945; "Ricostruzione a Fiume," 18 January 1946; "Ripresa della vita nel porto di Fiume," 28 January 1946.

127 "Università Popolari in Istria," Il Lavoratore, 11 December 1945.
} 
theme of eradicating illiteracy, it touted local campaigns to teach reading and writing skills to the working poor. Completely overlooked - or perhaps dismissed as motivated by a desire to create a more exploitable population - was the fact that the Fascist regime too had striven with great success to eliminate illiteracy in Italy. ${ }^{128}$ In the New Yugoslavia the literacy campaign was somehow different. It was motivated by the belief that even workers "have a right to be able to learn to read and write; they are humans and are not, as they have been considered until now, mere beasts of burden." 129 Through these and other programs provided in Fiume - art schools, popular theater, courses in languages, science, and math - workers developed a full sense of their own dignity and could achieve a personal elevation, which they had been denied under Fascism. ${ }^{130}$

At the same time, the paper portrayed Fiume as a fundamentally pacified, purified, and self-governing community - a microcosmic representation of the unified Yugoslav community of suffering and the exact opposite of a Monfalcone that was ruled from above and wracked by violence and discord even after war's end. The image of a pacified, purified, and empowered "people" of Fiume was directly related to the idea of the spontaneous surge of support in that city for the "anti-Fascist" organizations during the Resistance, which was said to have carried over unfettered from that struggle into the construction of local popular power loyal to Tito. Il Lavoratore readers learned of the structures of popular power in the city, including the local government of the People's Civic Committee (Comitato popolare cittadino), staffed by former

\footnotetext{
${ }^{128}$ Bruce F. Pauley, Hitler, Stalin, and Mussolini: Totalitarianism in the Twentieth Century, 4th ed. (Malden, MA and Oxford, England: Wiley-Blackwell, 2014), 125.

129 "Vita fiumana," Il Lavoratore, 28 February 1946.

130 This facet of the myth of Fiume (and wider Yugoslavia) has remained quite durable, perhaps because it was based in part in reality. It is a point of emphasis in the recollections of the monfalconese emigrant Giuseppe Franti, discussed further in chapter 7. Alfredo Bonelli, "Prima intervista con il monfalconese Franti Giuseppe," 27 March 1980, IRSML, Fondo Cominform, b 99, f 1. For further examples of emphasis on this type of cultural elevation, see "Dove veramente si lavora," Il Lavoratore, 13 December 1945; "180 rappresentazioni del Teatro popolare di Fiume," Il Lavoratore, 30 June 1947.
} 
workers and exercising power through their People's Tribunal, police, and militia. ${ }^{131}$ Beyond this, articles described the social and administrative functions of the city's pro-Yugoslav mass organization, including the oversight of food and clothing supply and consumers' cooperatives at the sector level and direction of urban hygiene campaigns, gate and roof repair, and street clearing at the street level. ${ }^{132}$ With power in its hands, claimed Il Lavoratore, the people were free to purge their community of local Fascists and philo-Fascists, a process culminating in a gathering of Fiume “anti-Fascists" outside the city's Palazzo Adria in March 1946, during which there was cathartic burning of "straw puppets that represented Fascism and reaction and a purse filled with the money of the businessmen who lived on the shoulders of the people." ${ }^{133}$ Ultimately, the paper suggested, all the exploiters who had imposed themselves on the productive system of the community had fled or been expelled, resulting in an absolute solidarity of the remaining individuals, the "true fiumani," who lived in perfect communion without privileges. ${ }^{134}$

Finally, Fiume was represented as a city in which Italo-Slavic fraternity had sunk deep roots and in which the community had overcome the nationalist antagonisms fanned by Fascism. Propagandists developed this theme most profoundly through coverage of the construction and inauguration in October 1946 of a footbridge across the River Eneo, which reversed the twentytwo-year partition between the Italian-majority Fiume and its Croatian-majority suburb of Sussak that had begun with the fixing of the Italo-Yugoslav border in $1924 .^{135}$ Tito's regime's inauguration of a major footbridge crossing this river became a symbol of transcending the Fascist

\footnotetext{
131 “A Fiume con il governo popolare," Il Lavoratore, 14 November 1945. This was not an exaggeration. The city government had mechanic's apprentices in the positions of police chief and political commissar, and a blacksmith as the head-of- cabinet. Questore Durante (Udine), "Venezia Giulia - Città di Fiume" (N. 01057), 5 June 1946, ACS, MI, DGPS, AA GG RR, 1944-46, b 59, f 116.

132 "Vita fiumana," Il Lavoratore, 28 February 1946.

133 "Uniti nella lotta, uniti e liberi nell'esercizio del potere," Il Lavoratore, 5 March 1946.

134 "Nel clima della vera libertà," Il Lavoratore, 6 June 1946.

${ }^{135}$ As one example, see "Dove veramente si lavora," Il Lavoratore, 13 December 1945.
} 
past and restoring wholeness to a community unjustly divided by Mussolini's regime. The linkage of Fiume to Sussak and thus to Croatia welcomed Italian-speakers into the Yugoslav community of nations, an action reinforced by Tito's widely-reported visit to the bridge the day after its inauguration. ${ }^{136}$ The event had such a great impact on monfalconesi that many, like Renato Rigonat, who had already emigrated to Yugoslavia at that time and was involved in constructing parts for the bridge. In his memoirs, Rigonat proudly recalls his contribution, claiming some seventy years later that the bridge "represented the brotherhood of the Italo-Yugoslav peoples." 137

\section{Myth, Manipulation, and "Contextual Redefinition"}

Within months of liberation, utopian thinking about Yugoslavia had become widespread in the Monfalconese and it continued to spread as monfalconesi engaged in postwar political and territorial struggles. Though former pro-Yugoslavs who reflect upon the period often claim to have been ignorant of Yugoslav conditions ("we knew nothing" and Yugoslavia was "all a guess"), the simultaneous tendency of these same monfalconesi to recall being inundated with pro-Yugoslav militants' talk of Yugoslavia and the Seventh Federative Republic bely such claims. ${ }^{138}$ The latter claims, though more accurate than the former, have their own problems. They capture the fact that the pro-Yugoslavs of the Monfalconese knew both confidently and falsely about Tito's Yugoslavia rather than knowing nothing, but they often carry implicit accusations of manipulation undertaken by the Communist Party and its capillary organs - of an intentional, rigidly controlled, and perfectly implemented process of pulling the wool over the masses' eyes.

\footnotetext{
136 "Non più barriera fra Fiume e Sussak," Il Lavoratore, 21 October 1946; "Il compagno Tito agli italiani e ai croati di Fiume," Il Lavoratore, 24 October 1946.

${ }^{137}$ Rigonat, Memorie, 52.

138 These statements come from interviews with future emigrants conducted by Alfredo Bonelli and Andrea Berrini respectively. See Bonelli, "Seconda intervista con il monfalconese Franti Giuseppe," 21 April 1980, IRSML, Fondo Cominform, b 99, f 1; and Berrini, Noi siamo la classe operaia, 66, 81-83. In the same interview with Franti in which he claimed ignorance of Yugoslavia, he would later say he became "enamored" with the vision of Yugoslavia he held before emigrating.
} 
An understanding of the myth of Yugoslavia that characterizes it purely as a product of manipulation by a single political party is inadequate and incomplete. Such a characterization ignores the critical role that ordinary monfalconesi played in accepting, repeating, and thus solidifying this myth in the postwar years, not to mention the fact that the myth of Yugoslavia, more than just reflecting a fascination with real events happening beyond the Morgan Line, was also (even chiefly) the means by which monfalconesi contemplated alternate visions of society, painting a picture of Yugoslavia as a way to work through these contemplations and to generate motivation for local struggles. As Anna Di Gianantonio and her colleagues assert, mythic thinking is best understood as "an intrinsic need of those who consider it possible to modify the power relations in which they live."139 The Monfalconese process of myth-making fits Paul Hollander's model of estrangement and affirmation. In his study of the myth of the USSR, he suggests that "social criticism must rest on a vision of alternatives" and "estrangement from one's society invariably precedes or accompanies the projection of hope and affirmation upon other ones." 140 In Hollander's analysis, an intimate familiarity with social ills at home created an estrangement among Western intellectuals from their own society. This manifested in a reinforcing cycle of criticizing the home society and projecting positive attributes onto the Soviet Union, even if this required a willful ignorance about certain aspects of Soviet society.

After twenty years of Fascism, monfalconesi were fundamentally estranged. In May 1945, from the sudden convergence of estrangement and hope emerged a society ripe for mythical thinking. Moreover, as time passed and the hopes of achieving a radical transformation of local society were dashed, this cycle of mythical thinking intensified. By the time the delegations of

\footnotetext{
${ }^{139}$ Di Gianantonio et al., L'immaginario imprigionato, 10-11.

${ }^{140}$ Hollander, Political Pilgrims, 8-9. Annemarie Sammartino has identified a similar dynamic as a central motivating factoy in the emigration of Germans to the USSR in the 1920s as part of the Ansiedlung Ost program. Sammartino, The Impossible Border, 72.
} 
monfalconesi began to arrive in Yugoslavia there had emerged the basis for what Hollander has termed "contextual redefinition." Observers selectively perceived and ultimately redefined the significance of negative conditions observed in a supposedly utopian society, reframing them to reinforce a positive view of the desired utopia. ${ }^{141}$ Monfalconesi thus remained quiet or explained away negative characteristics of Yugoslav society. For example, the shoelessness of the Yugoslav Partisans who walked Monfalcone's streets in May 1945 was taken as a mark not of their poverty, but instead of their virtue and self-sacrifice.

In the coming years, the myth of Yugoslavia would have a great impact on the postwar political struggle, inspiring participants, shaping and responding to the ways in which they thought about Communism, and influencing the ways in which they tried to navigate daily life as their district hung in limbo between two worlds. ${ }^{142}$ In some cases, faith in Tito's Yugoslavia became so durable and so deeply felt that proponents even disbelieved what they saw with their own eyes. Though not a monfalconese, an instructive case is that of Maria Casali. An organizer of proYugoslav women in nearby Trieste, Casali recalled that she sometimes visited Zone B in the postwar years, during which time she got the impression that

the situation in Yugoslavia was somewhat confused, but I was aware that the gravity of the situation was derived from the disasters of the war. I was convinced that Yugoslavia, under the leadership of the USSR, would succeed in reconstruction and construct socialism. I remember that at a meeting held at Capodistria the people complained about sour bread and compared it with the white bread that was eaten at Trieste; I encouraged them in this way: there will come a day when you will have white bread and we the sour bread. ${ }^{143}$

\footnotetext{
${ }^{141}$ An example is how Western visitors who observed poverty in the USSR interpreted this reality to be proof of the virtues and self-sacrificial nature of the Soviet citizen, rather than the oppression and exploitation of the ruling regime, as was their explanation for the same phenomenon at home. Hollander, Political Pilgrims, 109.

${ }^{142}$ Police repeatedly indicated the myth of Yugoslavia ("Titoist propaganda") as a motivating factor for monfalconesi to emigrate the Yugoslavia. As two examples, see the files of Nicolò L. and Lino B. at ASG, Questura 1948, b 6, f 975; and b 1, f 175 .

${ }^{143}$ Maria Casali, “Dopo la liberazione," Undated, IRSML, Fondo Cominform, b 99, f9. Casali was not alone. Giuseppe Franti spoke of his tendency in the late 1940s to explain away the fact that food was in such short supply in Yugoslavia, but so bountiful in Trieste with reference to the war. Even his experiences with the former did not kill the image of a bountiful socialist Yugoslavia, as "We had faith, one hoped: one said the war came and the revolution came; one was almost prepared for these things." Bonelli, "Seconda intervista con il monfalconese Franti Giuseppe," 21 April 1980, op. cit.
} 


\section{Chapter 4: Fascist Continuities: Everyday "Fascism" and the Struggle for Change in Contested Monfalcone}

Yugoslavia was not what interested us. We wanted only to be done with Italy. We believed that this would resolve the social problems. This was the point. We wanted to resolve, from an international and internationalist point of view, daily problems. The secession was not seen in the traditional [nationalist] manner, but rather one said: 'here and now we have the possibility to go and make socialism and everyone will have work, everyone can live well., ${ }^{1}$

- Testimony of the monfalconese, Sergio Parenzan.

As tens of thousands of monfalconesi saw things in the summer of 1945, Yugoslavia's bloody war of liberation had ended with a triumph of "popular power" and with the Yugoslav people following the fearless Tito down the path toward a radiant future. In Monfalcone, the people had given their blood and tears to free themselves from the oppressive Fascist regime but had then been denied the right to forge a radiant future of their own.

For those monfalconesi who viewed radical social transformation and the revolutionizing of everyday life as primary goals of Resistance, the substitution of the AMG for Yugoslav rule was a disaster. Sergio Parenzan, who for over a year had heard news from liberated Italy suggesting that the Anglo-Americans had a strictly military understanding of Resistance, saw the arrival of the AMG as an obstacle to rather than culmination of the local Resistance. Its dismantling of the institutions of "popular power" marked an end to what Enrico Cernigoi has termed "the period of potential dreams." 2 This perception was not unique to the Monfalconese; throughout the Italian peninsula, and especially in the north, the arriving Anglo-Americans had done their best to check and deconstruct revolutionary partisan governments that had seized control of local affairs upon the collapse of Axis power. ${ }^{3}$ What was unique about the Monfalconese was a persistent hope that

\footnotetext{
${ }^{1}$ Cernigoi, Scelte politiche e identità nazionale, 213-14. Italics added.

${ }^{2}$ Ibid., 272. Anna Di Gianantonio and her colleague write similarly that the AMG's arrival marked "the end of a dream of redemption and liberty." Di Gianantonio et al, L'immaginario imprigionato, 82.

${ }^{3}$ Dunnage (ed), After the War. Frustration with this tendency was also a key source of motivation behind various violent reprisals carried out by leftist partisans in the postwar. See Dondi, La lunga liberazione; Morgan, Rappresaglie dopo la resistenza.
} 
the social-revolutionary ambitions of the Resistance could be realized: that Tito would return with the signing of a peace treaty and remake Venezia Giulia as Yugoslavia's Seventh Federative Republic.

The arrival of the AMG accelerated efforts to construct a myth of Yugoslavia, and it also spurred a political realignment across Zone A. Completing a transformation that had begun in late 1944 with the fission of the region's CLNs, the primary axis of conflict shifted from that between Fascists and anti-Fascists to that between pro-Italians and pro-Yugoslavs. In the Monfalconese, which had fewer Slovenes than the areas around Gorizia and Trieste, this split manifested in a tenuous coalition of pro-Italians, motivated by varying mixtures of anti-Communism and nationalism (chauvinist or not), squaring off against a more homogenous pro-Yugoslav faction. The latter, though containing a handful of nationalist Slovenes, consisted largely of Italianspeaking workers. Within months of war's end, this division had generated not only vehemently opposed political blocs, but also a clear bifurcation of Monfalcone's associational life, with a range of parallel unions, cultural clubs, partisan associations, women's groups, and youth groups emerging, each standing on one side of the territorial question (Appendix B). ${ }^{4}$

The term "pro-Yugoslav" generally differentiates the majority strain among radical workers from a smaller strain of left-radicals who supported both revolution and continued belonging to Italy, but it is something of a misnomer. Like Sergio Parenzan, most Italian-speakers who struggled on behalf of Yugoslavia did not do so for pro-Yugoslav sentiment, but rather because Yugoslav annexation was seen as a means to resolve everyday grievances. ${ }^{5}$ Temporarily occupied

\footnotetext{
${ }^{4}$ On these organizations, see also Troha, Chi avrà Trieste?; and "L'azione della Jugoslavia e delle forze italojugoslave." On the activity of the pro-Italians, particularly the National League, see Buttignon, "Lega nazionale e Governo militare alleato," 63-116.

${ }^{5} \mathrm{Di}$ Gianantonio and her colleagues stress that it was "the idea that annexation to Yugoslavia would have allowed the resolution of concrete problems" that fueled the pro-Yugoslav struggle. Di Gianantonio et al, L'immaginario imprigionato, 143.
} 
by the AMG and facing the possibility of a permanent return to Italy, the town's pro-Yugoslav struggle reflected a hope that, once its aims were realized, they would facilitate the more important struggle to root out the "remnants of Fascism."

And Fascist remnants were key. Though the pro-Yugoslavs threw their weight behind the campaign for Yugoslav annexation, they did not suspend their struggle against everyday "Fascist" neighbors. There existed a concurrent push for radical transformations in the here-and-now, which the AMG blocked at every turn, due variably to anti-Communism, a cynical desire to protect the social bases of the pro-Italian faction, and a belief that such transformations were impossibilities. As everyday life under the AMG remained qualitatively similar to that under Fascism in key ways, there emerged ideas of "Fascist" continuities that not only fueled resentment toward the AMG, but also provided pro-Yugoslav myth-makers with an image against which they could construct their vision of Tito's utopia. This was the context in which 16,000 monfalconesi became members in the Italo-Slovenian Anti-Fascist Union (Unione antifascista italo-slovena, UAIS), the mass political organization tied to the Communist Party. From its foundation in June 1945, the Union's program had been both to secure Yugoslav annexation and to purge Fascist remnants. ${ }^{6}$ Its name signaled its aims to equate pro-Yugoslav and anti-Fascist sentiments - to claim Yugoslavia as the sole country in which this transformation would occur and to label as "Fascists" all those who opposed Yugoslavia. ${ }^{7}$ The name was a portent of the bitterness with which the coming struggle would be fought and the degree to which it would be shaped by notions of Fascist continuities.

\footnotetext{
${ }^{6}$ This figure (March 1946) includes members of the UAIS and its women's and youth affiliates (UDIAS and UGARG). PCRG-CDM, "IX Relazione straordinaria sulla situazione politica generale del distretto di Monfalcone," 8 April 1946, AS 1570, b 8, f 2.

${ }^{7}$ The label stuck. Alberto Clemente, then a young pro-Yugoslav, later recounted that "when you said, 'I am Italian,' it meant you opposed the [pro-Yugoslav] movement. You were considered a Fascist." Cernigoi, Scelte politiche $e$ identità nazionale, 263-64.
} 


\section{AMG Market Policy and the Persistence of "Fascist" Commerce}

The harsh reality of persistent material shortage and the resultant frustrations over marketplace experiences catalyzed the social and political polarization that soon swelled the ranks of Monfalcone's UAIS. ${ }^{8}$ With the coming of the AMG, very little improved in the market and rationing system from an experiential standpoint, and in some respects, conditions deteriorated. In the short term, there was a resurgence of the black market, particularly in the scarcely-patrolled outlying communes. At least in pro-Yugoslavs' estimation, this resulted from the dissolution of the DP. As one OF committee member reported from San Canzian d'Isonzo, there "the black market had been eradicated; but from the moment of the disarmament of the Dif[esa] Pop[olare] the practitioners of such a market are resuming it in grand style." ${ }^{9}$ In the longer term, the AMG created what it called a "disease and unrest" ration, but this was far from a comprehensive effort to resolve the supply and price problem. The ration consisted only of 200 daily grams of bread and monthly allocations of one kilo of pasta, 400 grams of peas or beans, 125 grams of sugar, 100 grams of salt, and 200 grams of canned meat, the last of which the AMG cut by late July $1945{ }^{10}$ In the field of pricing, the AMG set affordable prices for rationed goods but refrained on both ideological and practical reasons from setting prices for non-rationed goods like meats, vegetables, fruits, cloth, shoes, and items like razors and shaving cream, so the strict ration economy continued to be only one part of a system of exchange that also included semi-controlled and uncontrolled goods. ${ }^{11}$ Thus, the AMG system not only ignored repeated consumer demands for expanded

\footnotetext{
${ }^{8}$ This is a central premise of Di Gianantonio and her colleagues in L'immaginario imprigionato, though, because they only partially explored sources from NARA and the AS for the years 1945-47, the full utility of the approach is not realized.

${ }^{9}$ The true efficacy of the DP's anti-black-market campaign is difficult to judge. G. B[x] (OF-Monfalcone), "Difesa Popolare" (N. 58), 28 June 1945, AS 1815/1/1. See also CE, CLN-Staranzano, Interni, "Difesa Nazionale" (N. 68), 3 July 1945, AS 1815/1/1.

${ }^{10}$ Maj. Reid, "Rough Notes on the Present Position at Monfalcone," 17 June 1945, NARA, RG331, UD1981, b 9186, f 11304/115/278; SCAO Meeting Minutes, 28 July 1945, NARA, RG331, UD1981, b 9108, f 11302/115/88.

${ }^{11}$ Only in July 1947, for example, would the AMG implement price controls for shoes and clothing. SCAO Economics
} 
marketplace protections, but also unraveled protections put in place under past administrations. ${ }^{12}$

As a result, marketgoers regularly confronted exorbitant prices, which in turn sparked marketplace conflicts. As late as September 1946, the marketgoer could find butter sold at L1000 per kilo on the free market, which was well over two days' pay for a mechanical fitter at the CRDA, who took home just L420 daily even if he had a wife and child. ${ }^{13}$ Both the legal free and illicit black markets which ran alongside the ration economy were largely inaccessible to working-class families. In addition, workers lacked barterable products, closing avenues of direct barter. ${ }^{14}$ Combined with the unreliability of the supply of rationed goods (even through 1947), ${ }^{15}$ the perpetual failure of worker earnings to keep pace with postwar inflation, ${ }^{16}$ and the widespread black-marketeering of both rationed goods and non-rationed goods, ${ }^{17}$ this meant that the marketplace remained a site of major political contention. Many monfalconesi believed that marketplace "Fascism" remained intact.

Section Meeting Minutes, 6 June 1947 and 12 July 1947, both in NARA, RG331, UD1981, b 9210, f 11304/115/501. One practical reason for the AMG to refrain from this activity was its shortage of economists and enforcement officers. SCAO Economics Section Meeting Minutes, 15 December 1945, NARA, RG331, UD1981, b 9108, f 11302/115/88.

${ }^{12}$ When the AMG did intervene on issues of prices of non-rationed goods, it did so primarily by putting indirect pressure on wholesalers to sell in the AMG at reduced costs, often by passing on knowledge of lower wholesale prices in Italian markets to vendors so they had leverage in negotiations. This became common practice by early 1947. See SCAO Economics Sections reports of 14 February 1947, 14 March 1947, and 28 March 1947, all in NARA, RG331, UD1981, b 9185, f 11304/115/263.

13 AMG Labor and Wage Committee Meeting Minutes, 6 September 1946, NARA, RG331, P1035, b 11, f HOLD/137/82.

${ }^{14}$ This was a difference between postwar Berlin and postwar Monfalcone. Many Berliners viewed the black market with a certain moral flexibility. Though not absent in Monfalcone, the poor and relatively homogenous social composition of the Monfalconese meant that proportionally fewer monfalconesi could afford to engage in blackmarket exchange. They were thus less prone to develop complex, mixed feelings about such forms of exchange. Steege, Black Market, Cold War, 55-56, 121-22.

${ }^{15}$ Maj. Reid, "Weekly Report for the District of MONFALCONE...," 30 June 1945, op. cit.; SCAO Economics Section Meeting Minutes, 10 January 1947, 17 January 1947, and 7 March 1947, NARA, RG331, UD1981, b 9185, f $11304 / 115 / 263$.

${ }^{16}$ SCAO Bowman, "Notice No. 4," 28 July 1945; Labor Office-Trieste, "Table of Earnings for an 8-Hour Working Day," 18 January 1946, both in NARA, RG331, UD1981, b 9225, f 11304/115[A]/46; Capt. F. Hill (CAO Monfalcone), "Monthly Report-Monfalcone," 1 April 1946, NARA, RG331, UD1981, b 9186, f 11304/115/283; SCAO Meeting Minutes, 3 February 1947, NARA, RG331, UD1981, b 9226, f 11304/115[A]/51; SCAO Meeting Minutes, 14 April 1947, NARA, RG331, UD1981, b 9108, f 11302/115/90.

${ }^{17}$ AMG Charge Sheets, "B[x] Maria," 22 October 1945, and "D[x] Giovanni," 22 October 1945, NARA, RG331, UD1981, b 9187, f 11304/115/281. This would continue well into 1947. See HQ VGPC, Sottozona Uniforme Monfalcone, "Rapportino giornaliero delle novità," 21 May 1947, NARA, RG331, UD1981, b 9207, f 11304/115/478. 
The Communist press exploited these tensions and criticized the failure of the AMG to clear the "exploiters," (sfruttatori), "sharks" (strozzini), and "hoarders" (accaparratori) out of the local markets. ${ }^{18}$ According to Il Lavoratore, the persistent "antisociality" (antisocialità) of such individuals was not surprising, as they had either been Fascists or had profited from collaborating with Fascism, but had not been driven out of the region upon liberation. ${ }^{19}$ It stressed that there was no place in Julian society for such individuals, because war and Resistance had "opened a new period in the life of humankind, a period that affirms the solidarity of all the honest people, as there is no longer a place for slave-drivers, for exploiters." 20

At times, these grievances boiled over into confrontation between market-goers and "Fascist" merchants and between market-goers and the AMG, the latter occurring because monfalconesi saw the AMG as responsible for protecting marketplace "Fascism." The first such incident took place on 21 July 1945. The night prior, the CDLN, which ever since the AMG's arrival had organized the at-loss sale of foodstuffs to "serv[e] as an example to all the local merchants," declared certain "just" prices of goods for the entire Monfalconese, despite lacking authority to do so. ${ }^{21}$ When market-goers attempted to purchase goods at these low prices (called "uneconomic" by the AMG), sellers refused and confrontations ensued. ${ }^{22}$ Market-goers demanded the extension of the price control system (especially to meats, milk, vegetables, and cooking oils) and the elimination of the resale of rationed goods. CAO Cozens, the reporting AMG officer, conceded the demands "were fully justified." Still, the AMG responded to the disorders by posting

\footnotetext{
${ }^{18}$ For these terms, see respectively "Problemi attuali," Il Lavoratore, 11 July 1945; "Necessità del controlle dei prezzi," Il Lavoratore, 27 August 1945; "Il pane," Il Lavoratore, 3 October 1945.

19 "Perchè," Il Lavoratore, 27 June 1945.

20 "Problemi attuali," Il Lavoratore, 11 July 1945.

${ }^{21}$ CDLN-Monfalcone, Sez. Approvvigionamento, "Resoconto Sezione Approvvigionamento" (N. 152/VIII), 5 March 1946, op. cit.; PCRG-CDM, "Relazione generale della situazione politico-organizzativa del Distretto," 11 August 1945, AS 1570, b 8, f 2.

${ }^{22}$ For example, the CDLN declared potatoes would be sold at L8 per kilo. Lt Col J. Armstrong, Trieste Area Commissioner, "Disturbances at Monfalcone," 24 July 45, NARA, RG331, UD1981, b 9186, f 11304/115/283.
} 
military police to storefronts and stalls to assure the resumption of commerce. The crowd, originally "perhaps a thousand strong," grew throughout the day and became increasingly raucous in both the central piazza and the nearby marketplace. ${ }^{23}$ According to Cozens, at times Allied MPs were "almost torn from their vehicles whilst crossing the square" and the crowd "appeared to be about to tear the place down." Faced with a delegation demanding the abolition of this discriminatory economy and the implementation of a commerce of "justice," Cozens bent to popular demands, ordering a distribution of available goods at no charge, with the AMG footing the bill. ${ }^{24}$

The disturbance in Monfalcone had a ripple effect, instantly sparking a series of similarly riotous demonstrations throughout the zone. Women, as the primary marketgoers, played a key role. Though Communist Party leaders had decided after the Monfalcone disturbance that it was "necessary that we convince the women to accept a truce" regarding the problems of prices and market purges, the Party and its mass women's organization had spent much effort organizing the campaign "against the free market [and] for the increase of rationed goods" and the women would not cease their agitation. ${ }^{25}$ On 23 July, in the outlying commune of Pieris, a crowd of 2000 gathered at the Pieris train station, drawn by "rumors that on that train [from Venice to Trieste] there were many goods that were to supply the free market and fill the coffers of the sharks at Trieste." The crowd stopped and boarded the train and began unloading the cargo before machinegun-wielding British MPs intervened to restore order. According to Communist Party reports, the women became belligerent and "pushed themselves against the soldiers and called them Fascists and

\footnotetext{
${ }^{23}$ The central market in Piazza Cavour was roughly one block away from the main piazza, connected by a major walkway.

${ }^{24}$ Cozens stressed that his actions had appeased the crowd without setting a precedent for price-fixing. Maj. Cozens, "Interim Report on Disturbance at MONFALCONE on Sat. 21 Jul. 45," 22 July 1945, NARA, RG331, UD1981, b 9186, f 11304/115/278.

${ }^{25}$ PCI-Monfalcone, "Verbale della 23 seduta del giorno 23/7/45," 23 July 1945, op. cit.; Comitato Distrettuale UDAIS, "Relazione politica ed organizzativa delle D.A.I.S. del distretto Monfalcone," 4 January 1946, AS 1570, b 8, f 3, sf 1.
} 
starvers of the people, and shouted that they were the cause of everything that was happening, because they had ordered the free market and removed the controls the $[\mathrm{OF}]$ committees had on the prices of goods." ${ }^{26}$ After stopping this so-called "train of the black-marketeers," the workers and women pillaged the towns shops and made known, in the words of a British officer, that "if we [the AMG] can't break the Black-Market, they ca [sic], and will by force." ${ }^{27}$ As proof, the following day a crowd of women engaged in aggressive demonstration outside the shop of the merchant Barella at San Canzian d'Isonzo. Participants claimed he displayed goods at blackmarket prices and demanded the goods be confiscated and distributed. In this case, too, the English intervened, met with accusations that, as armed protectors of free-market exchange, they were "worse than Fascists" and "starvers of the people." 28 During these and later riots, demonstrators assumed a sharply anti-Anglo-American tone, shouting "Death to the Allies!" despite repeated Party efforts to prevent such direct confrontation. ${ }^{29}$

The form of these riots, including both the tendency to view shopkeepers as a class as "sharks" and attempts to seize goods for distribution at "just" prices, in many ways resembles the cost-of-living riots that gripped Italy in 1919 in the wake of the Great War. ${ }^{30}$ Yet a striking novelty of these later incidents is the tendency of these ordinary protesters - many of whom the Party explicitly indicated were not organized into the PCI or even a UAIS affiliate - to link marketplace exploitation with Fascism, even transferring the label "Fascist" from those engaged in market

\footnotetext{
${ }^{26}$ Unsigned, "Da Pieris il giorno 23.7.45," 25 July 1945, AS 1570, b 10, f 7, sf 14.

2744 Reconnaissance Regiment, "Report to AMG," 24 July 1945; Maj. Cozens, "Memo to AMG-Trieste," 24 July 1945, both in NARA, RG331, UD1981, b 9186, f 11304/115/278. The term comes from Silvano Cosolo. Cosolo, Amare... Sarajevo, 17.

28 "V," "Da San Canziano il giorno 24.7.45," 25 July 1945, AS 1570, b 10, f 1, sf 13.

${ }^{29}$ PCRG-CDM, "Verbale XXVIII seduta del comitato distrettuale di Monfalcone," 9 November 1945, AS 1570, b 8, $\mathrm{f} 1$. The prevention of direct confrontation (differentiated from non-cooperation) had been the PCRG strategy since its First Congress. PCRG-CDM, "Verbale della seduta 25 del comitato distrettuale," 23 October 1945, op. cit.

${ }^{30}$ Morris, "Retailers, Fascism," 293-94.
} 
exchange to the wider set of actors facilitating the free market. ${ }^{31}$ In the thinking of a large number of monfalconesi, "Fascist" meanings had been grafted on to any sort of free-market exchange.

In the following months, as AMG provisioning, pricing, and rationing policies continued to meet only partially the needs of monfalconesi, the pro-Yugoslav press reinforced associations between the ongoing hardship and the loss of Yugoslav administration. ${ }^{32}$ The AMG had responded to the July food riots with an attempt to control the prices of meat in the Monfalconese, setting prices at L90-120 per kilo. However, this simply caused meat to disappear from markets. Udinese smugglers who had formerly supplied the Monfalconese instead smuggled their goods to Trieste, where, in the absence of such controls, meat sold for L280-L350 per kilo. ${ }^{33}$ In this context, Il Lavoratore launched a full assault against the "free market," attempting to harness popular resentments. As with demonstrators on the ground, it demanded an extension of the price-control system, and criticized the very notion of a "free market," emphasizing that this market allowed commercial "sharks" (strozzini) to exploit urbanites' inescapable dependency upon them for food and concluding bitterly that "one cannot say 'free market' speaking of commerce exercised by sharks." 34 Two days later, it criticized the AMG for perpetuating the Fascist system of setting a "political price" on bread and goods of the first necessity, while allowing the prices of other goods to run up unchecked. ${ }^{35}$ In October, the paper cast the failure to sweep the "hoarders" (accaparratori) out of the markets as a failure of the Resistance, stressing that the problem was the speculators, who still wish to live like some months ago, that is before the Liberation. Today these speculators live and prosper freely, because there is no organ that acts

\footnotetext{
${ }^{31}$ PCRG-CCM, "Riunione No. 20 del Comitato Cittadino del P.," 5 February 1946, AS 1570, b 10, f 1, sf Monfalcone. ${ }^{32}$ AMG policies remained unchanged despite the local CAO urging that "drastic action" be taken to resolve the food and related political crises. Maj. Cozens, "Report for Week Ending 3 Aug," 2 August 1945, NARA, RG331, UD1981, b 9186, f 11304/115/278.

${ }^{33}$ Maj. Cozens, "Report for Week Ending 10 Aug 45," 9 August 1945, NARA, RG331, UD1981, b 9186, f $11304 / 115 / 278$.

34 "Necessità del controlle dei prezzi," Il Lavoratore, 27 August 1945.

35 "La situazione economica delle classi lavoratrici," Il Lavoratore, 29 August, 1945.
} 
in a repressive manner against them. ${ }^{36}$

\section{Chaos and Shared Power in the CRDA}

Though food was certainly the most pressing problem for monfalconesi in the first months after liberation, the same could not be said for the AMG. The AMG sought political stability and the containment of Yugoslavia's expansionist ambitions above all else, and in Monfalcone this required restoring stability and productivity to the war-damaged shipyard and breaking the proYugoslav organs' strength therein. ${ }^{37}$ Immediately upon the AMG's arrival, Major J. Reid indicated that the situation within the CRDA was not what the AMG hoped. The few contracts could not keep all 5000 employees working constantly and thus "a not inconsiderable number of hours are spent in listening to political speeches or taking part in political discussions." Moreover, the factory guards and management appeared "quite powerless to control the workers, the work or anything else," and many managers worked "in constant fear of being molested and even shot."38 Thus, from an early date, the AMG focused its attention on taming the restive workforce.

Yet as the AMG successfully dismantled "popular power" outside the shipyard in the late summer of 1945, it had far less success within the CRDA. Although the pro-Yugoslav Factory Committee was not all-powerful, during these months it simply "discharge[d] and employ[ed] men without reference to the management" and established internal purge commissions that claimed authority to remove even the highest directors of the firm. ${ }^{39}$ One militant reflected that the committee had "the capacity and the power to decide on some things that could affect the

\footnotetext{
36 "Il pane," Il Lavoratore, 3 October 1945.

${ }^{37}$ Maj. Reid, "Preliminary Report on Monfalcone," 13 June 1945, NARA, RG331, UD1981, b 9186, f 11304/115/278. CRDA estimates placed damages at $47 \%$ of total industrial capacity for the firm and "notably higher" at Monfalcone. Ispettorato (CRDA), "Nota riassuntiva riservata," 18 January 1947, ACS, Fondo IRI, Numerazione Rossa, b R1590. ${ }^{38}$ Maj. Reid, "Rough Notes on the Present Position at Monfalcone," 17 June 1945, op. cit.

${ }^{39}$ Maj. Cozens, "Report for Week Ending 10 Aug 45," 9 August 1945, op. cit.; Unsigned (SU), "Istruzioni per i comitati interni e per i Sindacati Unici in relazione al procedimento dell'epurazione," Undated (Late 1945), AS 1581, b 2, f 4-A.
} 
shipyard's activity. There was the capacity and the power to affect even those who represented the Direction. ${ }^{40}$ In other words, the workers - or at least the committee - had achieved a degree of self-management and power-sharing. A full two months after the AMG's arrival, AMG officials observing the state of affairs in the CRDA and the Solvay warned that "some drastic action, either by the nomination by A.M.G. of a representative Workers' Committee [i.e. one including proItalians and anti-Communists], or the taking over of the firms is required. ${ }^{441}$ Later that month, the AMG created a special Labor Office in Monfalcone to "come to the assistance of the plants," reassert managerial control, and restore a semblance of productivity where the pro-Yugoslav forces had left "Chaos." "42

Despite the pro-Yugoslavs' newfound power in the CRDA, as time passed, management began to reassert itself, and old questions re-emerged, including that of piecework. In July, with AMG support, the CRDA reintroduced piecework into contracts for the CRDA-Monfalcone's shipbuilding workshops, shortly thereafter extending it to the Electromechanical Workshops. ${ }^{43}$ Certainly, the power of the pro-Yugoslav Factory Committee within the yards led to a decrease in piecework's use as a tool of oppression and exploitation, as well as the real possibility of violence against abusive piecework enforcers. As the worker Sergio Parenzan reflected, in the last months of 1945 "the work pace was quite mild. The bosses who before had been arrogant, later stayed quiet because they were afraid." ${ }^{44}$ However, it did not have sufficient power to stop unilaterally the restoration of this "Fascist" form of labor. In this context, workers and Party organizers began

\footnotetext{
${ }^{40}$ Morena, "Intervista a Papais Renato," 0830hrs, 28 June 2001, op. cit.; Di Gianantonio et al., L'immaginario imprigionato, 143.

${ }^{41}$ Maj. Cozens, "Report for Week Ending 10 Aug 45," 9 August 1945, op. cit.

${ }^{42}$ Capt. [Illegible], "Labor Office," 31 August 1945, NARA, RG331, UD1981, b 9186, f 11304/115/278; Maj. Marshall, "Monfalcone Shipyards," 12 September 1945, NARA, RG331, UD1981, b 9202, f 11304/115/434. The office worked with pro-Italian propagandists to vilify pro-Yugoslavs as servants of Belgrade. Di Gianantonio et al., L'immaginario imprigionato, 128-30.

${ }^{43}$ CRDA, "Consiglio 28 novembre 1946," 28 November 1946, op. cit.

${ }^{44}$ Morena, "Intervista a Sergio Parenzan," 1000hrs, 30 May 2001, op. cit.
} 
to call again for the suppression of piecework. On 22 August 1945, Vittorio Cernigoi spoke before a crowd of workers, making such a demand and calling for a new system in which "the contracts will be drawn up by the workers of the very workshop and passed for the signature of the workshop head," allowing the workers to become "self-disciplining." Cernigoi's speech, perhaps the clearest articulation of a plan to reorganize the work process to date, suggests a desire to return to the organization of the factory to pre-Fascist forms and was met, at least in the Communist Party's estimation, with the "spontaneous approval of the totality of those present.",45

However, as months passed with no substantial improvement in the standard of living, no official recognition of the SU's elected "management councils," and instead the reconsolidation of the hated piecework system, cracks began to show in this consensus. ${ }^{46}$ Some workers began to strike for piece-rate increases, seeking short-term amelioration in lieu of a complete overturning of the system. ${ }^{47}$ In response, the Party - both in Monfalcone and Trieste - attempted to shore up worker discipline and assure the struggle was against piecework in its entirety, not just rates, with additional earnings to come through hourly wage increases. As one member of the Communist Party's CRDA cell commented, "piecework... is the whip of the worker and is that which serves the master to increase production and, naturally, then to lay off [workers] and thereby to create new miseries. Therefore, we must propagandize among the masses the absolute necessity to abolish piecework, to do his duty as a worker not to put back in place the abovementioned whip."48

\footnotetext{
${ }^{45}$ Vinicio (PCRG-Monfalcone, AgitProp), "Riunione in Cantiere tenuta dal compagno Radich" (N. 0152), 22 August 1945, AS 1570, b 11, f 8, sf Corrispondenza.

${ }^{46}$ Comp. V[x] (SU), "Relazione del Compagno V[x] sullo sciopero," 3 October 1945, AS 1570, b 13, f9.

${ }^{47}$ In November, the arc welders went on strike, winning a small raise in piece-rates. Comp. Marcello, "VI Riunione delle ore 10 alle 12 presenti pure i comp. Primo e Sullivan," 15 November 1945, AS 1570, b 10, f 1, sf Rapisniki raznih celic 1945.

${ }^{48}$ Comp. Corrado, "Relazione della riunione dei referati sindacale del PC," 10 December 1945, AS 1570, b 10, f 1, sf Rapisniki raznih celic 1945. Some, including Renato A., head of the PCRG within the CRDA, were skeptical about abolishing piecework, primarily because they believed it would cause disorder in the workplace. PCRG-Monfalcone, "Riunione del Biro' di cellula del P.C. della R.G. per il C.R.D.A.," 12 December 1945, AS 1570, b 10, f 1, sf Rapisniki raznih celic 1945 .
} 


\section{New "Communists" and a New Communist Party}

The bifurcation of the Monfalconese into clearly delineated political and organizational camps was well under way by the time the Communist Party was having these discussions over piecework. As a longtime militant and a principal Communist speechmaker in the CRDA, Cernigoi himself had taken on a leadership role with the zone's new pro-Yugoslav union, the Unitary Syndicates (Sindacati Unici, SU), which, funded by Belgrade, had emerged as the peacetime successor to the wartime Workers' Unity. In the markets, orchestrating the concurrent campaign for "just" commerce was the women's affiliate of the UAIS, the UDAIS.

But coordinating the activities of these pro-Yugoslav organizations, as well as several others, was the Communist Party, which had undergone substantial restructuring in the months after liberation. That summer, the PCI functionary Giacomo Pellegrini had negotiated with the KPS and KPJ to realize the creation of a "unified, largely autonomous Communist Party" in Venezia Giulia, stretching over both Zones A and B and including all Communists irrespective of nationality. ${ }^{49} \mathrm{He}$ did so largely to free the PCI from the discomforts of the "Trieste Question." The PCI hoped this arrangement would allow it to avoid directly condoning or rejecting Yugoslavia's annexation of Venezia Giulia, and the KPS accepted the move upon the condition that it have a predominant role in the new party, including a Yugoslav majority on the Directive Committee. Implicit in the agreement from the PCI's perspective was the assurance that the new PCRG would navigate the Trieste Question cautiously so as not to undermine the PCI's electoral prospects. ${ }^{50}$

In the first half of August, the PCI and KPS gave birth to the new, Trieste-based Communist Party of the Julian Region (Partito comunista della regione giulia, PCRG), and Monfalcone

\footnotetext{
${ }^{49}$ Giacomo Pellegrini to "Cari compagni” (PCI-Direzione) (N. 136), 26 June 1945, AM-IG, Jug e VG, mf 93, b 54, f D: Rapporti di Pellegrini, d D:3.

${ }^{50}$ Pellegrini to Togliatti (N. 3755), 30 July 1945, AM-IG, Jug e VG, mf 93, b 54, f D: Rapporti di Pellegrini, d D:8.
} 
emerged immediately as a party stronghold. Within the Monfalconese, the new PCRG consisted of roughly 200 full members (effettivi) in the CRDA and perhaps another hundred in the communes, flanked by several hundred candidates (candidati) and sympathizers (simpatizzanti) working toward promotion to full membership. Perhaps most importantly, between war's end and August, amid food riots, struggles over the workplace, and frustration over the AMG's undoing of “popular power," a further 2000 submitted applications for membership. ${ }^{51}$ By year's end, membership had ballooned to over 2200 , of whom nearly 1550 were sympathizers. ${ }^{52}$

The explosion of PCRG membership in the last half of 1945 had two major effects on the zone's politics. First, it changed radically the nature of the local Communist Party. Coupled with the long-term Fascist-era ban on socialist and communist texts, the explosion created a mass of rank-and-file militants who lacked significant theoretical knowledge of Marxism or Leninism. Even the most cursory glance at the PCRG party applications reveals that those seeking entry into the Party often were not familiar with even the rudiments of Marxist theory. In response to the application's question asking if the applicant knew such theory, answers such as "I don't know it," "no," and "very little" greatly outnumbered those that indicated some knowledge. Even in the latter case, the knowledge was most often limited to having read a few pamphlets or a Short Course. ${ }^{53}$

\footnotetext{
${ }^{51}$ In the Monfalconese, the PCRG was headed by a ten-member District Committee (CDM), which directed subordinate committees based on the workplace or, for those not employed in an industrial firm, village of residence. The most significant subcommittee was the Central Factory Committee in the CRDA, which in turn oversaw eight subordinate Department Committees, those of (1) the naval workers (Reparto Navali); (2) the wood group (Reparto Gruppo Legno); (3) the assembly and mounting workers (Reparto Allestimento); (4) the electromechanical workers (Reparto Elettromeccanica); (5) construction workers (Reparto Edili); (6) aeronautical workers (Reparto Aeronautica); (7) the clerks (Reparto Impiegati); and (8) the guards (Reparto Guardiani). Each department committee then oversaw workshop group committees, which were further divided into workshop cells. PCRG-CDM, "Relazione generale della situazione politico-organizzativa del Distretto," 11 August 1945, op. cit.

${ }_{52}$ PCRG-CDM, "Specchiatto organizzativo mensile," 31 December 1945, AS 1570, b 8, f 3, sf 1.

${ }^{53}$ There are hundreds of such applications held in AS 1815, bb 8-10. This assessment was shared by both the local PCRG and by Pellegrini, who commented throughout the first postwar months that it was crucial even for longtime militants to become "ideologically and politically more prepared." Giacomo Pellegrini to PCI-Direzione, 26 June 1945, AM-IG, Jug e VG, mf 93, b 54, f D: Rapporti di Pellegrini, d D:2; PCRG-CDM, "Relazione organizzativa," 29 October 1945, AS 1570, b 8, f 3, sf 1.
} 
This was especially the case for youth, who had spent their whole lives in an Italy subject to Fascist restrictions on the press. ${ }^{54}$ Certainly, this state of affairs was not unprecedented or exceptional when compared to Italy. In the Old Provinces, participants in a century-old subculture of sovversivismo (subversivism) had been broadly "red" without obediently following a single political party or even learning the party's guiding theory, and during the Fascist and war years, many had gravitated to the PCI (and USSR) because it appeared the sole effective pole of opposition. ${ }^{55}$ Yet the point remains: the lion's share of PCRG members, though calling themselves Communists, approached "Communism" with ideas and assumptions than differed from those of Party leaders, largely lacking the latter's Marxist theoretical lens. ${ }^{56}$

A second effect of Party growth was that it became a solid, yet covert control mechanism for the entire array of institutions involved in the pro-Yugoslav struggle. Each of its committees from the district down to the village level - possessed a liaison for the various mass organizations such as the UAIS, UDAIS, SU, and others. The PCRG placed these liaisons in key positions within their mass organs, forbidding them from revealing themselves as Communist militants. This afforded the Party a degree of control over the movement. These individuals served on the frontlines of constructing the myth of Yugoslavia and strove to funnel the wide range of popular

\footnotetext{
${ }^{54}$ One pro-Yugoslav indicated that his purpose in joining the pro-Yugoslav movement was "to achieve socialism, above all to change the system. But we youths were in the dark on such things because one couldn't read [socialist] newspapers... But those who were older, who had been able to read something... in short, the people wanted socialism, even under a different nation than Italy." "Intervista al. Sig. Manià," held at the CCM. The interviewer is unspecified, as is the date and location of the interview.

55 The monfalconesi were never part of Italy's tradition of sovversivismo, as (1) the Monfalconese was comparatively young; and (2) the Habsburgs had governed it until recently. Abse, "Italian Workers and Italian Fascism." See also Passerini's work on Turin and the idea of the "born rebel." Luisa Passerini, Fascism in Popular Memory: The Cultural Experience of the Turin Working Class, trans. Robert Lumley and Jude Bloomfield (Cambridge, England and New York: Cambridge University Press, 1987).

${ }^{56}$ Certain efforts were made in late 1945 and early 1946 to address this, especially by having theory lessons among the Communist Youth and by sending dedicated youth to the Party School. In all cases, instruction began with the absolute fundamentals of Marxism. Comp. Elle (SKOJ, CC-CRDA), "Lezione di Partito e teoria," 4 August 1945, AS 1570, b 13, f Gioventu' Comunista; PCRG-CDM, "Relazione sul corso di Partito iniziatasi al giorno 23 gennaio," 12 February 1946, AS 1570, b 8, f 1 .
} 
discontents into the pro-Yugoslav cause, though doing so was not easy. ${ }^{57}$

The PCRG's control over the workers' mass organizations became especially important when, in late September, the PCRG's Central Committee shocked the PCI and announced the new party's unqualified support for Yugoslav annexation. Pellegrini noted the pushback among a handful of outspoken Italian Communists in the centers of Muggia, Monfalcone, Gorizia, and Trieste and urged leaders in both Trieste and Rome to find a more fitting solution to avoid creating a schism among the "progressives" of the region. ${ }^{58}$ In the months that followed, the PCI failed in its efforts to convince the PCRG to backtrack. ${ }^{59}$ Taking orders from Ljubljana and Belgrade, the PCRG remained staunchly annexationist, and schism ensued. In early 1946, a splinter group of pro-Italian Communists created the Italian Communist Party of Venezia Giulia (PCIVG), which rejected the PCRG's pro-Yugoslav stance and which the PCI in Rome refused to recognize. ${ }^{60}$ Seeking to mitigate the electoral harm of the PCRG's declaration, the PCI responded by proclaiming the italianità of Trieste and established an Information Office in that city. The PCI thus aimed to change PCRG policy and undercut annexationism, but it created no party structure in Zone A that might serve as an organized alternative to the PCRG and the PCIVG. With this, Julian Communism had splintered into three strains - a state of affairs that would persist until the end of the AMG. ${ }^{61}$ In the Monfalconese, however, the vast majority of workers and Communists

\footnotetext{
${ }^{57}$ When the PCRG's AgitProp head in Turriaco revealed his leadership position to non-members, he suffered rebuke, the Party insisting that secrecy was essential "because the AMG, along with the local reaction, are trying to identify the leadership and they could be arrested." PCRG-Turriaco, Untitled Minutes of the Committee Meeting, 7 September 1945, AS 1570, b 10, f 7, sf 15.

${ }^{58}$ Giacamo Pellegrini to "Carissimi”" (PCI-Direzione) (N. 6921), 5 November 1945, AM-IG, Jug e VG, mf 93, b 54, f D: Rapporti di Pellegrini, d D:13.

${ }^{59}$ Giacomo Pellegrini to "Carissimo" (Togliatti?), 23 September 1945, AM-IG, Jug e VG, mf 93, b 54, f 1; DirezionePCI to Direzione-PCRG, 30 September 1945, AM-IG, Jug e VG, mf 93, b 54, f 1, d A:8; Pellegrini to PCI-Direzione, 27 November 1945, AM-IG, Jug e VG, mf 94, b 54, f D, d D:18.

${ }^{60}$ PCI-VG, "Compagni," 24 March 1946, AS 1570, b 9, fs, sf Informazioni. This group became quite noisy, launching the paper L'Unità giuliana that spring. AIS-Trieste, "Activites Report No. 37 for week ending 11th May 1946," Undated, NARA, RG331, UD1981, b 9138, f 11304/100/2.

${ }^{61}$ On the interparty negotiations, see Agarossi and Zaslavsky, Stalin and Togliatti, 143-51; Di Gianantonio et al, L'immaginario imprigionato, ch 2; Terzuolo, Red Adriatic, ch. 2.
} 
remained with the PCRG. For individuals like Sergio Parenzan, who himself would become a PCRG candidate, the choice was easy: fighting in the pro-Yugoslav movement offered the best chance to resolve the problems of everyday life. ${ }^{62}$

\section{Taming the CRDA and the Frustration of Anti-Fascist Purges}

According to Parenzan's recollection, "everyone [in the CRDA] was with the Communist Party of the Julian Region while, from the point of view of the syndicates, everyone was with the Unitary Syndicates." Though overstated, Parenzan's memory of the situation in the CRDA in the early AMG period holds a kernel of truth: the shipyard was the heart of the pro-Yugoslav movement in the Monfalconese and thus of PCRG and SU membership. As a result, the proYugoslav institutions within the CRDA, and particularly the SU Factory Committee, became primary targets for the AMG in its sustained efforts to destroy this movement.

The AMG worked aggressively to undermine the SU, first and foremost by collaborating with pro-Italian forces (including CRDA management) to nurture an alternate, pro-Italian and antiCommunist union. This union, the Julian Syndicates (Sindacati Giuliani, SG), arrived in the Monfalconese from its launching-point in Trieste by the last months of $1945 .{ }^{63}$ Under the principle of syndical choice, the AMG protected the SG branch established in Monfalcone, and the CRDA's Direction, as it reconsolidated some of its authority in the workshops, gave hiring preference to SG members over those of the SU. ${ }^{64}$ From the moment of its inception, Ruggero Bersa, who had emerged as the head of the PCRG in the Monfalconese, thus commented that it was clear that the SG had "some 'secret' agreements with the direction of the shipyard and that they are more or less

\footnotetext{
${ }^{62}$ Cernigoi, Scelte politiche e identità nazionale, 213-14.

${ }^{63}$ Cernigoi, Puppini, and Valcovich (eds), Cento anni di cantiere, 46.

${ }^{64}$ Unsigned [AMG], "Memorandum: Union Activities," 8 January 1946, NARA, RG331, UD1981, b 9228, f 11304/115[A]/67.
} 
in the pockets of the reaction." ${ }^{\prime 65}$ Though the SG membership was in reality more complex than mere "reactionaries," consisting of a mix of people from former Fascists to pro-Italian Socialists and unemployed pro-Yugoslav workers driven into its arms by desperation, it did exactly what the AMG hoped, particularly after it received the official recognition of the Italian General Confederation of Labor (CGIL) in January 1946: it divided the workforce and organized those (comparatively few) individuals willing to challenge the SU's hold over the CRDA. ${ }^{66}$

Along with injecting a high degree of political animosity into the workshops, syndical fission had the unintended consequences of forcing the SU to become an entirely "political" syndicate, which in turn had a dramatic impact on the ordinary worker. In particular, it undermined the leverage the SU could bring to bear in labor struggles and forced the SU to subordinate the push for workplace transformation to the two-pronged political struggle of (1) abolishing the SG entirely; and (2) securing Yugoslav annexation of the region. ${ }^{67}$ As such, the SU quickly subordinated the push to (re)abolish piecework to the exploitation of piecework frustration for political gain. When SU leaders met in early 1946 for discussions prior to a period of collective bargaining, the principal concern regarding piecework had suddenly become devising impossibly large demands for piece-rate increases. In doing so, the SU hoped to force the Direction to bear the stigma of having rejected worker demands and the SG to bear the stigma of having proposed lesser revisions. ${ }^{68}$ The proposal that emerged accepted piecework as fact, ending any discussion

\footnotetext{
${ }^{65}$ Ruggero Bersa (PCRG-CDM), "Lettera intima” (N. 98/45), 16 November 1945, AS 1570, b 8, f 3, sf Circolare e lettere.

${ }^{66}$ Cernigoi, Puppini, and Valcovich (eds), Cento anni di cantiere, 48.

${ }^{67}$ Cernigoi, Puppini, Valcovich (eds), Cento anni di cantiere, 48; Di Gianantonio et al, L'immaginario imprigionato, 128-30. These priorities became clear when the PCRG removed the economic-minded Ernesto Radich from the SU presidency in Zone A in early 1946. AIS-Trieste, Report No. TL.886237 to PID London, 8 April 1946, NARA, RG331, UD1981, b 9216, f 11304/115[A]/15.

${ }^{68}$ M. D[x] (Ref. Sindacale), "Riunione del Comitato Sindacale,” Undated (early 1946), AS 1581, b 1, f 3-B.
} 
of fundamentally restructuring work life. ${ }^{69}$ As Giacomo Pellegrini noted in January 1946, the SU's politicization - and particularly its subordination of the push for workplace reforms to the demands of the territorial question - isolated many "progressives" of the Monfalconese and elsewhere, for whom concrete reforms had been and remained the primary objective. ${ }^{70}$

In this context, the employees of the CRDA and of the Monfalconese's other firms began to line up behind one of these unions, with the political polarization largely (but not perfectly) reflecting divisions within the workplace hierarchy. While workers of all skill levels tended to favor the SU and the pro-Yugoslav organizations, the clerks and workshop heads overwhelming joined the pro-Italian SG. Even in the winter of 1945/46, when pro-Yugoslav violence was quite common, the enrollment figures for clerks, workshop heads, and directors in the SU and UAIS remained shockingly low, only one-third joining the former and one-eighth the latter. By comparison, eight in ten workers and team leaders belonged to the UAIS by December $1945 .{ }^{71}$ Given its pro-Italian stance and the high number of clerks among its members, the SG quickly became the union of "Fascists" in the minds of many workers. As a militant named Semini would later comment during an SU assembly, in his mind "the clerks enrolled in the SG are ex-Fascists without exception." ${ }^{72}$ For most workers, to be a clerk was to be pro-Italian and with the SG; to be pro-Italian and with the SG was to endorse the existing "Fascist" system of labor. Though this claim was objectively overstated, it is true that many leaders of the pro-Italian cause - including the violent wing of the movement - were former Fascists (sometimes Fascists-turned-Actionists)

\footnotetext{
${ }^{69}$ SU-Trieste, "Progetti proposte e modifiche all'accordo generale e a quello integrative per la categoria dei metallurgici," Undated (early 1946), AS 1581, b 1, f 2.

${ }^{70}$ Giacomo Pellegrini, "Appunti per una discussione sul problema di Trieste," 10 January 1946, AM-IG, Fondo JVG, mf 93, f 2, d D:20.

${ }^{71}$ PCRG-Monfalcone, VII Reparto, "Relazione," 3 November 1945, AS 1570, b 10, f 1, sf Rapisniki raznih celic 1945; Comp. M[x] (PCRG-Monfalcone, UO), "Al Comitato Circondariale del P.C.G.-Trieste," 18 December 1945, AS 1570, b 8, f 3, sf 1; PCRG-VII Reparto, "Relazione organizzativa," 13 March 1946, AS 1570, b 8, f 2.

${ }^{72}$ Valerio Beltrame (Ario) (AgitProp, PCRG-IV Rione), "I. assemblea [SU]," 27 May 1946, AS 1581, b 1, f 3-B.
} 
who were clerks and workshop heads in the CRDA, as was Umberto M., a Piecework Office clerk in the Electromechanical Department. ${ }^{73} \mathrm{PCRG}$ attempts to convince workers that a portion of these clerks might be broken off and welcomed into the UAIS bore little fruit. ${ }^{74}$

With these tensions at the fore, a principal question that emerged was who would control the purging of the worksites. Though the SU had continued to assert its own authority in directing purges into the winter of $1945 / 46$, insisting that it should even have the authority to remove directors in firms with over 10 employees, the AMG did not accept this. Instead, the previous fall, it had ordered the suspension of existing purge commissions and the retrial of cases that had passed through the pro-Yugoslav judicial and syndical bodies. ${ }^{75}$ Almost immediately, the AMG and its courts (especially the appellate courts) had begun overturning existing verdicts and sentences, both in high-profile trials of war criminals and collaborationists and those of workplace purges. From late 1945 through 1946, a flood of purged foremen and bosses returned to work, often provoking spontaneous strikes and violence. Thus, when the director of the CRDA's railcar workshop, Giovanni Giurissa, returned to work after the AMG found him to have "always conducted himself in a fit and proper manner," workers forcibly ejected him, refusing his readmittance. ${ }^{76}$ For proYugoslavs, the restoration of these individuals - not to mention the hiring of former Fascists from outside of the Monfalconese ${ }^{77}$ - appeared an AMG-sanctioned attempt to break the pro-Yugoslav network by restoring workplace "Fascism." Only in extreme cases, such as the March-on-Rome

\footnotetext{
73 “G," Report N. 330/Z, 12 September 1945, op. cit.; “Tritolo nazionalista a Monfalcone," Il Lavoratore, 7 January 1946.

${ }^{74}$ The PCRG often differentiated between the SG's clerks and the "progressive" clerks who joined the SU. See the broadsheet Il Compagno. Comp. G. (III Reparto), “Capi e impiegati," Il Compagno (Anno II, N. 1), 1 June 1946, AS 1570, b 12 , f 8.

${ }^{75}$ Unsigned (SU), "Istruzioni per i comitati interni e per i Sindacati Unici in relazione al procedimento dell'epurazione," Undated (Late 1945), op. cit.; SCAO Meeting Minutes, 1 October 1945, op. cit.

${ }^{76}$ Capt. Hobbs, "Alleged Expulsion of Manager by workers, CRDA-Monfalcone," 30 November 1945, NARA, RG331, UD1981, b 9186, f 11304/115/278.

${ }^{77}$ CLN-Osoppo, "F[x] G[x] - informazioni” (N. 6711/3-2), 19 September 1945, ASBCM, b 513, ctg III, sf Cl 2 Varie, 1945.
} 
participant Manlio Bigalia, did the AMG intervene to block the rehiring of such individuals. ${ }^{78}$

The pro-Yugoslav organs were quick to criticize the failures of AMG purges and to point out the return of "Fascists" to positions of authority in the workplace. Throughout the first half of 1946, the walls of the CRDA and other firms were plastered with broadsheets mocking AMG purges. ${ }^{79}$ Yet a closer look at why purging failed in the CRDA reveals a much more complex reality than the AMG simply turning a blind eye to Fascism. In reality, workers had a rather elastic view of "Fascism," and they themselves failed to perform the necessary tasks to provide the AMG with sufficient evidence. Though occurring slightly later, the case of the foreman Vidotto demonstrates how workers (especially pieceworkers) often associated domineering foremen with Fascism. When Vidotto returned to the CRDA in March 1947 to oversee the riveters there, 150 riveters engaged in a sit-down strike. Later AMG investigations revealed that "apparently the foreman made them work hard [in the past], and after the workers had enjoyed much freedom due to politics in the last eighteen months, this particular foreman's return to work came as a rude shock to the gallant riveters." ${ }^{\prime 0}$ While the AMG dismissed this, asserting Vidotto's blamelessness regarding Fascism, the riveters insisted the question was one of purging - of dealing with Fascism. ${ }^{81}$ Because of this elasticity, already by January 1946, the pro-Yugoslav CRDA broadsheets felt compelled to publish articles exhorting workers to fill out the formal statements (dichiarazioni) required by the AMG as evidence for the purging of specific individuals. Workers simply were not doing so to the

\footnotetext{
${ }^{78}$ Capt. Hill (CAO-Monfalcone) reported that "the 'Cantieri' Directors are trying to place as many ex-fascist [sic] in key places on the Monfalcone yard to counter the Communist element...." Capt. Hill, "Strike in Cantieri," 17 April 1947, NARA, RG331, UD1981, b 9186, f 11304/115/278.

${ }^{79}$ In one example from May 1946, a cartoon shows a man sitting behind a desk while another informs him that "the lists for the layoff of the squadristi have been delivered." To this, the sitting man responds "you are mad! Don't you know that they were hired in the Shipyard before 1940?" The cartoon, in short, mocks the tendency to ignore violent acts committed by Fascists before 1940 due to questions of legality. Unsigned, "All'arbitrato (Trieste)," Duemila (N. 11), 20 May 1946, AS 1570, b 12, b 8.

${ }^{80}$ Maj. Kitson-Harris (CAO-Monfalcone), "Monthly Report of Monfalcone Group CAO...," 31 March 1947, NARA, RG331, UD1981, b 9188, f 11304/115/288.

${ }^{81}$ Capt. Hill, “Monthly Report, Mar 1947,” 25 March 1947, NARA 331, 1981, b 9186, f 11304/115/278.
} 
degree required. ${ }^{82}$ The PCRG instructed its militants to stop workers from issuing "collective denunciations," which, since they dealt with entire strata of the workforce rather than particular individuals, had no juridical value in AMG courts. ${ }^{83}$ This seems to be the meaning of Lt. Col. Smuts's February statement that workers throughout the CRDA were demanding not just a "political epuration" - a purge of Fascist cardholders - but a "moral epuration," most likely referring to those having committed "Fascistic" actions or displayed "Fascist" tendencies. ${ }^{84}$

As worker discontent continued to grow due to the rehiring of formerly purged employees and the reconsolidation of the labor system inherited from the ventennio, the issue of purging became more pressing. Behind closed doors, certain PCRG members debated the value of a "direct" purge, with low-level militants often suggesting, as one Pieris militant did in February, that the "workers who know the elements to purge should purge them by themselves, without waiting for the consent of the factory committees or of other higher organs." ${ }^{" 85}$ And many workers agreed. That April, during a Party meeting, the liaison for the workers' quarter of Panzano reported the chilling fact that many in his neighborhood, seeing the "scandalous attitude of the authorities regarding the Fascists," supported "the methods of summary justice to eliminate the Fascists once and for all." However, the Party's agent from Trieste quickly silenced talk of unsanctioned purging and summary executions, deeming this an unviable strategy under AMG rule. ${ }^{86}$ The fact remained, however, that by early 1946 many workers believed the remaking of the workplace to be worth

\footnotetext{
${ }^{82}$ La Commissione [SU Epuration Commission-CRDA], "Epurazione," Unità Operaia (CRDA) (N. 10), 18 January 1946, AS 1570, b 12, f 8.

${ }^{83}$ PCRG-CCM, "Riunione No. 21 del Comitato Cittadino del P.," 18 February 1946, AS 1570, b 10, f 1, sf Monfalcone.

${ }^{84}$ SCAO Meeting Minutes, 4 February 1946, NARA, RG331, UD1981, b 9108, f 11302/115/88.

${ }^{85}$ PCRG-Pieris, "Riunione dei gruppi del P.C. del 19 febbraio 1946," 19 February 1946, AS 1570, b 10, f 7, sf 14.

${ }^{86}$ The Triestine liaison responded that it was "absurd to speak of summary justice, as this was admissible only in time of armed struggle against the occupier, while today we must act in perfect legality to give everyone their deserved punishment." He thus explicitly ordered "no violent actions ... but rather legal action, the legal struggle." Virgilio R[x], "Verbale della Riunione del Referenti per la Lotta Antifascista del Distretto di Monfalcone tenuta 1'8 aprile 1946," 8 April 1946, AS 1818/62/962.
} 
the spilling of blood.

\section{A Spring of Tension, 1946}

These debates over purges and summary justice took place amid an escalation of political tensions in the spring of 1946. In March, the UN Border Commission arrived in Venezia Giulia, foregrounding the territorial question once again. A product of the first peace conference in September 1945, the commission was tasked with studying the ethnic composition of the region and reporting to the foreign ministers who would serve as the ultimate arbiters of Monfalcone's fate. At that conference, the foreign ministers had decided a detailed ethnic survey was necessary before drawing the border, and the Anglo-Americans were particularly intent on this. ${ }^{87}$ The most effective way to keep Trieste out of Yugoslav - that is, Communist - hands was to reduce the border question to one of ethnicity and make the case for the italianità of Trieste. ${ }^{88}$ For both proYugoslavs and pro-Italians, the Commission visit seemed a prime opportunity to sway the foreign ministers' minds through mass politics. Thus, the stage was set for a tense spring.

In the first months of 1946, the pro-Yugoslavs had begun preparing for this visit, clashing regularly with the AMG in the process. By January, the AMG noted that extensive pro-Yugoslav graffiti had popped up overnight, these illicit writings often calling for Yugoslav annexation, claiming an aversion for Italy, and enumerating the local partisan who had given their lives fighting with Tito's forces. ${ }^{89}$ By February, the UAIS, on PCRG orders, had begun to construct celebratory arches praising Tito and Yugoslavia, which quickly became targets of both AMG and wider proItalian destruction. ${ }^{90}$ In protest, the pro-Yugoslavs of the Monfalconese held unauthorized

\footnotetext{
${ }^{87}$ On the stages of these negotiations and the varying proposals of the parties, see Novak, Trieste, 240-50.

${ }^{88}$ Anglo-American decision-makers often ignored their own intelligence bodies, which regularly reported that the ethnic criterion was only one of many that should be considered. Sluga, The Problem of Trieste, 118-26.

${ }^{89}$ Capt. Fowler (FSS-Monfalcone), "Political Activity," 31 January 1946, NARA, RG331, UD1981, b 9216, f $11304 / 115[\mathrm{~A}] / 15$.

${ }^{90}$ PCRG-CDM, "Verbale 32 seduta," 13 February 1945, AS 1570, b 8, f 1.
} 
demonstrations and marches, including a mid-February march that, in open defiance of AMG law, surpassed 5000 participants and was too large for the AMG to attempt to disperse. ${ }^{91}$

The commission thus arrived in Trieste with tensions on the rise locally, mirroring the rise in tensions internationally. Winston Churchill had just defined Trieste as an endpoint of the emerging Iron Curtain, and in this context, the Commission's arrival immediately kindled resentment that suffused pro-Yugoslav circles. In Servola, a Slovene-majority neighborhood of Trieste, the AMG's police force, the VGPC, clashed with Slovenes who had illegally hung a Yugoslav flag from a neighborhood church. The clash ended with the police opening fire, killing two and wounding seventeen. ${ }^{92}$ This "Servola Incident," sparked a brief general strike, as well as massive pro-Yugoslav demonstrations and marches in Trieste. The participants numbered in the tens of thousands, often brawling with pro-Italian counter-demonstrations. ${ }^{93}$

In the Monfalconese, too, the incident turned slow-burning resentments into a full-fledged conflagration. Monfalcone's pro-Yugoslavs briefly went on strike, but, more importantly, they also took to the streets and piazza, continuing to demonstrate through the last day of March, with tens arrested for assaulting either members of the VGPC or the participants in small, pro-Italian counter-demonstrations. ${ }^{94}$ The PCRG added fuel to the fire when it circulated a commentary on Stalin's rebuttal of Churchill, reminding monfalconesi that they stood on the fault line where "the forces of revolution and reaction converge and face off." 95 The March tensions climaxed with a

\footnotetext{
${ }^{91}$ SCAO Meeting Minutes, 18 February 1946, NARA, RG331, UD1981, b 9108, f 11302/115/88.

${ }^{92}$ Servola had long been fertile soil for Slovenian nationalism and anti-Fascism. During the war it became a hotbed of OF activity. Regarding the Incident, the AMG claimed that someone in the crowd opened fire on the police first. SCAO Meeting Minutes, 11 March 1946, NARA, RG331, UD1981, b 9108, f 11302/115/88.

${ }^{93}$ SCAO Meeting Minutes, 25 March 1946, NARA, RG331, UD1981, b 9108, f 11302/115/88. The VGPC struggled to control these contrasting demonstrations, to which participants brought "firearms, knuckledusters, hatchets, knives, ladies [sic] handbags containing bricks, lead filled rubber piping, and in one case a sword and an electric lamp bulb filled with a corrosive liquid." SCAO Meeting Minutes, 1 April 1946, in the same.

${ }^{94}$ Ibid.; Capt. Hill, "Monthly Report-Monfalcone," 1 April 1946, op. cit.

95 Unsigned (PCRG-Trieste), "Alcune considerazioni sulle dichiarazioni di Stalin a proposito del discorso di Churchill," Undated (Late March 1946), IFSML, Fondo Marini, b 6, f 116.
} 
mass rally in Monfalcone in favor of Italo-Slavic fraternity and Yugoslav annexation, estimated (likely over-optimistically) at 20,000 participants by the PCRG. ${ }^{96}$ Though tempers cooled over the Servola Incident in April, the response showed that popular frustrations with the AMG's treatment of the "remnants of Fascism" and of local reform initiatives had generated an explosive situation.

\section{Failed Reconstruction, Frustrated Ambitions, and Youth Departures}

As tempers cooled over Servola, there emerged a new source of frustration: the failures of AMG economic policy. Though the AMG's range of action was limited by physical damage to industrial plants, a shortage of industrial raw materials and fuel sources that lasted through winter 1946/47, and the difficulty of helping the CRDA secure contracts given the great uncertainty over its territorial fate, the AMG generally failed to revive the Julian economy, subordinating the needs of long-term reconstruction to the short-term management of public order. ${ }^{97}$ In fact, one of the first economic policies of the AMG had been to block layoffs in July 1945 to prevent political radicalization. Yet persistent economic difficulties left many firms in precarious financial circumstances, especially those forced to retain employees while having few contracts. ${ }^{98}$ Among the worst affected was the CRDA, which in 1945 regularly threatened the AMG with insolvency. ${ }^{99}$

As the tension between managing unemployment and the threat of major bankruptcies reached a breaking point in early 1946, the AMG felt compelled to devise a new labor policy.

\footnotetext{
${ }^{96}$ AgitProp (PCRG-Monfalcone), "Monfalcone" 31 March 1945, AS 1570, b 14, f 4-B, sf Relazione politiche del Rionale di Monfalcone, 1946. See Di Gianantonio et al. L'immaginario imprigionato, 115.

${ }^{97}$ The CRDA had formerly fulfilled $87 \%$ of foreign contracts with Italian shipbuilders, but by March 1946 was having troubles securing any at all. Direzione Centrale-CRDA, Letter to HQ AMG-VG, 16 March 1946, NARA, RG331, UD1981, b 9202, f 11304/115/434. On AMG reconstruction policy, see Mellinato, "L'occasione, le circostanze, il movimento," in Il mosaico giuliano, eds. Altieri and Puppini, op. cit. 95-114.

${ }_{98}$ SCAO Meeting Minutes, 21 July 1945 and 21 August 1945, both in NARA, RG331, UD1981, b 9108, f $11302 / 115 / 88$.

${ }^{99}$ The firm claimed it faced an unsustainable combination of low income (few contracts) and artificially high labor costs. It claimed that the Italian, German, and Yugoslav governments owed it more than three-billion lire in total, though none were settling accounts. Unsigned (CRDA Direzione), "Memoranda," 23 August 1945, NARA, RG331, UD1981, b 9202, f 11304/115/434.
} 
Under tremendous pressure from the CRDA and other Julian firms, the AMG issued Order 106, lifting the ban on layoffs, allowing the CRDA to lay off a fifth of its workforce, and attempting to absorb the mass of soon-to-be jobless in temporary AMG public works projects. ${ }^{100}$ In the Monfalconese, the effects were devastating. Unemployment, which already affected 1000 residents in Monfalcone alone, rose by $50 \%$ in many villages, remaining in the high 20 s throughout the following year. ${ }^{101}$

Though the AMG's public works programs soon provided work to a substantial number of (but not all) unemployed monfalconesi, the very nature of the work soon became a problem. ${ }^{102}$ These workers performed a variety of tasks including clearing debris from the CRDA, demolishing air raid shelters, reforestation, and land reclamation. ${ }^{103}$ In the largest of these projects, the reclamation of the Punta Sdobba just west of Monfalcone, some 1000 skilled workers laid off from the CRDA were to perform land reclamation labor. ${ }^{104}$ Though these projects provided workers with the means to survive, they fell short of meeting worker aspirations for dignified, proud work. It was employment that, for workers highly conscious of gradations of prestige and skill between various crafts, represented a complete loss of meaningful labor, a culmination of the deskilling

\footnotetext{
${ }^{100}$ SCAO Meeting Minutes, 8 April 1946, NARA, RG331, UD1981, b 9108, f 11302/115/88.

101 Capt. Hill, "Monthly Report-Monfalcone," 1 April 1946, op. cit.; Maj. Kitson-Harris, "Monthly ReportMonfalcone District, May 1946," May 1946; Kitson-Harris, "Monthly Report of Monfalcone Group CAO," 30 November 1946, both in NARA, RG331, UD1981, b 9186, f 11304/115/283.

102 The AMG faced many difficulties in maintaining public works programs, including the seasonal nature of the programs and a hesitancy to start projects that would not conclude before its departure. SCAO Meeting Minutes, 9 December 1946, NARA, RG331, UD1981, b 9108, f 11302/115/89; SCAO Meeting Minutes, 21 January 1947, NARA, RG331, UD1981, b 9226, f 11304/115[A]/51.

${ }^{103}$ On these respectively, see SCAO Economics Section Meeting Minutes, 9 August 1946, NARA, RG331, UD1981, b 9275, f 11304/129/48; Chief Public Works Officer Richardson, Monthly Report to SCAO, 4 March 1947, NARA, RG331, UD1981, b 9207, f 11304/115/470; Maj. Kitson-Harris, “'Highlights' of Interest in Monfalcone Group," 2 April 1947, NARA, RG331, UD1981, b 9188, f 11304/115/289; SCAO Meeting Minutes, 21 August 1945, op. cit.

${ }^{104}$ In fact, the project employed only 400 by June 1946 and faltered when pro-Yugoslav organizations ordered the Punta Sdobba workers to return to the CRDA. Referente Sindacale [Illegibile], "Relazione sulla riunione dei referenti sindacali...," 13 June 1946, AS 1581, b 1, f 3-B; "L'operato dei SU a Monfalcone," Il Lavoratore, 12 June 1946.
} 
process so closely associated with Fascism. ${ }^{105}$ The projects created a "restlessness" among these "workers turned into farmhands." 106 Thus, as top AMG officials pushed this policy, the Monfalcone CAO, Maj. Kitson-Harris, realized a more drastic solution was necessary, as "the unemployed craftsman is not content to use hands in digging holes in the ground to earn his daily bread, when that task can be left to the unskilled labourer." 107

Particularly hard hit by these economic conditions were the youth. With the April layoffs, many families compelled their young workers to cede their posts voluntarily in order to protect the jobs of more experienced (and higher-paid) brothers and fathers. ${ }^{108}$ This only exacerbated the limitation of career opportunities that youth had faced since 1943, when the CRDA put a virtual freeze on apprenticeship programs due to a surfeit of skilled labor. ${ }^{109}$

The effects were devastating, not only for this substratum of the workforce, but also for the pro-Yugoslav organizations. Within a month of the layoffs, some $90 \%$ of garibaldini in the CRDA lost their jobs, among them almost the entirety of the Antifascist Youth (UGARG) and Communist Youth (GC) leadership. ${ }^{110}$ Moreover, certain youth began to leave the SU and sign up for the SG, hoping that the SG's closer ties to the CRDA management would secure them re-employment. ${ }^{111}$ But beyond these organizational concerns, such developments were dangerous in the PCRG's eyes because the mass of unemployed youth became both increasingly aggressive and radical in their

\footnotetext{
${ }^{105}$ An acute awareness of gradations of prestige appears in many interviews and memoirs, especially when workers discuss their apprenticeship assignments. Renato Papais and Sergio Parenzan both recall that their fathers saved them from low-prestige career paths, intervening to secure apprenticeships in more prestigious workshops. Morena, "Intervista a Papais Renato," 0830hrs, 28 June 2001, op. cit.; Morena, "Intervista a Sergio Parenzan," 1000hrs, 30 May 2001, op. cit. The worker and future emigrant Renato Rigonat recalls proudly that his work required precision to a few hundreths of a millimeter. Rigonat, Memorie, 24, 56.

${ }^{106}$ Mellinato, "L'occasione, le circostanze, il movimento," 99-101.

${ }^{107}$ Maj. Kitson-Harris, “Monthly Report, Jun 1946," 1 July 1946, NARA, RG331, UD1981, b 9187, f 11304/115/283.

${ }^{108}$ PCRG-CDM, "Verbale della riunione odierna," 15 May 1946, AS 1570, b 8, f 1.

109 “Apprendisti," Il Lavoratore, 14 December 1946. An exception was welders, who were in demand by late 1946. Maj. Kitson-Harris, "Monthly Report of Monfalcone Group CAO...," 30 November 1946, op. cit.

${ }^{110}$ Bersa later lamented that the Party committed a grave error when it failed to protect key militants from termination. CE PCRG-Trieste, "Riunione del Comit. Esec. del PCRG per il Circ. di Trieste," 26 April 1946, AS 1570, b 1, f 2-B.

${ }^{111}$ PCRG-CDM, "Verbale della riunione odierna," 15 May 1946, op. cit.
} 
approach and, simultaneously, more difficult to control. Just two months after the layoffs began,

Bersa indicated that the situation had reached a near-crisis point, having become

notably aggravated because of the layoffs and the economic maneuvers of the Direction of the CRDA. Similar reactionary maneuvers have provoked a noisy discontent, such that, if the $\mathrm{P}[$ arty] does not exercise a strong hold over the masses... could lead to violent actions. Only with the direct intervention of the P[arty] has it managed to avoid some serious trouble. The youthful masses hardest hit by the layoffs were disposed to a thorough assault on the Direction of the shipyard and against the little Julian Camera [the SG]. They wanted to overthrow everything and in this they were supported by all the masses hit by the layoffs, not to mention by the extremist element, which goes into raptures when it comes to inciting others to action. ${ }^{112}$

As the PCRG's hold over the mass of unemployed youth waned, many young monfalconesi sought to solve their job problems with their feet, most often looking to Tito's Yugoslavia. One was Renato Rigonat, who had entered the CRDA workforce in 1938 at the age of fourteen, quickly gaining the designation of qualified worker in his capacity as a mechanical fitter (aggiustatore meccanico). Following the Special Tribunal's conviction of his older brother, Desiderio, for Communist infiltration of the military in 1941, the Fascists of Monfalcone severely beat Renato, inspiring him to join Monfalcone's Communist network, initiated by his mistro, Luciano Gratton. In his early twenties, Renato became a key participant in the "Montes" Intendency and, after liberation, a chief pro-Yugoslav orator. In mid-March 1946, however, his family received news that either he or his father would be laid off effective 1 April. Renato immediately ceded his position. For two weeks he searched for work, but, failing to find another job before 1 April, he made a sudden departure. He left on the day of his termination in hope of finding work at the Fiume shipyard, and two days later, alone in the city so valorized in the myth of Yugoslavia,

\footnotetext{
112 PCRG-CDM, "XI relazione quindicinale sulla situazione politica del distretto," 29 May 1946, b 8, f 2. Ottone Zanolla would reiterate these problems in June, stressing that Ronchi's youth were "very faithfully combative, but illdisciplined" and prone to "extremism." The garibaldini, though "always the most favorable to the adhesion to [Yugoslavia]," diplayed an "autonomistic tendency." PCRG-V Rione, "Relazione politica mensile," 29 June 1946, AS 1570, b 8, f 3, sf Relazione politiche di villaggio.
} 
Renato was hired as a machine miller (fresatore). ${ }^{113}$

Rigonat's experiences were not atypical. When the teenager Silvano Cosolo returned home to Pieris in 1945 after having spent what should have been his apprenticing years in a German concentration camp, he found neither an apprenticeship, nor an unskilled labor position. Unemployed and increasingly hounded by pro-Italians for his participation in the pro-Yugoslav struggle, Cosolo departed for Yugoslavia in the summer of 1946. With the help of a local SU guide, he crossed the forested border by foot, passing through Fiume before settling in Sarajevo, where he found employment in a rail stock workshop. ${ }^{114}$

Between April and May, tens, if not hundreds of young monfalconesi made similar decisions to depart, almost all of them unemployed and almost all single young men without wives or children. ${ }^{115}$ A large percentage had served as garibaldini and participated in the pro-Yugoslav movement (often as PCRG militants) in the year between the war's end and their departure. Though a handful sought out Western European or South American destinations, ${ }^{116}$ the vast majority crossed into Yugoslavia to seek work in places that ranged from the nearby and culturallyfamiliar ports cities of Pola (Pula) and Fiume to the distant inland capitals of Sarajevo and

\footnotetext{
${ }^{113}$ Rigonat, Memorie, 27-51.

${ }^{114}$ Cosolo, Amare... Sarajevo, 18-19.

${ }^{115}$ With the documentation available, it is impossible to provide a more specific estimate. The difficulty arises in part from the fact that clandestine expatriates like Cosolo often do not appear in any official documentation. In any case, two typical examples include Santo M. (born 1928), a CRDA worker from 1942 who fought in the Brigata Triestina and then the pro-Yugoslav ranks before departing for Fiume after losing his job; and Italo B. (born 1928), a CRDA welder who, unemployed since war's end, departed for Fiume in early 1946. See respectively ASG, Questura 1948, b 7, f 1145; b 1, f 174. Some migrants broke the common mold. Ottone N. is a rare exception to the single, childless migrant. He emigrated in early 1946 for the common reason of being unemployed, but he was recently married, bringing his wife to join him in Yugoslavia in March 1946. ASG, Questura 1948, b 1, f 90. Moreover, a handful of young monfalconesi quit stable jobs to relocate. The CRDA lathe operator and UAIS member Giulio C. (born 1927) quit and relocated near Belgrade in February 1946, followed in July by Stefano B. (born 1925), a CRDA mechanic and pro-Yugoslav ex-partisan who settled in Pola. See ASG, Questura 1948, b 3, f 397 and b 2, f 236 respectively.

${ }^{116}$ Common destinations were Switzerland, France, Belgium, Argentina, Brazil, and Venezuela. Passport requests can be found at ASBCM, b 521, f ctg XIII, sf 3. The pro-Yugoslavs pushed back against westward migration, urging in one broadsheet that comrades not "take the bait of emigration, but rather tirelessly fight so that work and wellbeing will arise in our Region, for us, for our families, for the community!” Ernesto (III Reparto), "Emigrazione!," Duemila (N. 11), 20 May 1946, AS 1570, b 12, f 8.
} 
Belgrade. Their departures resulted from the combination (in varying ratios) of commitment to the Yugoslav Communist experiment, frustration with the PCRG's failure to make good on the perceived promises of the Resistance, a refusal to perform the unskilled (even debasing) labor available through the AMG's stopgap public works projects, and a desire to not burden alreadystressed family economies. As the CRDA implemented its workforce reduction plan that spring, the departure of single, jobless men for Yugoslavia became a steady, if slow trickle.

For the PCRG, such departures were unacceptable, as they meant that gifted and trusted militants like Rigonat were no longer at the disposal of the pro-Yugoslav cause. Luckily for the Party, these departures coincided roughly with the announcement in Yugoslavia of an important new initiative of the Tito regime: the Brčko-Banovići Youth Railway. Constructed entirely by (Communist) Youth Labor Brigades from Yugoslavia and around the world, this railway was to link coal-rich, but inaccessible stretches of eastern Bosnia to the budding Yugoslav industries in Belgrade. The Youth Railway initiative offered to the Party a way to harness this disorganized flow of youthful emigrants - to assure that this mass of unemployed youth, much of which was increasingly alienated from the Party, remained enrolled in Party organizations and, equally importantly, returned to continue the pro-Yugoslav fight after having given their labor.

The Party thus aggressively recruited unemployed youths for two-month shifts on railway construction. Utilizing appeals ranging from the youth's duty to be emissaries of Italo-Yugoslav reconciliation to more concrete promises of work skill acquisition and five daily meals, militants like Mario Tonzar of the Communist Youth recruited monfalconesi for labor and helped direct the Brigades in action. ${ }^{117}$ In the end, the monfalconesi contributed substantially to the ranks of three

\footnotetext{
${ }^{117}$ For each of these appeals, see, respectively "La ferrovia della gioventù," Il Lavoratore, 18 June 1946 and "La Ferrovia della Gioventù," Il Lavoratore, 29 June 1946; "Dopo la vittoria, la ricostruzione," Il Lavoratore 23 July 1946 and "Alla 'Ferrovia della Gioventù," Il Lavoratore, 27 August 1946; "La ricostruzione ferve in Jugoslavia," Il Lavoratore, 3 June 1946; "Giovani triestini alla 'Ferrovia della Gioventù," Il Lavoratore, 20 August 1946; ibid. and
} 
different Youth Labor Brigades that worked on the Brčko-Banovići line. Internal reports of the Antifascist Youth (UGARG) suggest that the number of volunteers on the Brčko-Banovići line reached "hundreds" (a centinaia). ${ }^{118}$ Coupled with the somewhat disorganized flow of Rigonats and Cosolos, the Youth Brigade participants comprised a community of hundreds of young, single, jobless monfalconesi who arrived in Yugoslavia by the end of 1946, most often imagining their stay as temporary.

\section{The War of Cooperatives and the Politics of Shopping}

Coinciding with the departure of these youth was an apparent mellowing of the political situation in the Monfalconese in the final months of spring. Once the UN Border Commission left and the initial tremors of the Servola Incident and April layoffs subsided, people turned their focus back to the difficulties of everyday life. Even in the shipyard, the AMG noted an increase in "sobriety," so that "now the management are again at the helm, and their internal police are exercising proper control." 119 However, this mellowing was more apparent then real. Instead, the focal point of the struggle had merely shifted out of the streets and workshops and back into the marketplace, where widespread frustration over the AMG's policies toward food, rationing, and prices had continued to serve as a source of popular mobilization.

\footnotetext{
"Alla 'Ferrovia della Gioventu," op. cit. Like most individuals recounting the events after the fact, Tonzar puts heavy emphasis on the idealistic and ideological components of this activity, but undoubtedly the "everyday" aspects of receiving complementary room-and-board and a temporary respite from unemployment were equally significant. Tonzar, La valigia e l'idea, 103.

118 The Brigades were the Janko-Premri-Vojko Brigade and the Pino Tomasi Brigade in June-August 1946 and the Mario Blason Brigade in September-October. On the Janko-Premri-Vojko, see "La ferrovia della gioventù," Il Lavoratore, 31 May 1946. On the Pino Tomasi, see "La ferrovia della gioventù," Il Lavoratore, 18 June 1946; "Aiutiamo la 3a Brigata per la 'Ferrovia della Gioventù!," Il Lavoratore, 27 June 1946; "Una nuova brigata giovanile del lavoro," Il Lavoratore, 29 August 1946. On the Mario Blason, see "Per la 'Ferrovia della Gioventù," Il Lavoratore, 3 September 1946; "Giovani del Monfalconese partono per Brcko-Banovici," Il Lavoratore, 5 September 1946." For the estimate, see UGARG-IV Rione, "Partenza Brigata del lavoro" (N. 48 a/1), 29 August 1946, AS 1570, b 9, f 6, sf Archivio.

${ }_{119}$ Maj. Kitson-Harris, "Monthly Report-Monfalcone District, Apr 1946," 3 May 1946, NARA, RG331, UD1981, b 9186, f 11304/115/283.
} 
Sustaining popular frustration was the fact that neither the availability of unrationed foods, nor the AMG's ration policy had improved substantially since the food riots of summer 1945 . In fact, by spring 1946, the AMG had essentially given up on efforts to crack down on the black market or even to check the massive inflation that plagued the legal free market. AMG officials calculated that the average Zone A resident consumed 400 black- or free-market calories per day and viewed this as an essential supplement to the 800-calorie daily ration, itself incapable of sustaining human life over the long term. Even the AMG's Chief Food Officer urged the AMG to turn a blind eye to the phenomenon, suggesting that the tacit acceptance of the black market was necessary from a "human point of view" and that most of the black-marketed goods originated in Italy, anyways. ${ }^{120}$ Such a solution to the food crisis inherently disadvantaged the poor, most of whom, including the bulk of monfalconesi, could not afford these vital 400 daily calories from the free market. ${ }^{121}$ Instead, they relied almost exclusively on the 800-calorie starvation ration, which was notably smaller than rations in Germany, where by February 1946 even the lowest ration tier

\footnotetext{
${ }^{120}$ Maj. Myatt (Chief Food Officer, AMG), “Control of Foodstuffs,” 29 May 1946, NARA, RG331, UD1981, b 9291, f $11304 / 137 / 71 \mathrm{~b}$. An inspector of the VGPC in charge of policing markets captured the haziness of the boundaries between the free and black markets when he reported that "essential commodities are openly put up for sale at more or less prohibitive prices. Owing to the lack of a strict control chiefly on the sale of controlled and rationed essential foodstuffs it is difficult to make a clear distinction between the sale in question and actual black market. To be more realistic the every-day-shopping should be defined 'tolerated market'. The amount of foodstuffs distributed on ration cards is absolutely insufficient therefore the consumer is compelled to buy also at the 'free' or 'black' market, whatever one likes to call it. Unfortunately this illegal market is indispensable to the population." Chief Inspector A. Dolce, "Report on the Situation of the main markets in the 'A' Zone," 21 October 1946, in the same file. Discussions about inadequate rations continued even after the AMG increased the daily ration to 960 calories. SCAO Meeting Minutes, 6 January 1947, NARA, RG331, UD1981, b 9108, f 11302/115/89.

121 Though there are not statistics available specifically from mid-1946, those from January 1947 indicate that the cost of free- or black-market calories were 8.67 times higher than ration calories. Per the AMG, the purchase of a then"average" daily supplement (680 calories) on the black or free markets would cost over L11,564 per month for each individual, or L34,692 per month for a family of three. By contrast, even after the successful negotiations of higher wages and cost-of-living subsidies at the turn of 1947, a specialized CRDA worker who headed a three-member family and who worked six eight-hour days per week would make only L3200 per week in wages and cost-of-living subsidies. Maj. K. Cooper, Acting Chief Economics Officer, "Increase Food Ration," 7 January 1947, NARA, RG331, UD1981, b 9291, f 11304/137/71a; Comitato Centrale d'Intesa Sindacale-Trieste, "Contratto salariale e normative per dipendenti delle aziende industriali," Undated (Late 1946 or Early 1947), AS 1581, b 1, f 2.
} 
- that reserved for former Nazis - consisted of 1088 daily calories. ${ }^{122}$ Where they could, monfalconesi scraped together a few supplemental calories, but doing so involved engaging with black-marketeers or with seemingly extortionary shopkeepers who, in the eyes of workers, continued the "Fascist" practice of exploiting crisis for their own enrichment.

Given these conditions and persistent marketplace agitation (if not rioting) through the turn of 1946, the PCRG rightly viewed the redress of marketplace grievances as a primary means by which it could mobilize pro-Yugoslav forces. ${ }^{123}$ Thus, while the pro-Yugoslav organizations had engaged in an extended fight for increased and inflation-adjusted earnings, extended price controls, and an increased state role in the provisioning of food, shoes, clothing, and other basic goods ${ }^{124}-$ changes which the SU and the bulk of workers defined as criteria of an economy of "impartiality, comprehension, and justice" 125 - they had also spent the fall of 1945 elaborating an alternative vision of commerce that promised radically to improve workers' ability to secure the goods they needed to survive. This vision emerged most clearly in a November 1945 AgitProp piece, which provided Party militants with their central talking points as they discussed marketplace grievances with fellow townspeople as they shopped, worked, ate, drank, and went about everyday life. The

122 By October 1947, the lowest-tier ration in Berlin had risen to 1608 daily calories, Monfalconese rations lagging further behind. See Steege, Black Market, Cold War, 35-47, esp. 42 fn 74 and 46. Italians had long suffered lower rations than Germans. From mid-1942, the Italian ration was 950 calories, or two-thirds that of the German equivalent. Nützenadel, "Dictating Food," 103.

${ }^{123}$ In 1946, women of the UDAIS routinely visited with CAO Kitson-Harris to make demands about food. In one case, they threatened that "if it [the population] does not have something to eat before its children begin to suffer starvation, it will go to the bakeries and take the bread which it cannot buy because it is so expensive." A recurring theme was the VGPC's protection of the black-marketeers. CLN-Staranzano (OF), "Memoriale del Comitato di Lib. Naz. Staranzano," 4 February 1496, AS 1815/2/56.

${ }^{124}$ Only the first of these yielded successes. Though employers refused to tie wages proper to inflation, under joint SU-SG pressure, they conceded a cost-of-living allowance (contingenza) that would be adjusted quarterly for inflation, the tables determined, as were wages, by one's family status, qualifications, and age. This February 1946 agreement was the last of the type before cooperation with between the SU and SG ceased entirely. Cernigoi, Puppini, Valcovich (eds), Cento anni di cantiere, 48; Associazione degli industriali di Trieste, "Wages adjustment for industrial workers," 10 January 1946; AMG Labor Office-Trieste, "Table of Earnings for an 8-Hour Working Day," 18 January 1946, both in NARA, RG331, UD1981, b 9225, f 11304/115[A]/46.

125 Il Comitato di Coordinamento..., "Memoriale al Sig. Col. Smuts," 14 December 1945, NARA, RG331, UD1981, b 9225, f 11304/115[A]/46; Delegation of the Regional Confederation of the SU, Letter to Lt Col J. Smuts, 13 January 1946, NARA, RG331, UD1981, b 9228, f 11304/115[A]/67. 
piece observed that the reactionary AMG "does not move a finger to eradicate the black market and the illicit earnings of the profiteers" and stressed the AMG's partial free-market system merely assured "the uncontrolled increase in prices that widens evermore the distance between these and wages." More importantly, it put forward a vision of exchange that dovetailed with widespread worker frustration aimed at shopkeepers, implicitly postulating an alternative in which commerce by individuals had given way to direct exchange between classes of producers. It called for action, urging workers to join with the peasants, who had demonstrated their "notable anti-Fascism" by "creat[ing] cooperatives to help themselves along with the workers." In essence, the piece marked the commencement of an offensive to restructure the town's commercial system along cooperative lines and to extirpate long-resented "remnants of Fascism." 126

In the eyes of many monfalconesi, the dire conditions of everyday life lent credence to the need for such transformations, though the struggle was not without historical antecedents. Neither monfalconesi, nor giuliani generally were strangers to the idea of consumer cooperatives. ${ }^{127}$ Before the Great War, the Socialists of the region had helped found the Workers' Cooperatives of Trieste, Istria, and Friuli (CO), which it sought to use as a tool of class struggle. The cooperative had enrolled many monfalconesi before Mussolini's regime "Fascistized" it in 1935, selling much of the stock to the region's large banks and subordinating it to the Fascist Ministry of Corporations. ${ }^{128}$ In the immediate postwar, after the de-Fascistization of the CO statutes, the PCRG had launched a campaign to retake the cooperative, primarily by enrolling "progressives" and electing a

\footnotetext{
${ }^{126}$ PCRG-CDM, "Il mercato libero," 2 November 1945, op. cit.

127 This was also true of wider Italy. In cities like Milan, consumer cooperatives had been the topic of debate for nearly a century and, following the granting of universal manhood suffrage in 1912, many municipal councils had established cooperatives with moderate success. Morris, The Political Economy of Shopkeeping.

${ }^{128}$ The CO had fed into a wider push for cooperatives that swept over Italy during the biennio rosso. Nützenadel, "Dictating Food," 89-91. CO, "Statuto delle Cooperative Operaie di Trieste, Istria e Friuli," 1935, AS 1581, b 4, f Delavske Zadruga za Trst in Istro.
} 
favorable council, but this push failed even before the arrival of winter 1945/46. ${ }^{129}$ Despite this failure, over the course of the campaign the cooperative issue had revealed itself to be highly popular in the Monfalconese, with likely over 2000 heads-of-household enrolling in the $\mathrm{CO}$ by the time of defeat. ${ }^{130}$ It was precisely as this moment, then, that monfalconesi began looking for other options to realize their cooperative vision and combat local shopkeepers.

By November 1945, the PCRG's district leadership and the SU decided to try their hand at forming a new consumer cooperative, the Laborers' Consumer Cooperative of the Monfalconese (Cooperativa di Consumo Lavoratori del Monfalconese, CCLM). ${ }^{131}$ This cooperative was to be independent of the CO, flanked by local agricultural cooperatives, including one in Staranzano. ${ }^{132}$ Though the creation of the CCLM initially went unnoticed by the AMG, it soon became a key tool for unifying the pro-Yugoslav movement. In its first months, the CCLM (and wider cooperative push) became the subject of an intense propaganda and membership campaign, often merging with efforts to construct the myth of Yugoslavia. ${ }^{133}$ Local UAIS branches energetically disseminated this vision to every street corner and factory workshop, urging workers to sign up for the CCLM and presenting the replacement of private commerce with cooperatives as an essential part of the

\footnotetext{
${ }^{129}$ Ferdinand F[x] (Alleanza Nazionale delle Cooperative), Comunicazione (N. 4.CE/EV), 28 May 1945, AS 1581, b 2, f 4-A; Unsigned, "Relazione sulla seduta dei referenti sindacali...," 31 July 1945, AS 1581, b 1, f 3-A; Cooperativa per Acquisti in Trieste a resp.1., "Statuto," 12 November 1945, AS 1815/2/62.

${ }^{130}$ Unsigned, "Relazione Cooperative Operaie," Undated (1946?), AS 1581, b 1, f 1; CDLN-Monfalcone, "Verbale," 18 November 1946, AS 1815/1/4. Incomplete membership lists for the CO survive in the AS. Among them are lists from Monfalcone, Pieris, and Ronchi, which include roughly 700, 140, and 240 members respectively. Given the existing total of nearly 1100 confirmed members and the absence of many of the Monfalconese's communes from the list, a figure of at least 2000 seems likely. List of Cooperative Consumo di Trieste Members from MonfalconePanzano, Pieris, and Ronchi, 1945, AS 1581, b 5, f Cooperative Operaie.

${ }^{131}$ PCRG-CDM, "Verbale XXVIII seduta del comitato distrettuale di Monfalcone," 9 November 1945, op. cit.

132 Ottone Zanolla (UAIS-Staranzano), "Cooperative agricole," 8 November 1945, AS 1815/2/56.

${ }^{133}$ At a December meeting of PCRG members for Trieste Area (including Monfalcone), a comrade spoke at length about the successes of Yugoslav cooperatives in harmonizing peasant and worker interests and radically improving the lives of both. He concluded that there would be a conference in Monfalcone that weekend to discuss cooperative ideas and their implementation. PCRG-Trieste, "Prima riunione dell'attivo comunista della R.G. per il Circondario di TRIESTE," 14 December 1945, op. cit.
} 
"struggle against the remnants of Fascism." 134 Though there seems to be no surviving documentation from the CCLM from which one might learn its membership figures, PCRG sources suggest that large swaths of the population were receptive to the idea and that far more monfalconesi joined the new cooperative than had joined the CO. ${ }^{135}$ This popularity led Ruggero Bersa to describe the CCLM as a tool "of first-rate political importance" for the pro-Yugoslavs, ${ }^{136}$ asserting in late 1946 that "the greater part of the workers" had joined. ${ }^{137}$

The significance of the CCLM was not lost on the zone's pro-Italian faction, which recognized immediately the cooperative's role in mobilizing the pro-Yugoslavs. To counteract the PCRG's new tool, the pro-Italian SG quickly formed its own consumer cooperative, the Labor Cooperative (Cooperativa del Lavoro, CL). Founded the very same month as the CCLM, this cooperative aimed to sell basic goods at below-market costs "for the ends of Italian propaganda" and to splinter the pro-Yugoslav movement. It received subsidies from Italian governments led by Parri and De Gasperi, which even ordered all Italian prefects "to facilitate the transport of goods acquired in the respective provinces to Trieste" and pressured producers and wholesalers "to concede every possible aid" to this cooperative. ${ }^{138}$ Many of the latter obliged, fearing for their

\footnotetext{
${ }^{134}$ Commissione AgitProp-Ronchi, "Indirizzi pratici sul lavoro organizzativo in seno alla commissione AgitProp," 21 March 1946, AS 1570, b 11, f 8, sf AgitProp Relazione inviati a Trieste.

${ }^{135}$ Marcello, "VI Riunione delle ore 10 alle 12..." 15 November 1945, op. cit.; PCRG-Monfalcone, "Rapporto sulla III riunione dell'attivo ...," 17 January 1946, AS 1570, b 8, f 2.

136 On the successful enrollment campaigns of the CCLM, see PCRG-IV Rione, "I relazione quindicinale sulla situazione politica del IV rione," 15 June 1946, AS 1570, b 8, f Relazione politiche.

137 The statement was made in the context of discussion of a renewed campaign to retake the CO, in which Bersa suggested it might be difficult to get monfalconesi who were already members of the CCLM to also join the CO. CDLN-Monfalcone, "Verbale della riunione Plenaria di tutti i Comitati del Distretto di Monfalcone," 24 November 1946, AS 1815/1/4.

${ }^{138}$ Unsigned (Italian Military Intelligence), Untitled Report to MI, 31 January 1946, ACS, MI, Gab 1944-46, b 138, f 12148. On the PCRG interpretation, see Comp. B[x], "Relazione della riunione comm. sind. del Partito e dei reerenti sindacali rionali...," 3 October 1945, AS 1581, b 1, f 3-A. According to PCRG intelligence, the SG cooperatives had funding in the total of L7,000,000, much of which came from large landholders, nationalist parties, and the Italian state. PCRG-CDM, "Verbale XXVIII seduta del comitato distrettuale di Monfalcone," 9 November 1945, op. cit.
} 
businesses should Yugoslavia annex the Monfalconese. ${ }^{139}$

What had emerged by late 1945, then, was a situation in which everyday shopping was intensely politically charged. For many who joined the CCLM, their choice marked a commitment to the fundamental reordering of commerce and of the shopping experiences that went with it; those who joined the CL, by contrast, represented in pro-Yugoslavs' minds the fragmentation and enervation of this push. Thus, the PCRG responded to the CL challenge by propagandizing on behalf of the CCLM in the streets and workshops. In a CRDA workshop, broadsheets decried the CL as a "perfidious reactionary means" of those who, "not able to divide us in the political field, try to subjugate us in the economic field." It warned workers that "to adhere to the Julian Syndicates means to prepare the ground for the rebirth of a new Fascism." Such a seemingly innocuous decision in fact would serve to welcome back

bitter tears of blood, bestial exploitation of the people, confinement, torture and death of our best comrades.... To adhere to the Julian Syndicates means to sell yourself and your family to the enemies of the people, to betray your own class for a fleeting well-being, for a miserable dose of oil and fat at a better price: as Judas betrayed Christ for a small sum. ${ }^{140}$

In the struggle between the cooperatives, it was the CCLM that clearly gained the upper hand. However, driven by differing mixtures of desperation and pro-Italian sentiments, some 1500 monfalconesi enrolled in the CL, this membership holding steady through $1946 .{ }^{141}$

Though the campaign against the CL was relatively straightforward for the PCRG, the broader politics of shopping were not, particularly because the defeat of the CL was less a concern for most pro-Yugoslavs than the battle the CCLM would wage with the Monfalconese's

\footnotetext{
${ }^{139}$ Comitato Circondariale (PCRG-Trieste), "I Seduta straordinaria del comitato direttivo del Partito per il Circondario di Trieste," 19 November 1945, AS 1570, b 1, f 2-A.

${ }^{140}$ Unsigned, "Compagni!," Unità Operaia (CRDA) (N. 6), 22 November 1945, AS 1570, b 12, f 8; Marcello, "VI Riunione delle ore 10 alle 12..." 15 November 1945, op. cit.

${ }^{141}$ Presidente del Cooperativa del Lavoro-Monfalcone, Untitled Report to AMG-Monfalcone, Undated (Received 5 December 1945), ASBCM, b 516, f Ctg XIV; CDLN-Monfalcone (KNOO-Monfalcone), Sezione Ricostruzione, "Al Comitato Circondariale, Sez: Cooperazione" (N. X-133/46), 21 May 1946, AS 1815/4/78.
} 
commercial middle class. This posed a problem for the PCRG. On the one hand, the Party viewed the CCLM as a primary reason for workers to join the pro-Yugoslav movement; on the other, the CCLM had the potential to generate a new host of enemies: the private shopkeepers. In fact, though shopkeepers had emerged early as opponents of the pro-Yugoslav movement, they largely had refrained from actively expressing this opposition. ${ }^{142}$ As the PCRG understood it, shopkeepers and other groupings of the middle classes (ceti medi) were "not all decidedly partaking in the [proItalian struggle" because "they have need of the people and are afraid of the people. They would like Italy, but they do not put out flags and they do not make chauvinist manifestations for fear of losing their clientele." ${ }^{143}$ As the CCLM's growth emboldened workers bent on destroying private ("Fascist") commerce and concretely harmed shopkeeper's material interests, it thus threatened to transform shopkeepers' passive opposition to the pro-Yugoslav movement into active opposition.

To prevent this, the PCRG carried out a two-pronged propaganda campaign in the first of 1946. This campaign aimed simultaneously (1) to convince the shopkeeper that the CCLM's primary target in its commercial war was the wholesaler (grossista), a target which the shopkeeper allegedly shared; ${ }^{144}$ and (2) to minimize working-class consumers' resentment toward shopkeepers by explaining high prices in local shops as the result of wholesaler greed. ${ }^{145}$ Despite extensive

142 PCRG-CCM, "Riunione N. 13 del Comitato Cellula," 21 November 1945, AS 1570, b 10, f 1, sf Monfalcone; PCRG-CDM, "Verbale 31 seduta," 19 January 1946, AS 1570, b 8, f 1; Comp. S[x] B[x] (CE UAIS-Monfalcone), "Relazione sulla situazione politica del distretto" (N. 243/46), 4 May 1946, AS 1570, b 8, f 3, sf 1.

${ }^{143}$ PCRG-CDM, "X Relazione sulla situazione politica generale del Distretto di Monfalcone," 6 May 1946, AS 1570, b 8, f 2 .

${ }^{144}$ One report stressed that propagandists emphasize that the cooperatives aimed solely to "eliminate the wholesalers." PCRG-Panzano, "Relazione della IV riunione del Comitato Cellula Panzano," Undated (Late April or Early May 1946), AS 1570, b 11, f 7, sf 13. Even earlier, Monfalcone's AgitProp section assured that, in a society of popular power, "petty property will be respected; and to each is left the possibility of producing and selling undisturbed without the fear of the competition of great proprietors who have been swept out by the just popular struggle." Thus "the society of popular power is also [the shopkeepers'] society because it guarantees them by law the position they enjoy." Unsigned (PCRG-Monfalcone), "La paura dei ceti medi," 31 January 1946, AS 1570, b 8, f Relazioni politiche. See also PCRG-CDM, "Verbale 31 seduta," 19 January 1946, op. cit. This was part of a wider PCRG policy of moderation (anti-“leftism") in pursuit of a cross-class pro-Yugoslav alliance. Troha, Chi avrà Trieste?, 117.

${ }^{145}$ See the broadsheet Candidus, "Carestia," Unità Operaia (Spremitura), 3 May 1946, AS 1570, b 12, f 8; Ruggero Bersa (PCRG-CDM), “A tutte le cellule a tutti i gruppi di cellula del VI Rione," 26 June 1946, AS 1570, b 9, f 
efforts, the campaign bore little fruit, and instead the rapid expansion of the CCLM caused shopkeepers to abandon their feigned neutrality. ${ }^{146}$ This became especially clear in the spring of 1946 when the CCLM began selling rationed goods, cutting in on shopkeepers' most reliable source of business and driving many to combat the cooperatives head-on. ${ }^{147}$

The conflict climaxed in June. Early that month, CAO Kitson-Harris indicated that once again "the black market, or in a more genteel phraseology the 'free market'," had become "a cause of serious political grievance" and that shopkeeper-consumer antagonism was again reaching a boiling point. He warned that "the great temptation now flaunted before the people's eyes of shop windows amply laden with food at exorbitant prices" had driven a constant stream of wives and mothers into his office demanding the suppression of black and free markets and an end to an economy in which there was "one rule for the rich, and another for the poor."148 It was shortly thereafter, as both discontent with shopkeepers and support for radical alternatives continued to grow that the former realized they needed to change tack to safeguard their long-term interests. Thus, they gathered a substantial amount of capital - L2,000,000 by the PCRG's estimate - with the aim of engaging in a protracted price war with the CCLM, seeking to undercut its prices and drive it out of operation. With this development, pro-Yugoslav workers were forced to decide between remaining loyal to the idea of consumer cooperation at great personal cost or purchasing

Circolari. To a degree, the second claim appears to have been true. As a VGPC inspector would explain after investigating the conditions of the Pieris market later that year, there were critical shortages of a range of goods in what should have been a self-sufficient area because "local dealers have to compete unevenly with wholesalers to whom the former have to apply instead of purchasing land-products direct [sic] from farmers." Chief Inspector A. Dolce, "Report on the Situation of the main markets in the 'A' Zone," 21 October 1946, op. cit.

${ }^{146}$ Around that time, the PCRG noted that "our cooperatives... are very much more advanced than those that are found in [the rest of] Zone A. Thus, it can be seen that our economic success brings some difficulties to our own political camp, because those who in this case are harmed are the petty merchants, who see in our cooperatives an instrument that harms their interests... Combining this economic situation with our political line - of adhesion to Yugoslavia we will find these petty merchants hostile to our movement." PCRG-Panzano, "Relazione della IV riunione...," Undated (Late April or Early May 1946), op. cit.

${ }^{147}$ PCRG-IV Rione, "I relazione quindicinale sulla situazione politica del IV rione," 15 June 1946, op. cit.

148 Maj.J. Kitson-Harris, "Monthly Report-Monfalcone," 6 June 1946, NARA, RG331, UD1981, b 9186, f $11304 / 115 / 283$. 
their basic goods at suddenly-reduced prices from the very shopkeepers they had long deemed "Fascists." According to PCRG reports, the members of the CCLM generally remained loyal to the cooperative, but this commercial showdown led shopkeepers to more openly and hostilely engage with pro-Yugoslavs during everyday interactions:

We have done everything that was humanly possible to reconcile the shopkeepers with the laboring masses, but all our attempts and all our work have not achieved much... The comportment of the near-totality of the merchants is hostile to the people (who want Yugoslavia and popular power) and this feeling of theirs led them to mock those who wore (and still wear) the red star on their chest.... This fact goes to show that the people are not wrong if they do not want to use many of the shops of reactionaries.... All the shopkeepers, save a few individuals, are members of the disreputable National League and make of their shops shady centers of infamous anti-Slavic propaganda. ${ }^{149}$

Observing these antagonistic relations, which very well may have led to discriminatory treatment of pro-Yugoslavs as they shopped, ${ }^{150}$ Ottone Zanolla, head of the PCRG in Ronchi, commented that there existed a "profound abyss" between workers and shopkeepers. ${ }^{151}$ Such resistance of shopkeepers to cooperation only reinforced the idea that shopkeepers were participants in an egoistic and "Fascist" form of commerce.

In addition to the divide between workers and shopkeepers, by mid-1946 there had also emerged a gap between the PCRG strategy and popular visions. Party leaders noted critically that low-level militants and UAIS supporters - and particularly the increasingly large body of unemployed youth - had a certain "extremist" or "leftist" attitude in regards to shopkeepers, clashing with them openly and harming the PCRG's efforts to construct a broad pro-Yugoslav

\footnotetext{
${ }^{149}$ PCRG-IV Rione, "I relazione quindicinale sulla situazione politica del IV rione," 15, June 1946, op. cit.

${ }^{150}$ The ration system in Berlin, similarly to that in Monfalcone, left significant room for shopkeepers to make life easy or difficult for particular customers. If a Berliner was friendly with a particular shopkeeper, he or she could at time purchase rationed goods in advance, giving up their ration coupons for future periods early for registration in the shopkeeper's books. As some goods were delivered irregularly, this could have major consequences; advanced delivery to one favored customer could lead to another facing major delays. Thus, the shopkeeper-client relationship remained vital to personal survival. In a politically-charged atmosphere like that of Monfalcone, the pro-Yugoslav/proItalian divide almost certainly played into the decisions of shopkeepers to offer or withhold goods to particular shoppers. Steege, Black Market, Cold War, 42.

${ }^{151}$ PCRG-V Rione, "Situazione politica del V Rione quindicinale," 20 June 1946, AS 1570, b 8, f 1.
} 
front. ${ }^{152}$ On the one hand, the PCRG's strategy, which attempted to bring petty retailers into the pro-Yugoslav alliance by displacing blame for commercial hardships onto the wholesalers, contradicted popular hopes for post-Fascist commerce and clashed with the daily experiences of ordinary monfalconesi, for whom the shopkeeper was the quotidian point of contact and the only observable culprit behind skyrocketing prices. On the other, the CCLM simply lacked the economic and political backing necessary to live up to popular expectations and fundamentally transform the Monfalconese's commerce. As shopkeepers purposefully deflated their prices in June and as the SG offered select low-price goods subsidized by the Italian state, the PCRG dedicated substantial effort to maintaining support for the CCLM and preparing workers for a protracted struggle. ${ }^{153}$ By August, the CCLM's funds began to fail and it was forced to reduce its range of goods to simple food products. ${ }^{154}$ By late 1946, the push for a fundamental restructuring of commerce in the Monfalconese had failed. The CCLM would continue to operate, but always fighting a rearguard action, reduced to a shell of its former self. As the cooperative moderated its ambitions, monfalconesi once again had to turn to the prohibitively expensive black and free markets. They looked longingly to the east, asking why they should have to live without those transformations which they knew had so radically improved Yugoslavs' daily lives. In this, the myth of Yugoslavia had outrun its utility, becoming a source of discord and disillusionment among

\footnotetext{
152 In January 1946, Bersa indicated that the Party was struggling to convince workers to abandon "the narrow field of class struggle to come to an agreement with the other classes to create a struggle of the people against the enemy of all." PCRG-CDM, "VI Relazione politica del Distrettuale," 29 January 1946, AS 1570, b 8, f 2. See also PCRGCCM, "Riunione No. 21 del Comitato Cittadino del P.," 18 February 1946, op. cit.; PCRG-CCM, "Riunione No. 23 del Comitato cellula cittadino," 18 April 1946, AS 1570, b 10, f 1, sf Monfalcone; PCRG-V Rione, "IV Riunione del comitato del P.C.R.G.," 19 June 1946, AS 1570, b 8, f 1.

${ }^{153}$ A broadsheet hung in the CRDA in June exhorted workers to remain steadfast: "The commercial battle has begun and the workers, with their cooperatives, are ready to sustain it. It will be a harsh struggle because our end is that of bringing goods from the sources of production directly to the consumer, thus leading to the elimination of the intermediaries, and it is natural that these will defend themselves with any means at their disposal. They will attempt to defeat us with prices because this is the only possibility of success." Unsigned, "Le C.C.L.M. Comunicano," Il Compagno (N. 30), 3 June 1946, AS 1570, b 12, f 8.

${ }^{154}$ PCRG-IV Rione, "Relazione sulla IV riunione del Comitato rionale del PC-RG avvenuta il giorno 17.8.1946 in sede," 17 August 1946, AS 1570, b 10, f 1, sf Relazione del rionale.
} 
the faithful rather than one of inspiration.

\section{Food, Exchange, and Popular Radicalism}

But before the cooperative dream died entirely, a flash of violent protest in late June made Kitson-Harris's warning seem prophetic and lent credence to the notion that many monfalconesi were enamored by the vision of the peasant-worker alliance and cooperativistic commerce. Longstanding attempts by the sharecroppers (mezzadri) to renegotiate their contracts with their landlords reached a boiling point, with sharecroppers demanding a 75-25 split and landlords, backed by the AMG, insisting on the even split negotiated under the Fascist regime. ${ }^{155}$ This type of demand was not new - during the biennio rosso the sharecroppers had issued even more radical demands for a 90-10 split - but by May and June 1946, a certain portion of the sharecroppers backed by the PCRG and SU withheld their grain in pursuit of renegotiation. Their cause received a propagandistic boost when AMG policemen confronted and allegedly mistreated two Turriaco sharecroppers, before returning to arrest them days later. ${ }^{156}$

While allowing the pro-Yugoslav forces to cast AMG police as participating in a renewed form of squadrismo, these events also sparked rage among workers at the AMG's failure to address marketplace grievances. On 24 June, a large crowd of workers gathered in the main piazza of Monfalcone, demanding, in the words of the Monfalcone city CAO, "work, bread and houses" and particularly upset about food availability and prices. ${ }^{157}$ A delegation of disgruntled sharecroppers, having spoken to the $\mathrm{CAO}$ and been sent away with promises that their complaints would be

\footnotetext{
155 Di Gianantonio et al, L'immaginario imprigionato, 137-42.

156 AgitProp (PCRG-Monfalcone), Untitled Report from Turriaco, 4 June 1946, AS 1570, b 14, f 4-B, sf Relazione politiche del Rionale di Monfalcone, 1946. Given that the document discusses events up until mid-June, it should likely be dated 24 June 1946.

157 Though many merchants participated in the campaign to undercut the CCLM's prices, this does not mean that prices fell to what workers considered "just" levels. Instead, most non-rationed goods remained prohibitively expensive compared to worker earnings. Capt. Hill, "Monthly Report, Jun 1946," 30 June 1946, NARA, RG331, UD1981, b 9186, f 11304/115/283.
} 
transmitted to Trieste, joined them and returned to the piazza. It began to rile up the workers, shouting "we are tired of promises!" and calling for the crowd to march on the AMG prison and free the two arrested sharecroppers. ${ }^{158}$ The crowd of workers proved receptive, indicating that they understood their own protests over food and prices to be consonant with that of the peasants to keep their produce out of the hands of the large landholders and merchants. They formed into a column, which advanced on the prison, broke down the external gate, and assaulted the inner doors. Before the crowd could breach the doors, AMG police and Allied MPs arrived in armored cars and intervened with a "liberal" use of their truncheons until the crowd was dispersed. Seven policemen and an unknown number of demonstrators sustained injuried in the process. ${ }^{159}$

In the aftermath of this incident, the PCRG would have difficulty assessing the meaning of the event, as well as its own standing with the wider population. Though the AMG assumed that the PCRG had ordered the protest and proceeded to arrest known Party leaders, the reality was very different. Ruggero Bersa took this as decisive proof that the workers had become conscious of how their own fate was tied to "struggling for the rights of the peasants" and thus of their conviction in the peasant-worker alliance closely tied to the cooperativistic vision. ${ }^{160}$ Yet comments of the UDAIS leader Nerina betray that the Party neither sanctioned, nor directed this violence. Instead, Nerina, in concurrence with Ottone Zanolla, lamented that the willingness to take direct action to resolve market grievances betrayed "a strong extremism among the masses" and showed that the Party had much work to do to promote the cross-class, pro-Yugoslav unity line. ${ }^{161}$ This riot - a major escalation in popular antagonism with the AMG - highlights the role

\footnotetext{
${ }^{158}$ Valerio Beltrame (Ario) (AgitProp, PCRG-IV Rione), "Manifestazione a Monfalcone contro la disoccupazione e la miseria del popolo," 24 June 1946, AS 1570, b 12, f 8.

${ }^{159}$ Ibid; Capt. Hill, "Monthly Report, Jun 1946," op. cit.

${ }^{160}$ Ruggero Bersa, "Rapporto sulla Manifestazione Popolare del 24/6/1946," 25 June 1946, AS 1570, b 12, f 8.

${ }^{161}$ PCRG-V Rione, "V Riunione del Comitato Rionale del P.C.R.G.," 27 June 1946, AS 1570, b 8, f 1. This same point was made by Ottone Zanolla two days later. PCRG-V Rione, "Relazione politica mensile," 29 June 1946, op. cit.
} 
of continual hunger and marketplace resentments in pushing monfalconesi into spontaneous, unsanctioned street activism that further unraveled the town's social fabric.

\section{The “Twelve Days Strike," July 1946}

Hunger was not the sole factor that heightened tensions as Monfalcone entered the hot summer of 1946. Shortly after the UN Border Commission had departed from Venezia Giulia, the fourth meeting of the foreign ministers had begun in Paris, the Anglo-Americans now armed with the ammunition to prove (according to their ethnic calculus) that Trieste should not be Yugoslav. After some discussion, the foreign ministers accepted a revised version of the French border proposal, in which Italy would retain the urban centers of Monfalcone and Gorizia but lose the hinterlands to the east. In addition, they announced a critical revision to the French proposal: the coastal areas stretching from Duino in the north to Cittanova (Novigrad) in the south - an area including Trieste city - would not be allocated to either claimant, but instead would become an independent country called the Free Territory of Trieste (Figure 12). ${ }^{162}$

When word of this agreement reached the Monfalconese in late June, it satisfied very few. Pro-Italians fumed at the allocation of Istria to Yugoslavia, while pro-Yugoslavs felt the ministers had deliberately ignored their claims. For the pro-Yugoslavs, however, an opportunity to make their dissatisfaction known came just days later in the form of an annual bike race, the Giro d'Italia, which was to pass through Monfalcone on its way to Trieste. Viewing the race's passage to Trieste as an act of pro-Italian propaganda, a group of PCRG militants from Pieris, under orders from Trieste, set out to stop the cyclists at the Isonzo. They spread nails and a chain-link fence along

\footnotetext{
162 The Free Territory was to be temporarily divided into an Anglo-American-administered Zone A (including Trieste) and Yugoslav-administered Zone B until the members of the UN Security Council jointly appointed a governor. However, the inability of the UNSC to agree on a governor caused the division to become permanent, lasting until 1954. Novak, Trieste, 240-50.
} 
the road, temporarily stopping the race. As police intervened, they threw stones and fired pistols at police and cyclists, eliciting return fire. When the dust settled, four cyclists had been wounded, two policemen shot, several onlookers injured, the race stalled, and the attackers escaped. ${ }^{163}$

As news of the attack arrived in Trieste, followed closely by the Triestine team - the only cyclists to continue the race - the city and then Zone A descended into chaos. ${ }^{164}$ The SG called a protest strike against pro-Yugoslav violence, while bands of armed pro-Italians formed in Trieste and began beating Slovenes and pro-Yugoslavs, as well as assaulting Slovenian schools, shops, and cultural sites. ${ }^{165}$ For the pro-Yugoslavs, this violence smacked of a renewed squadrismo, and thus the SU called its own general strike, which soon overshadowed that of the SG. ${ }^{166}$ Though the SU quickly issued a set of economic demands to skirt AMG bans on political striking, the AMG immediately (and correctly) interpreted the strike as political - as an attempt to embarrass the AMG and impress upon the foreign ministers the strength of the pro-Yugoslav current. ${ }^{167}$ It declared the strike illegal and issued an ultimatum to the strike committee leaders to call it off. When the committee refused, the AMG arrested these leaders in Trieste, along with those it called the "Big Five" of the Monfalconese pro-Yugoslav movement. ${ }^{168}$

${ }^{163}$ Gen. Com. Brunetti (Carabinieri-USS), “Aggressione subita dalla carovana del giro ciclisto d'Italia” (N. 86/70), 1 July 1946, ASDMAE, AA PP 1946-50, Jug, b 4, f 5; Tonzar, La valigia e l'idea, 80. According to Mario Tonzar, a participant in the attack, the PCRG suspected that the Italian nationalist right had paid certain "Belogardists" (Slovenian collaborationists) to carry out a more lethal attack on the riders at Trieste with the aims of framing the proYugoslavs. He alleges the attack at Pieris was preventive.

164 The Triestine cyclists became national heroes in the pro-Italian press. Mariolina Fasola and Doretta Pettinato, "Il 'Giro' fermato a Pieris: Storie delle 'sassate patriottiche' del 1946 attraverso la cronaca dei giornali dell'epoca,' Il Territorio 9 (1983): 35-40.

165 According to Bersa, the district PCRG had refused to carry out the attack precisely because they feared this response. Thereafter, Franco Štoka of the Triestine PCRG, went directly to Pieris to organize the attack. Galliano Fogar, "Seconda parte dell'intervista registrata rilasciata da Ruggero Bersa," November 1981, IRSML, Fondo Cominform, b 99, f 9; Tonzar, La valigia e l'idea, 80.

166 In most narratives of postwar Venezia Giulia, this "Twelve Days Strike" is the climax of the postwar territorial struggle. See Di Gianantonio et al., L’immaginario imprigionato, 150-51; Puppini, "Il Controesodo Monfalconese,” in Il mosaico giuliano, eds. Altieri and Puppini, op. cit., 67-68.

${ }^{167}$ Maj. Scicluna (Chief Labor Officer), "Observations on the General Strike,” 11 July 1946, NARA, RG331, UD1981, b 9175, f 11304/115/217.

${ }^{168}$ Lt. Col. Smuts (Trieste Area Commissioner), Letter to Strike Committee, 3 July 1946, NARA, RG331, UD1981, b 9202, f 11304/115/440; Maj. Kitson-Harris, "Monthly Report, Jul 1946," 31 July 1946, NARA, RG331, UD1981, 
In the Monfalconese, the pro-Yugoslav organizations sank the entirety of their resources into the strike, and participation in the strike was outstanding, in large part because workers conceptualized the strike not just as a strike for Yugosalvia, but also as one against Fascism. Perhaps unsurprisingly, then, participation was highly colored by the worker-clerk divide. According to AMG figures, which tracked the strike only from its eighth day (8 July), on that day the strike had a $73 \%$ success rate among workers (4756 of 6545 ), though only $18 \%$ of clerks stayed home (184 of 1005). ${ }^{169}$ To maintain adhesion to the strike, the pro-Yugoslav organizations used both the carrot and the stick. The UAIS and the CCLM orchestrated the free distribution of flour, sugar, and fats to strikers as a "carrot," much of it smuggled in from Zone B. ${ }^{170}$ Concurrently, the UAIS formed enforcement squads, which patrolled the streets to turn back workers attempting to get the industrial sites and performed home checks of SU enrollees.

Toward their "Fascist" enemies - the "scabs," members of the SG, and members of the pro-Italian political parties - these squads were often violent, patrolling the CRDA to beat and threaten anyone they found on site and sometimes entering people's homes to threaten them into staying away. ${ }^{171}$ A large proportion of each of these groups of perceived enemies were clerks, and thus strike rhetoric took on a decidedly anti-clerk inflection, reinforcing the close relationship between the associational nexus of clerks-piecework-Italy-Fascism. Particularly active in

b 9187, f 11304/115/283. These were Vittorio Cernigoi, Albano Olivieri, Enrico Kormuller, Pietro Snidersič, and Giordano Tommasi. Though all five were pro-Yugoslav militants, the AMG knew very little about the pro-Yugoslav leadership. Only Cernigoi deserves the label. Kitson-Harris, "Monthly Report of Monfalcone Group CAO...," 31 August 1946, NARA, RG331, UD1981, b 9188, f 11304/115/288.

169 After a brief dip in worker adhesion on 11 July (down to 65\%), the figure had again retuned to $73 \%$ on the 12 July. Given the non-participation of the SG in this strike, these figures are quite high. AMG, General Strike Situation Reports, 8 July 1946, 11 July 1946, and 12 July 1946, NARA, RG331, UD1981, b 9202, f 11304/115/440.

${ }_{170}$ Direzione Centrale, CRDA, Memorandum to SCAO Bowman and Lt Col Smuts, 11 July 1946; Strike Committee, Strike Bulletin N. 11, July 1946, both in NARA, RG331, UD1981, b 9202, f 11304/115/440.

${ }^{171}$ As one example, on 1 July 1946, Dorino U. of Turriaco met up with six others and proceeded to sack the local DC headquarters. The next day, the group went to the home of the local DC president, where they "talked" to him about leaving the DC. S. Ten. A. Manzini (Carabinieri-Monfalcone), "U[x] Dorino di Giuseppe..." (N. 47/38), 20 August 1948, ASG, Questura 1948, b 12, f 1810. See Direzione Centrale, CRDA, Memorandum to SCAO Bowman and Lt Col Smuts, 11 July 1946, op. cit. 
reinforcing this theme were workplace broadsheets, which, though tied to the PCRG, were written by low-level militants, reflecting worker interpretations of the strike. In one such sheet, a worker referring to himself as the "flea of the First [Naval] Department" reported the high turnout of SGloyal clerks from that department's Piecework Office for work on the first day of the strike. The author indicated that two of them, when confronted by certain "anti-Fascists" who asked them to join the strike lest they be considered bolsterers of the Fascist system, retorted dismissively "then we're Fascists" and continued to work. ${ }^{172}$ In the same issue, the "flea" also attempted to link the piecework clerks with the pro-Italian cause, mocking Umberto Zuccolin, the head of the pro-Italian CLN and a clerk in the Labor Cost Office, as "comrade timekeeper Zuccolin." The "flea," after reminding readers of how a select few good clerks in the Piecework Offices had helped workers manipulate piecework reporting to aid the OF, also reminded them that Zuccolin, by contrast, had "always wanted to be "informed" of these activities even in a time when "no one wanted to be 'informed." The article thus linked the pro-Italian movement to "Fascistic" forms of labor organization and implied that Zuccolin had been a spy for management rather than a true antiFascist. ${ }^{173}$ In this context, clerks began rightly to fear for their physical safety.

At times, the strike spilled over from the workplace into the streets and marketplace. Such was the case on 5 July, when, according to an internal strike committee report, a large mass of monfalconesi gathered for an unauthorized demonstration in the central piazza, only to be dispersed with the "most brutal methods" of the Anglo-American forces, including a "savage charge" of club-swinging policemen and soldiers. ${ }^{174}$ The Strike Committee responded publicly by

\footnotetext{
${ }^{172}$ La pulce del I Reparto, "Crumiri o Laccapiedi [sic]?," La scintilla (N. 16), Early July 1946, AS 1570, b 12, f 8.

${ }^{173}$ La pulce del I Reparto, "Risposta all'art. Del 27/6/1946," La scintilla (N. 16), Early July 1946, AS 1570, b 12, f 8.

${ }^{174}$ Unsigned (Strike Committee), "Relazione sui fatti accaduti durante la manifestazione....," 6 July 1946, AS 1570, b 8, f 3, sf Sciopero. The shopkeepers' relationship to the strike is rather complicated. Though the local Commercial Association (Associazione Commercianti) had agreed to the closure of its members' shops during the strike, seemingly out of fear of worker reprisals, the AMG declared that shopkeepers who closed their doors would have their licenses
} 
issuing a bulletin mocking the AMG's "democracy" as little more than the Anglo-Americans ruling with "an attitude of colonial master." ${ }^{175}$ In a more immediate sense, various garibaldini and youth present at the gathering shouted bitterly that this certainly was not the democracy they had been promised, after which a group "detached themselves from the manifestation and quickly lashed out against the businesses that still were open, manhandling the violators of the strike who could be found there" until all shops were closed. ${ }^{176}$ And this violence against shopkeepers was not an isolated phenomenon. During the strike, low-level PCRG militants - particularly youth had repeatedly demanded that the Party authorize their formation into action squads, which were to vandalize shops that remained open for business. However, the PCRG rejected this "opportunism" and "extremism" as contrary to its cross-class unity line and leaders such as Bersa and Comar began instead to consider a purge of such "extremists" from its own ranks. ${ }^{177}$

Monfalcone and Zone A remained in this state of disorder for twelve days, but by 11 July, the pro-Yugoslav leadership had realized the strike was unsustainable. On the one hand, the AMG had arrested many key pro-Yugoslav organizers, and many ordinary pro-Yugoslavs had been unsettled by violent confrontation with the forces of order. On the other, resources were running low, and continuing the strike risked alienating desperate workers who needed these daily earnings. ${ }^{178}$ As a result, the Strike Committee announced that the strike would end at midnight of

revoked. Sottocomitato promotore dello sciopero-Monfalcone, "Al Comitato Promotore dello Sciopero di Trieste," 3 July 1946, AS 1570, b 8, f 3, sf Sciopero.

175 The bulletin also rather clearly cast the AMG as a "politer" version of Fascism, stressing that the AMG was "doing that which has been done for twenty-five years, but in a manner gentler and politer. Handcuffs. Previously they were of iron; today they are of soft silk. But they are still handcuffs." Strike Bulletin No. 10, July 1946, AS 1570, b 8, f 3, sf Sciopero. Italics added.

${ }^{176}$ Unsigned (Strike Committee), "Relazione sui fatti accaduti durante la manifestazione...," 6 July 1946, op. cit.

${ }^{177}$ PCRG-IV and V Rioni, "Riunione straordinaria comitati P.C.R.G. IV e V Rione," Undated (Late July 1946), AS $1570, \mathrm{~b} 8$, f 1 .

${ }^{178}$ Ibid. The SG and the pro-Italian paper La Voce Libera readily exploited this, drawing attention to how the SU's singular focus on the territorial question harmed workers' material interests. Di Gianantonio et al, L'immaginario imprigionato, 128-30. 
12 July, emphasizing that it had been successful in demonstrating the workers' intolerance of both the "remnants of Fascism" and the AMG's seeming protection of these remnants. ${ }^{179}$ Within Party circles, Bersa promised that, though "the strike is suspended, the struggle against Fascism continues." Like the Strike Committee, he reiterated that the strike had succeeded in demonstrating the popular will that Zone A go to Yugoslavia and reinvigorating the pro-Yugoslav movement. ${ }^{180}$ Of course, the fact that Bersa had to clarify that the strike was a success belied the fact that it had accomplished little. It had failed to resolve workers' workplace or marketplace grievances and worsened the material conditions of its already-destitute participants.

\section{In the Aftermath of the Strike: Violence and Disillusionment}

Though the cessation of the strike on 12 July provided the AMG with a brief respite, the lull was only temporary. The strike unleashed the antipathy between the strata of the workplace hierarchy in the CRDA, the Solvay, and elsewhere, and when SU-loyal workers returned to work, a violent aftershock played out on the shop floors. Though some SG loyalists had prepared for this violence, forming their own action squads equipped with pistols and grenades, ${ }^{181}$ UAIS action squads perpetrated a wave of attacks against supposed "Fascist" scabs and clerks, which paralyzed the firm. ${ }^{182}$ In the Shipbuilding Department, where a shocking $38.2 \%$ of workers belonged to the PCRG and $87.6 \%$ to the UAIS, ${ }^{183}$ returning pro-Yugoslavs hung six large Yugoslav and Italian red-starred flags from the cranes and bloodied several of their SG-loyal coworkers during the first hours of work. Pro-Yugoslavs of the aeronautical workshops did similarly, prompting police

\footnotetext{
${ }^{179}$ Unsigned, “Cittadini, lavoratori, antifascisti!," July 1946, AS 1570, b 8, f 1.

${ }^{180}$ Unsigned (PCRG-IV Rione), Untitled Political Report, 18 July 1946, AS 1570, b 8, f Relazioni politiche.

${ }^{181}$ One of these was Giuseppe I., a key participant in the terrorist bombing campaign against the pro-Yugoslav faction later that year (see chapter 5). "Anche a Monfalcone si è trovato il pretesto," Il Lavoratore, 17 July 1946.

${ }^{182}$ In the Aeronautical Department, for example, twenty scabs were "manhandled and beaten to a pulp" before police intervened. PCRG-IV Rione, "Relazione dell'attivo sulla prima giornata di lavoro nel CRDA," 15 July 1946, AS 1570, b 8, f 3, sf Sciopero.

${ }^{183}$ Comp. D[x], "Relazione politico-organizzativa," 21 August 1946, op. cit.
} 
intervention. When police arrived, electrical department workers struck, depriving the worksite of electricity and paralyzing production. By day's end, pro-Yugoslavs had posted lists of scabs throughout the CRDA, promising each a "just" punishment, and though management responded by declaring a suspension of work, many workers refused to leave until late that evening. When they returned the following day, the violence continued, and management declared a lockout. ${ }^{184}$

With the complete breakdown of order within the worksites, the AMG faced a difficult situation. Its longstanding strategy of fostering the SG as an alternative to the SU had proven insufficient, and it faced pressure from the SG and CRDA Direction to take a more active role in breaking the pro-Yugoslavs. The Direction, for example, requested the stationing of troops in the workshops, the banning of pro-Yugoslav broadsheets, the dissolution of the SU Factory Committee and removal of its offices from the worksite, and the depoliticization of the worksite by stripping away all political symbols. ${ }^{185}$ For many AMG officers, however, this violence provided the justification for a more aggressive and long-anticipated crackdown. According to CAO Kitson-Harris, the lockout "amounted to the salient fact that the Management had decided quite rightly to pass the 'buck' back to A.M.G.," a maneuver that, "quite unofficially of course..., may have been whispered into the Directors' ears many months ago." 186

Thus, on 19 July, the AMG sent troops to restore order in the CRDA, placing it under military occupation and granting full control to Lt. Col. Foden, the AMG's Chief Industry and Utilities Officer. SCAO Bowman granted Foden authority unilaterally to fire, remove, or arrest

\footnotetext{
${ }^{184}$ Direzione Centrale-CRDA, "Memoranda on the incidents which occurred within the 'CRDA' Establishments on 13, 15, and 16 July 1946," 16 July 1946, NARA, RG331, UD1981, b 9202, f 11304/115/440; SCAO Meeting Minutes, 22 July 1946, NARA, RG331, UD1981, b 9108, f 11302/115/88.

${ }^{185}$ Executive Committee, CdL-Trieste [SG], Motion of Protest to SCAO Bowman, 17 July 1946, NARA, RG331, UD1981, b 9202, f 11304/115/434; Direzione Centrale-CRDA, "Memoranda," 18 July 1946, NARA, RG331, UD1981, b 9202, f 11304/115/434; Maj. Montague (AIS-Trieste), Report to Maj. John Vernon, 'D' Section, 19 July 1946, NARA, RG331, UD1981, b 9140, f 11304/100/38.

${ }^{186}$ Maj. Kitson-Harris, "Monthly Report, Jul 1946," 31 July 1946, op. cit.
} 
anyone found causing disorder in the worksite, as well as to strip the shipyard of the red-starred flags and giant red stars that the SU workers had erected throughout the site. ${ }^{187}$ Immediately upon arrival of the soldiers, violence ceased, the SU committee "voluntarily" removing its symbols with "no protest or ill-will shewn [sic]." 188 Within a week, however, the shock had passed, and proYugoslavs began to restore their symbols throughout the CRDA. ${ }^{189}$ On 24 July, a procession of workers marched to the SU office and replaced the red flag that the AMG had removed from above its entryway, while others replaced red-starred tricolors, even laying traps designed to serious injure or kill those who might try to remove them. ${ }^{190}$ Two days later, during the launching ceremony for a completed ship, workers hung a red flag from the ship, leading the directors to suspend the launching. ${ }^{191}$ Simultaneous with this resurgence of defiance - and against strong warnings from both Foden and Trieste Area Commissioner Lt. Col. Smuts - top AMG officials made preparations to demilitarize the shipyard and return it to civilian management. ${ }^{192}$

The decision to demilitarize the shipyard so quickly, implemented on 31 July, proved a disaster, and during the hot August that followed, the CRDA guards again proved incapable of managing the site's pro-Yugoslav forces. Throughout the month, pro-Yugoslavs held mass rallies in the workshops with impunity, often drawing 3000 participants, and they faced little opposition

\footnotetext{
${ }^{187}$ The AMG also occupied the San Rocco shipyard in Trieste, which experienced similar turbulence. SCAO Bowman, Decree of 18 July 1946, NARA, RG331, UD1981, b 9333, f 11304/142/117; SCAO Meeting Minutes, 22 July 1946, op. cit.

${ }^{188}$ Lt. Col. Foden, "Control of Cantieri S. Marco and Monfalcone," 25 July 1946, NARA, RG331, UD1981, b 9202, f 11304/115/434.

${ }^{189}$ Vinicio, "È questa la libertà," Il Compagno, Anno II, N. 5, 29 July 1946, AS 1570, b 12, f 8.

${ }^{190}$ One soldier avoided potentially fatal injury when he was warned at the last moment that workers had sawn through the bolts on the top section of the ladder he was climbing. Lt. Col. Foden, "Note," 25 July 1946, NARA, RG331, UD1981, b 9202, f 11304/115/434; “A Monfalcone,” Il Lavoratore, 25 July 1946.

${ }^{191}$ During the rescheduled launching, workers unveiled another red flag, but only at the last moment, too late for the directors to intervene. "Si rimanda un varo per... una bandiera rossa!," Il Lavoratore, 29 July 1946; "Questa volta non è stato sospeso," Il Lavoratore, 30 July 1946.

${ }^{192}$ Lt. Col. Foden, "Control of Cantieri S. Marco and Monfalcone," 25 July 1946; Lt. Col. Smuts, "Military Control in the Yards," 25 July 1946, both in NARA, RG331, UD1981, b 9202, f 11304/115/434.
} 
in sacking the SG headquarters. ${ }^{193}$ Threatening posters reappeared, as did skulls-and-crossbones printed menacingly on the timecards of pro-Italian workers and clerks, and the targets invariably received beatings if they did not stay away from work. Though no reliable figures exist, it seems that hundreds were beaten and tens hospitalized. One particularly unfortunate pro-Italian, the Socialist and SG exponent Agostino Perin, died in the hospital from injuries suffered during an ambush as he biked to work. ${ }^{194}$ Significantly, much of this violence, both in the CRDA and elsewhere, fell upon clerks. ${ }^{195}$ Most notable was the beating of Umberto Zuccolin - the "comrade timekeeper" previously derided in a CRDA broadsheet during the Twelve Days Strike. As head of the pro-Italian CLN and a piecework clerk in the Labor Costs Office, Zuccolin was the perfect target for pro-Yugoslavs who inextricably linked pro-Italianism, clerk status, and the "remnants of Fascism," and thus two workers beat him with sticks as he toured the aeronautical workshops on 23 August. ${ }^{196}$ Zuccolin's active role in the pro-Italian CLN was not sufficient proof of antiFascism. Fascism was something amorphous, and Zuccolin, arriving in the workshop as "comrade timekeeper," was a remnant.

As a result of the August violence, the AMG came under a new wave of pressure to remilitarize the CRDA and to extend the occupation to the Solvay. The SG threatened a strike of "nearly all clerks" if their safety could not be guaranteed, while pro-Italian political figures pushed the AMG to occupy both sites and CRDA management threatened another lockout if the AMG

\footnotetext{
${ }^{193}$ PCRG-Monfalcone, "Report N. 51," 23 August 1946, AS 1570, b 9, Folder Posta in arrivo.

${ }^{194}$ Direzione Centrale-CRDA, "Memorandum to Lt Col T. Foden, Chief of the AMG Industry Division," 9 August 1946; Lt Col Foden, "C.R.D.A. Shipyard Control," 13 August 1946; "Minutes of the Meeting of the $14^{\text {th }}$ August 1946, CAO Monfalcone, Pres of Communal Council ..." 14 August 1946; Direzione Centrale-CRDA, "Worker Agostino Perin," 16 August 1946, all in NARA, RG331, UD1981, b 9202, f 11304/115/434. Cernigoi, Puppini, and Valcovich (eds), Cento anni di cantiere, 53-54.

${ }^{195}$ In early August, several Solvay clerks were beaten, leading to the arrest of eight workers. SCAO Economics Section Meeting Minutes, 9 August 1946, op. cit.

${ }^{196}$ Direzione Centrale, CRDA, "Incidents at our Monfalcone Shipyard," 23 August 1946, NARA, RG331, UD1981, b 9202, f 11304/115/434. See also Direzione Centrale, CRDA, "Incidents at our Monfalcone Shipyard," 21 August 1946 , in the same.
} 
failed to intervene. ${ }^{197}$ The AMG thus ordered another occupation of the shipyard before month's end, but this time by the VGPC. It constructed a new VGPC station at the CRDA gate and implemented a new ID card system aimed at eliminating "political transients" (UAIS squads). ${ }^{198}$ By the last day of the month, Kitson-Harris could report that police patrolled the "entirety" of the CRDA, which he suggested become a "permanent fixture" of AMG occupation policy, as "a firm political control in the shipyard must be the corner-stone of our administration in this area." 199

With these actions, violence declined, and the AMG set itself to the task of definitively breaking the pro-Yugoslav organs. The AMG's primary target was the SU Factory Committee, which it had planned to dissolve during the occupation of late July before deciding not to publish the drafted decree, fearing it would prompt another general strike. ${ }^{200}$ In the wake of August, the AMG, realizing it still operated from a position of weakness, again postponed this act, awaiting a time in which the balance of forces had shifted drastically. ${ }^{201}$ In the meantime, the CRDA continued to push for the displacement of workers from the worksite to the public works projects at Punta Sdobba and elsewhere, to which the SU now acceded, given rising unemployment rates. ${ }^{202}$ During these last months of 1946, the SU sank all of its efforts into the struggle against the SG, at times putting forward demands for raises in piecework rates, but failing to take on the system of

\footnotetext{
${ }^{197}$ Unsigned [SG], "Memo on the Necessary Measures to Protect the Safety of Workers of C.R.D.A.," August 1946; Secretary Geppi (CdL-Trieste), "Situation of CRDA of Monfalcone," 21 August 1946; Direzione Centrale-CRDA, "Incidents at the Monfalcone Shipyard," 19 August 1946; "Minutes of the Meeting of the $14^{\text {th }}$ August 1946, CAO Monfalcone, Pres of Communal Council ...," all in NARA, RG331, UD1981, b 9202, f 11304/115/434.

${ }^{198}$ Unlike the first occupation, this time the AMG did not assume control of management. Lt. Col. Foden, "C.R.D.A. Shipyard Control," 13 August 1946, op. cit.; Unsigned [AMG], "Status of Identity Cards," 22 August 1946, NARA, RG331, UD1981, b 9202, f 11304/115/434; Maj. Kitson-Harris, "Monthly Report of Monfalcone Group CAO...," 31 August 1946, op. cit.

${ }^{199}$ Maj. Kitson-Harris, "Monthly Report of Monfalcone Group CAO...," 31 August 1946, op. cit.

${ }^{200}$ SCAO Bowman, Draft of Order No 188, Undated [July 1946]; Maj. Scicluna, "Final Draft-Ordinance Governing the Election of Shop Steward Committees," 24 July 1946, both in NARA, RG331, UD1981, b 9202, f 11304/115/434.

201 This would only come in May 1947. Maj. F. Hill, "Monthly Report, May 1947," 28 May 1947, NARA, RG331, UD1981, b 9186, f 11304/115/278.

${ }^{202}$ SCAO Economics Section Meeting Minutes, 9 August 1946, op. cit.
} 
piecework itself. ${ }^{203}$ The result was the frustration of worker ambitions for a transformation of the workplace and the creation of an ever-greater body of workers subjected to the humiliation of unor low-skilled labor, all of which occurred contemporaneously with the clear defeat of the proYugoslav cooperative in its struggle with Monfalconese shopkeepers. ${ }^{204}$

But it was not only the combined opposition of the AMG and the local pro-Italian forces that caused many monfalconesi to lose heart. By mid-1946, the contradictions within the PCRG and UAIS programs had become apparent and even clashed with popular aspirations to remake local society. From the outset, the two most important points of the UAIS program had been to fight for the annexation of Venezia Giulia to its "natural hinterland" of Yugoslavia and to achieve the uncompromising "liquidation of the remnants of Fascism." 205 Yet the strategies to achieve the first - the creation of the broadest pro-Yugoslav coalition possible, including the shopkeeper and, to a lesser extent, the clerk - could not be reconciled with popular expectations for the "liquidation of the remnants of Fascism" in the marketplace and workplace. ${ }^{206}$ As time passed and the worlddiplomatic balance of forces shifted decidedly in the pro-Italians' favor, the PCRG doubled down on its policy of fostering cross-class, pro-Yugoslav unity, while certain elements of the proYugoslav faction lost patience with the subordination of reform efforts to the territorial question. By the fall of 1946, the most observant Party members would begin to correlate the Party's failure to achieve concrete reforms with a lessening of popular enthusiasm for its initiatives. In one particularly telling meeting of the Ronchi communal committee, after one member suggested that

\footnotetext{
${ }^{203}$ Unsigned (PCRG-Monfalcone), "Relazione dell'attivo," 14 August 1946, AS 1570, b 10, f 1, sf Rasni rapisniki 1946.

${ }^{204}$ PCRG-IV Rione, "Relazione sulla IV riunione del Comitato rionale," 17 August 1946, op. cit.

${ }^{205}$ PCRG-V Rione, "III Riunione del comitato del P.C.R.G.," 13 June 1946, op. cit. There were several additional points, but all can be subsumed within these two fields. See "Dichiarazione dell'Unione antifascista italo-slovena," Il Lavoratore, 21 June 1945.

${ }^{206}$ Kardelj himself had devised this soft policy toward the various strata of the Italian middle class during the period of Yugoslav administration, seeking to bring them into the pro-Yugoslav coalition, or at least to prevent the coalescence of these strata into a unified anti-Yugoslav bloc. Fogar, Trieste in guerra, 255.
} 
the various shortcomings of the cooperatives were at least partly to blame for increasing popular apathy, another cast the blame more widely. He stated simply that popular disengagement resulted from "a lack of faith that [the people] have in their leaders, who for over a year have led them in struggle and have not yet learned how to satisfy their demands." ${ }^{207}$ It seems likely that the "people" to whom he referred were the same "extremists" demanding an uncompromising push for social revolution - the same whom the PCRG hierarchs increasingly viewed as a liability.

${ }^{207}$ PCRG-Ronchi, "Verbale della riunione dei membri effettivi di partito...," 21 September 1946, AS 1570, b 10, f 7, sf 17. 


\section{Chapter 5: The Loss of "Monfalcone antifascista:" Demonstrations, Dynamite, and Disillusionment}

Writings of all colors, but of a democratic tendency adorn the facades of homes, fences, telephone poles, etc.... above Monfalcone, on the Rocca, an enormous red star with the writing 'W la RFPJ' [Long live the Federal People's Republic of Yugoslavia] has appeared as if by magic. The walls of the workshops are covered with writings. Red stars appear on the most visible points. Others more colossal will yet appear. ${ }^{1}$

- Monfalcone UAIS report in anticipation of the UN Delegation visit, March 1946.

When the AMG ended the first occupation of the CRDA, the pro-Yugoslavs' first response was to restore the symbols of their movement, including the red flag above the SU offices and the red-starred tricolors throughout the workshops. This pro-Yugoslav practice of symbolically marking the Monfalconese's physical space had begun in the first hours after liberation, when the pro-Yugoslavs erected a giant red star on the façade of the town hall. It had then taken on an even greater intensity in the spring of 1946 as monfalconesi awaited the arrival of the UN Border Commission. From the walls of the humblest homes to those of iconic buildings such as Monfalcone's hilltop castle (the Rocca), the zone's exposed surfaces came to bear the symbols of the pro-Yugoslav cause (Figure 13). For much of 1946, monfalconesi drinking coffee in the central piazza could view a giant red star and the phrase "we don't want Italy here" on display from the Rocca. Though periodically purged by the AMG, they always popped back up as the proYugoslavs sought to project their political desires as those of the entire zone (Figure 14).

Such markings and their removal were part of an ongoing battle to define the "true" Monfalcone between pro-Yugoslavs and their myriad opponents. For the pro-Yugoslavs, it was part of a wider strategy of developing an image of Monfalcone as a town that was unanimous in its opposition to Fascism in all forms - and thus, according to its political calculus, in favor of

\footnotetext{
${ }^{1}$ Comitato Esecutivo UAIS-Monfalcone, "Relazione Mensile" (N. 106/46), 1 March 1946, AS 1570, b 8, f 3, sf 1. Italics added, ellipses in original.
} 
Yugoslav annexation. For such individuals, the appearance of these symbols was, in the words of the above-cited UAIS report, almost magical. It was an inevitable occurrence and one without a subject. If there had to be a subject, it was a disembodied, collective subject - certainly not a concrete collection of militants assigned the tasks of spreading pro-Yugoslav symbols and purging symbols of the opposition, but rather "Monfalcone antifascista."

Yet it was not only through physical marking that the pro-Yugoslavs fostered the idea of "Monfalcone antifascista." Quite often, it was fostered through Il Lavoratore, which discursively "mapped" the politics of the town. Most illustrative of this tendency is the paper's narration of a 28 March demonstration, which took place around the time of the Servola Incident and the UN Delegation's visit. On that day, some 10,000 pro-Yugoslavs were said to have come out to fill the principal roads and crowd the piazza, singing partisan and popular songs and waving red-starred tricolors. Opposing this massive formation was a much smaller group of pro-Italians huddling into a corner of the square, of whom fifty were "beardless young students," all shouting in favor of Italy and able to do so only "under a formidable escort of Civil and Military Police." As the rally ended and night came, "the city echoe[d] with partisan songs, an imposing crowd with hundreds of flags moving through the principle streets to blunt any action that revealed the existence of the neo-Fascist reaction, while about five-hundred people ["neo-Fascists"], now rendered hysterical, ran through the peripheral streets, protected by the darkness." By juxtaposing the ability of the pro-Yugoslavs to fill the central pizza in open daylight to that of the "neo-Fascists" (pro-Italians) to exist only on the peripheries under the protection of police or nightfall, the paper reinforced its claim that "Monfalcone antifascista pronounced yesterday evening to all the Fascists that its popular will is unshakable." There was one true Monfalcone, and it was indivisibly anti-Fascist. ${ }^{2}$

\footnotetext{
2 “Una folla di oltre 10 mila persone manifesta a Monfalcone...," Il Lavoratore, 29 March 1946.
} 
Though the concept of a singular "Monfalcone antifascista" did not reflect an objective political consensus, it had a clear impact. It provided a unifying myth for a large subsection of monfalconesi and channeled broadly anti-Fascist popular sentiments into the pro-Yugoslav cause. With the spaces of everyday life flooded with symbols of "Monfalcone antifascista," proYugoslavs received regular reminders of the stakes of their struggle, namely that the conditions of everyday life in those very lived spaces would be shaped entirely by the outcome of the territorial struggle. But it also served to impose a silence and exclusion on all others. The ubiquity of proYugoslav symbols provided a daily reminder of the pro-Yugoslavs' strength (real or projected) to all monfalconesi who lined up with the pro-Italian cause, while the concept implicitly condemned them as "Fascist." At its most extreme, it removed any moral obligation the pro-Yugoslavs had to hear the voices of their opponents and legitimized violence such as that of the Twelve Days Strike. ${ }^{3}$

For over a year after liberation, this symbolic practice served its purpose. It created the image of a politically indivisible zone and helped the pro-Yugoslavs maintain their primacy in the piazza and public space despite strong AMG opposition. But with the coming of winter 1946/47, major cracks began to show in the façade of "Monfalcone antifascista." Frustration with the lack of tangible change in the zone had reached a critical level, and the pro-Yugoslavs' monopoly on public space came under assault from multiple directions.

\section{Confrontation and Conflict in the Wake of the Twelve Days Strike}

By fall 1946, the pro-Yugoslavs of the Monfalconese faced an increasingly uphill battle. The faction remained committed to Yugoslav annexation, but the defeat of the Twelve Days Strike

\footnotetext{
${ }^{3}$ In this sense, the myth of "Monfalcone antifascista" was one variant of the wider Resistance myth that emerged in postwar Italy. On this myth see R.J.B. Bosworth and Patrizia Dogliani (eds), Italian Fascism: History, Memory and Representation (New York: St. Martin's Press, 1999) and Philip Cooke, The Legacy of the Italian Resistance (New York: Palgrave MacMillan, 2011).
} 
and the subsequent CRDA occupation effected a "hardening" of PCRG and UAIS tactics as it tried to retain its dominance over the public space of Monfalcone. ${ }^{4}$ Shortly after the AMG occupied the CRDA, Branko Babič and the PCRG leadership in Trieste directed their Monfalconese comrades to engage in "clear action against the AMG."5 The PCRG-Monfalcone leadership in turn informed its militants that, given the example of "the Fascism of the [pro-Italian] CLN that, supported by the $A M G$, has passed entirely to the offensive in the decisive struggle, the $P C[R G]$ too changes its parliamentary line to the decisive struggle against Fascism." ${ }^{6}$ Rather than seeing the AMG as simply facilitating the resurgence of Fascism through ignorance or incompetence, the proYugoslavs increasingly saw the AMG's actions as intentional. As such, they threw out their former approach of non-cooperation and unconfrontational protest - an approach that had never fully been accepted by the wider body of followers - replacing it with one of more direct confrontation. The AMG itself, rather than merely the "remnants of Fascism" it protected, was now the target.

Many pro-Yugoslav militants welcomed the shift, in part because they had long resented PCRG hesitancy, but also because they had endured a wide range of abuses on behalf of the AMG's police force, the VGPC. Internal PCRG reports indicate various instances in which VGPC agents arrested militants, beating them at police headquarters before releasing them without charges. ${ }^{7}$ At times, VGPC agents assaulted the headquarters of the UAIS and APG in acts comparable to Fascist

\footnotetext{
${ }^{4}$ With a late-September circular, the PCRG reinforced that "Italy has never given us anything," but rather "persecuted us, oppressed us, vilified us," and reassured militants that "Yugoslavia will not sign any accord that is contrary to the interests of the people who it so courageously defends." Unsigned [PCRG], Untitled Circular, 26 September 1946, AS 1570, b 9, f 6, sf Archivio.

${ }^{5}$ PCRG-IV Rione, "Relazione sulla III riunione del IV rione del Monfalconese," 7 August 1946, AS 1570, b10, f 1, sf Relazione del rionale.

${ }^{6}$ Unsigned (PCRG-Monfalcone), "Relazione dell'attivo," 14 August 1946, op. cit.

${ }^{7}$ Often such agents were identified as formerly fervent Fascists and even X Mas members. Comp. M. Z[x], "Rapporto," 5 October 1945, AS 1570, b 9, f 6, sf Informazioni. Silvano Cosolo writes in his memoirs that a spur for his own emigration was harassment by a VGPC inspector against whom Cosolo had testified for his role in the Servola Incident. Cosolo, Amare... Sarajevo, 17-18.
} 
squadrismo, beating those on guard duty. ${ }^{8}$ As one former agent would later recount, the AMG stringently vetted new police recruits to assure their anti-Communism. This agent, assigned to the political branch of Monfalcone, was soon convinced that the majority of workers supported the UAIS. They threw bolts at VGPC agents who entered the shipyard and once even shot at him on the street. And since "the people were not messing around," the VGPC did not mess around either:

When there were manifestations one had to remain attentive, above all in Trieste. They came into the city with trucks. Most were Titoists from Monfalcone and its environs, but there were also some Southerners, whom we always beat up. When we captured someone, we brought him to the station. Because of this, I know that there weren't only locals, but also Sicilians, Friulans, Abruzzians. And I remember one whom the sergeant asked, 'ah, you're Sicilian?' The scrap of a boy responded 'Yes' and, since the sergeant was also Sicilian, he treated him like a traitor and beat him down. We too pounded him because here we saw them like enemies. ${ }^{9}$

In fact, from its inception, there were serious doubts about the VGPC's impartiality, as the new force was composed largely of Fascist-era officers and agents. ${ }^{10}$ In the rather euphemistic language of an AMG intelligence officer, "the Allies were more or less compelled to build the new V.G. Police Force around the trained officers remaining from the old Italian Public Safety bodies and the Allied Police officers themselves realise that the system they have built up is for this reason not as perfect as they would have liked," particularly because many of these officers were Fascists from the Mezzogiorno. ${ }^{11}$ Indicative of this reality was the placement of the VGPC's Criminal Investigative Division (CID) in the hands of Feliciano Ricciardelli, a longtime Fascist from Avellino Province who had directed the political office of the Trieste Questura in the late ventennio. ${ }^{12}$ During the German occupation, Ricciardelli had plotted against the Germans to help

\footnotetext{
${ }^{8}$ Comp. S. B[x], “Al Partito comunista-Monfalcone,” 7 March 1946, AS 1570, b 9, f 6, sf Informazioni,

${ }^{9}$ Cernigoi, Scelte politiche e identità nazionale, 229.

${ }^{10}$ Continuity of police personnel is just one facet of the wider phenomenon of the "continuity of state" between the Fascist and postwar eras. Pavone, Alle origini della repubblica; Imbriani, Vento del sud; Hans Woller and Enzo Morandi, I conti con il fascismo: l'epurazione in Italia, 1943-1948 (Bologna: Il Mulino, 1997); Dunnage (ed), After the War.

${ }^{11}$ Maj. Montague (AIS-Trieste), Report to Maj. John Vernon, 'D' Section, 19 July 1946, op. cit.

${ }^{12}$ Ricciardelli entered the PS in 1928, three years after joining the PNF, so it is unlikely he joined simply for careerism. He remained a cardholder until the collapse of the regime. Cap. Com. Mario (Carabinieri-Trieste), "Segnalazione" (N.
} 
save the lives of Triestine Jews and, once discovered, was deported to Dachau, but he returned in the postwar to direct the CID. Immediately upon appointment, he had written a top-secret letter to the Italian Chief of Police, pledging that "the writer, the Functionaries, and the entirety of the personnel, inspired by a highly patriotic sentiment, will work in every way possible to defend the italianità of these lands in the supreme interest of the Patria." ${ }^{13}$ Without doubt, the anti-Communist and nationalist sentiments of Ricciardelli trickled down the ranks, with the result that the VGPC was the only body of pro-Italians regularly willing to contest the pro-Yugoslavs' control of Monfalcone's public space in the year after liberation. ${ }^{14}$

Despite this early and persistent VGPC opposition, the pro-Yugoslavs had been the masters of public space in Monfalcone well into 1946, with few pro-Italians willing to organize political meetings, let alone public demonstrations (Figures 15 and 16). As the pro-Yugoslav worker, Luigi Pasqualini, would later recount, while at Trieste there was always organized opposition in response to pro-Yugoslav demonstrations of 1945 and 1946, "at Monfalcone there was no opposition, at least at the first moment. There were some against it, but not many.” In fact, Pasqualini recalls that when speakers like Renato Rigonat drew large crowds to Monfalcone's central piazza and made speeches in favor of the Seventh Federative Republic, the Communist Party, and the syndicates, it was the AMG rather than native pro-Italians that fight back: "They came in a truck and began to

3/1), 7 January 1944, ACS, MI, DGPS, A5G II Guerra, b 150, f 226, sf 2; Dir. Capo della Div. Personale di PS (MIDGPS), "Venezia Giulia - Informazioni" (N. 333/9186-I), 13 September 1946, ACS, MI, DGPS, Div AA GG RR 1944-46, b 58, f VG 1944-46.

${ }^{13}$ It was precisely due to their strong nationalist sentiments, and often their sympathy with Fascism, that the regime had sent these men to the border territories years earlier. The CID even carried out a surveillance program of VGPC officers of Slovenian origins with the hopes of catching exposing their untrustworthiness to the AMG and securing their expulsion. Insp. F. Ricciardelli, Untitled Report to Capo della Polizia, Roma (N. 800 - Riservatissima), 7 October 1945, ACS, MI, DGPS, AA GG RR 1944-46, b 59, f 115; Ricciardelli, "Relazione mensile" (N. 800), 30 November 1945, ACS, MI, DGPS, Div SIS, AA GG 1944-49, b 77, f OP6.

${ }^{14}$ By 1948, the Italian security apparatus had running files on VGPC agents with far-right, anti-democratic sentiments and viewed them as threats alongside the "Slavo-Communists." See ASG, Questura 1948, b 4, f 626; b 5, f 685; and b 6, f 857 . 
run around with manganelli until it all became a stampede. Those were the only opponents."15

In this context, recently defeated in the Twelve Days Strike and facing the foreign ministers' decision to return the Monfalconese to Italy, the PCRG made it a point to reaffirm its mastery of public space and to display the vitality of "Monfalcone antifascista." Despite the "Big Five" still languishing in AMG prison and senior militants like Angelo Comar having been sent to Paris in a last-ditch effort to sway the foreign ministers, the UAIS orchestrated a mass demonstration on 11 August 1946, which filled the Monfalcone piazza and involved calls for Yugoslav annexation and the dissolution of the VGPC. The most important speech, that by the PCRG militant Sergio Mori, reveals this increasingly confrontational language, as well as the turn to viewing the AMG as conscious facilitators of a "new Fascism:"

How does one explain the birth of a new Fascism that functions, organized by the so-called CLN [pro-Italian] and protected by elements of the Civil Police? We explain it with the partiality of the AMG, with the leniency of its laws in the face of Fascists.... The masters, those who have exploited us for 25 years, have been returned to their places of command to continue to oppress us.... And it is precisely so, precisely because we have seen these masters - the scraps of a defunct Fascist regime - struggle so that Italy returns here, that we are fighting and will fight with all our strength not to allow this to happen. ${ }^{16}$

Though Kitson-Harris dismissed the demonstration as "a miserable failure" of 3000 participants lacking "vim and vigour," the content of the speech and visual evidence suggests otherwise (Figure 17). Kitson-Harris's own report indicated that the AIS had estimated a turnout of $14,000 .{ }^{17}$

Though the August demonstration was imposing, it was two months later, on 1 October,

\footnotetext{
${ }^{15}$ Cernigoi, Scelte politiche e identità nazionale., 228-29. Pasqualini contrasts the absence of an organized pro-Italian opposition in Monfalcone to the strength of that of Trieste: "At Trieste the manifestations very often ended with pure violence. They shot at us and beat us as we passed by in ranks and some people, who were part of the mass, threw coins at us and called us sell-outs."

16 "Monfalconesi e friuliani hanno parlato," Il Lavoratore, 12 August 1946.

${ }^{17}$ It is possible that CAO Kitson-Harris meant to type "UAIS" rather than "AIS," but the Allied Information Services also routinely surveyed pro-Yugoslav demonstrations. In any case, there is no indication in PCRG reports that they were disappointed with the demonstration's turnout. Maj. Kitson-Harris, "Monthly Report of Monfalcone Group CAO...," 31 August 1946, op. cit. Other estimates, seemingly of clandestine pro-Italian intelligence services, put the demonstration at rounghly 4000-5000. CVO-SS, "Bollettino N. 11" (N. 224/83354), 26 August 1946, ACS, MI, DGPS, Div SIS, AA GG 1944-49, b 77, f OP6.
} 
that the PCRG's new confrontational strategy would reach its apex. In the interim, the pro-Italian faction had scored two major victories, one locally and one internationally. Locally, the communal council had secured the AMG's approval to refashion the toponymy of the town, replacing Fascistera street names with names drawn primarily from Roman antiquity and thus reinforcing the town's italianità. ${ }^{18}$ Internationally, in the last days of September, the UN's Political Territorial Commission officially adopted the foreign ministers' July proposal regarding the Free Territory of Trieste and the partitioning of Venezia Giulia, in effect sealing Monfalcone's fate. ${ }^{19}$ When news arrived of this decision, an incensed Bersa called a meeting of the PCRG's District Committee on the morning of 1 October, deciding that the pro-Yugoslavs must "paralyze the Monfalconese for four hours" in opposition to the "absurd decisions of Paris." ${ }^{20}$ Immediately, the SU issued a strike order, which reached $80 \%$ efficiency in the CRDA and Solvay. ${ }^{21}$ Moreover, the PCRG decided to unleash a mass, unauthorized UAIS demonstration in the piazza with full political regalia, once again defying AMG bans on unauthorized gatherings and political symbols. Most importantly, during the meeting, Bersa addressed the question of the police, authorizing the use of violence against them: "If the people are attacked by the C[ivil] $\mathrm{P}$ [olice], they will need to respond in kind. The people are tired of suffering their bullying, which resembles Fascist methods too closely."22

Shortly before two in the afternoon, UAIS members obediently began to assemble in the piazza. For twenty minutes, CAO Kitson-Harris waited in his office for a delegation to arrive,

\footnotetext{
${ }^{18}$ Almost entirely excluded were names of Slavic origins or drawn from the town's deep leftist tradition. The sole exception was Via Vincenzo Rusciani, renamed Via Fratelli Fontanot after the sons of Giovanni Fontanot. Presidente Rovatti (Monfalcone), "Estratto dal Processo Verbale delle deliberazioni del Presidente in data 7 settembre 1946," 7 September 1946, ASBCM, b 221.

${ }^{19}$ Novak, Trieste, 248.

${ }^{20}$ PCRG-IV Rione, "Riunione del Comitato rionale del PCRG Monfalcone," 1 October 1946, AS 1570, b 10, f 1, sf Relazione del rionale.

${ }^{21}$ Maj. Kitson-Harris, "Monthly Report of Monfalcone Group CAO to AMG HQ Trieste Area," 31 September 1946 [sic], NARA. 331, UD1981, b 9188, f 11304/115/288.

${ }_{22}$ PCRG-IV Rione, "Riunione del Comitato rionale del PCRG Monfalcone," 1 October 1946, op. cit. Italics added.
} 
meanwhile witnessing from his window the arrival of individuals "carrying crudely enscribed [sic] wooden posters" that "took an extremely dim view of returning themselves to the Italian State Republic or no Republic.” When none arrived, Kitson-Harris took decisive action:

The crowd had by now grown to possibly 3 thousand with many a stalwart standing on the pavement giving vocal support to his more courageous comrades who were prancing about shouting weird calls on the square itself. In order to avoid the stigma of these people holding a [sic] unauthorized demonstration in Monfalcone and getting away with it without intervention, it was with reluctance that the V.G. Police, numbering 50 men, and 1 officer, and 20 men (military) were unleashed on the crowd to break up the party.

The Police of both denominations, then entered the arena at 1430 approx at the double, swinging batons and blowing whistles in a glorious offensive 'war cry'. At 1435 the piazza was clear except for bits of broken wooden tokens, odd bicicles [sic], Communist flags and various types who, in their haste, had moved faster than their shoes or sandals would allow, and returned to claim them. A few remained to argue the toss after this offensive wave had passed, but the majority of the men were soon claimed by anxious spouses who had come to claim their menfolk and take them home. ${ }^{23}$

And thus, in a period of just five minutes, the attempt by the PCRG to make a direct challenge to the AMG ended unceremoniously, both Communist militants and the wider body of UAIS supporters dispersed with batons and scattered throughout the town. Shortly after the abortive demonstration, unidentified individuals - almost certainly pro-Yugoslavs - fired a number of pistol shots at patrolling policemen, but the pro-Yugoslavs managed very little physical resistance.

This was a decisive moment for the pro-Yugoslavs of the Monfalconese. From 1 October, the AMG "invariably disallowed" pro-Yugoslav manifestations. Moreover, it more engaged in a more aggressive campaign to arrest key militants - including the just-released "Big Five" - forcing many to flee to Zone B and thus depriving the pro-Yugoslav organizations of many gifted orators and organizers. ${ }^{24}$ From October, there began a steep decline in the pro-Yugoslavs' public presence.

\footnotetext{
${ }^{23}$ Maj. Kitson-Harris, "Monthly Report of Monfalcone Group CAO to AMG HQ Trieste Area," 31 September 1946, op. cit.

${ }^{24}$ Ibid.; Maj. Kitson-Harris, "Monthly Report of Monfalcone Group CAO to AMG HQ Trieste Area," 31 October 1946, NARA, RG331, UD1981, b 9188, f 11304/115/288.
} 


\section{A Change in Line: Union with the Free Territory}

This decline was not solely the product of AMG and VGPC actions. It also resulted from a simultaneous change in pro-Yugoslav strategies, which amplified long-developing frustrations over the failures of the pro-Yugoslav organizations to deliver concrete change. In the wake of the UN announcement and the disastrous October demonstration, the PCRG and UAIS in Monfalcone suddenly modified their lines. While the PCRG and UAIS in Trieste and its immediate environs quickly turned their attention to constructing a multi-party "anti-Fascist bloc" that could secure influence over the statutes and government of the soon-to-be Free Territory of Trieste, ${ }^{25}$ the Monfalcone branches announced in mid-October that their focus was now that Monfalcone not return to Italy, but rather become part of the Free Territory. This would not only prevent Monfalcone from returning to "reactionary" Italy, but also increase the strength of the "progressive" faction within the Free Territory and pave the way for an electoral takeover there, at which point the territorial question could be revisited. ${ }^{26}$

The new line proved disastrous for the local PCRG and UAIS, and it served to spread disillusionment and enervate the PCRG and UAIS. Immediately, Party leaders noted that the faithful either failed to understand or openly rejected the new line, having become so enamored with their mythical image of Yugoslavia that they could not conceive of a fight for a lesser solution. In the villages, women were particularly bitter about the abandonment of the old line. ${ }^{27}$ In the CRDA, those who informed militants of the line noted that militants "were not enthusiastic about

\footnotetext{
${ }^{25}$ Maj. Patti, AIS “D” Section, Report to Capt. Clarke, GSI GHQ, 7 October 1946, NARA, RG331, UD1981, b 9140, f 11304/100/38.

${ }^{26}$ PCRG-CDM, "Relazione politica," 14 October 1946, AS 1570, b 8, f 2. In Trieste, this change in line became official only after the signing of the Peace Treaty in February 1947. See Troha, "L'azione della Jugoslavia e delle forze italo-jugoslave," 460-61.

${ }^{27}$ Ruggero Bersa, "Relazione sulla situazione politica del distretto di Monfalcone," 19 December 1946, AS 1570, b 14, f 4-B, sf Relazione politiche del Rionale di Monfalcone, 1946.
} 
the new tactic..., the effect of a certain extremism and nothing else." ${ }^{28}$ Few saw the appeal of fighting an uphill battle for annexation to the TLT, the only reward for which would be another uphill battle to conquer political power. When the PCRG's CRDA cell held a meeting at month's end to assess militants' responses to the new line, it found that it was in former Party strongholds that the new line had failed to take hold. In the Shipbuilding Department,

the comrades at first would not hear it and, in these cases, we have been forced to review with them the rules of the $\mathrm{P}$ [arty] [that is, of Party discipline]. This department has always been the department most in line with the Party because it is the most combative, but also the most extremist. One cannot directly blame the comrades of this department if they do not manage to throw off this certain extremism, the workers of this department having in the past always been more exploited than any others. ${ }^{29}$

Within certain workshops of the Shipbuilding Department it would take three meetings before the militants would even consider the new tactic. Within the Electromechanical Department, another PCRG and UAIS stronghold, there was not the same open turmoil as in Shipbuilding. Party leaders that many militants had begun to murmur about transferring to Yugoslavia, but there were many "who are more conscious and who see the necessity of struggling forward without abandoning the battlefield." Across all departments, however, youth and garibaldini remained the most problematic and "extremist" groups, which was no surprise. Their "extremism" had already led many Youth Brigade volunteers simply to refuse to return to the Monfalconese after their service - a trend strongly criticized by the local PCRG leaders. ${ }^{30}$ As youth and garibaldini clung strongly to Yugoslav annexationism, it proved necessary for Party leaders to "call them one by one to explain to them all the particularities so that they are convinced." ${ }^{31}$ With the new line, the gap

\footnotetext{
${ }^{28}$ PCRG-IV Rione, "Verbale della riunione del comitato IV rione per il PC-RG," 22 October 1946, AS 1570, b 10, f 1 , sf Relazione del rionale. A similar rejection was noted in the outlying villages. PCRG-V Rione, "Rassegna sulla situazione politica del villaggio," 31 October 1946, AS 1570, b 8, f 3, sf Relazione politiche di Villaggio.

${ }^{29}$ PCRG-Monfalcone, "Relazione politica sulla situazione del CRDA," 24 October 1946, AS 1570, b 8, f 2.

${ }^{30}$ PCRG-IV Rione, "Conferenza di tutti gli effettivi di P; [sic] per il IV Rione," 28 September 1946, AS 1570, b 8, f 2.

${ }^{31}$ Comp. M. C[x], “Ordina del giorno,” 26 October 1946, AS 1570, b 10, f 1, sf Rasni rapisniki 1946.
} 
between Party and population had widened substantially.

If defeat in the Twelve Days Strike had marked the decisive turning point for the proYugoslavs of Trieste, the same was not the case in Monfalcone. ${ }^{32}$ There, participation in mass proYugoslav rallies endured well beyond the July strike, only falling off after the violent defeat in the Monfalcone piazza on 1 October and, more importantly, the pro-Yugoslav organizations' sudden and unpopular shift in political line. Whereas in Trieste the pro-Italian faction had claimed a public presence since the first days after liberation, in Monfalcone it had remained dormant. Except for a small contingent of nationalist students and Lega Nazionale (LN) members, who at times gathered in the southwestern corner of the piazza and displayed Italian tricolors (often with the Savoyard crest) under protection from the VGPC, pro-Italians had largely worked in the shadows during these months, failing even to hold public celebrations in the wake of the October publication of the Peace Treaty. ${ }^{33}$ With the winter of $1946 / 47$, this began to change.

\section{The Arrival of the Esuli and the Re-Emergence of the Pro-Italian Faction, Winter 1946/47}

The UN's adoption of the foreign ministers' proposal in October not only hastened the proYugoslavs' shift to confrontation; it also bolstered the pro-Italian faction of the zone. It boosted the confidence of many native pro-Italians, but more importantly it prompted another wave of ethnic Italians to flee from eastern-Adriatic territories destined for Yugoslav annexation. As monfalconesi became increasingly confrontational in their attempts to realize Yugoslav annexation, the Italian state embraced the settlement of such "exiles" (esuli) in disputed border

\footnotetext{
32 Novak, Trieste, 257.

${ }^{33}$ This emphasis on a very small number of pro-Italians gathered in a corner, protected by the VPGC is a staple of both pro-Yugoslav and pro-Italian recollections of the time - as a mark of pride for the latter. Cernigoi, Scelte politiche $e$ identità nazionale, 236-37, 240; Di Gianantonio et al, L'immaginario imprigionato, 145-49. The lack of a public pro-Italian presence is attested to in AMG reports as well. Maj. Kitson-Harris, "Monthly Report of Monfalcone Group CAO to AMG HQ Trieste Area," 31 September 1946, op. cit.; Kitson-Harris, "Monthly Report of Monfalcone Group CAO to AMG HQ Trieste Area," 31 October 1946, op. cit.
} 
territories like the Monfalconese as a conscious political strategy. Just days after the official publication of the Peace Treaty, Italy's Ministry of Foreign Affairs set as an urgent priority the "spiritual, economic, and political normalization of the Lower Monfalconese, which suffers at present the most acute aggravation of the Italo-Slavic racial struggle," and proposed as a solution the settlement of large numbers of esuli "to counterbalance the action of Slavic propaganda." 34 Even in its infancy, before the end of 1946, thousands of participants in this exodus had passed through or settled in the territory administered by the AMG, of whom hundreds had settled in the Monfalconese. ${ }^{35}$

The settlement of esuli in the Monfalconese had a major political impact. Though the esuli were an internally varied group - they included not just Fascists as pro-Yugoslavs often claimed, but also Italian Socialists whose politics were leftist and pro-Italian - they were united in their rejection of Yugoslavia. ${ }^{36}$ Taken as a whole, however, their politics tended to be more than just pro-Italian. They were also often virulently anti-Communist and nationalistic. Many held deep

\footnotetext{
${ }^{34}$ MAE-DGAP, "Notiziario di Informazioni N. 18” (N. 42582/802), 11 October 1946, ACS, MI, DGPS, Div AA GG RR 1944-46, b 58, f VG 1944-46. On the use of esuli in borderland demographic politics, see Pamela Ballinger, “'National Refugees', Displaced Persons, and the Reconstruction of Italy: The Case of Trieste," in The Disentanglement of Populations, eds. Reinisch and White, op. cit., 115-40 and Sandi Volk, Esuli a Trieste: bonifica nazionale e rafforzamento dell'italianità sul confine orientale (Udine: Kappa Vu, 2004). On their role in Gorizia Province specifically, see Stefano Olivo, "Comunisti ed esuli istriani nella provincia di Gorizia del secondo dopoguerra. Isolamento e discriminazione a confronto," Quaderni 12 (1991): 61-89.

35 According to AMG lists, there were over 800 esuli in Monfalcone proper and 300 in Ronchi by February 1947, which Stefano Olivo shows reached 2138 in Monfalcone city, 408 in Ronchi, and many more in the villages by the 1951 census. See the lists in NARA, RG331, UD1981, b 9198, f 11304/115/388. Olivo, "Comunisti ed esuli istriani," 68. The Italian state planned to continue settling esuli in border territories with populations of dubious loyalty even after the peace treaty went into effect, relying especially upon the "proud, hardened" esuli from Pola. PCM-UZC, "Situazione del goriziano," 12 March 1947, AGPCM, Fondo UZC, Sez II Gorizia, b 3.1, f 1. In a Lega Nazionale note of July 1946, the Lega indicated that there were 25,000 prospective esuli from Pola seeking resettlement in the urban centers of Trieste Area (Trieste, Muggia, Monfalcone), as "the working class and specially those specialized in ship building are part of this movement and it would be inopportune to send them in the mountains or else drainage work." Lega Nazionale-Pola, "Exodus," 9 July 1946, NARA, RG331, UD1981, b 9169, f 11302/115/150.

${ }^{36}$ Fogar, "Seconda parte dell'intervista registrata rilasciata da Ruggero Bersa," November 1981, op. cit.; Morena, "Intervista a Sergio Parenzan," 1000hrs, 30 May 2001, op. cit. Whereas the former two sources synonymize "Fascists," "esuli," and "Lega Nazionale," Spartaco Romano indicates that alongside the Fascist esuli there were also "esuli of certain democratic extraction" who helped combat the former. Bonelli, "Seconda testimonianza del monfalconese Romano Spartaco," 19 March 1981, op. cit.
} 
personal grievances toward Tito's nascent regime, which motivated them to take immediate, often violent action in opposing the pro-Yugoslavs of the Monfalconese. Moreover, conditions of scarcity in housing, food, and employment sharpened this antipathy and drove many esuli to engage in pro-Italian activity as a way to demonstrate support for the Italian cause and secure critical patrons in Rome, the AMG, the LN, and the CRDA Direction. ${ }^{37}$

Thus, the arriving esuli significantly altered the balance of political forces in the Monfalconese, and especially in Monfalcone proper. Soon a neighborhood composed almost exclusively of esuli arose to the south-southeast of Monfalcone's train station on Via Romana, creating an anti-Communist, Italian nationalist stronghold that could offset the "red neighborhoods" to the north, west, and southwest of the historic center. ${ }^{38}$ Moreover, esuli of the political right often turned rather quickly to violence and intimidation as a means of political struggle. As Sergio Parenzan would later recount, "with [the esuli] the trouble began. We were already at the end of ' $46 \ldots$. At Monfalcone the nationalists won; at Ronchi and the surrounding areas, no. At Monfalcone, a climate of violence was established. By contrast, these squads [of esuli] were afraid to go outside of the city because the people had remained together." ${ }^{\prime 39}$ A similar sentiment is captured in the testimony of the Umberto Sanzin, a monarchist and pro-Italian monfalconese who joined the DC at war's end:

In the piazza, there were 10,000 Italians who praised Tito and 150 students who praised Italy. If not for the Civil Police, [the pro-Yugoslavs] would have massacred us.... Then the esuli arrived... They did punitive expeditions, leaving with a truck and going to the villages. They were very active, true action squads.

Furthermore, the esuli had poisoned blood.... They had lost everything and therefore they were enraged. The fact that they arrived by the thousands caused a certain

\footnotetext{
${ }^{37}$ Anna di Gianantonio, "Politiche e sociali e questione nazionale nell'Isontino tra storia e memoria 1945-1950," in Il mosaico giuliano, eds. Altieri and Puppini, op. cit., 28-29. The LN was a particularly influential patron for esuli seeking work, helping significant numbers gain work in the CRDA. Buttignon, "Lega Nazionale e Governo Militare Alleato," 102-103.

${ }^{38}$ Fogar, "Terza parte dell'intervista registrata rilasciata da Ruggero Bersa," November 1981, op. cit.

${ }^{39}$ Cernigoi, Scelte politiche e identità nazionale, 237-38.
} 
rebalancing of forces and ideas. ${ }^{40}$

Bolstered by the esuli, the pro-Italian faction slowly re-emerged. From failing to hold any public celebrations when word arrived in fall 1946 that the UN had adopted the foreign ministers' border proposal, the Action Party, Republican Party, and DC by 1947 held public meetings and even initiated a series of processions that at times surpassed 1000 participants. ${ }^{41}$ Moreover, the arrival of what would soon be over a thousand esuli afforded the leaders of the SG and CRDA Direction with a mass of politically trustworthy workers who could be substituted for those tied to the SU, UAIS, and PCRG. ${ }^{42}$ In the winter of 1946/47, the struggle over resources between esuli and native monfalconesi caused an acute sharpening in the social antagonism between these groups, further poisoning a political atmosphere already made tense by the territorial question.

\section{The "Psychosis of Violence," September 1946-September 1947}

The arrival of the esuli, together with the PCRG's shift toward confrontation, initiated a new period of the postwar territorial contest, marked by a decisive escalation of violence. This is not to say that violence had not been a central characteristic of the struggle until late 1946 - the pro-Yugoslavs had long used threats and beatings to maintain their primacy in the zone - but, with the escalation of tensions in the winter of 1946/47, militants of both factions upped the ante, fists and rods giving way to firearms and explosives as the weapons of choice.

The first hints of this escalation occurred in September. In that month, CAO Kitson-Harris

\footnotetext{
${ }^{40}$ Ibid., 240.

${ }^{41}$ On Signing Day (10 February 1947), roughly 1000 pro-Italians, mostly women and children, held an unauthorized procession in which they sang patriotic songs and displayed Italian tricolored cockades and flags. Inspector Olimpio Lendaro (VGPC-Monfalcone), "Monthly Report on the Corps Activity, Feb 1947," 24 February 1947, NARA, RG331, UD1981, b 9186, f 11304/115/278. By contrast, the political meetings never surpassed 200 attendees. Maj. KitsonHarris, "Monthly Report of Monfalcone Group CAO to AMG HQ Trieste Area, 31 October 1946, op. cit.; Maj. Hill, "Monthly Report, Jun 1947," 25 June 1947; Maj. Hill, "Monthly Report, Jul 1947," 26 July 1947, both in NARA, RG331, UD1981, b 9186, f 11304/115/278.

${ }^{42}$ See fn 35 .
} 
noted that various high-profile pro-Italians of the area, almost all LN members, had "been challenged, threathened [sic], and shot at with the obvious intent to kill them, sometimes in broad daylight." Particularly notable were an incident on 12 September, in which explosives rocked the home of a leading Actionist strong-arm and CRDA piecework clerk Umberto M., who escaped injury, and another two weeks later, in which the PSI and SG leader Gaetano Minervini was shot three times in broad daylight while cycling past the Monfalcone cemetery. ${ }^{43}$ After the October demonstration, the pro-Yugoslavs extended their offensive to attacks on the police, with VGPC agents regularly attacked with firearms and grenades. Most shockingly, in early November, an unidentified pro-Yugoslav fired a Panzerfaust into the fully staffed Panzano station, causing serious damage, though no injuries. The next morning, VGPC agents escalated the general antagonism when they beat random shipyard workers in retaliation. ${ }^{44}$

Despite the escalation of violence carried out by pro-Yugoslavs, this was not the most striking development in October. In the assessment of CAO Kitson-Harris, that title belonged to an "armed campaign of retribution" that began suddenly that month, in which pro-Italians brought "machine guns and home-made bombs" to bear against their pro-Yugoslav opponents. The perpetrators backed up this armed terror campaign with threats sent to prominent UAIS members warning them of what could "reasonably be expected to happen to them if they continue to reside

\footnotetext{
${ }^{43}$ Maj. Kitson-Harris, "Monthly Report of Monfalcone Group CAO to AMG HQ Trieste Area," 31 September 1946, op. cit. The anti-Fascist and staunchly pro-Italian Minervini survived the attack. He would later head Monfalcone's $\mathrm{CdL}$ and provide leadership to the local leftist coalition, the Popular Democratic Front, that same year, thus oddly cooperating with the PCI, which by then included many of the pro-Yugoslavs who had formerly attacked him. ASG, Questura 1948, b 8, f 1201.

${ }^{44}$ Maj. Kitson-Harris, "General Situation in Monfalcone," 6 November 1946, NARA, RG331, UD1981, b 9186, f 11304/115/283. As examples of attacks, on 17 October, two VGPC officers were shot at with small arms; on 24 October, someone threw a grenade into the VGPC station at the CRDA; and on an unspecified October day, unknown individuals shot up a VGPC Jeep with a machine gun. Though in these cases there was no serious injury, on 25 November, the body of a hated VGPC agent involved in the Servola Incident turned up in a Monfalcone canal, bearing "marks of violence." SCAO Meeting Minutes, 28 October 1946, NARA, RG331, UD1981, b 9108, f 11302/115/89; Maj. Kitson-Harris, "Monthly Report of Monfalcone Group CAO to AMG HQ Trieste Area," 31 October 1946, op. cit; SCAO Meeting Minutes, 9 December 1946, op. cit.
} 
here. ${ }^{45}$ Prominent pro-Yugoslavs found written threats in their mailboxes (Figure 18), ${ }^{46}$ primed TNT charges left outside the doors of their homes, ${ }^{47}$ and the printing of their names in the "Register of Infamy" of the clandestine far-right paper, Rocca d'Italia. ${ }^{48}$ When they did not heed the warning or were too slow to respond, then bombs flew. As Kitson-Harris reported, in October, "there has hardly been a single night when firearms or bombs have not been used offensively against private individuals' house [sic], or some political HQs." 49

The violence continued thereafter, and by the turn of the new year, Monfalcone had descended again into a near civil war. The two opposing factions were gripped by what the Italian CLN president, Umberto Zuccolini, termed a "psychosis of violence and consequent vendettas," violent members of each perpetrating acts that stood "in defiance of even the most basic democratic standard." ${ }^{50}$ In the leadup to the long-awaited Signing Day (10 February 1947), as pro-Italians felt both emboldened locally and enraged over Italy's loss of Istria and Dalmatia, the psychosis deepened. In the last half of December, "revolutionary Italian types" carried out 31 bombings of UAIS militants' homes, sixteen on the weekend of 14-15 December alone. ${ }^{51}$ The assault continued the following month, including the ignition on 26 January of a large explosive charge outside a Panzano home housing six families, among them three mid-level leaders in the pro-Yugoslav movement (Alberto D., Aldo V., and Emilio F.) and the partisan commandant Mario Fantini. The

\footnotetext{
${ }^{45}$ Maj. Kitson-Harris, “Monthly Report of Monfalcone Group CAO to AMG HQ Trieste Area,” 31 October 1946, op. cit.

46 "Le bombe non servono," Il Lavoratore, 30 September 1946. Kitson-Harris's October report confirms these threats.

47 "I depositi funzionano," Il Lavoratore, 4 January 1947.

${ }^{48}$ Three extant copies can be found at ACS, MI, DGPS, Div SIS, Sez II, AA GG 1944-49, b 90, f QP180. Threats also came in illegal broadsheets posted at night throughout the town. General Staff Intelligence, General HQ of Central Mediterranean Force, "NE Italy ISUM No. 26 for Period 22 to 28 Jan [1947]," 29 January 1947, NARA, RG331, UD1981, b 9212, f 11304/115/534.

${ }^{49}$ Maj. Kitson-Harris, "Monthly Report of Monfalcone Group CAO to AMG HQ Trieste Area,” 31 October 1946, op. cit.

${ }^{50}$ Umberto Zuccolini (CLN-Monfalcone [pro-Italian]), "Seduta straordinaria del C.L.N.," 31 January 1947, NARA, RG331, UD1981, b 9186, f 11304/115/278.

${ }^{51}$ Maj. Kitson-Harris, "Monthly Report of Monfalcone Group CAO to AMG HQ Trieste Area," 31 December 1946, NARA, RG331, UD1981, b 9188, f 11304/115/288.
} 
blast "lightly" injured a young girl inside and shattered eighty panes of glass, leaving the homes frigidly cold. ${ }^{52}$ Despite UAIS efforts to form squads of "red guards" who would disarm suspect individuals entering pro-Yugoslav neighborhoods, ${ }^{53}$ that February there were a further 38 attacks against Communists and pro-Yugoslavs in the Monfalconese. Particularly malicious was an attack on the former gappista and Ronchi resident, Vinicio Fontanot, whose home was the target not just of a bomb, but also of machinegun fire, though everyone present escaped harm. ${ }^{54}$ In the wake of such attacks, Il Lavoratore decried that the pro-Italians were attempting to create an "atmosphere of italianità using bombs, TNT, and threatening letters." ${ }^{.55}$

Despite these attacks occurring under cover of darkness, the perpetrators became known rather quickly. In fact, by the turn of 1947, the AMG knew that the perpetrators involved a complex nexus of individuals directed locally by extreme nationalists (often ex-Fascists) of the LN and proItalian ex-partisans of the PDA, often using Italian nationalist students and recently-arrived esuli as muscle. ${ }^{56}$ The PDA group, headed by the Actionist partisan and CRDA worker Pietro Dominutti, consisted of an odd mix of former-Fascists-turned-Actionists (Umberto M.), Fascistera "imported" Southerners with nationalist tendencies (Giuseppe I.), and even a former garibaldino of the Natisone who rejected Yugoslav annexation and who became a leading postwar PSI and API figure (Pietro G.). ${ }^{57}$ Cooperating with the Dominutti group were many ex-Fascists of

\footnotetext{
52 Ibid.; VGPC-Monfalcone, "Rapportino degli incidenti verificatisi delle ore 7.30 del 26.1.1947 alle ore 7.30 delle 27.1.1947," 27 January 1947, NARA, RG331, UD1981, b 9207, f 11304/115/478.

${ }^{53}$ GSI GHQ CMF, "NE Italy ISUM No. 29 for Period 12 to 18 Feb 47," NARA, RG331, UD1981, b 9212, f $11304 / 115 / 534$.

${ }^{54}$ Maj. Kitson-Harris, "Monthly Report of Monfalcone Group CAO to AMG HQ Trieste Area," 28 February 1947, NARA, RG331, UD1981, b 9188, f 11304/115/288. The eighteen attacks in the Monfalconese during first half February matched the figure for the entire remainder of the AMG. SCAO Meeting Minutes, 17 February 1947, NARA, RG331, UD1981, b 9108, f 11302/115/89.

55 "I nemici d'Italia operano nel Monfalconese," Il Lavoratore, 12 February 1947.

${ }^{56}$ Maj. Kitson-Harris, "Monthly Report of Monfalcone Group CAO to AMG HQ Trieste Area," 31 January 1947, NARA, RG331, UD1981, b 9188, f 11304/115/288.

${ }^{57}$ In March 1946, PCRG intelligence revealed that Dominutti, Giuseppe I., Pietro G., and three others were circulating town in a car with Roman plates, removing wall writings. Unsigned, Handwritten Report "Petronio Vinicio," Undated, AS 1570, b 9, f 6, sf Informazioni. Regarding Umberto M., Il Lavoratore identified him as an "old and notorious
} 
the local LN headquarters (such as the president of the Ronchi branch, whose home was searched in March 1947, revealing a submachine gun, 800 rounds of ammo, and 10 grenades), as well as a range of nationalist students and esuli, the latter including some neo-Fascists such as the former SS volunteer Giuseppe Milocchi. ${ }^{58}$ According to former participants' testimony, arms and bombs flowed through the PDA headquarters, with the low-level muscle receiving a small bounty for each bomb thrown. ${ }^{59}$ Finally, it is possible that Monfalcone's pro-Italian terrorists had direct connections to the Italian state or indirect connections mediated by pro-Italian paramilitary formations such as the Divisione Gorizia of Gorizia Area or the Third Corps of Volunteers of Liberty in Udine, the latter of which had an information office that, as of March 1947, "maintained, and perhaps still maintains, the connection both with the Allies and with Monfalcone."60

Though the outlying limits of this organization are hazy, the motives that brought them all together are clear. Though some have classed the terror campaign as an expression of "neo-Fascist" vendettas against Resistance fighters, the real unifying motivation was the desire to protect Italian

Fascist." "25.000 cartucce per mitra scoperte a Monfalcone," Il Lavoratore, 17 August 1946. On Giuseppe I.'s background, see Bonelli, "Seconda testimonianza del monfalconese Romano Spartaco," 19 March 1981, op. cit. On Pietro G., see ASG, Questura 1948, b 5, f 796.

${ }^{58}$ On the Ronchi LN president see Maj. Kitson-Harris, "Monthly Report of Monfalcone Group CAO...," 31 March 1947, op. cit. On Milocchi, see Di Gianantonio et al, L'immaginario imprigionato, 145.

${ }^{59}$ Di Gianantonio et al, L'immaginario imprigionato, 147-48. When the VGPC caught a group of five men in the act of bombing a pro-Yugoslav residence in February, all the perpetrators turned out to be student-aged esuli who had settled in Monfalcone. VGPC-Monfalcone, "Rapportino delle novità giornaliero," 7 February 1947, NARA, RG331, UD1981, b 9207, f 11304/115/478.

${ }^{60}$ Italian state intelligence believed the unit received support from a Marshall De Stefano and various lieutenants of the alpini. Unsigned, "Relazione sulla costituzione e sul funzionamento del 3o Corpo Volontari della Liberta'," 5 March 1947, ACS, MI, Gab 1948, b 38, f 11795. PCRG intelligence suggests that the Dominutti group had stronger ties to Udine Province than Gorizia, as it was primarily from Udine that members recruited strongly pro-Italian students to arrive for protests in Monfalcone and strongly pro-Italian guards to be hired by the CRDA. "Sandro" (PCRG Intelligence), "Alla Segreteria [PCRG]," 30 March 1946; Handwritten Report, 5 April 1946, both in AS 1570, b 9, f 6, sf Informazioni. The role of such paramilitaries (particularly the Divisione Gorizia) is disputed, though it is of note that the threat delivered to Sergio Bortolutti (Figure 18) bore the Divisione Gorizia's stamp. It is possible the letter was forged, as Roberto Spazzali, the first historian to recieve access to the internal records of the Divisione Gorizia, finds no documentation that explicitly links the Divisione to the terror campaign in the Monfalconese. Moreover, he suggests that the Divisione had little organization in the Monfalconese proper. Roberto Spazzali, Gorizia 1945-1948: la difesa dell 'identità italiana con la 'Divisione Volontari Gorizia' (Gorizia: Ed. Lega Nazionale, 1991), esp. ch. 2. 
sovereignty over and the italianità of the area. ${ }^{61}$ For many, "italianità" was inflected with a parallel meaning of "anti-Communism." For some, the desire to protect Italian sovereignty was tied to a deep-seeded sense of Italian racial superiority relative to Slavs, like that which drove Fascist-era brutalities. Whatever the individual's conception of italianità, beginning in late 1946, neo-Fascists like Giuseppe Milocchi and former anti-Fascist partisans like Pietro Dominutti joined in a temporary alliance to eradicate threats to Italian sovereignty in the region. As one participant in the pro-Italian struggle later recalled, "the Italian faction was unified by the name Italy! Italy! Italy! You were first an Italian and only afterwards a Christian Democrat, Liberal, Social Democrat, or missino [neo-Fascist of the MSI]. ${ }^{.62}$

In the first months of this terror campaign, the AMG neglected to prosecute these crimes vigorously, almost certainly due to the campaign's efficacy in sowing disorder among the proYugoslav organizations. As far back as October, Kitson-Harris reported with more than a hint of satisfaction that "[t]he general reaction of the UAIS faction to this onslaught, has not been one which may be said to have caused their dwindling followers to regain their former braggadocio." In fact, because of it, the "Big Five" had "decamped" from Monfalcone, fleeing with wives and children into Zone B. ${ }^{63}$ Even two months into the campaign, the AMG merely warned both the perpetrators and their known political supporters "through unofficial channels that these activities had better cease or action would be taken accordingly." 64

Compounding the AMG's initial hesitancy to root out the perpetrators of such attacks was

\footnotetext{
${ }^{61}$ Olivo, "Comunisti ed esuli istriani," 71-72. For a work that attributes this terror campaign to "neo-Fascism," see Gombač, "Controesodo tra poteri popolare e GMA," in Il mosaico giuliano, eds. Altieri and Puppini, op. cit. 57-58. ${ }^{62}$ Olivo, "Comunisti ed esuli istriani," 75.

${ }^{63} \mathrm{CAO}$ Kitson-Harris also rather darkly reported that "the cynic may assert that the solution to the problem may be for either side to continue to eliminate its undesirable characters, but as public order must be maintained, the cynic's possible assertion cannot, unfortunately, prove the answer in this matter." Maj. Kitson-Harris, "Monthly Report of Monfalcone Group CAO to AMG HQ Trieste Area," 31 October 1946, op. cit.

${ }^{64}$ Maj. Kitson-Harris, "Monthly Report of Monfalcone Group CAO to AMG HQ Trieste Area, 31 December 1946, op. cit.
} 
the inability - or, more accurately, unwillingness - of many VGPC agents and officers to bring perpetrators to justice. Ricciardelli himself had already indicated his willingness to subvert AMG justice in pursuit of helping the Italian cause, and when the pro-Yugoslavs demanded in February that the VGPC be dissolved due to its "manifest disinterest... in maintaining order" and for "support[ing] the Fascist squads in their activities," Kitson-Harris conceded that the force had been "singularly unsuccessful in arresting many of the culprits." 65 Though VGPC officers themselves always maintained that their failure to arrest suspects was due to a lack of evidence, it is telling that the AMG decided to sack Ricciardelli and his closest associates in the VGPC's CID less than two weeks later, by which time the violence was spiraling out of control. ${ }^{66}$

The removal of Ricciardelli did not rectify the partiality of the VGPC, nor did it stop the pro-Yugoslavs from calling for a stronger AMG crackdown on those responsible for the attacks. ${ }^{67}$ Though attacks nearly ceased in March and April, by mid-May both the businesses and homes of pro-Yugoslavs again came under fire. A particularly large explosion rocked the home of the SU organizer Volmaro Buttignon on the night of 15 May, resulting in thirty broken windowpanes, severe damage to the doorway and terrace, and the destruction of much of the kitchen. ${ }^{68}$ In no case

\footnotetext{
${ }^{65}$ Strike Committee in the Name of All Workers of the Monfalcone Zone, Protest to AMG-Monfalcone, 13 February 1947, NARA, RG331, UD1981, b 9186, f 11304/115/278; Maj. Kitson-Harris, “Attached protestation," 19 February 1947, NARA, RG331, UD1981, b 9186, f 11304/115/316. An exception was a group of five young nationalist students who were caught in the act. Maj. Kitson-Harris, "Monthly Report of Monfalcone Group CAO to AMG HQ Trieste Area, 28 February 1947, op cit.

${ }^{66}$ Insp. Olimpio Lenardo, VGPC-Monfalcone, "Relazione Mensile sull'Attività del Reparto, Jan 1947," 24 January 1947, NARA, RG331, UD1981, b 9207, f 11304/115/478; Insp. F. Ricciardelli, Untitled Report to the Capo della Polizia, Roma (N. 800 - Riservatissima), 1 March 1947, ACS, MI, Gab 1947, b 13, f 496.

${ }^{67}$ In March, the pro-Yugoslavs published an "informative warning" for the AMG, revealing eleven individuals who PCRG intelligence believed to be orchestrating the terror campaign and calling for the AMG to arrest the culprits. Among the suspects were various members of the Dominutti group (Dominutti, Umberto M., Milocchi), VGPC members known to help cover the activities of the terrorists, community leaders thought to be involved in organizing and outfitting the "neo-Fascist squads," organizer of squads within the CRDA and Solvay, and even the AMGappointed communal president, Riccardo Rovatti, who served as "a connecting bridge with representatives of the AMG to protect the Fascists of the [pro-Italian] CLN." L'occhio che vede tutto, "Avvertimento informativo per il G.M.A.," 1 March 1947, NARA, RG331, UD1981, b 9186, f 11304/115/316.

${ }^{68}$ SCAO Meeting Minutes, 31 March 1947, NARA, RG331, UD1981, b 9108, f 11302/115/90; Maj. Kitson-Harris, "Monthly Report of Monfalcone Group CAO to AMG HQ Trieste Area," 30 April 1947, NARA, RG331, UD1981, b 9188, f 11304/115/288; Maj. Hill, “Monthly Report, May 1947,” 28 May 1947, op. cit.
} 
did the VGPC make an arrest, and Kitson-Harris, who now saw this terror campaign as more of a liability than a blessing, wrote the VGPC a scathing reminder that "if the police fail to obtain bodies after one of these incidents, they have failed in their mission. Whether the body so obtained is the correct and guilty one is, in the earlier stages of investigation, immaterial." ${ }^{69}$ Despite the fact that the AMG thereafter ordered the VGPC to engage in night patrols to stop these attacks, attacks continued through year's end, and by early 1948, Il Lavoratore claimed that pro-Italian terrorists had used 1100 grenades and explosive charges in their campaign of the two years prior. ${ }^{70}$

Though this campaign of violence was clearly disruptive for the victims on an individual level, it is worth considering its effects on the community from the perspective of daily life. Notable is a pattern to the attacks, in which those enduring multiple attacks tended to be individuals who provided a source of social cohesion to the pro-Yugoslav community - those who ran taverns, barbershops, and cultural associations frequented by pro-Yugoslavs. Two taverns in particular became the sites of multiple bombings. The first, bombed four times between December 1946 and May 1947, was the Hunter's Tavern (Trattoria Al Cacciatore) on Via Ponziana, which was owned by a pro-Yugoslav and managed by another. The second, run by the staunchly pro-Yugoslav Barbo family, was situated in the Piazza Cavour. ${ }^{71}$ Similarly, pro-Italians struck repeatedly at the

\footnotetext{
${ }^{69}$ The catalyst for the report was that various "Italian students of a neo-fascist type" had sacked the Communist HQ in Monfalcone, and though police arrived while the perpetrators were still there, they "forgot or decided not, to arrest anyone of the agitators." Maj. Kitson-Harris, "Anti-terrorist precautions in Monfalcone," 21 May 1947, NARA, RG331, UD1981, b 9207, f 11304/115/478.

${ }^{70}$ The VGPC never made meaningful arrests. Maj. Kitson-Harris, "Monthly Report of Monfalcone Group CAO to AMG HQ Trieste Area," 31 May 1947; Kitson-Harris, "Monthly Report of Monfalcone Group CAO to AMG HQ Trieste Area," 31 July 1947, both in NARA, RG331, UD1981, b 9188, f 11304/115/288; Maj. Hill, "Monthly Report, Jun 1947," 25 June 1947, op. cit. For the estimate, see "Dopo il recente delitto a Monfalcone," Il Lavoratore, 17 January 1948. Though this figure should be taken with several grains of salt, the total number of attacks was certainly in the hundreds, with many militants attacked repeatedly. In the 1970s, the researchers of the IRSML compiled a list of attacks in the Monfalconese during these years, based on in Il Lavoratore and other sources. Thought this work is highly valuable to anyone seeking to understand postwar Monfalcone, a comparison with AMG documentation indicates that not all attacks received coverage in the papers and thus the list is far from exhaustive. IRSML, Nazionalismo e neofascismo nella lotta politica al confine orientale, 1945-75 (Trieste: IRSML-FVG, 1977).

${ }^{71}$ These were on 14 December, 9 February, 26 April, and 14 May, with the last causing over 100,000L in damages. VGPC-Monfalcone, "Rapportino giornaliero delle novità," 14 May 1947, NARA, RG331, UD1981, b 9207, f
} 
barbershop and home of the brothers Cesare and Alessandro Passudetti, both PCRG militants, whose shop on the Corso del Popolo became a pro-Yugoslav haunt. ${ }^{72}$ As these attacks fell upon the social nodes of the community, the Italian terror campaign not only threw the pro-Yugoslav organizations into disorder by driving away key militants; it also deprived pro-Yugoslavs of those spaces in which they tightened the community bonds that reinforced the perception of "Monfalcone antifascista" and in which they articulated visions for the future. ${ }^{73}$

\section{The Disintegration of the Pro-Yugoslav Movement, Spring 1947}

By early 1947, the Monfalconese's pro-Yugoslav movement - or, rather, its pro-Free Territory of Trieste movement - was in complete disarray. ${ }^{74}$ Threatened with arrest and violent attacks, many of its leaders had fled to Zone B or Yugoslavia, leaving its organizations without

11304/115/478; TRUST, Intelligence Summary No. 2, May 1947, NARA, RG331, UD1981, b 9084, f 11300/200/8. The case of the Barbos is more complex. The owner, the pro-Yugoslav Rodolfo Barbo, had seen one son die in the Resistance, his other son, Ferruccio, serving in the Brigata Triestina and with the GAP, becoming a close associate Mario Fantini and Vinicio Fontanot. In the period after liberation, Barbo was implicated in various actions against pro-Italian militants, and particularly members of the Dominutti group, including being identified by police as a suspect in the attempted murder of Umberto M. in 1946. Thus, though this case is inflected with a high degree of personal vendetta, the point stands that the Barbos, in operating their tavern, provided a point of cohesion for the proYugoslavs. Brigata Triestina, Scheda Personale: Ferruccio Barbo, 13 July 1944, IRSML, Fondo Jaksetich, b 9, f 76; "Bombe fasciste a Monfalcone," Il Lavoratore, 2 November 1946; Comandante Grieco (VGPC-CID-Monfalcone), "BARBO Rodolfo fu Pietro..." (N. 2730), 2 December 1946, ASBCM, b 517, f Ctg 3, sf Cl 1; VGPC-Monfalcone, "Rapportino giornaliero delle novità, 30 April 1947, NARA, RG331, UD1981, b 9207, f 11304/115/478. On police suspicion about Ferruccio Barbo's role in the attempted murder of Umberto M., see the Italian state's surveillance file on Ruggero Bersa. Prefetto Palamara, "BERSA Ruggero di Giovanni...," 3 February 1949, MI, DGPS, Div AA RR, Ctg Perm, Ctg Z b 65, f Ruggero Bersa di Giovanni.

${ }^{72}$ Their shop was bombed twice, their home threatened once with an unexploded charge hung from the door handle. VGPC Sub-Inspector Grieco, "Act of sabotage against the hairdresser's shop belonging to the brothers PASSUDETTI...," 11 July 1947; VGPC-Monfalcone, "Daily News Report," 10 August 1947, both in NARA, RG331, UD1981, b 9207, f 11304/115/478; "Dopo il recente delitto a Monfalcone," Il Lavoratore, 17 January 1948.

${ }^{73}$ By contrast, both Il Lavoratore and the Insp. Lendaro (VGPC-Monfalcone), considered the campaign to have more concrete, material motives, Il Lavoratore emphasizing how this was a method by which esuli could drive native businesses out of the town and thus create a space for their own economic activity, Lendaro suggesting it served the purpose of freeing up housing for the esuli in a time when housing was in dire shortage. "Se non bastano offerte ci sono le bombe," Il Lavoratore, 11 July 1947; Insp. Lendaro, "Relazione Mensile sull'Attività del Reparto, Jan 1947," 24 January 1947, op. cit.

${ }^{74}$ In late December, CAO Kitson-Harris had likened the UAIS to "a circus which is due to leave town after its 'tour de force' and is more interested in sorting and collecting its props and living on past memories, than in continuing to fan the flames of political re-action." Kitson-Harris, "Monthly Report of Monfalcone Group CAO to AMG HQ Trieste Area," 31 December 1946, op. cit. 
clear direction. Moreover, the signing of the Peace Treaty and the resurgence of the pro-Italian faction - both in its terroristic and democratic forms - put the remaining militants in a hopeless position. Unlike nearby Trieste, where the pro-Yugoslav struggle reconfigured itself as a struggle by the pro-Yugoslavs to capture the soon-to-be Free Territory's government and then reopen the question of Yugoslav annexation, in Monfalcone, the prospects of annexation had simply disappeared. Thus, throughout the spring of 1947, there was a significant institutional realignment in the Monfalconese, as the formerly pro-Yugoslav organizations adapted to the new situation and prepared for participation in the Italian political contest.

One by one, the pro-Yugoslav institutions of the Monfalconese disbanded. The first to go was the SU. The CGIL's formal recognition of the SG and the signing of the Peace Treaty left the Monfalconese branch with little choice but to negotiate a fusion treaty with the SG. ${ }^{75}$ Its overwhelmingly Communist leadership pursued a settlement in which Communists would hold a preponderance of influence within the united union, and by April the branch dissolved itself, ordering its members to join the SG as individuals. ${ }^{76}$ With this decision, the syndical movement within the Monfalconese was once again institutionally unified, though the membership of the united syndicate remained deeply divided, not least of all along the clerk-worker divide. As a result, much of the former SU membership fell into apathy and inactivity. ${ }^{77}$

While the negotiations for syndical fusion were nearing their conclusions, the leaders of the PCRG too were attempting to adapt to the looming return of Italy, negotiating with PCI leaders

\footnotetext{
${ }^{75}$ Since the previous summer the SU and SG had been discussing the prospects of fusion under the guidance of the World Trade Union Congress, but the antipathy between the rank-and-file and leaders of the unions, as well as logistical disagreements, prevented concrete accomplishments. Maj. Kitson-Harris, "Monthly Report of Monfalcone Group CAO...," 31 March 1947, op. cit.; Cernigoi, Puppini, and Valcovich (eds), Cento anni di cantiere, 50-51. This change in SU line did not apply within the TLT.

76 "Verbale di accordo per il raggiungamento della unità sindacale tra tutti i lavoratori di Monfalcone e zona Monfalconese in seno alla C.G.I.L," 28 April 1947, AGPCM, Fondo UZC, Sez II: Gorizia, b 3.1, f 4.

77 The apathy is demonstrated by the anemic turnout in Monfalcone for the May Day celebrations of 1947, the first since syndical fusion. SCAO Meeting Minutes, 12 May 1947, NARA, RG331, UD1981, b 9108, f 11302/115/90.
} 
who had been their near-enemies just months prior. In January, Giordano Pratolongo of the PCI's Information Office in Trieste met with the PCRG leadership for areas destined for Italy and sought to convince them of the necessity of propagandizing in favor of the PCI and preparing for the reconstitution of the PCI in that area. Though the leaders proved to be "fully in agreement," Pratolongo recognized that this process would be very difficult. The rank-and-file of the PCRG was less willing to adapt to the new situation than longtime leaders, who had lived through many sudden and shocking changes in the Party line during the Fascist era. Moreover, the postwar territorial struggle had tainted the pro-Yugoslav militants in the eyes not just of anti-Communists, but even of some PCI members with strong national sentiments. To solve this, Pratolongo suggested that the Party carefully choose a new, untainted leadership core to head a reconstituted Gorizia Federation, imported from outside of Gorizia. ${ }^{78}$ By late April, the Monfalconese's PCRG organs had ceased to exist, replaced by sections of the PCI's Gorizia Federation, headed by the former partisan commandant Lino Zocchi (Ninci). ${ }^{79}$ As the Federation prepared for its First Conference that summer, questions remained as to whether it would be able to convince the other parties that it was not, in the words of one worried PCI leader, a "fifth column of a foreign power," but rather a "national party not driven by an agenda regarding the definitiveness of the borders." $\$ 0$ The distrust between many former PCRG militants and the PCI was slow to dissipate.

As the institutions that had previously channeled the pro-Yugoslav movement dissolved, the pro-Yugoslavs of Monfalcone found themselves living in a town that was no longer the

\footnotetext{
${ }^{78}$ Giordano Pratolongo, Letter to PCI-Segretaria (N. 0555), 14 January 1947, AM-IG, Fondo Jug e VG, mf 134, f Partito Comunista Giuliano, Ufficio Informazioni PCI-Trieste.

79 Luigi Longo and PCI-Direzione, "Risoluzione," 29 March 1947, NARA, RG331, UD1981, b 9186, f 11304/115/278; Mario Fantini and PCI-Monfalcone, Letter to the CAO-Monfalcone, 28 April 1947, NARA, RG331, UD1981, b 9161, f 11304/115/94; Vinicio Fontanot and PCI-Ronchi, Letter to the CAO-Ronchi, 30 April 1947, NARA 331, UD1981, b 9186, f 11304/115/316.

${ }^{80}$ Franco Verzegnassi, "Nota sulla situazione politica nei territori della Venezia Giulia...," May 1947, AM-IG, fondo Jugoslavia e VG, mf 134, f Trieste e Pola.
} 
"Monfalcone antifascista" they had known during the first eighteen months after liberation. As the pro-Yugoslavs' ability to mark public space deteriorated, the symbols associated with the proYugoslav struggle receded from public view. Indicative of this trend was a commemorative plaque that the UAIS and APG had constructed in the town's central piazza, outfitted with a red star and dedicated to the fallen in the Liberation Struggle (a tribute to the Slovenian Liberation Front). Since war's end, this plaque had served as the focal point of pro-Yugoslav demonstrations and processions. It served as a physical location at which UAIS processions typically ended, and, located in the central piazza, it made a symbolic claim as to the true "heart" of Monfalcone. Though this plaque had stood undisturbed for over a year since war's end, with the resurgence of the proItalian faction, it became a focal point of the symbolic war over the town. In November 1946, the plaque had been "besmirched with a thick slime," but it was in the wake of Signing Day that it was most clearly targeted. ${ }^{81}$ On 24 February, a group of esuli, supported by various anti-Communist members of Monfalcone's API were dispersed by the VGPC when they attempted to cut the red star from the plaque. That same night, they returned, removing the star and placing it in a sack bearing the phrase "Tito died in MONFALCONE on the night of 24 February." When news of this iconoclasm reached the CRDA the next day, some 2500 workers engaged in a protest strike. ${ }^{82}$ Faced with the likelihood of repeated acts of vandalism, the APG elected to relocate the plaque from the piazza to the garden in front of its own headquarters, where there was always a handful of partisan guards on duty. ${ }^{83}$ In doing so, the UAIS and APG conceded that their symbols were no longer those of the town as a whole and that their control over the piazza had been broken.

\footnotetext{
${ }^{81}$ Maj. Kitson-Harris, "Monthly Report of Monfalcone Group CAO...," 30 November 1946, op. cit.

${ }^{82}$ GSI GHQ CMF, “Combined Venezia Giulia ISUM No. 2 for period 26 Feb to 4 Mar 47," 4 March 1947," NARA, RG331, UD1981, b 9212, f 11304/115/534.

${ }^{83}$ APG-Monfalcone, Lettera al Consulta comunale-Monfalcone, 8 March 1947, AS-BCM, b 525, f Ctg XIV; VGPCMonfalcone, "Rapportino giornaliero delle novità," 17 March 1947, NARA, RG331, UD1981, b 9207, f $11304 / 115 / 478$.
} 
With the pro-Yugoslavs beating an increasingly disorganized retreat, the pro-Italians struck directly at the heart of the pro-Yugoslav stronghold: the CRDA. From the moment of liberation, this site had been marked with several massive, red, sheet-metal stars hung from cranes and the firm's water tower. With the coming of Signing Day, this symbolic supremacy came under assault. In concert with the CRDA Direction, members of the SG entered the CRDA under cover of darkness and cut the supports for these giant stars, sending them crashing to the factory floor. In the place of the stars they left Italian tricolors, thus openly challenging the pro-Yugoslavs' control over what CAO Kitson-Harris termed the UAIS "Holy of Holies." 84 Though the UAIS and SU restored the largest of the stars, in early April a group of pro-Italians again cut them down, this time for good. The act sparked no notable protests or agitation, and thus when AMG officials met in Trieste just days later, the Area Commissioner for Trieste Area noted with relief that this certainly marked 'the end of the 'reign' of the UAIS in Monfalcone Area." ${ }^{85}$ A week later, this hope was confirmed when the pro-Yugoslavs of the Solvay voluntarily removed the giant red star at that worksite when they learned that a group of esuli were planning to cut it down. ${ }^{86}$

The death knell for Monfalconese's pro-Yugoslav movement came the following month, with a major public order incident outside the UAIS headquarters. In the early evening of 24 May, a group of esuli began to form outside the UAIS HQ near the intersection of the Corso del Popolo and the Viale San Marco, shouting threats at UAIS members gathered there. The latter returned the vitriol and a fifty-man scuffle ensued when the esuli moved to tear down the UAIS sign.

\footnotetext{
${ }^{84}$ Maj. Kitson-Harris, "Monthly Report of Monfalcone Group CAO...," 28 February 1947, op. cit.

${ }^{85}$ SCAO Meeting Minutes, 14 April 1947, op. cit. As Anna Di Gianantonio and her colleagues have shown, in the memory of the strongly pro-Italian, anti-Communist monfalconesi, it is this moment rather than the Twelve Days Strike that marked the climax of the postwar territorial struggle, as this was the moment the town had been definitively "rescued" from the grasps of Yugoslavia. Di Gianantonio et al., L'immaginario imprigionato, 156-57. Only in late June did the AMG order the VGPC to vacate the shipyard, leaving internal security in the hands of private company guards after ten months of occupation. Maj. Kitson-Harris, "Monthly Report of Monfalcone Group CAO to AMG HQ Trieste Area," 30 June 1947, NARA, RG331, UD1981, b 9188, f 11304/115/288.

${ }^{86}$ Capt. Hill, "Monthly Report, Apr 1947," 25 April, NARA, RG331, UD1981, b 9186, f 11304/115/278.
} 
Though the police soon arrived to end the original quarrel, in the interim, each side had called in reinforcements and the police lost control of the situation. As esuli continued to flow to the location, the UAIS ranks were swelled by groups of garibaldini (not all pro-Yugoslav) including the Romano brothers, Ferruccio Barbo, and Mario Fantini. According to one pro-Italian observer, the groups met and began punching one another. As police from a nearby Jeep disembarked near the UAIS headquarter, "the rioters, instead of carrying on their fight, turned against the Police who were attempting to clear out the crowd. ${ }^{, 87}$ With the arrival of more police, the brawl escalated from one pitting esuli against UAIS supporters to one that also involved a major confrontation between the garibaldini and the VGPC. According to a (potentially sensationalized) police report, at various points, police agents became isolated and had to be "rescued" from garibaldini who knocked them to the ground and pummeled them without mercy. Only after an hour was order restored, with an untold number of injuries and eleven arrests (six esuli and five garibaldini). ${ }^{88}$ The same pro-Italian observer cited above would claim that "everybody is hoping - for peace's sake - that A.MG. [sic] would become - in time - strict as ever and more than ever" against the UAIS leaders, who "stir up their followers against ALL which is not RED STARRED." ${ }^{89} \mathrm{He}$ would get his wish. Immediately following the disturbance, the AMG expelled the UAIS from its HQ and, with the local Communist Party no longer lending support to the organization, the UAIS collapsed. ${ }^{90}$

Though only in mid-1947 did the UAIS close its doors, disillusionment had long reigned

\footnotetext{
${ }^{87}$ Ezio Bartolomei (trans.), Untitled Report to Maj. Hill, Undated (Late May 1947), NARA, RG331, UD1981, b 9207, f 11304/115/478.

${ }^{88}$ Inspector Lenardo (VGPC-Monfalcone), “Incident nearby the local U.A.I.S. H.Q.,” 24 May 1947, NARA, RG331, UD1981, b 9207, f 11304/115/478.

${ }^{89}$ Bartolomei, Untitled Report to Maj. Hill, Undated, op cit.

${ }_{90}$ Maj. Kitson-Harris, "Public Disorder - Incident in Monfalcone," 24 May 1947, NARA, RG331, UD1981, b 9207, f 11304/115/478. The PCI's leadership in Rome also moved against the UAIS of Monfalcone in the wake of the incident, sending the Central Committee member Ruggero Grieco to speak at the Gorizia Federation's first conference, where he pushed for the dissolution of the UAIS and the migration of its members into the new PCI. Ruggero Grieco, "Intervento del comp. Grieco del Comitato Centrale del PCI," 16 June 1947, Archivio PCI-IG, Federazioni, 1947, Gorizia, mf 140, p 1847.
} 
among the pro-Yugoslavs. Not only had their hopes for Resistance and liberation been frustrated, but, in recent months, many had lost faith in their movement's institutions. The image of "Monfalcone antifascista" had been shattered by a resurgence of a pro-Italian factions that attacked pro-Yugoslavs in their homes, destroyed the social nodes of community cohesion, broke the proYugoslav hold over the CRDA, and purged the town of pro-Yugoslav and pro-Communist symbols. As one pro-Italian informant reported to the Italian police that July, "Monfalcone is reassuming its Italian character." 91 As the pro-Yugoslav stranglehold over public space deteriorated, individuals associated with Fascism - whether actual Fascists or simply members of social categories associated with Fascism - again openly walked the streets. In May, a new chapter of the neo-Fascist MSI opened its doors in Monfalcone. ${ }^{92}$

Though disillusionment was widespread, pro-Yugoslav reactions to this disillusionment varied. Many, like Ruggero Bersa, continued to fight for Communism at home. Bersa adapted to the new context of the democratic political contest in Italy, become a key figure in the PCI's reconstituted Gorizia Federation. Others reacted quite differently. During the winter of 1946/47, as the implementation of the Peace Treaty loomed ever-closer on the horizon, many had begun to look for an escape-route, seeking a way to liberate themselves with their feet. The question for those considering departure was, naturally, where should they go? For the overwhelming majority, the choice was clear, and Tito's New Yugoslavia possessed a near-irresistible magnetism.

\footnotetext{
${ }^{91}$ Unsigned, "MONFALCONE” (N. 224/57711), 9 July 1947, ACS, MI, DGPS, Div SIS, AA GG 1944-49, b 77, f OP6.

92 TRUST, Intelligence Summary No. 2, May 1947, op. cit.
} 
Part II: Monfalconesi on the Move 


\section{Chapter 6: The Controesodo of 1946-47: Ideology, Ethnicity, and Necessity in the Choice to Cross the Iron Curtain}

Immediately laborers and their families began to depart, above all from the shipyard: qualified workers, specialists, and technicians too. But laborers from other factories and categories also left, peasants included. It seemed that our population had been taken by the 'psychosis of departure.' They abandoned jobs, homes, property, the land: and they departed at once for Yugoslavia. The sacrifices were immense: but our people were sustained by the ideal of socialism. ${ }^{1}$

- Mario Tonzar, Communist organizer and emigrant.

On the morning of 4 February 1947, three Bandelli brothers arrived at the gates of the CRDA. At 40 years old, Stanislao, was the oldest. Vittorio was two years younger, and the youngest, Ladislao, was thirty-five. The three had likely walked together to work, as each lived on the east side of town near the train station. If they did, they would have had much to talk about. All three were pro-Yugoslav militants and had served on the frontlines of the political struggle that had wracked the town in the twenty-one months since liberation. The two eldest, who worked together in the fifth workshop of the CRDA's Shipbuilding Department, had even headed their workshop's PCRG and UAIS cells. Whatever they discussed that winter morning, when they arrived at the shipyard, they did not take their normal path to their normal workshops. Instead, they headed to the personnel offices and announced that they were done working for the CRDA. They had decided that they and their families would depart for Yugoslavia. ${ }^{2}$

In reality, the Bandellis' resignations might not have gone so smoothly. Upon arriving at the personnel offices, they may have had to wait in line for some time. Though the personnel staff certainly had been expecting at least a handful of workers to arrive to announce their intention to

\footnotetext{
${ }_{1}^{1}$ Alfredo Bonelli, "Memorie del monfalconese Tonzar Mario," 6 March 1978, IRSML, Fondo Cominform, b 99, f 8.

${ }^{2}$ There was another Bandelli brother, Miroslao, who would also quit his job at the CRDA and depart, though on a different date. Stanislao settled in Fiume with his family, but I have not found documents that reveal the others' settlement location. UAIS-Monfalcone, Untitled List of CRDA Cadres, Undated (Late 1946), AS 1570, b 9, f Segretari Org Quadri Relazioni; Comp. D[x], "Relazione politico-organizzativa," 21 August 1946, op. cit.; Unsigned, "Elenco degli operai licenziati spontaneamente il 4 febbraio 1947," 5 February 1947, NARA, RG331, UD1981, b 9189, f $11304 / 115 / 308$.
} 
depart, the forty-eight who made a showing on 4 February were nearly double the twenty-seven of the day before. It was not their busiest day - sixty-seven had quit on 17 January - but it was the greatest turnover in well over a week. That said, it is possible that the personnel offices were expecting a rush. The pro-Yugoslav sentiments among the CRDA workers was well known and signing day for the Peace Treaty was less than a week away. It was perhaps foreseeable that many of these workers would be anxious to leave the Monfalconese before Italy returned. The Bandelli brothers and most of the others who visited the personnel offices on 4 February felt this way, as did most of the 510 others who had quit since the beginning of January. ${ }^{3}$

\section{Those who Left Before}

Though the bulk of the monfalconesi who left for Yugoslavia, including the Bandelli brothers, did so in 1947, a substantial number - at least several hundred - had preceded them in the two years prior. As with the emigrants of 1947, those of 1945 and 1946 left in different waves, with different motivations and different expectations. It is worth recalling the diversity of these earlier migrants in terms of both motives and social profile. An understanding of these earlier waves is necessary to comprehend fully why the 1947 migration wave played out the way it did.

The first three waves of emigrants have been discussed in previous chapters. The first were twenty-seven members of the Monfalconese Difesa Popolare who refused to put down their guns, instead electing to pass into Zone B still under arms, escorted by Anglo-American military forces. ${ }^{4}$ Little is definitively known about who they were, what drove them to this decision, or how long they imagined they would remain in Yugoslavia. What evidence remains suggests that they were revolution-minded Communists of the Monfalcone GAP, who sought to maintain their unit intact

\footnotetext{
${ }^{3}$ See the various lists in NARA, RG331, UD1981, b 9159, f 11304/115/86.

${ }^{4}$ There were 340 total members of the Monfalcone DP, meaning that just $8 \%$ elected to relocate. They were joined by 60 triestini and 40 goriziani. Capt. Welsh, "Disbanding of the 'Difesa Populare"' [sic], 24 June 1945, op. cit.
} 
beyond Anglo-American reaches. ${ }^{5}$ The second wave consisted of hundreds of single, unemployed young men who departed from Monfalcone after the April 1946 layoffs. Many had partisan pasts or were involved in pro-Yugoslav organizations, though their means and methods of departure varied widely, as did their level of skill. Some were skilled laborers who had given up their jobs so that higher-paid family members might remain employed (Renato Rigonat), while others, like Silvano Cosolo, entirely lacked industrial skills and saw no possibility for employment, let alone apprenticing in Monfalcone. ${ }^{6}$ Third, there were a handful of pro-Yugoslav organizers, propagandists, and militants who took refuge beyond the Morgan Line after the AMG issued arrest warrants for their participation in illegal political activity. Most notable were the Monfalconese's "Big Five," who had fled in the wake of the abortive 1 October demonstration, but there were also several low-level militants on the lam, accused of assaulting VGPC officers or political murder during the period of Yugoslav administration. ${ }^{7}$ Thus already by fall 1946, hundreds of monfalconesi had relocated to Yugoslavia for a range of reasons using a range of methods.

In fall 1946, however, as news sank in that Yugoslavia would not return, two new emigratory streams emerged. The first was a group of head technicians (capi tecnici) from the CRDA, headhunted by the Croatian branch of the SU for employment in Fiume's newly-renamed

\footnotetext{
${ }^{5}$ One was Egone Settomini, who gave testimony about his departure to Enrico Cernigoi. The documents of Riccardo Giacuzzo held at the IFSML in Udine reveal that Settomini was a GAP member. Giacuzzo continued to command this unit from Yugoslavia into 1946. Cernigoi, Scelte politiche e identità nazionale, 103-04; Riccardo Giacuzzo, "Elenco dei comb. della lotta di lib. app. alla G.A.P.," 27 June 1974, IFSML, Fondo Giacuzzo, b 5, f 134; Riccardo Giacuzzo (VII Compagnia-GAP, Bgt MG, II Div KNOJ), "Situazione interna e esterna della Compagnia G.A.P.," 6 December 1946, IFSML, Fondo Giacuzzo, b 2, f 41.

${ }^{6}$ Cosolo, Amare... Sarajevo, 17-18; Rigonat, Memorie, esp. 51. For examples of other partisan youth who had some industrial work experience, but were laid off in the spring of 1946 include Aldo G., Santo M., and Virgilio V. ASG, Questura 1948, b 5, f 769; b 7, f 1145; and b 12, f 1876. For an example of a young man who, like Cosolo, had been unable to find work since war's end, see Italo B., ASG, Questura 1948, b 1, f 174.

${ }^{7}$ On the "Big Five" and Cernigoi, see Maj. Kitson-Harris, "Monthly Report of Monfalcone Group CAO to AMG HQ Trieste Area," 31 October 1946, op. cit.; PCRG-IV Rione, "Relazione della riunione del comitato rionale," 5 October 1946, AS 1570, b 10, f 1, sf Relazione del rionale. For examples of individuals who fled for reasons of anti-police violence or political murders, see Fiorenzo P. and Rodolfo V., respectively in PCRG-CDM, "Al comitato popolare di Capodistria," 28 May 1946, AS 1570, b 9, f Posta in arrivo; ASG, Questura 1948, b 12, f 1918.
} 
Third of May Shipyard. Already by the winter of 1946/47, the SU of Trieste was responding to such requests, asking the SU of Fiume to make guarantees that these technicians' pensions would be honored, that their children would receive a quality education, and that their living quarters would be satisfactory and affordable. Though a small stream - the first request targeted only ten individuals, of whom five are known to have accepted - this development was significant. It marked a major shift in the nature of emigration. For the first time, the migrants were highly skilled and securely employed heads of families. Moreover, their concerns about pensions and their children's education indicate a clear assumption of permanent residence rather than temporary employment. But the recruitment of such technicians also indicated a shift in how the leadership of pro-Yugoslav organizations in Trieste and Belgrade viewed the Monfalconese after receiving news that the zone would remain Italian. It made clear that the Trieste and Belgrade leadership now viewed the Monfalconese workforce not as a bastion of pro-Yugoslav sentiment for the westward projection of Yugoslavia's borders, but instead as a repository of labor upon which labor-scarce Yugoslavia could draw. For this reason, the SU stressed the need to assure the positive experience of these first recruits to assure that "other whole groups can be found like the first." 8

A second and far more contentious new stream of emigrants involved the wider mass of shipyard workers, who since September 1946 (and especially since the October 1946 change in the UAIS line) had increasingly requested that the local SU find them jobs in Yugoslavia. ${ }^{9}$ Such requests followed upon the SU's creation of an Unemployment Coordination Office (Ufficio coordinatore disoccupati) in September 1946, which sought to balance the pro-Yugoslav

\footnotetext{
${ }^{8}$ The five known to have accepted this offer were in their late 30s or 40s and had nineteen dependents between them, each with a wife and at least two children. They included three capi tecnici navali, one capo tecnico attrezzatura, and a capo tecnico sala tracciatore. Unsigned (SU), Untitled List of Monfalcone Tecnici to Recruit to Cantiere 3 Maggio, Undated, op. cit

${ }^{9}$ Increasing worker discontent can be seen in Comp. M. C[x], "Ordina del giorno," 26 October 1946, op. cit.
} 
organizations' competing needs in Zone A, particularly with regard to labor and unemployment.

On the one hand, it was to coordinate welfare activities to support unemployed pro-Yugoslav workers and keep them in place, so they could continue the territorial struggle; on the other, it sought to funnel into Yugoslavia those workers intent on leaving, to meet Yugoslav labor needs. ${ }^{10}$

The emergence of these two emigratory streams caused major tensions between the proYugoslav bodies of the Monfalconese. Already by the end of September, the Monfalconese PCRG was trying to nip worker emigration in the bud. During a critical meeting of the Monfalconese leadership on 24 September, the district's organizational secretary, Fioravante B., had noted "a continual influx of comrades with requests for Party statements to support them going to work in Zone B or elsewhere." Given his belief that this was an "abandonment of the struggle," he requested of the SU liaison, Attilio Battilana, that the SU "be more rigid in its issuance of statements for going to work outside the zone." Battilana pushed back. Though he agreed that the Party should not indiscriminately honor such requests, he indicated that the PCRG's regional leadership in Trieste had already authorized the SU to help fulfill a request for 300-400 skilled Monfalconese workers that had arrived from the Communist Party of Fiume. Though the meeting concluded with agreement that "the Party reserves the right to issue statements only for those it believes opportune or depending on circumstances," it was clear that there were major disagreements between Monfalcone and Trieste as to which requests were "opportune."11

\footnotetext{
${ }^{10}$ The secretaries of the new office, one of whom was Rudi Uršič, wrote in their initial report that "currently we also have contacts in 'Zone B' and, specifically, with the Sindacati Unici of the PNOO of Aidussina. Frequent requests have been made on their part to send manpower to Zone B. Our Office responds fully also to this task and this might further develop in the future." Noni and Ursich (SU-Trieste), "Funzioni e sviluppi dell'Ufficio coordinatore disoccupati...," 23 September 1946, AS 1581, b 1, f 3-B.

${ }^{11}$ PCRG-IV Rione, "Relazione della riunione in data 24.9.1946," 24 September 1946, AS 1570, b 10, f 1, sf Relazione del rionale. In one successful request for such a statement - from the cousin of the very Rudi Uršič who headed the Unemployment Coordination Office - the request mobilizes the potential migrants' specialized labor capacity, partisan past, and PCRG membership to secure approval. Illegible (SU-Monfalcone), Handwritten Letter to Comp. V[x] (SUTrieste), Undated (1946), AS 1581, b 2, f 4-C.
} 
Such disagreements were not easily resolved. Four days later, at a conference of all the full PCRG members of the Monfalconese, Ruggero Bersa responded to a question about these transfers with an unambiguous statement that the Party had been forced to grant some requests due to personal need, but that "the $\mathrm{P}$ [arty] will do everything possible to end this emigration and ensure that comrades remain here to fight." Moreover, to questions about Monfalconese youth who had departed as members of the Youth Brigades and refused to return after their service ended, he stressed that the leadership would "try within the limits of our abilities to make these youth return." 12 What Bersa found, however, was that Battilana and the Monfalconese SU pushed forward with recruitment, despite local PCRG objections. When Bersa travelled to Trieste to voice opposition to both the recruitment itself and the SU's perceived insubordination, he found Branko Babič, Rudi Uršič, and others unwilling to shut off the tap, almost certainly due to orders originating in Belgrade. Instead, they gave him an order: cooperate with the SU. ${ }^{13}$

\section{Opening the Floodgates in Early 1947}

With this order, the floodgates of emigration truly opened. Bersa returned to Monfalcone and brought it before a hesitant district PCRG committee. Though prominent members like Otto

\footnotetext{
12 PCRG-IV Rione, "Conferenza di tutti gli effettivi di P; per il IV Rione," 28 September 1946, op.cit. Credit for discovering this source belongs to Anna di Gianantonio and her collaborators. Di Gianantonio et al, L'immaginario imprigionato, 159-60.

${ }^{13}$ Bersa recalls: "After the [Twelve Days Strike], in fact, a guest of the Sindacati Unici arrived at Monfalcone, directly from Belgrade, a syndical leader certainly of a high level and he requested that as large a number possible of laborers, technicians, and specialized workers relocate to Yugoslavia, where the massacres resulting from the merciless NaziFascist occupation had created created [sic] some appalling voids among the workforces of the great industries.... A request all too comprehensible, but which, before being accepted, would have to be deeply discussed and evaluated in all its implications and possible political, economic, and social consequences! Now, in that time, we had in the Party's district committee a syndicalist who clearly, given the nature of the syndicate, was used as a true and proper transmission belt of our political intentions. Well, on that occasion, contrary to what, in fact, had occurred until then, they Party found itself neatly and oddly bypassed without any opposition to the syndicate, which, indeed, initiated immediately a massive propaganda campaign within the factories... I went to Trieste where I had an exchange of ideas on the issue with Comrades Babic, Ursic, and other leaders, at the conclusion of which, however, I had to accept that this directive be accepted...." Fogar, "Seconda parte dell'intervista registrata rilasciata da Ruggero Bersa," November 1981, op. cit.
} 
Ferlettich spoke out against the idea, fearing that departures would hamstring Monfalconese Communism, the committee ultimately accepted the orders for reasons of Party discipline. Thus, in the first half of January, Bersa dutifully called a conference of pro-Yugoslav leaders at the UAIS headquarters, informing them that their organizations should work to coordinate the transfer of pro-Yugoslav workers to Yugoslavia, though with one important condition: high- and mid-level Party members were to remain in place to protect the organizational integrity of the Party. ${ }^{14}$ The directive, in Bersa's recollection, was "generally favorably received," after which militants went into the district's worksites to issue the call for departure, propagandizing loudly enough that their activity became a point of discussion on the pro-Italian Radio Venezia Giulia. ${ }^{15}$

When UAIS activists arrived in the workshops of the CRDA and Solvay, they found large swaths of the workforce not only receptive to the idea of relocation, but eager to do so. In the words of one SU official, enthusiastic workers "literally occupied the syndicate for the entire day" following the announcement. ${ }^{16}$ It was in this context that scenes like this chapter's introductory vignette unfolded, the CRDA's personnel office bombarded with resignations as workers jumped at the chance to live the Yugoslav dream. Departures began immediately and, in the words of CAO Hill, "almost every day [workers] leave Monfalcone in small groups of 25/30." 17 The fervor was such that Anglo-Americans predicted the phenomenon would turn into a large-scale population transfer. Early AMG reports indicated that 1700 specialized workers would go to Pola alone, while

\footnotetext{
${ }^{14}$ The precise date of the directive is difficult to determine. Mario Tonzar, who was present at the meeting, at one time indicated that the directive came in December 1946, but in another said it was in the "first half of January 1947." The historian Alessandro Morena is confident that the date was 7 January 1947. Nevenka Troha's account is the most convincing, setting the date as 13 January. On Tonzar, see respectively Bonelli, "Memorie del monfalconese Tonzar Mario," 6 March 1978, op. cit.; Tonzar, La valigia e l'idea, 84-85. See also Morena's comments in ibid., 28-29; Troha, Chi avrà Trieste?, 269-72.

${ }^{15}$ Fogar, "Seconda parte dell'intervista registrata rilasciata da Ruggero Bersa," November 1981, op. cit.; Radio Venezia Giulia, Summary of Broadcast, 2000hrs, 18 January 1947, AGPCM-UZC, Sez II, Jug, b 2, f 30.

${ }^{16}$ Cited in Troha, Chi avrà Trieste?, 269-72.

${ }^{17}$ Capt. Hill, "Monthly Report, Jan 1947," 28 January 1947, NARA, RG331, UD1981, b 9186, f 11304/115/278.
} 
CAO Kitson-Harris believed that the Yugoslavs were targeting 5000 recruits, especially skilled welders, carpenters, and electricians of the CRDA. ${ }^{18}$ The intelligence services of the AngloAmericans' Central Mediterranean Force thought even bigger, believing that some 2000 CRDA "specialists" and 400 "young workers" had already left the Monfalconese and that another 5000 would soon follow. ${ }^{19}$ Whatever the expectations, CAO Kitson-Harris made the wave of resignations and departures the centerpiece of his January report on the district. ${ }^{20}$

The readiness of monfalconesi to depart should not have been surprising, given that the local PCRG had been struggling to check workers' expressed desire to emigrate even before 1947, but the popular response was so great that the question of migration immediately became a source of contention between Communist Parties both within and outside the region. First to respond was the PCI, whose representatives Giordano Pratolongo (head of the Information Office in Trieste) and Lino Zocchi (head of the Udine Federation), were in Zone A laying the groundwork for the post-treaty reconstitution of the PCI's Gorizia Federation. As Bersa recalls, both leaders immediately “more or less explicitly asked [the PCRG's local leaders] to block the worker exodus to Yugoslavia." ${ }^{21}$ Despite claims by some historians that the PCI orchestrated the Monfalconese

\footnotetext{
${ }^{18}$ SCAO Economics Section Meeting Minutes, 17 January 1947, NARA, RG331, UD1981, b 9185, f 1104/115/263; Maj. Kitson-Harris, "Monthly Report of Monfalcone Group CAO to AMG HQ Trieste Area," 31 January 1947, op. cit. Capt. Hill came up with much lower estimates, perhaps due to his focus on Monfalcone commune. In late January, he estimated that some 300 had already resigned from the CRDA and 30 from the Solvay, with the total number of individuals who had recruited from past to present (seemingly including the youth emigrants of 1946) being 1000. Capt. Hill, "Monthly Report, Jan 1947," 28 January 1947, op cit.

${ }^{19}$ GSI GHQ CMF, "NE Italy ISUM No. 25 for Period 15 to 21 Jan," 21 January 1947, NARA, RG331, UD1981, b 9212, f 11304/115/534. See the GSI's continued interest in reports No. 26 (29 January) and No. 28 (12 February) in the same file.

${ }^{20}$ He wrote that "during January the Yugo-slavs commenced through the medium of the local Sindacati Unici, a big recruiting drive for skilled and, to a lesser degree unskilled workers, for re-construction work in Yugo-slavia.... So far as can be ascertained 250 workers from the local Shipyard have in the past four weeks resigned in order to take up this employment offered, 60\% of them are skilled workers. Families of these Yugo-Slavia bound workers will remain here. It is of course superflous [sic] to add that $75 \%$ of these workers are communists who were extremely active as political agitators in the shipyards or in demonstrations locally during the last eighteen months." Later investigations revealed the actual number of January resignations to be over double his estimate. Maj. Kitson-Harris, "Monthly Report of Monfalcone Group CAO to AMG HQ Trieste Area," 31 January 1947, op. cit.

${ }^{21}$ Fogar, "Seconda parte dell'intervista registrata rilasciata da Ruggero Bersa," November 1981, op. cit.
} 
emigration, the opposite was, in fact, the case. ${ }^{22}$

Most important in this regard were the efforts of Pratolongo, which he described in a lengthy letter sent to Palmiro Togliatti on 14 January. According to Pratolongo, he had spoken with the Monfalconese leaders at length shortly after the directive. He had impressed upon them the political danger of "depriv[ing] a zone such as this of the most combative portion of the working class, of all the Communists, of the cadres of our Party." He had insisted that this was particularly dangerous because the Monfalconese was to serve as "a barrier against reactionary Fascist forces, maneuvers, and provocations in relation to the Free Territory of Trieste and from this to Yugoslavia," which would be impossible if the district lost its mass of radical workers. Though the Monfalconese leadership had agreed on the political point, they concluded that Yugoslavia's reconstruction and Five-Year Plan took precedence over Italian political concerns. ${ }^{23}$ Despite the initial rebuttal of Pratolongo's pleas, affairs within the local Party were not as calm as they appeared. From the moment Bersa gave the directive to depart, it became apparent that vital Party cadres were among the most eager to go and that they were prepared to disregard the Party order to remain in place. In line with Kitson-Harris's assessment, Bersa recalls that "some $70 \%$ of the Party members took the path of Yugoslavia." ${ }^{24}$ This display of indiscipline, combined with the conflicting orders of the Italian and Yugoslav Parties and the certainty that Monfalcone

\footnotetext{
${ }^{22}$ Arrigo Petacco, an anti-leftist journalist-historian, writes that “'Operation Counter-Exodus,' planned in absolute secrecy, was the product of an agreement between the leaders of Yugoslav and Italian communism. Pietro Secchia, the Vice-Secretary of the Italian Communist Party, personally arranged matters on the Italian side. The operation involved the clandestine transfer to Yugoslavia of Italian volunteers, recruited from the shipyards of Monfalcone and from factories in Gorizia, Trieste, and Friuli." There is evidence that there was an effort to recruit Italian Communists from elsewhere in Italy (including Friuli) to go to Yugoslavia, but the PCI's response to the Monfalconese emigration was the opposite. Petacco, A Tragedy Revealed, 125.

${ }^{23}$ Giordano Pratolongo, Letter to Segretaria del PCI (Rome) (N. 0555), 14 January 1947, op. cit. Marco Puppini deserves credit for uncovering this letter. Puppini, "Il 'controesodo' Monfalconese," in Il mosaico giuliano, eds. Altieri and Puppini, op. cit., 73-74.

${ }^{24}$ Bersa recalls that district leaders "convened a second meeting of the UAIS in which we forcefully laid out the problem of immediate stopping the departures." Fogar, "Seconda parte dell'intervista registrata rilasciata da Ruggero Bersa," November 1981, op. cit; Maj. Kitson-Harris, "Monthly Report of Monfalcone Group CAO to AMG HQ Trieste Area," 31 January 1947, op. cit.
} 
would soon return to Italy, provoked a schism within the local PCRG. A short time after the initial announcement, a portion of the PCRG backtracked, cancelling the call for departures. The result was severe disorientation. As Sergio Parenzan recounts, at the first UAIS meeting "an order of the day was given: EVERYONE TO YUGOSLAVIA. After twenty-four hours, however, there was a counter-order: NO ONE TO YUGOSLAVIA."25

The schism remained unresolved in the days and months that followed. Just days after Pratolongo's meeting with the Monfalconese leaders, the Yugoslav-controlled Il Lavoratore responded with its 17 January article praising the self-sacrificing monfalconesi who were "ready to leave everything" so they could help build Yugoslav socialism, departing with a "fever of construction." It reinforced key themes of the myth of Yugoslavia, including the idea of ItaloSlavic fraternity, the availability of skilled labor positions and training programs, and the fact that, with the country now purged of speculators and economic disorder, workers could find their "daily bread." 26 Implicitly, the article - along with several others published subsequently - urged more monfalconesi to depart. ${ }^{27}$ On the other side, Togliatti and the PCI's Central Committee worked to convince monfalconesi to stay, even dispatching the esteemed partisan-politician Luigi Longo in

\footnotetext{
${ }^{25}$ Parenzan's testimony continues: "There had been a division in the leadership of the movement for and against the exodus. The part that was for the Yugoslav solution wanted to bring the people to Yugoslavia. Another part, always inside the movement, that was not pro-Italian but also not pro-Yugoslav, expressed a contrary desire.... There were two spirits in our movement. Because if we all went away, who would remain?" Cernigoi, Scelte politiche e identità nazionale, 272-73.

${ }^{26}$ The article did also warn monfalconesi not to expect a "worldly paradise" in Yugoslavia, but it did so in such a way that was reconcilable with the myth of Yugoslavia. The precise warning was this: "you will not find every amenity: there is a just wage as agreed by the Sindacati, there is food, there will be a place to sleep, but each will need to made do a bit on their own; it will not be easy, because the Country has suffered much from the war and Yugosalvia is not a worldly paradise; it takes discipline." "E questi perchè se ne vanno?," Il Lavoratore, 17 January 1947.

27 Particularly significant were three articles published in 1947 that reported on the experiences of various monfalconesi in Yugoslavia, emphasizing their perfect harmony with locals, their opportunities to participate in cultural activities and advancement, the high pay and high sense of personal fulfillment gained through their skilled positions leading Yugoslav industries, and the abundance of food in Yugoslavia. See the Il Lavoratore articles "A Tuzla, centro minerario della Bosnia," 26 Feburary 1947; "Lavoratori italiani in Jugoslavia," 19 March 1947; "Una lettera dalla Slovenia," 11 August 1947. For an article that specifically aimed to juxtapose the controesodo to the "Fascist" esodo for the purpose of rehabilitating Yugoslavia's image, see "Seguaci di Goebbels," Il Lavoratore, 1 February 1947.
} 
another attempt to dam the flow of emigrants. ${ }^{28}$ Bersa himself, who for reasons of PCRG party discipline had ordered the emigration in January, by the late spring of 1947 was speaking out against emigration in his capacity as a member of the new PCI-Gorizia's directive council. ${ }^{29}$

With these contradictory messages coming from several directions, Tito and the myth of Yugoslavia often won out among the workers. Despite the efforts of both central PCI figures and respected local leaders to slow the emigration, monfalconesi continued to depart by the hundreds, particularly as the signing of the Peace Treaty approached and passed in February. ${ }^{30}$ The Bandelli brothers made their decision to quit and transfer weeks after both Pratologno's visit and Bersa's counter-directive. There too was Sante G., who, after twelve years doing hull-work as an iron carpenter, resigned in favor of a new life in Fiume. ${ }^{31}$ By late February, Kitson-Harris indicated that 700 CRDA workers and 42 Solvay workers had resigned. ${ }^{32}$ From the outset, this emigratory wave was qualitatively different than waves prior. For the first time, large number of highly skilled and economically secure workers flanked the efflux of unemployed monfalconesi, many of them heads of families. ${ }^{33}$ Moreover, for the first time, emigrants left in open defiance of local and Italian

\footnotetext{
${ }^{28}$ Tonzar, La valigia e l'idea, 84-85. Longo had been one of two vice-commanders of Italy's combined partisan command staff, the Corpo volontari della libertà (CVL). Pavone, A Civil War, 195.

${ }^{29}$ Ruggero Bersa, "Relazione del Comp. Ruggero Bersa," 15 June 1947, APC-IG, Federazioni: Gorizia, Anno 1947, $\mathrm{mf} 140, \mathrm{p} 1811$. Togliatti's opposition to the controesodo was not merely a public show. According to Bersa, at some time between the PCI-Gorizia's First Provincial Conference (mid-June 1947) and Monfalcone's return to Italy (midSeptember), he was invited by Lino Zocchi to meet with the PCI's national leadership in Rome. According to Bersa, Togliatti indicated that he did not begrudge the monfalconesi their participation in the PCRG and pro-Yugoslav movement, but he asked Bersa (in Bersa's words) "who and how many were the Communists who had not abandoned the struggle in the location?" (Italics added). Fogar, "Seconda parte dell'intervista registrata rilasciata da Ruggero Bersa," November 1981, op. cit.

${ }^{30}$ In the testimony of Rino Russian, given to Andrea Berrini, Russian indicates that his father, Dante, was counseled to stay by the PCI's provincial secretary, though to no avail. Berrini, Noi siamo la classe operaia, 74-75.

${ }^{31}$ ASG, Questura 1948, b 5, f 793. See also the case of Paolo D., a pro-Yugoslav militant who gave up his position as an electric welder after 28 years at the CRDA, and that of Amedeo T.. ASG, Questura 1948, b 4, f 612; b 11, f 1755. ${ }^{32}$ Maj. Kitson-Harris, Monthly Report of Monfalcone Group CAO to AMG HQ Trieste Area, 28 February 1947, op. cit.

${ }^{33}$ Unemployment remained critical in the Monfalconese in early 1947, despite the fact that the CRDA began to receive new contracts in late 1946. By November 1946, the firm had secured contracts (mainly from Scandinavian firms) that would allow it to employ 8200 individuals through 1948 and it even relaunched apprenticeship programs for certain categories of workers (esp. welders), if in small number. Still, the estimated workforce of 8200 was several thousand less than the wartime figure. In January there were still some 4563 unemployed in the district, of whom 2113 were
} 
Communist leaders. Though it is impossible to say precisely how many had resigned and emigrated by the end of February or how many unemployed monfalconesi joined them in departing, certainly in the first two months after the directive, over a thousand monfalconesi made the choice to leave. ${ }^{34}$

\section{Pathways to Yugoslavia}

Once a monfalconese made the choice to depart, he or she then had to find the means and methods of relocation. For those heads-of-family who quit secure jobs to depart in early 1947, it was the SU offices that did most of the heavy lifting. Though most envisioned their departure as a permanent family relocation, in the short term, almost all left their families behind. ${ }^{35}$ Instead, the district SU assembled groups of roughly 25-80 emigrant workers and technicians, which, once organized, departed together. ${ }^{36}$ Accompanied by an SU guide, they travelled by train or truck to checkpoints near Sesana or Trieste, where they crossed into Zone B with little resistance. ${ }^{37}$ In accordance with the terms of the Duino and Belgrade Agreements that had established the AMG and YMG, monfalconesi arriving at a Morgan Line checkpoint needed only to flash their blue AMG ID card to gain free access to Zone B. As Ruggero Bersa recounts,

at the time, no one armed himself with a [formal Italian] passport to pass into Yugoslavia: entire families, with all their household goods loaded on the most varied means of

men (1553 heads of families), 1592 women (530 heads of families), and 858 would-be apprentices. Kitson-Harris, "Monthly Report of Monfalcone Group CAO...," 30 November 1946, op. cit.; Kitson-Harris, "Monthly Report of Monfalcone Group CAO to AMG HQ Trieste Area," 31 January 1947, op. cit.

${ }^{34}$ The three most important reasons are that (1) the regulations governing movement across the Morgan Line made it difficult to track migrants (discussed below); (2) not all migrants crossed at legal crossings; and (3) there are often problems of definitions in the documents. Many documents list workers who have left for "Yugoslavia," not clarifying if Pola or Zone B are included in this term. Both would be annexed to Yugoslavia with the implementation of the treaty, but until September 1947 Pola was legally part of Zone, A and Zone B legally distinct from Yugoslavia. Officials were inconsistent and imprecise in their usages of these terms.

${ }_{35}^{35}$ SCAO Meeting Minutes, 3 March 1947, NARA 331, UD1981, b 9188, f 11304/115/289.

${ }^{36}$ Per CAO Hill, these were "offered good terms and good jobs in Jugo-Slavian industries newly built or under construction and at the time of the signature of the contract they will receive an amount of money (rumours say of 50.000 lire but it's uncertain)." Capt. Hill, "Monthly Report, Jan 1947," 28 January 1947, op. cit. For emigrant testimony, see Alfredo Bonelli, "Testimonianza del monfalconese Buttignon Angelo," 28 April 1978, IRSML, Fondo Cominform, b 99, f 8; "Testimonianza del monfalconese Donda Onorio," 5 March 1978, IRSML, Fondo Cominform, b 99, f 8; "Testimonianza del monfalconese Nicola Angelo," 10 March 1978, IRSML, Fondo Cominform, b 99, f 5.

${ }^{37}$ The Gorizia Questura files indicate that some individuals organized these expatriations full-time. ASG, Q 1948, b 4 , f 516. 
transport, crossed the demarcation line between Zone A and B without the slightest check or hindrance by the Allied border authorities; rather, one almost had the feeling that they would have built golden bridges for whomever left Zone A. ${ }^{38}$

And so the bulk of monfalconesi crossed the Iron Curtain with ease, though, as will be seen in the final chapter, the AMG was far less eager to see them go than Bersa suggests.

But not all monfalconesi found the emigration process so straightforward, especially those who, for one reason or another, lacked the proper AMG ID card to pass freely across the Morgan Line. Those who had misplaced their ID card or who were under the age of 18 had to find another way across, though doing so was no more difficult in the first months of 1947 than it had been when Silvano Cosolo crossed the border clandestinely on foot the summer before. ${ }^{39}$ In fact, the pro-Yugoslav institutions of Monfalcone and Trieste had a well-developed network of peoplesmugglers, which had been used in the past to aid the clandestine expatriation of various "partisanrefugees." Most often, trained Communist militants brought such individuals across the border into Zone B, either hiding them in trucks that passed through rarely-staffed rural checkpoints near Gorizia or guiding them by foot through the wilderness, as with Cosolo. ${ }^{40}$

Whether emigrants crossed into Zone B legally or illegally, they tended to go through a similar process of integration upon arrival in Yugoslavia. Though some of the most skilled workers and technicians learned of their work destination before departure, most did not. ${ }^{41}$ The majority

\footnotetext{
${ }^{38}$ Fogar, "Seconda parte dell'intervista registrata rilasciata da Ruggero Bersa," November 1981, op. cit.

${ }^{39}$ Cpt. M. Heaton Armstrong, "Control of MORGAN Line," 15 April 1947, NARA, RG331, UD1981, b 9211, f $11304 / 115 / 529$.

40 "Partisan-refugees" were typically Communist partisans sought by the Italian or AMG courts for various Liberationera crimes, especially the violent settling of scores against former Fascists. The Monfalcone Communist Party HQ, for example, helped the perpetrators of the infamous Schio Massacre expatriate to Yugoslavia. Comm. Gen. del Governo Palamara (Trieste), B[x] Giovanni di Antonio..." (N. 13/1/1405-55) and attached, 15 February 1955, AGPCM-UZC, Sez II, Jug, b 18, f 163. In September 1947, the Italian Foreign Ministry indicated that the SU possessed "a well-organized 'recruitment' network" and "means to send those with interest over the frontier of Zone A unbeknownst to both our Frontier Authorities and those of the Allies." Legazione d'Italia (Belgrado), "Lavoratori italiani in Jugoslavia" (Tel. N. 266/44), 4 September 1947, ASDMAE, AP 1946-50, Jug, b 30, f 3.

${ }^{41}$ Bonelli, "Testimonianza del monfalconese Nicola Angelo," 10 March 1978, op. cit.
} 
passed through Vipava (Vipacco) on their way to Fiume, which served as a sorting and allocation center for workers trying to make Yugoslavia their new home. ${ }^{42}$

\section{Movements in Fits and Starts, Spring-Summer 1947}

If January and February were months of frenetic activity for those tasked with organizing the transfer of monfalconesi to Yugoslavia, the months that followed were much calmer. By March, Inspector Lendaro of the local VGPC noted a deceleration in the rate of departure. He reported that "the communists have almost suspended their settings-out," explaining this as a result of monfalconesi having become aware of the true reality of life in Tito's Yugoslavia. ${ }^{43}$ Rather than realizing Lendaro's prediction that departures would cease, however, the months of spring and summer 1947 saw emigration continue, if in less spectacular form than the mass departures of early that year. From month to month, a continual stream of departures ebbed and flowed, made up of disparate groups of emigrants.

First among them were the dependents and family members of those heads-of-families who had left so suddenly in January and February. By the late spring of 1947, many of these workers had established themselves in Yugoslavia, at which time they sent for wives, children, and elderly parents to be brought across the border by SU aids. ${ }^{44}$ In March 1947, the twenty-two-year-old

\footnotetext{
42 This applied to both legal and clandestine border-crossers. Legazione d'Italia (Belgrado), "Lavoratori italiani in Jugoslavia" (Tel. N. 266/44), 4 September 1947, op. cit; ; Pin-Giuricin, "I motivi di una scelta," 360-64; Cosolo, Amare... Sarajevo, 18-19.

${ }^{43}$ Insp. Lendaro, "Monthly Report on the Corps Activity, Mar 1947," 22 March 1947, NARA, RG331, UD1981, b 9186, f 11304/115/278.

${ }^{44}$ ASG, Questura 1948, b 8, f 1167. There are a great many files in the Gorizia Questura's cabinet records detailing such migrants. Another was the Vermegliano electrician Ermanno D. P. and his stepbrother Nereo V., who, as late teenagers, emigrated in July 1947 to join their father/stepfather, who had been working in Yugoslavia for months. ASG, Questura 1948, b 12, f 1902. See also ASG, Questura 1948, b 1, f 90; b 2, f 205; b 8, f 1298; b 9, f 1407; and b 10, f 1483 . On the guides, see ASG, Q 1948, b 4, f 516. In some cases, the emigratory activity of a family played out in three different stages involving three different generations. The mechanic and father Tullio B. departed for Yugoslavia in May 1947, seeking to join his parents, who had previously settled in Abbazia (Opatija). He left his wife and two children behind until he could organize their transfer the month after - and all of this despite Tullio being not particularly politically active. ASG, Questura 1948, b 1, f 165. In some cases, young monfalconesi who had passed into Yugoslavia in years prior pulled their siblings across in mid-1497, as with the pair of brothers from Staranzano,
} 
Mafalda P. of San Pier d'Isonzo departed in May to join her husband, a pipefitter, who had settled in Fiume in the first days of March 1947. Hundreds of such reunions occurred in the middle of 1947. They became so common that the AMG held discussions over the high number of monfalconesi whose attempts to cross into Zone B at Sesana en route to Fiume had been foiled due to their lack of the required blue AMG ID card. Such cards were not issued to people under 18 years of age and, almost certainly to prevent the separation of children from their parents, the AMG made an exception, allowing Monfalcone residents to pass the border using only their communal identity card. ${ }^{45}$ For those families whose end-goal was reuinification inside Yugoslavia, it was primarily in the middle third of 1947 that this occurred.

But not all of those who left in mid-1947 were dependents of workers who had departed in the frantic emigratory wave that kicked off that year. Though the pro-Italian Radio Venezia Giulia waged an anti-Yugoslav broadcast campaign to slow emigration in mid-1947 - it warned that Yugoslavia was a haven for expatriated Italian criminal assassins and that emigrant workers would be "at the mercy of the Titoist exploiters with no way out" - both Il Lavoratore and delegations of pro-Yugoslav monfalconesi and triestini who toured Yugoslavia pushed back against such negative images. ${ }^{46}$ With so many conflicting ideas about Yugoslavia in circulation, many workers continued to give up their jobs as the months passed, making the decision to migrate well after the

\footnotetext{
Romano and Alfredo D. Alfredo, a young mechanic and one of the earliest emigrants, had been working in the Belgrade naval yards since December 1945. It was in May 1947 that his younger brother Romano finally joined him. ASG, Questura 1948, b 4, f 514.

${ }^{45}$ The report was sent to GSI of the Allies' Central Mediterranean Force, indicating an uneasiness with this procedure. This was seen above all as a practical necessity. Cpt. M. Heaton Armstrong, "Control of MORGAN Line," 15 April 1947, op. cit.

${ }^{46}$ Radio Venezia Giulia, Summary of Broadcast, 2000hrs, 23 April 1947, AGPCM-UZC, Sez II, Jug, b 2, f 30. The reference to Yugoslavia as a haven for criminal assassins is in RVG, Summary of Broadcast, 2000hrs, 20 June 1947, AGPCM-UZC, Sez II, Jug, b 2, f 30. SU-Trieste, "Viaggio della delegazione triestina dei Sindacati Unici a Belgrado," May 1947, op. cit.
} 
original UAIS directive and its counter-directive. ${ }^{47}$ Included in this wave were a number of peasants, sharecroppers, and fishers, as well as many strongly pro-Yugoslav women - most young and single - certainly not recruited by the SU for their industrial skills. ${ }^{48}$ This new emigratory wave of mid-1947 disabused both Inspector Lendaro and AMG officials of the illusion that this emigration would soon come to an end. ${ }^{49}$ By late May, the AMG had confirmed the emigration of 76 whole families and another 1294 individual workers from the Monfalconese. ${ }^{50}$

A final emigratory wave then came shortly before the implementation of the Peace Treaty. In those early September days, many who had hesitated or otherwise delayed their departure made the jump, fearing that their access to Yugoslavia might be cut off. Typical of these eleventh-hour migrants, was the twenty-three-year-old Liliana V., engaged to a pro-Yugoslav worker named Alberto, who had worked in Belgrade since quitting his job at the CRDA in February. Seemingly fearing that the Italo-Yugoslav border would be sealed following the arrival of Italy, Alberto

\footnotetext{
${ }^{47}$ Though in early April the CRDA seems to have stopped reporting the names of workers who resigned with the intention of transferring to Yugoslavia, the final list available (or at least the latest that I have been able to locate) lists 23 resignations between 29 March and 4 April. Unsigned (CRDA), "Elenco degli operai licenzati spontaneamente dal 29 marzo a 4 aprile 1947," Undated (April 1947), NARA, RG331, UD1981, b 9189, f 11304/115/308.

${ }^{48}$ For agriculturalists and fishers, see Attilio B. (peasant), Gregorio Z. (sharecropper), Dorino U. (sharecropper), Giulio F. ("agriculturalist"), and Nicolò L., respectively at ASG, Questura 1948, b 2, f 264; b 12, f 1993; b 12, f 1810; b 5, f 717; b 6, f 675. Regarding women emigrants, the police most often explained their emigration as motivated by fear of reprisals. In one instance, an emigrant was identified as one of the "most fervent antinational propagandists, provokers, insulters, and abusers" of the pro-Yugoslav movement. ASG, Questura 1948, b 5, f 704. See also ASG, Questura 1948, b 3, f 366.

${ }^{49}$ Communal President of Ronchi, Letter to Monfalcone CAO (Kitson-Harris), 2 April 1947; Maj. Kitson-Harris, "Rations [sic] cards - Unentitled persons," 3 May 1947, both in NARA, RG331, UD1981, b 9159, f 11304/115/86. The wave included 107 Zone A residents, mostly monfalconesi, who relocated to Pola alone that May. TRUST, Intelligence Summary No. 2, May 1947, op. cit.

${ }^{50}$ Such figures were inevitably incomplete, as many individual migrants had emigrated clandestinely, leaving no traces of their departure. The figures by commune were the following: (1) Doberdò del Lago: 4 whole families and 16 individual workers; (2) Duino-Aurisina: 2 families and 10 workers; (3) Fogliano: 2 families and 45 workers; (4) Grado: 0 families and 7 workers; (5) Monfalcone (including Panzano): 29 families and 699 workers; (6) Ronchi: 11 families and 180 workers; (7) San Canzian d'Isonzo: 11 families and 136 workers; (8) San Pier d'Isonzo: 2 families and 43 workers; (9) Staranzano: 8 families and 89 workers; (10) Turriaco: 7 families and 69 workers. Notable is that so few left Doberdò, the Monfalconese's only Slovene-majority commune. The survey lists provide the workers' names, paternity, and addresses, but no information about the size or composition of their families. Unsigned (AMG), "Lists of Workers and Families Emigrated to Zone B (Jugo-Slavia)," Undated (May 1947), NARA 331, UD1981, b 9159, f 11304/115/86. Boris Gombač found a separate copy of this list in the Civilian Labor section of NARA's AMG holdings. Gombač, "Controesodo tra poteri popolari e GMA," in Il mosaico giuliano, eds. Altieri and Puppini, op. cit., 60 .
} 
returned to Monfalcone the day before Transfer Day, marrying Liliana. The two then ran off back to Belgrade. In doing so, Liliana left behind her parents and a stable job, but she assured she would not be separated from her partner. ${ }^{51}$ She was one of the last monfalconesi to depart for Yugoslavia before the return of Italy, bringing to a close an eight-month period of intense emigration that, like the exodus in the opposite direction, occurred in fits and starts, its participants often waiting until the last moment to jump into the unknown.

\section{Socialism}

For the thousands of monfalconesi who departed in the first two months of 1947, as well as those who would departed later, there were a thousand individual choices to depart. Though all monfalconesi lived in a certain shared context - the looming return of Italy, daily terror attacks, persistent ration problems, unresolved workplace grievances, and ever-greater competition with arriving esuli - each had unique circumstances, which created unique constellations of motivations for departure. Though it is impossible to determine accurately the number of migrants who departed for each particular motivation, it is worthwhile to examine the various shades of these motivations and the complex ways in which they combined to motivate individuals' departures.

The controesodo has been mythologized as an ideologically motivated departure of selfsacrificing workers committed to constructing socialism with their industrial skills and political fervor. ${ }^{52}$ As Ruggero Bersa recalled in a late-Cold-War interview, the monfalconesi emigrants were "comrades who enthusiastically emigrated to Yugoslavia with the precise intention of contributing, with their experience as highly qualified workers and technicians to the rehabilitation and development of partially obsolete industries." In a statement that is far from unique in its

\footnotetext{
${ }^{51}$ ASG, Questura 1948, b 12, f 1850.

52 Il Lavoratore's article of 17 January 1947 had already attempted to frame the controesodo in this way.
} 
linkage of industrial skill and left-wing sensibilities, Bersa suggested that the controesodo served as "a brilliant example of internationalist sensibilities, and in the shipyards of Fiume and Spalato and in the factories of every party of Yugoslavia where they were employed, they were highly respected for their technical capacity and for their political commitment." ${ }^{, 53}$ Mario Tonzar put it more succinctly when he recalled that the monfalconesi emigrated due to "the idea of socialism, of a new humanity.... We... abandoned work, home, everything. We went away only with our suitcase. Our suitcase and the idea." ${ }^{54}$

Included among the monfalconesi emigrants were many skilled workers with long leftist pasts and a commitment to "constructing socialism" in Yugoslavia. Individuals like Valerio Beltrame, who had been a PCI militant in the CRDA during the Fascist period, a confinanti after the Fascist crackdowns of 1942, a partisan, and then a primary AgitProp organizer for the PCRG clearly fit this bill. The welder Paolo D., who had spent 28 years as one of the CRDA's staunchest anti-Fascists, gave up his job in February 1947 to move to Yugoslavia. ${ }^{55}$ In fact, of the 47 members of the workshop-level PCRG cells for the CRDA's Shipbuilding Department, at least 24 (51\%) would emigrate. Most of these twenty-four, Paolo and the two eldest Bandelli brothers among

\footnotetext{
${ }^{53}$ Fogar, "Terza parte dell'intervista registrata rilasciata da Ruggero Bersa," November 1981, op. cit. Berrini believes this sentiment is best captured by the active verb "to forge" (forgiare) rather than the term "faith" (fede) with its connotations of irrationality and passivity. Berrini, Noi siamo la classe operaia, 7-9.

${ }^{54}$ Tonzar contrasts the motivations of monfalconesi with those of esuli, who he says moved under "hardships and miseries" caused by Tito's regime and the harsh Istrian environment. Tonzar, La valigia e l'idea, 78. Bersa and Tonzar were far from unique in their assessment. Spartaco Romano recalls that monfalconesi left to "collaborate in the construction of socialism," while the goriziano Franco Giraldi recounts that they were "the best specialized workers of the shipyards of Monfalcone [who] chose to go voluntarily to Yugoslavia, to Fiume to help the... modernization and the growth of socialism." Alfredo Bonelli believed that the monfalconesi "were [in Yugoslavia] voluntarily, to remain here, to stay here for the rest of their lives." They were "the greater part of the Party of the Monfalconese, a group of comrades among the most combative and most solid of Western Europe, and an elite, too, from a technical and professional point of view." Bonelli, "Sesta testimonianza del monfalconese Romano Spartaco," 23 October 1981, IRSML, Fondo Cominform, b 99, f 2; Giraldi, "Intervista a Franco Giraldi," interview by Alessando Cattunar and Kaja Širok, 8 August 2009, Strada della memoria: Archivio della memoria, transcript at http://www.stradedellamemoria.it/easyne2/LYT.

aspx?Code=4704\&IDLYT=6605\&ST=SQL\&SQL=ID_Documento=267 (accessed 3/22/2017); Bonelli, "Prima intervista con il partigiano profugo Ballardini Sauro (Topo)," 2 July 1980, IRSML, Fondo Cominform, b 99, f 4.

${ }_{55}$ Bonelli, "Memorie del monfalconese Beltrame Valerio," 29 November 1977, op. cit; ASG, Questura 1948, b 4, f 612. Examples of such militant-migrants are numerous. ASG, Questura, b3, f 355; b 8, f 1207.
} 
them, would leave in the first months of $1947 .{ }^{56}$ Politics was likely the primary motivating force for such individuals, as is suggested by several participants, among them the CRDA joiner and PCRG member Angelo Nicola. Nicola stressed that many were "convinced [they could] give their technical contribution and labor for the construction of socialism." ${ }^{57}$ It is even possible that they undertook this emigration with reluctance, understanding their actions as self-sacrificial, the subordination of one's own desires to the needs of socialist reconstruction.

But departures in pursuit of socialism could take on other inflections. In the case of young Communists in particular - those often dubbed dangerous "extremists" by the local Communist leadership - there seems to have been a generational divide at play, with those closely tied to partisan movement feeling that the old leadership, the Comars and Bersas and Ferlettiches, did not demand enough and were, in fact, blocking the new, Resistance-tested generation from assuming leadership of the local "progressive" movement. As the former Communist Youth organizer and emigrant Giuseppe Franti would later attest,

I attended the Party School at Monfalcone: and I was amazed by the fact, for example, that one such as Comar could give lessons on Marxism while, in fact, he didn't know a thing about Marxism: certain youth already knew it much better than he and [the old leaders]. Personally, I respected and admired Comar, but I recognized that there were some youth capable of giving him lessons.

And there was the problem. Certain intelligent youths had to expatriate or be thrown out of the Monfalconese movement. ${ }^{58}$

Though Franti himself would emigrate with the agreement that he would serve on the BrčkoBaroviči railway and then be released from his position as a Party functionary, there were certainly some who felt that it was not only Italy, but also the entrenched leadership of their own movement,

\footnotetext{
${ }^{56}$ Comp. D[x], "Relazione politico-organizzativa," 21 August 1946, op. cit. Those 24 who are known to have emigrated appear in the various sources from which I have compiled a list of all emigrants. See Appendix C for information on this list.

${ }^{57}$ Bonelli, "Testimonianza del monfalconese Nicola Angelo," 10 March 1978, op. cit. See similar phrases in the testimony of Angelo Buttignon and Onorio Donda. Bonelli, "Testimonianza del monfalconese Buttignon Angelo," 28 April 1978, op. cit.; "Testimonianza del monfalconese Donda Onorio," 5 March 1978, op. cit.

${ }^{58}$ Bonelli, "Prima intervista con il monfalconese Franti Giuseppe," 27 March 1980, op. cit.
} 
that would prevent them from achieving that which they had aimed to create in 1945.

The tension between individual workers and the Communist Party became more acute in the spring of 1947 as the zone's Party, syndicates, and cultural associations were reconstituted within an Italian national framework. This process was painful and difficult. ${ }^{59}$ At the First Provincial Conference of the reconstituted PCI-Gorizia, held in mid-June, Ruggero Bersa suggested that the primary problem facing the provincial Party was that "the middle class - the intellectuals and, still worse, the white-collar class - has not been approached by us," but instead, because of certain "prejudicial" actions of the district's Communists, had succumbed to chauvinism and entered into battle against the local "democratic" forces. ${ }^{60}$ He urged Monfalconese Communists to form an increasingly close alliance with the retailers and clerks that had become so reviled, as this was the PCI's path to a democratic seizure of power. Far from reflecting all monfalconesi's hopes for the future, then, the new PCI line often worked directly against them. If, under the PCRG, many workers had become frustrated that the territorial struggle required a crossclass, pro-Yugoslav alliance and the indefinite postponement of the showdown with the "remnants of Fascism," under the PCI, the goal of getting rid of these social categories no longer seemed to exist. It is perhaps unsurprising, then, that disillusioned Monfalconese came to realize that they had no place in these new organizations and made their exit. As they continued to emigrate through

\footnotetext{
${ }^{59}$ Some historians have underestimated the difficulties. See the comments of Cernigoi, Puppini, and Valcovich on the syndical fusion of April 1947, which brought an end to Monfalcone's SU. They write that "from this moment, syndical activists who until a short time before had considered themselves adversaries, divided by political and national choices [that is, SU or SG], found themselves collaborating on behalf of the interests of the shipyard workers." They stress that the May Day demonstration that followed afterwards showed that there was "a renewed unity." Cernigoi, Puppini, and Valcovich (eds), Cento anni di cantiere, 51. This mistakes the SU's organizational decision to accept syndical fusion - a strategic necessity - as indicative of popular sentiments. AMG reports reveal that reconciliation on the ground was much slower than reconciliation in the syndical offices. Maj. Hill, "Monthly Report, May 1947," 28 May 1947, op. cit.

${ }^{60}$ Bersa, "Relazione del Comp. Ruggero Bersa," 15 June 1947, op. cit.
} 
the summer of 1947, almost none joined the reconstituted PCI branch. ${ }^{61}$

Finally, the notion of constructing socialism was often a misnomer. In many cases, individuals hoped to escape to a society with already constructed socialism. This was especially common for older monfalconesi, and particularly those with long leftist pasts. Spartaco Romano's father said as much to his son as he set off for Fiume, leaving Spartaco behind in Monfalcone. As Romano recalls, "my father said, 'I want to live the last years of my life under socialism. I'm packing up and getting out of here." 62 As such, it was not the appeal of suffering and toiling to construct the new world that won these longtime militants to the idea of emigration, but rather a hope that a lifetime of unrewarded struggle could be made right by stepping across the border. And Romano has no illusions: "Many comrades had to have thought like him."63

\section{Fear}

But for monfalconesi whose efforts to construct local socialism had driven them to fight within the UAIS and PCRG, there was another clear reason to depart: personal safety. In early 1947, right around the time of the signing of the Peace Treaty, the wave of threats and attacks against pro-Yugoslav militants reached its climax. Such attacks were certainly a crucial factor in motivating pro-Yugoslavs to depart, and they did not stop after the signing. Instead, there was a lull in the middle of the year, which gave way to a string of increasingly bold attacks as the

\footnotetext{
${ }^{61}$ In 1948 there were only 70 PCI members at Fiume, despite there being thousands of monfalconesi. Moreover, because there were many non-Monfalconese Italian emigrants to Yugoslavia who had settled in Fiume, it is possible that very few of these 70 were monfalconesi. Unknown (PCI), Situazione comp. italiani in J., Undated (1948), APCIG, AM, Fondo JVG, MF 135, f MF 135, d 6. Similarly, during his Conference speech, Bersa reminded the attendees that the PCI-Gorizia's low membership figure (4738) resulted from these departures, which implies that few had joined the PCI before setting out. Whatever the exact figure, Petacco's claims that "all [controesodo participants] were members of the Italian Communist Party" and that all "maintained close ties with the federation of the Italian Communist Party in Trieste" are simply false. Petacco, A Tragedy Revealed, 126.

${ }^{62}$ Bonelli, "Terza testimonianza del monfalconese Romano Spartaco," 3 April 1981, op. cit.

${ }^{63} \mathrm{Ibid}$. The same motivation can be gleaned from Antonia Comar (Antonia Iaconcich) in comments about her father. After talking about the frustrated struggle for popular power in Monfalcone, she recalls how "my father said 'I'm going there, because if they're not coming here, we're going there.' It was most simple at that time." Cernigoi, Scelte politiche e identità nazionale, 244-45.
} 
implementation of the treaty approached in September. On 29 August, for example, a group of fifteen esuli headed by a pro-Italian CRDA clerk chased down and attempted to murder a proYugoslav naval mechanic in broad daylight just outside the shipyard. The worker, who, unlike his brother, had refused to bend to threats and take refuge in Yugoslavia, survived only due to the intervention of three plainclothes policemen. ${ }^{64}$ For the pro-Yugoslavs of Monfalcone, the events raised a terrifying question. If such violence occurred under the "impartial" AMG, what could they expect when their home district returned to the Italy, which saw them as sellouts and traitors? ${ }^{65}$

For many, the fear of potential violence was too great to remain, though anonymous terror and targeted attacks were not universally effective in driving pro-Yugoslavs and former garibaldini out of the zone. Though many of those threated made the choice to depart, seasoned partisans such as Mario Fantini, Vinicio Fontanot, and Ferruccio Barbo refused to bend to such violence, perhaps because they were convinced that departure meant acknowledging that "Fascists" had triumphed. Although Fantini did not depart following the bombing of his building (see chapter five), all three of the UAIS militants residing in the building with him did, taking their families with them. ${ }^{66}$

The choice to depart was easiest for those who, due to egregious acts of violence that they or their family members had committed against pro-Italian neighbors, felt themselves at great risk

\footnotetext{
${ }^{64}$ As the attack unfolded, the leader allegedly yelled "Strike! Strike! It's time to finish him! Kill him! Throw him into the sea!" As the plainclothes officers intervened, the esuli assaulted them, chased off only when a uniformed and armed policeman arrived on the scene. Insp. Lendaro, "Assault at [sic] C.P. personnel carried out by italian [sic] people in via Cosulich, Monfalcone,” 29 August 1947, NARA, RG331, UD1981, b 9207, f 11304/115/478.

${ }^{65}$ It was widely expected, including at the Allies' General Staff Intelligence in Rome, that the transfer would be accompanied by a "pogrom" against the pro-Yugoslavs. GSI GHQ CMF, "NE Italy ISUM No. 26 for Period 22 to 28 Jan," 29 January 1947, op. cit.

${ }^{66}$ Even many seasoned partisans chose to depart. Armando D., for example, had been one of the handful of partisans who had gone with Vinicio Fontanot to fight with the OF before Mussolini's first fall. He emerged from the war a chief gappista, suspected OZNA agent, and, alongside one of his sisters, a leading pro-Yugoslav propagandist. Though this sister emigrated to Fiume with her husband and their newborn son already in 1946, it was only in the days immediately before Transfer Day that Armando left Monfalcone, bringing his wife, mother, and second sister with him. ASG, Questura 1948, b 4, f 511.
} 
of targeted retribution. In early 1947, for example, three families from San Pier d'Isonzo with ties to the local GAP uprooted themselves because one of the GAP's members had gunned down the twenty-two-year-old pro-Italian Ottavio Nonnino in the hot autumn of 1946 "solely because he was of Italian sentiments" (or so the local carabinieri commander believed) ${ }^{67}$ Though the AMG sentenced the shooter to sixteen years in prison, those with ties to the GAP knew that Ottavio's father, Primo, would seek revenge for the death of his only son. Family members of the suspected murderers of Agostino Perin did the same ${ }^{68}$ For such individuals, the border served as a buffer that could protect them from those esuli and native monfalconesi who would readily answer the call to avenge the martyrs of the pro-Italian cause. ${ }^{69}$

\section{Survival}

But the Morgan Line was not only a shield; it was also a tool. For many Monfalconese families, it served as a vital instrument in family survival strategies that, when paired with bordercrossing, aimed to mobilize resources from each side of the border. The porosity of the border and the inability of the AMG to impose discipline on crossings allowed clever monfalconesi to use the border to ameliorate, if not eliminate the joblessness and hunger that pervaded the home district. In some cases, this was an end in itself, detached from or even despite the participant's political beliefs. Most often, however, strategies of border exploitation were informed by deeply held proYugoslav beliefs, playing out among families that for other reasons had decided to relocate

\footnotetext{
${ }^{67}$ Brig. Com. Rocco (Carabinieri-S Pier d'Isonzo), "Esito informazioni," (N. 31/4), 3 Feburary 1948, ASG, Questura 1948, b 3, f 418. On this incident, see also VGPC-Monfalcone, "Rapportino giornaliero delle novità," 21 May 1947, op. cit.; Commissario Capo di PS-Gorizia, "B[x] A[x] fu Pietro" (N. 02286), 23 April 1948, ASG, Questura 1948, b 2 , f 263.

${ }^{68}$ VGPC-Monfalcone, "Rapportino giornaliero delle novità," 16 May 1947, NARA, RG331, UD1981, b 9207, f 11304/115/478. See too the follow-up report from 21 May.

${ }^{69}$ In a similar position were certain pro-Yugoslavs from San Pier d'Isonzo who had patrolled the Isonzo River after 1945 to stop, abduct, and hand over esuli wanted by Tito's regime as the esuli tried to escape into Italy. ASG, Questura, b 2, f 204; b 3, f 364 .
} 
permanently to Tito's new state, either partially or wholly.

The most common way that monfalconesi exploited the existing bordering system was the simplest: families sent their young sons and daughters or, less commonly, their male heads across the border in pursuit of work and to lessen the family's burden in meeting food and lodging needs. This had become a common strategy beginning with the layoffs of 1946, and in 1947 many monfalconesi continued to treat Yugoslavia as a resource, a land of work. ${ }^{70}$ For some bordercrossers, as with the twenty-two-year-old Nerina M., the assumption of work in Yugoslavia was envisioned as a short-term transactional necessity. Despite never having been politically active, the bachelorette Nerina, whose father was unemployed and whose family had no means to live, emigrated to Yugoslavia in early February 1947 to help her family meet its basic needs. She would remain there working until December, at which point her father found a job. As soon as word reached Nerina of her father's employment, she packed her bags and returned home. For her and many emigrants who crossed the border with these limited material motivations, the temporary nature of their expatriation was never in doubt. ${ }^{71}$ The archival records are filled with cases in which families straddled the border in the attempt to find employment for all members. ${ }^{72}$

The allure of employment was so powerful that it drew across the border even some avowed anti-Communists and pro-Italians. Indicative of this trend is the worker Carlo C., born in

\footnotetext{
${ }^{70}$ Thus, while Pier Paolo Pasolini's novel Il sogno di una cosa (1962) details the departure of three Friulan youth to Yugoslavia in this period, casting their choice to emigrate largely as a product of youthful exuberance detached from wider familial concerns, this was not often the case. Certainly, there are some cases in which young migrants had few family ties or in which participants recall that their departure was motivated in part by a "enthusiasm for adventure," but rarely did this occur in isolation from wider family concerns. On the use of that phrase by an emigrant, see Berrini, Noi siamo la classe operaia, 76-77.

${ }^{71}$ ASG, Questura 1948, b 8, f 1257. On this view in general, see many of the testimonials gathered by Enrico Cernigoi, including those with Mario Pahor and Mario Storni. Cernigoi, Scelte politiche e identità nazionale, 274, 276. Another apolitical, job-seeking emigrant was Laerte C. of Fogliano, who emigrated to Fiume to take a position in the shipyard's Statistical Office, despite never having been politically active. ASG, Questura 1948, b 10, f 1619.

${ }^{72}$ See the cases of Pietro D., Elvio D. N., Ranieri O., Giulio P., Livio P., the M. family, Nerina M., in all of which cases the families straddled the border, with employed members remaining behind. These cases can be found respectively at ASG, Questura 1948, b 3, f 482; b 4 f 529; b 8, f 1298; b 9, f 1408; b 9, f 1424; b 8, f 1204; and b 8, f 1257.
} 
Monfalcone in 1924. Despite being a staunch pro-Italian and member of the DC, he found himself out of work in the postwar and departed for Yugoslavia to find a job. His pro-Yugoslav cousin, Antonio P., had recently relocated to Pola with his family, and, though this cannot be known with certainty, it seems likely that Carlo tapped his cousin to find him a job, overcoming both intrafamilial political divisions and his ideological aversion to Tito's Yugoslavia to assure his ability to survive. ${ }^{73}$ Another pro-Italian, Antonio A., married to a Southerner from a family of "distinguished" pro-Italian activists, made a similar choice, leaving his wife behind and heading to Yugoslavia for work. ${ }^{74} \mathrm{~A}$ final case, that of Luciano S., is particularly illuminating. Though his father was a UAIS member and Communist, Luciano joined the DC in the postwar and worked as a clerk at the CRDA. However, when he lost his job, he ingratiated himself with the pro-Yugoslav movement in March 1947, securing a job as a drafter in Fiume's shipyard through the SU. And so Luciano, an anti-Communist pro-Italian, went to Yugoslavia, leaving behind his pro-Yugoslav, Communist father. ${ }^{75}$ Carlo, Antonio, and Luciano were joined by a surprising, if still small number of pro-Italians - most anti-Communist - who chose Yugoslavia out of necessity or convenience. ${ }^{76}$

But steady paychecks were not the only thing that families sought when they sent members across the Morgan Line. Many families of the Monfalconese also sought to straddle the border so that they could maximize the goods they received through state provisioning systems, particularly by collecting rations on both sides of the border. Though families had almost certainly used the border in this way from the first moment of departures, in early April 1947 the Ronchi communal

\footnotetext{
${ }^{73}$ ASG, Questura 1948, b 3, f 424; Unsigned (AMG), "Famiglie cancellate dal registro di popolazione del comune di Monfalcone per stabilirsi in 'Zona B',' Undated (Late Summer or Early Fall 1947), NARA 331, UD1981, b 9198, f $11304 / 115 / 388$.

${ }^{74}$ His pro-Italian stance is evident from carabinieri comments on his good political conduct. ASG, Questura 1948, b $1, \mathrm{f} 24$.

${ }^{75}$ ASG, Questura 1948, b 11, f 1705.

${ }^{76}$ See also ASG, Questura 1948, b 9, f 1454; b 9, f 1424. The second of these was a Communist, but of pro-Italian persuasions.
} 
president informed CAO Kitson-Harris that some families had continued to collect rations in the name of youth who no longer resided in the Monfalconese. Whereas families who sought to bring furniture and property across the border had to register their departure at the communal offices, individual migrants who left families and property behind could cross the border under pretext of a quick stay and instead remain in Yugoslavia to work, leaving their ration cards behind to be filled by family members. ${ }^{77}$ With rations provided by Yugoslavia to both participants in the Youth Brigades and workers at the major, state-run industrial sites, the migrant, in theory, would be no worse off. All that was required was the migrant's periodic return to the commune to renew the card - an easy thing to do especially for those monfalconesi working in Fiume or Pola.

Though such survival strategies created situations in which families often found themselves divided by the border and tapping into rationing systems on both sides, it would be a mistake to interpret this phenomenon as evidence that economic necessity (to the exclusion of politics) was the primary motivation for most monfalconesi's departures or that they envisioned their relocation lasting only so long as such strategies remained viable. ${ }^{78}$ Individual monfalconesi's responses to everyday necessity cannot be separated from ideology, as ideological lenses - for many, the myth of Yugoslavia - framed the range of opportunities they believed the border to provide. Faith in Yugoslavia's economic recovery and just provisioning system gave many the confidence needed, for example, to cede voluntarily their invaluable ration cards to family members and depart for unknown corners of Yugoslavia, at times without pre-arranged labor contracts.

In some cases, economic opportunities provided by border-straddling functioned as a brake

\footnotetext{
${ }^{77}$ In this case, the communal president requested that the VGPC search for and seize ration cards of nine residents known to be residing permanently in Yugoslavia, whose rations were still being claimed. Communal President of Ronchi, Letter to Monfalcone CAO (Kitson-Harris), 2 April 1947, op. cit.

${ }^{78}$ Mellinato frames the controesodo as something that must be either political or economic, never exploring how ideology and myth shaped migrants' interpretations of economic possibilities. Mellinato, "L'occasione, le circostanze, il movimento," op. cit.
} 
upon the speed of family relocations - an encouragement to stagger departures - rather than a force driving monfalconesi rapidly across the Iron Curtain. This is confirmed by the responses of many monfalconesi to the eventual breakdown of this method of collecting double rations in mid-1947, when the AMG moved quickly to stamp it out. Shortly after receiving notice of the phenomenon, CAO Kitson-Harris dispatched a memo to all subordinate CAOs and communal presidents, reminding them that such activities - particularly collecting rations in someone else's name - were serious criminal offences. He ordered each to carry out a detailed survey of the departures from the district so the AMG could invalidate the ration cards of such individuals. ${ }^{79}$ When the AMG completed its survey in May 1947, many families lost the ability to exploit the border in this way. Yet the response of many was not what might have been expected had their border-crossing been purely pragmatic. Rather than returning home, it was in this context that many families finally reunited across the border. The AMG's crackdown removed one of the main forces that tethered certain members of Monfalconese families to their home zone while relatives began putting down roots in Yugoslavia. This is part of the reason that the late spring of 1947 marked a low-point in emigration, as these were the months in which these strategies remained most effective.

\section{Family}

Family ties also had an impact on individuals' decisions to emigrate based on interpersonal bonds. It was often the case that one or two eager family members could exert a strong pull on others, dragging people behind them. This was inevitable for young children. But for many spouses and adolescent children of would-be emigrants, it was not always certain that they would depart with their family member, especially in cases where extended family members remained with whom a resistant individual might stay. Archival records are generally insufficient to allow the

\footnotetext{
${ }^{79}$ Maj. Kitson-Harris, "Rations [sic] cards - Unentitled persons," 3 May 1947, op. cit.
} 
disentanglement of the various motivations that spurred a decision to emigrate, but it is clear that many less-than-eager spouses were dragged across the Morgan Line. Most often, politically active husbands pulled their wives across the border, as when Elvina C. brought herself and her daughter across the Morgan Line to join her radically pro-Yugoslav husband Angelo in Pola, despite her persistent opposition. ${ }^{80}$ But eager wives could also pull their husbands across the border, as when the fanatically pro-Yugoslav wife of one Aldo F., "forced [him] to expatriate to Yugoslavia against his will." ${ }^{\prime 1}$

But "pulling" was not the only way in which family concerns had an impact on emigration decisions. The prospects of a radically transformed family life in Yugoslavia also served as a key motivation for some migrants. Even for migrants with a strong commitment to radical leftism and an active record of service in the PCI or PCRG, familial concerns weighed heavily on their minds as they contemplated departure. Eugenio Pin, a longtime anti-Fascist and skilled welder elected as a worker representative to protest piecework in the 1930s, had taken on a leadership role within the CRDA's pro-Yugoslav organizations in the postwar years, even becoming the head of the PCRG cell in his workshop. ${ }^{82}$ For all his concern with workplace reform, Pin was also deeply troubled with his family life. As his daughter Mirella recounts in her memoirs, since the early 1930s, Eugenio had been in a committed relationship with Mirella's mother, who found herself married to a husband from whom she had been separated for nearly a decade, but from whom she could not secure a divorce under Italian law. Eugenio was thus unable to marry his partner, and Mirella, born two years into the relationship, took the name of his partner's estranged husband. To

\footnotetext{
${ }^{80}$ ASG, Questura 1948, b 3, f 362. Police files almost never indicate the reason for the opposition, namely whether the opposition was political or apolitical in nature. It is possible that opposition arose from apolitical concerns such as resistance to leaving behind extended family members or frustration with the logistical difficulties of relocating. For another case involving a less-than-eager wife, see ASG, Questura 1948, b 2, f 265. The familial dynamic is best explored in Berrini's Noi siamo la classe operaia.

${ }^{81}$ ASG, Questura 1948, b 2, f 265.

${ }^{82}$ Comp. D[x], "Relazione politico-organizzativa," 21 August 1946, op. cit.
} 
add insult to injury, Pin had been forced to bear the burden of Fascism's punitive "bachelor tax," while supporting his unrecognized daughter and de facto spouse. For Pin, when the UAIS directive came in early 1947, it was a moment of liberation. He could not only to pursue his dream of living in a socialist country, but also right a fifteen-year-old injustice. In early March, he resigned and set in motion a plan to relocate his family to Fiume, certain that Yugoslavia would grant Mirella's mother a divorce and allow them to marry. ${ }^{83}$ Eugenio Pin fits the archetype of the skilled, leftmilitant worker, but his choice to depart was more complex than a desire to "construct socialism." It was based also upon his faith that Yugoslav Communism meant liberation from oppressive social norms. ${ }^{84}$

\section{Ethnicity}

Though the controesodo occurred alongside with mass relocations of ethnic minorities across the Europe, ethnicity appears not to have been a determining factor in motivating monfalconesi to depart for Yugoslavia. Only a handful of residents of Doberdò del Lago, the zone's single universally-acknowledged "Slovenian" village, chose to relocate. ${ }^{85}$ Moreover, throughout the district, the vocabulary of the pro-Yugoslav struggle was from its first moments that of ItaloSlavic fraternity - of the well-defined and distinct category of Italians joining Yugoslavs upon the grounds of shared politics. From contemporary speeches to factory broadsheets (and appearing

\footnotetext{
${ }^{83}$ Eugenio soon secured a job working at the Viktor Lenac naval repair yards and in April he sent for Mirella, her mother, and the family furniture. Pin-Giuricin, "I motivi di una scelta," esp. 344-45, 360-64.

${ }^{84}$ Eugenio Pin's situation was not exceptional. Many couples went to Yugoslavia to seek marriage by a "progressive state," often because one participant first needed a divorce that was unforthcoming in Italy. Such was the case with Aida A. and Bruno P. When, for unclear reasons, Yugoslavia refused to grant Bruno a divorce from his estranged wife, Aida returned to Italy, indicating that this marriage was likely the motivation for her departure. ASG, Questura 1948, b 1, f 13. See also b 1, f 123.

${ }^{85}$ As of May 1947, only four families and sixteen individual workers had left the village. Unsigned (AMG), "Lists of Workers and Families Emigrated to Zone B (Jugo-Slavia)," Undated (May 1947), op. cit. It is possible that Slovenes of Doberdò felt less sympathy for Tito's regime than other Slovenes, as the village had long been part of Italy and thus had not experienced the degree of wartime violence, pillaging, and civil war endured by Slovenes of the occupied and partitioned Kingdom of Yugoslavia.
} 
also in ensuing reflections of participants), the Italianness of the pro-Yugoslavs remained a key theme in political discourse. ${ }^{86}$

Borderland residents often do not treat ethnicity as a fixed category of identity. Rather, they possess a range of cross-ethnic skills that allow them to deploy particular identifications in particular contexts. ${ }^{87}$ Eugenio Pin, as a fluent Slovene-speaker, is an example. ${ }^{88}$ Though Pin participated fully in the political battles of Italo-Slavic fraternity and though he had a range of ideological and personal motivations that inspired his departure, it is possible his choice was eased by his possession of skills that would allow him thrive in Yugoslavia. ${ }^{89}$ In such cases, ethnic ambiguity should be seen as a facilitating, if not sufficient factor in the choice to migrate.

\section{Choosing to Remain}

Though a large number the district's pro-Yugoslav departed, not all did, which begs the question: why did some remain? Here too, the question was not simply one of supporting Communism, or even supporting Yugoslav Communism. Instead, monfalconesi made the choice to stay based on a complex mixture of political commitment, personal ties, familial obligation, and fear of the uncertain and unfamiliar.

For some, the choice to remain was strictly political - even for many committed Communists. Spartaco Romano was one such individual. Despite Romano's partisan past and Communist convictions, he had broken from the UAIS and local Communist Party shortly after liberation, when both embraced the pro-Yugoslav stance. The problem was not so much that he disliked the Yugoslavs, but rather that he felt Monfalcone to be Italian. Romano was not so

\footnotetext{
${ }^{86}$ Mario F[x] (CLN-Turriaco [OF]), "Turriaco libera ha eletto ieri sera il suo Comitato," 25 May 1945, op. cit.; Comp. Nicola, "Agli amici meridionali," La stella rossa (N. 23), 27 May 1945, op. cit.

${ }^{87}$ D'Alessio, "Istrians, Identifications, 18-19.

${ }^{88}$ Berrini, Noi siamo la classe operaia, 238.

${ }^{89}$ Completely absent from the archival records, however, are indications that particular migrants departed solely or even primarily because they considered themselves to be Slovenian or ethnically hybrid.
} 
opposed to the pro-Yugoslavs as to find himself unable to socialize with or engage in political activity alongside them. In fact, he regularly fought against esuli alongside the mostly proYugoslav garibaldini. He simply left them when they marched for Yugoslavia. ${ }^{90}$ When the UAIS directive came in 1947 and Romano's entire family elected to depart - father, mother, brother, sister, and brother-in-law - he instead chose to stay. As Romano would recount over three decades later, he made that choice "because everyone should struggle for socialism in the place where he finds himself, and not go to do it where he will be safer." ${ }^{\prime 91}$ It seems that many of the other longtime Communist militants felt the same way, among them key partisan figures like Mario Fantini and Vinicio Fontanot. Fontanot's choice must have been particularly difficult, as, after losing his father and both his brothers in the struggle against the Axis, his sister Elsa made the decision to depart with her husband and children, leaving Vinicio alone in Ronchi. ${ }^{92}$

However, just as the choice to depart was very rarely determined by politics alone, so too was the choice to stay. Personal ties and everyday concerns like those that pulled many monfalconesi to depart also worked in the opposite direction, exerting a sort of gravitational pull on would-be eager migrants. Such was the case for Sergio Parenzan, a respected CRDA worker who had risen to candidacy in the PCRG, motivated by a faith that the return of Tito would solve the multitudinous daily problems left unresolved with liberation. As Parenzan recalls, over the course of 1947 he watched three-quarters of his friends depart to the east. As those friends had prepared to depart, they had often asked him "Sergio, are you not coming?" To this he had always responded sadly that he could not. His father had died the year prior and his mother could not get by without him. Thus Sergio, a longtime militant for Yugoslavia who otherwise undoubtedly

\footnotetext{
90 Bonelli, "Seconda testimonianza del monfalconese Romano Spartaco," 19 March 1981, op cit.; "Terza testimonianza del monfalconese Romano Spartaco," 3 April 1981, op. cit.

${ }^{91}$ Bonelli, "Sesta testimonianza del monfalconese Romano Spartaco," 23 October 1981, op. cit.

92 ASG, Questura 1948, b 5, f 707.
} 
would have departed with his comrades, remained at home. ${ }^{93}$

Whatever the reason, the active decision of many Monfalconese Communists to remain in their home town contributed further to the division of the district's families and often served to make this not just a temporary arrangement - a product of family survival strategies - but rather a permanent state of affairs. For those who chose to remain while their families departed, the decision could be just as much a jump into the unknown as that undertaken by those departing for Yugoslavia. Moreover, with Italy set to return in September 1947 and Cold War tensions on the rise, many had to wonder how if such decisions might soon become permanent and irreversible.

\section{Monfalcone italiano: Monfalcone after Transfer Day}

On 15 September 1947, Monfalcone returned to Italy, and as had long been predicted, the bombs began to fly again. ${ }^{94}$ On 16 September, the day after the Allied soldiers withdrew, proItalians unleashed a wave of grenades and explosives that rocked the homes of former proYugoslavs and Communist-aligned organizations in Monfalcone, Pieris, Ronchi, and Staranzano. ${ }^{95}$ In Staranzano, three trucks filled with anti-Communist partisans and esuli arrived in the afternoon, whereupon they disembarked and split up. Some broke into the homes of pro-

\footnotetext{
${ }^{93}$ Morena, "Intervista a Sergio Parenzan," 1000hrs, 30 May 2001, op. cit. Many monfalconesi remained because of apolitical considerations, though these decisions elude quantification because they rarely show up in historical documentation. Berrini recounts the case of Giovanni and Maria Balanza, as told by their grandson, Fabio Songa. According to Songa, his grandfather believed the family should go, while his grandmother felt the opposite. Unable to agree, Giovanni decided to go alone and leave Maria behind, only to change his mind at the last minute and remain. Berrini, Noi siamo la classe operaia, 215-217.

${ }^{94}$ Some have claimed that the Italian state gave free rein to esuli and native anti-Communists to terrorize leftists and pro-Yugoslavs into departure. For many, it certainly seemed that way, even if this was not wholly true. Speaking of Gorizia, the pro-Italian Communist Italico Chiaron recalls that "for three days the city remained without any power, without police or anything else. Probably done on purpose [ $d a$ arte], according to me it was done on purpose." Italico Chiaron, "Intervista a Italico Chiaron," interview by Alessando Cattunar and Kaja Širok, 11 August 2009, Strada della memoria: Archivio della memoria, transcript at http://www.stradedellamemoria.it/easyne2/LYT.aspx?Code=4704\&IDLYT=6605\&ST=SQL\&SQL=ID_Documento $=99$ (accessed 3/22/2017).

${ }^{95}$ Prefetto Palamara, "Elenco degli attentati - incidenti - ecc. nella Provincia di Gorizia dal 16 settembre al 20 novembre 1947," Undated (November 1947), ASDMAE, AA PP 1946-50, Jug, b 17, f 2.
} 
Yugoslav families, threatening "grave harm" to anyone who remained after midnight. Other surrounded the headquarters of the Communist-aligned orchestra and popular theater, breaking the ground-floor windows with stones and throwing five grenades into the building. Those present escaped serious harm by fleeing upstairs as the grenades exploded on the ground floor, but several received light injuries. As the attacks unfolded over sixty minutes, the perpetrators faced no police or military resistance. Only when the truck from Monfalcone tried to return and wreak havoc closer to the town center did the carabinieri intervene, firing three shots that convinced the partisans and esuli to disperse and to abandon their cache of unused explosives. ${ }^{96}$ As for the anti-Communist partisan association ANPI-Gorizia, its secretary suggested that these incidents had been provoked by Communist (and especially pro-Yugoslav) attacks on esuli and police and that his partisans has been active in intervening to prevent a "natural popular reaction" of summary justice against those who had perpetrated Titoist abuses and pushed for Yugoslav annexation just shortly before. ${ }^{97}$

Even after the restoration of order some days later - an order periodically shattered by new flurries of bombings - the conditions of life for monfalconesi of leftist and especially pro-Yugoslav extraction were far from rosy. One of the first actions of the newly appointed and anti-Communist prefect, Giovanni Palamara, was to outlaw unauthorized public gatherings under the pretext that "public manifestations, in the present difficult times, represent an effective danger of great disturbances. ${ }^{" 98}$ This was followed soon by orders to erase any physical signs of what the proYugoslavs had formerly called "Monfalcone antifascista," including the various graffiti that still sprung up, asserting that "this here is Yugoslavia." ${ }^{\circ 9}$ Replacing these would be the physical signs

\footnotetext{
${ }^{96}$ Cap. Com. Casini (Carabinieri-Monfalcone), "Segnalazione” (N. 9/15), 16 September 1947, ASG, Pref. Gab. 194582, b 211, f 479, sf Legione territorial carabinieri.

${ }^{97}$ Segretario G. Altran (ANPI-Gorizia), "Relazione dei fatti avvenuti durante i festeggiamenti per la riunione alla Madre Patria del Zona del Monfalcone," 18 September 1947, ACS, MI, Gab 1947, b 48, f 2870.

${ }^{98}$ Prefetto Palamara, Decree of 4 October 1947 (N. 1224/Gab), ASBCM, b 522, f Ctg III, sf 2.

${ }^{99}$ Sindaco Rovatti (Monfalcone), "Cancellazione scritte ineggianti a regimi esteri” (N. 14072/6.1), 17 December 1947, ASBCM, b 523, f Ctg VI, sf Cl 1.
} 
of what might be termed "Monfalcone italiano." But beyond Palamara's authoritarian style, monfalconesi faced persistent housing shortages, high unemployment, a limited number of apprenticeships for the district's youth, and persistent food shortages, the last of which the communal president predicted would require a continuation of rationing for some time, lest there be widespread famine. ${ }^{100}$ Those on the far left, especially pro-Yugoslavs, faced unapologetic discrimination from the anti-Communist personnel directing the communal labor offices and the CRDA personnel department. ${ }^{101}$ With the tacit approval of Palamara, the CRDA management proceeded with its longstanding strategy or replacing such workers with esuli, using the latter as spies and anti-Communist muscle within the shipyard. ${ }^{102}$

Despite the departures of 1947 and the repressive measures against Communists of all territorial allegiances, Monfalcone continued to be the center of left-radicalism in Gorizia Province, even if the leftist forced remained deeply divided. Even with the exodus of CRDA workers, the Communists won a majority (nearly 54\%) of the votes in the CRDA's syndical elections of May 1947 - the first since syndical fusion occurred. ${ }^{103}$ Moreover, several monfalconesi, among them Bersa, Mario Geromet, Ottone Zanolla, and Mario Fantini, sat on key positions within the PCI-Gorizia's Federal Committee. ${ }^{104}$ But under the surface, the reconciliation of the mass of working monfalconesi with the PCI was uneven at best. Throughout 1947 and 1948,

${ }^{100}$ Capo del Comune Rovatti (Monfalcone), Report to Prefettura di Gorizia (N. 10961/1-1), 22 September 1947, ASBCM, b 522, f Ctg 1, sf Cl 5.

101 Direttore Burba, MLPS, Ufficio del Lavoro-Gorizia, "Situazione della disoccupazione a Monfalcone," (N. 10132PB/pe), 11 November 1947, ASG, Pref Gab 1945-82, b 222, f 494, sf Ufficio Emigrazioni operai all'estero.

102 Fogar, "Terza parte dell'intervista registrata rilasciata da Ruggero Bersa," November 1981, op. cit. The antiCommunist violence of "Fascist" and virulently nationalistic esuli is a common theme in Spartaco Romano's recollections, and Sergio Parenzan recalls pretending to carry a pistol in his jacket pocket to avoid being attacked by the fifteen esuli of his workshop. Bonelli, "Seconda testimonianza del monfalconese Romano Spartaco," 19 March 1981, op. cit.; "Sesta testimonianza del monfalconese Romano Spartaco," 23 October 1981, op. cit.; Morena, "Intervista a Sergio Parenzan," 1000hrs, 30 May 2001, op. cit.

${ }^{103}$ The Socialists gained just over $15 \%$ and the "Unitaries," a coalition of Actionist, Liberal, and DC-aligned workers, gained just over 31\%. Maj. Hill, "Monthly Report, May 1947," 28 May 1947, op. cit.

${ }_{104}$ PCI-Gorizia, "Composizione del Comitato Federale del P.C.I. per la Provincia di Gorizia," December 1947, APCIG, Federazioni: Gorizia, Anno 1947, mf 140. 
PCI leaders fretted over the degree to which monfalconesi accepted the PCI's moderate, democratic line and whether the zone's revolutionary "deviationism" might prove to be a liability. ${ }^{105}$ Party leaders noted that large numbers of working monfalconesi rejected the PCI's conciliatory policy toward the lower middle class and its electoral strategy of allying with the PSI in the looming 1948 election. What seemed a reasonable alliance on paper meant on the ground an alliance of workers who just the year prior had been bitterly divided on the territorial question. ${ }^{106}$

Such comments reveal the deep frustration and alienation felt by many monfalconesi who had long fought to transform radically their community, but who had achieved very few of their ends. In this context of hardship and alienation, a steady, if much smaller stream of eastward clandestine expatriations persisted even after September 1947 - these now unquestionably illegal under Italian law - as monfalconesi sought relief or utopia in Yugoslavia. ${ }^{107}$ Though the new year did not bring a complete stoppage of expatriations to Yugoslavia, by the beginning of 1948 they had slowed to such an extent that one can say that the controesodo had ended. By and large, monfalconesi had made their choices about which side of the Iron Curtain promised them the best lives and the most secure futures. Some five-thousand ended up in the East.

105 Lino Zocchi, "Cari compagni” (Letter to PCI-Direzione), (N. 1981), 31 December 1947, APC-IG, Federazioni: Gorizia, Anno 1947, mf 140; PCI-Gorizia, Comitato Federale, Verbale n. 30, 10 October 1948, APC-IG, mf 182, p 1293.

${ }^{106}$ At a meeting of the Federal Committee for the PCI-Gorizia, Rodolfo Batti, head of syndical organizing, commented that this coalition "exists at the top, but does not at the bottom. See the example of Monfalcone." PCI-Gorizia, Comitato Federale, Verbale n. 8, 4 March 1948, APC-IG, mf 182, p 1119.

${ }^{107}$ A large portion of these late-1947 and early-1948 emigrants were unemployed. See, for example, the family of Virgilio C., which was of "anti-Italian" Communist sentiments and which emigrated to Yugoslavia in mid-October 1947 because the family members could not find work. ASG, Questura 1948, b 10, f 1613. Another example is Sergio D. L., a young electrician who, though seemingly a pro-Italian Communist, found no work and emigrated to Fiume in November 1947 to join his parents and step-sister. ASG, Questura 1948, b 4, f 531. See also ASG, Quesutra 1948, b 3 , f 482; b 10, f 1616 . 


\section{Interpreting the Controesodo}

Though the precise number of those who emigrated to Yugoslavia will likely never be known (see Appendix $\mathrm{C}$ for a closer examination of the numbers), there were a range of motivations, processes, and timelines for those five-thousand who decided to depart. The complexity of the choice to emigrate exemplified in the cases of Eugenio Pin and Sergio Parenzan was the norm, rather than an exception. In recent years, historians and even participants have come to recognize the multidimensionality of the emigrant motivations. They have broken free from earlier interpretations that ascribed a universal explanatory role to the desire of monfalconesi to "construct socialism," adding to these an awareness of economic hardship related mainly to the decline of the CRDA and a fear of pro-Italian retribution. ${ }^{108}$ To these, one might fruitfully add two more categories of primary motivations that have received little attention. The first, touched on slightly by Berrini and Pin-Giuricin, includes familial concerns, understood both in the narrow terms of seeking to keep families intact and in the wider terms of seeking out a society that would allow the full flowering of one's family life. ${ }^{109}$ The second involves family survival strategies. For many, Yugoslavia offered resources - particularly jobs and doubled rations - that could be exploited by straddling the border, and even a number of pro-Italians and anti-Communists put aside their politics and made use of these opportunities. They formed a small subcurrent of the wider population flow, diverging from broader controesodo in spirit, if not in the direction of migration.

\footnotetext{
108 These three factors have become the foundation of most interpretations since the publication of Puppini and Altieri's Il mosaico giuliano in 2003. At various times, historians have added other peripheral explanations - Puppini alluded to residual anti-Italian sentiment, Morena stressed the discontent caused by Italy and the AMG's persecution of left-wing partisans (as distinct from their persecution of pro-Yugoslavs), and Pin-Giuricin and Berrini have drawn attention to familial motivations - but those three factors are almost universally accepted. Puppini, "Il 'controesodo' Monfalconese in Jugoslavia," 72; Morena's introductory comments in Tonzar, La valigia e l'idea, 27-28; Pin-Giuricin, "I motivi di una scelta,' 344-45; Berrini, Noi siamo la classe operaia.

${ }^{109}$ See fn 112.
} 
Most migrants were pro-Yugoslavs of varying intensity and activity, and to try to break their motivations down into distinct categories of "political" and "apolitical" or "political" and "mundane" is difficult. The way in which such monfalconesi thought about "apolitical" or "mundane" motivations was often informed by the myth of Yugoslavia and by their understanding of Communism as a negation of everyday Fascism. It was a faith in the existence of the bountiful Yugoslav marketplace and its just system of exchange that allowed monfalconesi to conceive of border-straddling strategies. It was faith in the New Yugoslavia's liberal divorce laws and its commitment to individual liberation and happiness - faith in the "radiant future" - that led so many to see their familial ambitions as realizable only across the Morgan Line.

Whatever the motivations of the individual emigrant, the controesodo as a whole cannot be separated from the long experience of Fascism and the failures of purging the "remnants of Fascism" from local society. If anything, the controesodo was a revolt against the district's PCRG and its PCI successor, in part because they failed to achieve concrete results, but also because they reframed the struggle and the social coalitions of the struggle in a way that ignored the principal grievances of people on the ground. In this, scholars like Anna di Gianantonio are right to stress that the emigration was as much about fatigue and disillusionment as optimism about Yugoslavia. ${ }^{110}$ This is why, as Gombač has stressed, spontaneity and individual choice were the defining features of the controesodo, not organization and central direction. ${ }^{111}$ This is not to say that organization did not exist or that Yugoslavia did not exploit the willingness of monfalconesi to emigrate in order to gain propagandistic and economic advantages; rather it is to suggest that emphasizing organization attributes causation to something that was merely a source of

\footnotetext{
${ }^{110}$ Di Gianantonio et al, L'immaginario imprigionato, 158-59.

111 Gombač quotes an emigrant Ermete Soranzio, who recalls that "the choice to depart was personal and the party had nothing to do with this transfer." Gombač, "Controesodo tra poteri popolari e GMA," 59-61.
} 
acceleration and facilitation. The UAIS directive of January 1947 - or, more accurately, the SU's transfer network, which became known by way of this directive - was merely a set of resources that provided the necessary logistical support for individuals who otherwise had had a longstanding desire to relocate. The fact that so many youths refused to return to the Monfalconese after their Youth Brigade service and that so many monfalconesi clamored for relocation already in the fall of 1946 is proof of this spontaneity. Among them was Silvano Cosolo of Pieris. 


\section{Chapter 7: A New Life Beyond the Iron Curtain}

A breath of fresh air. It's easy to say! First of all, in order to change the air definitively it was absolutely necessary to expatriate. Expatriate where? To the west, Italy. To the north, Austria. To the east, Yugoslavia.... I chose Yugoslavia. But to expatriate alone one needed to be an adult. At the time, I was just sixteen....

- Silvano Cosolo, emigrant to Yugoslavia.

Shortly after the young Silvano Cosolo passed into Yugoslavia on foot in the summer of 1946, he arrived at a predetermined police station and was placed on a train to Fiume. Once Cosolo disembarked at his destination, he met up with several young monfalconesi who had preceded him, among the first to have emigrated. After a short while, he took his leave and headed to the local SU headquarters, which served as a hub for gathering and then placing Italians arriving from the west. There, he faced a question that he probably should have expected, even though he had not: where would you like to live? Caught off guard, Cosolo pondered the question for a short while. Then, recalling a story he had heard in school about Franz Ferdinand, he answered "Sarajevo!"2

For those who ventured into the land of Tito, differences in experience emerged from the moment of arrival, often resulting from answers to questions as simple and predictable as this. There was no universal experience of Yugoslavia. Monfalconesi experienced life in Tito's new country differently based on the time of their arrival, the location in which they settled, and their own choices once in Yugoslavia. ${ }^{3}$ Political affiliation and the possession or lack of an SU labor contract were often decisive factors in shaping migrants' first experiences, including settlement location and employment opportunities. Those who arrived individually, without ties to the PCRG or its mass organizations, could expect a month or more of miserable "voluntary" labor brigade work before receiving a permanent position - a reality that caused many to flee before earning a

\footnotetext{
${ }^{1}$ Bonelli, "Prima intervista con il monfalconese Franti Giuseppe," 27 March 1980, op. cit.

${ }^{2}$ Cosolo, Amare... Sarajevo, 18-19.

${ }^{3} \mathrm{Di}$ Gianantonio et al, L'immaginario imprigionato, 169. This idea is also implicit in Berrini's Noi siamo la classe operaia.
} 
permanent job. Those with PCRG ties or an SU contract, both because of political connections and the skills implied by the SU contract, mostly ended up in a major Yugoslav city, where, in the estimation of Italy's Frontier Police, one could live well, depending on one's family conditions. ${ }^{4}$

Despite this variance, there were also experiences shared by a majority of monfalconesi, which shaped how they assessed life in their adopted homeland. All needed to navigate not just concrete difficulties of relocation - finding a place to live, finding a school for one's children, and establishing social networks - but also potentially more jarring encounters with cultural difference and with the fulfillment or disappointment of their aspirations. Since most came to Yugoslavia with high hopes and expectations, they had to weather the storm as their hopes for and vision of Yugoslav socialism bumped up against Yugoslav realities. Given a lack of contemporaneous documentation, it is exceedingly difficult to reconstruct migrants' range of experiences and reactions, not least of all because the PCI destroyed the single greatest set of records on the topic in the 1950s during destalinization. ${ }^{5}$ Nevertheless, it is worth the attempt, as their reactions reveal much about how they thought about socialism.

As for Cosolo, who left behind detailed memoirs, his first experienced hinged upon his answer: Sarajevo. As a teenager with no notable work skills, but a demonstrable history of proYugoslav activity, he had an unusual freedom to choose his settlement location. Yugoslav authorities thus honored his request, shipping him to the Bosnian capital.

\footnotetext{
${ }^{4}$ Direttore Capo Div FF TT, "Espatrio di operai italiani in Jugoslavia” (N. 300/62674-171C), 1/3/49, ACS, MI, DGPS, Div SIS, Sez II: AA GG 1944-49, b 79, f OP52. This report spoke of late-1947 Carnian migrants, but the trend is applied also to monfalconesi.

${ }^{5}$ Bonelli, Fra Stalin e Tito, 158.
} 


\section{Encountering a New Land: Monfalconesi in Bosnia}

In choosing Sarajevo, Cosolo chose the Yugoslav interior over the more commonly selected Croatian coastal towns. In turn, this meant electing to live in a comparatively underdeveloped and diverse region. Despite these conditions, he was not the only foreigner to choose Bosnia. He had been preceded by several of his neighbors, as well as workers from southern Italy and other European countries, all of whom would experience Sarajevo differently. ${ }^{6}$

For a young man like Cosolo, having lived his entire life in a Fascist Italy with Catholic values and limited tolerance for national minorities, life in Bosnia was liberating. On the one hand, for a young man coming of age, the atmosphere of gender equality and sexual liberation provided a wide range of novel experiences. Particularly remarkable to Cosolo was the degree to which Bosnian girls were "available" (disponibili), not in a strictly sexual sense, but rather in the sense that they could freely socialize and freely pursue physical and emotional love in a way prohibited in Catholic, bourgeois Italy. ${ }^{7}$ On the other, Cosolo marveled at the Baščaršija neighborhood - the "Kasbah" of Sarajevo - and the easy cohabitation of Muslims and Christians:

A few steps beyond Tito Street [a main boulevard ending at the Baščaršija] and there it is, in the place of the large palaces of before, everything is a series of hovels where wood is abundant, small streets that are narrow and flooded with women in Arabian garb and with the classic veil and with men with the same clothes and the red fez, as can be seen in the images from documentaries shot in the Middle East. ${ }^{8}$

In his mind, the shared Partisan struggle, in which monfalconesi could rightly claim a place, truly had united the Yugoslav nations, allowing Muslim, Catholic, and Orthodox believers to "mix comfortably without any difficulty in work or in the city's social gatherings." ${ }^{\prime 9}$ In this atmosphere

\footnotetext{
${ }^{6}$ Cosolo, Amare... Sarajevo, 23-25.

${ }^{7}$ Ibid., 61-67, 73-76.

${ }^{8}$ Ibid., 41. See also Di Gianantonio et al, L'immaginario imprigionato, 171.

${ }^{9}$ Cosolo, Amare... Sarajevo, 43. Cosolo recounts the example of a Bosniak work-team leader, who regularly interrupted his work to pray in the middle of the workshop, never once teased by his coworkers or harassed by the state or his superiors. Ibid., 46.
} 
of cultural freedom and mutual tolerance, Cosolo, like other young monfalconesi who ventured to Bosnia in 1946 and 1947, recalls feeling that he belonged and that he was truly understood. ${ }^{10}$

For all the perceived advances of the new socialist culture, the choice of Bosnia also had its drawbacks. Most monfalconesi in Bosnia, Cosolo included, found work at the Zelejeznička Radiona, a rolling stock workshop tasked with disassembling old and damaged stock, salvaging parts, and assembling new stock. There, whether single or with families, they lived as a cohesive colony, lodging in military-style barracks without running water or electricity. Though Cosolo found these accommodations acceptable - his primary complaint was a lack of soap, which left him feeling perpetually dirty and undignified - those workers who were heads-of-family quickly became frustrated with the lack of privacy in the barracks. Such workers found the lodging to be well below their expectations and their pay insufficient to remedy this situation. Though as a single man Cosolo soon had sufficient savings to rent his own apartment in the city, those with familial expenses found themselves trapped in the barracks, unable to save enough for rent and facing longterm detachment from their families whom they refused to subject to such conditions. ${ }^{11}$

It was because of these conditions that the Monfalconese colony at Sarajevo went on strike in the winter of 1946/47. Fed up with perceived violations of their contracts and convinced that these conditions were a result of the "old regime" director who refused to listen to their demands and who exploited workers without regard for their well-being, the older men put down their tools, soon joined in solidarity by Cosolo and young colonists. The strike, conceptualized as not just an economic action in the workplace but also a political action against the old regime, garnered political attention and brought a visit by the Bosnian president. Cosolo recalls that the president listened to the workers' demands, judging them legitimate, after which the authorities came and

\footnotetext{
${ }^{10}$ See, for example, Mario Tonzar's account of his time at Zenica. Tonzar, La valigia e l'idea, 87.

${ }^{11}$ Cosolo, Amare... Sarajevo, 27-29.
} 
took the firm director away. ${ }^{12}$ In this early period, then, the Sarajevo colonists, whose experiences were so determined by their family conditions, lived both the reality and myth of socialist Yugoslavia. On the one hand, they soon realized that Yugoslav workplaces were not all so fundamentally transformed as to allow for dignified, autonomous, and well-remunerated work. On the other, the responsiveness of Tito's state to worker demands appeared both swift and just. To many, the strike must have seemed a demonstration of monfalconesi and Yugoslavs constructing socialism together.

\section{Awaiting Tito in Pola}

If Sarajevo was a marvelous novelty, the same could not be said of Pola, the second most common migration destination. In Pola, where monfalconesi could live along the familiar Adriatic Sea and where, like Fiume and Spalato, the town bore a familiar cultural heritage, the experience of arrival was very different, not least of all because the town remained under AMG administration until its transfer to Yugoslavia in September 1947. Most monfalconesi in Pola arrived under SU guidance as the Yugoslav government negotiated the purchase of Pola's Scoglio Olivi Shipyards in early 1947, anticipating and preceding Yugoslavia's arrival in the town. ${ }^{13}$ The shipyard had seen an exodus of its skilled, mainly Italian laborers beginning in summer 1946, which had, per Italian intelligence, left at the shipyard "only a small band of unskilled manual laborers of Slavic origin."14 For monfalconesi who arrived to take these vacant positions, the first impression was certainly one of having climbed the status hierarchy and realized career ambitions long frustrated in Monfalcone.

Yet in other respects, monfalconesi arrivals in Pola found the town in conditions much like the violent, divided Monfalcone they had left behind. Like Monfalcone, Pola had long been

\footnotetext{
12 The director was rumored to have received a seven-year prison sentence. Cosolo, Amare... Sarajevo, 48-55.

${ }^{13}$ SCAO Meeting Minutes, 17 March 1947, NARA, RG331, UD1981, b 9108; f 11304/115/90.

${ }^{14}$ Capo di Stato Maggiore dell'Aeronautica, "POLA" (N. 753377/C) and Attachment, 8 August 1946, op. cit.
} 
gripped by a struggle between pro-Yugoslavs and pro-Italians, the AMG estimating upon its arrival a roughly 60-40 split in favor of Italy. Monfalconesi arrived just as the struggle reached its violent climax. ${ }^{15}$ In fact, in early January 1947 a pro-Yugoslav crowd attempting to prevent the removal of local flour mill to Italy had assaulted the police escort sent to aid the removal. The police had responded by shooting into the crowd, killing three and wounding nine more. ${ }^{16}$ These tensions remained high throughout the signing of the Peace Treaty in February, during which time a veritable flood of monfalconesi arrived in Pola. So many arrived during that period that a young pro-Italian tough from Trieste, formerly implicated in the knifings of pro-Yugoslavs in his native city, could knock on the door of Pola's UAIS headquarters on the day before the signing of the Peace Treaty and claim to be another comrade recently arrived from Monfalcone. The doorman, unable to keep track of all the arriving monfalconesi, opened the door, at which point the undercover triestino greeted Pola's UAIS members and their Monfalconese comrades with a grenade, killing one and wounding three more. ${ }^{17}$ Though the political situation cooled down considerably in the spring with the departure of many pro-Italians for Italy, monfalconesi found that the flight of a large share of the town's shopkeepers and merchants brought a supply crisis and a worsening of black-market conditions. ${ }^{18}$ For monfalconesi who had chosen Pola, most of 1947 was spend in anxious expectancy. The arrival of Tito's government could not come soon enough.

\footnotetext{
${ }^{15}$ Public Safety Office, AMG-Pola, "Monthly Report for JULY, 1945,” 25 July 1945, NARA, RG331, UD1981, b 9133, f 11303/115/101.

${ }^{16}$ SCAO Meeting Minutes, 6 January 1947, op. cit.

${ }^{17}$ See the case file at NARA, RG331, UD1981, b 9332, f 11304/142/104; SCAO Meeting Minutes, 17 February 1947, op. cit.; Capt. Montague (AIS-Trieste), Report to Maj. John Vernon, 'D' Section, 19 June 1946, op. cit.

${ }^{18}$ TRUST, Intelligence Summary No. 1, April 1947, NARA, RG331, UD1981, b 9084, f 11300/200/8; SCAO Meeting Minutes, 9 June 1947, NARA, RG331, UD1981, b 9108; f 11304/115/90.
} 


\section{Fiume and the Broad Horizon of Possibilities}

While monfalconesi arriving in Bosnia experienced the dual shocks of that region's extreme diversity and economic backwardness and those arriving in Pola experienced grenades and tension, those who chose Fiume arrived to a fêting. Seeing the monfalconesi as central to the realization of the Five Year Plan and Yugoslavia's successful socialist transition, the Yugoslav authorities did all they could to make their transition enjoyable. ${ }^{19}$ As $I l$ Lavoratore described to monfalconesi who remained back home, those who made the jump were greeted at the Sušak train station by representatives of Fiume's municipal council, who bestowed upon them food, lodging, and a bit of spending money, "lavishing the workers so that they feel at home." They received rooms in the best hotels of Abbazia (Opatija) and nearby suburbs, "where one time were housed the great magnates of industry and commerce," and ate ample breakfasts and dinners in the mess of Fiume's largest hotel. ${ }^{20}$ And these claims, though written for propagandistic ends, do not appear to be too much of an exaggeration, nor did they apply solely to Fiume. When the SU-Trieste sent a delegation to inspect conditions of recently-arrived workers in the country's larger cities, the report suggested that it could not describe how workers in Belgrade and other cities were treated "because never in the history of the world was a worker treated in such a way." ${ }^{21}$ All throughout Yugoslavia, skilled Italian workers who arrived in early 1947 reported high pay and the receipt of quality housing at the expense of the state. ${ }^{22}$ Thus, even if Mirella Pin-Giuricin recalls certain lingering "economic discomforts" related to lingering wartime destruction, the more important fact was that the monfalconesi "were welcomed with open arms" by the new city and the new state. ${ }^{23}$

\footnotetext{
${ }^{19}$ On Yugoslavia's Five Year Plan, see Susan Woodward, Socialist Unemployment, ch. 3.

${ }^{20}$ Marino, "Lavoratori italiani in Jugoslavia," Il Lavoratore, 19 March 1947. Puppini deserves credit for discovering this article.

${ }^{21}$ SU-Trieste, "Viaggio della delegazione triestina dei Sindacati Unici a Belgrado," May 1947, op. cit.

${ }^{22}$ Capo della Polizia, "Segnalazione” (N. 224/64264), 16 December 1947, ACS, MI, Gab 1947, b 48, f 2849.

${ }^{23}$ Pin-Giuricin, "I motivi di una scelta," 364.
} 
This welcome was cultural as well as economic. Monfalconesi soon found ways to participate in organizations like the Union of Italians of Istria and Fiume (Unione degli Italiani dell'Istria e di Fiume, UIIF). Created late in the war, the Union aimed to facilitate left-wing Italians' contributions to a new socialist culture for Tito's Yugoslavia. ${ }^{24}$ Other monfalconesi made their contributions outside official cultural organizations. Mirella Pin-Giuricin's mother organized a Monfalconese acting troupe that put on typical anti-Fascist partisan theater, including such original works as Heroic Youth, a play about a young partisan who, captured by his enemies, endured torture and blinding without giving up the names of his comrades. After showings in Pola and Fiume, the troupe received an invitation to Zagreb, where it put on the show to much official acclaim. ${ }^{25}$ Expressing shared values with the host state, free to use their own language, and living in a city in which native working-class radicals had risen to control the offices of Political Commissar and People's Tribunes, the monfalconesi at Fiume would have felt welcome. ${ }^{26}$

Moreover, for those who arrived in early and mid-1947, the grievances of marketplace Fascism, as well as economic hardship itself, appeared something already or soon to be relegated to the past. ${ }^{27}$ A glimpse of their conditions can be had from a report sent back to Rome from the Italian Legation in Belgrade in early September. At that time, skilled Monfalconese laborers received higher pay than local workers of comparable skill - between 15-19 dinars per hour with a steady 200 monthly hours of work - not to mention a month of annual paid vacation, health

24 “Gli italini dell'Istria a Convegno," Il Lavoratore, 3 February 1947; Puppini, "Il “controesodo' monfalconese," 75. ${ }^{25}$ Pin-Giuricin, "I motivi di una scelta," 356-58.

${ }^{26}$ Similarly, monfalconesi received a prominent position in the official May Day celebrations of 1947. In Belgrade, they marched in procession alongside (or rather, between) native intellectuals, craftsmen, and peasants, carrying with them the red-starred Italian flag. SU-Trieste, "Viaggio della delegazione triestina...," May 1947, op. cit. Regarding local officials, see ch. 3, fn 133.

${ }^{27}$ Early 1947 marked the high point of Yugoslav postwar recovery. Though the country had lost $11 \%$ of its population, $35 \%$ of prewar industry, $50-70 \%$ of livestock, $80 \%$ of machinery, and over $50 \%$ of railways, by late 1946 some $90 \%$ of prewar railways had been repaired and industrial production stood at 79\% of the prewar level. In 1947, industrial production surpassed prewar levels, at least according to official statistics. Rusinow, The Yugoslav Experiment, 19. 
insurance, access to the price-controlled ration system, and free or subsidized meals in the mess halls of their firms. ${ }^{28}$ Moreover, for those who had left their families in Zone A, the Morgan Line offered an opportunity for enrichment. The ability to live well and cheaply in Yugoslavia combined with Tito's "political" fixing of an artificially high dinar-to-lira exchange rate to create conditions in which monfalconesi could send previously unthinkable amounts of money back home. ${ }^{29}$ It was not uncommon for skilled workers to remit as much as 50,000-70,000 lire per month in 1947 while still living comfortably in Yugoslavia. ${ }^{30}$ For monfalconesi such as Fioravante, interviewed by Andrea Berrini, the conditions of material life were quite good at that time. ${ }^{31}$

But the changes in the economy went well beyond an increased ability to secure the means of subsistence, also affecting the nature of commercial or shopping interactions. By the time the monfalconesi arrived in Fiume, Tito's regime was already well on its way to transforming these sectors. In mid-1946, it had launched an offensive against private commerce in Fiume, "unmasking" and punishing sixty merchants for alleged obstruction of normal provisioning and for speculation on worker hardship. ${ }^{32}$ The campaign against private merchants should not be surprising, as prominent Yugoslav leaders such as Slovenian President Boris Kidrič had long seen commercial speculation as the most "primitive form of exploitation." He envisioned reorganizing urban commerce to be carried out by way of largescale shops within state-run firms. He believed this would achieve increased economies of scale, a reduction of transfer costs, increased worker

\footnotetext{
${ }^{28}$ Engineers and technicians earned roughly 5000-6000 dinars per month along with substantial supplements if they were married or had children. Legazione d'Italia (Belgrado), "Lavoratori italiani in Jugoslavia" (Tel. N. 266/44), 4 September 1947, op. cit.

${ }^{29} \mathrm{Ibid}$. This also was a focus of Il Lavoratore. See "Una lettera dalla Slovenia," Il Lavoratore, 11 August 1947.

${ }^{30}$ Legazione d'Italia (Belgrado), "Emigrazione e condizione dei lavoratori italiani in Jugoslavia," 7 February 1950; and "Viaggio di servizio a Sarajevo" (Unnumbered), 29 January 1950, both in ASDMAE, AA PP 1946-1950, Jug, b $72, \mathrm{f} 2$.

${ }^{31}$ Berrini, Noi siamo la classe operaia, 78.

${ }^{32}$ This was as likely aimed at driving out anti-Yugoslavs as affecting a revolution in distribution. Capo di Gabinetto (MI), "Notizie di carattere politico della Jugoslavia" (N. 37979/1308), 30 June 1946, ASDMAE, AA PP 1946-1950, Jug, b 32, f 2 .
} 
loyalty to their firm, and an easy way for the state to accumulate capital for state investment. ${ }^{33}$ To implement this vision, in mid-1947 the leadership introduced the "guaranteed provisions" system in all industrial firms with over 200 employees, officially shifting the provisioning of industrial workers into the hands of their firms and the state-run stores, and de facto prioritizing industrial workers in the battle to secure provisions. ${ }^{34}$ For monfalconesi, gone were the days of dealing with the "Fascist" shopkeepers intent on gouging and exploiting by nature of their monopoly over vital goods. Finally, they realized a demand they had made since the war years.

In the workplace, too, everyday Fascism appeared to have been dealt a significant blow. The Titoist regime had carried out a purge of the 3 May Shipyard in 1946 and frightened many native skilled workers, technicians, and directors into flight, leaving the shipyard a sort of virgin land at a time when Yugoslavia was embarking on its ambitious Five Year Plan. ${ }^{35}$ Monfalconesi such as Angelo Buttignon and Onorio Donda recall immediately assuming leadership positions in both the technical staff and, as Donda indicates, "accepting syndical appointments at the level of the factory." 36 No migrant speaks to this broadening of horizons as clearly as Giuseppe Franti, who himself rose to be a major figure in the shipyard's Planning Office:

It wasn't just a political force that arrived at Fiume, but also one working, technical, scientific. The nerve points of the shipyard and of the industries of Fiume were staffed by monfalconesi. These were not bums who had arrived from Monfalcone, but rather trained people with all the trappings. Workshop heads, head technicians, department heads from the Monfalcone shipyard had taken directive positions in the establishment of Fiume. ${ }^{37}$

\footnotetext{
${ }^{33}$ Woodward, Socialist Unemployment, 68, 71, 76-77, 104-105.

34 Though most Yugoslav workers appear to have been paid in coupons redeemable at these stores, it appears that the monfalconesi and other Italians, as foreign citizens, received cash wages instead. Woodward, Socialist Unemployment, 104-105.

35 See ch. 3, fn 116.

${ }^{36}$ Bonelli, "Testimonianza del monfalconese Donda Onorio," 5 March 1978, op. cit. Bonelli, "Testimonianza del monfalconese Buttignon Angelo," 28 April 1978, op. cit. In Communist Yugoslavia, unions served primarily as (1) cultural or social clubs and (2) conduits between workers and regime to pass along official policy and worker grievances. The appointment of monfalconesi indicated a recognition of their cultural, political, and industrial preparedness. Woodward, Socialist Unemployment, 71, 85-87.

${ }^{37}$ Bonelli, "Prima intervista con il monfalconese Franti Giuseppe," 27 March 1980, op. cit.; Tonzar, La valigia e l'idea, 105.
} 
Of the Planning Office's thirty-one employees, Franti recalls that twenty-seven were monfalconesi, though the other four were "people of the Party," including the Bosnian Serb director who "knew nothing." Though the manager retained ultimate authority over production decisions under the theory of "one-man management," in practice he leaned heavily on his Monfalconese vicedirector, allowing the monfalconesi to run the firm. ${ }^{38}$ For those who rose into the ranks of management, work life attained the autonomy, respect, and meaning that they so closely associated with workplace socialism. They had become Il Lavoratore's "master-workers."

The attainment of workplace liberation was not exclusive to the technicians and directors. Italian sources indicate that it was easy for Italian workers to gain recognition for skilled status, as "they know how to do more than the local workers, which is very easy because... one speaks of workers coming from the country, while even an unskilled Italian can be considered a headworker. ${ }^{39}$ No longer finding themselves on the lower rungs of the labor totem pole, many experienced a newfound workplace freedom. One worker interviewed by Berrini recalls that in Yugoslavia there was, at the very minimum, "the rule of the workers," which meant freedom to take smoke and restroom breaks at will and freedom from the foreman's rigorous checks on labor intensity and piece production. ${ }^{40}$ But such freedom was not absolute. Limits remained for those who had been less successful at climbing the labor hierarchy, and one-man management meant that unions and workers' councils lacked authority to determine unilaterally the methods and paces of production. Still, accompanied by steady work under the Five Year Plan and the Yugoslav state's investment in the most modern production machinery - chief among it a 43-meter-tall, 50-

\footnotetext{
${ }^{38}$ Bonelli, "Seconda intervista con il monfalconese Franti Giuseppe," 21 April 1980, op. cit.; Woodward, Socialist Unemployment, 85.

${ }^{39}$ Capo della Polizia, "Segnalazione" (N. 224/64264), 16 December 1947, op. cit.

${ }^{40}$ This particular migrant emphasized the importance of being able to smoke and use the restroom freely twice during his talks with Berrini, revealing its importance to his conception of liberation. Berrini, Noi siamo la classe operaia, 68-69, 83-84.
} 
ton electric crane defined as the "most modern and largest in the Balkans" - it appeared to most monfalconesi in Fiume that quotidian work life was undergoing a serious transformation. ${ }^{41}$

In addition to experiencing broadened horizons with their pocketbooks and in the workplace, monfalconesi in Fiume saw new opportunities for cultural and educational advancement. This had been a key theme in Il Lavoratore as far back as December 1945. When Fiume inaugurated its People's University, the paper had announced the "pruning away [of] all veils in which Fascism wrapped [education] to make it a political instrument," later declaring that, in Fiume, "to elevate ever more the people - this is the order of the day." 42 To a degree, such claims were realized in those first years at Fiume. Giuseppe Franti, who arrived after service on the Youth Railway, recalls fondly his time at the Fiume schools, attended by "monfalconesi and fiumani, half and half." At evening school, Franti found "teachers of fame, even scientists" and the opportunities "stupendous." There, workers who, like him, had done only two years of postelementary schooling before leaving for a CRDA apprenticeship, could learn math, physics, chemistry, history, economics, philosophy, political science, and languages. In his memory, at least, the schooling was so effective that "in one year, two years were done: I did two years of it, and thus four years. At the end they gave me a diploma, we'll say for general culture." ${ }^{43}$ If Fascist education had meant the closing of opportunities to working-class families, then socialism meant broadened educational opportunities and cultural elevation, which Yugoslavia delivered. ${ }^{44}$

\footnotetext{
${ }^{41}$ MI, SIS, II Sez, "Segalazione," 25 September 1947, ACS, MI, Gab 1947, b 48, f 2849. The shipyard went from wholly inactive due to a "lack of materials and technical personnel" (1946) to full operation by 1948. Unsigned (Stato Maggiore-Uff Informazioni), "Situazione di Fiume e della zona 'B'," 7 August 1946, ASDMAE, AA PP 1946-1950, Jug, b 6, f 3; Capo Ufficio, PCM-UZC, "Situazione oltre frontiera (Jugoslavia)," (N. 200/4546/4/78), 13 July 1948, AGPCM, Fondo UZC, Sez II, Jug, b 6.2, f 78.

42 "Università Popolari in Istria," Il Lavoratore, 11 December 1945; "Vita fiumana," Il Lavoratore, 28 February 1946.

${ }^{43}$ Bonelli, "Prima intervista con il monfalconese Franti Giuseppe," 27 March 1980, op. cit.

${ }^{44}$ The theme of free, open education appears in other recollections of Yugoslavia. See those of the goriziana, Iolanda Scolaris. Iolanda Scolaris, interview by Alessandro Cattunar and Kaja Sirok, Gorizia, 23 June 2007, accessed 22 March

2015, transcript 
For the monfalconesi who arrived in 1947, the concurrent departure of Italian fiumani for Italy must have been a mystery. Hidden from sight was the fact that just the year prior, Fiume's streets and shops had been nearly bare. Italian-speakers had feared to walk the streets in groups or at night lest an OZNA agent appear and cause minor or major problems. The shops had sold "rarely distributed" and "absolutely insufficient" rations of bread and peas, while Italian fiumani, "literally suffer[ing] starvation," struggled to scrape together the basic means of subsistence on the black market and by traveling to Trieste. ${ }^{45}$ If the monfalconesi were aware that their comfort was purchased with expropriated property of fiumani who had fled and left apartments, furniture, and possessions behind, they were not deeply troubled. ${ }^{46}$ Identifying departed fiumani with the esuli who had terrorized them back in Zone A, their position toward those fiumani whose apartments they occupied and even toward those Italian-speakers who remained was predominantly hostile. ${ }^{47}$ For all the positive novelties that monfalconesi in Fiume experienced as they encountered Yugoslav socialism, their integration into local society was thus neither seamless, nor complete. Beyond hostility toward the local Italian-speakers, monfalconesi increasingly came into conflict with their Slavic compatriots - a condition that worsened significantly as the Five Year Plan unfolded. As the plan progressed, thousands of Croatian peasants arrived in Fiume to assume factory jobs, often lacking entirely in industrial skills and failing to meet monfalconesi's standards of hygiene and manners. ${ }^{48}$ In the words of Giuseppe Franti, which betray a condescension that has

http://www.stradedellamemoria.it/easyne2/LYT.aspx?Code=4704\&IDLYT=6605\&ST=SQL\&SQL=ID_Documento $=89$.

${ }^{45}$ Questore Durante, "Venezia Giulia...” (N. 01057), 5 June 1946, op. cit. See also Gen. Com. Brunetti (CarabinieriUSS), "Situazione nella Venezia Giulia" (N. 87/6), 25 January 1946, ACS, MI, Gab 1944-46, b 138, f 12148; Capo dell'Ufficio Santini (Stato maggiore R. Aeronautica), Trasmissione notizie (N. 751593-C), 4 April 1946, ASDMAE, AA PP 1946-1950, Jug, b 6, f 3; Unsigned (SM-UO), "Situazione di Fiume..." 7 August 1946, op. cit.

${ }^{46}$ By June 1946, some 11,000 fiumani had requested authorization to leave Fiume, but none had received official approval. Questore Durante, ““Venezia Giulia...” (N. 01057), 5 June 1946, op. cit.

${ }^{47}$ Vincenzo Marini, "Relazione," Undated (November 1948), AM-IG, b mf 135, f mf 135, d 43, sd 2.

${ }^{48}$ Berrini, Noi siamo la classe operaia, 51-52, 68. 
long outlasted his time in Yugoslavia, the arriving Croats were "ugly, filthy, bad." 49 Many of these Croats soon realized that monfalconesi received preferential treatment, which exacerbated their often deep-seeded resentments toward Italians for the destruction wrought during the Fascist period ${ }^{50}$ Others, including even those Croats who had been industrial workers for some time, came to resent that the monfalconesi rose so rapidly up the labor hierarchy. Though freed from rigid workplace discipline and gaining a substantial increase in their own autonomy, the monfalconesi, now as work-team leaders and directors attempting to make good on FYP projections, directed Croat workers in ways that fueled the latter's resentment. ${ }^{51}$ The confluence of longstanding resentment with short-term frustrations led many Croats in Fiume (and Yugoslavs in other cities) to label monfalconesi as unwanted, privileged foreigners. They voiced their anger in a nationalist language that ran counter to the idea of Italo-Slavic fraternity cherished by many monfalconesi. ${ }^{52}$ As months passed, the relationship between Croats and monfalconesi deteriorated and, by year's end, the monfalconesi existed in a largely contented isolation from wider Croatian Fiume. ${ }^{53}$

Though many monfalconesi accepted their existence as a hermetic community, there was a single feature of this isolation that appeared as a repeated source of frustration: their detachment from the KPJ. While many did not care to join the Yugoslav Party, likely thinking that membership in the Party (still a demanding party of cadres) was not worth the effort in a socialist country,

\footnotetext{
${ }^{49}$ Bonelli, "Seconda intervista con il monfalconese Franti Giuseppe," 21 April 1980, op. cit. See also Berrini, Noi siamo la classe operaia, 104.

${ }^{50}$ In late 1948, one resident of Koper (Capodistria) claimed that monfalconesi in Yugoslavia had "had every privilege" and that they "were treated better than Yugoslav citizens." Unsigned, "Dichiarazione di una persona che ebbe un colloquio con un elemento di Capodistria," 10 November 1948, AM-IG, Fondo Jug e VG, b mf 135, f mf 135, d 46. ${ }^{51}$ Such a tendency only exacerbated longstanding grievances of Yugoslav workers, who even in the interwar period had often worked under the direction of skilled foreign laborers. Woodward, Socialist Unemployment, 47.

${ }^{52}$ See particular examples of Yugoslavs using nationalist language in Berrini, Noi siamo la classe operaia, 107-108, $171-74$.

${ }^{53}$ Di Gianantonio et al, L'immaginario imprigionato, 169; Pin-Giuricin, "I motivi di una scelta," 362.
} 
others like Giuseppe Franti sought to join, but to no avail. ${ }^{54}$ In fact, even the most devoted, lifelong Communists from Monfalcone - including those who had spent years in Fascist confino and then headed the pro-Yugoslav struggle - had difficulty gaining admission. ${ }^{55}$ Only a very select group made such inroads or found ways to integrate with local Party networks. Renato Rigonat was one. Recruited into the Party's youth wing as an organizer, he then struck up a relationship with the KPJ member Mila Siaz in 1947, marrying her the following year. ${ }^{56}$ Two others were the multilingual Eugenio Pin and his daughter Mirella, who would later marry the Voce del Popolo writer and KPJ member Luciano Giuricin, an Italian speaker from Rovinj (Rovigno). ${ }^{57}$ But even without Party membership, for most monfalconesi in Fiume, the first months seemed to vindicate their choice to leave the Monfalconese behind. From the hero's welcome they received to their systematization within the local factories and markets, life appeared to be good and getting better.

\section{The Limits of Liberation: Everyday Grievances in Yugoslavia}

By the second half of 1947, this began to change, and it changed in large part because of the Five Year Plan for which monfalconesi had been brought to Yugoslavia. Because of shifting diplomatic and economic contexts, the regime drastically reworked the FYP as it unfolded beginning in 1947. Due to the plan's wide-ranging transformative aspirations, these changes radiated outward from the economic sphere to have an impact on nearly all aspects of life in Yugoslavia, proving to be a drastic and negative turning-point for most monfalconesi.

The primary cause for this shift was that Yugoslav planners had predicated the entire

\footnotetext{
${ }^{54}$ Bonelli, "Prima intervista con il monfalconese Franti Giuseppe," 27 March 1980, op. cit.; Scotti, Italiani nel gulag di Tito, 9.

55 "Mario," Untitled Report on the Italians at Fiume, 13 September 1948, IRSML, Fondo Cominform, b 99, f 1. This is confirmed by the Emilian partisan exile, Sauro Ballardini, who lived in Fiume at the time. See Bonelli, "Prima intervista con il partigiano profugo Ballardini Sauro (Topo)," 2 July 1980, op. cit.

${ }^{56}$ Rigonat, Memorie, 52-55.

${ }^{57}$ Berrini, Noi siamo la classe operaia, 238.
} 
funding program for the country's rapid industrialization on the receipt of large amounts of foreign aid, which failed to materialize as the plan got underway. From the outset, KPJ leadership had envisioned a transition more akin to Lenin's New Economic Policy than Stalinism, believing that regulated private ventures (especially in agriculture) should be allowed to coexist with and gradually fall prey to developing state and cooperative ventures. The state would foster the latter two categories relying upon capital accumulated from state control of agricultural exchange, the expropriation of foreigner and "collaborator" property, and, most importantly, the inflow of foreign loans, machinery, and consumables from both its partners in the victorious Grand Alliance and the new community of Soviet-aligned states. ${ }^{58}$ However, from the first months of the FYP, the expected aid and trade was forthcoming from neither the Soviet Union, nor the Soviet satellites, nor the Anglo-Americans. Instead, the British had frozen $\$ 47$ million in gold reserves that Yugoslavia's royal government-in-exile had brought to London, while Truman's United States, rather than providing Yugoslavia with cheap consumables, removed Yugoslavia from a list of priority aid targets in January 1947 and then indefinitely banned the shipment of American foodstuffs, machinery, and war-related materials to Yugoslavia. ${ }^{59}$ From the Soviets, the Yugoslavs also received little, despite the April 1945 mutual aid treaty and various Soviet promises. With relations soured by Tito's persistent independent streak and Stalin's attempts to control Yugoslavia like a satellite, the USSR even cut off deliveries of war-related materials by 1948, forcing Yugoslavia to dedicate an unexpectedly large share of its budget and developmental focus to

\footnotetext{
${ }^{58}$ Among the conditions that Titoist leaders believed made the Stalinist method inappropriate for Yugoslavia were the role of the Yugoslav peasantry in supporting the Partisan struggle and the KPJ's resultant sense of obligation to placate peasant demands for private land ownership; the extreme overpopulation and undercapitalization of the countryside and resultant trap of low agricultural productivity; the preexistence of the Soviet Union as a strong and friendly state; and Yugoslavia's ability to appeal also to the Western Allies for assistance. Bokovoy, Peasants and Communists, 2930, 35-36. On the Yugoslav FYP and its operational mechanisms, see Bokovoy, Peasants and Communists, 55-56, 73-76; Woodward, Socialist Unemployment, 65, 68-70, 77, 79-81.

${ }^{59}$ Woodward, Socialist Unemployment, 81-83, 95-97.
} 
military production. ${ }^{60}$ The only substantial aid the regime received in the postwar years, some $\$ 415$ million of UNRRA aid, expired in early 1947 as the FYP began. ${ }^{61}$

The failure to secure aid, trade, and loans compelled the KPJ to issue radical revisions to its methods of funding the plan, which rippled outward with an equally radical impact on the experience of everyday life in Yugoslavia beginning in the second half of 1947. To fund the country's industrialization drive - viewed as a goal the regime must realize at any cost - Yugoslav planners saw only one realistic option: they would use up-front cash payments to purchase the necessary goods and machinery from whomever would sell. To garner this cash, the state would increase its exports of chief domestic goods - livestock, timber, and agricultural products - while simultaneously driving workers to produce at greater efficiencies and demanding that they and their families consume far less of the domestic product now destined for export. ${ }^{62}$

The new policy's stress on cash exports proved particularly disastrous in the workplace for those monfalconesi - the vast majority - employed in the state sector. For many, especially those employed in the interior regions of the country, work conditions in Yugoslavia had always left much to be desired, as the Sarajevo strike of winter 1946/47 shows. The presence into 1947 of Cosolo's hated "old regime" boss reflected a concession to necessity in a Yugoslavia that lacked experienced technical and managerial personnel and had a dire need to maintain high-efficiency

\footnotetext{
${ }^{60}$ Even during the war, Stalin had become frustrated with KPJ leaders' early emphasis on the social-revolutionary aspect of their National Liberation Struggle - a claim that threatened the Grand Alliance - and with Tito's aggressive push for Trieste. Bolstered by his beliefs that his Partisans had done the lion's share of work in liberating Yugoslavia and that his party had developed a more contemporarily relevant pathway to socialism than Stalinism, Tito maintained this independent streak in subsequent years. Chief among his offenses were his support for Communist insurgents in the perceived tinderbox of the Greek Civil War, his attempts to incorporate Bulgaria and Albania into a Yugoslavdominated Balkan Federation, and the fact that his regime devised its own FYP to pursue rapid industrialization. These decisions contravened Stalin's judgement and threatened to establish Tito as a leader of Balkan Communism in potential rivalry with Stalin. John Campbell, Tito's Separate Road: America and Yugoslavia in World Politics (New York: Harper \& Row, 1967), 11; Johnson, The Transformation of Communist Ideology, 5, 27-35, 46-52; Ivo Banac, With Stalin against Tito, 28-43. On the lack of Soviet aid to Yugoslavia, see Woodward, Socialist Unemployment, 81, 108-109.

${ }^{61}$ Woodward, Socialist Unemployment, 83.

${ }^{62}$ Ibid., 95-98.
} 
production in state firms. This need only increased as the FYP got underway, as did the regime's attendant reliance upon "old regime" managers. ${ }^{63}$ This became apparent to Cosolo who, after leaving the rolling stock workshop for a brief stint in a youth labor brigade, took a job making cigarettes at Sarajevo's tobacco factory. There, too, he found the director to be harsh, domineering, and prone to sexual harassment of female employees. When Cosolo asked one of the factory guards - a friend and ex-Partisan - why this boss remained, the guard explained that cigarettes were a chief source of state revenues. Thus, the director would remain until someone of equal managerial skill could be found. ${ }^{64}$ Over time, many monfalconesi must have asked themselves questions similar to the one Cosolo posed himself, namely "how it could be possible that the new power, administered by those forces that had fought in the Resistance to liberate themselves from this type of scum, had failed, even in the immediate postwar, to throw that filthy individual out of the factory." ${ }^{95}$ Unaware of the international conditions that shaped Yugoslav policy, Cosolo and others certainly realized that encounters with "old regime" management were far from atypical in Tito's young regime. With the introduction of a system of labor booklets (radne knjižice) in March 1947 and strict regulations placed on the ability of foreign workers to change jobs - enacted so the state could better control labor for the FYP - many found these managers impossible to escape. ${ }^{66}$

But beyond mere manager-employee tensions in the workplace, the productivity and export drive of 1947-48 also led to concrete and often frustrating changes in labor culture and labor law. Chief among these was a redoubled effort to promote participation in voluntary labor campaigns

\footnotetext{
${ }^{63}$ The decision to empower managers with the theory of one-man management came much earlier, in mid-1946. Ibid., 85.

${ }^{64}$ Seemingly in 1948, this manager was replaced by the vice-director, an ex-Partisan. Cosolo, Amare... Sarajevo, 13339.

${ }^{65}$ Ibid., 134.

${ }^{66}$ Foreigners had to secure a formal release from their employer before switching jobs. Thus, when Cosolo wanted to leave the railcar workshop, he had to first perform a stint in the Youth Brigades, which guaranteed him a release. Ibid., 93-94; Woodward, Socialist Unemployment, 88-89.
} 
and "socialist competition" in the workplace. These programs, which the regime had early on made central to its efforts to accumulate capital, became more important as the state sought to cut wage expenses and increase returns on its domestic investments. Regime theorists believed socialist competition to be an effective means by which it could draw out "hidden" reserves of productivity that had been unrealized under the uninspiring capitalist labor system. Presented as great opportunities by which workers might gain both material bonuses and prestige, more often than not monfalconesi experienced these programs as a series of unwanted and uncomfortable pressures ${ }^{67}$ At times, tensions over the obligation to work and to work quickly caused divisions within the monfalconesi themselves. Such was the case with the migrant Renato Valcovich, who, after a time in Sarajevo, ended up working in the Belgrade aeronautical industry. He recalls being approached and asked to do "voluntary" shock labor on a day off. Exhausted and already a bit disillusioned, he refused, at which point the head of the factory committee, a monfalconese, accused him of being a troublemaker and Trotskyite. ${ }^{68}$ One can imagine that such cultural pressures to perform voluntary labor and to work at breakneck paces might not have appeared too different from the pressures exerted by the Fascist piecework clerk back home.

By the middle of spring 1948, any actual distinction between shock work and piecework ceased to matter. Under continual pressure to maximize production, the regime announced on 29 May that a new pay system was coming to Yugoslavia in July. A new piecework system would replace existing wage pay, with bonuses granted for production at above-normal efficiency ${ }^{69}$ The return to piecework, foreshadowed by the year-long campaign to increase productivity by non-

\footnotetext{
${ }^{67}$ Of course, there were concrete prizes to be won with "socialist competition." At the firm level, firms began to keep a portion of their above-projected earnings as a "manager's fund," which could then be used to build housing, libraries, cultural clubs, canteens, and other buildings beneficial to the workers. Woodward, Socialist Unemployment, 77, 8687, 103, 109.

${ }^{68}$ Puppini, "Il 'controesodo' monfalconese," 76-77.

${ }^{69}$ Woodward, Socialist Unemployment, 112.
} 
pay-related measures, restored a key component of what many monfalconesi considered a "Fascist" labor system and provoked complaints of Italian workers in Yugoslavia for years. When an Italian diplomatic delegation visited Italian workers in Bosnia over two years later, workers lamented that work was done by piecework, "or, in local terms, 'as usual.",70 Far from being the country they had envisioned, in which workers were freed from regimentation and hyperdiscipline, Yugoslavia was reviving such sources of frustration, merely shrouding them in the language of worker pride and socialist progress. Even for those lucky enough to be in Fiume and Pola, the changes of 1947-48 showed the liberated workplace to be, at best, a project deferred for the foreseeable future.

If changes in the workplace caused serious resentments, those in the marketplace were even more pronounced. Over the biennium of 1947-48, with aid halted, products increasingly oriented toward export, and the Yugoslav state attempting to implement a new system of exchange that would both look socialist and afford greater state control over the flow of goods, supply conditions crashed from their precarious recovery the year prior. As two Italian defectors from OZNA would report upon their return to Italy in August 1948, "the internal conditions in this area have deteriorated continually in the past year. Production declines with the latest nationalization decree and has reached a disastrous point. Goods and foods cannot be found. When they put to market after a delay of some months they have deteriorated." ${ }^{\text {"1 }}$ With the decline in the availability of goods and a new system put in place to oversee the distribution of these goods, monfalconesi encountered new difficulties in procuring food, which revived old or generated new resentments.

\footnotetext{
${ }^{70}$ Legazione d'Italia (Belgrado), "Viaggio di servizio a Sarajevo," 29 January 1950, op. cit.

${ }^{71}$ Guido Botazzi and Ermanno Forti (Modena), "Esito Rapporto Verbale Profughi dalla Jugoslavia," 10 August 1948, AM-IG, Fondo Jug e VG, b mf 135, f mf 135, d 3. Italian diplomatic services in Yugoslavia confirm the critical decline of the year 1948. Legazione d'Italia (Belgrado), "Emigrazione e condizione dei lavoratori italiani...," 7 February 1950, op. cit.
} 
Neither all monfalconesi, nor all Italians experienced the weight of Yugoslavia's changing policies equally, and those in Fiume appear to have had it worst. There the state's campaign against private commercial interests was well underway by February 1948, by which point only state stores and factory cooperatives were allowed to sell goods of the first necessity, driving many small shops out of business or serving as the means by which they could be "absorbed by the Government of the people" into the "cooperative complex." 72 The campaign to quash private commerce was so intense that several Fiuman shopkeepers and merchants committed suicide as winter gave way to spring. Yet even with the mechanisms of exchange reordered - or perhaps because of it - residents of Fiume could find only "laughable quantities" of goods through the state supply system, much of the domestic food product having been redirected abroad as cash exports. ${ }^{73}$ Bureaucratic blunders and inefficiencies contributed to widespread shortage in Fiume in 1948, as when, in the words of one official, "in the Fiume markets a tomato could not be found," while many sat unsold on the nearby Adriatic island of Lusinj (Lussino). ${ }^{74}$ In April and May, as the state extended the same measures to the interior cities of Monfalconese settlement in the pursuit of liquidating private commerce, state stores and cooperatives in Belgrade, Ljubljana, and elsewhere failed to meet basic ration standards, let alone monfalconesi's expectations for a just standard of living. ${ }^{75}$

\footnotetext{
${ }^{72}$ Console Purini (Klagenfurt), "Situazione a Fiume” (Tel. N. 1103/79), 18 February 1948, ASDMAE, AA PP 19461950, Jug, b 32, 2.

${ }^{73}$ Capo di Gabinetto (MM), "Notizie sulla situazione di Fiume" (N. B.2091), 3 March 1948, ASDMAE, AA PP 19461950, Jug, b 6, f 3.

${ }^{74}$ The official was reflecting in 1949 on the difficulties of incorporating Istria into the Yugoslav economy. MAE, DGAP, Uff IV, "Minoranza italiana e politica jugoslava" (Tel. N. 15/06937), 9 April 1949, AGPCM, Fondo UZC, Sez II, Jug, b 6.2, f 78.

${ }^{75}$ Woodward, Socialist Unemployment, 114-15; ANSA, "Notiziario per la Stampa N. 15," 28 April 1948; "Notiziario per la Stampa N. 20," 24 May 1948, both in ASDMAE, AA PP 1946-1950, Jug, b 32, f 2. In Belgrade, the Italian Legation noted the inability of the city's 2041 state stores to meet the basic rations and substantial shopkeeper resistance to their coercive entry into cooperatives. Black-marketing appears to have been more common there than in Fiume, but still limited by an absolute lack of goods. See Legazione d'Italia (Belgrado), "Borghesia e regime jugoslavo..." (Tel. N. 1814/806), 23 September 1948; Legazione d'Italia (Belgrado), "Commercio ed approvvigionamento a Belgrado" (Tel. N. 1954/885), 9 October 1948, both in ASDMAE, AA PP 1946-1950, Jug, b 33, f 1; Vincenzo Marini, "Relazione," Undated (November 1948), op. cit.; Unsigned, "Relazione sulla situazione di Belgrado," Undated (Late 1948 or early 1949), AM-IG, Fondo Jug e VG, b mf 135, f mf 135, d 46.
} 
In all cases, single men were most able to bear the brunt of Yugoslavia's new austerityexport economy and system of exchange, with larger families finding it increasingly difficult to get by. Already by January 1948, the Belgrade Legation reported that the pay received by Italian workers was, in many cases, "sufficient just for the maintenance of a single person" and that many of them - most likely those who had come over without SU contracts - no longer received the supplemental rations reserved for heavy laborers, nor access to the workplace messes or subsidized lodging. ${ }^{76}$ For single workers, at least, the provision of meals in factory messes and the rooting of the new distribution system in the factory shops provided some relief. ${ }^{77}$ As late as March, there were still some exceptionally lucky skilled workers who, slotted for work in well-supplied workplaces and possessing state housing and mess access, could send half of their earnings home in remittances. ${ }^{78}$ Such discrepancies in pay and benefits almost certainly generated resentments within the monfalconesi community that operated along the fault lines of "privileged" versus "unprivileged" worker and single workers versus families of migrants.

But if resentments were growing within the community, the most intense resentments were those turned outward, toward the host community and host state. As more Monfalconese families found it difficult to meet their basic needs within the confines of the regular supply system, they witnessed others within Yugoslav society - particularly those that possessed the membership in the KPJ or OZNA - gain special treatment. For these individuals, the state made available special stores, always prioritized higher than the standard workplace shops. Thus, Mario Tonzar recalls a joke common in Monfalconese circles during those months, namely that the KPJ was "the party

\footnotetext{
${ }^{76}$ According to the report, privileged workers paid 400 dinars monthly for lodging and 30-40 dinars dialy for meals in the workplace mess, while unprivileged workers paid 2000 and 100 dinars respectively. Legazione d'Italia (Belgrado), "Invio lavoratori italiani in jugoslavia" (Tel. N. 149-85), 30 January 1948, ASDMAE, AP 1946-50, Jug, b 47, f 5. Underlining in original.

${ }^{77}$ Vincenzo Marini, “Relazione,” Undated (December 1948) AM-IG, b mf 135, f mf 135, d 43, sd 3.

${ }^{78}$ Console Generale Pinto (Zagreb), "Connazionali venuti in Jugoslavia senza passaporto ed emigrazione clandestina" (Tel. N. 79/21), 11 March 1948, ASDMAE, AP 1946-50, Jug, b 47, f 5.
} 
of the sacks," because one could identify a Party member by the full packet of goods carried around under arm. ${ }^{79}$ At Pola, Valerio Beltrame and his Monfalconese comrades observed the same thing. Beltrame had come to Pola from Fiume in January 1948, tasked with running the mess hall at the Pola Arsenal, where roughly 800 workers, including many monfalconesi, labored. Under the new austerity conditions, he found the task exceedingly difficult, as there was a complete lack of goods. At the same time, he witnessed well-stocked mess halls for the military, with "food stores put at the disposition of the officers and their families in enormous quantities, while nothing could be found for families of the laborers; and all this in the full light of day." 80

By the spring of 1948 at the latest, "shopping" in Yugoslavia had shifted from a relatively easy and self-affirming activity for monfalconesi to one of contention; from a position of being among the "most equal of equals" in Tito's Yugoslavia, they steadily fell to a subaltern position. As the availability of goods retracted, the experience of "shopping" made clear the limits of their inclusion into Yugoslavia and the limits of Yugoslavia's transformation. Though the mechanisms of goods allocation and exchange were different from those of Fascist-era and postwar Monfalcone - gone was the hated shopkeeper - the central characteristic of discrimination had manifested itself again in the form of dual systems of stores. The cooperatives and factory stores of the real Yugoslavia were not those of mythical Yugoslavia, and monfalconesi once again found themselves on the losing end of a discriminatory economy due to their exclusion from a ruling party. The emigrant Riccardo Bellobarbich, fairly unique for having retained a somewhat favorable view of Tito and Yugoslavia even after his return, recalls that the existence of special stores was perhaps the chief failing of Yugoslav socialism. Though "the musicians had changed," the stores betrayed

\footnotetext{
${ }^{79}$ Tonzar, La valigia e l'idea, 88.

${ }^{80}$ Bonelli, "Memorie del monfalconese Beltrame Valerio," 29 November 1977, op. cit.
} 
the fact that "the music was still the same." ${ }^{81}$ By that spring, such frustrations had given birth to "concrete forms of protest" in Fiume, in which Monfalconese women "spontaneously" expressed their discontent. ${ }^{82}$ Women composed the vanguard in the campaign to create a just form of commerce in Yugoslavia, exactly as they had during the campaign against the Monfalconese's shopkeepers. As in Monfalcone, they had little success.

\section{Reversing Course}

As monfalconesi lived, worked, and shopped in Yugoslavia, they became aware of the limits of liberation provided by that country. Though the speed at which they made this realization varied, the longer monfalconesi lived in the New Yugoslavia, the clearer it became that Tito's regime would not or could not deliver on their vision of socialism. For some - and particularly those who arrived in 1946 without skills or SU contracts - it took only months for the mythic image of Yugoslavia to crumble. At that point, they began to look back longingly toward the town and social networks they had left behind. In fact, just as the controesodo reached its apex, the first consequences of this disillusionment were felt back in Monfalcone. In February 1947, Monfalcone's police inspector indicated that, though migrants continued to set for Yugoslavia, some had begun to return, and it was "not often [that] they can hide their disappointment and disillusion [sic]." ${ }^{\prime 83}$ In March too, a small trickle of monfalconesi returned home, passing back into the AMG using their AMG ID cards. ${ }^{84}$

It was only as Yugoslavia's austerity-export regime ushered in a new host of everyday grievances, however, that disillusionment translated into the attempted repatriation of a sizeable

\footnotetext{
81 The quote is Bonelli's paraphrasing of Bellobarbich. Alfredo Bonelli, 'Intervista con il monfalconese Belobarbic' Riccardo," April 1979, IRSML, Fondo Cominform, b 99, f 1.

${ }^{82}$ Vincenzo Marini, "Relazione," Undated (November 1948), op. cit.

${ }^{83}$ Insp. Lendaro, "Monthly Report on the Corps Activity, Feb 1947," 24 February 1947, op. cit.

${ }^{84}$ Insp. Lendaro, "Monthly Report on the Corps Activity, Mar 1947," 22 March 1947, op. cit.
} 
number of monfalconesi. In September 1947, as Yugoslavia's economy straining under the weight of socialist transition and workers' real earnings plummet, the Italian Legation in Belgrade noted the beginnings of "a repatriation movement, if until now still rather limited in relation to the total number of co-nationals present here. ${ }^{\Perp 5}$ In the post-Treaty contexts of late 1947 and early 1948, which saw an end to free mobility across the Morgan Line, monfalconesi began appealing to a wide range of Yugoslav and Italian diplomatic offices for authorization to return home ${ }^{86}$ Luigi B., a fellow traveler of the UAIS and PCRG who had emigrated to Spalato in March 1947, found that, contrary to the promises of the myth of Yugoslavia, he was not able to "make a fortune and improve the economic situation of his family composed of a wife and three children." Due to "bad treatment existing in Yugoslavia for the workers" - or at least citing that reason to police upon his return - he repatriated in late February $1948 .{ }^{87}$ Returning shortly on Luigi's heels were many more, including the young brothers, Giuseppe and Guido D. These two, having been some of the district's most vocal supporters of Yugoslav annexation, spent just over a year working together at the Tito Shipyard in Kraljevica (Croatia). However, with meat having disappeared from the town in mid1947 and the distributions of goods through factory shops regularly carried out with three weeks' delay, they decided that life had been better in Italy. ${ }^{88}$

The early repatriation movement was particularly evident in Sarajevo, where Silvano Cosolo observed the dissolution of the Monfalconese "colony" to which he belonged. In the winter of 1947/48 that colony experienced "a slow but continuous outflow of village neighbors and of Bisiachs who returned to the Monfalconese and Pieris." ${ }^{89}$ Among them was the quadragenarian

\footnotetext{
${ }^{85}$ Legazione d'Italia (Belgrado), "Lavoratori italiani in Jugoslavia" (Tel. N. 266/44), 4 September 1947, op. cit.

${ }^{86}$ Console Pinto, "Connazionali venuti in Jugoslavia senza passaporto..." (Tel. N. 79/21), 11 March 1948, op. cit.

${ }^{87}$ ASG, Questura 1948, b 1, f 147.

${ }^{88}$ ASG, Questura 1948, b 3, f 478; Unsigned, "La situazione attuale nei Cantieri di Tito...," 1 October 1947, ACS, MI, DGPS, Div SIS, AA GG 1944-49, b 77, f OP6. See also ASG Questura, b 1, f 173; b 5, f 810; b 6, f 975; b 8, f 1234; b 9, f 1355; b 9, f 1408.

${ }^{89}$ Cosolo, Amare... Sarajevo, 57-60.
} 
garibaldino, Giuseppe D., who had worked alongside Cosolo in Sarajevo's railcar workshop. Having tired of life in Sarajevo after eight hard months, Giuseppe transferred to Fiume in late summer 1947, from where he returned to Monfalcone in January of the following year. ${ }^{90}$ Having stood at 200 in the winter of 1946/47 when it went on strike for socialism in Tito's Yugoslavia, by summer 1948 the Sarajevo colony was reduced to just Cosolo and one other, a Pieris native nicknamed "Toni Suarin." 91

By early 1948, repatriation had become a notable phenomenon. Though scholars briefly touched on these early repatriations in the initial scholarship on the controesodo, none have followed up on this line of inquiry. ${ }^{92}$ For most scholars of the controesodo, it was not the persistence (or reemergence) of everyday grievances that proved to be a catalyst for repatriation, but rather a cataclysmic event with its origins in the distant centers of power. ${ }^{93}$

\section{The Cominform Resolution: Stalin, Tito, Monfalconesi}

That event was the publication of the Cominform Resolution on 28 June $1948 .{ }^{94}$ SovietYugoslav relations had deteriorated markedly in the winter of 1947/48, particularly as Tito continued to provide active support to the Greek Communists and to push to establish himself as the leader of Balkan Communism against Stalin's wishes. When Tito supported a purge of the anti-

\footnotetext{
90 ASG, Questura 1948, b 4, f 512.

${ }^{91}$ Cosolo, Amare... Sarajevo, 57-60. See also ASG, Questura 1948, b. 1, f 172; b 9, f 1331.

92 See the pieces by Marco Puppini and Boris Gombač in Altieri and Puppini (eds), Il mosaico giuliano, esp. 59-61 and 76-77.

93 Thus, pre-Resolution repatriation is not seriously discussed in Di Gianantonio et al, L'immaginario imprigionato. Similarly, in many memoirs and interviews, the Resolution serves at the critical moment for repatriation. See PinGiuricin, "I motivi di una scelta;" 367-69; Bonelli, "Seconda intervista con il monfalconese Franti Giuseppe," 21 April 1980, op. cit.

${ }^{94}$ For the diplomatic and other consequences of the Cominform Resolution, see Wayne Vucinich (ed), At the Brink of War and Peace: The Tito-Stalin Split in a Historic Perspective (New York: Social Science Monographs, Brooklyn College Press, 1982); Marco Galeazzi (ed), Roma-Belgrado: gli anni della guerra fredda (Ravenna: Longo, 1995); Lorraine Lees, Keeping Tito Afloat: The United States, Yugoslavia, and the Cold War (University Park: Pennsylvania State University Press, 1997). For works looking more specifically at the Split's impact on Venezia Giulia, see Novak, Trieste; Olivo, "Comunisti ed esuli istriani," 80-88.
} 
Yugoslav faction within the Albanian Communist Party in February-March 1948, events came to a head. ${ }^{95}$ A series of exchanges ensued between the Soviet and Yugoslav Parties, in which the Soviets minimized the role of the Yugoslav Partisans in the liberation process and accused the KPJ of ideological deviationism and in which the KPJ insisted that the situation was all a big misunderstanding. Fearing that Stalin's disfavor might provoke schisms within the Yugoslav Party - schisms that might fall along national fault lines and embolden Croatian leaders like former KPH secretary Andrija Hebrang to challenge Tito's primacy - the security forces of Aleksandar Ranković moved quickly to nip this in the bud. Tito loyalists arrested Hebrang, as well as leaders who had expressed agreement with Soviet criticisms, whom they implicated in a supposed Soviet plot to infiltrate and control Yugoslavia. When Stalin finally issued an ultimatum that the Yugoslav leadership appear before the Cominform and accept "socialist criticism," the Titoists refused. With this, they assured both their excommunication from the Moscow church and the outbreak of an internecine conflict within Yugoslavia between Titoists and "Cominformists," fought with all means of espionage and state repression. ${ }^{96}$ In the words of Ivo Banac, "the split that emancipated the KPJ from the Soviet Union promoted home-grown Stalinism."97

The Cominform Resolution was a "bomb" for the monfalconesi in Yugoslavia. They had certainly felt the impact of hidden international developments as their standard of living plummeted through early 1948. However, they were in no way prepared for the news of late June. They did not realize, for example, that the climaxing food and fuel crisis resulted in part from the KPJ's decision to stockpile such vital supplies in preparation for a potential Soviet invasion. ${ }^{98}$

\footnotetext{
95 Banac, With Stalin against Tito, 38-43.

96 The Cominformists posed a real threat to Tito's rule. A propaganda war followed the Resolution, along with an abortive military coup by Cominformist officers. Banac, With Stalin against Tito, 117-36, 145-46; Campbell, Tito's Separate Road, 13-14.

${ }^{97}$ Banac, With Stalin against Tito, 136.

${ }^{98}$ Woodward, Socialist Unemployment, 108-109.
} 
Catching them entirely by surprise, the Tito-Stalin Split pitted the "two myths of the Communist world" against each other. ${ }^{99}$ It ushered in a period of chaos and disorientation in which individual monfalconesi and Monfalconese communities struggled to come to grips with competing claims, often assessing these claims in light of their own experience of Tito's now-"rogue" state.

The range of experiences and circumstances faced by monfalconesi led to a variety of responses to the Resolution. The smaller, interior communities - most notably those of Zagreb, Belgrade, and Ljubljana - found themselves particularly isolated and limited in their range of potential responses. In Zagreb, where there lived some 1000 Italians, of whom 200 belonged to the PCI and a separate 200 were monfalconesi, members of the Italian Cultural Circle listened to Radio Moscow and, in the words on the Ligurian partisan exile Adolfo Sottile, decided on "the justness of the [Soviet] criticism." 100 They resisted initial attempts by Italian Titoist leaders to convince them to see the Yugoslav perspective and, when it became clear that the Titoists would deny them the ability to contact the Italians of Fiume and Pola, decided to lay low and camouflage themselves as best as possible given their relatively small numbers. ${ }^{101}$ In Belgrade, the Italian Cultural Circle that organized some 300 "Italian workers from Monfalcone, Trieste, and other Italian provinces" likewise sided overwhelmingly with Stalin. However, following a heated debate with a local KPJ leader over the correctness of the Resolution, its leaders elected to dissolve the circle, fearing it would otherwise be considered an organized oppositional body. ${ }^{102}$ In Ljubljana, dread was omnipresent and "politics [was] little discussed" among the Italian expatriates. ${ }^{103}$

\footnotetext{
${ }^{99}$ Pin-Giuricin, "I motivi di una scelta," 367.

${ }^{100}$ Adolfo Sottile, Untitled Report, Undated (Late 1948), AM-IG, Fondo Jug e VG, b mf 135, f mf 135, d 36; Unknown (PCI), "Situazione comp. italiani in J.," Undated (1948), op. cit. On the estimate of 1000, see Console Pinto, "Connazionali venuti in Jugoslavia senza passaporto..." (Tel. N. 79/21), 11 March 1948, op. cit.

${ }^{101}$ Sottile, Untitled Report, Undated (Late 1948), op. cit.; Di Gianantonio et al, L'immaginario imprigionato, 177.

${ }^{102}$ Unsigned, "Estratto di Una Relazione Inviataci da un Gruppo di Compagni di Fiume," Undated (1948), AM-IG, Fondo Jug e VG, b mf 135, f mf 135; Unsigned, "Relazione sulla situazione di Belgrado," Undated, op. cit.

${ }^{103}$ Unsigned, "Estratto di Una Relazione...," Undated (1948), op. cit.
} 
In the Croatian coastal towns, where monfalconesi resided in greater numbers, they responded more vocally. At Fiume, where the bulk of the old leadership resided, the response was decisive. Though a handful sided with Tito, among them the confinato Desiderio Rigonat (brother of Renato), the distinguished gappista Riccardo Giacuzzo, and a portion of the staff of the Italianlanguage Voce del Popolo, the majority of monfalconesi at Fiume came out strongly in favor of the Cominform. ${ }^{104}$ The leadership, including a core prominently placed within the shipyard's Technical Office, accepted the Cominform Resolution as just criticism and made their stance known. One participant recalls that "I resigned from my syndical appointment and abandoned any type of political activity. I worked at the shipyard and that was it. Many other comrades did the same."105 Among the most vocal were the longtime Communist militants and dedicated Stalinists, Ferdinando Marega and Angelo Comar, who even led pro-Stalin rallies in the naval yards, urging workers to drown out concurrent Titoist rallies with the singing of the "International." 106 When Croatian president and KPH head Vladimir Bakarić arrived shortly thereafter to try to shore up support from the economically indispensable monfalconesi, the latter shouted down his suggestions that the Cominform Resolution was a mere misunderstanding, causing him to depart with great disappointment. In early July, the monfalconesi at Fiume refused similar entreaties by the shipyard director, Triestine Titoist leaders, and another key KPH official, Slavko Komar, the last of whom told monfalconesi that they were foreigners who should mind their own business. ${ }^{107}$

\footnotetext{
${ }^{104}$ Notable among the La Voce del Popolo staff were Luciano Giuricin (future husband of Mirella Pin) and Giacomo Scotti, author of several books on Goli Otok. Unsigned, "Estratto di Una Relazione...," Undated (1948), op. cit.; Vincenzo Marini, "Relazione," Undated (December 1948) AM-IG, b mf 135, f mf 135, d 43, sd 1; Unsigned, Untitled Report from a Staff Member of La Voce del Popolo, Undated (August or early September 1948), AM-IG, Fondo Jug e VG, b mf 135, f mf 135, d 14; Cernigoi, Scelte, 288-89; Scotti, Italiani nel gulag di Tito, 16-17.

${ }^{105}$ Bonelli, "Testimonianza del monfalconese Donda Onorio, 5 March 1978, op. cit.; Sottile, Untitled Report, Undated (Late 1948), op. cit.

${ }^{106}$ Scotti, Italiani nel gulag di Tito, 12-13.

${ }^{107}$ Puppini, “Il 'controesodo' Monfalconese," 79-80; Scotti, Italiani nel gulag di Tito, 13-14; Sottile, Untitled Report, Undated (Late 1948), op. cit.; Unsigned, "Estratto di Una Relazione ...," Undated (1948), op. cit.
} 
Similar scenes unfolded in Pola. Following the initial meetings at Fiume, Bakarić travelled there to attempt to break the monfalconesi of Pola away from the position of those at Fiume. Gathering thirty Monfalconese leaders in Pola, Bakarić expounded upon the contributions made by monfalconesi to the construction of Yugoslav socialism and implored them to disavow the Resolution. The monfalconesi, Valerio Beltrame among them, rejected the plea and instead issued four criticisms of Yugoslav socialism: (1) the discriminatory provisioning system, which privileged KPJ officials and Yugoslav Army officers over ordinary workers; (2) the lack of democracy, given that workers were free to discuss KPJ policy only when they supported it; (3) the coercive cooperativization of agriculture, which was causing major food shortages; and (4) the national chauvinism of Croats and Croatia. ${ }^{108}$ To the surprise of the monfalconesi, Bakarić recognized these problems, but countered. He laid out concrete measures Yugoslavia was taking to build socialism and insisted that Yugoslavia would not allow Soviet calumnies to undermine the gains made by the long-suffering Yugoslav peoples during the liberation struggle. For a brief time, Beltrame recalls, the Pola leadership found this argument "quite persuasive," but, when they arrived in Fiume some days later on a mission to bring the monfalconesi of Fiume back into the Titoist fold, things fell apart. The monfalconesi of Fiume remained "resolutely against Titoism," which drove the Pola delegation to reconsider its position. By the time the delegation members left Fiume, they once again were on the side of Stalin and they too had adopted the strategy of their comrades at Fiume: withdraw and cease participation in all forms of syndical life, political meetings, cultural organizations, and voluntary labor. ${ }^{109}$

The overwhelming coherence of monfalconesi to the Cominform Resolution is striking,

\footnotetext{
108 Puppini, "Il 'controesodo' Monfalconese," 81.

109 Bonelli, "Memorie del monfalconese Beltrame Valerio," 29 November 1977, op. cit. Di Gianantonio and her colleagues date this meeting somewhat later in August, but they agree on the outcome. Di Gianantonio et al, L'immaginario imprigionato, 179.
} 
particularly given that so few had maintained ties with either the PCI or the PCTLT, from which they might have received aid in the struggle. A mere 70 PCI members resided in Fiume in 1948, few monfalconesi. ${ }^{110}$ In Pola, too, Beltrame recalls that "there were no contacts with members of the PCRG [PCTLT] or the PCI" and that the community made its decisions "on local initiative." The monfalconesi of Pola understood themselves to be "comrades thrown into battle and abandoned to [their] fate." ${ }^{111}$ In part, this rapid decision had to do with the figure of Stalin and his primacy within the postwar Communist pantheon, though this is far from a sufficient explanation. ${ }^{112}$ An unwavering loyalty to Stalin can explain the actions of those militants who had been fighting for the USSR long before Tito's Partisans even existed but is less compelling for the mass of ordinary workers. More significant for these individuals seems to be that, for those not yet disillusioned by the difficulties of everyday life in Yugoslavia, the Resolution shattered the lens of contextual redefinition. ${ }^{113}$ Cominform critiques of Titoist "deviationism" provided monfalconesi a compelling framework through which to understand the failures of Yugoslavia to make good on their vision of socialism; at the moment of its publication, monfalconesi ceased viewing the persistence of everyday grievances in Yugoslavia as the result of an incomplete passage to socialism and instead took them as indicative of Tito's fundamentally mistaken path. Mario Tonzar indicates in his memoirs that, "despite certain difficulties that could be seen there, the sentiment that had brought us to Yugoslavia made us overlook certain things that we found

\footnotetext{
${ }^{110}$ Unknown (PCI), "Situazione comp. italiani in J.," Undated, op. cit.

${ }^{111}$ Bonelli, "Memorie del monfalconese Beltrame Valerio," 29 November 1977, op. cit.

${ }^{112}$ Loyalty to Stalin shows up with varying degrees of explanatory weight in both memoirs and historical studies. In an interview with Berrini, Luciano Giuricin explained the reaction as a result of migrants' belief that "Stalin was god on earth." Berrini, Noi siamo la classe operaia, 235. See Puppini, "Il 'controesodo' monfalconese," 78; Di Gianantonio et al, L'immaginario imprigionato, 178; and Alfredo Bonelli's comments in Bonelli, "Prima intervista con il monfalconese Franti Giuseppe," 27 March 1980, op. cit.

${ }^{113}$ Francesco Privitera has put forward a similar idea, though without theoretical or empirical elaboration. Privitera, "Socialismo vero, socialismo falso: la lotta dei cominformisti italiani nella Jugoslavia di Tito," in Roma-Belgrade, ed. Galeazzi, op. cit., 131
} 
nearly exactly in the Resolution." In a statement echoed by Beltrame, Tonzar concludes that, "when the pot was uncovered, we got the sense that that which we had seen before, but kept inside, corresponded to reality." 114 Thus, at the meeting between Pola and Fiume monfalconesi, the leadership of both communities decided to follow the lead of those individual monfalconesi who long before had been disabused of contextual redefinition; they decided on mass repatriation, urging their comrades to go quickly to the Italian Consulate at Zagreb to secure passports. ${ }^{115}$

As the monfalconesi of Pola, Fiume, and elsewhere awaited their exit documents, the situation in Yugoslavia deteriorated rapidly following the failed reconciliations of early July. This was especially the case at Fiume, where a portion of the Monfalconese leadership refused to accept the withdraw-and-expatriate strategy and instead maintained a stance of belligerent support for the Cominform. According to a report written by an anonymous "Mario" and smuggled to the PCI that September - the best single source from which to reconstruct a series of confused events monfalconesi took the lead in criticizing the Yugoslav regime in public meetings, among them Albano Olivieri (one of the "Big Five"), Giuseppe Franti (a former Communist Youth organizer), and Alfredo Brenci (former director of the UAIS publication Il Progresso). ${ }^{116}$ In many cases, this took the form of public speeches in the Fiume shipyard. Franti himself recalls leading one mass meeting in which some 4500-5000 workers participated: "I climbed on a crane and shouted, 'Stalin is right, it's not true, what's this talk about Stalin, why?' I was the stupidest out of everyone."117 By the first days of August, such activities had landed Franti in the clutches of UDBA, accompanied by Brenci and Olivieri. Though Bakarić again held a meeting with the Monfalconese

\footnotetext{
114 Tonzar, La valigia e l'idea, 87-88; Bonelli, "Memorie del monfalconese Beltrame Valerio," 29 November 1977, op. cit.

115 Bonelli, "Memorie del monfalconese Beltrame Valerio," 29 November 1977, op. cit.

116 "Mario," Untitled Report, 13 September 1948, op. cit.

117 Bonelli, "Prima intervista con il monfalconese Franti Giuseppe, 27 March 1980, op. cit.
} 
leadership, attempting to use heavyweights such as Ferdinando Marega, Otto Ferlettich, Fioravante B., Volmaro Buttignon, and Angelo Comar to win over the mass of workers, he again met stubborn refusal. The Titoist press of Fiume and wider Croatia responded with a vitriolic campaign against the Italian Cominformists at Fiume, while the police, alleging sabotage, arrested Adriano Fontanot and other Monfalconese technicians who had earlier been headhunted from the CRDA. ${ }^{118}$

While the most outspoken critics found their way to jail in August 1948, life became quite hard even for those monfalconesi not involved in anti-Tito protests. State-controlled firms such as the Fiume and Pola shipyards fired hundreds of workers for suspected Cominformist sentiments, often after they were denounced as Il Lavoratore or L'Unità readers, while also ceasing payment for the "distance indemnity" that was contractually guaranteed to workers whose families had remained in Monfalcone. ${ }^{119}$ When workers sought the assistance of Italy's diplomatic services to enforce their contracts, Yugoslavia informed Italy that this was no concern of Italy, given that monfalconesi had contracted individually with the Yugoslav state rather than through Italian state services. ${ }^{120}$ In the context of the unfolding Titoist-Cominformist struggle, even the most innocuous of monfalconesi could find themselves the objects of suspicion, as did Pino Petean, who, full of youthful enthusiasm, had emigrated to Yugoslavia in his early 20s. Though Petean abstained from the various anti-Tito activities in which most monfalconesi engaged, he still found himself in jail shortly after the split on suspicion of sabotage. Another young worker had accidentally broken an engine in the Fiume shipyard and UDBA was searching for a saboteur. Luckily for Petean, he was dating the sister of the shipyard director and, through her influence, was released eight days later.

\footnotetext{
118 "Mario," Untitled Report, 13 September 1948, op. cit.; Sottile, Untitled Report, Undated (Late 1948), op. cit.; Puppini, "Il ‘controesodo' Monfalconese," 81-82; Scotti, Italiani nel gulag di Tito, 120-21.

${ }^{119}$ Unsigned, "Estratto di Una Relazione," Undated (1948), op. cit.; Botazzi and Forti, "Esito Rapporto Verbale...," 10 August 1948, op. cit; Vincenzo Marini, "Relazione," Undated (December 1948), AM-IG, b mf 135, f mf 135, d 43, sd 3 .

${ }^{120}$ Legazione d'Italia (Belgrado), "Contratti di lavoro per la Jugoslavia” (N. 6006/269), 23 October 1948, ASDMAE, AP 1946-50 Jug, b 47, f 5
} 
Without her, he may well have ended up in the same cells as Olivieri and Fontanot. ${ }^{121}$

These worsening conditions served as the backdrop for the mid-August climax of Fiume's unfolding drama. Likely with the intention of circumventing the obstinate monfalconesi leadership and going directly to the wider community, Croatian and Triestine Titoists organized a conference at Fiume's Partizan Theater (Teatro Fenice), inviting the Italian community. By the time the gathering started, the theater hall was, in the words of the attendee Riccardo Bellobarbich, "chock full, in large part with Italians." ${ }^{122}$ Yet, even before the event began, a poor outcome seemed evident. As Bellobarbich recalls, the chief Titoist representatives, Bakarić and Ivan Regent, had positioned themselves on the stage, leaving all monfalconesi to sit in the crowd as passive observers. There was no doubt that this was to be a one-sided exchange. As Mario Tonzar recounts, with this power dynamic in place, any attempt at true dialogue could only corroborate Titoists' preconceptions of Monfalconese subversion. ${ }^{123}$ Bellobarbich recalls that the monfalconesi themselves came to the theater with "more a desire to clash than to come together." ${ }^{124}$ With both sides feigning a will for dialogue, the conference devolved into disaster. As Regent read his prepared statement, monfalconesi tried to shout him down, even letting fly cries of "Viva Stalin!" Regent pressed forward, but, in the words of Bellobarbich, "at a certain point everyone got to their feet singing the 'International' and we left the theater." 25 After exiting, the monfalconesi marched through town in an ill-conceived display of defiance before dispersing back to their residences in Abbazia. ${ }^{126}$ Far from resolving the Cominform Resolution crisis, the conference did much to

\footnotetext{
${ }^{121}$ Berrini, Noi siamo la classe operaia, 153-64.

122 Bonelli, "Intervista con il monfalconese Belobarbic' Riccardo," April 1979, op. cit.

123 Alfredo Bonelli, "Memorie del monfalconese Tonzar Mario, Terza Trancia," 5 April 1978, IRSML, Fondo Cominform, b 99, f 8.

${ }^{124}$ Bonelli, “Intervista con il monfalconese Belobarbic' Riccardo," April 1979, op. cit.

125 Ibid.

${ }^{126}$ The Partizan theater showdown, universally understood as a watershed moment for the monfalconesi in Yugoslavia, is corroborated by many testimonies, as well as archival material. See Sottile, Untitled Report, Undated (Late 1948), op. cit. "Mario," Untitled Report, 13 September 1948, op. cit. "Mario" places the conference "about eight days" after
} 
generalize the threat of the monfalconesi in the eyes of Yugoslav officials.

The fallout from the Partizan conference was immediate. The atmosphere in Fiume had become, in the words of an anonymous La Voce del Popolo staff member, "extremely agitated." 127 Feeling themselves increasingly insecure, the Monfalconese leadership decided to smuggle Ferdinando Marega back to Italy to re-establish contact with the PCI, dispatching him just before UDBA agents arrived at his door. ${ }^{128}$ Those who sent him were less lucky. In the last third of August, UDBA agents arrested a large portion of the Monfalconese leadership, among them Vittorio Cernigoi, Volmaro Buttignon, Salvatore Bersa, Fioravante B., and Otto Ferlettich, bringing the total detainees to roughly fifty. ${ }^{129}$ Included too was the elderly father of Spartaco Romano who had departed for Yugoslavia so full of hope to live the last years of life under socialism. ${ }^{130}$ Yugoslav security forces shipped their prisoners, along with their spouses and children, to a mining colony at Zenica in the interior of Bosnia, where they were to work out the remainder of their labor contracts in both physical and social isolation. Though several spouses asked to return to Italy, Yugoslav authorities made it clear this was not an option. ${ }^{131}$ Buried within their labor contracts was a provision stating that the signatories would work wherever the Yugoslav authorities deemed opportune, so long as transportation of family and goods was provided free of

another minor arrest, which came a few days after the arrest of Olivieri, Franti, and Brenci. Franti, whom, according to "Mario," many monfalconesi had come to suspect as a treacherous informant, corroborates the broad outlines, even if he insists he was at the Theater and not an informant. Bonelli is inclined to believe Franti did not, in fact, inform. Bonelli, "Prima intervista con il monfalconese Franti Giuseppe," 27 March 1980, op. cit. Italian state documents indicate the turning point in Fiume to be August 20, on which there was a "mass meeting" at the shipyard. It is likely this meeting was on the day of the Partizan theater incident, either in anticipation or as part of the anti-Tito procession. Console Pinto, "Arresto connazionali a Fiume" (Tel. N. 7330/375), 31 August 1948, ASDMAE, AP 1946-50, Jug, b 47, f 5. See also Scotti, Italiani nel gulag di Tito, 21-23.

${ }^{127}$ Unsigned, Untitled Report from a Staff Member of La Voce del Popolo, Undated (August or September 1948), op. cit.

${ }^{128}$ Sottile, Untitled Report, Undated (Late 1948), op. cit.; "Mario," Untitled Report, 13 September 1948, op. cit.

${ }^{129}$ Console Pinto, "Arresto connazionali," 31 August 1948, op. cit. There are discrepancies as to the precise dates of certain arrests. The document indicates Adriano Fontanot was arrested after August 20, whereas most others date this before the Partizan incident.

${ }^{130}$ Bonelli, "Seconda testimonianza del monfalconese Romano Spartaco," 19 March 1981, op. cit.

${ }^{131}$ Console Pinto, “Arresto connazionali," 31 August 1948, op. cit. 
charge. ${ }^{132}$ Crammed into barracks and semi-finished apartments, they were forbidden from leaving Zenica, which many found disagreeable for its weather and its large Muslim population. ${ }^{133}$ By year's end, the entire group had requested that the Italian Consulate at Zagreb aid them in repatriation to the Italy that they had so eagerly left behind in $1947 .{ }^{134}$

For the Monfalconese community at Fiume, deportations heightened an already dizzying sense of disorientation. If many had initiated the repatriation process before the Cominform Resolution or immediately afterward, the cataclysm of deportations accelerated the process, though the choice often remained difficult, even in the context of UDBA repression. In his secret letter to the PCI, the anonymous "Mario," a former Party leader who had escaped the recent arrests, explained the dilemma of both the mass of monfalconesi and the leaders who remained at large:

the Italians... are not in a condition to be able to repatriate. Who would give them work in Italy? Here they have their families and some furniture. Should they abandon everything? They lack even the financial means for the travel expenses. The ex-leaders of the P[arty], including the writer, do not want to repatriate under these conditions. The masses would claim to have been abandoned. They have always demonstrated faith in us. Therefore, if one must and one can depart, we will depart for good and what will be, will be. ${ }^{135}$

As "Mario" recognized, for some - particularly those with few remaining ties to the Monfalconese - the decision of where to go was equally problematic as whether to go. Many continued to look east. For a brief time, some monfalconesi hoped the PCI might arrange their extraction en masse to Romania, Bulgaria, or Hungary. Still others, including many from Belgrade and interior settlements, proved unwilling to wait for passports. Instead they made their own arrangements for

\footnotetext{
${ }^{132}$ MAE, DGAP, Uff IV, “Arresto connazionali a Fiume e 'deportazioni in Bosnia”' (Tel. N. 15/27764), 12 October 1948, AGPCM, Fondo UZC, Sez II, Jug, b 6.2, f 78.

${ }^{133}$ A letter sent from an anonymous "Angelo," suspected to be Angelo Comar, complained that "Muslim women with veils fill the streets like masks Carnival" and that there were "a dozen minarets and as many chimneys." "Angelo," "Lettera di un comp. internato nella Bosnia," 30 October 1948, AM-IG, Fondo Yug e VG, b mf 135, f mf 135, d 38. On the travel ban, see Console Pinto, "Arresto connazionali a Fiume..." (Tel. N. 9144), 22 September 1948, ASDMAE, AP 1946-50, Jug, b 47, f 5.

${ }^{134}$ MAE, DGAP, Uff IV, "Emigrati clandestini in Jugoslavia - Arresti e invio in Bosnia" (Tel. N. 31940), 10 December 1948, AGPCM, Fondo UZC, Sez II, Jug, b 6.2, f 78.

135 "Mario," Untitled Report, 13 September 1948, op. cit.
} 
extraction to Romania or Czechoslovakia or fled back toward the Italian border, several seemingly shot dead by Yugoslav border guards in the process. ${ }^{136}$ Whether leaving illegally or legally, by the end of September, the vast majority of monfalconesi in Yugoslavia appear had made clear moves to depart. Even if temporarily torn between their possessions and their safety, most chose the latter. For those who requested formal passports, the process could take a shockingly long time, subjecting one to a long period of police harassment. Monfalconesi often had to wait months to secure their Italian travel documents and then months more to secure a Yugoslav exit visa, during which time one was likely to be hounded by Tito's security forces. The winter of 1948-49 was thus one that monfalconesi spent in fear and hiding. In the interim, monfalconesi developed survival strategies, including reviving the Fascist-era clandestine support network called the Soccorso Rosso, keeping the same name. The group collected aid and food donations for the family members of political detainees, while also helping keep track of those who were arrested. ${ }^{137}$ Though the majority of monfalconesi appear to have departed Yugoslavia by early 1949, that year saw the extension of the anti-Cominformist repression to the monfalconesi community of Pola, now devoid of potential Fiuman allies, and its renewal in Fiume itself. ${ }^{138}$ By year's end, Yugoslavia had expelled many of those it arrested in 1949 and the year prior, dumping them at the Italian border.

\footnotetext{
${ }^{136}$ An ethnically Italian OZNA agent who defected back to Italy after the Split recounted that in this moment of chaos, "comrades were forced to make individual decisions to go to other newly democratic [Communist] countries or to return to Italy." Botazzi and Forti, "Esito Rapporto Verbale...," 10 August 1948, op. cit. Scotti suggests that leaders like Comar and Marega had begun discussing the movement en masse of monfalconesi to Romania since late July. Scotti, Italiani nel gulag di Tito, 25-26. See also, Unsigned, Untitled Report from a Staff Member of La Voce del Popolo, Undated (August or September 1948), op. cit.; Unsigned, “Estratto di Una Relazione...," Undated (1948), op. cit.; Unsigned, "Relazione sulla situazione di Belgrado," Undated, op. cit.

${ }^{137}$ Bonelli, "Testimonianza del monfalconese Buttignon Angelo," 28 April 1978, op. cit.

${ }^{138}$ The repression at Pola played out much slower. Over the course of 1949, Tito's regime slowly removed monfalconesi from positions of power, vilified them in the press, and finally placed thier leaders under arrest. Bonelli, "Memorie del monfalconese Beltrame Valerio," 29 November 1977, op. cit. The new wave of arrests in Fiume came in July and impacted Riccardo Bellobarbich, Giuseppe Buttignon, and others. Puppini, "Il 'controesodo' Monfalconese," 87. In 1950, UDBA carried out another wave of arrests against Italian Cominformists, including the group headed by Alfredo Bonelli, which had connections to external Cominform Parties but not to the monfalconesi. See Bonelli, Fra Stalin e Tito; Privitera, "Socialismo vero, socialismo falso," 132-36.
} 
Among them were several members of the Zenica group, including Angelo Nicola, who later lamented that he lost all his carpentry equipment and his workbench in the process. ${ }^{139}$

Despite this loss, Nicola was in retrospect quite lucky. A small number of monfalconesiroughly fifty - ended up on Goli Otok and other of Tito's gulag islands, enduring (or succumbing to) years of backbreaking labor and torture for their real or supposed Cominformism. ${ }^{140}$ Though Goli Otok is beyond the scope of this dissertation, the single example of bojkot (boycott) will suffice to demonstrate the suffering of those on the island. When placed under bojkot, a prisoner had to remain silent, perform strenuous physical labor at the quarries, "guard" buckets of excrement for periods of hours in the middle of the night, and sleep separate from the other prisoners, all while being denied precious cigarette ration and subjected to insults and beating by non-boycotted inmates, many of whom participated in the cruelty lest they be boycotted themselves. This horror often lasted up to two months and, in exceptional cases, even longer. ${ }^{141}$ Mario Tonzar was one of the unfortunate exceptions, enduring four long months of bojkot in Goli Otok. He emerged from the island prison only in 1953, following the death of Stalin. ${ }^{142}$

139 Bonelli, "Testimonianza del monfalconese Nicola Angelo," 10 March 1978, op. cit; Prefetto Palamara, "Connazionali espulsi dalla Jugoslavia," (N. 09303), 12 August 1949, AGPCM, Fondo UZC, Sez II, Jug, b 6.2, f 113.D.

${ }^{140}$ Tonzar, La valigia e l'idea, 47-50. The number of those interned in Goli Otok is often overestimated in the popular imagination. Franco Giraldi, an ex-partisan and film director born not far from Monfalcone, stressed in an interview on the postwar years that "the best specialized workers of the shipyards of Monfalcone chose to go voluntarily to Yugoslavia... and almost all ended up in Goli Otok" (Italics added). Franco Giraldi, interview by Alessandro Cattunar and Kaja Sirok, Gorizia, 8 August 2009, op. cit.

${ }^{141}$ Scotti, Italiani nel gulag di Tito, 153-54. See the testimony of monfalconesi who lived through Goli Otok, among them Giuseppe and Angelo Buttignon, Riccardo Bellobarbich, and Emilio Cirstian, at IRSML, Fondo Cominform, b 99; Banac, With Stalin against Tito, ch. 6; Giacomo Scotti, Goli Otok: ritorno all'isola calva: a quarant'anni di distanza le rivelazioni su gulag dell'Adriatico voluto da Tito (Triste, LINT, 1991); Luciano Giuricin, La memoria di Goli Otok-Isola Calva (Rovinj: Centro di ricerche storiche di Rovigno, 2007); Giacomo Scotti, Il gulag in mezzo al mare: nuove rivelazioni su Goli Otok (Trieste: LINT, 2012).

${ }^{142}$ Tonzar, La valigia e l'idea, 95. 


\section{Big Moments and Small Moments}

Goli Otok was one endpoint for monfalconesi in Yugoslavia. For many historians and many participants, Goli Otok is now the dominant "meaning" to be taken from the narrative of the controesodo. In such interpretations, the Cominform Resolution and the Partizan theater incident mark high points in the drama of the monfalconesi as a collective body, the catalyst for a nearuniversal move toward repatriation. This is a somewhat natural outcome, as much of the research to date has been undertaken with the aim of exposing Titoist oppression or has relied on sources written by or drawn from those exceptional individuals who lived through this extreme side of the emigration. Yet ordinary people often experienced (and recount) this period less with reference to the great "breaks" or "turns" of history and more within the framework of everyday life. ${ }^{143}$ The focus on June 1948 and Goli Otok obscures as much as it reveals, particularly if we take the stories of Goli Otok survivors such as Franti and Tonzar as representative. In fact, the experiences of monfalconesi in Yugoslavia were much more varied.

The focus on the Cominform Resolution and Goli Otok has not only obscured the variety of experiences in Yugoslavia; it has also shaped how historians have interpreted the testimonies left by surviving monfalconesi. Even Anna Di Gianantonio and her colleagues, while attempting to reconstruct the experiences of monfalconesi in Yugoslavia, have fallen prey to overemphasizing the Cominform Resolution. They have taken the vastly different explanations of the quality of life in Yugoslavia as the result of memory in the wake of the Resolution: either the trauma of the postResolution experience results in monfalconesi remembering their entire time in Yugoslavia as horrible or that same trauma leads them to frame the pre-Resolution experience as one of plenty

\footnotetext{
${ }^{143}$ Morena, "Il Monfalconese tra guerra e lungo dopoguerra," in Il mosaico giuliano, eds. Altieri and Puppini, op. cit., 136-37.
} 
and happiness and thus as a paradise shattered by the intra-Communist rift. ${ }^{144}$ Though this may be true to a degree, such clashes in emigrant testimonies are at least as likely to reflect extreme and rapid changes in living conditions during the emigrants' stay in Yugoslavia.

In the end, not all monfalconesi would leave Yugoslavia after the Cominform Resolution, nor be pressured to do so. Those who had integrated most actively in Yugoslav society or sided openly with Tito received better treatment. Such was the case with Mirella Pin. She remained with her father, her mother, and her future husband, Luciano Giuricin, who carried the vital KPJ card. Even a half-century after the fact, Mirella and Luciano maintain that Tito was constructing socialism in Yugoslavia and that their family was right to say. ${ }^{145}$ In the interim period, Luciano continued writing for La Voce del Popolo, which even through 1949 encouraged monfalconesi to renounce the Cominform Resolution, pledge allegiance to Tito, and continue assisting in the construction of Yugoslav socialism. ${ }^{146}$ Eugenio Pin, perhaps confident that Luciano's Party ties would shield him from suspicions, aided monfalconesi released from Goli Otok in their efforts to reintegrate into Fiuman society, though few chose to stay. ${ }^{147}$ Even among those who remained, faith in Yugoslavia was not universal. Renato Rigonat, long active in KPJ youth organizing in Fiume and married to a Serbo-Croatian Communist, remained until 1953, experiencing minimal abuse in the anti-Cominform campaign. Only after applying for an exit visa to return to Ronchi in 1952 did UDBA hound him and his family. But his decision to remain after 1948 was more due to inertia and his wife's desires than his view of Yugoslavia. Well before his departure he had become

\footnotetext{
144 For their discussion of memory and the Cominform Resolution, see Di Gianantonio et al, L'immaginario imprigionato, 169-83.

${ }^{145}$ Berrini, Noi siamo la classe operaia, 236-40; Pin-Giuricin, "I motivi di una scelta."

146 MAE, DGAP, Uff IV, "Politica jugoslava nei riguardi della popolazione italiana nel territori ceduti" (Tel. N. 08620), 4 May 1949, AGPCM, Fondo UZC, Sez II, Jug, b 6.2, f 78.

${ }^{147}$ Pin had shared a PCRG cell with Angelo Buttignon in Monfalcone, whom he helped find employment in Fiume after the latter's release, but Buttignon's stay was shortlived. Bonelli, "Testimonianza del monfalconese Buttignon Angelo," 28 April 1978, op. cit.
} 
convinced that Tito's new state was not building socialism. ${ }^{148}$

Equally important, however, were the forgotten hundreds who left before the Resolution. Some of them had likely never expected to reside permanently in Yugoslavia, but many were monfalconesi who had eagerly departed for Tito's land of nascent socialism only to find that Yugoslavia was not what they had expected. The developmentalist socialism of Tito's Yugoslavia precluded the realization of many of their hopes, while the changing international conditions of 1947-48 - particularly Yugoslavia's isolation from both West and East - forced Yugoslav leadership to adopt new policies in direct contrast with Monfalconese hopes for a socialist society. These changes replicated some of the experiences in the workplace and marketplace that monfalconesi had long associated with Fascism. Capturing their frustration are the words of the Emilian partisan, Sauro Ballardini, who lived in Fiume between 1946 and 1948 as a partisan exile. Speaking of the Italians in Fiume, Ballardini recalls that "we wanted to leave the country because the existing socialism that we found there was different than that which we had imagined during the Resistance."149 Many monfalconesi who thought like Ballardini returned to Italy before the Resolution, returning to a country that was itself going through major Cold War convulsions.

\footnotetext{
148 Rigonat, Memorie, 57-60.

149 Bonelli, "Prima intervista con il partigiano profugo Ballardini Sauro (Topo)," 2 July 1980, op. cit.
} 


\section{Chapter 8: West-East Migration, Cold War Paranoia, and the Construction of the Iron Curtain}

He is constantly and secretively surveilled by the corps. ${ }^{1}$

- Monfalcone carabinieri on the recently repatriated, Mario R., November 1948.

On 7 October 1948, Mario R., a middle-aged mariner from San Canzian d'Isonzo, passed westward through an Italian border checkpoint, showing repatriation papers he had received from the Italian Consulate at Zagreb. After fifteen months spent working in Pola, he returned to his hometown, but his homecoming was far from convivial. Informed of Mario's imminent return by the consul, carabinieri began to track his activity as soon as he crossed the border. As a former UAIS member, he was known to harbor "Communist philo-Slavic sentiments" and was considered a threat to the country. For over fifty days the carabinieri tracked his movements and contacts, attempting to uncover anything that would reveal the presumably sinister motives for his return. What they found, however, was unexceptional. Mario had never assumed a major leadership position in any pro-Yugoslav organization, nor committed violent acts against pro-Italians. Moreover, his commitment to Yugoslavia and Communism was in doubt, as he had initiated the repatriation process well before the Cominform Resolution due to disillusionment with life in Pola, and he had abstained from politics since his return. All evidence refuted fears that Mario was a threat. Nevertheless, even after fifty days of surveillance, the carabinieri concluded their report with a telling line: "He is constantly and secretively surveilled by the corps."2

The disparity between the resources dedicated to surveilling Mario and the actual threat that he posed to the Italian state is both striking and informative. It reflects the intense paranoia

\footnotetext{
${ }^{1}$ Ten. Com. De Palma (Carabinieri-Monfalcone), "R[x] Mario fu Angelo...” (N. 2/124), 27 November 1948, ASG, Questura 1948, b 10, f 1506.

${ }^{2}$ Ibid. In reality, Mario had been a minor member of a UAIS workshop committee in the CRDA, though this did not warrant mention. UAIS-Monfalcone (CRDA), List of CRDA Cadres, Undated (Late 1946), op. cit.
} 
generated by the back-and-forth movements of monfalconesi from Yugoslavia, which unfolded in an era of deep uncertainty - one of territorial contestation, Cold War polarization, and the first postwar Italian elections. The movements of Mario not only occurred within this context of uncertainty, they also helped create and shape it. And he was just one of thousands.

\section{The "Troika:" Yugoslav Infiltration, Communist Plots, and the Red Revolution, 1945-46}

Understanding the paranoia surrounding Mario's repatriation in 1948 requires a deeper look at how the Italian state viewed the Communist world's policy toward Italy in preceding years, which in turn cannot be disentangled from different actors' attempts to achieve their own goals by influencing state or societal perceptions of this policy. Whether due to genuine belief or more opportunistic instrumentalization, Italian officials denied that June 1945 had marked the end of Tito's (and Stalin's) aggression and instead wove complicated narratives about Communist plots, in which Monfalcone and monfalconesi came to play prominent roles.

Chief among the weavers was Feliciano Ricciardelli, who from his peripheral position as head of the VGPC's Criminal Investigative Division continued with the central task set for him during his Fascist-era service as director of Trieste's political police - namely protecting Italian Trieste from "Slavo-Communism." During the biennium 1945-46, he repeatedly and loudly sounded alarm bells about impending Communist aggressions, providing the interpretive lens through which the state would view Monfalconese politics and mobility. This process began in late November 1945 when Ricciardelli sent an urgent message to Police Chief Luigi Ferrari in Rome warning of plans by the Yugoslav military and the PCRG to resolve the "Trieste Question" by fait accompli. He advised that "the Carsic territory up to the suburbs of Trieste" had been organized militarily under the command of the garibaldino leader, Anton Ukmar, with even "the smallest village" possessing a cell and each cell a cache of weapons, vehicles, and foodstuffs. 
Should the Yugoslavs not receive Trieste through negotiations, Ricciardelli alleged they planned to "unleashed an upheaval of a social character, followed immediately by an insurrection of partisans, giving way to an intervention of the regular Yugoslav Army," which they believed would succeed due to Western Allied "fatigue" and a "predisposition of America and England to yield to violence, rather than come to armed conflict with Russia."

Though fear that a red eastern wave would wash over part or all of Italy was not new, the detail of Ricciardelli's reporting raised the specter of Communist aggression to new heights and garnered the attention of Italy's top echelons of military and security leadership. ${ }^{4}$ In the two months that followed, his warning appeared nearly verbatim in intelligence reports issued to Prime Ministers Ferruccio Parri and Alcide De Gasperi by the heads of the national carabinieri and Naval Ministry cabinet. ${ }^{5}$ It became a model for subsequent analyses of Venezia Giulia's vulnerability, particularly in its articulation of both the process of armed takeover - social upheaval, partisan insurrection, and regular military invasion - and uncertainty over the Anglo-Americans'

\footnotetext{
${ }^{3}$ Insp. F. Ricciardelli (VGPC-CID), "Situazione politica nella Venezia Giulia" (N. 800), 30 November 1945, ACS, MI, DGPS, Div SIS, AA GG 1944-49, b 77, f OP6 Venezia Giulia.

${ }^{4}$ A report from summer 1945 suggested that Modenese Communists believed that "invincible Soviet Russia" and "Tito as absolute master of the Balkans" would soon unleash a red wave that would wash over Italy. Unsigned (MAE), “Agenti di Tito all'Estero,” Undated (Mid-1945), ASDMAE, AA PP 1931-45, Jug, b 149 f 5. On Emilia-Romagna as a region persistently seen as more radical than others, see Raoul Pupo, "Alcuni documenti sull'ordine pubblico nel 1946," Qualestoria 7, no. 3 (1979): 14.

${ }^{5}$ Gen. Com. Brunetti (Carabinieri-USS), "Situazione nella Venezia Giulia" (N. 86/62), 7 December 1945, ACS, MI, Gab 1944-46, b 138, f 12148; Head of Cabinet Marini (Naval Ministry), "Azione jugoslava contro la Venezia Giulia" (N. 34/UT), 7 January 1946, ASDMAE, AA PP 1946-50, Jug, b 6, f 1.3 Segnalazioni riservate del MG VG 1946. Another of Brunetti's reports, sent two months later, confirmed ongoing preparations to seize control of Zone A by means of a "Slavic insurrection, with the support of philo-Slavic Italian elements." Gen. Com. Brunetti (CarabinieriUSS), "Situazione nella Venezia Giulia" (N. 87/23), 22 March 1946, AA PP 1946-50, Jug, b 3, f 5. In a general sense, reports about impending Communist aggressions in Italy must be taken with a grain of salt, particularly those shared with the Anglo-Americans, as De Gasperi and other anti-Communist politicians often tried to leverage fears of a Communist takeover for increased Anglo-American aid. De Gasperi and others had been exploiting the "SlavoCommunist threat" to Venezia Giulia and wider Italy since before war's end. In mid-July 1945, Ambassador Quaroni in Moscow explicitly laid out this strategy in a cable to De Gasperi. After expressing his faith in the goodwill of the Anglo-Americans "toward Italy in general and Venezia Giulia in particular," he expressed doubts about "their capacity and will to realize these good intentions," concluding that Truman and the British ought to be spurred to take a strong stand. Ambassador Quaroni (Moscow), "VENEZIA GIULIA" (N. 523/222) to Foreign Minister De Gasperi, 16 July 1945, ASDMAE, AA PP 1946-50, Jug, b 6.
} 
willingness to defend the region against armed aggression. Equally important, as part of his November warnings to Ferrari, Ricciardelli also drew attention to efforts by the PCRG and OZNA to provide military training to "philo-Slavic" Triestine youth in the forests around Sesana (Sežana), just beyond the Morgan Line, with the purpose of preparing them for armed insurrection. ${ }^{6}$ Thus buried within the wave of reports - and largely overlooked for the time being-was the idea that Yugoslavia might serve as a training-ground for "anti-Italian" paramilitary forces destined for deployment within Italian territory.

If fears of a Yugoslav seizure of Zone A were firmly entrenched within the Italian security apparatus by the turn of 1946, a series of key Cold War developments both at home and abroad led Italian statesmen and security figures to reconsider the scope of "Slavo-Communist" ambitions that same winter and spring. At home, Parri's unity government collapsed in early December 1945 and the tensions between monarchist and republican factions intensified in the run-up to Italy's 1946 referendum on the monarchy. Abroad, the re-ignition of the Greek and Chinese Civil Wars, Stalin's election speech in February 1946, and Churchill's "Iron Curtain" speech in March called into question the fragile postwar peace. Moreover, as the Council of Foreign Ministers debated Venezia Giulia's territorial fate and pro-Yugoslav giuliani made their position known in the piazze of Monfalcone and elsewhere, Italy's ministers received a flood of reports that Soviet and Sovietallied forces were amassing millions of soldiers in Yugoslavia in preparation for a drastic action. ${ }^{7}$ In the wake of these developments and Monfalcone's strong pro-Yugoslav showing during

\footnotetext{
${ }^{6}$ Insp. F. Ricciardelli (VGPC-CID), Untitled Report to Chief of Police (Rome), 4 November 1945, ACS, MI, DGPS, AA GG RR 1944-46, b 59, f 116.

${ }^{7}$ In March, the War Ministry indicated that some 150,000 Soviet and 700,000 Hungarian soldiers had been deployed to Yugoslavia and that Hungarian airbases were stockpiling petrol and other supplies. Reports of a Soviet military build-up continued to arrive through early June. Col. Capo Ufficio Pasquale (Ministero della Guerra-Ufficio Informazioni), "Unità sovietiche in Jugoslavia e nella Venezia Giulia" (N. 86498/3/3), 25 March 1946; Pasquale (MGUI), "Forze sovietiche in Jugoslavia" (N. 86937/3/3), 8 June 1946, both in ASDMAE, AA PP 1946-50, Jug, b 6, f 1.3 Segnalazioni riservate del MG VG 1946; Questore di Udine, "Venezia Giulia" (N. 01057), 12 June 1946, ACS, MI, DGPS, AA GG RR 1946-46, b 59, f 116.
} 
the Border Commission visit, Italian security forces, with Ricciardelli's prodding, both became increasingly concerned with a potential Communist aggression extending into Italy proper (beyond Zone A) and placed Monfalcone increasingly at the center of Yugoslavia's projection into Italian territory. In a report that eventually reached the desks of both Ferrari and De Gasperi, the Questore of Udine described an "extremely strong” OZNA organization stretching from Fiume through the vital node of Monfalcone and into Udine Province at Cervignano, which plotted to seize for Yugoslavia not just Zone A, but also Italian territory up to the Tagliamento River on the coming May Day. ${ }^{8}$ And though May Day passed without incident, fears did not dissipate.

Instead many began to consider that the looming referendum on the monarchy might serve as just the spark that domestic and foreign Communists needed to put their plans into action. Ferrari soon informed De Gasperi and other ministers that former garibaldini leaders of Friuli, most notably Mario Lizzero (Andrea), had reconstituted GAP cells in various Udine communes, the units loyal to Yugoslavia. ${ }^{9}$ De Gasperi regularly corresponded with leaders of the Allied occupation force to seek assurances in case Italians voted that June to keep the monarchy and the PCI responded with a coup attempt. In mid-April, perhaps trying to leverage the Communist threat into greater Anglo-American aid for the DC, De Gasperi even raised the possibility with the Allied Commission that Tito's forces might be involved in helping the PCI prepare for a larger aggression aimed at overturning the sociopolitical order of Italy. However, top Allied commanders dismissed this. In May, Admiral Stone informed De Gasperi that the Western Allies considered a Communist

\footnotetext{
${ }^{8}$ Questore di Udine, "Attività e propaganda Jugoslava" (N. 01057), 12 March 1946, ACS, MI, DGPS, AA GG RR 1944-46, b 59, f 116. Italics added. This threat was taken seriously in some circles. Just days before the action was supposed to occur, the War Ministry transmitted to De Gasperi an elaborate report on what it claimed were the precise details of the insurrectional component of the aggression. Pasquale (MG-UI), "Piane insurrezionale delle formazioni partigiane filo-slave" (N. 86669/3/3), 20 April 1946, ASDMAE, AA PP 1946-50, Jug, b 6, f 1.3 Segnalazioni riservate MG VG 1946.

${ }^{9}$ Capo della Pol. Ferrari, "Venezia Giulia” (N. 442/10548), 27 May 1946, ACS, MI, DGPS Div AA GG RR, b 58, f VG 1944-46.
} 
uprising of national scope "improbable" due to a strong Anglo-American presence, even if the situation regarding Friuli and Zone A was less certain. ${ }^{10}$

However, not all Anglo-American and Italian officials shared this skepticism, and this was especially the case for Friuli-Venezia Giulia. This is made clear by their support for the rapid expansion of pro-Italian paramilitary bodies in the region, organized with the primary purpose of resisting a Yugoslav invasion or pro-Yugoslav insurrection. To Ricciardelli's delight, in mid-1946 both Anglo-American military officials (especially the British FSS) and certain security figures in Rome began to look upon units like the Divisione Gorizia and the Fratelli d'Italia (Udine) with increasing favor. Already by late 1945, AMG intelligence indicated that De Gasperi was actively funding the Divisione Gorizia. In May 1946, Ferrari urged him to go further and help coordinate the paramilitary preparations of the Divisione Gorizia with those of Gorizia Province's antiYugoslav Italian Partisan Association (API), which refused to cooperate with the former due to the inclusion of monarchists and ex-Fascists in its ranks. ${ }^{11}$ Simultaneously, Army Chief of Staff Raffaele Cadorna Jr. sent an emissary to Trieste to reassure the two- or three-thousand-strong proItalian paramilitary apparatus there that, in case of Yugoslav aggression in Zone A, the men could consider themselves in regular service to the Italian Army, with all the benefits it entailed. ${ }^{12}$

Though all of this came to naught - Italians voted away the monarchy in June and deprived

\footnotetext{
${ }^{10}$ Pupo has suggested that De Gasperi did not himself believe that the PCI had plans in place for a national uprising, but rather he was exploiting Anglo-American anti-Communism for DC gain. On a regional level - particularly regarding Friuli and Emilia-Romagna - there was less confidence. For example, Stone indicated that it was possible that the former, a PCI stronghold, could suffer a PCI-backed uprising to create an independent republic if Italy retained the monarchy. Pupo "Alcuni documenti," 14.

${ }^{11}$ AMG-13 Corps, Appendix "D" to 13 Corps Monthly Intelligence Summary No. 3, Undated (late 1945), NARA, RG331, UD1981, b 9294, f 11304/137/93. On the Italian state's knowledge of the Divisione Gorizia see ACS, MI, DGPS, AA GG RR 1944-46, b 59, f 116; ACS, MI, Gab, 1944-46, b 138, f 12148; and ACS, MI, Gab, 1944-46, b 271, f 26232. Particularly relevant from the latter is Capo della Polizia, "Divisione Gorizia" (N. 224/74103), 7 May 1946, in which Ferrari suggests that Italy facilitate cooperation between the DG and API. However, this reconciliation was very slow to develop. Buttignon, "Il sentimento nazionale italiano," 111-12.

${ }^{12}$ Cadorna also granted the unit L1,000,000 in monthly support. Ferrari, "Venezia Giulia" (N. 442/10548), 27 May 1946, op. cit.
} 
the Communists of their alleged pretext for agitation - both the Italian state and Western Allied forces continued to grow concerned about the fate of Zone A and the activity of monfalconesi as territorial negotiations neared their conclusion. In the lull between the visit of the UN Border Commission and the Twelve Days' Strike, Trieste Area Commissioner Smuts informed SCAO Bowman that many pro-Italians of the zone had grown frightened of a coup due to the proYugoslavs" “ominous" quiet. ${ }^{13}$ Meanwhile, Ricciardelli continued to funnel alarming news both directly to Ferrari and through the Udine questura. ${ }^{14}$ In June, the latter informed the Interior Ministry of a meeting of "Slavophiles," held at a farmhouse outside of Cervignano, where a former political commissar of the Divisione Natisone and two Slovenian officers met with thirty members of the Monfalcone UAIS and the Cervignano OZNA. The monfalconesi and cervignanesi were tasked with organizing civilians and partisans into "armed units, ready for every eventuality," including serving as the spearhead of a future Yugoslav invasion. ${ }^{15}$

In this context, just days before De Gasperi ceded the Foreign Ministership to Pietro Nenni, his office dispatched a seventeen-page report directly to Ferrari. It stressed that, apart from dealing with the soon-to-be Free Territory of Trieste, "the most urgent problem in regards to Italy's new eastern frontier is that of the spiritual, economic, and political normalization in the Lower Monfalconese," considered "the entry point for a vast politico-social agitation in Italy."16 It was also in this context that Ferrari issued the so-called "Troika" circular of 19 September 1946, informing his subordinates of the existence of a 280,000-person organization - primarily Italian

\footnotetext{
${ }^{13}$ SCAO Meeting Minutes, 10 June 1946, NARA, RG331, UD1981, b 9108, f 11302/115/88.

${ }^{14}$ Insp. F. Ricciardelli (VGPC-CID), "Notizie confidenziali riguardanti avvenimenti di carattere politico e militare nella Venezia Giulia..." (N. 800 - Riservatissima), 30 May 1946; Questore Durante, Letter to Ferrari (?), 5 June 1946, both in ACS, MI, DGPS, Div SIS, AA GG 1944-49, b 77, f OP6 Venezia Giulia.

${ }^{15}$ Questore Durante, "Venezia Giulia" (N. 01057), 5 June 1946, op. cit.

${ }^{16}$ MAE-DGAP, "Notiziario di Informazioni N. 18" (N. 42582/802), 11 October 1946, op. cit. Italics added. This had also been the view of the British Eighth Army's General Staff Intelligence since 1945. GSI(b), HQ Eighth Army, "Security Intelligence Summary No. 28, 1 June to 30 June 45," 13 July 1945, NARA, RG331, UD1981, b 9294, f $11304 / 137 / 93$.
} 
Communists - which, under Stalin's command and with Yugoslav backing, was ready to engage in insurrection on a national scale. ${ }^{17}$ What had emerged within the top political and police offices was an image of a subversive network of national scope, connected to foreign Communist powers by way of intermediaries in the disputed Julian lands. The regional nodes were said to be composed in part of trained OZNA agents, but also "ordinary" UAIS members and garibaldini, above all from the Monfalconese. ${ }^{18}$ Indeed, the Foreign Ministry (MAE) report stressed that the PCI's new Gorizia Federation would be the primary vehicle for Yugoslav projection into Italy, as "details are already available proving that the organizations now dependent on the UAIS will pass en masse into the Communist Party, where they will be able to operate with a certain ease."19

If Ricciardelli had helped transform Monfalcone from a regional problem into a national menace by the summer of 1946, he also began to court more significant patrons in his struggle against Yugoslav influence in Zone A. Certainly, Italian forces had provided aid to pro-Italian paramilitaries, but such aid seemed far from sufficient to stem the Titoist tide, let alone to roll it back. Thus, he began to seek out avenues of communication with US President Harry Truman. In early June 1946, Ricciardelli indicated in a top-secret report to Ferrari that he had successfully impressed upon a major of the US Army the precarious political situation in the zone. This major,

\footnotetext{
17 The document was discovered by the PCI and published mockingly in L'Unità. Pupo, 13. Pupo and others, while suggesting that De Gasperi was skeptical of Ferrari's "Troika" circular, have also expressed doubt as to whether Ferrari believed its content or merely leveraged the Communist threat for an alternative end, such as undercutting the purge of the security apparatus. When one considers he had been inundated with reports of Yugoslav-backed subversion for a year and that he himself urged De Gasperi to foster paramilitaries to defend against such an eventuality, it seems likely that Ferrari fully believed in the threat of an insurrection-invasion, at least as regarded Friuli-Venezia Giulia. Moreover, even if De Gasperi was doubtful about the prospects of a PCI uprising on a national scale, the same was not necessarily true regarding the Julian PCI, as heirs to the UAIS. Pupo, 18-19.

${ }^{18}$ For a similar assessment by the carabinieri, see Gen. Com. Brunetti (Carabinieri-USS), "Situazione nella Venezia Giulia" (N. 87/81), 29 July 1946, ASDMAE, AA PP 1946-50, Jug, b 4, f 5. In the ACS holdings on the MI's intelligence service there is a file titled "Monfalcone: attività di jugoslavi in Italia." Within the collection, Monfalcone is the sole city-level file, the others being province-level. According to the file cover, the documents have been merged with "V2 Friuli-Venezia Giulia 1948," but neither I, nor the staff could locate this. ACS, MI, DGPS, Div SIS AA GG 1944-49, b 78, f OP13.

${ }^{19}$ MAE-DGAP, “Notiziario di Informazioni N. 18” (N. 42582/802), 11 October 1946, op. cit.
} 
set to return to Washington from his present observation mission, had agreed "to submit for the examination of President Truman the political situation in this area."20

\section{Emigration Fears: Yugoslavia as a Staging Ground and the "Greek Thesis"}

It was just as Italian and (to a lesser extent) Anglo-American anti-Communists reached this peak in their obsession over Monfalcone's role in a westward projection of Communist power that thousands of these suspect monfalconesi began to move eastward into Tito's New Yugoslavia, often clandestinely. Given their nature as instruments of power, territorial states have always perceived as threatening any undisciplined movement of peoples across their borders, and postwar Italy and the AMG were no exception to this rule. ${ }^{21}$ The contested and ideologically-charged nature of the Italo-Yugoslav border and the distrust that both Italy and the AMG bore for many borderlands residents only intensified this anxiety. Thus, from the very moment that the Allied and Italian forces registered the departure of thousands of monfalconesi to Yugoslavia in midJanuary 1947, they kept tabs on this movement, even if most observers explained it in its early days as the result of economic necessity. ${ }^{22}$

It was only in March that the perceived security implications of this migration began to change. On 12 March, across the Atlantic, President Truman had gone before the US Congress. There he made his famous speech in which he laid out the Truman Doctrine, defining the victory of the anti-Communist faction in the Greek Civil War as vital to US security interests and

\footnotetext{
${ }^{20}$ Insp. F. Ricciardelli (VGPC-CID), "Confidenziale” (N. 800 - Riservatissima), 2 June 1946, ACS, MI, DGPS, Div SIS, AA GG 1944-49, b 77, f OP6 Venezia Giulia. The Trieste Crisis of May-June 1945 had been the first foreign policy test Truman faced upon assuming the presidency in mid-April, and he felt himself invested in it. Rabel, "Prologue to Containment," 159-60.

${ }^{21}$ On the idea of "territoriality," see Charles Maier, Once Within Borders: Territories of Power, Wealth, and Belonging Since 1500 (Cambridge, MA and London: The Belknap Press of Harvard University Press, 2016).

${ }^{22}$ GSI GHQ CMF, "NE Italy ISUM No. 25 for the Period 15 to 21 Jan [1947]" (N. GI/1182), 21 January 1947, op. cit. An exception to this was the Italian War Ministry's intelligence service, which predicted early on that the migrants were Communist zealots who would commit sabotage on their way out the door. Pasquale (MG, UI), "Organizzazoni politiche jugoslave a Monfalcone" (N. 88151/3/3), 10 October 1946, ASDMAE, AA PP 1946-50, Jug, b 6, f Segnalazioni riservate del MG VG.
} 
requesting Congressional approval for an economic aid package to be sent to bolster faltering antiCommunist governments in Greece and Turkey. Perhaps with Trieste and Italy in mind, Truman warned that "terrorist activities" of foreign-backed Greek Communists threatened "the very existence of the Greek state" and that the collapse of Greece could lead to a rapid westward and southeastward spread of Soviet influence. ${ }^{23}$ In this context, it did not take long, for the motivations of Monfalcone's emigrants, as well as a smaller stream of Italian emigrants from the Old Provinces, ${ }^{24}$ to be distorted by Cold War paranoia, brought into discussion of both the Communist "Troika" in Italy and wider Communist aggressions throughout Europe. ${ }^{25}$

By all indications, the first step in this process came not from the Italian or AMG security forces, but from the newspaper L'Ora d'Italia in Rome. Just two weeks after Truman's speech, the paper, directed by the monarchist, qualunquista Constitutional Assemblyman Emilio Patrissi, placed monfalconesi front-and-center in this global drama with an article entitled "Soviet Intrigues at Our Eastern Border." Assuming the "Troika" to be a reality, L'Ora d'Italia criticized the "careless indifference" of the Italian government in confronting the situation of the eastern border. Having received secret intelligence reports from confidential Julian sources - likely Ricciardelli or the pro-Italian paramilitaries - the paper drew attention to joint Yugoslav and PCI scheming, namely a supposed recruitment campaign in Friuli to send fighters to join "the bands that infest the Greco-Macedonian frontier." According to the author, Lino Zocchi ("Ninci"), ex-commander

\footnotetext{
${ }^{23}$ President Truman, "Address of the President of the United States Delivered before a Joint Session of the Senate and the House of Representatives, Recommending Assistance to Greece and Turkey," 12 March 1947, NARA, 233, Records of the United States House of Representatives, 80th Congress, 1st Session, doc 171.

${ }^{24}$ The administration of the Monfalconese by the AMG between 1945 and 1947 creates a gap in the documentation regarding state assessments of eastward emigration of monfalconesi. Often, Italian state reports on clandestine emigration to Yugoslavia did not explicitly mention monfalconesi until September 1947. But this does not mean that the emigration from Monfalcone was not problematic for the Italian state, as monfalconesi remained Italian citizens. As a result, this section will talk about how the security apparatuses of both Italy and the AMG conceived of WestEast emigration broadly, whereas subsequent sections will deal specifically with the difficulties Italy had upon inheriting those thousands of Monfalcone emigrants in 1947.

${ }^{25}$ A few historians have picked up on these fears but left them understudied. See Terzuolo, Red Adriatic, 86-90.
} 
of the Garibaldi Divisions in Friuli and PCI secretary in Udine, oversaw the transfer of the recruits to Yugoslavia and then Greece by way of collection stations at Monfalcone. Such recruitment, he claimed, ran parallel to another military organization headquartered at Monfalcone. This body "link[ed] the Italian partisans of the Friulan plain with those Slovenes of the mountains" and “dispatch[ed] groups of young Communists into the mountains, where Titoist Partisans train them in arms" and prepare them for "a common action, in the mountains and in the plains," at the moment of the Allied withdrawal. ${ }^{26}$ With this article, L'Ora d'Italia transformed West-East migration into a question of dire importance for Italian security. It painted a picture of concerted subversive activity with its epicenter at the dreaded "philo-Slavic" stronghold of Monfalcone, in which the PCI, in concert with the PCRG and KPJ, purposefully funneled young Communists and garibaldini into Yugoslavia for two interrelated ends: (1) fighting for Communism abroad in the Greek Civil War (the "Greek Thesis"); and (2) preparing guerrilla fighters who would bring the armed struggle home at the earliest opportunity, perhaps as soon as the looming implementation of the Peace Treaty. It globalized perceptions of the Cold War at home by stressing the interconnectedness of its theaters and served as a key piece in Italian anti-Communists' campaign to pull the American containment umbrella over Italy by mobilizing the eastern threat. ${ }^{27}$

In the spring months that followed, the Greek Thesis blossomed from a fanciful

\footnotetext{
26 "Le mene sovietiche al nostro confine orientale," L'Ora d'Italia, 27 March 1947. The article reproduced almost verbatim sections of intelligence reports sent to Prefect Vittadini of Udine from "confidential, unverified sources," though publication came the day before Vittadini forwarded the last of these reports to Police Chief Ferrari, suggesting a more direct connection between the paper and the source. Unsigned, "Informazione riservate sull'attività dei elementi comunisti filoslavi," Undated (Early 1947); Unsigned, Untitled Report "Negli ambienti garibaldini...," 2 Apr 1947, both in ASU, Pref, Gab, b 56, f 194; Prefetto Vittadini (Udine), "Attivita' slava" (N. 01057) and Attached, 28 March 1947, ACS, MI, DGPS, SIS, AA GG 1944-49, b 55, f MP30. Another anonymous source that made it to Vittadini identified the APG-Monfalcone secretary as the primary Monfalconese liaison. Unsigned, "Questione guerriglieri in jugoslavia e grecia," Undated (Early 1947), ASU, Pref, Gab, b 56, f 194.

${ }_{27}$ At the time, the US had only just begun to view Italy's looming election (April 1948) as a potential watershed. Mistry, "The Case for Political Warfare," 305-10. For other press pieces that played up the eastern threat in the wake of Truman's speech, see "Potentemente armata: la quinta colonna jugoslava," Gazzettino Sera (Udine), 2-3 April 1947; "La minaccia slava ai nostri confini orientali," Messaggero Veneto (Udine), 13 April 1947.
} 
proclamation of Italy's anti-Communist press into a subject of deep concern for the state, though the state arrived at no internal consensus as to the true depths of the threat posed by eastward migration. After investigations, local carabinieri in Udine concluded that a recruitment ring existed, shipping recruits to join "guerilla bands, which from foreign soil, would later be called to work against Italy in this zone," but the provincial police chief, Questore Durante, expressed skepticism given that most were "not of young age, nor of excessively extremist ideas," but rather "unemployed and in large part bricklayers." ${ }^{28}$ In Rome, Interior Ministry intelligence sided with the carabinieri, asserting repeatedly that the Yugoslavs, aided by Lino Zocchi, actively recruited youths from northern Italy to train near Fiume as guerrilla combatants and then go to Greece, still other recruits from wider Italy trained as OZNA agents and then returned to their respective home cities (a clear allusion to the "Troika" idea). ${ }^{29}$ In May, Prefect Vittadini of Udine confirmed that at least 117 Italian citizens had been recruited in Udine alone, though he sided with Questore Durante, stressing that there was little to indicate that udinesi emigrated for anything other than finding employment as mechanics, bricklayers, and carpenters in war-damaged Yugoslavia. ${ }^{30}$ Nevertheless, Ministerial intelligence issued an order on behalf of Ferrari instructing Durante, despite his skepticism, to identify recruiters and combat their activity with vigor, as the Allied authorities had neither "the ability nor the will to stop it."31

\footnotetext{
${ }^{28}$ Questore Durante, “Attività slava” (N. 01057), 2 April 1947, ACS, MI, DGPS, SIS, AA GG 1944-49, b 79, f OP52. Though skeptical about emigration-related threats, Durante did fear that Udinese Communists received guns and aid from "Titoist emissaries." Unsigned [likely Questore Durante], Report to Prefetto di Udine, 27 Feb 1947, ASU, Pref, Gab, b 43, f 153, sf 1

${ }^{29}$ SIS (Unsigned), Untitled and Unnumbered Report, 10 April 1947; SIS (Unsigned), Untitled Report (N. 224/55389), 6 May 1947, both in ACS, MI, DGPS, SIS, AA GG 1944-49, b 79, f OP52.

${ }^{30}$ Prefetto Vittadini, "Udine e Provincia - Ingaggio di lavoratori friulani per la Jugoslavia" (N. 224/62R), 11 April 1947, ACS, MI, DGPS, SIS, AA GG 1944-49, b 79, f OP52. Vittadini's appreciation of a longstanding "emigratory tradition of Friulian laborers" colored his interpretation of clandestine emigration to Yugoslavia. Vittadini, "Emigrazione friulana" (N. 3366 Gab.), 22 September 1946, ACS, MI, Gab 1947, b 60, f 3649.

${ }^{31}$ SIS, "Arruolamento di volontari per paesi stranieri" (N. 224/69R), 30 May 1947, ACS, MI, DGPS, SIS, AA GG 1944-49, b 79, f OP52.
} 
No later than July, as monfalconesi and others continued to flow into Yugoslavia, the problem of clandestine emigration reached the desk of De Gasperi. In a comprehensive report, Police Chief Ferrari indicated that such emigration had changed in nature and scope. It had shifted from an emigration of individuals fleeing prosecution for Resistance- and Liberation-era crimes - one can think here of the perpetrators of the Schio Massacre of July 1945, helped to escape to Yugoslavia by none other than the Monfalcone Communists - to a more organized efflux of PCIor PSI-loyal workers recruited by agents of "philo-Slavic" organs. Moreover, recruits from distant regions of Southern Italy increasingly joined the typical borderland recruits in departing. ${ }^{32}$ Police paranoia came out in the form of internal contradictions in the report. First stating that there "does not appear that up to now there have been created in Yugoslavia any units destined for the guerrilla war in northern Greece," the report concluded that "one Zocchi or Zolli [Lino Zocchi] ... is presently at Ljubljana, where he organizes units of young Italian Communists, especially friulani, which are then sent clandestinely... to the southern frontier of Albania and to Bulgaria in support of the Greek guerrilla fighters." Moreover, building upon long-developing fears that Yugoslavia's Youth Brigade program served as cover to train young radicals in revolutionary and propagandistic activities, the report ended with a cryptic warning. It advised that "it has been confirmed that Italian youths in Yugoslavia who show themselves in possession of the necessary aptitude are subjected... to special courses of Communist catechization, to transform them into capable and obedient militants, who will be utilized, where and when necessary, in important and risky Party missions." ${ }^{33}$ With this, clandestine West-East emigration was defined at the highest

\footnotetext{
32 The Schio Massacre of 6/7 July 1945 involved a group of ex-garibaldini and partisan auxiliary policemen entering a jail at Schio (Vicenza), killing 54 men and women held there for Fascist crimes. As one of the perpetrators would later testify upon returning to Italy, the monfalconesi helped him escape to avoid a thirty-year sentence. Comm. Gen. del Governo Palamara (Trieste), B[x] Giovanni di Antonio..." (N. 13/1/1405-55), 15 February 1955 op. cit. On this event, see Morgan, Rappresaglie dopo la resistenza.

${ }^{33}$ SIS (Unsigned), "Risultanze delle indagini fatte sull'espatrio clandestino..." and attached dichiarazioni, 5 July 1947, ACS, MI, DGPS, SIS, AA GG 1944-49, b 79, f OP52. On fears regarding the Youth Brigades, see SIS
} 
levels of state as a first-rate security problem. ${ }^{34}$

But the Italians were not the only ones for whom this migration proved troubling; the Anglo-Americans in Italy and Venezia Giulia, long suspicious of the zone's pro-Yugoslavs, also lost sleep over West-East migration. Lt. Col. Gardner, the Area Commissioner of Trieste, warned the SCAO repeatedly of "anti-Allied and anti-De Gasperi" youth crossing the Morgan Line near Muggia to receive guerrilla training for later service in "the International Army or some contingent of the Jugoslav forces." 35 The Trieste United States Troops (TRUST), stationed at Trieste to deter Yugoslav and Soviet aggression, entertained this same idea throughout that spring and early summer. ${ }^{36}$ Only after several months did they indicate that "interrogation of persons apprehended by both British and Americans for illegal attempts to enter Jugoslavia [sic] has not shown in any instance that the subject had been recruited for military training or service." ${ }^{37}$ In the meantime, Truman's cabinet had drafted contingency plans for a US response to a potential Communist coupinvasion in Italy, and it launched a "political warfare" campaign there, the means of which had previously been "dysfunctional or nonexistent." 38 It is quite possible that Ricciardelli's warnings

(Unsigned), Untitled Report (N. 224/56759), 17 June 1947, ACS, MI, DGPS, SIS, AA GG 1944-49, b 79, f OP52. There was at least one Youth Brigade training in Yugoslavia for deployment in Greece - Silvano Cosolo indicates as much - though there is no evidence to suggest that there was a primarily Italian brigade-in-training, nor that migrants were recruited for this purpose. Cosolo happened to end up in just such a military brigade, but by accident, his enrollment coming after he had individually migrated. Nevertheless, he writes of his experience that "it wasn't long before I discovered the true nature of that strange brigade that should have constructed a railway but which didn't do any work and which instead performed military preparations. It was a brigade of young volunteers who were preparing to intervene in Greece and support the republican Communist partisans, who there were fighting against the monarchists and the English who supported them." Cosolo, Amare... Sarajevo, 94-103.

${ }^{34}$ Not coincidentally, just three days later Ferrari instructed all prefects of the republic to root out clandestine recruitment rings within their respective provinces, with special empahsis on recruiters for Greece. DGPS, Div AA GG RR, Telegraph N. 40658/441/07134 to the Prefects of the Republic and others, 8 July 1947, ACS, MI, DGPS, SIS, AA GG 1944-49, b 79, f OP52.

${ }^{35}$ SCAO Meeting Minutes, 28 April 1947 and 23 June 1947, NARA, RG331, UD1981, b 9108, f 11302/115/90. CAO Kitson-Harris maintained this stance until the end of the AMG. Maj. Kitson-Harris, "Monthly Report," 31 August 1947, NARA, RG331, UD1981, b 9188, f 11304/115/288.

${ }^{36}$ TRUST, Intelligence Summary No. 3, June 1947 and Intelligence Summary No. 4, July 1947, both in NARA, RG331, UD1981, b 9084, f 11300/200/8.

37 TRUST, Intelligence Summary No. 5, August 1947, NARA, RG331, UD1981, b 9084, f 11300/200/8.

${ }^{38}$ Mistry, "The Case for Political Warfare," 307, 310. 
or even paranoid contemplation of West-East migration played a part in that escalation.

\section{The First Efforts to Halt Emigration: Bordering the AMG (1947)}

Despite eventually rather decisively refuting the Greek thesis, in the interim months, the Anglo-American forces in Italy took no chances. Beginning in summer 1947, the AMG and TRUST joined the Italian state in attempting to construct a more rigorous border regime with the aim of keeping Italian Communists on the western side of the emerging Iron Curtain. For the AMG, the impetus to solidify the border came too from the realization that, at least since early 1947, many suspect monfalconesi had easily moved back and forth undetected. ${ }^{39}$ Yet until September 1947, when the peace treaty formally went into effect, efforts to construct this Iron Curtain were critically limited by the fact that, according to the terms of the agreements establishing the AMG in 1945, the AMG could not obstruct the free passage of residents of Zone A (including monfalconesi) into Zone B. Despite desiring to halt ongoing emigration from Zone A, it had no legal basis to do so. ${ }^{40}$ Thus anti-emigration measures were applied primarily in two ways during the summer of 1947: (1) by both Italy and the AMG to those entering Zone A from Italy; and (2) by the AMG to all non-residents of Zone A crossing into Zone B or Yugoslavia.

Within the bounds of legality, TRUST, the AMG, and the Italian state thus sought to stamp out West-East movement and transform Churchill's metaphorical Iron Curtain into a real and existing border regime that would keep suspect individuals in the West. This project began in June

\footnotetext{
${ }^{39}$ Silvano Cosolo recounts, for example, that around Easter of 1947, he sought to return to Pieris to see his family, joined in his journey by Panzano man who, having murdered an AMG collaborator, had been forced to flee to Sarajevo to escape a long prison sentence. They returned to the Monfalconese on foot with ease, aided across the border near Sistiana by two Yugoslavs who very well may have been OZNA agents. Though Cosolo went undetected and returned to Sarajevo, police had somehow gotten word of his partner's return, attempting but failing to arrest him in his home. Cosolo, Amare... Sarajevo, 77-87. Gorizia Questura files indicate the police knew of many emigrants who had returned and departed the Monfalcone several times, often clandestinely, during the AMG period. At times, police explained such visits as personal in nature, but deep suspicion permeates the reports. See the cases of Renato F., Aldo G., and Alberto G. in, respectively, ASG, Questura 1948, b 5, f 700; b 6, f 840; b 12, f 1850.

${ }^{40}$ Lt. Col. Gardner, Trieste Area Commissioner (AMG), "Control of Morgan Line," 26 April 1947, NARA, RG331, UD1981, b 9211, f 11304/115/529.
} 
1947 when, prior to discounting the Greek thesis, TRUST attempted to root out and close rural expatriation points used by Old-Province emigrants. One of the first it discovered was an unguarded footbridge across the Isonzo at Volaria (Volarje), just southeast of Caporetto (Kobarid) and far enough away from the nearby American block post at Dolla (Dolje) to be crossed undetected under cover of darkness. When TRUST discovered this, it immediately increased military patrols. ${ }^{41}$ The Italian state simultaneously instituted patrols along the Italo-AMG border to prevent Italian citizens from even entering Zone A, mainly targeting the west bank of the Isonzo abutting the Monfalconese. ${ }^{42}$ The AMG and Italy also worked to break existing recruitment networks, arresting those responsible for guiding Old-Province Italians across the Volaria route and recruiting migrants from the south of Udine Province. ${ }^{43}$

Of course, all of these were merely half-measures, limited by legal restrictions and by the looming shift in the border, but this did not stop Italian security forces from looking forward. In mid-July, just weeks after Ferrari's critical report to De Gasperi and in anticipation of Italy's imminent return to Zone A, the Military Command of Udine issued internal border control guidelines for the first months after the transfer, during which the military was expected to play a key role in bordering efforts. The commanding general defined Monfalcone as one of the zone's critical "nuclei of philo-Slavic populations" and deemed the halting of clandestine eastward emigration as one of the force's high-priority concerns. Drawing upon notions of Communist "embedding" within wider population movements, the memo warned border forces that saboteurs

\footnotetext{
${ }^{41}$ TRUST, Intelligence Summary No. 3, June 1947, op. cit.

42 Direttore Capo Divisione SIS, “Arruolamento di volontari per paesi stranieri” (N. 224/56870), 3 July 1947, ACS, MI, DGPS, SIS, AA GG 1944-49, b 79, f OP52. See also TRUST, Intelligence Summary No. 4, 5 August 1947, op. cit.

${ }^{43}$ Unsigned [likely Questore Durante, Udine], Report to Prefetto di Udine, 13 May 1947, ASU, Pref, Gab, b 43, f 153, sf 1; Ferrari, "Emigrazione clandestina" (N. 441/06382), 1 July 1947, ACS, MI, Gab 1949, b 25, f 1550, sf 2; Prefetto Vittadini, "Udine e Provincia..." (N. 224/62R), 11 April 1947, op. cit.; Questore di Udine, "Arruolamento di volontari per paese stranieri” (N. 07911), 12 June 1947, ACS, MI, DGPS, SIS, AA GG 1944-49, b 79, f OP52.
} 
and guerrillas might appear "camouflaged" as workers or refugees attempting to enter the country. ${ }^{44}$ If Italy could only combat West-East migration in the margins before September 1947 , targeting the minority of emigrants who came from the Old Provinces, a clear framework was in place to interpret the movements taking place in Zone A and beyond.

\section{The Year 1948: Prefect Palamara, Repatriation, and the Election}

It was with "Transfer Day" that the thousands of expatriated monfalconesi became an Italian problem, and in late 1947 hundreds began banging on the door, demanding they be let back into a reconstituted Gorizia Province. The deep sense of vulnerability generated by economic, social, and political chaos in the province, felt by both native goriziani and the movers and shakers in Rome, affected responses to the Monfalconese emigration. Having long realized that Gorizia's situation would be delicate, Prime Minister De Gasperi had created the Office for the Border Zones (UZC) the year prior, tasking it with protecting the territorial integrity and cultural "Italianness" (italianità) of Italy’s borderlands. ${ }^{45}$ The UZC had almost immediately determined that Gorizia Province would require a prefect of "exceptional capabilities" to manage economic crisis, a large Slovenian minority, and the population of the Monfalconese, which, though "Italian in race, is largely philo-Slavic in sentiment." 46 To govern this tinderbox, the UZC and De Gasperi chose Giovanni Palamara, granting him a mandate to protect the border province from national and political threats at all costs. ${ }^{47}$

When Palamara arrived in Gorizia in September 1947, he immediately went to work

\footnotetext{
${ }^{44}$ Gen. di Div. Com. Cappa (Comando Militare-Udine), "Memoria 'S.F.O.”" (N. 18/OP/SP), 17 Jul 1947 , ASU, Questura, Massime, b 44, f 14.

${ }^{45}$ The UZC was not part of any ministry, but rather responsible directly to the prime minister. D'Amelio, Di Michele, and Mezzlira (eds.), La difesa dell'italianità.

${ }^{46}$ PCM-UZC, "Situazione del goriziano," 12 March 1947, op. cit.

${ }^{47}$ On Palamara and how he carried out his task in Gorizia, see the third part of Di Gianantonio et al., L'immaginario imprigionato.
} 
taming the "philo-Slavs," including those perceived as most threatening: repatriates from Yugoslavia. Though repatriations had been ongoing since mid-1947, the flow increased at the turn of 1948, creating major public security concerns. From the very beginning of Palamara's tenure, both he and his provincial security forces opposed repatriation en masse of expatriated "philoSlavs." They foresaw that mass repatriation would lead to violent encounters between "philoSlavic" repatriates and anti-Communist, nationalist residents such as the esuli. ${ }^{48}$ More critically, they feared the reconstitution of a strong far-left movement in the Monfalconese - one with radical goals and (suspected) conspiratorial methods. Italian consular offices in Zagreb and Belgrade reported a spike in repatriation requests, and the central carabinieri offices warned the Foreign Ministry that these former residents were "anti-Italian" in their "near-entirety." Echoing sentiments of local carabinieri, they asked that passports be denied because the applicants sought "to undertake actions in favor of the philo-Slavic elements residing in Italy and, if necessary, to provoke disorders and use violence to impose their ideas and achieve their ends." 49 The same was suspected of the many monfalconesi who simply ignored the passport issue and repatriated clandestinely over a still-porous Italo-Yugoslav border. ${ }^{50}$

Despite the security forces' strong and persistent opposition to the repatriation of "philoSlavs," the Italian consular offices in Yugoslavia ignored these warnings. Operating under the

\footnotetext{
${ }^{48}$ Fears of violent encounters between pro-Italians and pro-Yugoslavs drew on two years of precedents, discussed in chs 4-5, including the wave of violence that swept the Monfalconese in September 1947 on Transfer Day. For a proItalian perspective, see Segretario Altran (ANPI-Gorizia), "Relazione dei fatti avvenuti durante i festeggiamenti...," 18 September 1947, op. cit.

${ }^{49}$ Magg. Ruggieri (Carabinieri-USS), Untitled Segnalazione to Conte V. Zoppi (MAE-DGAP) and Appunto, 17 November 1947; MI-DGPS Div AA GG RR-III Sez., "Segnalazione" (N. 443/74838), 31 December 1947, both in ASDMAE, AP 1946-50, Jug, b 42, f 1. As an example of the carabinieri resistance, see ASG, Questura 1948, b 6, f 839.

${ }^{50}$ In cases where such emigrants had left the district before it returned to Italy and who clandestinely repatriated afterwards without being caught, they could often escape prosecution by claiming they had been traveling within Italy the whole time, the state having no proof to the contrary. This was the case with Silvano Cosolo. Cosolo, Amare... Sarajevo, 181-83.
} 
assumption that closely-monitored subversives at home were less dangerous than free-ranging subversives abroad - an assumption that, as will be seen, had been in place for some time - the Foreign Ministry facilitated repatriation of passport-less monfalconesi and other Italians expatriated to Yugoslavia since 1945, of which they estimated there were 10,000, including some 2400 working at the Fiume shipyard alone. ${ }^{51}$ By freely issuing one-way fogli di rimpatrio (repatriation passes) or, less commonly, short-duration regular passports, the Foreign Ministry sought to bring about what it called the definitive repatriation of Italians in Yugoslavia. ${ }^{52}$

As "philo-Slavic" repatriates flooded back into Gorizia Province both legally and clandestinely, Palamara and the carabinieri faced mounting security concerns, particularly as they looked forward to a historic moment in the life of the young Italian Republic: the first postwar election, scheduled for April 1948. In the months preceding the election, a widespread belief developed that the leftist Democratic Popular Front, headed by the PCI, had a good chance to win. This translated into a profound dread for anti-Communists. Given the imminence and stakes of the coming election, it is not surprising, then, that Palamara and the Italian security forces, whose confidence had been shaken further by unfolding Communist advances in Greece and Czechoslovakia, began to suspect the repatriation of monfalconesi to be not the result of hundreds of individual choices (as it largely was), but rather concerted Yugoslav and Soviet machinations

\footnotetext{
${ }^{51}$ Legazione d'Italia (Belgrado), "Lavoratori italiani in Jugoslavia" (Tel. N. 266/44), 4 September 1947, op. cit; Console Pinto, "Connazionali venuti in Jugoslavia senza passaporto ed emigrazione clandestina" (Tel. N. 79/21), 11 March 1948, op. cit.

52 The former were low-information documents allowing a single crossing into Italy and nothing more, provided mainly to would-be repatriates who were single or lacked corroborating identification. The latter were more detailed documents allowing back-and-forth movement in a fixed time frame, typically issued for very short windows of three to six months. The Italian authorities typically issued regular passports in cases where entire families needed to repatriate and identities could be confirmed by the Gorizia Questura. This process can be inferred by examining the Questura files for the year 1948 held at the ASG, but it was also laid out retrospectively by Consul Pinto in 1949. Console Pinto, "Rimpatri di elementi compromessi durante l'occupazione jugoslava del goriziano" (Tel. N. 4983/390), 17 March 1949, ASDMAE, AA PP 1946-50, Jug, b 72, f 2 Emigrazione clandestina in Jugoslavia.
} 
to sway this election. ${ }^{53}$ By mid-February, Palamara and provincial carabinieri forces warned their superiors that "philo-Slavic" repatriates, including women, returned in order "to undertake intense Slavo-Communist propaganda." ${ }^{, 5}$ Such suspicions were amplified by the fact that, in the case of many repatriates, Yugoslav authorities had made exceptions to state policies barring the granting of exit visas to foreign nationals who lacked passports from their home countries (into which category most monfalconesi fell). ${ }^{55}$

But beyond fears that Yugoslavia was orchestrating the return of voters and propagandists, Palamara feared he was witnessing the deployment of a highly-trained Communist paramilitary force nested within this wider repatriation wave, just as L'Ora d'Italia and state security forces had predicted a year prior. In early February, Palamara learned that eight young men from San Pier d'Isonzo had repatriated to their home town using various checkpoints. Carabinieri investigations had revealed, however, that all eight were pro-Yugoslavs who had been members of the town's GAP and who seemed to be operating under orders from Yugoslavia. ${ }^{56}$ Though the simultaneous return of this San Pier d'Isonzo GAP cell was a bit exceptional, as the carabinieri and police launched investigations into (often clandestine) repatriations, they realized that tens, if not hundreds of threatening individuals had returned in the first weeks of 1948. Among them were the twenty-one-year-old garibaldino, Otello L, who had sat on the Titoist district council in May 1945, and Rodolfo F., a twenty-six-year-old gappista from Staranzano known for his UAIS

\footnotetext{
${ }^{53}$ In Greece, the Communist insurgents had declared a Provisional Government in December. In Czechoslovakia, the Communist forces of Klement Gottwald, backed by the Soviets, were in the process of finalizing their consolidation of power with the February Coup. Agarossi and Zaslavsky, Stalin and Togliatti, 248-49, 258, 263-65.

${ }^{54}$ Prefetto Palamara, "Rimpatrio di connazionali" (N. 689/Gab), 14 February 1948, ASG, Pref. Gab. 1945-82, b 222, f 494, sf Rimpatrio di connazionali. On women, see carabinieri reports on Aladina V. and Angela M. Demichelis, "Persone rientrate dalla Jugoslavia" (N. 2/53), 16 Feb 1948; Demichelis, "Persone rientrate dalla Jugoslavia" (N. 44/1), $21 \mathrm{Feb}$ 1948, both in the same file.

${ }^{55}$ Legazione d'Italia (Belgrado), "Rimpatrio connazionali dalla Jugoslavia" (Tel. N. 116), 21 August 1947, ASDMAE, AP 1946-50, Jug, b 30, f 3.

${ }^{56}$ Magg. Com. del Gruppo Demichelis (Carabinieri-Gorizia), "Rimpatri di connazionali," (N. 2/41), 9 Feb 1948, ASG, Pref-Gab 1945-82, b 222, f 494, sf Rimpatrio di connazionali.
} 
activism and for having threatened pro-Italians. ${ }^{57}$ Such reports elicited an immediate increase in surveillance, Palamara ordering the carabinieri to "follow these repatriations closely" and to monitor carefully "the activity of the repatriates themselves." 58

This suspiciously-timed repatriation of numerous gappisti came on the heels of a flurry of news and events that seemed to confirm Palamara's fears, both of PCI plotting generally and of the specific role of repatriated emigrants in this plot. During the first weeks of January there were at least two instances in which representatives of the revolution-minded Milanese Federation of the PCI arrived in the Monfalconese to hold meetings with the province's partisan leaders, the second of which supposedly yielded the creation of seven-man, well-armed Communist squads to be held at the ready in anticipation of an "opportune moment." 59 Simultaneously, on 14 January, the leader of the district's clandestine pro-Italian paramilitary, Pietro Dominutti, was gunned down on the streets of Staranzano after the pro-Yugoslavs accused him of orchestrating a recent wave of terrorist attacks against the homes of Mario Fantini, the Barbo family, and others. One explanation for this murder, soon well-known not just to Palamara but also Ferrari and Interior Minister Mario Scelba, was that it was a settling of scores; just as likely, it could be read as an effort to decapitate the pro-Italian paramilitary in anticipation of the election. ${ }^{60}$

\footnotetext{
${ }^{57}$ See respectively ASG, Questura 1948, b 6, f 987; b 4, f 657. As two further examples, see the cases of Mario D. B., a twenty-year-old Monfalcone resident who had repatriated from Fiume in December 1947 and who was known for his aggressive pro-Yugoslav stance and his service in the Brigata Triestina and Intendenza Montes; and the gappista Giovanni C. of San Pier d'Isonzo, who throughout the AMG period had promised the "elimination" of antiTito neighbors upon the arrival of Tito's regime. He had repatriated clandestinely in January 1948, just weeks before his eight GAP comrades. ASG, Questura 1948, b 4, f 516; b 3, f 355.

${ }^{58}$ Prefetto Palamara, "Persone rientrate dalla Jugoslavia" (N. 760-Gab), 19 February 1948, ASG, Pref. Gab. 1945-82, b 222, f 494, sf Rimpatrio di connazionali.

${ }^{59}$ He quickly sent news to Ferrari and Interior Minister Scelba. Prefetto Palamara, "Riunione di elementi di sinistra in Ronchi dei Legionari” (N. 405-Gab), 29 January 1948; Magg. Com. del Gruppo Demichelis (Carabinieri-Gorizia), Report of 8 January 1948, both in ASG, Pref, Gab 1945-82, b 28, f 72, sf 1949.

60 The police immediately arrested Fantini, Ferruccio Barbo, Spartaco Romano, and other former garibaldini, supposedly for their own "protection." Subsequent investigations yielded no convictions. Questore Giuliano (Gorizia), "Situazione politica del Monfalconese e ripercussioni del delitto Dominiutti [sic]" (N. 02020 P.S.), 26 January 1948, ACS, MI, Gab 1948, b 61, f 13249.
} 
A final piece of information coloring Palamara's view of monfalconesi repatriation was a report detailing the interrogations of a man named Alfonso D. B., whom Gorizian frontier police had arrested for attempting clandestine repatriation. Under interrogation, Alfonso admitted to having emigrated clandestinely to Yugoslavia for work, claiming that Yugoslav forces had arrested him, sent him to a concentration camp, and forcibly repatriated him due to his hesitancy to embrace Communism. While at the camp, Alfonso and other Italian internees, of which there were many, had been approached by PCI agents seeking volunteers for various paramilitary forces. Among these were a brigade destined for Greece, and also multiple units that, aided by 30,000-40,000 heavily armed Yugoslav soldiers amassed at Vipacco (Vipava), which would serve as the spearhead of a Yugoslav invasion of Italy if the Communists lost the election. Grimly, Alfonso concluded his testimony with an assertion that "the purpose of the invasion is not solely the conquest of Trieste and of Gorizia, but of all of Italy." 61

By mid-February, Palamara felt compelled to warn his superiors of the grave danger posed to Italy by a combination of foreign and domestic Communist enemies. He passed on Alfonso D. B.'s testimony and, in a critical top-secret report to Ferrari, he signaled the existence of a thousand-strong "Slavo-Communist" paramilitary apparatus in Gorizia, formed of ex-garibaldini and decommissioned Titoist soldiers who during the AMG period had proven themselves committed to Yugoslav annexation. ${ }^{62}$ The latter report identified Monfalcone, Ronchi, Cormons, and Gradisca as the primary bases of this paramilitary, presenting it as an heir to the "Natisone" Division, but reorganized into self-contained, isolated cells. The unit possessed "light and heavy

\footnotetext{
${ }^{61}$ The veracity of this testimony might be doubted given the oddly specific claimes about troop placement. Alfonso D. B., "Dichiarazione," 17 February 1948, ASG, Questura 1948, b 4, f 517.

${ }^{62}$ Prefetto Palamara had forwarded the Alfonso D. B. testimony to the Interior Ministry, which then forwarded it to the Foreign Ministry and Army General Staff. See the Foreign Ministry's copy in ASDMAE, AP 1946-50, Jug, b 32, f 2 .
} 
machine guns, assault rifles, submachine guns, and a good supply of ammunition and hand grenades," hidden in the hills along the Italo-Yugoslav border. Heading the cells of Monfalcone and Ronchi were said to be Mario Fantini and Vinicio Fontanot, while the entire paramilitary, part of a wider Communist military zone in Friuli and Venezia Giulia, came under the command of Lino Zocchi and his lieutenant, Mario Lizzero. Zocchi specifically captured Palamara's attention. The prefect indicated that Zocchi "spoke Italian with a foreign accent" and that, between his time as ANPI and PCI secretary in Udine and his current secretaryship in Gorizia, this capable guerrilla commander had been assigned "special duties" in Trieste. ${ }^{63}$ By referencing Zocchi and his special duties, Palamara did more than just sound the alarm on the paramilitary's ties to a foreign power. He also connected the paramilitary to the longstanding phenomenon of West-East emigration, as Zocchi had long been labelled the chief architect of those clandestine emigration rings by which the Communist Party covered its efforts to prepare a guerrilla army. ${ }^{64}$

In the final two months before the election, renewed fears of a Communist invasioninsurrection, reinforced by Palamara's reporting, drove forward what Elena Agarossi and Victor Zaslavsky have termed a "Italy's drift toward civil war." ${ }^{65}$ Such reporting began to have an impact at the central levels of state, eliciting the direct involvement of Interior Minister Scelba. In March, as election day approached, Scelba, who in his capacity as a member of the DC's Executive Committee had played a key role in pushing the DC to create its own "defensive" paramilitary, enquired as to the concrete actions that Police Chief Ferrari had undertaken to dismantle the APG

\footnotetext{
${ }^{63}$ Prefetto Palamara, "Segnalazione" (N. 736 Gab), 18 February 1948, ACS, MI, Gab 1948, b 66, f 13442. The DGPS had heard vague rumors of this apparatus in August 1947 and Palamara's report confirmed their suspicions. MI-DGPS, Div SIS, "Gorizia: situazione politica" (N. 224/58999) and Attached Appunti, 8 August 1947, ACS, MI, DGPS, Div SIS, b 86, f QP29 Gorizia.

${ }^{64}$ Zocchi had been accused of such activity in the original L'Ora d'Italia article of March 1947, whereas Lizzero was implicated in January 1948 following investigations into another clandestine expatriate. ASG, Questura 1948, b 4, f 615.

${ }^{65}$ Agarossi and Zaslavsky, Stalin and Togliatti, 246.
} 
organization and seize its weapons. ${ }^{66}$ Rather than receiving positive news, Scelba learned that the situation had grown worse. In the interim, the prominent Milanese Communist Giancarlo Pajetta, known for having led the temporary occupation of Milan's prefectural headquarters in 1947 when Scelba sacked the partisan-prefect Ettore Troilo in favor of a strongly anti-Communist candidate, had stopped in Gorizia on a return trip from Belgrade. There he had met with key Gorizian Communists, including monfalconesi, supposedly ordering the creation of five more PCI assault brigades, which would aid "a Communist seizure of power should the elections turn out unfavorable to the Popular Front," particularly by eliminating policemen. ${ }^{67}$

The possibility of civil war was certainly on Scelba's mind, and less than two weeks later - three days before the election - he circulated the famed (but likely apocryphal) "Plan K" document to each of the republic's prefects, carabinieri commanders, and police commissioners. Purported to be a blueprint of PCI plans to seize power in the case of Popular Front defeat, it detailed PCI plans to announce a Popular Front victory, accuse De Gasperi of falsifying the results, and seize power through a combination of sabotage, mass protest, and partisan actions. ${ }^{68}$ Though the document did not explicitly mention Gorizia Province (nor any other), nor repatriated monfalconesi, it is easy to see how the latter could be understood to fit within the scheme. Since March 1947, Monfalcone had been viewed as the ingress point for Communist agitation in Italy, and Palamara's reporting from this vulnerable periphery only reinforced the idea in the months before the election. It propelled Italy's polarization and its drift toward civil war. As Italians sat

\footnotetext{
${ }^{66}$ Capo di Gabinetto Broise (MI), "GORIZIA = Organizzazione filo-slavo A.P.G.” (N. 15265/13442), 26 March 1948, ACS, MI, Gab 1948, b 66, f 13442. According to the meeting minutes of the DC Executive from 3-4 December 1947, all members of the Executive accepted the necessity of the DC to form a defensive paramilitary. Agarossi and Zaslavsky, Stalin and Togliatti, 247-48.

${ }^{67}$ These units, including one in Monfalcone, were supposedly armed with "mortars, heavy and light machineguns, submachine guns, rifles, grenades," and large quantities of explosives. Prefetto Palamara, "Costituzione di brigate d'assalto del P.C.I. nel Goriziano" (N. 1242-Gab Segretissima), 2 April 1948, ASG. Pref, Gab 1945-82, b 28, f 72, sf 1952.

${ }^{68}$ Agarossi and Zaslavsky, Stalin and Togliatti, 265-67.
} 
anxiously awaiting news of the results from 18 April, many also oiled their guns, preparing to defend their faction's expected victory in the case of the opposition's treachery.

\section{After the Election: Combatting "Fuoruscitismo" and Constructing the Iron Curtain}

When the results finally came in, they showed that the DC had scored unexpectedly large victories both nationally and in Gorizia Province - and, to the surprise of many, the guns proved unnecessary, with the PCI honoring the outcome. The Communist paramilitaries of Gorizia and Udine did not rise up in concert with a Yugoslav invasion, nor did the PCI on a national scale implement any variant of Plan K, though fear of such action had certainly pushed many voters into the arms of the DC and solidified its parliamentary majority. ${ }^{69}$ Nevertheless, Palamara remained on edge, particularly as rumors circulated that many monfalconesi, including many repatriates, were discussing the possibility of "return[ing] to the mountains." 70 The experience of managing the public order crisis in the months before the election had left him deeply suspicious of repatriated monfalconesi and those still abroad. Thus, when there was a renewed wave of clandestine emigrations from Gorizia Province in the wake of the Popular Front defeat, Palamara repeated the well-worn ideas that such emigrants - or at least some of them - emigrated to engage in activity directly threatening to Italy's security. ${ }^{71}$

\footnotetext{
${ }^{69}$ In Udine, where rumors of Communist conspiracies combined with the proximity of the border to create a "state of fear" among the population, police believed that fear allowed the DC to garner votes from many "who are not even fervid believers, but who are decidedly hostile to Italian Communism." As a result, the DC gained an absolute majority of votes in the province. Unsigned [likely Questore Durante], Reports to Prefetto di Udine, 15 February 1948 and 4 May 1948, ASU, Pref, Gab, b 43, f 153, sf 1.

${ }^{70}$ Magg. Com. del Gruppo Demichelis (Carabinieri-Gorizia), “Attività del P.C.I." (N. 42/34), 27 April 1948, ASG, Pref. Gab. 1945-82, b 28, f 72, sf 1949. The security forces generally thought that any meeting of garibaldini held in late April (of which there were many) was an indication of the PCI putting Plan K into action, and they obsessed accordingly. Demichelis, "Formazioni paramilitari” (N. 42/22), 20 April 1948, ASG, Pref. Gab. 1945-82, b 28, f 72, sf 1952; Prefetto Palamara, "Attività del P.C." (N. 1681/Gab), 26 April 1948, ASG, Pref. Gab. 1945-82, b 28, f 72, sf 1949. Scelba too continued to enquire about the actions against the APG paramilitary. MI-DGPS, Div AA GG RR (Pel Ministro), "Gorizia - Organizzazione filo-slava A.P.G." (N. 442/12122), 7 June 1948, ASG, Pref. Gab. 1945-82, b 229, f 504.

${ }^{71}$ Prefetto Palamara, "Espatrio clandestino lungo la frontiera Italo-Jugoslava" (N. 2570/Gab), 20 May 1948, ASG, Pref. Gab. 1945-82, b 222, f 494, sf Emigrazioni clandestini; Palamara, "Espatrio clandestino lungo la frontiera ItaloJugoslava" (N. 02570/Gab/P.S.), 26 June 1948, ACS, MI, Gab 1949, b 25, f 1550, sf 2. When much of Italy (but not
} 
Alongside this recent expatriation wave, however, was a new and equally problematic wave of monfalconesi heading the opposite direction, returning home in the wake of the Cominform Resolution of late June 1948. In fact, as UDBA initiated its first wave of repression against "Cominformists" in Yugoslavia that fall, what had been a moderate stream of repatriation requests became a deluge. For Italian (and American) policymakers, who for some time remained uncertain whether the Tito-Stalin Split was genuine or merely a ruse meant to lower the guard of the anti-Communist camp, such individuals remained the object of deep suspicion. Thus, the Italian state decided that, even with the election threat passed, the further stabilization of the democratic-capitalist order required a definitive resolution of the problem of movement across its eastern border. Claims that Yugoslavia served as a staging-ground for Italian expatriates to prepare for Communist actions in Italy had never been definitively proven or disproven, and with such high stakes, uncertainty could not be tolerated. As the combined efforts of the Interior and Foreign Ministries were brought to bear on this problem in mid-1948, it soon became clear that such a resolution would require not just the prevention of further clandestine emigration, but also an increasingly coordinated effort to deal with those already abroad.

It was the latter of these questions that the state addressed first, as it was the issue that generated the greatest tensions, particularly as ministerial forces sought to balance the security needs of Gorizia with those of Italy generally. This had been a concern regarding the monfalconesi ever since Gorizia Province returned to Italy in 1947. As with the pre-election period, various members of the public security apparatus and broad nationalist swaths of society continued to push back against repatriation. Palamara himself, at the same time that he built up fears of their

Gorizia Province) experienced major upheavals following the failed assassination of Palmiro Togliatti in mid-July, Palamara claimed that it was individuals like those trained at Abbazia who had fomented the disorder. Palamara, "Espatri clandestini lungo la frontiera Italo-Jugoslava" (N. 02570/Gab/P.S.), 27 July 1948, in the same. 
subversive activities in Yugoslavia, argued against allowing them to repatriate to the borderlands, instead suggesting that they might be resettled in the country's interior. ${ }^{72}$ But this did not stop the Foreign Ministry, which forged ahead with repatriation. In July, under continual pressure to disallow the return of "philo-Slavs," Vittorio Zoppi, head of the Foreign Ministry's Political Office, informed consular offices in Yugoslavia that, after careful consideration, the ministry had decided that "the denial of the passport, even limited to cases of especially undoubtable gravity, would end up creating an exile-ism [fuoruscitismo] that it is in our interests to avoid, above all in such a delicate frontier zone." Thus, the consular offices should "abstain from any discrimination in the granting of passports and continue to report immediately the individual names [of those granted documents] to the relevant Questure and to the Interior Ministry."73 With this cable, Zoppi reaffirmed the state's year-old approach to the clandestine expatriate community in Yugoslavia, articulating this policy clearly for the first time as a fight against fuoruscitismo.

The term used by Zoppi - "fuoruscitismo" - was a familiar one to career bureaucrats within the Foreign and Interior Ministries. Though the term derives from "fuoruscito," or "exile," the Fascist-era security apparatus had used this same term to describe the formation of combative

\footnotetext{
${ }^{72}$ The justifications were the same as before the election: fear of social antagonism, violent encounters, and political subversion. To a degree, Palamara was proven right in his fear of the effects of repatriation on local society. In early 1949 , he received various demands from esuli and nationalist groups that ranged from banning repatriates from being able to settle in their home province upon their return to the creation of "a special Concentration Camp where all the undesirables [indesiderabili] should be sent." Though Palamara and the Foreign Ministry were amenable to the first of these suggestions, seeing it as a way to balance otherwise irreconcilable security concerns, the Interior Ministry informed them that there was no legal basis for the Italian state to compel these Italian citizens to settle elsewhere. Prefetto Palamara, "Situazione dell'ordine pubblico in relazione a rimpatri di elementi filo-jugoslavi" (N. 350/Gab), 3 February 1949, AGPCM, Fondo UZC, Sez II Yugoslavia, b 6.2, f 113.D. The reference to the creation of a concentration camp can be found in Palamara, "Situazione dell'ordine pubblico in relazione a rimpatri di elementi filo-jugoslavi" (N. 350/Gab), 7 February 1949, in the same. On Palamara's wider views and actions, see Di Gianantonio, "Politiche e sociali e questione nazionale," in Il mosaico giuliano, eds. Altieri and Puppini, op. cit., 2341. On resettlement, see MAE, DGAP, IV Ufficio, "Passaporti connazionali emigrati clandestinamente in Jugoslavia" (Tel N. 15/05600/C), 24 March 1949, ASDMAE, AA PP 1946-50, Jug, b 72, f 2 Emigrazione clandestina in Jugoslavia; MI, DGPS, Div AA GG RR, "Passaporti connazionali emigrati clandestinamente in Jugoslavia" (N. 442/8036), 29 March 1949, AGPCM, Fondo UZC, Sez II Yugoslavia, b 6.2, f 113.D.

${ }^{73}$ MAE-DGAP, IV Uff., "Passaporti” (N. 21762/C), 12 July 1948, ASDMAE, AP 1946-50, Jug, b 47, f 5. Italics added.
} 
anti-Fascist communities abroad. In a sense, then, "exile-ism" does not capture the entire meaning of fuoruscitismo, which connotes continuing subversive political activities targeted at the homeland. During the Fascist era, OVRA and various other Fascist security forces had been deeply troubled by the subversive potential of Italian exiles in France. Such forces rightly identified groups like Carlo Rosselli’s Justice and Liberty (Giustizia e Libertà) as a threat, which proved prescient when GL transformed into the Resistance-era Action Party (Partito d'Azione). ${ }^{74}$ More closely related to this study, many Socialist and Communist monfalconesi had fled from the regime in the 1920s and joined the community of fuorusciti in France, often later fighting in the Spanish Civil War or Italian Resistance and were some of these even among the postwar expatriates to Yugoslavia. ${ }^{75}$ In Zoppi's order, then, there was a certain continuity of language with the Fascist regime, but also a continuity of a logic of control: political enemies should be kept in the country so much as possible where they can be denied a free range of activity. ${ }^{76}$ Even if unarticulated, this had been the state's policy toward expatriates in Yugoslavia before Zoppi's order and would remain so thereafter, despite the rapid deterioration of Soviet-Yugoslav relations, which made Yugoslavia a less threatening haven for fuorusciti. Throughout 1949, the Foreign Ministry repeatedly reaffirmed this policy, indicating that the value gained from repatriation outweighed any problems former fuorusciti might cause upon return. ${ }^{77}$

\footnotetext{
${ }^{74}$ Stanislao Pugliese, Carlo Rosselli: Socialist Heretic and Antifascist Exile (Cambridge, MA: Harvard University Press, 1999); Mario Giovana, Giustizia e Libertà in Italia: Storia di una cospirazione antifascista 1929-1937 (Turin: Bollati Boringhieri, 2005).

${ }_{76}^{75}$ Puppini, "Quel viaggio dall'Isonzo all'Ebro."

${ }^{76}$ The Fascists also used the term "abusive emigration" and combatted it similarly. This strategy stood in marked contrast to that adopted by the Soviet Union to deal with the much larger communities of Russian and other émigrés abroad in the 1920s. In that case, the USSR revoked émigré travel documents, making them de facto stateless individuals and stranding them abroad. Torpey, The Invention of the Passport, 124-25. The Italian approach was also significantly different than that taken by the United States' diplomatic forces regarding the American workers stranded in the USSR in the 1930s. Under very different security conditions, the American services paid little heed to the "captive Americans" in the USSR. Tzouliadis, The Forsaken, 61-64, 105-06.

${ }^{77}$ Console Pinto, "Rimpatri di elementi compromessi durante l'occupazione jugoslava del goriziano" (Tel. N. 4983/390), 17 March 1949, op. cit.
} 
Yet the preference to have monfalconesi expatriates back on the western side of the Iron Curtain did not equate to comfort with these individuals being in the country, even after the Cominform Resolution. Most were still Communists and loyalty to Stalin had helped put many at odds with Tito's regime. Moreover, the difficulties of balancing the provincial security needs of Gorizia with those of Italy nationally generated significant tension between ministerial offices. To overcome contradictory interests, Italy developed a rigorous surveillance regime to track suspect citizens in the latter half of 1948, the first line of defense being a set of standardized repatriation practices involving both Italy's police and its consular offices. In May, even before the Cominform Resolution, the Foreign Ministry ordered its consular offices in Zagreb and Belgrade to exercise "greater cautions in the issuance of documents to Italian citizens who would present themselves [for repatriation] without a regular passport." ${ }^{\prime 78}$ Here the term "documents" refers specifically to the low-detail repatriation sheets (fogli di rimpatrio), which had, in the past, often been issued to expatriates lacking other identification. Instead, the ministry now favored the use of more detailed short-term regular passports, which the consular services issued only after the police or carabinieri in an expatriate's hometown had confirmed certain details about him or her (such as address, birthdate, and paternity). This measure, which combined with the subsequent consular norms of granting such passports in a slow and steady trickle and providing police with weekly lists of passports issued, facilitated the tracking of even the most unexceptional of repatriates such as Mario R., discussed in this chapter's introduction. ${ }^{79}$ Each and every repatriate was (theoretically) subjected to weeks of surveillance upon return, those deemed exceptional often

\footnotetext{
${ }^{78}$ MAE, DGAP, IV Ufficio, "Emigrazione clandestina - frontiera italo-jugoslava (Tel. N. 15/15977), 22 May 1948, ASG, Pref. Gab. 1945-82, b 222, f 494, sf Emigrazioni clandestini.

${ }^{79}$ The subsequent measures were developed in May of 1949, when Prefect Palamara, Consul Pinto, and the Questore of Gorizia met at Gorizia in the final of the important meetings regarding this policy. Pinto, "Elementi filoslavi di Gorizia" (Tel. N. 9101/782), 21 May 1949, ASDMAE, AA PP 1946-50, Jug, b 72, f 2 Emigrazione clandestina in Jugoslavia.
} 
given the police designation "Category Z" (threats to the state), which in many cases resulted in well over a decade of surveillance. ${ }^{80}$

Yet the assurance that expatriates returned in an ordered and manageable fashion was just one side of the coin in the fight against fuoruscitismo. The other was the prevention of additional clandestine crossings that might bolster this potentially subversive community-in-exile. And so the Italian state, with Palamara at the helm, began to take steps to construct an impermeable Iron Curtain along its eastern border, the primary purpose of which, somewhat counterintuitively, was not to prevent infiltration (immigration) from the Communist East. ${ }^{81}$ Rather, just as East Germany constructed the Berlin Wall in 1961 as a barrier to emigration, so too Italy began turning a metaphorical dividing line into a real bordering system with the aim of keeping people in.

\footnotetext{
${ }^{80}$ Short-term surveillance can be seen in ASG, Questura 1948. Palamara confirmed this was standard practice when he reported in January 1949 that "all those who repatriate from Yugoslavia are subjected to close surveillance on the part of the Police organs." Prefetto Palamara, "Provincia di Gorizia - Ordine pubblico" (N. 99/083), 27 January 1949, AGPCM, Fondo UZC, Sez II Gorizia, b 3.1, f 1. On longer-term serveillance, see ACS, MI, DGPS, AA RR, Ctg Perm, $\mathrm{Ctg} \mathrm{Z}$.

${ }^{81}$ This is not to say that clandestine East-West crossings were not a concern to Palamara or the state. In fact, after assuming office, Palamara would attempt to address state concerns over clandestine immigration, primarily combatting (1) border-crossings into Gorizia City of individuals living in the nearby now-Slovenian countryside, these often trying to exploit the Italian rationing system, for which they were often still registered; and (2) the influx of various "white Slovenes" and other political refugees from Tito's regime. However, Palamara's responses to these problems did not involve sustained efforts to strengthen the border. In response to economically-motivated crossings, he rearranged the police and carabinieri deployments in the Gorizia City and urged SEPRAL to be careful in its issuance of ration cards. Regarding political refugees, he demonstrated relatively little urgency in trying to screen them before entry into Italy, instead pursuing assurances that they would be resettled into the interior of Italy away from volatile Gorizia. In neither case, despite initial UZC proposals to this end, were there sustained efforts to improve state control over the large stretches of porous border that consist of unwieldy forested hills and mountains. Prefetto Palamara, "Intensificazione servizio vigilanza confine..." (N. 1100/Gab), 7 October 1947, ASG, Pref. Gab. 1945-82, b 22, f 494, sf Vigilanza frontiera; Capo della Polizia (SIS), "Notizie dalla zona di frontiera Italo-Jugoslava) (N. 224/64503), 22 December 1947, ACS, MI, Gab 1947, b 48, f 2849; MAE, DGAP, IV Ufficio, "Immigrazione clandestina dalla Jugoslavia" (Tel. N. 15/66), 11 April 1949, AGPCM, Fondo UZC, Sez II Yugoslavia, b 6.2, f 115; Prefetto Palamara, "Carte annonarie intestate a persone passate in territorio jugoslavo..." (N. 1138/Gab), 1 April 1948, ASG, Pref. Gab. 1945-82, b 222, f 494, sf Emigrazione - Espatri - Rimpatri - Sconfinamenti 1947-48; Palamara, "Disordini nella RFPJ (N. 03884), 18 March 1949, AGPCM, Fondo UZC, Sez II Yugoslavia, b 6.2, f 115. At times, other officials demonstrated concern about potential military thraeats posed by easy Yugoslav penetration of Italian national territory. In August 1948, the commissar of the Gorizia Frontier Police suggested that bordering ought not only seek to achieve "the stoppage and arrest of the Italian who believes to be going to the Yugoslav 'paradise,' or of the Slav fleeing that "hell," ' but that surveillance was also essential "from a military perspective." Comm. Agg. di PS Santamaria (Polizia di Frontiera-Gorizia), "Servizi di vigilanza in frontiera" (N. 612/4), 21 August 1948, ASG, Pref. Gab. 1945-82, b 267, f 601, sf 1949.
} 
Though an integral component of the fight against fuoruscitismo, the implementation of a more rigorous border regime required an immediate catalyst, which came in spring 1948 in the form of reports that clandestine emigration to Yugoslavia was again on the rise. In May, the Gorizia carabinieri signaled a resurgence of clandestine emigration among friulani and other Italians, with crossings taking place at San Floriano to the north of Gorizia. The commandant reported that tens of workers had already emigrated, with hundreds more lingering in San Floriano and nearby towns awaiting the assistance of the guide Bruno G., the former director of the local UAIS and the town's current PCI head. Moreover, he stated unambiguously that this was "a vast organization directed, without doubt, by exponents of the PCI" and primarily seeking to expatriate Communist cardholders. Though he indicated that the primary motivation was seemingly finding employment, he also specified that each was outfitted with a giant military backpack filled with food and clothing effects. ${ }^{82}$ Palamara responded by forwarding the report to the UZC and the Interior and Foreign Ministries, stressing the necessity of "energetic measures to cut such clandestine activity off at the root," which he followed two weeks later with assertions that there was not sufficient evidence "to exclude that the organization, mainly organized for the ends of labor, could also serve the purpose... of the formation of guerrilla brigades for possible future use in Greece and within the National territory [Italy]." 83 With Palamara having re-sparked discussions of the "Greek thesis," Scelba's Interior Ministry enquired further about the potential of Yugoslavia forming guerrilla units from labor emigrants, though Palamara had no concrete

\footnotetext{
82 Magg. Com. del Gruppo Demichelis (Carabinieri-Gorizia), "Rapporto speciale n. 40: Attività emigratoria clandestina lungo la frontiera italo-jugoslava" (N. 3/42), 4 May 1948, AGPCM, Fondo UZC, Sez II Yugoslavia, b 6.2, f 89 .

${ }^{83}$ Palamara's comments are pinned to ibid. Carabinieri intelligence forwarded the report to De Gasperi, the Army General Staff, and the Ministers of Defense, Interior, and Foreign Affairs. Col. Capo Sacchi (Carabinieri-USS), "Attività emigratoria clandestina lungo la frontiera italo jugoslava" (N. 521/2), 10 May 1948, ASDMAE, AP 194650, Jug, b 47, f 5. On the reiterated Greek thesis, see Prefetto Palamara, "Espatrio clandestino lungo la frontiera ItaloJugoslava (N. 2570/Gab), 20 May 1948, op. cit.
} 
evidence. ${ }^{84}$ Even after the carabinieri informed Palamara that the Greek thesis was "completely baseless," he insisted that this did not discount the possibility of Yugoslavia serving as a trainingground and marshalling-ground for later efforts to spearhead a takeover of Italy. ${ }^{85}$

With these fears in mind, Palamara took the initiative to shore up the border. He directed the Gorizia carabinieri to "stamp out this clandestine activity" through an "intensification of services" at the San Floriano crossing-points, by which he probably meant a reallocation of existing manpower to more strongly target that area. ${ }^{86}$ However, manpower was scarce, and this was little more than a stopgap measure like those introduced by the AMG in $1947 \cdot{ }^{87}$ In the face of increased patrols around San Floriano, would-be emigrants simply adjusted their route, crossing the border further north, near Caporetto. In July, Palamara ordered a redeployment of border forces there, but such measures again proved ineffective. ${ }^{88}$

Palamara's individual initiatives were salvaged, however, following the increased interest in the problem in Rome, and particularly the intervention of Undersecretary of State Giulio Andreotti, De Gasperi's right-hand-man. In May, Andreotti enquired with Prefect Vittadini (Udine) and Police Chief Ferrari as to what concrete measures might be implemented in concert with Palamara to put a stop to such emigration. ${ }^{89}$ Though Vittadini personally thought the Greek

\footnotetext{
${ }^{84}$ Prefetto Palamara, "Emigrazione clandestina di lavoratori italiani al confine orientale" (N. 2252/3-Gab), 23 June 1948, ASG, Pref. Gab. 1945-1982, b 222, f 494, sf Emigrazioni clandestini.

${ }^{85}$ Ten. Col. Com. Grimaldi (Carabinieri-Gorizia), "Segnalazione” (N. 15/8), 5 July 1948, ASG, Pref. Gab. 1945-1982, b 222, f 494, sf Emigrazioni clandestini; Prefetto Palamara, "Espatri clandestini lungo la frontiera Italo-Jugoslava" (N. 02570/Gab/P.S.), 27 July 1948, op. cit.

${ }^{86}$ Prefetto Palamara, "Attività emigratoria clandestina lungo la frontiera italo-jugoslava," 7 May 1948, ASG, Pref. Gab. 1945-1982, b 222, f 494, sf Emigrazioni clandestini.

${ }^{87}$ The Gorizia Sector of the Frontier Police, one of three sectors (along with Cormons and Monfalcone Sectors) responsible for patrolling Gorizia Province's frontier with Yugoslavia, had initially been allocated just 60 policemen, one Jeep, two motorcycles, and ten bikes for bordering services. Even with some carabinieri and finanzieri assistance, this was entirely insufficient. Isp. Gen. di PS Salvatore, "Frontiera Italo-Iugoslava," 3 May 1947, ASU, Questura, Massime, b 44, f 14.

${ }^{88}$ Prefetto Palamara, "Emigrazione clandestina di lavoratori italiani al confine orientale" (N. 2252/GAB), 20 July 1948, ASG, Pref. Gab. 1945-1982, b 222, f 494, sf Emigrazioni clandestini.

${ }^{89}$ Sottosegretario di Stato Andreotti, "Attività emigratoria clandestina lungo la frontiera italo-jugoslava" (N. 200/3097), 13 May 1948, AGPCM, Fondo UZC, Sez II Yugoslavia, b 6.2, f 89.
} 
thesis was baseless and the emigration not as threatening as Palamara claimed, he responded with a two-pronged plan that would become the basis of the Italy's bordering efforts along the ItaloYugoslav border. First, there would be the reinforcement of the block post network, targeting known problem areas. Second, he would oversee the implementation of police and carabinieri patrols along roads leading to the border to halt would-be expatriates upon approach, which bordering officials such as Inspector Bicchi of the Fourth Zone of the Frontier Police recognized as the weak point in the current anti-emigratory system. ${ }^{90}$

Throughout the second half of 1948, then, Italian officials - especially Palamara and Bicchi - worked to put these and other measures into practice. The two repeatedly requested additional men, police dogs, and Jeeps from the Interior Ministry. ${ }^{91}$ More importantly, in late 1948 they suggested the deployment of various immobile bordering tools, particularly in the problem areas along the Isonzo to the north of Gorizia city, which, due to the hilly terrain and dense foliage, were a preferred location for clandestine crossing (Figures 19 and 20). In fact, already by June the two had begun pushing for the creation of an extensive barrier network (rete di sbarramento) along that section of the Isonzo. Though military authorities were wary of devoting significant resources to a permanent barrier at that time and thus refused - ongoing Italo-Yugoslav negotiations cast doubt upon the finality of the border - the two received support for a system of floodlights to illuminate the river at night, as well as for the extensive use of barbed wire netting. ${ }^{92}$

\footnotetext{
${ }^{90}$ Prefetto Vittadini, "Espatri clandestine lungo la frontiera Italo-Jugoslava" (N. 08039-Gab), 3 June 1948, AGPCM, Fondo UZC, Sez II Yugoslavia, b 6.2, f 89; Insp. Bicchi, "Dislocazione delle forze operanti in frontiera" (N. 743/4), 19 Jul 1948, ASU, Questura, Massime, b 44, f 14. The two-tiered approach appears to have originated during a meeting between Questore Durante and the MI's Inspector General of Public Security Barletta, who in December 1946 made such proposals for Udine Province's eastern border, though implementation lagged behind planning. Questore Durante, "Udine - Servizi di frontierra (N. 023490-Gab), 6 Dec 1946, ASU, Questura, Massime, b 16, f 5.

${ }^{91}$ Insp. Bicchi, "Tratto di confine fra Merna-Rupa Dosso Giulio" (N. 612/4); Prefetto Palamara, "Servizi di frontniera - Deficenza persoanle" (N. 4217/Gab), 10 December 1948, both in ASG, Pref. Gab. 1945-82, b 267, f 601, sf 1949.

${ }^{92}$ On the barrier, see Prefetto Palamara, "Vigilanza forntiera fra Ponte Peuma e Salcano" (N. 2303/Gab), 14 June 1948; Insp. Bicchi, "Sbarrametno con rete del corso dell'Isonzo" (N. 2553/4), 13 September 1948, both in ASG, Pref. Gab. 1945-82, b 267, f 601, sf 1949. On the floodlight system, see Palamara, "Impianto proiettori per vigilanza del
} 
Their regular requests for funds to construct a network of sentry boxes (garitte), particularly at minor crossing points, seems to have met with less favor. ${ }^{93}$

If Palamara's and Bicchi's attempts to secure immobile resources for their border forces yielded only mixed results, the situation regarding personnel and mobile resources was much more successful. To demonstrate the fruits of their labor it is necessary only to examine the state of the Cormons Sector in April 1949, which was responsible for the portion of the border between the Casa Noris (just outside of Gorizia along the Isonzo) and Mernicco (to the northwest of Cormons near where Udine and Gorizia Provinces meet). In that month, Bicchi reported that this twentykilometer stretch now had regular block posts staffed by 10 brigades of the Guardia di Finanza, not to mention two stations each of carabinieri and regular police. Supplementing the "frontline" (prima linea) forces were also six carabinieri stations in the hinter-areas, in "direct contact with the front line" and tasked with patrolling roads leading up to the border. The border regime in place, then, was three kilometers deep and twenty long, occupying the full-time attention of 230 men from various bordering services at a ratio of one man per 285 feet of border. Despite the vastness of the resources dedicated to this endeavor, Bicchi indicated that the existing bordering regime was still insufficient, mainly because of the terrain and the lack of coordination between the three groups tasked with bordering (carabinieri, Guardia di Finanza, and regular police). Due to poor coordination, there were major gaps in patrols, which could only be fixed with "a unity of command" or the construction of a metal fence (rete metallica) along the section. ${ }^{94}$

confine sull'Isonzo" (N. 3104/5-Gab), 24 November 1948; Palamara, "Vigilanza confine dell'Isonzo" (N. 36/2-Gab), 28 March 1949, in the same. Silvano Cosolo recounts that he was caught off-guard by Italy's use of barbed wire when he repatriated in July 1948. Amare... Sarajevo, 168-78

${ }^{93}$ Prefetto Palamara, "Garitte per vedette lungo il confine" (N. 3755/Gab), 26 October 1948; Insp. Bicchi, "Garitte per la vigilanza alla Frontiera" (N. 64/4), 3 March 1949, both in ASG, Pref. Gab. 1945-82, b 267, f 601, sf 1949.

${ }^{94}$ Insp. Bicchi, "Sconfinamenti” (N. 681/4), 19 April 1949, ASG, Pref. Gab. 1945-82, b 222, f 494, sf Emigrazioni Espatri... 1949. The poor coordination of the border services had long been viewed as a problem. Mag. Com. Pagliaro (Guardia di Finanza-Gorizia), "Punti di riunione in zona di frontiera" (N. 9581/2), 29 October 1948, ASG, Pref. Gab. 1945-82, b 267, f 601, sf 1949. 
The state of the border regime at Cormons was not typical of the rest of the border - at least not at the time of the report - although throughout the remainder of 1949 Palamara would push to extend this system to the entire border. In May, Palamara again informed the Interior Ministry that he had insufficient men to guarantee a "continuity" of service along the entire frontier, with the result that he had to rely on paltry "sweeping services" in certain stretches. ${ }^{95}$ The Ministry, now dedicated to stamping out all clandestine emigration, ordered Prefects Palamara and Carnevali (who had replaced Vittadini at Udine) to continue developing their "coordinated plan of services of repression and surveillance," which soon resulted in a drastic extension of the rigorous patrol system operated by the carabinieri and other forces, to include significant stretches that had formerly remained only irregularly patrolled. ${ }^{96}$ In Gorizia Province, the security forces implemented continuous and coordinated motorized patrols along the twelve-kilometer stretch running from the small village of Jamiano - roughly a kilometer east of Monfalcone and essentially the southernmost point along the Italo-Yugoslav border - to Merna (Miren) Airport, just south of Gorizia City. ${ }^{97}$ With this key development, the rigorous patrol system now stretched over the entirety of the Italo-Yugoslav border for Gorizia Province, and all indications are that Carnevali established similar practices in Udine Province.

Despite continual efforts to increase manpower and supplies, regularize patrols, and increase inter-service coordination, clandestine expatriations continued, and by the summer of 1949, Palamara came to believe that the deficiencies of the existing border regime were not so

\footnotetext{
${ }^{95}$ Prefetto Palamara," Settore di Polizia di Frontiera di Cormons - Sorveglianza e sconfinamenti” (N. 789/6-Gab), 2 May 1949, ASG, Pref. Gab. 1945-82, b 222, f 494, sf Emigrazioni - Espatri... 1949.

${ }^{96}$ MI, DGPS, Div FF TT (Unsigned), "Frontiera italo-jugoslava. Emigrazione clandestina" (N. 300/52589/17), 3 May 1949, ASG, Pref. Gab. 1945-82, b 222, f 494, sf Emigrazioni - Espatri... 1949.

${ }^{97}$ Prefetto Palamara, "Riunione" (N. 1144-Gab), 19 May 1949; Insp. Bicchi, "Intensificazione servizi di vigilanza alla frontiera...” (N. 114 Gab), 19 May 1949, both in ASG, Pref. Gab. 1945-82, b 222, f 494, sf Emigrazioni - Espatri... 1949.
} 
much quantitative as qualitative. ${ }^{98}$ Having wracked his brain for potential solutions, he returned to a suggestion that Bicchi had made nine months prior when analyzing the problems of patrolling the Cormons Section. On 11 July, writing to the DGPS and the new Chief of Police, Giovanni D'Antoni, Palamara stressed that he felt "compelled" to point out the insufficiency of antiemigration measures along the border. The terrain simply did not allow patrols to be effective, no matter the number of men assigned the task. And so, he proposed a radical solution to a radical problem: the only possibility was to construct "an adequate protective metal fence" (adeguata rete metallica di protezione) along the entirety of the border. ${ }^{99}$

It remains unclear exactly how or if D'Antoni responded to this request. The file detailing these bordering efforts ends rather abruptly, but D'Antoni's decision in late 1949 to dissolve Italy's four Inspectorates for the Frontier Police (including Bicchi's Fourth Zone office in Udine) and place Frontier Police agents under the regular provincial commands suggests a normalization of the border regime in the post-Cominform Resolution context, not its intensification. ${ }^{100}$ Regardless of the outcome of Palamara's proposal, the proposal is significant in itself. Though radical Fascists of the 1930s had proposed to "hermetically seal" the Italo-Yugoslav border with a fence that would protect Italy against the political and ethnic threats of "Slavdom," the fence had not been imagined as a tool to keep people inside Italy, but rather a means of keeping foreign and deported threats beyond national borders. ${ }^{101}$ The novelty of Palamara's proposal came from

\footnotetext{
98 Prefetto Palamara, "Emigrazione clandestina” (N. 1144-Gab), 24 May 1949; Palamara, "Intensificazione servizi di vigilanza alla frontiera..." (N. 1226/Gab), 28 May 1949; Palamara, "Frontiera italo-jugoslava. Emigrazione clandestina" (N. 04316-Gab.P.S.), 29 May 1949, all in ASG, Pref. Gab. 1945-82, b 222, f 494, sf Emigrazioni Espatri... 1949.

99 Prefetto Palamara, "Frontiera italo-jugoslava - Emigrazione clandestina" (N. 1537/Gab), 11 July 1949, ASG, Pref. Gab. 1945-82, b 222, f 494, sf Emigrazioni - Espatri... 1949.

${ }^{100}$ Capo della Polizia D’Antoni, “Nuova organizzazione dei servizi di polizia di frontiera” (N. 300/59533.2), 1 Sep 1949, ASU, Questura, Massime, b 44, f 14.

${ }^{101}$ Hametz, "Borderlands," in The Politics of Everyday Life in Fascist Italy, eds. Arthurs, Ebner, and Ferris, 151; Cattaruzza, Italy and Its Eastern Border, 132. Livio Ragusin Righi, one-time secretary for the PNF in Trieste Province and supporter of such a fence, indicated that the primary reason such a hermetic seal was necessary was to protect
} 
its motivation of penning citizens in, which emerged as a universal method of fighting the Cold War, even if applied differently on each side of the Iron Curtain. ${ }^{102}$ Moreover, even if Palamara's proposal was denied, his radical solution is noteworthy when compared to contemporary bordering situations along the rest of the Iron Curtain. Regarding the intra-German border admittedly an imperfect comparison given the fact that East Germany did not function as an independent state until that October - Palamara's proposal preceded the DDR's first intra-German border fence by three years. ${ }^{103}$

Even if Palamara did not secure his metal fence, he had overseen the creation of a border regime that rivaled and likely surpassed any other in the history of Italy in terms of its rigor and resources. Italy's eastern border, which for most of its history had remained untamed wilderness only sporadically patrolled by border forces, had become, over the course of a year, the grounds of an extensive, motorized patrol system functioning with unprecedented coordination and regularity, supplemented at vital points by barbed wire and floodlights. Though the rapprochement between Italy and Yugoslavia that followed the Cominform Resolution undercut efforts to further strengthen this border, the forceful initial push of 1948-49 should not be dismissed, nor should the fact that Italy constructed this border as a blockade to would-be fuorusciti travelling east.

In the process of expatriating and repatriating, "ordinary" monfalconesi and Italians had provided a small but real contribution to the polarization of Italy and the world into Cold War camps. Their politics and movement had seemingly corroborated narratives of regional and global Communist conspiracies and helped generate the fears that solidified the DC majority and drew

against the "gusts of Balkan wind" from the east. Livio Ragusin Righi, Politica di Confine (Trieste: Società Editrice Mutilati e Combattenti, 1929), 95.

${ }^{102}$ Many West German leftists were barred from entering East Germany, for example, though the impetus behind their blacklisting from receiving passports was the United States. Torpey, The Invention of the Passport, 146-47.

${ }^{103}$ Schaefer, States of Division, ch. 2; Sheffer, Burned Bridge, ch. 5. 
Italy under the United States' containment umbrella. Their mobility indirectly contributed to the creation of a new and imposing border regime, while concretizing an Italian state doctrine of controlling and repatriating fuorusciti that defined its approach for years to come. ${ }^{104}$ In short, Mario R. and his fellow monfalconesi had helped define the grammar of the early Cold War.

${ }^{104}$ In 1958, for example, when Italy confronted the question of repatriating or stranding abroad certain youth who had clandestinely travelled to the USSR and Czechoslovakia for political and military training, it pursued the same course it had with the monfalconesi ten years earlier. See ACS, MI, Gab, Arch Gen, Partiti Politici, 1944-66, b 49, f 161 $\mathrm{P} / 3 / 94$. 


\section{Conclusion}

We were not a foreign body, but rather a force that could have revolutionized all of Fiume. ${ }^{1}$

- Giuseppe Franti, Monfalconese emigrant.

Giuseppe Franti's reflections on his time in Yugoslavia, recorded some thirty years after the fact, highlight a duality of hope and disappointment. In a single sentence, Franti expressed both a sense of rightful belonging in that country - of familiarity rather than foreignness - and a sense of alienation. In his mind, the monfalconesi were a force that could have revolutionized Fiume, because they shared the values that undergirded the Communist project and they were committed to constructing the society they saw in their imaginations. But they never received the opportunity. His story of Yugoslavia is one of promise unrealized and, ultimately, hope unraveled.

If Franti's words reflect the common interpretive framing of the controesodo - one that ends up at Goli Otok, as Franti himself did - it is equally important to shine light on the tremendous sense of hope that he and others felt as they departed, as well as the processes by which these hopes emerged and took form. The Monfalconese migration cannot be understood outside the context of Monfalcone's wider twentieth-century experience, and particularly its experience of the Fascist dictatorship and the long anti-Fascist struggle, all of which bore a unique inflection due to monfalconesi's position at the peripheries of the state and nation.

The duality of Fascism and anti-Fascism runs like a red thread through the actions of monfalconesi for the entire period of 1943-48. Particularly important is the understanding that "Fascism" for many of Monfalcone's residents was not a narrowly defined set of state institutions or PNF cardholders, but rather a wider constellation of individuals with whom they had repeated social interactions and to whom they attributed culpability for everyday grievances that correctly

\footnotetext{
${ }^{1}$ Bonelli, "Prima intervista con il monfalconese Franti Giuseppe," 27 March 1980, op. cit.
} 
or incorrectly became identified as "Fascist." Chief among these were marketplace reforms that opened new opportunities for shopkeeper graft - connected at times, but not always to PNF members - and the implementation of new work processes that deskilled work and increased paces to frenetic rates, using piecework and the squadrista-clerk as the "Fascist whip." Whether these associations reflected objective reality or not, many monfalconesi made the chasing of "everyday Fascists" like the shopkeeper and piecework clerk a central component of their local conception of anti-Fascist Resistance.

As the Second World War unfolded, the location of contested Monfalcone between the Anglo-Americans arriving from the West and Tito's Partisans in the East granted to monfalconesi and exceptional range of choice as to how they would pursue their liberation from Fascism. It granted their Resistance an additional dynamic largely unaccounted for in Claudio Pavone's classic history of the wider Italian experience. ${ }^{2}$ As the limits of transformation in liberated Italy became clear, support for the annexationist ambitions of Tito's Partisans became a means by which monfalconesi could pursue the most radical conception of Resistance. Put differently, fighting for the arrival of this supposedly "foreign" power became a means to pursue Pavone's class and civil wars. Due to the guiding role of the Italian and Slovenian Communist Parties in organizing this armed struggle, monfalconesi came to understand their vision of Resistance as largely coterminous with the construction of "socialism" or "Communism." And though the hopes of monfalconesi appeared to be realized in May 1945 during the brief period of Yugoslav occupation, cracks quickly began to show between the monfalconesi and the Yugoslav state. Radical monfalconesi's uncompromising demands to purge the "remnants of Fascism" bumped up against the needs of Tito's regime as a state struggling to survive its infancy in a hostile international setting. Already

\footnotetext{
${ }^{2}$ Pavone, A Civil War.
} 
in May 1945 the autonomy and rebelliousness of monfalconesi at home foreshadowed what would happen in Yugoslavia some three years later.

Even after war's end, the desire to purge society of the "remnants of Fascism" far more than Marxist-Leninist conviction drove many monfalconesi to throw themselves headlong into the territorial struggle on behalf of Yugoslavia. In doing so, they privileged the potential transformative effects of Yugoslav annexation over ethnic ties to Italy. Encouraged by an everevolving myth of Yugoslavia that directly responded to their grievances toward Fascism and by frustrations over the AMG's allowance of the persistence of perceived "everyday" Fascists, tens of thousands of ordinary monfalconesi fought vigorously, if futilely for Tito's return. It was for this reason that the self-identified "anti-Fascist population of the City and District of Monfalcone" wrote to CAO Kitson-Harris during the climactic Twelve Days Strike, defining their struggle as one against a "resurgent neo-Fascism" and for the "destruction of a past of hunger, misery, oppression, and disastrous war."3 Local monfalconesi understood the territorial struggle less through the framework of a forward-looking global struggle of Communism against liberaldemocratic capitalism than through the backward-looking framework of Resistance and the struggle of local Fascism versus anti-Fascism. Though propagandists dovetailed the Monfalconese conception of socialism-as-anti-Fascism with a more doctrinal Marxism-Leninism, their most effective propaganda was that which expressed Yugoslavia's transformation through the lens of everyday concerns relevant to monfalconesi, not through an emphasis on class warfare and the dictatorship of the proletariat. Ultimately, the contours and impact of the myth of Yugoslavia in Monfalcone suggest not only that Marxism-Leninism might have played a less important role than once assumed in the ideological bifurcation of the continent after 1945, but also that there was no

\footnotetext{
${ }^{3}$ Per le masse popolare la loro delegazione, "Al Signor Governatore del Distretto di Monfalcone," 12 July 1946, AS 1570, b 8, f 3, sf Sciopero. Italics added.
} 
single myth of the Communist world.

In the end, global diplomatic circumstances militated against Monfalcone's incorporation into Yugoslavia, and a combination of AMG and Italian opposition, local pro-Italian violence, and popular disillusionment broke the pro-Yugoslav movement by spring 1947. But popular frustration was not only aimed at the AMG, Italy, and Monfalcone's pro-Italians. It also fell directly upon both the PCI and the PCRG. The former's moderate, democratic line promised little redress for monfalconesi's grievances, whereas the PCRG, operating first and foremost as a mechanism for the westward projection of Yugoslavia's borders, engaged in the inconsistent strategy of stoking monfalconesi's expectations of a defascistized society, while simultaneously trying to forge crossclass alliances that would bring the greatest number of giuliani into the pro-Yugoslav camp.

Disillusionment and the desire to escape the vestiges of Fascism spurred thousands of monfalconesi to seek liberation through emigration. Though the participants in this migration left in distinct waves and with different constellations of motives, they believed their aspirations in the realms of community, work, safety, and material well-being could be realized in Tito's New Yugoslavia. This dynamic of local disillusionment and outwardly-projected hope is particularly evident in the migrants of early 1947, who jumped at the chance to relocate and who left secure sources of income, bringing whole families along with them. But the migrants of early 1947 are indicative of the controesodo in another way, too: they left against the will of local and Italian Communist leaders, forging their own path using the opportunities provided them and undermining local Communism in the process.

If the Monfalconese experience of Fascism, war, and postwar fit within a wider Italian or European experience and reveals much about borderland politics, popular notions of liberation, and the legacies of totalitarian dictatorship generally, the same generality does not apply to the 
population transfer of 1946-47. That transfer appears sui generis in history, the result of universal hopes and processes flowing together perfectly with a set of circumstances particular to the Monfalconese. It was not the first time that large numbers of workers and even their families had migrated to a Communist country. Waves of German workers and then idealistic American feminists and "new women" arrived in the Soviet Union in the early interwar period, followed closely by a wave of American workers who departed the Depression-ravaged States in the 1930s. ${ }^{4}$ Yet several characteristics distinguish the Monfalconese controesodo from these other migratory movements. Among them are the facts that it occurred (for many, if not all) without economic necessity, it involved multigenerational family movements, it was envisioned by many to be a permanent move, and it involved a community that - from the time of departure through the Cominform Resolution - remained remarkably cohesive. Undoubtedly this cohesion was at least partially the result of a final distinguishing factor: many migrants had participated actively in the anti-Fascist Resistance, including in armed struggle.

If Giuseppe Franti and his fellow monfalconesi failed to revolutionize Fiume, their migration, particularly in light of this final distinguishing characteristic, did not fail to have a revolutionary impact on the Cold War. Their migration, misunderstood from the very beginning by Anglo-American military leaders and by Italian politicians, served to escalate Cold War tensions, legitimate the US policy of containment, generate a fever-pitch of paranoia around Italy's 1948 election, and motivate Giovanni Palamara to construct the first workings of what would have likely become a robust Italian Iron Curtain, had not the Cominform Resolution radically altered the region's diplomatic contexts. In an instance of notable historical irony, monfalconesi thus helped create, albeit inadvertently and indirectly, the conditions that led their lives in Yugoslavia

\footnotetext{
${ }^{4}$ See respectively Sammartino, The Impossible Border; Mickenberg, American Girls in Red Russia; Tzouliadis, The Forsaken.
} 
to become so miserable by the turn of 1948. Serving as a focal-point of suspicion, they helped drive forward the polarization that led Western powers like the US to intensify the economic strangulation of Tito's regime, which in turn forced the latter's reorientation toward an austerityexport economy. As a result, monfalconesi experienced changes in their Yugoslav workplaces and marketplaces that not only contradicted the myth of Yugoslavia but also appeared to reconstitute the very "Fascist" abuses from which they had fled. Convinced that the Cominform Resolution could not but be correct given this experience, monfalconesi responded to that Resolution with an intransigence that reinforced the intra-Communist schism opened in the summer of 1948.

Ultimately, the Monfalconese experience highlights multiple avenues for future research, not all exclusive to Italian or Adriatic history. First, one might ask to what degree the process of ideological formation described in the Monfalconese case occurred within wider Italy and Europe. In the case of Italy, it is likely that regional or local variations in Fascism resulted in distinct conceptions of "everyday" Fascism at those levels, which in turn might have created distinct understandings of Resistance and socialism. Outside of Italy, the applicability of this processual model becomes less clear. Italy's Fascist dictatorship was unique in that it was the first of Europe's fascist regimes; the ventennio provided the lengthy period necessary for everyday grievances to graft themselves on to the term "Fascism." More could be done to explore the degree to which this same process played out in Nazi Germany. ${ }^{6}$ If it did not play out similarly in Germany, this

\footnotetext{
${ }^{5}$ The Francoist regime in Spain lasted longer, but it lived the lion's share of its life in a different era (the Cold War) than did the Fascist Italy and Nazi Germany.

${ }^{6}$ A substantial literature on Germany's post-Nazi transition is available, but much of it deals with the trials and amnesties of actual NSDAP cardholders or with German collective memory, in both cases regarding the Nazis' extraordinary, generally outward-facing war crimes and crimes against humanity. There appears to be little focus on the ways in which the term "Nazi" became grafted on to particular actions or social categories due to Germans' everyday experiences of the regime or how this shaped postwar political possibilities. See Richard Bessel, Germany 1945: From War to Peace (New York: Harper Collins Publishers, 2009); Konrad Jarausch, After Hitler: Recivilizing Germans, 1945-1995 (Oxord: Oxford University Press, 2008); Robert Moeller, War Stories: The Search for a Usable Past in the Federal Republic of Germany (Berkeley: University of California Press, 2003).
} 
might help explain certain distinguishing features of postwar Italy, including its possession of the largest Communist Party in Western Europe. If, for many Italians, the discourse of the "remnants of Fascism" was more than just a propagandistic smear - if instead it was something that responded to longstanding grievances and deeply rooted associations - this may have driven them directly into the arms of the party perceived to be the most radical in its opposition to Fascism.

Two additional avenues of research appear particularly compelling. First, across the continent more research is needed on both popular and regime understandings of "socialism" and the complex interactions between them. Particularly in the immediate postwar and for "ordinary people," the Communist world was not necessarily one understood through the prism of "Marxistbased options for social change."7 The process of mediation between popular aspirations and the leading doctrines of Communist parties and regimes must be examined more closely. Second, this research raises the question of whether there were additional cases of permanent, voluntary relocation across the Iron Curtain and the degree to which they resembled the controesodo. One might compare the Monfalconese departures to the migration activities of the thousands of other Italians, including friulani, who migrated across the Iron Curtain in smaller groups during those same years. Such a comparison would not only provide a more complete picture of West-East migration from Italy but also explore the degree to which the unique features of the Monfalconese migration - the cohesion, partisan history, and pro-Yugoslavism of the Monfalconese community - shaped Italian and Anglo-American responses to this mobility.

As for those monfalconesi who departed for the East in 1946-47, by the 1950s most returned to the Monfalconese, though not all remained. Silvano Cosolo, who had expatriated clandestinely in 1946, returned equally clandestinely in 1948 in the wake of the failed assassination

\footnotetext{
${ }^{7}$ Romero, "Cold War Historiography," 697.
} 
attempt of Palmiro Togliatti, which he believed might spark a revolutionary moment. Interrogated by carabinieri as to his recent activities, he stated he had been touring Italy the whole time. With no tangible proof to the contrary and no legal basis to charge him with clandestine emigration given the postwar territorial ambiguities of Monfalcone, the marshal in charge of Cosolo's investigation let him go. ${ }^{8}$

Some five years later, Renato Rigonat returned, though he found Ronchi still deeply divided over the past territorial struggle and suffered continual harassment. When he sought out work in the CRDA, an office head told him that he should go back and seek a job from the Titoists; when he sought to enroll himself and his son in the state's compulsory social security program, he found the clerk to be an old squadrista who told him to go seek his "rights" over there as well. And so Rigonat made only a temporary stop back in the Monfalconese. In late 1953, he departed Ronchi for Switzerland and then France, from whence he would return only in 1981, after thirtyfive years of living abroad between East and West. ${ }^{9}$

Just as Rigonat was leaving, Mario Tonzar and other Goli Otok survivors made their return. Like many of the more committed militants who had departed Monfalcone in 1947, Tonzar immediately went to the PCI headquarters, where he found a warm welcome. Though many of the old comrades who had headed the local PCRG were still there, the leadership was largely new, including many monfalconesi who had remained behind while their neighbors departed by the thousands. ${ }^{10}$ Among them were Spartaco Romano, who had been the local PCI secretary until 1949, after which he assumed leadership of the local metallurgical union and then a seat on the municipal council. ${ }^{11}$ There too was Sergio Parenzan, who would play a key role in the labor

\footnotetext{
${ }^{8}$ Cosolo, Amare... Sarajevo, 161-183.

${ }^{9}$ Rigonat, Memorie, 62-70, 166.

${ }^{10}$ Tonzar, La valigia e l'idea, 98.

${ }^{11}$ ACS, MI, DGPS, Div AA RR, Ctg Z, b 508, f "Romano Spartaco di Pietro."
} 
movement within the shipyard for years to come. ${ }^{12}$ Silvano Cosolo, who had temporarily emigrated to Switzerland in search of work after his return to Monfalcone, arrived back the following decade, assuming, along with Mario Tonzar, a position on one of the zone's municipal councils as part of the PCI ticket. ${ }^{13}$

Thus, within a decade of their departure, many of those youths who had participated in the anti-Fascist struggle and the cross-Curtain migration of the 1940s had returned and had assumed once again leadership roles in their community's political struggle. Though largely against their own desires and intentions, Cosolo and Tonzar finally fulfilled Romano's prescription that the Communist militant "struggle for socialism in the place where he finds himself, and not go to do it where he will be safer." 14 In the middle and later periods of the Cold War, these men continued to pursue their visions of progress and liberation, though with a more gradualist approach. Gone were the attempts to remake the world in a day and to eradicate fully and uncompromisingly the remnants of "everyday" Fascism. Gone too was the hope that these difficulties could be overcome by migrating beyond the confines of Italy. The shift in the monfalconesi's approach and aspirations is captured well by Romano's reflections on his own transformation during the tumultuous 1940s:

At the beginning, in my enthusiasm, I too thought that I would be able to rule the world in twenty days. Now that I am older, I've realized that historical periods are slower to mature, and who knows how many years will still have to pass before it is possible to create a society a little more just, more humane, more free. ${ }^{15}$

\footnotetext{
${ }^{12}$ See Parenzan's perspective on this struggle in his article, "Le lotte dei lavoratori al cantiere di Monfalcone: Dal dopoguerra alle esperienze nel ‘Consiglio di Fabbrica' Italcantieri," Il Territorio 9 (1983): 19-28.

13 "Morto Silvano Cosolo," Messaggero Veneto, 11 September 2008.

${ }^{14}$ Bonelli, "Sesta testimonianza del monfalconese Romano Spartaco," 23 October 1981, op. cit.

${ }^{15}$ Bonelli, "Terza testimonianza del monfalconese Romano Spartaco," 3 April 1981, op. cit.
} 


\section{Appendices}




\section{Appendix A: Glossary of Political, Economic, Cultural, Social, and Other Organizations in the Monfalconese:}

Allied Military Government (AMG) - The Allied Military Government was a caretaker government established by the Anglo-American occupiers in the wake of the Duino and Belgrade Agreements. Its purpose was to administer Zone A of the contested Italo-Yugoslav border territories until a formal peace treaty went into effect. Operated by the Allied $13^{\text {th }}$ Corps and organizationally distinct from the AMG in the rest of Italy, the AMG of Venezia Giulia functioned in the large Zone A (including the Monfalconese) until September 1947 and then in the smaller Zone A of the Free Territory of Trieste until 1954. Though nominally neutral, it had an anti-Communist and thus proItalian orientation in practice, putting it at odds with the local pro-Yugoslav movement. Heading the AMG in Trieste was SCAO Col. Alfred Bowman, while CAOs Maj. J. Kitson-Harris and Capt./Maj. F. Hill were the responsible officers for Monfalconese district and Monfalcone commune respectively.

Associazione partigiani giuliani (APG) - The APG, or Julian Partisan Association, was a partisan association that spanned Zones A and B of the contested borderlands, consisting mostly of proYugoslav ex-garibaldini, many of whom had served in units that fought under Yugoslav command from 1944-45. Between 1945-47, it had tense relations with the regional API and the largest partisan association in Italy, ANPI, because of its perceived support for Yugoslav annexation of Zone A.

Associazione partigiani italiani (API) - The API, or Italian Partisan Association, was a partisan association operating primarily in Zone A between 1945 and 1947, consisting of pro-Italian partisans from a range of political parties. It enrolled partisans with politics ties to the DC, PDA, and PSIUP, and, to a limited extent, those with Communist sympathies, but a pro-Italian stance on the territorial question. It developed close ties with ANPI in Italy. In the Monfalconese, it was dwarfed by the APG. Most of its support came from areas closer to Trieste and Gorizia.

Comitato distrettuale di liberazione nazionale (CDLN) - The CDLN, or District Committee of National Liberation (in Slovenian ONOO, or Okrajni narodnoosvobodilni odbor), was the districtlevel organization of anti-Fascist, anti-German Resistance that was loyal to the Slovenian Liberation Front. It was distinct from the pro-Italian CLN. After liberation, the CDLN administered the zone until the AMG's General Order 11 (August 1945), after which it operated as a shadow government for the zone's pro-Yugoslav forces.

Cooperativa del Lavoro (CL) - The CL, or Cooperative of Labor, was a consumer cooperative founded in November 1945 by the pro-Italian syndicates (SG) to compete with the district's proYugoslav consumer cooperative (CCLM). The CL received subsidies from Italian governments due to its perceived ability to draw monfalconesi away from the pro-Yugoslav movement.

Cooperativa di Consumo Lavoratori del Monfalconese (CCLM) - The CCLM, or Workers' Consumer Cooperative of the Monfalconese, was a consumer cooperative formed in the Monfalconese by the zone's pro-Yugoslav forces in November 1945. It had close ties with the PCRG through the liaison Mario Geromet and was understood as a critical tool for mobilizing supporters of the pro-Yugoslav movement. The cooperative failed in its initial ambitions of 
replacing the district's shopkeepers and facilitating Yugoslav annexation but has survived in the form of the Coop grocery stores that today populate towns and cities of northeastern Italy.

Cooperative operaie di Trieste, Istria e Friuli (CO) - The CO, or Workers' Cooperative of Trieste, Istria, and Friuli, was founded in Trieste in the late-Habsburg period with a strong working-class, anti-shopkeeper orientation and close Socialist ties. It survived the arrival of Italy, but the Fascists subordinated it to the Ministry of Corporations in the 1930s and sold shares to major banks, eliminating its previous working-class orientation. Several postwar attempts by left-wing and proYugoslav organizations to regain controlling interest in the cooperative failed.

Democrazia Cristiana (DC) - The DC, or Christian Democracy, was a postwar political party build upon the legacy of Italy's intewar Popolari and headed by Alcide De Gasperi. The party was greatly underrepresented in the Monfalconese relative to its strength in Italy, but it did have some local support among monfalconesi of anti-Communist and/or pro-Italian sentiments. Though numerically weak, the Monfalconese DC was a key party of the AMG's anti-Communist unity council from 1945-47, just as the national party became the United States' party of choice in Italy's 1948 elections.

Difesa Poplare (DP) - The Difesa Popolare, or Popular Defense, was the Communist-led partisan police force formed by the Garibaldi Brigades of Venezia Giulia in the last period of the Resistance. Its functions were primarily those of uncovering and punishing black-market activities, spying on and detaining Fascists and "reactionaries," and maintaining public order. The organization was generally pro-Yugoslav in orientation, responsible to Yugoslav commanders and the pro-Yugoslav CDLN, but not all members were pro-Yugoslav. The AMG dissolved the DP in June 1945.

Divisione Gorizia (DG) - The Divisione Gorizia, or Gorizia Division, was an anti-Communist, pro-Italian paramilitary founded in late 1945 in Gorizia, but soon operating in much of Zone A. Its primary purpose was to collect information on the pro-Yugoslav movement and resist a potential Yugoslav aggression in Zone A. Its members ranged from ex-Fascists to anti-Fascist partisans of anti-Communist bent, and thus it had tense relations with more stringently anti-Fascist pro-Italian paramilitaries such as the API. Thought the AMG looked unfavorably upon the DG, the latter received support from individual Anglo-American military officers and the Italian state.

Gioventù comunista (GC) - The GC, or Communist Youth (also known as SKOJ, or Savez komunističke omladine Jugoslavije) was the youth branch of the Communist Party in the Monfalconese. Versions of it existed under the PCdI, PCI, and PCRG. In the clandestine period, it remained organizationally distinct from the normal Party to protect its members.

Gruppo d'azione pattriotica (GAP) - The GAP, or Patriotic Action Group, was a network of urban partisan cells consisting primarily of Communist garibaldini and operating mainly from 1943-45. The Monfalconese GAP had close ties with the PCdI/PCI and the Titoist intelligence services. Its members, organized into small, isolated cells, performed actions including intelligence-gathering, requisitioning, sabotage, and the execution of the zone's leading Fascists. After the establishment of the AMG, much of the Monfalconese GAP withdrew to Yugoslavia and remained intact under the command of Riccardo Giacuzzo. 
Komunistička partija Slovenije (KPS) - Founded in 1937, the KPS, or Slovenian Communist Party, was a component party of the wider Yugoslav Communist Party (KPJ). Important leaders included Edvard Kardelj and Boris Kidrič. Though Communist Slovenes of the Monfalconese had organized within the PCdI during the interwar period, after the OF's declaration of its intention to annex the Primorska, the KPS fostered a network of cells parallel to those of the PCdI. In August 1945, the parallel KPS and PCI organizations in Venezia Giulia merged to form the PCRG.

Lega nazionale $(L N)$ - The LN, or National League, was and Italian irredentist organization founded in Trieste during the late Habsburg period. Though dissolved under Fascism after the successful "Redemption" of much of the eastern Adriatic lands, Italian nationalists of Venezia Giulia refounded it in 1946 during the territorial struggle. Its nominal function was to foster and protect Italian culture in the eastern Adriatic, but in practice it did much more than this. It became a focal-point for pro-Italian politics and served as an umbrella under which otherwise opposed proItalians from ex-Fascists to pro-Italian Socialists might cooperate for the ends of protecting Italian territorial integrity. The Monfalconese branch was involved in gun-running and supporting proItalian paramilitaries.

Odjeljenje za zaštitu naroda or Odeljenje za zaštitu naroda (OZNA) - Founded in mid-1944 under the leadership of Aleksandar Rankovič, OZNA, or the Department for People's Protection, was the primary security and secret police agency of early Titoist Yugoslavia. OZNA's methods were typically Stalinist, modelled after the USSR's GPU/NKVD. During the war period, the organization developed ties with the Monfalconese GAP, and several of the zone's leading PCRG members were OZNA agents. The department was later reorganized and renamed UDBA.

Osvobodilna fronta $(O F)$ - The OF, or Slovenian Liberation Front, was a unity council of antifascist, anti-Axis political parties that arose in April 1941 after the Axis invasion of Yugoslavia. Though it incorporated several parties, the KPS retained de facto power over the organization and gave to the OF its two main leaders, Boris Kidrič and Edvard Kardelj. The OF engaged in political and civil resistance and became a key component of Tito's Partisan coalition. The OF program emphasized the complete liberation of Slovenia, understood as all territories inhabited by largely Slovenian populations, and stressed the need for Slovenian borders to be pushed westward up to the Isonza (Soča) River. Late in the war the OF organized cells in the Monfalconese, which became the basis for the postwar CDLN.

Partito comunista d'Italia (PCdI) - The PCdI, or Communist Party of Italy, was Italy's primary Communist Party of the interwar period, founded in 1921 and responsible to the Comintern. It was a party of disciplined cadres. The PCdI garnered much support in the Monfalconese before Mussolini outlawed the party in 1926. It continued to operate in clandestinity and became the most active anti-Fascist party of the Monfalconese, though its program remained that of conspiratorial preparation rather than direct confrontation with the regime. In 1943, the PCdI was renamed the PCI and soon took on a very different program.

Partito comunista della Regione Giulia (PCRG) - The PCRG, or Communist Party of the Julian Region, was founded in August 1945 after the merging of the parallel PCI and KPS organizations in Venezia Giulia. Thought nominally autonomous, the PCRG took orders from the KPS and 
emerged as the backbone of the Julian pro-Yugoslav movement. It was a party of cadres and exercised tight control over a range of pro-Yugoslav organizations in Zone A, including the CDLN, SU, APG, UAIS, UDAIS, UGARG, and CCLM. It was the most influential political party in early postwar Monfalcone. The directive body in the Monfalconese was the CDM, or District Committee of Monfalcone (Comitato distrettuale di Monfalcone). For a brief time in 1946, the CDM split into separate districts for Monfalcone (IV Rione) and Ronchi (V Rione), but this was shortlived. The PCRG dissolved in the Monfalconese in mid-1947 in anticipation of the zone's return to Italy, though it remained active in the Free Territory of Trieste as the Communist Party of the Free Territory of Trieste (PCTLT).

Partito comunista italiano di Venezia Giulia (PCIVG) - The PCIVG, or Italian Communist Party of Venezia Giulia, was a splinter communist party that operated in Zone A during the period of the AMG. The party was vociferously pro-Italian, breaking from the pro-Yugoslav PCRG, but also from the PCI in Rome, which it criticized for its hesitancy to embrace an openly pro-Italian position on the Trieste Question. Though the PCIVG was vocal and gained some support in Gorizia, it was far less prominent in the Monfalconese.

Partito comunista italiano (PCI) - The PCI, or Italian Communist Party, was the direct descendant of the former PCdI, renamed in 1943. Following Italy's armistice with the Allies in September 1943, the PCI embraced armed resistance, giving birth to the Garibaldi Brigades, but its political line de-emphasized the social-revolutionary nature of the Resistance in order to facilitate its participation in an anti-Fascist unity coalition. In the last years of the war it transitioned from a party of cadres to a mass, democratic party set on winning power at the polls. The "Trieste Question" thus emerged as a major problem for the PCI, which feared to appear "anti-national" by supporting Yugoslav territorial claims. Only gradually did the PCI come out as pro-Italian on the question of Trieste and the Monfalconese. The PCI was the dominant Communist Party of the Monfalconese until August 1945, when the parallel PCI and KPS organizations in Venezia Giulia merged to form the PCRG. Following the signing of the peace treaty in February 1947, the PCI reconstituted its Gorizia Federation, including in the Monfalconese.

Partito d'Azione (PDA) - The PDA, or Action Party, was a liberal-socialist political party that was heir to Carlo Rosselli's network of exiled anti-Fascists called Giustizia e Libertà. The party played a key role in the anti-Fascist Resistance under the leadership of Ferruccio Parri. It sat left-of-center on a national scale, with its republican, liberal-socialist platform. However, due to its outspoken pro-Italian position on the Trieste Question, the Monfalconese (and Julian) PDA became home to a much wider range of supporters inconsistent with its national profile. These included some chauvinistic nationalists and ex-Fascists, drawn to the PDA because it was the most active and organized opposition to the pro-Yugoslav movement. The PDA was part of the AMG's antiCommunist unity council from late 1945. From 1946, several of its leading members carried out a terrorist bombing campaign against prominent pro-Yugoslavs.

Partito socialista italiano di unità proletaria (PSIUP) - The PSIUP, or Italian Socialist Party of Proletarian Unity, was the largest Socialist party in Resistance-era and postwar Italy and likely the second-largest party overall in postwar Monfalcone. Headed by Pietro Nenni, the party aspired to social revolution and was generally favorable to the USSR, but it rejected Yugoslav annexationism. It was the primary organizational pole for left-wing radicals of the Monfalconese 
and Trieste who were committed to maintaining Italian sovereignty in their region. It became a component of the AMG's anti-Communist unity council in the Monfalconese.

Sindacati Giuliani (SG) - The SG, or Julian Syndicates, was a pro-Italian trade union that arose in Zone A in late 1945 in opposition to the pro-Yugoslav SU. The union was backed by the AMG, the pro-Italian political parties of the zone, and even to some degree by the region's industrialists. Members came largely from supporters of the pro-Italian parties and the zone's white-collar workers. After an initial period of tense and partially successful cooperation between the SU and SG on labor issues in the winter of 1945/46, the divisiveness of the territorial question caused cooperation between the two to break down entirely. In November 1945, the SG gave birth to the $\mathrm{CL}$ as an alternative to the pro-Yugoslav cooperatives and continued to pursue other workerfriendly measures, if with little success. With the return of the Monfalconese to Italy in 1947, the zone's SG branch was incorporated into the Italian General Confederation of Labor (CGIL).

Sindacati Unici (SU) - The SU, or Unitary Synidcates, was a pro-Yugoslav trade union that operated in Zone A, Zone B, and Yugoslavia. In the Monfalconese, the SU was a direct descendant of the Resistance-era UO network. The SU dominated the CRDA factory council during both the period of Yugoslav administration and the AMG years. It was responsible to the PCRG, which controlled the SU by placing veteran militants in key SU leadership positions. In cooperation with the SG, the SU achieved some concrete gains for Monfalconese workers in late 1945 and early 1946, but by mid-1946 relations had entirely broken down. The Monfalconese section of the SU dissolved in mid-1947 following the signing of the peace treaty but continued to operate in Trieste and Yugoslavia.

Unione antifascista italo-slavo (UAIS) - The UAIS, or Italo-Slavic Anti-Fascist Union, was a proYugoslav mass organization controlled by the PCRG and operating in Zones A and B of the contested Italo-Yugoslav borderlands. Though the PCRG remained a restrictive party of cadres, it engaged a much larger group, including anti-Communists, in its politics through the UAIS. The latter put forward a program of Italo-Slavic fraternity, the eradication of Fascism in all forms, and the annexation of Venezia Giulia to Yugoslavia. The group attempted to influence treaty- and border-makers through a politics of mass protest and demonstration, which often put it at odds with the AMG and its police. The organization dissolved in the Monfalconese after the signing of the peace treaty in 1947, but it continued to operate in Trieste thereafter.

Unione delle donne antifasciste italo-slava (UDAIS) - The UDAIS, or Italo-Slavic Union of AntiFascist Women, was an affiliate organization of the UAIS that spanned the same time period and focused on organizing women. Like the UAIS, the UDAIS was controlled by PCRG members. Much of the group's activity involved honoring the fallen partisans of the zone and engaging in marketplace protests against the AMG's rationing and supply system.

Unione gioventù antifascista della Regione Giulia (UGARG) - UGARG, or the Union of AntiFascist Youth of the Julian Region, was a youth-based affiliate of the UAIS that operated during the same period. It was controlled by the GC and organized protests against youth unemployment.

Unità operaia $(U O)$ - The UO, or Workers' Unity, was a clandestine, multiethnic anti-Fascist organization that operated throughout the Julian region during the Resistance era (1943-45), 
specifically within the region's factories and workplaces. The organization had its basis in PCIKPS negotiations in Trieste, though it was not an exclusively Communist organization. The Monfalcone shipyard emerged as the stronghold of the UO with some 6000 supporters, where it conducted partisan-support activities, sabotage, and other operations. Shortly after liberation, the UO transformed into the SU.

Venezia Giulia Polizia Civile (VGPC) - The VGPC, or Venezia Giulia Civil Police, was the AMG police force constructed rapidly in the second half of 1945 to police Zone A. It included both Italian and Slovenian agents. The force was nominally neutral on the territorial question, though in practice it was pro-Italian and anti-Communist because most of the senior officers were Fascistera appointees noted for their Italian nationalism. Such officers consistently marginalized the Slovenian agents and clashed with Zone A's pro-Yugoslav forces. In September 1947, the VGPC ceased to have jurisdiction in the Monfalconese, though it continued to operate in Trieste. 
Appendix B: Chart of Postwar Organizations in the Monfalconese by Type and Stance on the Territorial Question (Table 1):

\begin{tabular}{|l|l|l|}
\hline & Pro-Yugoslav & Pro-Italian \\
\hline Political Parties & PCRG & DC \\
& GC & $\begin{array}{l}\text { PDA } \\
\text { PSIUP } \\
\text { PLI } \\
\text { PCIVG }\end{array}$ \\
\hline $\begin{array}{l}\text { Mass Cultural-Political } \\
\text { Organizations }\end{array}$ & UAIS & LN \\
& UDAIS & \\
\hline Trade Unions & SGARG & SG \\
\hline Consumer Cooperatives & CCLM & CL \\
\hline $\begin{array}{l}\text { Partisan Associations and } \\
\text { Paramilitaries }\end{array}$ & APG & API \\
\hline Police and Administration & GAP & DG \\
& & AMG (nominally neutral) \\
& & VGPC (nominally neutral) \\
\hline
\end{tabular}




\section{Appendix C: The Monfalconese Emigration by the Numbers:}

The controesodo is perhaps the only instance of mass West-East migration during the Cold War. It is worth establishing as accurately as possible the number of monfalconesi who left, as well as if they have any defining demographic features. However, any such attempt runs up against source limitations. These limitations are many, but they fall into three general categories. First, there are problems of terms and specificity. Whereas AMG officials often used locational terms inconsistently, Italian state documents produced from 1947 onwards talk of "Italians" or giuliani in Yugoslavia, rarely talking of monfalconesi specifically. Second, there are problems of documentary gaps. On the one hand, there were many monfalconesi who crossed the border clandestinely or without registering their departure, leaving official statistics incomplete (for example, Silvano Cosolo does not appear in any official documents, despite having spent years in Yugoslavia). On the other, official reports tend to focus on "workers" or heads-of-family, leaving children and (often) wives unaccounted more. Finally, there are issues of timing. Given that a notable number of monfalconesi began to return from Yugoslavia by the turn of 1946/47, estimates that came after are inevitably incomplete.

Because of these difficulties, existing estimates of the number of controesodo participants have varied widely. Conservative estimates have tended to come in at roughly 2000 . This is implied with the title of Andrea Berrini's book on the topic, which is subtitled "the two-thousand from Monfalcone."1 The historian Enrico Cernigoi has estimated that some 800 total monfalconesi arrived at Pola, with "more or less the same number" settling in Fiume and a handful of smaller communities dispersed throughout Yugoslavia. ${ }^{2}$ On the other end of the spectrum, the participant Giuseppe Franti has claimed that some "tens of thousands" of monfalconesi relocated to the

\footnotetext{
${ }^{1}$ Berrini, Noi siamo la classe operaio.

${ }^{2}$ Cernigoi, Scelte politiche e identità nazionale, 295. Boris Gombač falls in this same camp.
} 
supposed eastern utopia. ${ }^{3}$ Between these two extremes is Marco Puppini, who has guessed that there were some 2000-2500 workers from the CRDA who, together with their families and workers from other worksites, totaled roughly $3500 .^{4}$

Based on the available documentation it seems that Puppini's figure is the closest, though he too may have underestimated the total by as many as 1500 people. In an effort to establish a baseline figure for the Monfalconese emigration to Yugoslavia and to learn as much as possible about emigrant monfalconesi, I have kept a running list of emigrants. The list includes information about each emigrant I have come across, including the migrant's name and, when available, demographic, occupational, familial, and political data. Though the data is incomplete and uneven, the list is helpful in establishing a baseline figure for emigrant population and for drawing attention to certain qualities of the emigrant population.

Before discussing my findings, it is necessary to describe the sources and methods I used to compile the list. To create the list, I have used a wide range of sources, including primarily archival documents and published memoirs. The most significant sources fall into three categories. First there are various lists generated by (or archived by) the AMG, including ration-control surveys and lists of CRDA workers who quit their jobs to go to Yugoslavia. ${ }^{5}$ Such sources tend to list only workers and heads-of-family, leaving out the spouses, children, and parents who emigrated alongside the listed workers. The second major source base consists of the individual police files compiled by the Gorizia Questura in 1948 as they attempted to surveil repatriating

\footnotetext{
${ }^{3}$ Bonelli, "Prima intervista con il monfalconese Franti Giuseppe, 27 March 1980, op. cit.

${ }^{4}$ Puppini, "Il 'controesodo' Monfalconese in Jugoslavia, op. cit, 71. This is roughly in line with Ruggero Bersa's recollections. Bersa estimated that "no less than 2400 workers of the shipyard, another hundred laborers from the Solvay, and numerous peasant families" left the district. Fogar, "Seconda parte dell'intervista registrata rilasciata da Ruggero Bersa," November 1981, op. cit.

${ }^{5}$ These lists are primarily held in NARA, RG331, UD1981, b 9159, f 11304/115/86; b 9189, f 11304/115/308; and b 9198, f 11304/115/388.
} 
monfalconesi. ${ }^{6}$ I received exceptional access to these files, but only for 1948. Inevitably, many migrants repatriated after 1948 have gone undetected. Third, I have used a wide array of documents from Italian state archives which contribute random additions. Between the Gorizia Questura files and the random archival documents, I have identified nearly 350 additional emigrants beyond those in the AMG sources, which reveals how incomplete the original AMG lists were.

In terms of methods, there are two notable concerns worth mentioning. The first involves the methods of utilizing data from different AMG lists, especially the lists of workers who quit their positions at the CRDA in early 1947 and the lists of workers confirmed to have emigrated. Given the context, it should be assumed that most of those who quit their jobs in early 1947 did so to emigrate, particularly given that the UAIS directive had recently been issues. Still, for workers who show up on the list of resignations but are not specifically listed as emigrants in other sources, I have not included them in my list. There are some 200-300 such workers.

A second methodological decision involved the treatment of potential double-listings. Given that I am drawing information from many lists and that a single individual might appear on multiple lists, I have had to be careful to cull out repeats. Because I have addresses, birthdates, and paternity information for most migrants, I have been able to eliminate many of these rather easily. In some cases, however, there are variations within migrant information that raised questions of whether I was dealing with two similarly-named individuals or one. The two most common ways this problem manifested itself was (1) when I came across a single name listed in various sources under different addresses and (2) when I found similar names with slight differences in spelling. In the first case, I operated under the assumption any additional shared information between the two lists (i.e. the same birthdate or same paternity) was sufficient to indicate that this was one

\footnotetext{
${ }^{6}$ These files are at ASG, Questura 1948, bb 1-12.
} 
individual who had simply moved residence. In the second, I removed one of the two names when there were only slight variations in spelling (i.e. the surname Capputto vs Caputo) without additional evidence to suggest these were distinct people or when the two names simply reflected differences of Italian and Slovenian spelling (i.e. the given name Giovanni vs Ivan or the surname Bandelli vs Bandelj). The only instance in which I did not eliminate doubled in this way was when there were two individuals with the same name, the same addresses or no address information available, no birthdate information available, and the same name for their fathers, but with one case listing the father as deceased (i.e. "fu Antonio") and the other listing the father as living (i.e. "di Antonio"). In such rare cases, I left both individuals on the list, since there is the possibility that these were father-son duos living together in the same home.

To date I have identified 1923 emigrants by name, but, because the sources tend to focus on workers and heads-of-family rather than these workers' dependents, it is safe to say that the figure was much higher. Of the 1923 listed emigrants, 348 are known to have emigrated with families, though no information is provided on the families. Of these heads-of-families, almost all either settled in Pola (217) or Fiume (125). Even if one assumes each of these migrants had a spouse and just two children - a conservative estimate - this would add an additional 1044 migrants. Moreover, from cases in which family composition is a bit more defined but in which no specific names are provided, I have identified a further 55 emigrant spouses and children. In cases where a family has been said to have brought "children," of which there were six, I assumed the lowest possible figure of two. Given that most of the emigrants I know by name come from lists of workers who quit the CRDA, there are relatively few women on the list. Moreover, the women listed were always specified as young and single, meaning it is unlikely there is doubling between nameless spouses and the named women on the list. 
Taking the sum of these figures, the baseline to this point would be 3022 . However, there remain roughly 1200 emigrants on my list for whom I simply do not have enough information to determine if there were dependents brought along or not. For such cases, it should be assumed that many did. The majority of individuals on my list come from the AMG's May 1947 ration-control survey, in which there were 1294 workers listed as having emigrated as individuals rather than with families. This categorization should be taken as provisional, however, as the AMG's rationcontrol survey was completed before many emigrant workers had time to establish themselves in Yugoslavia and send for their children, spouses, and/or parents in Monfalcone to join them. If one takes the totality of this data into consideration, as well as the shortcoming of the sources, a total population of 5000 monfalconesi migrants seems most likely.

Such a figure is largely borne out by contemporary reports. Immediately before Transfer Day, the Italian Legation in Belgrade submitted a report on the question of Italians in Yugoslavia, estimating cautiously that there "are about 10,000 [postwar Italian migrants in Yugoslavia], coming in large part from Friuli, from Trieste, and from Monfalcone" alongside whom there were much smaller numbers from Central Italy and the Mezzogiorno. ${ }^{7}$ Subsequent Italian Foreign Ministry reports indicate that some 400 Italian managers and technicians and 2000 workers arrived to work in the Fiume shipyard after liberation, which roughly parallels the PCI's own estimate that "in 1947 there emigrated over 3000 workers from the district of Monfalcone solely to the region of Fiume." "Such estimates, however, only counted the workers who emigrated, failing to account

\footnotetext{
${ }^{7}$ Legazione d'Italia (Belgrado), "Lavoratori italiani in Jugoslavia" (Tel. N. 266/44), 4 September 1947, op. cit. Though the document talked of "clandestine emigrants," a term that theoretically should have excluded the bulk of monfalconesi, who passed into Yugoslavia legally during the period of the AMG, subsequent documents clarify that monfalconesi are included under this category. Legazione d'Italia (Belgrado), "Emigrazione clandestina in Jugoslavia" (N. 1758/180), 21 August 1947, ASDMAE, AP 1946-50, Jug, b 30, f 3.

${ }^{8}$ Console Pinto, "Connazionali venuti in Jugoslavia senza passaporto ed emigrazione clandestina" (Tel. N. 79/21), 11 March 1948, op. cit.; MAE, DGAP, VI Ufficio, "Protesta dal Partito Comunista Italiana" (Telegraph N. 24469) with Attachment, 12/21/49, ASD-MAE, AA PP 1946-50, Jug, b 72, f 2 Emigrazione clandesta in Jugoslavia. In line with
} 
for the many non-working migrants that could include children, spouses, and elderly parents. With these figures and with the knowledge that so many of the monfalconesi technicians and skilled laborers had sought assurances that their families could be well accommodated upon arrival, it seems safe to establish a figure of 3500 for Fiume.

Establishing the baseline for other communities is much more difficult. There is scant evidence on the number of monfalconesi at Pola, where many monfalconesi found jobs in the shipyards, though Pola is without doubt the second-most-common location for settlement. My list includes 250 individuals who emigrated to Pola, 217 of whom were heads-of-family known to have brought their dependents with them, but about whose dependents nothing is known. Given the presence of so many whole families, Cernigoi's estimate of 800 feels like an appropriate baseline, though the figure may well have been closer to 1000. Regarding Sarajevo and its environs, which seems to have been the third-most-common destination, especially populated by the youth emigrants of 1946, Silvano Cosolo recalls living in what he terms a "colony" of monfalconesi, with 200 working alongside him in the railcar workshops alone as early as winter $1946 / 47 .{ }^{9}$ With this, a figure of 250-300 seems likely for Sarajevo. Making estimates for the other, less common migration destinations is nearly impossible, though it is known that in many cities (Maribor, Ljubljana, Jesenice, Belgrade, Spalato, Zagreb), there were sufficient Italian migrants to warrant the creation of Italian cultural circles. Each of these locations likely served as the home of 50-200 monfalconesi transplants. ${ }^{10}$ Finally, dispersed throughout the country in various worksites that stretched from Bosnia (Tuzla and Kragljevica) to Slovenia (Kočevje) to Croatia (Mali Losinj,

\footnotetext{
the PCI's later estimate, Bersa claimed in June 1947 that 2500 workers from the soon-to-be-reconstituted Gorizia Province had left for Yugoslavia. Bersa, "Relazione del Comp. Ruggero Bersa," 15 June 1947, op. cit.

${ }^{9}$ Cosolo, Amare... Sarajevo, 47-48.

${ }^{10}$ Consul Pinto estimated that roughly 1000 Italians had migrated clandestinely to Zagreb by early 1948, for example, though, based on the wider body of documents, monfalconesi appear to have been a minority there. Console Pinto, "Connazionali venuti in Jugoslavia senza passaporto ed emigrazione clandestina" (Tel. N. 79/21), 11 March 1948, op. cit.
} 
Koper, and Porec) were some 100-200 others, more often than not young, single migrants.

In addition to tracking numbers, my list allows me to provide at least some basic statistical data about the Monfalconese migrant community. The tables and charts below tell that story. 
Table 2. Decade of Birth of Monfalcone Emigrants:

\begin{tabular}{|l|l|l|}
\hline Decade & Number & Percentage \\
\hline Before 1900 & 99 & $10.55 \%$ \\
\hline $\mathbf{1 9 0 0 s}$ & 220 & $23.45 \%$ \\
\hline $\mathbf{1 9 1 0 s}$ & 258 & $27.51 \%$ \\
\hline $\mathbf{1 9 2 0}$ & 291 & $31.02 \%$ \\
\hline $\mathbf{1 9 3 0}$ & 35 & $3.73 \%$ \\
\hline $\mathbf{1 9 4 0}$ & 35 & $3.73 \%$ \\
\hline Total & 938 & $100.00 \%$ \\
\hline
\end{tabular}

Note: Of the 938 emigrants whose birthdate is known, the oldest was born in 1875. There were 17 infants (born 1945 or later).

\section{Chart 1. Migration Destination in Yugoslavia:}

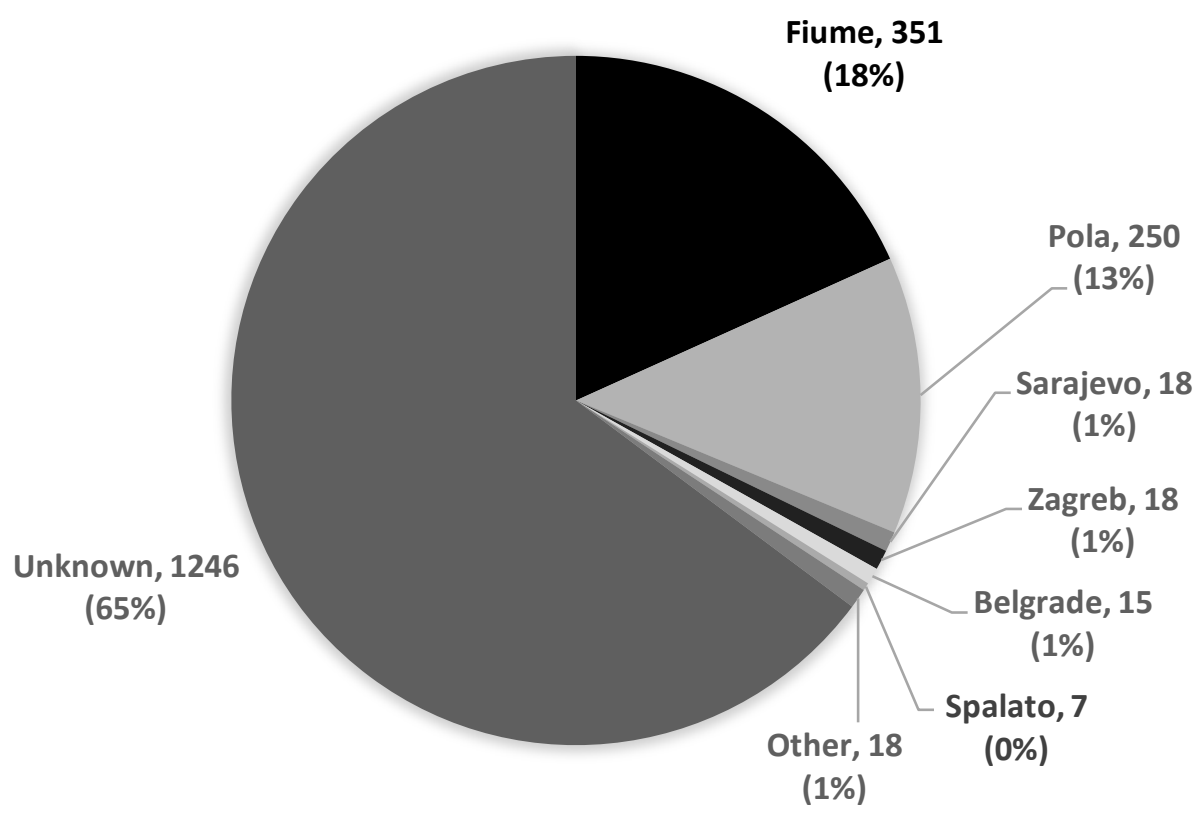

Note: data taken from 1923 emigrants known by name. 
Chart 2. Migrants to Fiume with Unaccounted-For Families:

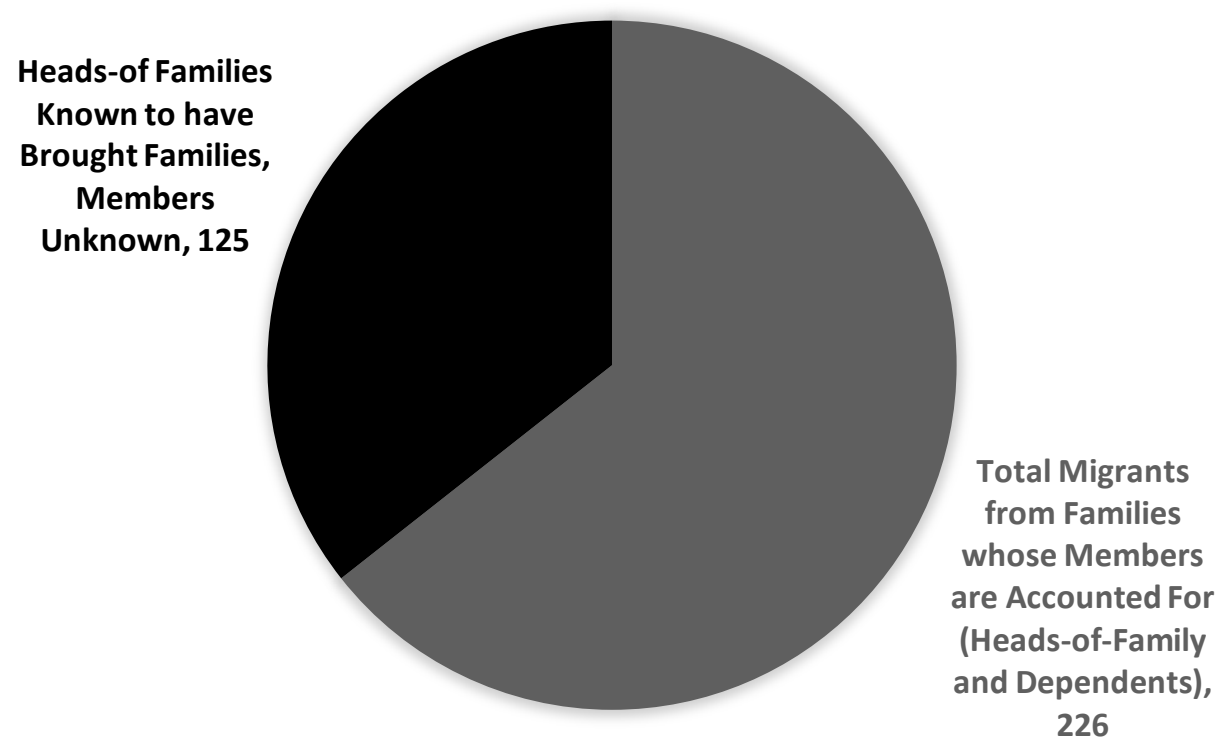

Note: Based on the 351 individually-identified migrants known to have settled in Fiume.

Chart 3. Migrants to Pola with Unaccounted-For Families:

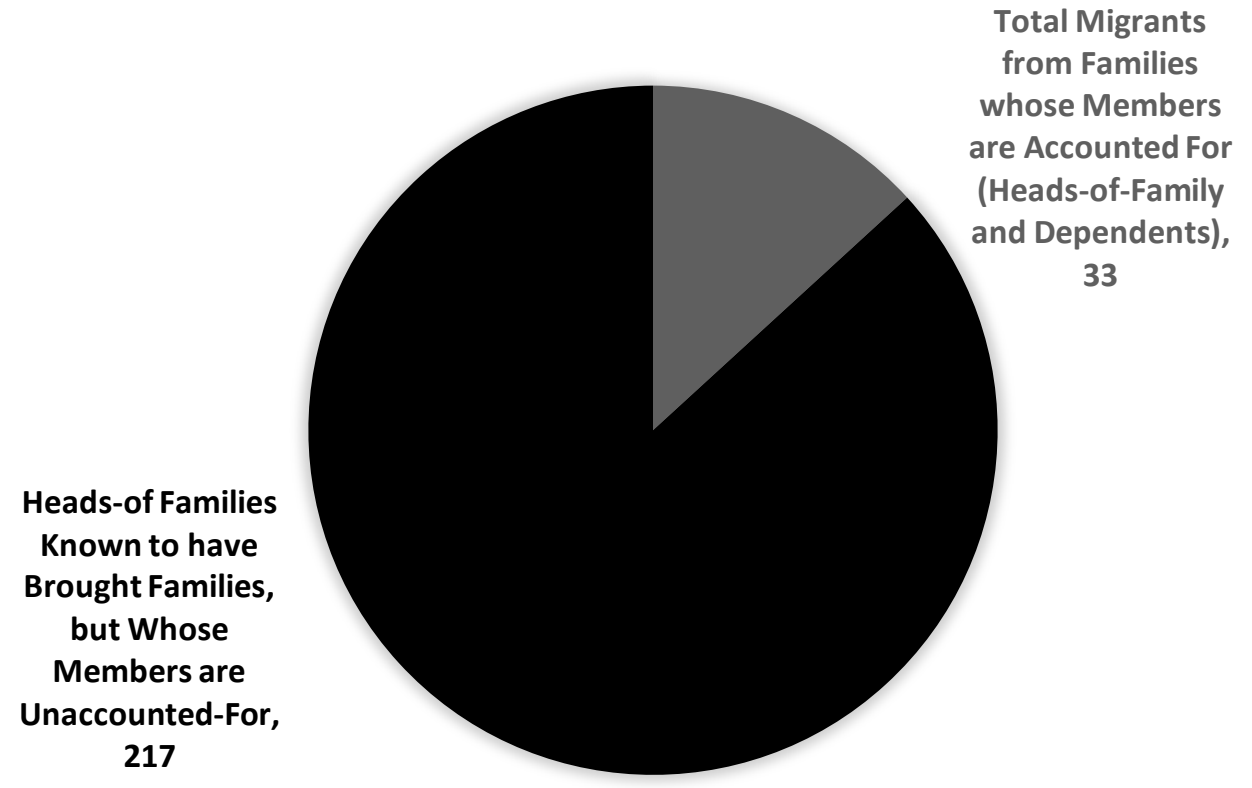

Note: Based on the 250 individually-identified migrants known to have settled in Pola. 


\section{Chart 4. Primary Occupation of Monfalconese Migrants:}

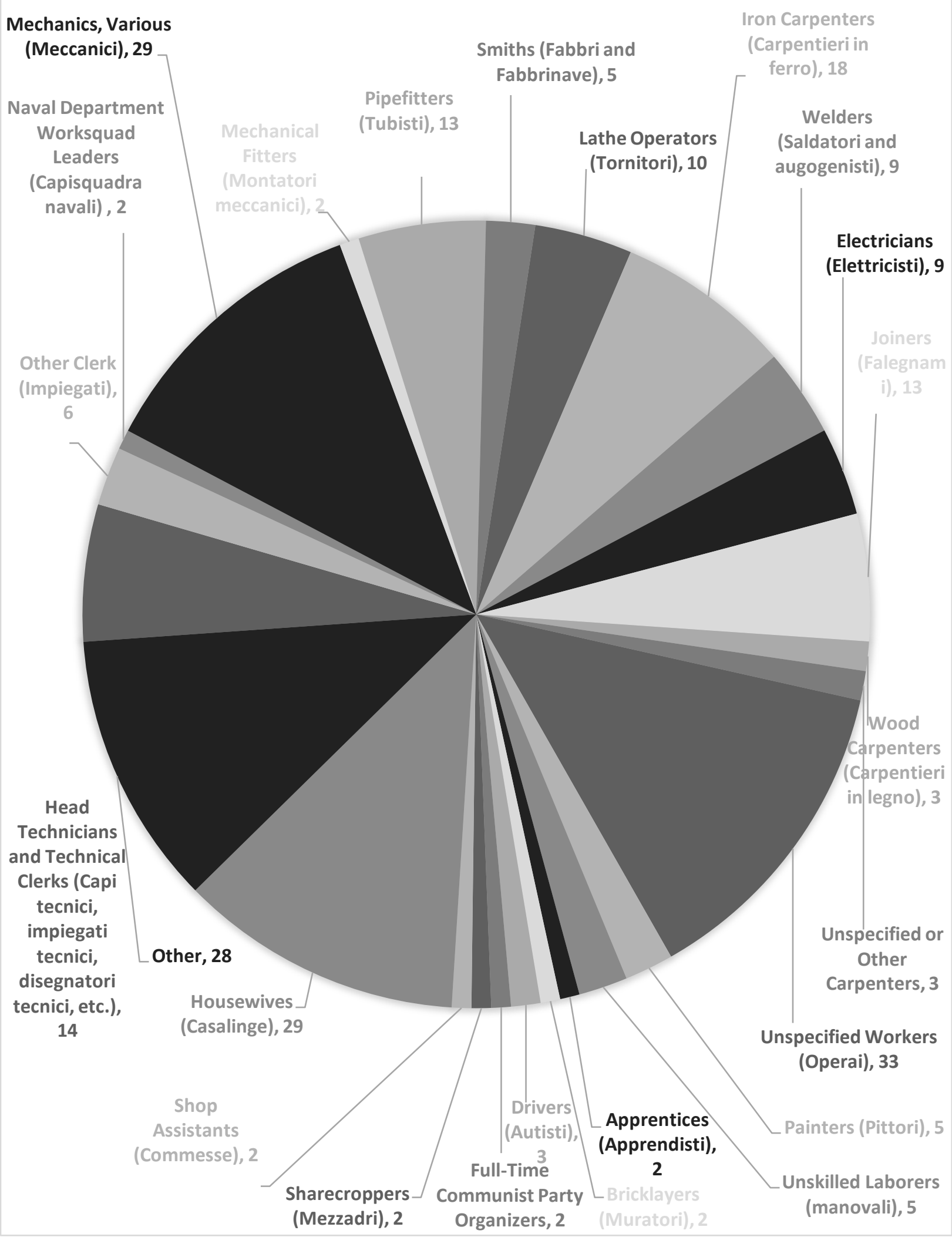

Note: Of the 249 migrants whose occupations are definitively known. 
Figures (Photographs and Maps) 


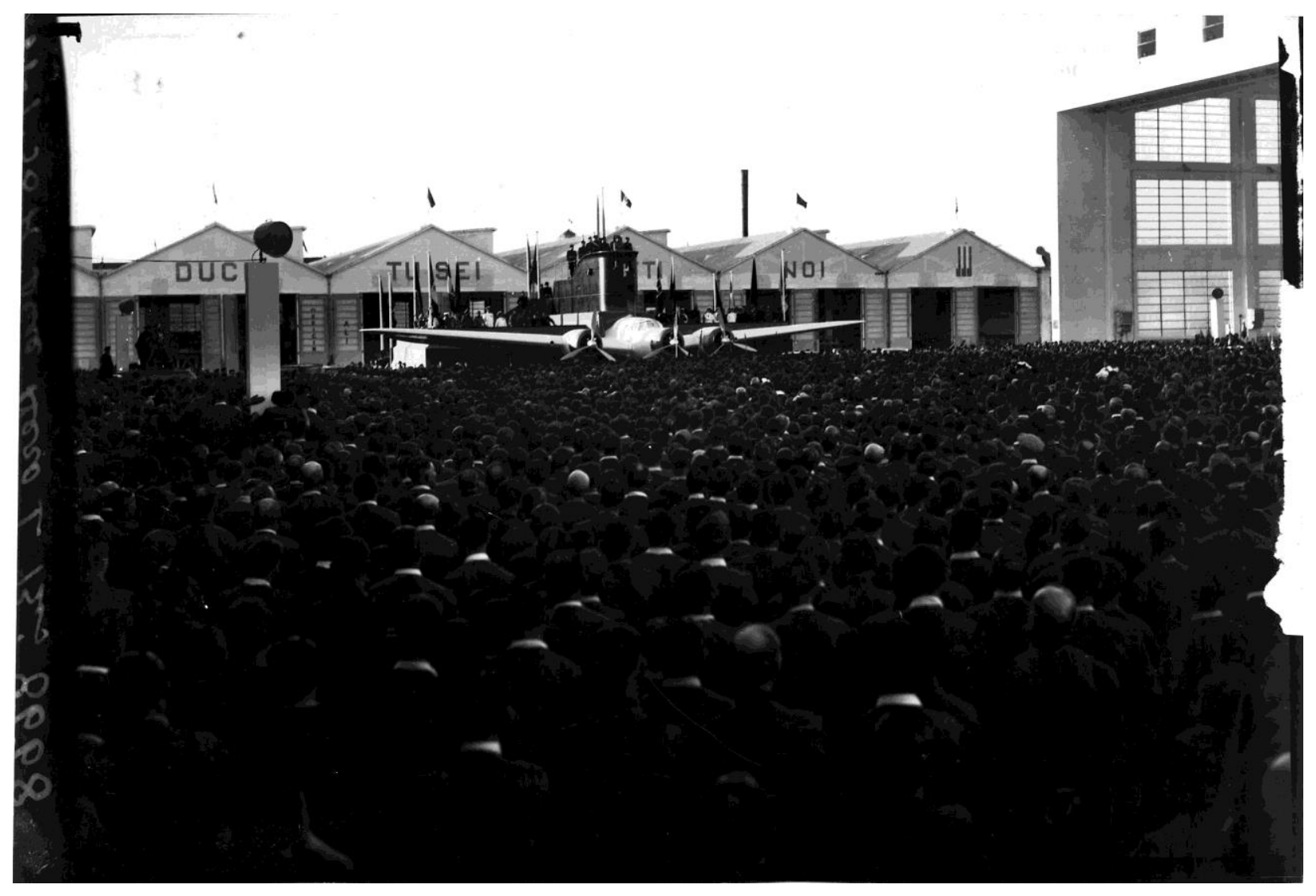

Figure 1. Mussolini speaks to a crowd of workers at the Monfalcone shipyard, 19 September 1938. "Mussolini parla ai lavoratori del Cantiere (18 settembre 1938)." Photo courtesy of the Museo Cantieristica di Monfalcone's digital multimedia gallery (www.mucamonfalcone.it). The date in the MUCA archive photo title is incorrect. 


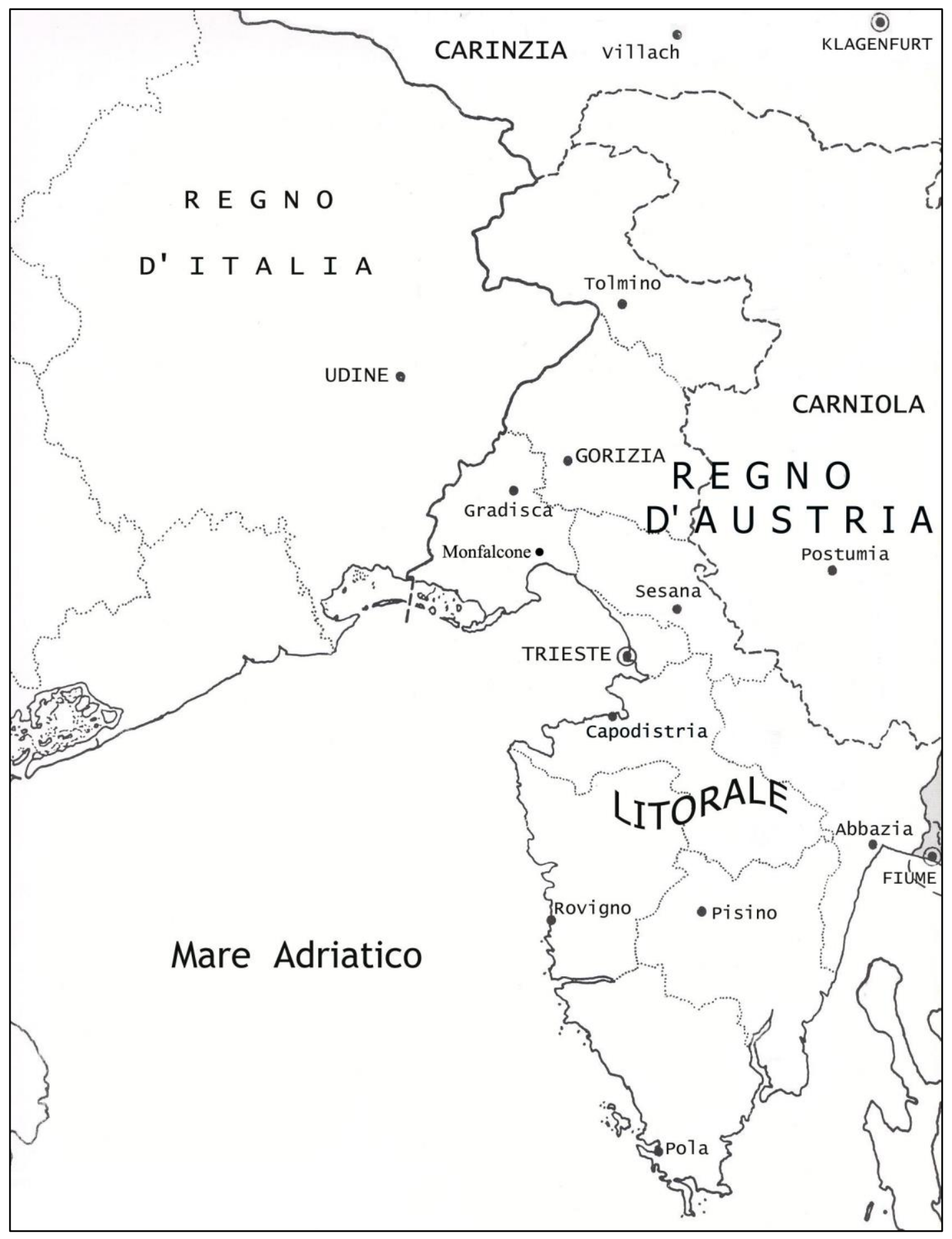

Figure 2. Map of Friuli and Venezia Giulia before the Great War. The Isonzo River flows southward through Gorizia, passing just to the east of Gradisca and to the west of Monfalcone, emptying into the Adriatic. "Il Litorale Adriatico prima della grande guerra." Map courtesy of the Museo Cantieristica di Monfalcone's digital multimedia gallery (www.mucamonfalcone.it). 


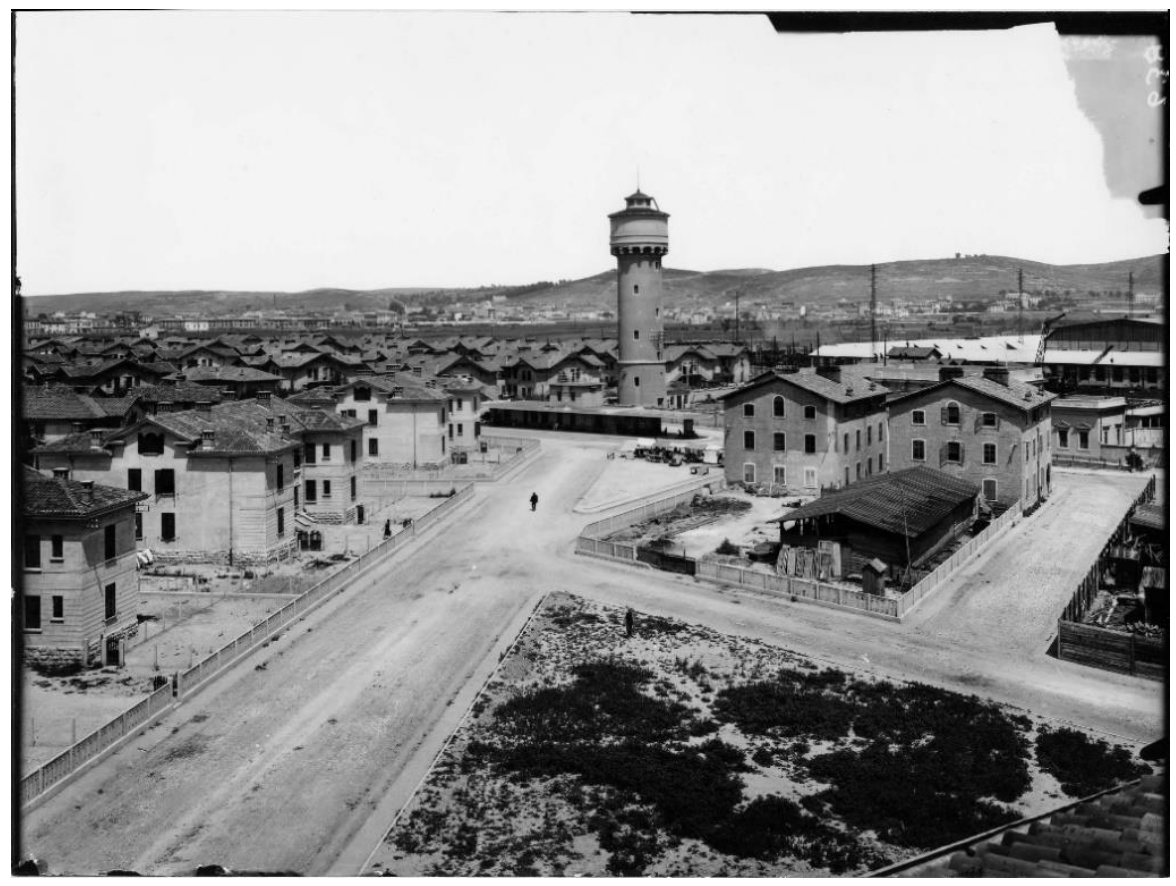

Figure 3. The workers' quarter of Panzano with the shipyard to the right. Notice historic Monfalcone in the background (left), along with the distant Carsic hills. "Quartiere operaio." Photo courtesy of the Museo Cantieristica di Monfalcone's digital multimedia gallery (www.mucamonfalcone.it).

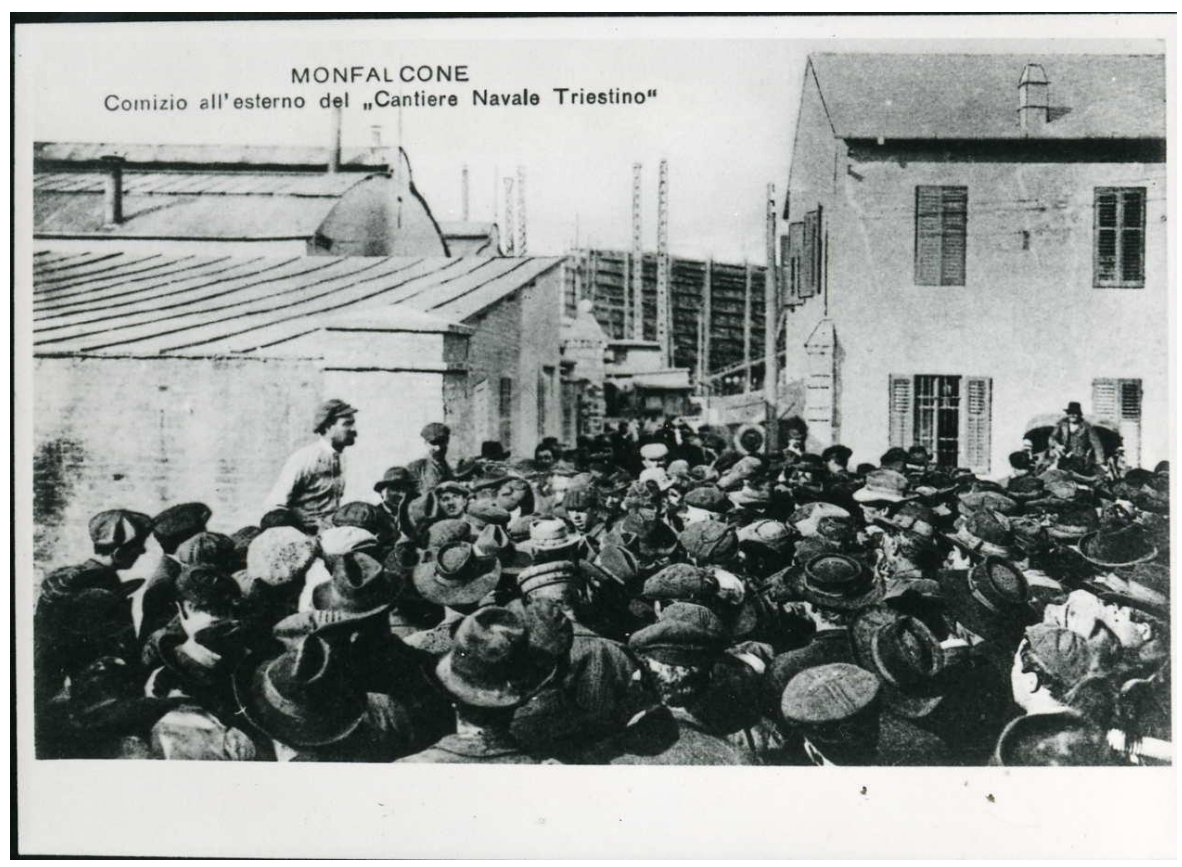

Figure 4. Socialist meeting outside of the Monfalcone shipyard during the biennio rosso (1920). "Comizio socialista all'esterno del CNT, 1920 circa." Photo courtesy of the Museo Cantieristica di Monfalcone's digital multimedia gallery (www.mucamonfalcone.it). 


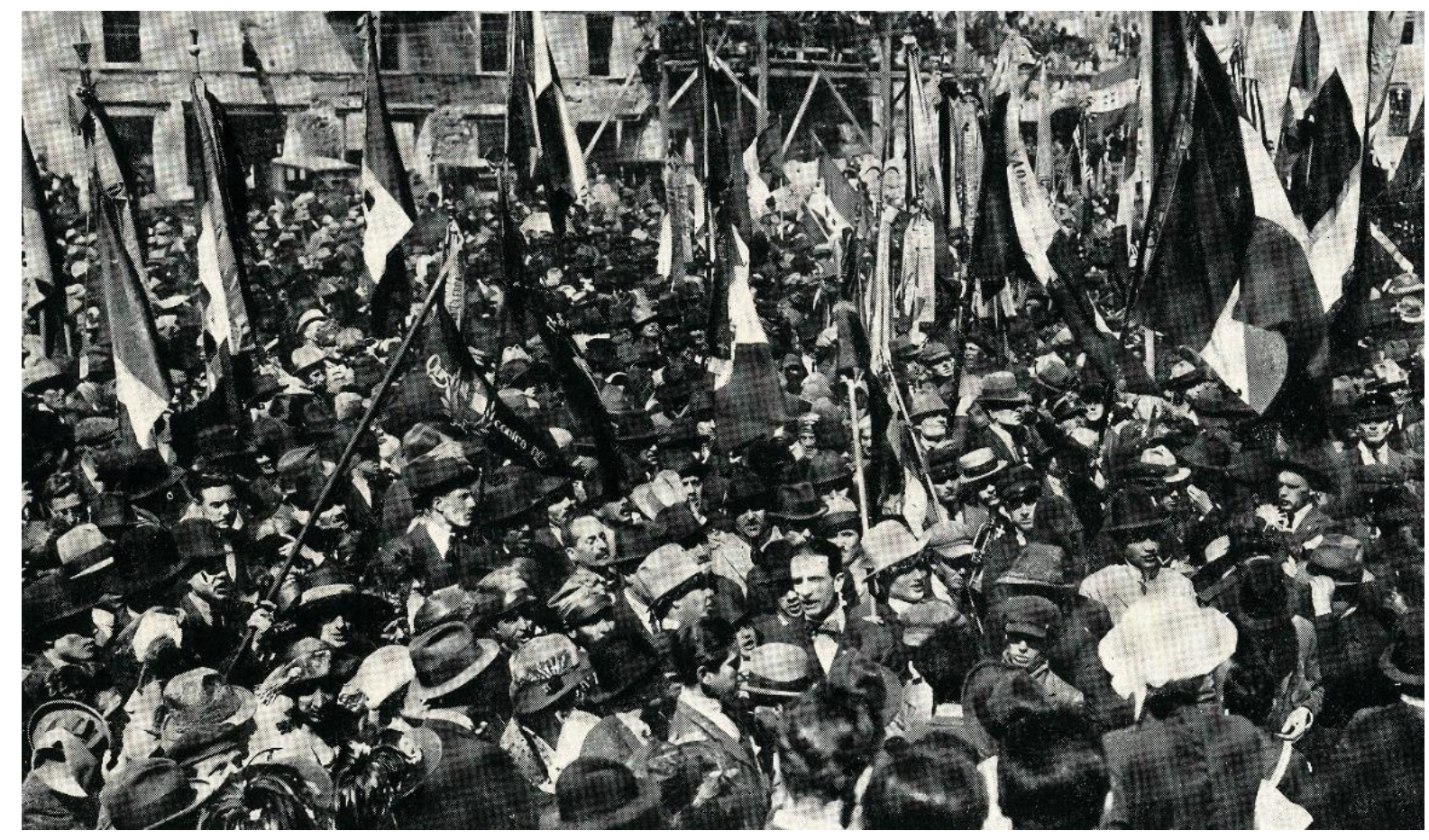

Figure 5. Monfalconese Fascists surround Francesco Giunta (bottom center, facing the camera), early 1920s. "Fascisti monfalconesi attorniano Francesco Giunta." Photo courtesy of the Museo Cantieristica di Monfalcone's digital multimedia gallery (www.mucamonfalcone.it). 


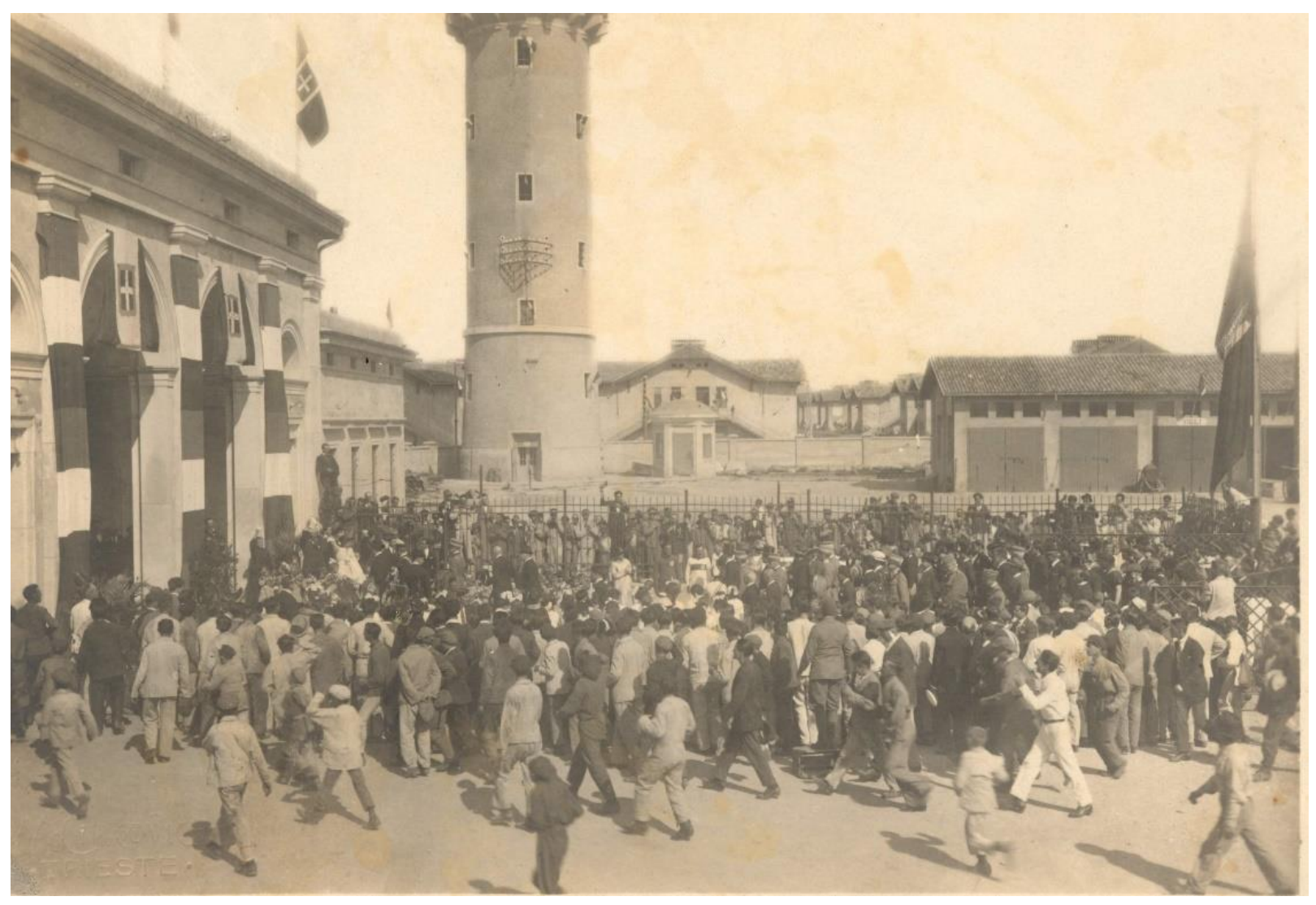

Figure 6. Workers gather outside the CRDA in anticipation of an anti-Fascist, anti-war march, 26 July 1943. "Manifestazione antifascista ai CRDA di Monfalcone, 26 luglio 1943." Photo courtesy of the Museo Cantieristica di Monfalcone's digital multimedia gallery (www.mucamonfalcone.it). 


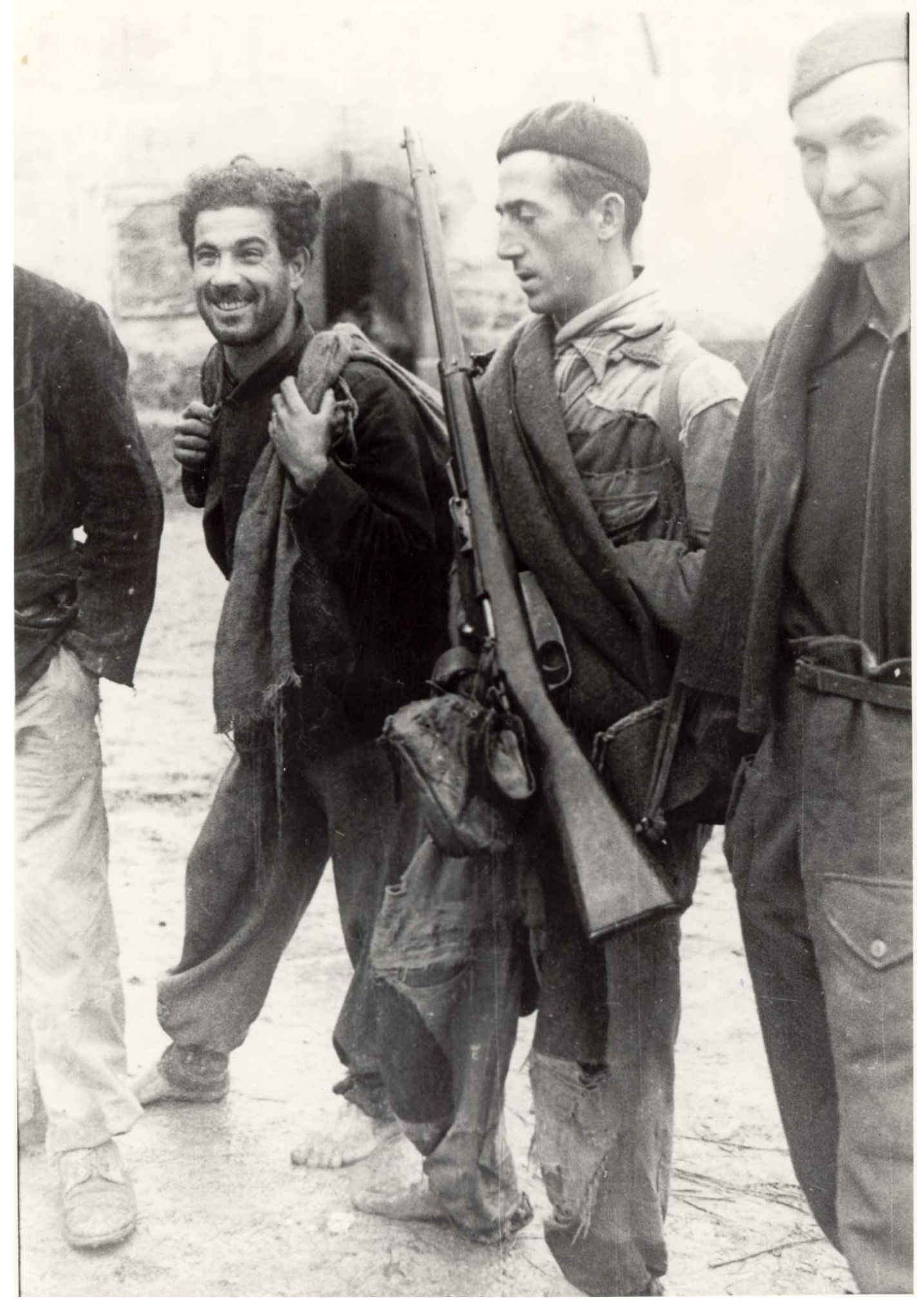

Figure 7. Partisans of the Fontanot Brothers Brigade. Notice the two barefooted partisans. "Brigata Fratelli Fontanot [3]." Photo courtesy of the Museo Cantieristica di Monfalcone's digital multimedia gallery (www.mucamonfalcone.it). 


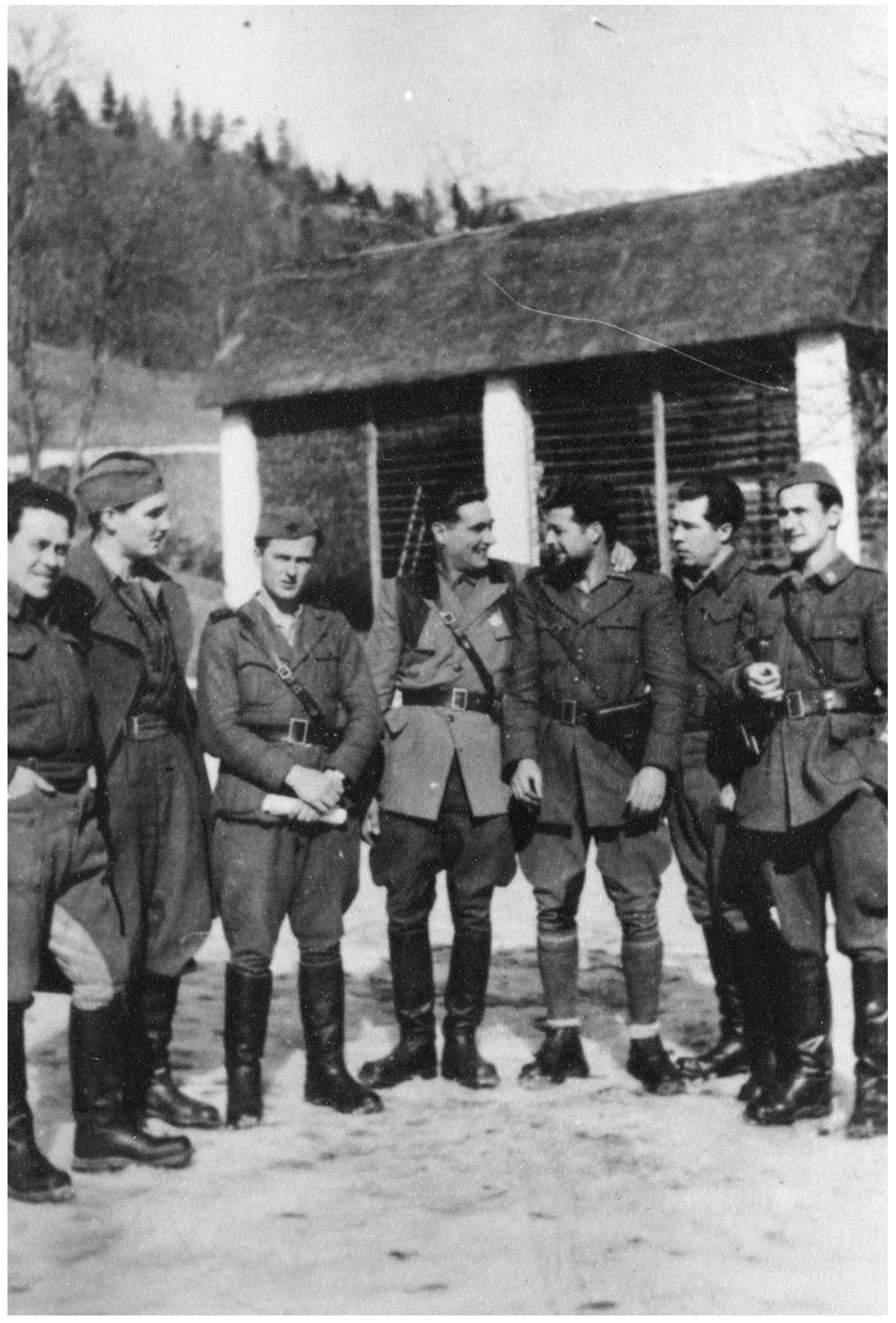

Figure 8. The Central Command of the Garibaldi Division-Natisone along with Yugoslav Partisan officers. The commandant, the monfalconese and CRDA worker Mario Fantini (Sasso), is third from the right, looking at the division's political commissar, Giovanni Padoan (Vanni) of Cormons. "Comando Divisione Garibaldi Natisone." Photo courtesy of the Museo Cantieristica di Monfalcone's digital multimedia gallery (www.mucamonfalcone.it). 


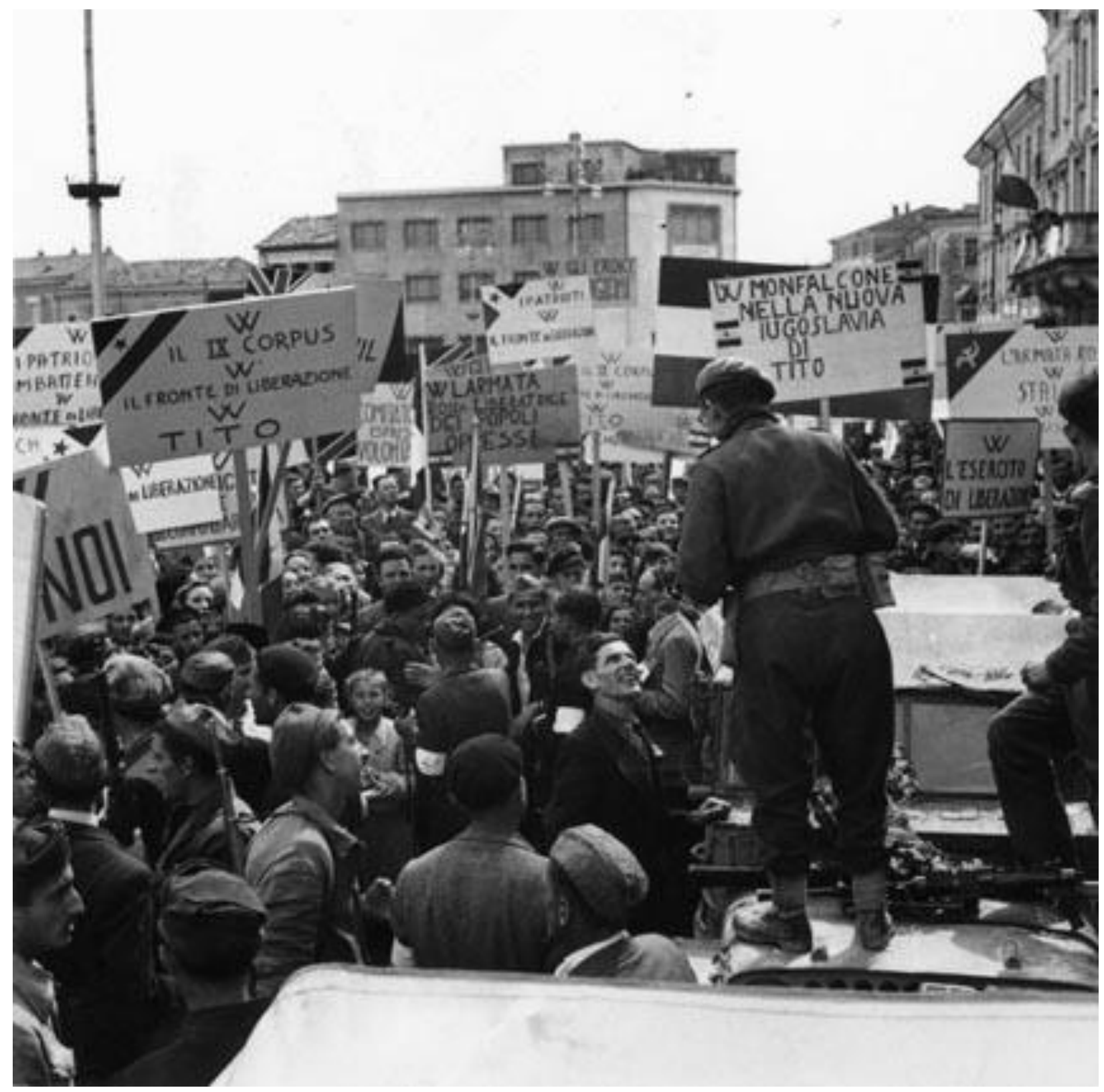

Figure 9. Monfalconesi greet the Yugoslav troops, 1 May 1945. Notice the sign in the center-right: "Monfalcone in the New Yugoslavia of Tito." "The Celebrations of the IX Corpus." Photo courtesy of the Museo Cantieristica di Monfalcone's digital multimedia gallery (www.mucamonfalcone.it). 


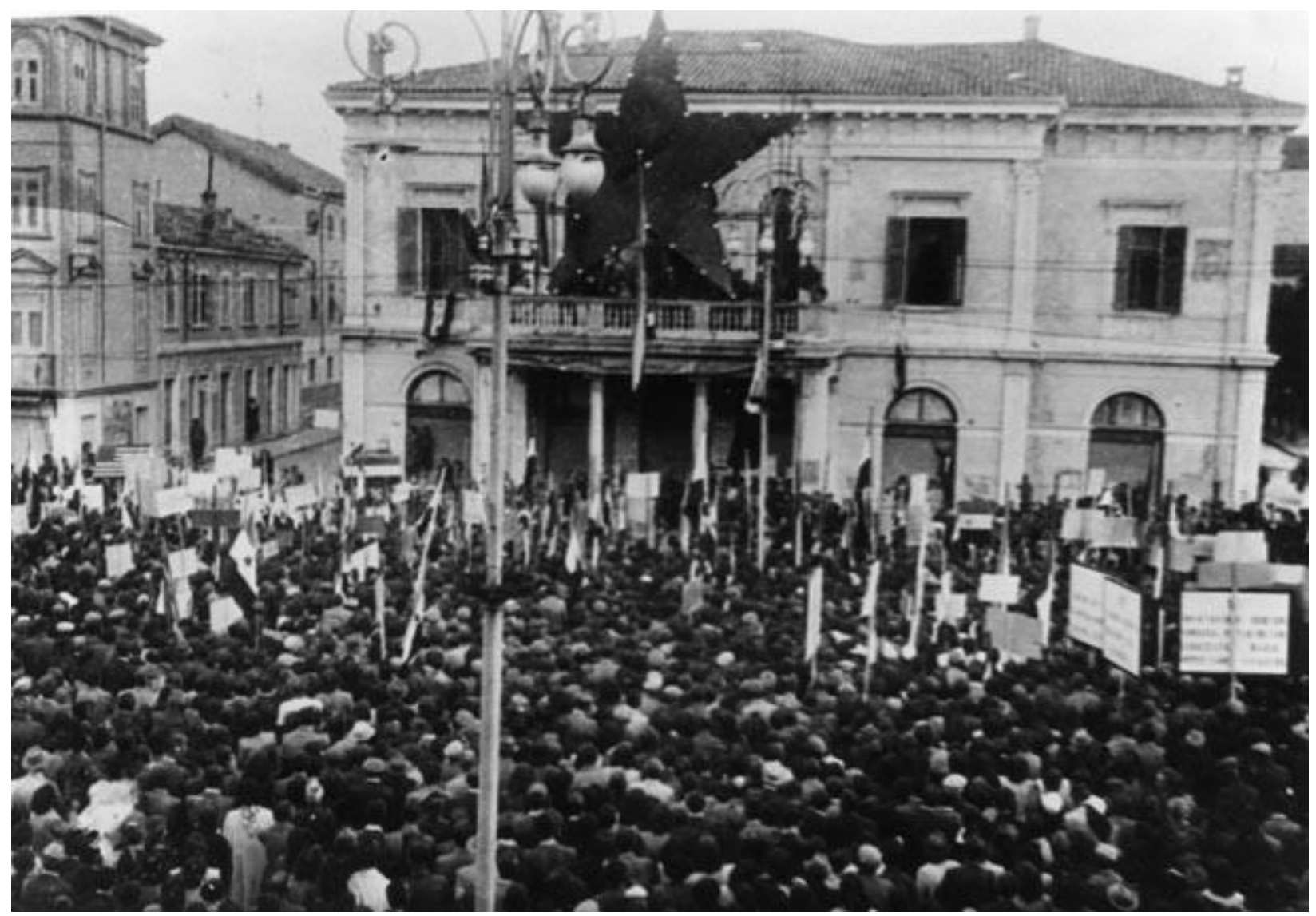

Figure 10. A crowd of pro-Yugoslavs gather outside Monfalcone City Hall shortly after liberation, 1 May 1945. Note the giant red star and the Yugoslav and Italian red-starred flags. "Festeggiamenti." Photo courtesy of the Museo Cantieristica di Monfalcone's digital multimedia gallery (www.mucamonfalcone.it). 


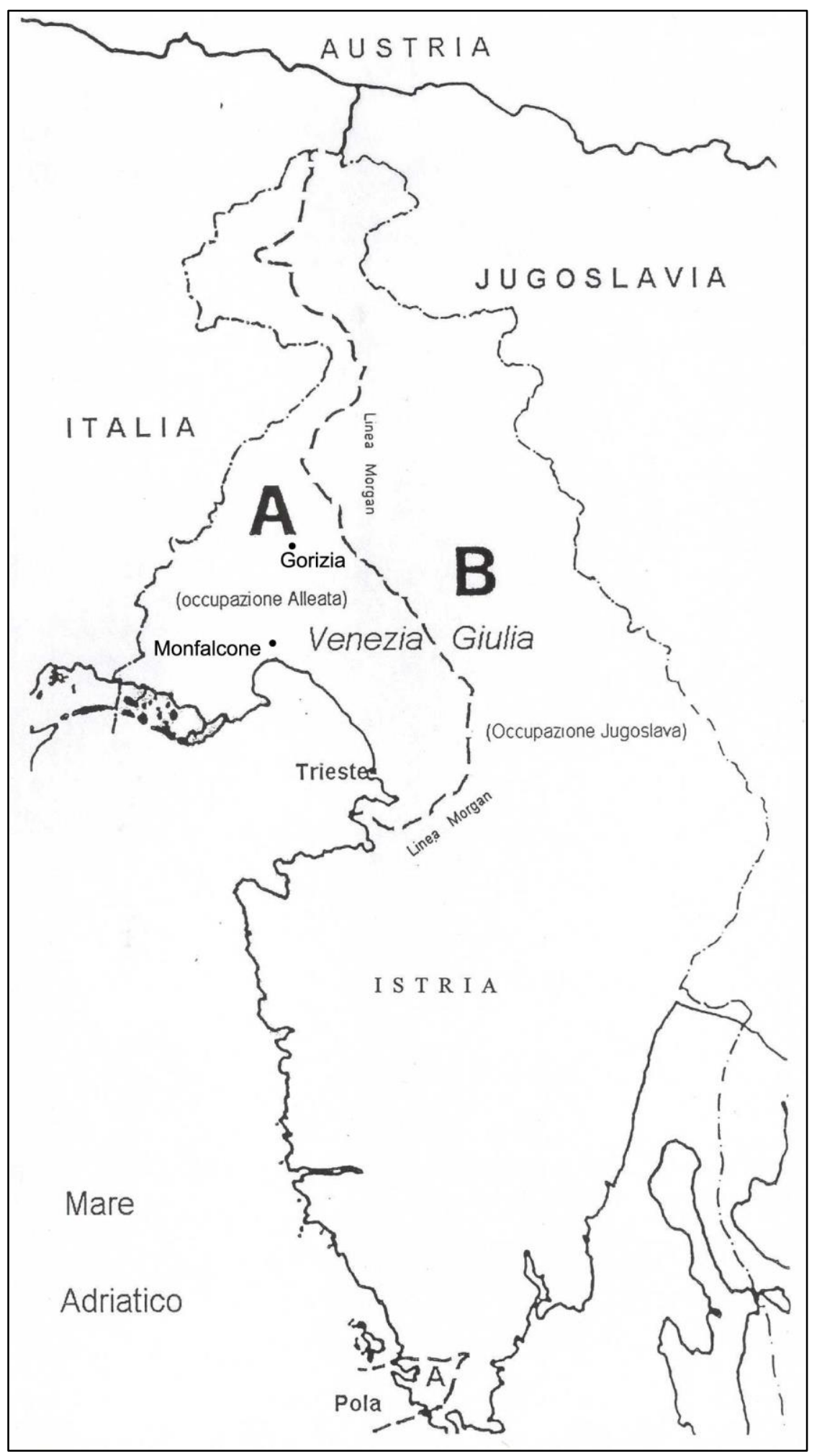

Figure 11. Map of the two military occupation zones as they existed between June 1945 and September 1947. Monfalcone is part of Zone A, administered by the AMG. "La 'Linea Morgan' con la Zona A e B della Venezia Giulia." Map courtesy of the Museo Cantieristica di Monfalcone's digital multimedia gallery (www.mucamonfalcone.it). 


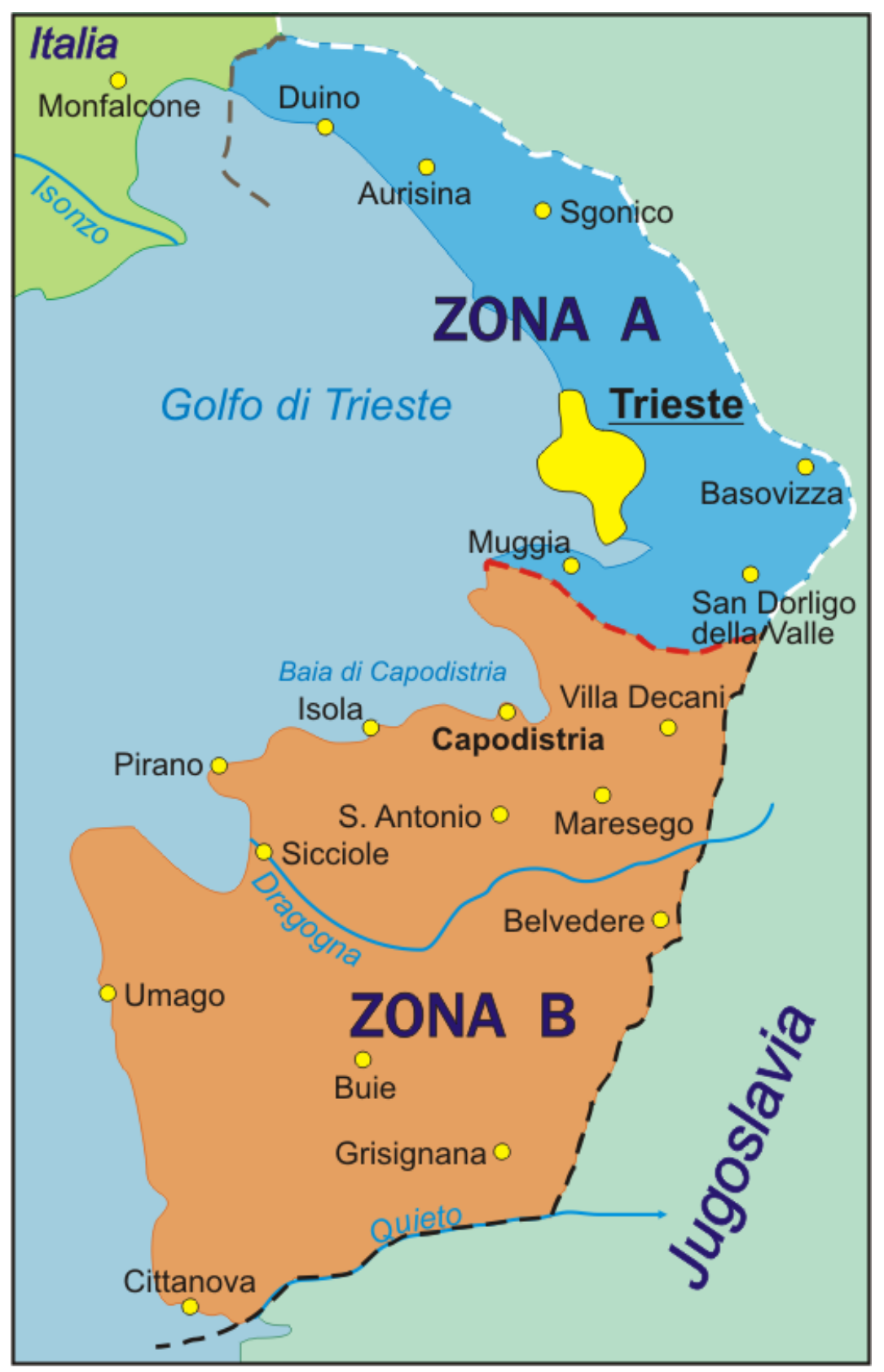

Figure 12. Map of the Free Territory of Trieste (1947-1954) showing Monfalcone as part of Italy's reconstituted Gorizia Province. Despite plans for the entire Free Territory to transition to selfgovernment, in practice Zone A remained under Anglo-American administration until 1954, Zone B remaining under Yugoslav administration. "Carta del Territorio libero di Trieste 1947-1954." Public domain source taken from WikiCommons. https://commons.wikimedia.org/wiki/File: Territorio_libero_di_Trieste_carta.png. Retrieved 14 August 2017. 


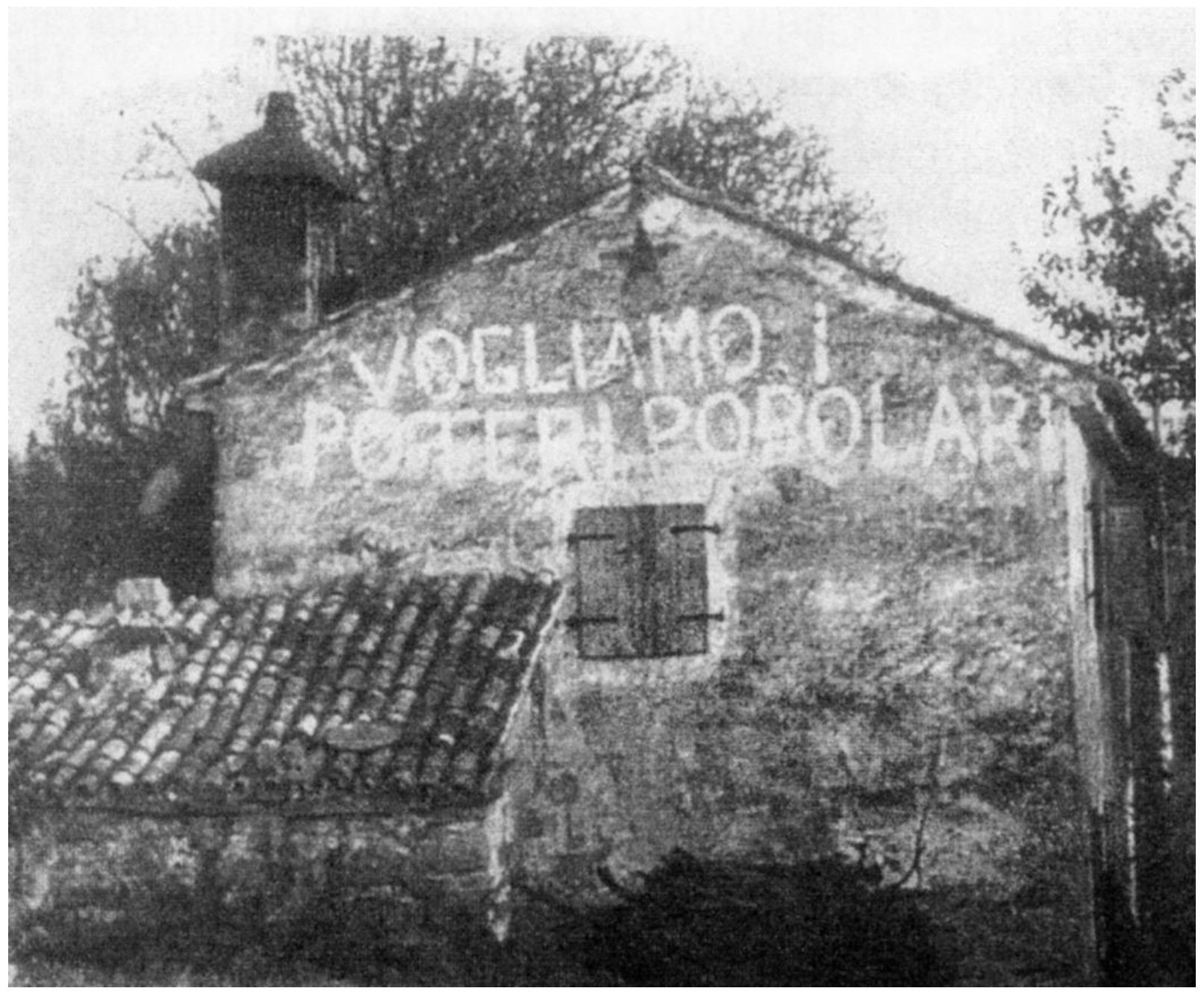

Figure 13. The common pro-Yugoslav slogan "we want popular power" adorns the wall of a Zone A home, paired with a red star. The photo is without date, but it is likely from the time of the UN Delegation's visit in March 1946. Photo courtesy of the Museo Cantieristica di Monfalcone's digital multimedia gallery (www.mucamonfalcone.it). 


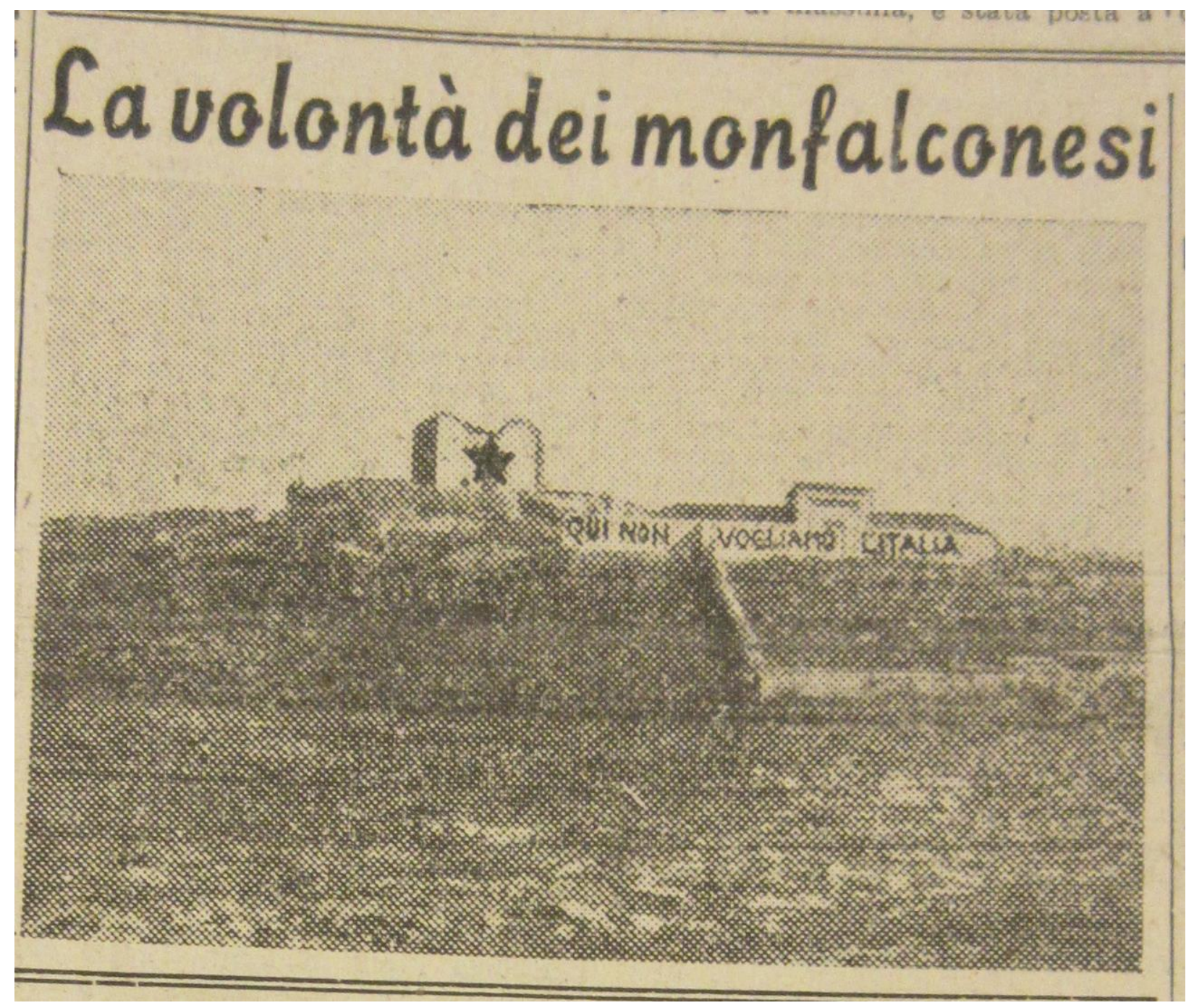

Figure 14. "The Will of the Monfalconesi." In this article, Il Lavoratore shows the Rocca bearing a red star and the phrase "we don't want Italy here," as seen from Monfalcone's central piazza. Though this image is from October 1946, the Rocca had borne similar symbols and phrases from the moment of liberation. Il Lavoratore, "La volontà dei monfalconesi," 5 October 1946. 


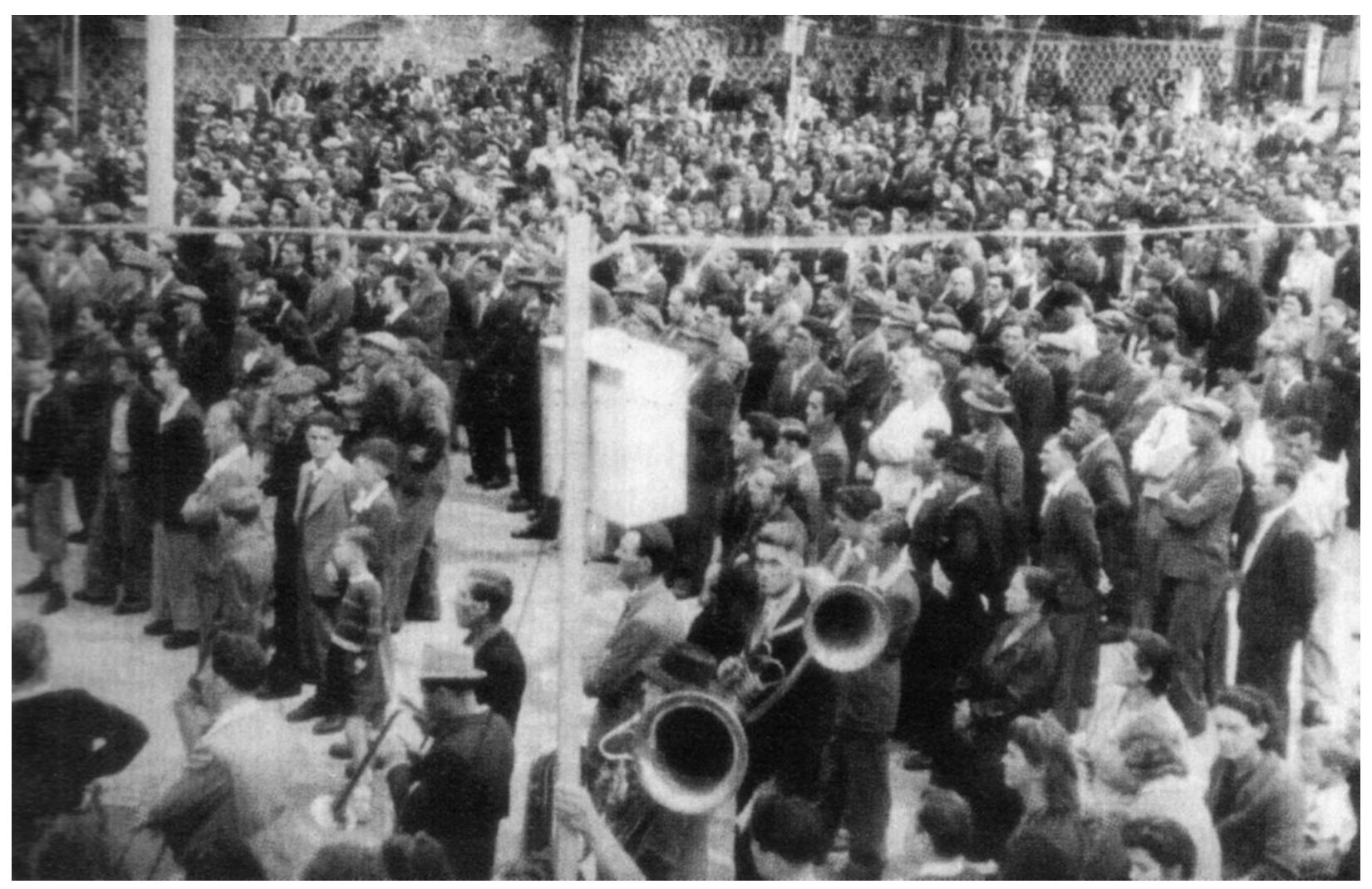

Figure 15. The pro-Yugoslav residents of the outlying village of Pieris gather in the village's central piazza as part of an UAIS demonstration on an unknown date. Photo courtesy of the Museo Cantieristica di Monfalcone's digital multimedia gallery (www.mucamonfalcone.it). 


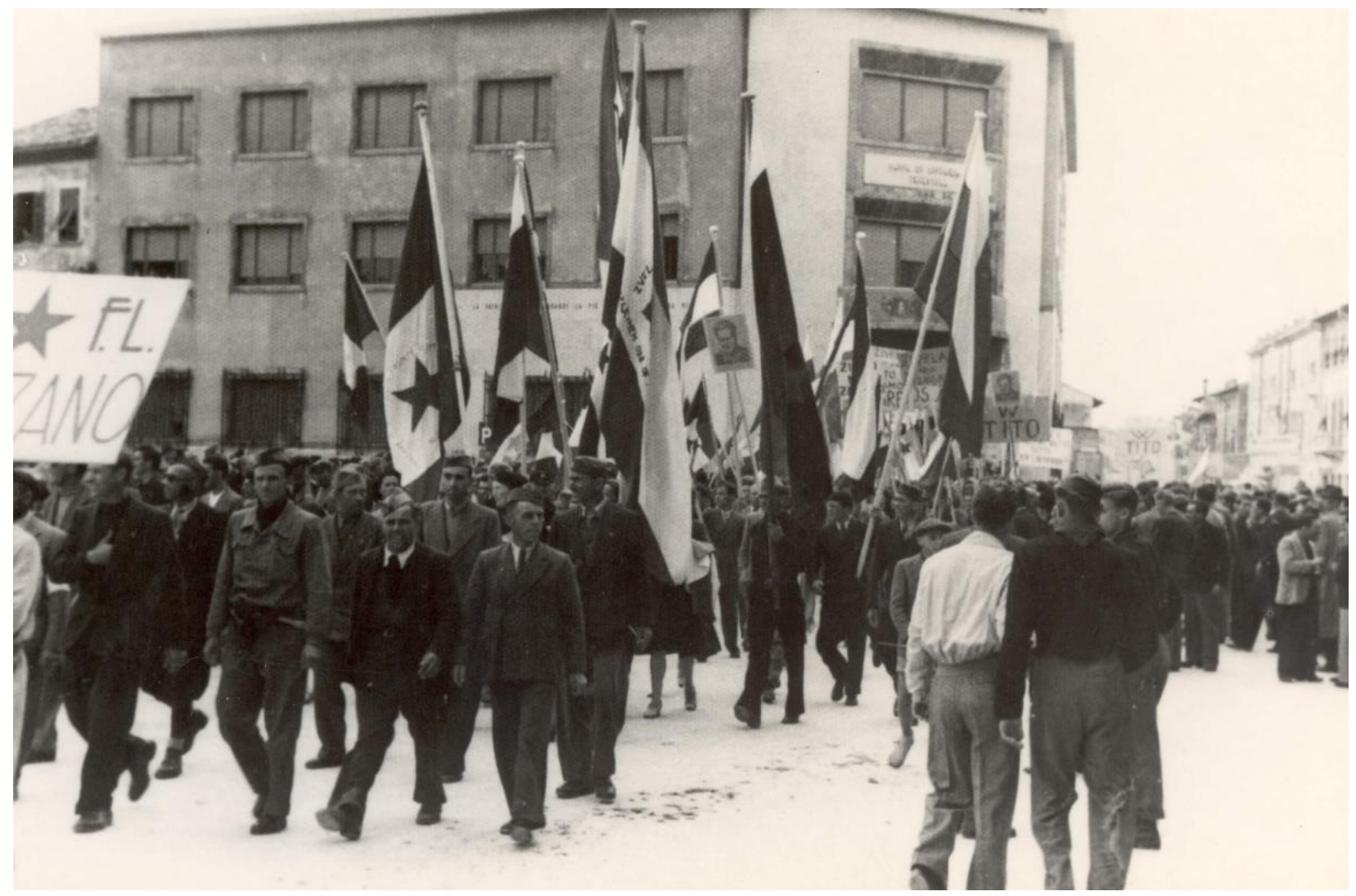

Figure 16. A pro-Yugoslav procession passes through Monfalcone on an unknown date. Note the prominence of red-starred tricolors, Tito portraits, and posters bearing the phrase "long live Tito!" Though it is cut off, the poster on the left seems to indicate that the marchers at the front of the column belonged to the Liberation Front (OF/FL) partisan network of Panzano. Photo courtesy of the Museo Cantieristica di Monfalcone's digital multimedia gallery (www.mucamonfalcone.it. 


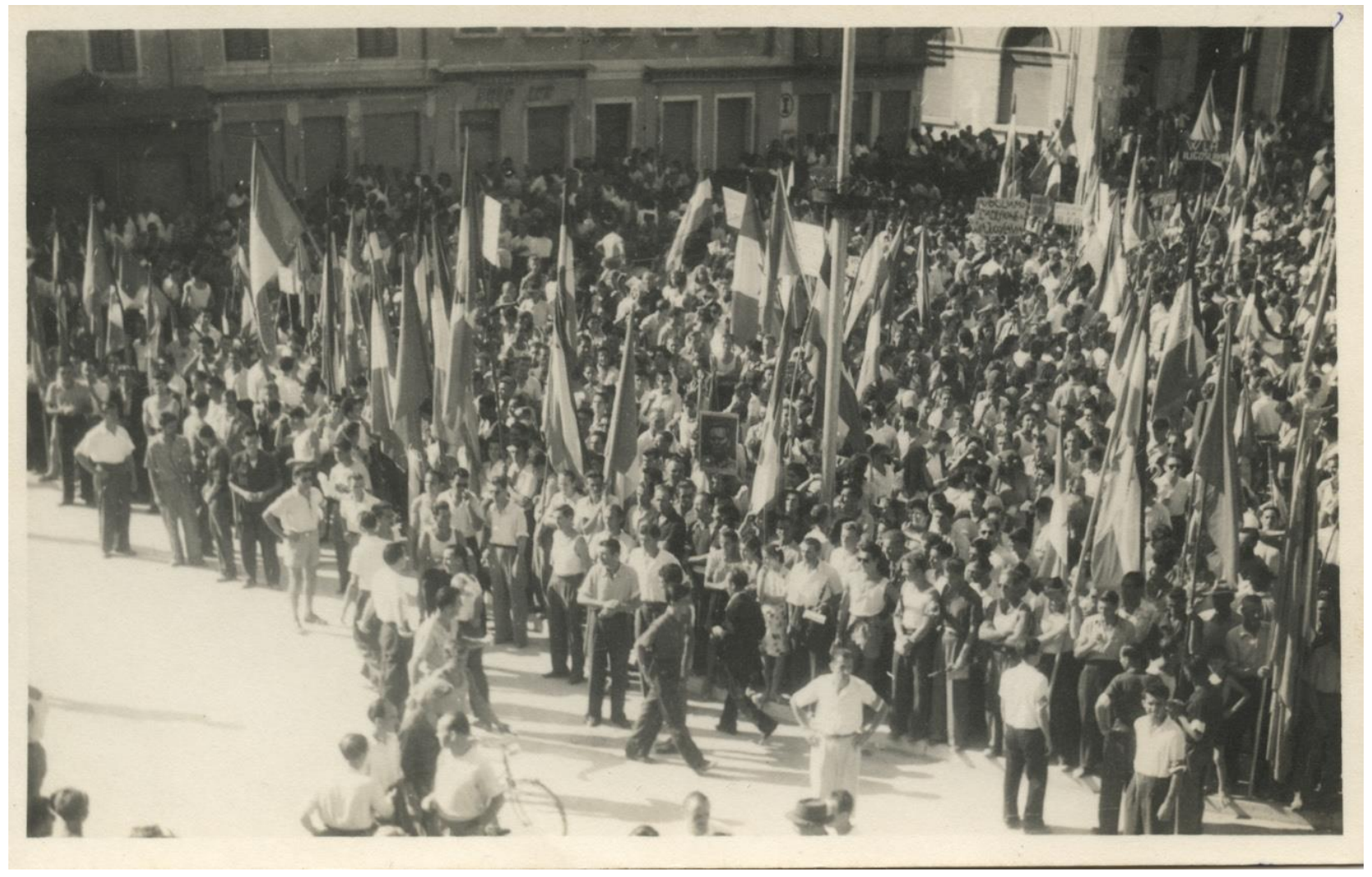

Figure 17. The pro-Yugoslavs of the Monfalconese gather in Monfalcone's central piazza for a mass demonstration on 11 August 1946. Note the red stars on the various tricolors, as well as the portrait of Tito in the front center of the crowd. Unknown photographer, IFSML, Fondo Riccardo Giacuzzo, b 3, serie 21, n 265, G01/00031/0021/0000/0000/00001. 


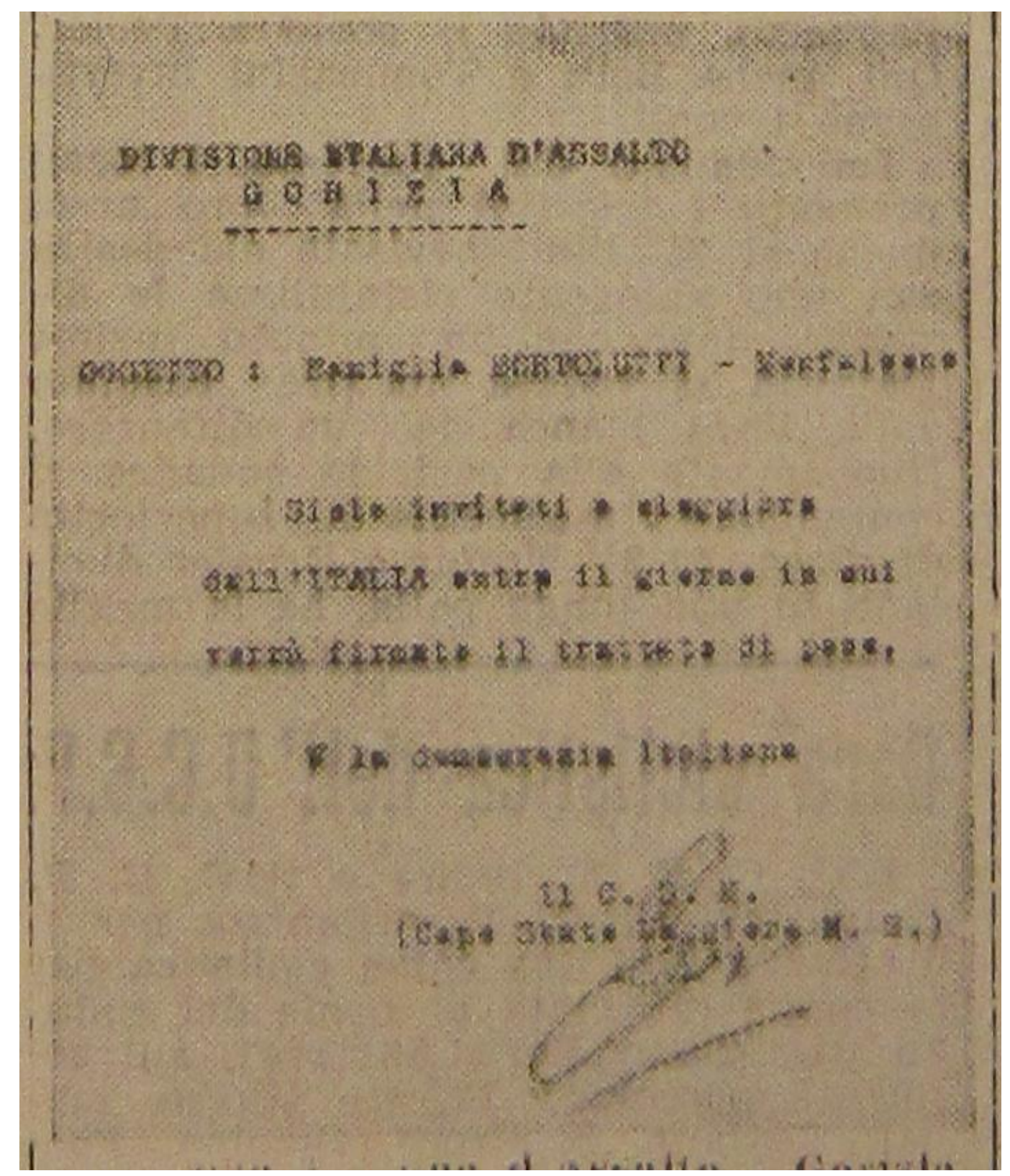

Figure 18. Reproduction of a threat letter delivered to the home of Sergio Bortolutti, head of the UAIS in the Monfalconese, in September 1946. Bortolutti and his family are "invited to depart from ITALY before the day on which the Peace Treaty is signed." The letter is signed by the Divisione Gorizia, whose role in the wider terrorism campaign is disputed. Il Lavoratore, "Le bombe non servono," 30 September 1946. 


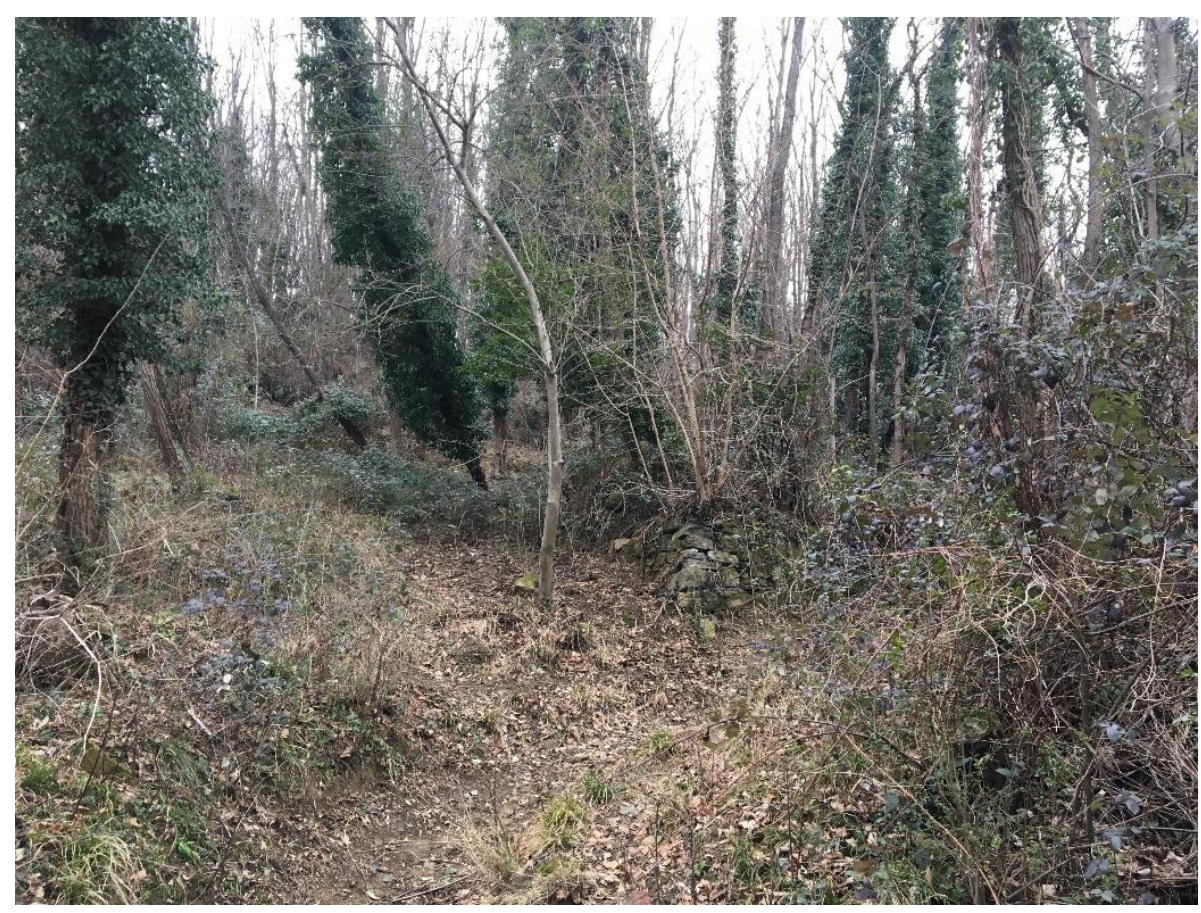

Figure 19. A photograph of the terrain between Gorizia and San Floriano, where many Italians continued to expatriate to Yugoslavia well into 1948. It is easy to see how the hilliness of the terrain and the density of the foliage would limit the effectiveness of border patrols. Photo taken by the author, February 2017.

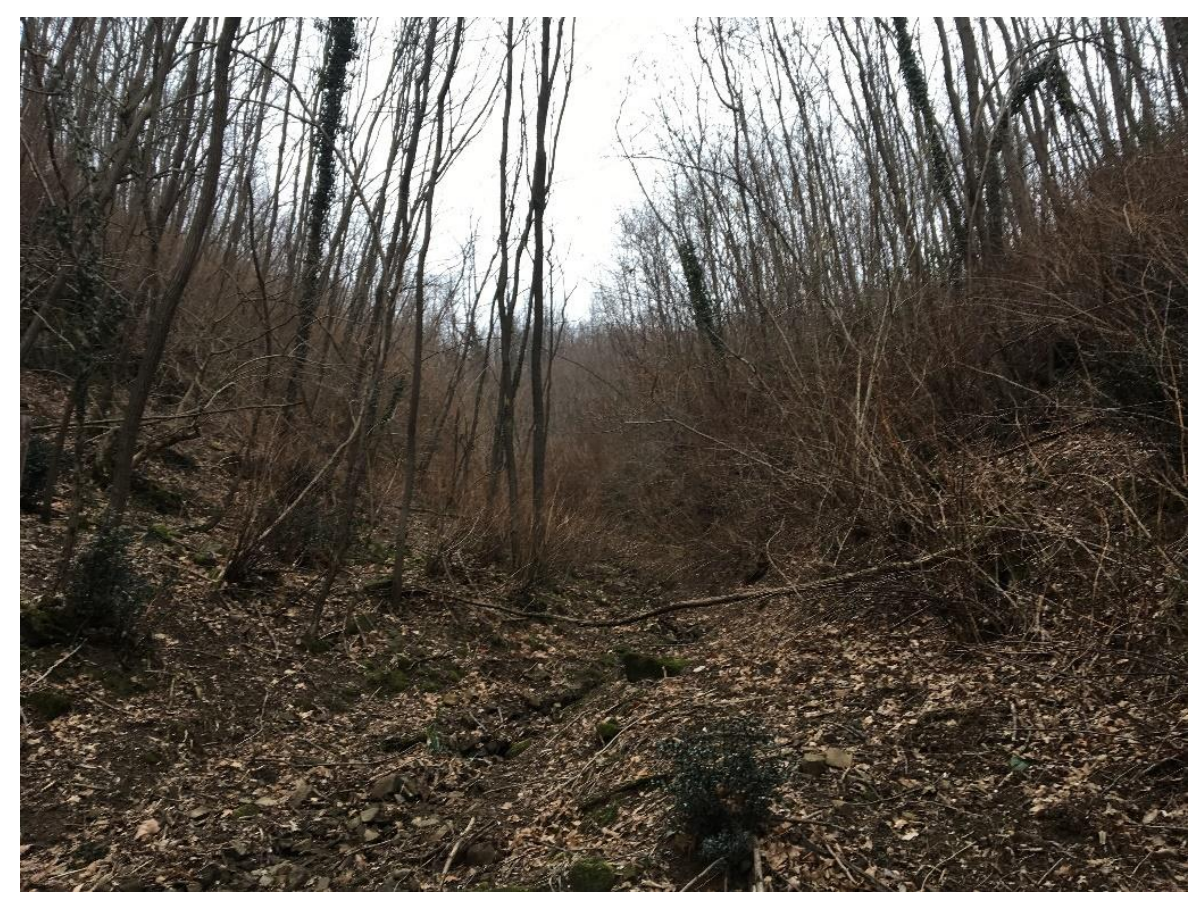

Figure 20. Another photo of the terrain between Gorizia and San Floriano. Photo taken by the author, February 2017. 


\section{Bibliography}

\section{Primary Source}

\section{Archives}

Archivio centrale dello stato (ACS), Rome, Italy

Casellario Politico Centrale (CPC)

Fondo IRI (Istituto per la ricostruzione industriale)

Numerazione Nera (Pratiche degli uffici)

Numerazione Rossa (Pratiche societarie)

CRDA: Cantieri riuniti dell'Adriatico

Ministero dell'Intero (MI)

Direzione Generale Pubblica Sicurezza (DGPS)

Divisione Affari Generali e Riservati (Div AA GG RR)

Anni 1944-1946

Anni 1947-1948

Anno 1949

Categorie Permanenti, A5G: II Guerra, 1940-45

Divisione Affari Riservati (Div AA RR)

Anni 1948-1950

Anni 1951-1953

Anni 1954-1956

Categorie Permanenti, Ctg. Z

Divisione Polizie (DP)

Affari Generali di Polizia Giudiziaria: Sezione Prima, 1943-51

Divisione Servizi Infromativi e Speciali (SIS)

Sezione II: Affari Generali, 1944-49

Segretario del Capo della Polizia: Servizi di Polizia Attiva

Gabinetto

Archivio Generale

Anni 1944-46

Anno 1947

Anno 1948

Anno 1949

Anni 1950-1952

Anni 1953-1956

Presidenza del Consiglio dei Ministri

Gabinetto

Affari Generali, Fascc per categorie

Anni 1944-1947

Anni 1948-1950

Anni 1951-1954

RSI, Fascicoli per categoria, 1943-1945

Segretaria Particolare De Gasperi

Tribunale Speciale per la Difesa dello Stato 


\section{Fascicoli Processuali}

Archivio della memoria at Strade della memoria

Memorie di confine e identità plurime: Il goriziano, 1930-1955, digitized interview collection accessible at http://www.stradedellamemoria.it/.

Trieste dal fascismo agli anni Cinquanta, digitized interview collection accessible at http://www.stradedellamemoria.it/.

Archivio di stato di Gorizia (ASG), Gorizia, Italy

Prefettura, Gabinetto, 1945-1982

Questura di Gorizia, Anno 1948

Archivio di stato di Trieste (AST), Trieste, Italy

Prefettura, Gabinetto, 1923-1952

Archivio di stato di Udine (ASU), Udine, Italy

Prefettura, Gabinetto

Questura, Gabinetto, Disposizioni di massima, Ctg Z2

Archivio generale della Presidenza del Consiglio dei Ministri (AGPCM), Rome, Italy

Fondo Ufficio Zone di Confine (UZC): Sezione II

Gorizia

Trieste

Yugoslavia

Archivio partito comunista (APC) at the Istituto Gramsci (IG), Rome, Italy

Archivio Mosca

Fondo Jugoslavia e Venezia Giulia

Archivio Partito comunista italiano

Direzione Nord: Friuli VG Jugoslavia

Federazioni:

Anno 1947: Gorizia

Anno 1948: Gorizia

Anno 1949: Gorizia

Archivio storico della Biblioteca comunale di Monfalcone (ASBCM), Monfalcone, Italy

Archivio storico diplomatico (ASD) at the Ministero Affari Esteri (MAE), Rome, Italy

Affari Politici, 1931-45: Jugoslavia

Affari Politici, 1946-50: Jugoslavia

Arhiv Republike Slovenije (AS), Ljubljana, Slovenia

AS 1570: Okrožni komite Komunistične partije Julijske krajine za tržaško okrožje

AS 1581: Glavni odbor Enotnih sindikatov Svobodnega tržaškega ozemlja

AS 1815: Okrajni narodnoosvobodilni odbor Tržič (Monfalcone)

AS 1818: Pokrajinski narodnoosvobodilni odbor za Slovensko primorje in Trst, 1944-1947 
European Resistance Archive

The Resistance Movement in Italy, collection of digitized interviews accessible at https://www.resistance-archive.org/en/resistance/italy/.

Fondazione Luigi Micheletti

Notiziari della Guardia Nazionale Repubblicana, digitized collection accessible at http://www.notiziarignr.it/home/default.asp.

Istituto friulano per la storia del movimento di liberazione (IFSML), Udine, Italy

Fondo Giacuzzo

Fondo Marini

Fondo Simsig

Fondo Slovenia: Documenti in copia

Istituto regionale per la storia del movimento di liberazione, Friuli-Venezia Giulia (IRSML-FVG), Trieste, Italy

Fondo Archivio materiali da lavoro

Fondo Cominform

Fondo Gasparini

Fondo Jaksetich

National Archives and Records Management II (NARA II), College Park, MD, USA

Record Group 331:

Entry P 1031 Allied Military Government (AMG) General Correspondence Files, 1947-1954

Entry P 1035: AMG, Numeric-Subject Files, 1952-1954

Entry P 1041: AMG, Reports, 1952-1954

Entry UD 1981: AMG Subject Files Relating to Venezia Giulia, 1945-47

Gorizia Province

Pola Province

Trieste Province

Venezia Giulia

\section{Newspapers and Periodicals}

Il Lavoratore, daily of the PCI in Trieste (May-June 1945), the PCRG (1945-1947), and the PCTLT-Vidali (1947-1954)

\section{Published Document and Interview Collections}

Giuricin, Luciano, ed. La memoria di Goli Otok-Isola Calva. Rovinj: Centro di ricerche storiche di Rovigno, 2007. 


\section{Diaries and Memoirs}

Cosolo, Silvano. Amare... Sarajevo (estate 1946-estate 1948). Ronchi dei Legionari: Consorzio Culturale del Monfalconese, 2008.

Pin-Giuricin, "I motivi di una scelta. Una vita vissuta tra Monfalcone e Fiume." Quaderni 17 (2006): 335-373.

Rigonat, Renato. Memorie. Ronchi dei Legionari: Consorzio Culturale del Monfalconese, 2012.

Tonzar, Mario. La valigia e l'idea: memorie di Mario Tonzar. Edited by Alessandro Morena. Ronchi dei Legionari: Consorzio culturale del monfalconese, 2006.

\section{Novels}

Magris, Claudio. Blindly. Translated by Anne Milano Appel. New Haven and London: Yale University Press, 2012.

Pasolini, Pier Paolo. Il sogno di una cosa: romanzo. Milan: Garzanti, 1962.

\section{Other}

Consiglio di Liberazione per la Città di Trieste. The Activity of the Council of Liberation of Trieste (from May 17 to September 21, 1945): With a Short Historical Introduction. Trieste: Consiglio di Liberazione per la Città di Trieste, 1945.

Istituto Editoriale della Croatzia, Gli Italiani nella Repubblica Popolare Federativa di Jugoslavia. Zagreb: Istituto Editoriale della Croazia, 1948.

Righi, Livio Ragusin. Politica di Confine. Trieste: Società Editrice Mutilati e Combattenti, 1929.

\section{Secondary Sources}

Arthurs, Joshua, Michael Ebner, and Kate Ferris, eds. The Politics of Everyday Life in Fascist Italy: Outside the State? New York: Palgrave Macmillan, 2017.

Abse, Tobias. "Italian Workers and Italian Fascism." In Fascist Italy and Nazi Germany: Comparisons and Contrasts, edited by Richard Bessel, 40-60. Cambridge, England: Cambridge University Press, 1996.

Aga Rossi, Elena and Victor Zaslavsky. Stalin and Togliatti: Italy and the Origins of the Cold War. Washington, DC and Stanford, CA: Woodrow Wilson Center Press and Stanford University Press, 2011.

Anderson, Benedict. Imagined Communities: Reflections on the Origin and Spread of Nationalism. London and New York: Verso, 1991. 
Andri, Adriano, and Giulio Mellinato. Scuole e confine: Le istituzioni educative della Venezia Giulia, 1915-1945. IRSML-FVG, 1994.

Appy, Christian. Cold War Constructions: The Political Culture of United State Imperialism, 1945-1966. Amherst: University of Massachusetts Press, 2000.

Bade, Klaus. Migration in European History. Malden, MA: Blackwell Publishing, 2003.

Ballinger, Pamela. "Borders of the Nation, Borders of Citizenship: Italian Repatriation and the Redefinition of National Identity after World War II." Comparative Studies in Society and History 49, no. 3 (2007): 713-741.

------. History in Exile: Memory and Identity at the Borders of the Balkans. Princeton: Princeton University Press, 2003.

Banac, Ivo. With Stalin against Tito: Cominformist Splits in Yugoslav Communism. Ithaca, NY: Cornell University Press, 1988.

Baracetti, Gaia. "Foibe: Nationalism, Revenge and Ideology in Venezia Giulia and Istria, 19435." Journal of Contemporary History 44, no. 4 (October 2009): 657-674.

Bartov, Omer and Eric Weitz, eds. Shatterzone of Empires: Coexistence and Violence in the German, Habsburg, Russian, and Ottoman Borderlands. Bloomington, IN: Indiana University Press: 2013.

Belmonte, Laura. "A Family Affair?: Gender, the US Information Agency, and Cold War Ideology." In Culture and International History, edited by Jessica Gienow-Hecht and Frank Schumacher, 79-93. New York: Berghahn Books, 2003.

------. Selling the American Way: U.S. Propaganda and the Cold War. Philadelphia: University of Pennsylvania Press, 2008.

Ben-Ghiat, Ruth. Fascist Modernities: Italy, 1922-1945. Berkeley: University of California Press, 2001.

Benvenuti, Silvano. "Fabbrica e Società: Il gruppo metallurgico di Monfalcone nel 1911 e il ruolo dei fratelli Fontanot." Il Territorio 10 (1984): 45-60.

-------. "I primi anni del cantiere di Monfalcone: Partito socialista, gruppo metallurgico, organizzazione operaia in fabbrica (1908-1911)." Il Territorio 8 (1983): 33-48.

-------. "Il cantiere di Monfalcone: Gli anni dello sviluppo: 1911-1914. Aspetti generali." Il Territorio 5 (1980): 17-28.

-------. "La nascità del cantiere di Monfalcone e le prime lotte operaie (1908-1910)." Il Territorio 4 (1980): 23-30.

-------. 'L'Isontino nel maggio 1920: Il giudizio dei Comandi militari sulla situazione politica e sociale." Il Territorio 7 (1982): 35-48.

Bergerson, Andrew Stuart. Ordinary Germans in Extraordinary Times: The Nazi Revolution in Hildesheim. Bloomington: Indiana University Press, 2004.

Berrini, Andrea. Noi siamo la classe operaia: i duemila di Monfalcone. Milan: Baldini Castoldi Dalai, 2004.

Bessel, Richard. Germany 1945: From War to Peace. New York: Harper Collins Publishers, 2009.

Blackbourn, David and James Retallack, eds. Localism, Landscape, and the Ambiguities of Place: German-Speaking Central Europe, 1860-1930. Toronto: University of Toronto Press, 
2007.

Blaive, Muriel and Berthold Molden. Grenzfälle: österreichische und tschechische Erfahrungen am Eisernen Vorhang. Weitra: Bibliothek der Provinz, 2009.

Blaive, Muriel and Thomas Lindenberger. "Border Guarding as Social Practice: A Case Study of Communist Governance and Hidden Transcripts." In Walls, Borders, Boundaries: Spatial and Cultural Practices in Europe, edited by Marc Silberman, Karen Till, and Janet Ward, 97-112. New York: Berghahn Books, 2012.

Boileau, Anna Maria. "I Bisiachi descrivono se stessi." Il Territorio 4 (1980): 41-46.

------. "I Bisiachi descrivono se stessi (II parte)," Il Territorio 5 (1980): 37-46.

Bokovoy, Melissa. Peasants and Communists: Politics and Ideology in the Yugoslav Countryside, 1941-1953. Pittsburg: University of Pittsburgh Press, 1998.

Bokovoy, Melissa, Jill Irvine, and Carol Lilly, eds. State-Society Relations in Yugoslavia, 1945 1992. Basingstoke: Macmillan, 1997.

Bolletti, Caterina. "La condizione femminile a Monfalcone negli anni del regime fascista." Il Territorio 8 (1997): 5-16.

Bonelli, Alfredo. Fra Stalin e Tito: cominformisti a Fiume, 1948-1956. Edited by Franco Cecotti. Trieste: Istituto regionale per la storia del movimento di liberazione nel Friuli-Venezia Giulia, 1994.

Borioli, Carlo Alberto. "Bombe su Monfalcone." Il Territorio 3 (1995): 48-56.

Bosworth, R. J. B. Mussolini's Italy: Life under the Dictatorship, 1915-1945. New York: Penguin Books, 2006.

------ and Patrizia Dogliani, eds. Italian Fascism: History, Memory and Representation. New York: St. Martin's Press, 1999.

Burella, Walter. “Gli 'Accordi di Monfalcone'.” Il Territorio 19 (2003): 3-9.

Burton, Eric. "Navigating Global Socialism: Tanzanian Students in and beyond East Germany." Cold War History. Published online, 25 June 2018. https://doi.org/10.1080/14682745.2018.1485146.

Buttignon, Ivan. "Lega Nazionale e Governo Militare Alleato. La lotta per l'egemonia cultura nella Venezia Giulia." Quaderni 24 (2013): 63-116.

------. "Il sentimento nazionale italiano durante il periodo di occupazione alleata della Zona A (1945-1954) secondo l'Archivio del Ministero dell'Interno italiano.” Quaderni 25 (2014): 97-141.

Campbell, John. Tito's Separate Road: America and Yugoslavia in World Politics. New York: Harper \& Row, 1967.

Castles, Stephen and Mark Miller. The Age of Migration: International Population Movements in the Modern World. New York: Guilford Press, 1993.

Cattaruzza, Marina. Italy and Its Eastern Border, 1866, 2016. London and New York: Routledge, 2017.

Cernigoi, Claudia. Operazione "foibe": tra storia e mito. Udine: Kappa Vu, 2012.

------. Operazioni foibe a Trieste: come si crea una mistificazione storica: dalla propaganda nazifascista attraverso la guerra fredda fino al neoirredentismo. Udine: Kappa Vu, 1997. 
Cernigoi, Enrico. Scelte politiche e identità nazionale: ai confini orientale d'Italia dalla Resistenza alla guerra fredda. Udine: Gaspari, 2006.

Cernigoi, Enrico, Marco Puppini, and Sergio Valcovich. Cento anni di cantiere: un secolo di storia di emancipazione umana e sociale al cantiere navale di Monfalcone. Rome: Ediesse, 2010.

Chersovani, Licia. "Alcuni aspetti della politica del partito comunista sloveno (Pcs-KPS) nella zona d'operazioni dell'Adriatisches Küstenland (1943-1945)." Qualestoria 23, no. 1/2 (1995): 17-49.

Clark, Katerina. Moscow, the Fourth Rome: Stalinism, Cosmopolitanism, and the Evolution of Soviet Culture, 1931-1941. Cambridge, Mass: Harvard University Press, 2011.

Clarkson, Alexander. Fragmented Fatherland: Immigration and Cold War Conflict in the Federal Republic of Germany, 1945-1980. New York and Oxford: Berghahn Books, 2013.

Cohen, Gary and Johannes Feichtinger, eds. Understanding Multiculturalism: The Habsburg Central European Experience. Oxford and New York: Berghahn Books, 2014.

Colarizi, Simona. "Vita alimentare degli italiani e razionamento (1941)." In L'Italia in guerra. Cinquant'anni dopo l'entrata dell'Italia nella 2 a guerra mondiale. Aspetti e problemi storici, vol. 2, 279-289. Rome: Commissione Italiana di Storia Militare, 1991.

Cole, Laurence, ed. Different Paths to the Nation: Regional and National Identities in Central Europe and Italy, 1830-70. Basingstoke, England and New York: Palgrave Macmillan, 2007.

Conway, Martin. "The Rise and Fall of Western Europe's Democratic Age, 1945-1973." Contemporary European History 13, no. 1 (2004): 67-88.

Cooke, Philip. "From Partisan to Party Cadre: The Education of Italian Political Emigrants in Czechoslovakia." Italian Studies 61, no. 1 (2006): 64-84.

------ “'Oggi in Italia': The Voice of Truth and Peace in Cold War Italy.” Modern Italy 12, no. 2 (2007): 251-265.

------- "Red Spring: Italian Political Emigration to Czechoslovakia." The Journal of Modern History 84, no. 4 (December 2012): 861-896.

------. The Legacy of the Italian Resistance. New York: Palgrave Macmillan, 2011.

Corner, Paul. The Fascist Party and Popular Opinion in Mussolini's Italy. Oxford: Oxford University Press, 2012.

Coslovich, Marco. "Riflessioni sulla crisi del Cominform a Trieste: testimonianze di militant." Qualestoria 14, no. 3 (November 1986): 89-105.

Crainz, Guido. Il dolore e l'esilio: l'Istria e le memorie divise d'Europa. Rome: Donzelli, 2005.

D'Alessio, Vanni. "From Central Europe to the Northern Adriatic Hapsburg Citizens between Italians and Croats in Istria." Journal of Modern Italian Studies 13, no. 2 (2008): 237-258.

-----. Il cuore conteso: il nazionalismo in una comunità multietnica: l'Istria asburgica. Naples: Filema, 2003.

------. "Istrians, Identifications, and Habsburg Legacy: Perspectives on Identities in Istria." Acta Histriae 14, no. 1 (2006): 15-39.

D’Amelio, Diego, Andrea Di Michele, and Giorgio Mezzalira, eds. La difesa dell'italianità: l'Ufficio per le zone di confine a Bolzano, Trento e Trieste (1945-1954). Bologna: Il 
Mulino, 2015.

Daneo, Camillo. La politica economica della ricostruzione, 1945-1949. Turin: Einaudi, 1975.

David-Fox, Michael. Showcasing the Great Experiment: Cultural Diplomacy and Western Visitors to the Soviet Union, 1921-1941. Oxford and New York: Oxford University Press, 2012.

De Felice, Renzo. Mussolini il rivoluzionario 1883-1920. Turin: Einaudi, 1965.

De Grazia, Victoria. Irresistible Empire: America's Advance through Twentieth-Century Europe. Cambridge, MA: Belknap Press of Harvard University Press, 2005.

Demshuk, Andrew. The Lost German East: Forced Migration and the Politics of Memory, 1945 1970. New York: Cambridge University Press, 2012.

Di Gianantonio, Anna, Tommaso Montanari, Alessandro Morena, and Sara Perini. L'immaginario imprigionato: dinamiche sociali, nuovi scenari politici e costruzione della memoria nel secondo dopoguerra monfalconese. Ronchi dei Legionari: Consorzio culturale del monfalconese, 2005.

Di Gianantonio, Anna and Gloria Nemec. Gorizia operaia: i lavoratori e le lavoratrici isontini tra storia e memoria, 1920-1947. Gorizia: LEG, 2000.

Di Loreto, Pietro. Togliatti e la "doppiezza”: il Pci tra democrazia e insurrezione (1944-49). Bologna: Il Mulino, 1991.

Diner, Dan. Cataclysms: A History of the Twentieth Century from Europe's Edge. Madison, WI: University of Wisconsin Press, 2008.

-------. "European Counterimages: Problems of Periodization and Historical Memory." Translated by Bill Templer. New German Critique 53 (April 1991): 163-174.

Djilas, Aleksa. The Contested Country: Yugoslav Unity and Communist Revolution, 1919-1953. Cambridge, MA: Harvard University Press, 1991.

Djokić, Dejan, ed. Yugoslavism: Histories of a Failed Idea, 1918-1992. Madison: University of Wisconsin Press, 2003.

Djokić, Dejan and James Ker-Lindsay, eds. New Perspectives on Yugoslavia: Key Issues and Controversies. New York: Routledge, 2010.

Domenico, Roy Palmer. Italian Fascists on Trial, 1943-1948. Chapel Hill: University of North Carolina Press, 1991.

Dondi, Mirco. La lunga liberazione: giustizia e violenza nel dopoguerra italiano. Rome: Editori riuniti, 1999.

Donno, Gianni. La gladio rossa del PCI, 1945-1967: con 180 documeenti inediti. Soveria Mannelli, Catanzano: Rubbettino, 2001.

D'Onofrio, Federico. Observing Agriculture in Early Twentieth-Century Italy: Agricultural Economists and Statistics. New York: Routledge, 2016.

------- "The Microfoundations of Italian Agrarianism: Italian Agricultural Economists and Fascism." Agricultural History 91, no. 3 (2017): 369-396.

Doria, Mario. "Contributo sulle origini della Bisiacaria: Alcune ipotesi sul periodo protostorico di questo territorio." Il Territorio 11 (1984): 23-25.

-------. 'Nè friulano, nè triestino: Il Vocabolario fraseologico del dialetto 'bisiàc'. Un dizionario sorpredentemente ricco di parole." Il Territorio 15 (1985), 53-61. 
Dunnage, Jonathan, ed. After the War: Violence, Justice, Continuity and Renewal in Italian Society: Papers Given at the Contemporary History Conference, 'After the War was Over', University of Sussex, July 1996. Market Harborough, England: Troubador Publishing Ltd, 1999.

Ebner, Michael. Ordinary Violence in Mussolini's Italy. New York: Cambridge University Press, 2011.

Eley, Geoff. "Labor History, Social History, 'Alltagsgeschichte': Experience, Culture, and the Politics of the Everyday--a New Direction for German Social History?" The Journal of Modern History 61, no. 2 (1989): 297-343.

-------. "When Europe was New: Liberation and the Making of the Post-War Era." In The Lasting War: Society and Identity in Britain, France and Germany after 1945, edited by Monica Riera and Gavin Schaffer, 17-46. New York: Palgrave Macmillan, 2008.

Ellwood, D. W. "Allied Occupation Policy in Italy, 1943-1946." PhD diss., Reading University, 1976.

Fabi, Lucio. “1943-1945 guerra civile al confine orientale.” Il Territorio 3 (1995): 5-26.

Faenza, Roberto and Marco Fini. Gli americani in Italia. Milan: Feltrinelli, 1976.

Fasola, Mariolina and Doretta Pettinato. "Il 'Giro' fermato a Pieris: Storie delle 'sassate patriottiche' del 1946 attraverso la cronaca dei giornali dell'epoca.” Il Territorio 9 (1983): 35-40.

Ferris, Kate. Everyday Life in Fascist Venice, 1929-40. London: Palgrave Macmillan, 2012.

Fiori, Giuseppe. Uomini ex: la strano destino di un gruppo di comunisti italiani. Turin: Einaudi, 1993.

Flood, Christopher, Political Myth: A Theoretical Introduction. London and New York: Routledge, 2013.

Flores, Marcello, ed. Il Mito dell'URSS: la cultura occidentale e l'Unione Sovietica. Milan: Franco Angeli: 1990.

-------. "Realtà del dopoguerra italiano: il problema dell'ordine pubblico." Qualestoria 8, no. 2 (1980), 11-15.

Fogar, Galliano. "Gli anni della clandestinità: violenza di stato e di classe a Monfalcone." Il Territorio 2 (1979): 59-68.

-------. "Gli scioperi del marzo 1943 in Alta Italia.” Il Territorio 3 (1979): 45-52.

-------. L'antifascismo operaio monfalconese tra le due guerre. Milan: Vangelista Editore, 1982.

------. Trieste in guerra 1940-1945: società e Resistenza. Trieste: IRSML-FVG, 1999.

Foot, John. "Memories of an Exodus: Istria, Fiume, Dalmatia, Trieste, Italy, 1943-2010." In Totalitarian Dictatorship: New Histories, edited by Daniela Baratieri, Mark Edele, and Giuseppe Finaldi, 232-250. New York: Routledge, 2014.

Foteva, Ana. Do the Balkans Begin in Vienna?: The Geopolitical and Imaginary Borders between the Balkans and Europe. New York: Peter Lang, 2014.

Fragiacomo, Chiara. "La lotta politica a Gradisca tra fascismo e resistenza." Il Territorio 3 (1995): 27-36.

Fragiacomo, Paolo. La grande fabbrica, la piccola città: Monfalcone e il cantiere navale: la 
nascita di una company town 1860-1940. Milan: Angeli, 1997.

Fragiacomo, Silvia. “'Allora il mondo finiva a Panzano': la memoria del quartiere in una ricerca di sociologia." Il Territorio 4 (1995): 29-42.

-------. Fabbrica e comunità a Monfalcone: dal sogno alla realtà: il villagio del Cantiere, la colonia della Solvay. Ronchi dei Legionari: Centro culturale pubblico polivalente del Monfalconese, 1996.

Gaddis, John L. The Cold War: A New History. New York: Penguin Press, 2005.

------- "The Emerging Post-Revisionist Synthesis on the Origins of the Cold War." Diplomatic History 7, no. 3 (1983): 171-190.

Galeazzi, Marco. Roma-Belgrado: gli anni della guerra fredda. Ravenna: Longo, 1995.

Gallerano, Nicola. L'Altro dopoguerra: Roma e il Sud, 1943-1945. Milan: Franco Angeli, 1985.

------- “A Neglected Chapter in Italy's Transition from Fascism to the Republic: The Kingdom of the South (1943-1944).” Journal of Modern Italian Studies 1, no. 3 (1996): 391-399.

Gaspari, Paolo. "La protesta contadina: Le agitazioni agrarie del 1919-20 nel Basso Isontino e Cervignanese." Il Territorio 14 (1985): 25-36.

Gentile, Emilio. The Sacralization of Politics in Fascist Italy. Translated by Keith Botsford. Cambridge, MA: Harvard University Press, 1996.

Ginzburg, Carlo. The Cheese and the Worms: The Cosmos of a Sixteenth-Century Miller. Translated by John and Anne Tedeschi. New York: Penguin Books, 1980.

Giovana, Mario. Giustizia e Libertà in Italia: Storia di una cospirazione antifascista 1929-1937. Turin: Bollati Boringhieri, 2005.

Goedde, Petra. GIs and Germans: Culture, Gender, and Foreign Relations, 1945-1949. New Haven: Yale University Press, 2003.

Ghosh-Schellborn, Martina. "Spaced In-Between: Transitional Identities." In Borderlands: Negotiating Boundaries in Post-Colonial Writing, edited by Monika Reif-Hülser, 29-42. Amsterdam and Atlanta, GA: Rodopi, 1999.

Gienow-Hecht, Jessica. Transmission Impossible: American Journalism as Cultural Diplomacy in Postwar Germany, 1945-1955. Baton Rouge: Louisiana State University Press, 1999.

Giuricin, Luciano. "Il settembre '43 in Istria e a Fiume." Quaderni 11 (1997): 9-115.

-------. "L'azione della gioventù comunista e antifascista a Fiume dal 1941 al 1945." Quaderni 9 (1988-1989): 49-65.

-------. "Le vittime del Cominform. Un'altra tragedia istriana: introduzione alle testimonianze rilasciate dai protagonist diretti." Quaderni 13 (2001): 247-289.

------. "Trent'anni di battaglie: Il movimento operaio in Istria e a Fiume tra le due guerre." Il Territorio 25 (November 1989): 197-202.

Gundle, Stephen. Between Hollywood and Moscow: the Italian Communists and the Challenge of Mass Culture, 1943-1991. Burham, NC: Duke University Press, 2000.

Haider, Carmen, Capital and Labor under Fascism. New York: AMS Press, Inc, 1930, reprint 1968.

Hametz, Maura. Making Trieste Italian: 1918-1954. Woodbridge, England and Rochester, NY: 
Boydell Press, 2005.

Healy, Maureen. Vienna and the Fall of the Habsburg Empire: Total War and Everyday Life in World War I. Cambridge and New York: Cambridge University Press, 2004.

Helstosky, Carol. Garlic and Oil: Politics and Food in Italy. Oxford and New York: Berg, 2004. Highmore, Ben. The Everyday Life Reader. London and New York: Routledge, 2002.

Hobsbawm, Eric. The Age of Extremes: A History of the World, 1914-1991. New York: Pantheon Books, 1994.

Hobsbawm, Eric and Terence Ranger. The Invention of Tradition. Cambridge, England and New York: Cambridge University Press, 1983.

Holian, Anna Marta. Between National Socialism and Soviet Communism: Displaced Persons in Postwar Germany. Ann Arbor: University of Michigan Press, 2011.

Hollander, Paul. Political Pilgrims: Travels of Western Intellectuals to the Soviet Union, China, and Cuba, 1928-1978. New York: Oxford University Press, 1981.

Horvat, Branko. The Yugoslav Economic System: The First Labor-Managed Economy in the Making. White Plains, NY: M.E. Sharpe, 1976.

Iaksetich, Giorgio and Mario Lizzero. La brigata "Fratelli Fontanot": partigiani italiani in Slovenia. Milan: La Pietra, 1982.

Imbriani, Angelo Michele. Vento del sud: moderati, reazionari, qualunquisti: 1943-1948. Bologna: Il mulino, 1996.

Istituto regionale per la storia del movimento di liberazione nel Friuli-Venezia Giulia. Nazionalismo e neofascismo nella lotta politica al confine orientale, 1945-1975. Trieste: Istituto regionale per la storia del movimento di liberazione nel Friuli-Venezia Giulia, 1977.

Jarausch, Konrad. After Hitler: Recivilizing Germans, 1945-1995. Oxford: Oxford University Press, 2008.

Jennings, Christian. Flashpoint Trieste: The First Battle of the Cold War. Lebanon, NH: ForeEdge, 2017.

Johnson, A. Ross. The Transformation of Communist Ideology: The Yugoslav Case, 1945-1953. Cambridge, MA: MIT Press, 1972.

Judt, Tony. Past Imperfect: French Intellectuals, 1944-1956. Berkeley, CA: University of California Press, 1992.

-----. Postwar: A History of Europe since 1945. New York: Penguin Books, 2005.

Kacin-Wohinz, Milica. Alle origini del fascismo di confine: gli sloveni della Venezia Giulia sotto l'occupazione italiana, 1918-1921. Gradisca and Gorizia: Centro isontino di ricerca e documentazione storica e sociale "Leopoldo Gasparini" and Fondazione Sklad Dorče Sardoč, 2010.

Karlsen, Patrick. "Il Pci, il confine orientale e il contesto internazionale, 1941-1955." PhD diss., Università degli Studi di Trieste, 2009.

Kind-Kovacs, Friederike. "Memories of Ethnic Cleansing and the Local Iron Curtain in the CzechGerman Borderlands." Nationalities Papers 42, no. 2 (2014): 199-222.

Kladnik, Mateja Čoh, ed. Slovenia in the $20^{\text {th }}$ Century: The Legacy of Totalitarian Regimes. 
Ljubljana: Study Centre for National Reconciliation, 2016.

Kramsch, Olivier, Henk Van Houtum, and Wolfgang Zierhofer, eds. B/Ordering Space. Burlington, VT and Aldershot, England: Ashgate, 2005.

Kranjc, Gregor Joseph. To Walk with the Devil: Slovene Collaboration and Axis Occupation, 1941-1945. Toronto and Buffalo: University of Toronto Press, 2013.

Kulischer, Eugene. Europe on the Move: War and Population Changes, 1917-47. New York: Columbia University Press, 1948.

Lampe, John. Balkans into Southeastern Europe: A Century of War and Transition. Basingstoke, England and New York: Palgrave Macmillan, 2006.

Laqueur, Walter. The Dream that Failed: Reflections on the Soviet Union. New York: Oxford University Press, 1994.

Lees, Lorraine. Keeping Tito Afloat: the United States, Yugoslavia, and the Cold War. University Park, PA: Pennsylvania State University Press, 1997.

Levi, Giovanni, Inheriting Power: The Story of an Exorcist. Translated by Lydia G. Cochrane. Chicago: University of Chicago Press, 1988.

Lilly, Carol. Power and Persuasion: Ideology and Rhetoric in Communist Yugoslavia. Boulder, CO: Westview Press, 2001.

Lindenberger, Thomas. "Everyday History: New Approaches to the History of Post-War Germanies." In The Divided Past: Rewriting Post-War Germany, edited by Christoph Klessmann, 44-89. Oxford and New York: Berg, 2001.

Lowe, Keith. Savage Continent: Europe in the Aftermath of World War II. New York: St. Martin's Press, 2012.

Lüdtke, Alf. The History of Everyday Life: Reconstructing Historical Experiences and Ways of Life. Translated by William Templer. Princeton: Princeton University Press, 1995.

Lusenti, Luigi. Una storia silenziosa: gli italiani che scelsero Tito. Milan: Comedit, 2009.

Maier, Charles. Once Within Borders: Territories of Power, Wealth, and Belonging Since 1500. Cambridge, MA and London: The Belknap Press of Harvard University Press, 2016.

Marrus, Michael Robert. The Unwanted: European Refugees in the Twentieth Century. Philadelphia: Temple University Press, 2002.

Martínez, Oscar. Border People: Life and Society in the U.S.-Mexico Borderlands. Tuscon, AZ and London: The University of Arizona Press, 1994.

Marzo Magno, Alessandro. "La guerra tiepida. Spionaggio e contraspionaggio tra Italia e Jugoslavia 1948-1953 nel fondo Affari riservati della Pubblica Sicurezza, nell'Archivio centrale dello Stato." Qualestoria 40, no. 1 (June 2012): 95-110.

May, Ernest. “America's Berlin: Heart of the Cold War." Foreign Affairs 77, no. 4 (1998): 148160.

Mellinato, Giulio. Cosulich: dinastia adriatica. Cinisello Balsamo, Milan, Italy: Silvana, 2008.

------. Crescita senza sviluppo: l'economia marittima della Venezia Giulia tra impero asburgico ed autarchia, 1914-1936. Ronchi dei Legionari: Consorzio culturale del monfalconese, 2001.

------. "L'economia locale nel trapasso di poteri tra il governo asburgico e quello italiano." $\mathrm{Il}$ 
Territorio 10 (1998): 19-30.

------. "Strategie imprenditoriali e sviluppo del Cantiere di Monfalcone." Il Territorio 9 (1988): 7-33.

Mickenberg, Julia. American Girls in Red Russia: Chasing the Soviet Dream. Chicago and London: University of Chicago Press, 2017.

Midgal, Joel, ed. Boundaries and Belonging: States and Societies in the Struggles to Shape Identities and Local Practices. Cambridge, England and New York: Cambridge University Press, 2004.

Mihelj, Sabina. "Drawing the East-West Border: Narratives of Modernity and Identity in the Northeastern Adriatic (1947-1954)." In Cold War Cultures: Perspectives on Eastern and Western European Societies, edited by Annette Vowinckel, Marcus Payk, and Thomas Lindenberger, 276-296. New York: Berghahn Books, 2012.

Miletto, Enrico. Istria allo specchio: storia e voci di una terra di confine. Milan: Franco Angeli, 2007.

Miller, Robert. Socialism and Agricultural Cooperation: The Soviet and Yugoslav Cases. Canbera: Dept. of Political Science, Research School of Social Sciences, Australian National University, 1974.

Millo, Anna. La Difficile intesa: Roma e Trieste nella Questione Giuliana, 1945-1954. Trieste: Italo Svevo, 2011.

Mistry, Kaetan. "The Case for Political Warfare: Strategy, Organization and US Involvement in the 1948 Italian Election." Cold War History 6, no. 3 (2006): 301-329.

Moeller, Robert. War Stories: The Search for a Usable Past in the Federal Republic of Germany. Berkeley: University of California Press, 2001.

Morgan, Philip. The Fall of Mussolini: Italy, the Italians, and the Second World War. Oxford and New York: Oxford University Press, 2007.

Morgan, Sarah. Rappresaglie dopo la resistenza: l'eccidio di Schio tra guerra civile e guerra fredda. Milan: Paravia Bruno Mondadori Editori, 2002.

------. "The Schio Killings: A Case Study of Partisan Violence in Post-War Italy." Modern Italy 5, no. 2 (2000): 147-160.

Morris, Jonathan. "The Fascist 'Disciplining' of the Italian Retail Sector, 1922-40.” Business History 40, no. 4 (October 1998): 138-164.

------. The Political Economy of Shopkeeping in Milan, 1886-1922. Cambridge: Cambridge University Press, 1993.

------. "Retailers, Fascism and the Origins of the Social Protection of Shopkeepers in Italy." Contemporary European History 5, no. 3 (1996): 285-318.

Moscarda Oblak, Orietta. "Le memorie contrapposte di Goli Otok-Isola Calva." Quaderni 18 (2007): 69-101.

Muir, Edward and Guido Ruggiero, eds. Microhistory and the Lost Peoples of Europe. Translated by Eren Branch. Baltimore: Johns Hopkins University Press, 1991.

Murdock, Caitlin. Changing Places: Society, Culture, and Territory in the Saxon-Bohemian Borderlands, 1870-1946. Ann Arbor, MI: University of Michigan Press, 2010. 
Murgia, Pier Giuseppe. Il vento del Nord: storia e cronaca del fascismo dopo la Resistenza (19451950). Milan: SugarCo, 1975.

Nemec, Gloria. Un paese perfetto: storia e memoria di una comunità in esilio: Grisignana d'Istria, 1930-1960. Gorizia: Libreria editrice goriziana, 1998.

Novak, Bogdan. Trieste, 1941-1954: The Ethnic, Political, and Ideological Struggle. Chicago: University of Chicago Press, 1970.

Nützenadel, Alexander. "Dictating Food: Autarchy, Food, Provision, and Consumer Politics in Fascist Italy, 1922-1943." In Food and Conflict in Europe in the Age of the Two World Wars, edited by Flemming Just and Frank Trentmann, 88-108. London: Palgrave Macmillan, 2006.

Oats-Indruchová, Libora and Muriel Blaive. "Introduction: Border Communities: Microstudies on Everyday Life, Politics and Memory in European Societies from 1945 to the Present." Nationalities Papers 42, no. 2 (2014): 195-198.

Ohliger, Rainer and Karen Schönwälder. European Encounters: Migrants, Migration, and European Societies Since 1945. Aldershot, England and Burlington, VT: Ashgate, 2003.

Olivo, Stefano. "Comunisti ed esuli istriani nella provincial di Gorizia del second dopoguerra. Isolamento e discriminazione a confronto." Quaderni 12 (1999): 61-89.

Panjek, Aleksander. Ricostruire Trieste: politiche e pratiche migratorie nel secondo dopoguerra. Trieste: Edizioni Università di Trieste, 2006.

Pansa, Giampaolo. Il sangue dei vinti. Milan: Sperling \& Kupfer, 2003.

Parenzan, Sergio. "Le lotte dei lavoratori di Monfalcone: Dal dopoguerra alle esperienze nel 'Consiglio di Fabbrica' Italcantieri," Il Territorio 9 (1983): 19-28.

Passerini, Luisa. Fascism in Popular Memory: The Cultural Experience of the Turin Working Class. Translated by Robert Lumley and Jude Bloomfield. Cambridge, Engalnd and New York: Cambridge University Press, 1987.

Patat, Luciano. La battaglia partigiana di Gorizia: la resistenza dei militari e la "Brigata proletaria": (8-30 settembre 1943). Gorizia: Centro isontino di ricerca e documentazione storica e sociale "Leopoldo Gasparini," 2015.

------. Mario Fantini "Sasso": comandante della Divisione "Garibaldi Natisone." Udine: IFSML, 2000.

Pauley, Bruce F. Hitler, Stalin, and Mussolini: Totalitarianism in the Twentieth Century. 4th ed. Malden, MA and Oxford, England: Wiley-Blackwell, 2014.

Pavlowitch, Stevan. Hitler's New Disorder: The Second World War in Yugoslavia. New York: Columbia University Press, 2008.

Pavone, Claudio. Alle origini della repubblica: scritti su fascismo, antifascism e continuità dello stato. Turin: Bollati Boringhieri, 1995.

------. A Civil War: A History of the Italian Resistance. Edited by Stanislao Pugliese. Translated by Peter Levey and David Broder. London and New York: Verso, 2013.

Payne, Stanley. Civil War in Europe, 1905-1949. New York: Cambridge University Press, 2011.

Petacco, Arrigo. A Tragedy Revealed: the Story of the Italian Population of Istria, Dalmatia, and Venezia Giulia, 1943-1956. Toronto and Buffalo: University of Toronto Press, 2005. 
Pick, Daniel. Faces of Degeneration: A European Disorder, c. 1848-1918. Cambridge: Cambridge University Press, 1989.

Pin, Gualtiero and Edino Valcovich. "Il quartiere di Panzano: La seconda fase costruttiva (19131921)." Il Territorio 5 (1980): 65-80.

------. "Il quartiere di Panzano (1908-1912). I primi edifici per la residenza." Il Territorio 3 (1979): 73-82.

------. "Il quartiere di Panzano e le condizioni socio-economiche del territorio (1850-1913)." Il Territorio 2 (1979): 85-92.

Pirjevec, Jože, ed. Foibe: una storia d'Italia. Turin: Einaudi, 2009.

Pittaway, Mark. From the Vanguard to the Margins: Workers in Hungary, 1939 to the Present: Selected Essays by Mark Pittaway, Edited by Adam Fabry. Leiden: Brill, 2014.

-----. "The Reproduction of Hierarchy: Skill, Working-Class Culture, and the State in Early Socialist Hungary." The Journal of Modern History 74, no. 4 (2002): 737-769.

Planović, Mladen. "O nekim zbivanjima u Rijeci vezanim uz objavljivanje Rezolucije Informbiroa 1948, godine." Dometi 18, no. 11 (1985): 57-70.

Popescu, Gabriel. Bordering and Ordering the Twenty-First Century: Understanding Borders. Plymouth, England: Rowman \& Littlefield Publishers, Inc., 2012.

Pugliese, Stanislao. Carlo Rosselli: Socialist Heretic and Antifascist Exile. Cambridge, MA: Harvard University Press, 1999.

Pupo, Raoul. “Alcuni documenti sull'ordine pubblico nel 1946." Qualestoria 7, no. 3 (1979): 1321.

-----. Il lungo esodo. Istria: le persecuzioni, le foibe, l'esilio. Milan: Rizzoli, 2006.

------. "La più recente storiografia italiana di frontiera: alcune questioni interpretative." Acta Histriae 20 (2012): 293-306.

------. "La questione di Trieste: un panorama interpretative." Qualestoria 23, no. 3 (December 1995): 63-110.

------. "Le foibe giuliane 1943-1945: i nodi del dibattito." Qualestoria 22 (1994): 87-98.

-----. Trieste '45. Roma: Laterza, 2010.

------. "Violenza Politica tra Guerra e Dopoguerra: Il Case delle Foibe Giuliane 1943-1945." Clio 32, no. 2 (1996): 115-137.

Puppini, Marco. Costruire un mondo nuovo: un secolo di lotte operaie nel Cantiere di Monfalcone: storie di uomini, di passioni e di valori. Gradisca d'Isonzo: Centro isontino di ricerca e documentazione storica e sociale "Leopoldo Gasparini," 2008.

-------, ed. Il mosaico giuliano: società e politica nella Venezia Giulia del secondo dopoguerra (1945-1954). Gradisca d'Isonzo: Centro isontino di ricerca e documentazione storica e sociale "Leopoldo Gasparini," 2003.

------. "L'emigrazione del Monfalconesi in Jugoslavia nei primi anni del secondo dopoguerra." $\mathrm{Il}$ Territorio 17 (2002): 53-58.

------. "Quel viaggio dall'Isonzo all'Ebro: Attraverso ricerche d'archivio e interviste, dodici 'internazionali' isontini rievocano quegli anni di lotta in Spagna." Il Territorio 13 (1985): $31-42$. 
Rabel, Roberto. "Prologue to Containment: The Truman Administration's Response to the Trieste Crisis of May 1945.” Diplomatic History 10, no. 2 (1986): 141-160.

Radossi, Giovanni. Documenti dell'Unione degli italiani dell'Istria e di Fiume (gennaio 1947maggio 1948). Rovinj, Croatia: Unione degli Italiani dell'Istria e di Fiume, 2010.

Ramet, Sabrina. The Three Yugoslavias: State-Building and Legitimation, 1918-2005. Washington, DC and Bloomington, IN: Woodrow Wilson Center Press and Indiana University Press, 2006.

Reill, Dominique. Nationalists Who Feared the Nation: Adriatic Multi-Nationalism in Habsburg Dalmatia, Trieste, and Venice. Stanford, CA: Stanford University Press, 2012.

Reinisch, Jessica and Elizabeth White, eds. The Disentanglement of Populations: Migration, Expulsion, and Displacement in Post-War Europe, 1944-9. Basingstoke, England and New York: Palgrave Macmillan, 2011.

Roberts, David D. The Syndicalist Tradition and Italian Fascism. Chapel Hill: University of North Carolina Press, 1979.

Rodogno, Davide. Il nuovo ordine mediterraneo: le politiche di occupazione dell'Italia fascista in Europa (1940-1943). Turin: Bollati Boringhieri, 2003.

Romero, Federico. "Cold War Historiography at the Crossroads." Cold War History 14, no. 4 (2014): 685-703.

Rossi, Marina. “L’organizzazione metallurgica a Monfalcone (1908-1918): Appunti per una storia del movimento organizzato." Il Territorio 10 (1984): 39-44.

Rusinow, Dennison. The Yugoslav Experiment: 1948-1974. Berkeley: University of California Press, 1978.

Said, Edward. Orientalism. New York: Vintage Books, 1979.

Sammartino, Annemarie. The Impossible Border: Germany and the East, 1914-1922. Ithaca: Cornell University Press, 2010.

Sapelli, Giulio. Organizzazione lavoro e innovazione industriale nell'Italia tra le due Guerre. Turin: Rosenberg and Sellier, 1978.

Sawyer, Benjamin. "Shedding the White and Blue: American Migration and Soviet Dreams in the Era of the New Economic Policy." Ab Imperio 1 (2013): 65-84.

Schaefer, Sagi. "Hidden Behind the Wall: West German State Building and the Emergence of the Iron Curtain." Central European History 44, no. 3 (September 2011): 506-535.

-------. States of Division: Border and Boundary formation in Cold War Rural Germany. Oxford and New York: Oxford University Press, 2014.

Scotti, Giacomo. Goli Otok: Italiani nel gulag di Tito. Third edition. Trieste: LINT, 2002.

------. Goli Otok: ritorno all'isola calva: a quarant'anni di distanza le rivelazioni su un gulag dell'Adriatico volute da Tito. Trieste: LINT, 1991.

------. Il gulag in mezzo al mare: nuove rivelazioni su Goli Otok. Trieste: LINT, 2012.

Sheffer, Edith. Burned Bridge: How East and West Germans Made the Iron Curtain. Oxford and New York: Oxford University Press, 2011.

------- "On Edge: Building the Border in East and West Germany." Central European History 40, no. 2 (2007): 307-339. 
Sites, Richard. Revolutionary Dreams: Utopian Vision and Experimental Life in the Russian Revolution. New York: Oxford University Press, 1989.

Sittmann, Julia. "Illusions of Care: Iraqi Students between the Ba'thist State and the Stasi in Socialist East Germany, 1958-89.” Cold War History 18, no. 2 (2018): 187-202.

Sluga, Glenda. The Problem of Trieste and the Italo-Yugoslav Border: Difference, Identity, and Sovereignty in Twentieth-Century Europe. Albany, NY: State University of New York Press, 2001.

Spazzali, Roberto. Gorizia 1945-1948: la difesa dell'identità italiana con la "Divisione Volontari Gorizia." Gorizia: Ed. Lega Nazionale, 1991.

Steege, Paul. Black market, Cold War: Everyday Life in Berlin, 1946-1949. Cambridge: Cambridge University Press, 2009.

------. "Ordinary Violence on an Extraordinary Stage: Incidents on the Sector Border in Postwar Berlin." In Performances of Violence, edited by Austin Sarat, Carleen Basler, and Thomas L. Dumm, 140-163. Amherst: University of Massachusetts Press, 2011.

Steege, Paul, Andrew Stuart Bergerson, Maureen Healy, and Pamela E. Swett. "The History of Everyday Life: A Second Chapter.” The Journal of Modern History 80, no. 2 (2008): 358378.

Stella, Gianfranco. Rifugiati a Praga: i partigiani italiani in Cecoslovacchia. So.Ed.E, 1993.

Stern, Ludmila. Western Intellectuals and the Soviet Union, 1920-40: From Red Square to the Left Bank. London and New York: Routledge: 2006.

Storchi, Massimo. Combattere si può, vincere bisogna: la scelta della violenza fra Resistenza e dopoguerra: Reggio Emilia, 1943-1946. Venice: Marsilio, 1998.

-------. Il sangue dei vincitori: saggio sui crimini fascisti e I processi del dopoguerra (1945-46). Reggio Emilia: Aliberti, 2008.

Stuper, R. 'La 'Divisione labori in economia' e la lotta alla disoccupazione da parte del Gma (1945-1951)." Qualestoria 31, no. 1 (2003): 103-124.

Swain, Geoff. Tito: A Bibliography. London and New York: I. B. Tauris, 2011.

Tallet, Frank. "Writing the History of Daily Life in the Cold War." In Daily Lives of Civilians in Wartime Twentieth-Century Europe, edited by Nichola Atkin, 141-162. London: Greenwood Press, 2008.

Terzuolo, Eric. Red Adriatic: the Communist Parties of Italy and Yugoslavia. Boulder, CO: Westview Press, 1985.

Todorova, Marija. Imaging the Balkans. Oxford and New York: Oxford University Press, 1997.

Tomasevich, Jozo. War and Revolution in Yugoslavia, 1941-1945: Occupation and Collaboration. Standford: Stanford University Press, 2001.

Torpey, John. The Invention of the Passport: Surveillance, Citizenship, and the State. Cambridge: Cambridge University Press, 2000.

Troha, Nevenka. Chi avrà Trieste?: sloveni e italiani tra due stati. Trieste: IRSML-FVG, 2009.

-------. "La regione Giulia fra Italia e Jugoslavia. 1945-1947." Translated by Giuditta Giraldi. Storia contemporanea in Friuli 33 (2003): 9-47.

Turi, Rocco. Gladio rossa: una catena di complotti e delitti, dal dopoguerra al caso Moro. Venice: 
Marsilio, 2004.

Tzouliadis, Tim. The Forsaken: An American Tragedy in Stalin's Russia. New York: Penguin Books, 2008.

Uršič, Rudolf. Attraverso Trieste: un rivoluzionario pacifista in una città di frontiera. Rome. Studio I,1996.

Valdevit, Giampaolo. Il dilemma Trieste: guerra e dopoguerra in uno scenario europeo. Gorizia: Libreria editrice Goriziana, 1999.

Valerio-Jiménez, Omar. River of Hope: Forging Identity and Nation in the Rio Grande Borderlands. Durham, NC: Duke University Press, 2013.

Varsori, Antonio. "Cold War History in Italy.” Cold War History 8, no. 2 (2008): 157-187.

Vinci, Annamaria. Sentinelle della patria: il fascismo al confine orientale: 1918-1941. Rome: Laterza, 2011.

Volk, Sandi. Esuli a Trieste: bonifica nazionale e rafforzamento dell'italianità sul confine orientale. Udine: Kappa vu, 2004.

Vucinich, Wayne, ed. At the Brink of War and Peace: The Tito-Stalin Split in a Historical Perspective. New York: Social Science Monographs, Inc., 1982.

Wachtel, Andrew. Making a Nation, Breaking a Nation: Literature and Cultural Politics in Yugoslavia. Stanford: Stanford University Press, 1998.

Wagnleitner, Reinhold. Coca-Colonization and the Cold War: The Cultural Mission of the United States in Austria after the Second World War. Chapel Hill: University of North Carolina Press, 1994.

Weber, Eugen. France: Fin de Siècle. Cambridge, MA and London: Harvard University Press, 1986.

------. Peasants into Frenchmen: The Modernization of Rural France, 1870-1914. Stanford, CA: Stanford University Press, 1976.

White, Timothy. "Cold War Historiography: New Evidence Behind Traditional Typographies." Internatioanl Social Science Review 75, no. 3/4 (2000): 35-46.

Whittam, J. R. "Drawing the Line: Britain and the Emergence of the Trieste Question, January 1941-May 1945." The English Historical Review 106, no. 419 (April 1991), 346-370.

Wolff, Larry. Venice and the Slavs: The Discovery of Dalmatia in the Age of the Enlightenment. Stanford: Stanford University Press, 2001.

Woller, Hans and Enzo Morandi. I conti con il fascismo: l'epurazione in Italia, 1943-1948. Bologna: Il mulino, 1997.

Woodward, Susan. Socialist Unemployment: The Political Economy of Yugoslavia, 1945-1990. Princeton: Princeton University Press, 1995.

Wörsdorfer, Rolf. Il confine orientale: Italia e Jugoslavia dal 1915 al 1955. Bologna: Il Mulino, 2009.

Zahra, Tara. "Imagined Noncommunities: National Indifference as a Category of Analysis." Slavic Review 69, no. 1 (April 2010), 93-119.

------. Kidnapped Souls: National Indifference and the Battle for Children in the Bohemian Lands, 1900-1948. Ithaca, NY: Cornell University Press, 2008. 
-------. The Lost Children: Reconstructing Europe's Families after World War II. Cambridge: Harvard Unviersity Press, 2011.

Zartman, I. William, ed. Understanding Life in the Borderlands: Boundaries in Depth and in Motion. London and Athens, GA: University of Georgia Press, 2010.

Zertal, Idith. From Catastrophe to Power: Holocaust Survivors and the Emergence of Israel. Berkeley: University of California Press, 1998.

Zuccari, Maurizio. Il ditto sulla piaga: Togliatti e il Pci nella rottura fra Stalin e Tito, 1944-1957. Milan: Mursia, 2008. 